
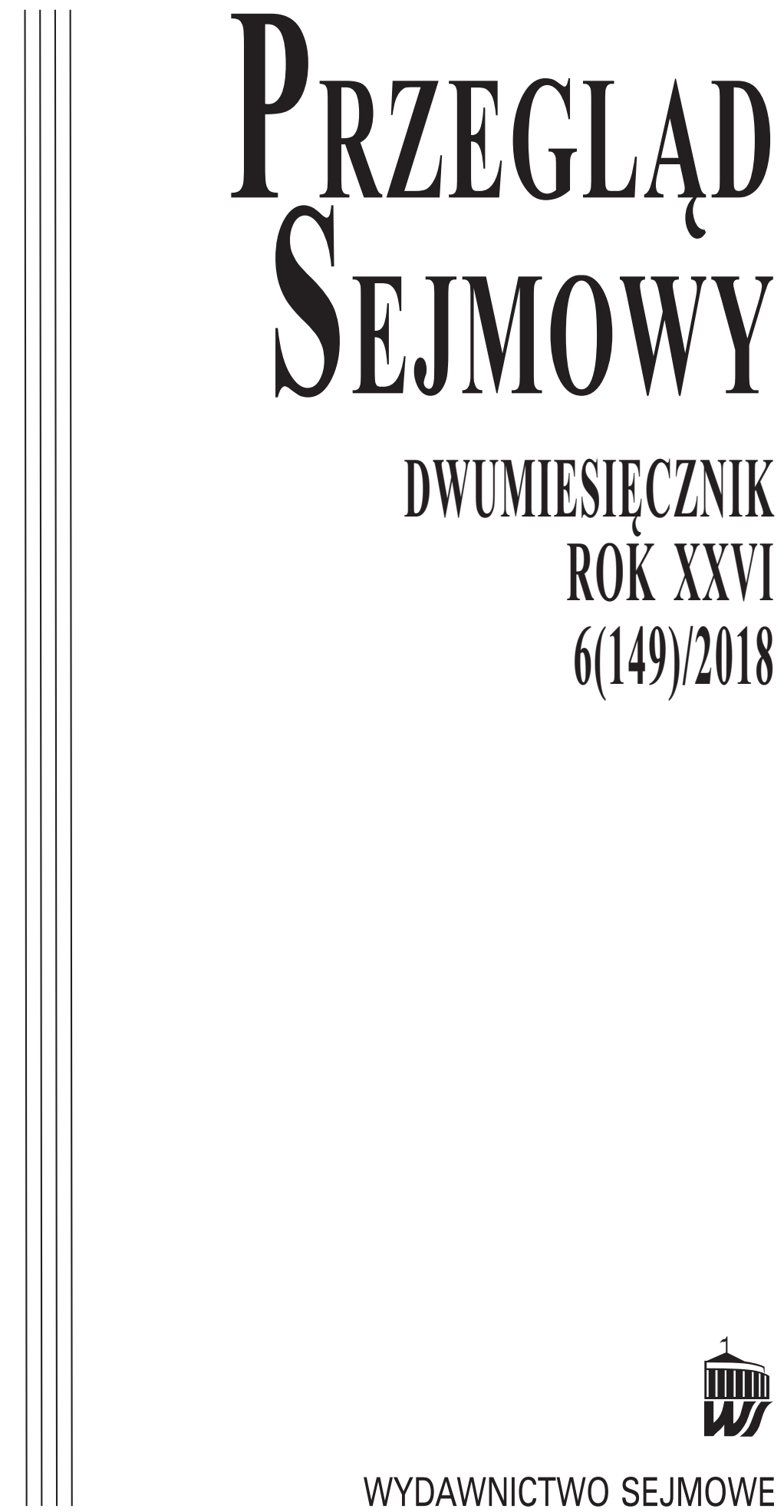

DWUMIESIECZNIK

ROK XXVI

6(149)/2018

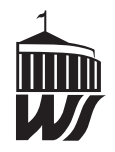

WYDAWNICTWO SEJMOWE 
KOMITET REDAKCYJNY

Redaktor naczelny WALDEMAR PARUCH

Sekretarz naukowy WOJCIECH ARNDT

Redaktorzy tematyczni ARKADIUSZ ADAMCZYK, MAREK DOBROWOLSKI, PAWEŁ SOBCZYK, BOGDAN SZLACHTA, JAROSŁAW SZYMANEK, BARTOSZ WOJCIECHOWSKI

Członek WOJCIECH KULISIEWICZ

\section{RADA NAUKOWA}

Waldemar Paruch (Rzeczpospolita Polska - przewodniczący), Marek Bankowicz (Rzeczpospolita Polska), Igor Cependa (Ukraina), Tihomir Cipek (Chorwacja), Wojciech Dajczak (Rzeczpospolita Polska), Andrzej Dziadzio (Rzeczpospolita Polska), Maria Gintowt-Jankowicz (Rzeczpospolita Polska), Jan Holzer (Czechy), Ferenc Hörcher (Węgry), Bohdan Hud (Ukraina), Jolanta Jabłońska-Bonca (Rzeczpospolita Polska), Károly Kocsis (Węgry), Tomasz Kuczur (Rzeczpospolita Polska), Semjon Kundas (Białoruś), Pavol Mačala (Słowacja), Sergiu Miscoiu (Rumunia), Xavier Moreno Julia (Hiszpania), Vytautas Nekrošius (Litwa), Béla Pokol (Węgry), Herman H. Shugart (Stany Zjednoczone Ameryki), Tomasz Sikorski (Rzeczpospolita Polska), Vojtěch Šimiček (Czechy), Wojciech Sokół (Rzeczpospolita Polska), Rafał Sura (Rzeczpospolita Polska), Ewa Thompson (Stany Zjednoczone Ameryki), Antonio Varsori (Włochy), Michał Warciński (Rzeczpospolita Polska), Jan Wintr (Czechy).

Redaktorzy EWA ĆWIĘKAŁA, URSZULA NAŁĘCZ-RAJCA

\section{Asystent redaktora naczelnego BARTOSZ JANIK}

Tłumaczenia na język angielski KATARZYNA BARTUZI

„Przegląd Sejmowy” znajduje się w wykazie czasopism naukowych prowadzonym przez Ministra Nauki i Szkolnictwa Wyższego na potrzeby oceny jednostek naukowych z przyznaną liczbą 11 punktów.

„Przegląd Sejmowy” jest indeksowany w międzynarodowej bazie Index Copernicus Journals Master List ze wskaźnikiem ICV na poziomie 66.09.

„Przegląd Sejmowy” jest dostępny w bazach danych C.E.E.O.L., CEJSH, POL-index, Index Copernicus, BazHum, EBSCO Legal Source oraz w serwisie informacyjnym EMJS.

1 Clarivate „Przegląd Sejmowy” został objęty wsparciem Clarivate Analitics. Analytics

W wypadku wykorzystania tekstów i informacji z „Przeglądu Sejmowego” w innych publikacjach prosimy o powolanie się na nasze czasopismo.

U w a g a: Zastrzegamy sobie prawo do skrótów w tekstach nadesłanych do publikacji.

Na okładce intronizacja króla polskiego, ok. 1510

(C) Copyright by Kancelaria Sejmu, Warszawa 2018

„Przegląd Sejmowy” ukazuje się od 1993 r.

ISSN $1230-5502$

KANCELARIA SEJMU

Przygotowanie: Wydawnictwo Sejmowe

Wydanie pierwsze

Nakład 500 egzemplarzy

Warszawa, styczeń 2019

Adres: „Przegląd Sejmowy”, ul. Zagórna 3, 00-441 Warszawa, tel. 22 694-13-00

e-mail: przegsejm@sejm.gov.pl; http://www.sejm.gov.pl/publikacje/przegladsejmowy 


\section{SPIS TREŚCI}

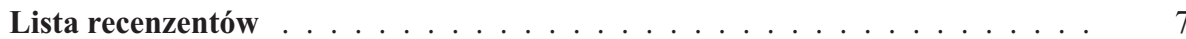

\section{ARTYKULY}

Arkadiusz Adamczyk

Wizerunek Sejmu Ustawodawczego w opinii politycznych przedstawicieli spoleczeństwa polskiego okresu II Rzeczypospolitej . . . . . . . . . . . . . . . . . . . . . . .

Zdzisław Ilski

Wybory do Sejmu Ustawodawczego w 1919 roku. Rysy kampanii . . . . . . . . . 27

Kamil Kacperski

Prawo wyborcze do Sejmu Ustawodawczego . . . . . . . . . . . . . . . . . . . .

Grzegorz Kuca

Między jednolitościq a podziałem władzy: pozycja ustrojowa Sejmu Ustawodawczego

Andrzej Kulig

Relacje Sejmu Ustawodawczego z rzqdem i Naczelnikiem Państwa: system rzadów wlatach 1919-1921 . . . . . . . . . . . . . . . . . . . . . . . .

Lidia Michalska-Bracha

Sejm Ustawodawczy w historiografii polskiego parlamentaryzmu . . . . . . . . .

Piotr A. Tusiński

Procedury ustawodawcze w pierwszym sejmie odrodzonej Rzeczypospolitej Polskiej (1919-1922). Regulacja prawna i praktyka parlamentarna

\section{OPINIE, GLOSY, RECENZJE}

\section{OPINIE}

Tomasz Żyro

Kontrola cywilna nad wojskiem w Stanach Zjednoczonych Ameryki ...... .

\section{GLOSY}

Grzegorz Maroń

Glosa do wyroku Sądu Najwyższego Stanów Zjednoczonych z dnia 4 czerwca 2018 r. w sprawie Masterpiece Cakeshop, Ltd. v. Colorado Civil Rights Commission . . .

\section{RECENZJE}

Kamil Kacperski, Koncepcje systemu wyborczego do Sejmu na ziemiach Królestwa Polskiego w latach 1917-1918 (Ewa Maj) . . . . . . . . . . . . . . . . . . . . . . Andrzej Piasecki, Wiek burzy i spokoju. Kalendarium dziejów Polski 1918-2018 (Jarosław Szymanek) . . . . . . . . . . . . . . . . . . 


\section{ŹRÓDLA}

Sejm, struktura i linie rozwojowe. Przyczynek do poczatków działalności Sejmu Ustawodawczego 1919-1922 (Maciej Wojtacki) . . . . . . . . . . . . . . . . .

Australia: wyrok Sądu Najwyższego z 27 października 2017 r. w sprawie Re Canavan i inni, sygn. (2017) HCA 45 (tłumaczenie i opracowanie Marcin Rulka) 


\section{TABLE OF CONTENTS}

List of the Reviewers $\ldots \ldots \ldots \ldots \ldots \ldots$

\section{ARTICLES}

Arkadiusz Adamczyk

The Legislative Sejm in the opinion of political representatives of the Polish society in the period of the Second Republic of Poland . . . . . . . . . . . . . . . . . . .

Zdzisław Ilski

Elections to the Legislative Sejm in 1919. An outline of the campaign . . . . . . .

Kamil Kacperski

Electoral law to the Legislative Sejm . . . . . . . . . . . . . . . . .

Grzegorz Kuca

Between uniformity and separation of powers: the systemic position of the Legislative Sejm

Andrzej Kulig

Relations between the Legislative Sejm, the Government and the Chief of State:

system of governance between 1919 and 1921 . . . . . . . . . . . . . . . .

Lidia Michalska-Bracha

The Legislative Sejm in the historiography of Polish parliamentarism . . . . . . .

Piotr A. Tusiński

Legislative procedures in the first sejm of the renascent Republic of Poland (1919-

-1922). Legal regulations and parliamentary practice . . . . . . . . . . . . . . .

\section{OPINIONS, COMMENTARIES, REVIEWS}

OPINIONS

Tomasz Żyro

Civilian control over the military in the United States of America . . . . . . . . .

\section{COMMENTARIES}

Grzegorz Maroń

Commentary to the judgment of the Supreme Court of the United States of 4 June 2018 in Masterpiece Cakeshop, Ltd. v. Colorado Civil Rights Commission case . .

\section{REVIEWS}

Kamil Kacperski, Concepts of the electoral system to the Sejm at the lands of the Polish Kingdom in the years 1917-1918 (Ewa Maj) . . . . . . . . . . . . . . . . Andrzej Piasecki, The age of storm and peace. The calendar of Polish history 1918-2018 (Jarosław Szymanek) . . . . . . . . . . . . . . . . . 


\section{SOURCES}

Sejm, structure and development lines. Beginnings of the functioning of the Legislative Sejm 1919-1922 - a contribution (Maciej Wojtacki) . . . . . . . . . . . .

Australia: judgment of the High Court of Australia of 27 October 2017 in the case Re Canavan et al., case ref. no. (2017) HCA 45 (translated and prepared by Marcin Rulka) 


\section{LISTA RECENZENTÓW 2018}

\section{Marek Białokur, Uniwersytet Opolski}

Leszek Bosek, Uniwersytet Kardynała Stefana Wyszyńskiego w Warszawie

Piotr Chybalski, Uniwersytet Kardynała Stefana Wyszyńskiego w Warszawie

Jerzy Ciapała, Uniwersytet Szczeciński

Krystian Complak, Uniwersytet Wrocławski

Piotr Czarny, Uniwersytet Jagielloński

Ryszard M. Czarny, Uniwersytet Jana Kochanowskiego w Kielcach

Paweł Czubik, Uniwersytet Ekonomiczny w Krakowie

Rafał Dudała, Uniwersytet Jana Kochanowskiego w Kielcach

Andrzej Dziadzio, Uniwersytet Jagielloński

Ewelina Gierach, Uniwersytet Kardynała Stefana Wyszyńskiego w Warszawie

Genowefa Grabowska, Wyższa Szkoła Menedżerska w Warszawie

Sabina Grabowska, Uniwersytet Rzeszowski

Marian Grzybowski, Uniwersytet Jagielloński

Grzegorz Janusz, Uniwersytet Marii Curie-Skłodowskiej w Lublinie

Piotr Kapusta, Uniwersytet Zielonogórski

Krzysztof Kawalec, Uniwersytet Wrocławski

Marzena Kordela, Uniwersytet Adama Mickiewicza w Poznaniu

Józef Koredczuk, Uniwersytet Wrocławski

Monika Kowalska, Uniwersytet Marii Curie-Skłodowskiej w Lublinie

Maria Kruk-Jarosz, Uczelnia Łazarskiego w Warszawie

Józef Krukowski, Towarzystwo Naukowe KUL Jana Pawła II

Anna Krzynówek-Arndt, Akademia Ignatianum w Krakowie

Lech Krzyżanowski, Uniwersytet Śląski w Katowicach

Adam Krzywoń, Uniwersytet Warszawski

Grzegorz Kuca, Uniwersytet Jagielloński

Radosław Kubicki, Uniwersytet Jana Kochanowskiego w Kielcach

Paweł A. Leszczyński, Akademia im. Jakuba Paradyża w Gorzowie Wielkopolskim

Dorota Lis-Staranowicz, Uniwersytet Warmińsko-Mazurski w Olsztynie

Tomasz Litwin, Akademia Ignatianum w Krakowie

Maria Marczewska-Rytko, Uniwersytet Marii Curie-Skłodowskiej w Lublinie

Grzegorz Maroń, Uniwersytet Rzeszowski

Maciej Marszał, Uniwersytet Wrocławski

Małgorzata Masternak-Kubiak, Uniwersytet Wrocławski

Artur Mezglewski, Uniwersytet Opolski

Jacek Męcina, Uniwersytet Warszawski 
Barbara Mikołajczyk, Uniwersytet Śląski w Katowicach

Mateusz Pękala, Akademia Ignatianum w Krakowie

Andrzej Pogłódek, Uniwersytet Kardynała Stefana Wyszyńskiego w Warszawie

Krzysztof Prokop, Uniwersytet w Białymstoku

Rafał Prostak, Uniwersytet Ekonomiczny w Krakowie

Mieczysław Ryba, Katolicki Uniwersytet Lubelski Jana Pawła II

Viktoria Serzhanova, Uniwersytet Rzeszowski

Dariusz Skrzypiński, Uniwersytet Wrocławski

Wojciech Sz. Staszewski, Katolicki Uniwersytet Lubelski Jana Pawła II

Aleksander Stępkowski, Uniwersytet Warszawski

Włodzimierz Suleja, Uniwersytet Wrocławski

Aleksandra Syryt, Uniwersytet Kardynała Stefana Wyszyńskiego w Warszawie

Wojciech Szczepan Staszewski, Katolicki Uniwersytet Lubelski Jana Pawła II

Mirosław Szumiło, Uniwersytet Opolski

Wojciech Śleszyński, Uniwersytet w Białymstoku

Andrzej Świątkowski, Akademia Ignatianum w Krakowie

Krystyna Trembicka, Uniwersytet Marii Curie-Skłodowskiej w Lublinie

Tomasz Tulejski, Uniwersytet Łódzki

Kazimierz Michał Ujazdowski, Uniwersytet Łódzki

Przemysław Waingertner, Uniwersytet Łódzki

Dariusz Walencik, Uniwersytet Opolski

Piotr Wawrzyk, Uniwersytet Warszawski

Tomasz Wieciech, Uniwersytet Jagielloński

Marcin Michał Wiszowaty, Uniwersytet Gdański

Bartosz Wojciechowski, Uniwersytet Łódzki

Jerzy Zalewski, Wojskowa Akademia Techniczna w Warszawie

Maria Zmierczak, Uniwersytet Adama Mickiewicza w Poznaniu 


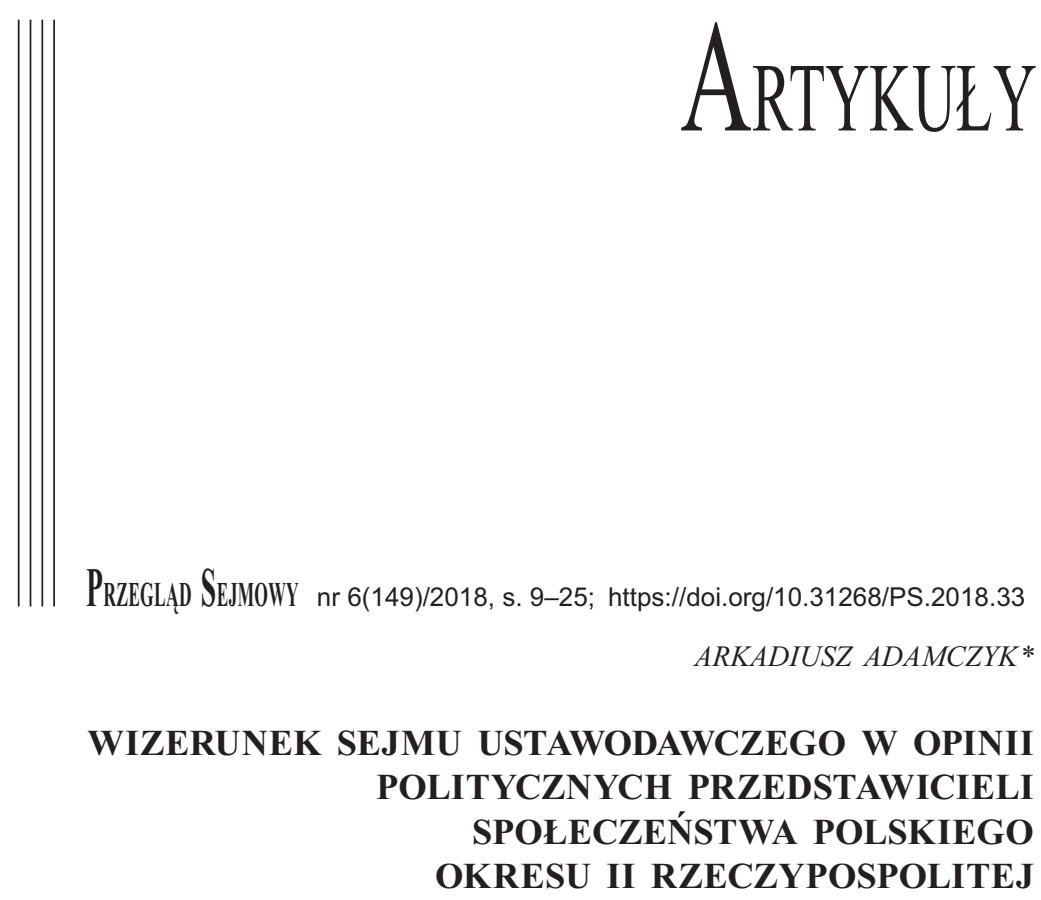

\author{
THE LEGISLATIVE SEJM IN THE OPINION \\ OF POLITICAL REPRESENTATIVES OF THE POLISH SOCIETY \\ IN THE PERIOD OF THE SECOND REPUBLIC OF POLAND
}

One of the greatest mysteries, which the time was to solve, was the political, systemic, economic and social form of the state resulting from the processes accompanying the summoning of the Legislative Sejm. An argument may be propounded that the way the Sejm was perceived had been decisively influenced by the atmosphere of the electoral campaign, which differed considerably from the Poles' general enthusiasm expressed less than three months earlier. When Józef Piłsudski ceremonially opened the sitting on 10 February 1919, the opinion on the Sejm had already been established. When the Chief of State declared that he "is honoured to open the Polish Sejm, which shall again be the sole master and host of its homeland", he was evoking a vision rather than reality. The divisions established during the rivalry for Deputies' mandates caused the reception of the Sejm by the society to be conditioned not on the authority of the legislative body formed by the sovereign's will, but rather on political support of the voters of individual parties and the reaction to success (or failure) of the supported party. For those supporting the left, the parliament elected in January 1919 was not peasant enough. For the national right, especially when the Deputies' chamber was joined by minority representatives, it was not consistent with the Poles' national interests. Particularly disappointed were all those, whose representatives had not been elected, especially representatives of the radical intelligentsia. The disappointment with the election results greatly affected the social reception of the re-established parliament.

Słowa kluczowe: Sejm, parlamentaryzm, konstytuanta, większość sejmowa, przedstawicielstwo narodowe

Key words: Sejm, parliamentarism, constituent assembly, Sejm majority, national representation

* Dr hab. Arkadiusz Adamczyk, Uniwersytet Jana Kochanowskiego w Kielcach, aradamczyk@ujk.edu.pl 


\section{UWAGI WSTĘPNE}

$\mathrm{W}$ powszechnym odczuciu i odbiorze społecznym 11 listopada 1918 r. uchodzi za moment restytucji państwa polskiego. Nie sposób jednak nie zauważyć, że data ta wynika wyłącznie z kodu kulturowego, odpowiadającego na społeczne zapotrzebowanie i nie ma wiele wspólnego z ówczesnymi realiami. Nawet ortodoksyjni zwolennicy marszałka Józefa Piłsudskiego starający się w następnych latach znaleźć uzasadnienie dla celebrowania tego dnia uznawali, że przejęcie przez niego władzy wojskowej z rąk Rady Regencyjnej stanowiło dopiero pierwszy krok do budowy niepodległego państwa ${ }^{1}$. Dnia 11 listopada nie rozwiązano bowiem niemal żadnego z problemów, przed jakimi stanęła powstająca z niebytu Rzeczpospolita. Nie wiadomo było przede wszystkim, w jakim ostatecznym kształcie terytorialnym i w jakim otoczeniu międzynarodowym przyjdzie Polakom funkcjonować. Otwarta pozostawała nie tylko kwestia przebiegu granic, ale nie ustalono też, z jakimi państwami Polska będzie graniczyć ${ }^{2}$. Największą jednak zagadką pozostawał kształt polityczny, ustrojowy, gospodarczy i społeczny kraju — większość tych kwestii miało rozwiązać zwołanie Sejmu Ustawodawczego [dalej: SU]. Co jednak charakterystyczne, moment odrodzenia tego organu ustawodawczego, który miał odegrać tak dużą rolę, w ogóle nie był uważany za ważną cezurę. Szczególnie istotny był odbiór społeczny parlamentu, wyłonionego w wyborach 26 stycznia 1919 r.

Wizerunek wskrzeszonego przedstawicielstwa narodowego stanowił pochodna wymienionych uwarunkowań. Im bardziej polskie środowiska polityczne zaczynały zdawać sobie sprawę z ograniczonych możliwości ingerencji w kwestie związane z polityką zagraniczną i ukształtowaniem granic. Rozwiązanie tych problemów leżało w gestii delegacji polskiej na paryską konferencję pokojową oraz Naczelnika Państwa, tym bardziej starały się zdobyć decydujący wpływ na bieg spraw krajowych. Było to jedno z podstawowych uwarunkowań sprawiających, że polski Sejm był kształtowany w warunkach odbiegających od narodowego konsensu. Między innymi ten właśnie fakt sprawił, że społeczny odbiór izb ustawodawczych został w zasadniczych zrębach ukształtowany w momencie restytucji Sejmu w 1919 r. Można również zaryzykować tezę, że decydujący wpływ na ukształtowanie opinii o Sejmie miała atmosfera kampanii wyborczej, zasadniczo odmienna od powszechnego entuzjazmu wyrażanego przez Polaków niespełna trzy miesiące wcześniej³ . Kiedy 10 lutego 1919 r. Józef Piłsudski

${ }^{1}$ A. Cienciałła, 11 listopada 1918 roku. Józef Pitsudski i niepodleglość Polski, „Przegląd Polski” nr 45, 8 XI 2002, s. 3-11.

${ }^{2}$ Trafnie stwierdził przywódca PPS, Ignacy Daszyński, że „wszystkie bowiem granice Polski jako młodego państwa są sprawą sporną i to tak dalece, że na wszystkich niemal albo krew się leje, albo nastaje wrogie napięcie. Na rynku międzynarodowej polityki każdy «przybysz» ma licznych wrogów. Jedni zwalczają nową republikę jako zbyt «rewolucyjną», drudzy jako zbyt «reakcyjną». Łączą się przeciwko nam wrogowie np. socjaliści niemieccy z junkrami niemieckimi, podkopują nas «przyjaciele» i dotychczasowi sojusznicy” I. Daszyński, Przypomnienie na czasie, „Robotnik” nr 2, 2 I 1919, s. 1.

${ }^{3}$ We wspomnieniach jednego z uczestników wydarzeń listopadowych zachował się następujący passus: „Kto tych krótkich dni nie przeżył, kto nie szalał z radości w tym czasie wraz z całym narodem, ten nie dozna w swym życiu największej radości. Cztery pokolenia czekały, piąte się doczekało. Od rana do wieczora groma- 
dokonywał uroczystego otwarcia Izby, wizerunek Sejmu był już uformowany. Naczelnik Państwa, wypowiadając słowa, że ,,przypadł mu zaszczyt otwierać Sejm polski, który znowu będzie swego ojczystego domu jedynym panem i gospodarzem", przedstawiał obraz postulowany, bynajmniej nie rzeczywisty. Podziały, jakie zaistniały w trakcie zmagań o mandaty poselskie, sprawiły, że odbiór Sejmu w opinii ówczesnego społeczeństwa zależał nie od autorytetu tego ciała ustawodawczego - ukształtowanego z woli suwerena - ale w większym stopniu od politycznych sympatii wyborców poszczególnych stronnictw i reakcji na sukces (względnie porażkę) popieranego przez nich ugrupowania. W znacznej mierze pozostawał funkcją politycznych pragnień, względnie negatywnych emocji czy wręcz frustracji.

\section{SEJM USTAWODAWCZY W ODBIORZE REPREZENTANTÓW LEWICY}

Nie ulegało najmniejszej wątpliwości, że środowiska mieniące się reprezentacją mas pracujących rozumiały doniosłość chwili i wagę rozgrywających się wydarzeń. Miały też pełną świadomość, że wybierane zgromadzenie stanie się w przyszłości miejscem wykuwania przyszłego kształtu Rzeczypospolitej ${ }^{5}$. Nie miały również złudzeń co do tego, że w kwestii świadomości politycznej potencjalny elektorat lewicy będzie przegrywać z dobrze wykształconym mieszczaństwem i grupami stanowiącymi zaplecze prawicy. Kluczem do zwycięstwa miała być próba nadania Sejmowi jednoznacznie ludowego wizerunku. Jak 14 stycznia 1919 r. wskazywał Bronisław Siwik, „Konstytuanta, czyli sejm ustawodawczy ma być tem przedstawicielstwem narodu, które postanowi jaki ma być ustrój Polski, jakie mają zapanować w niej stosunki gospodarcze, społeczne i polityczne. Do Konstytuanty mają wybierać posłów wszyscy: zarówno robotnik miejski, jak fabrykant; zarówno robotnik wiejski włościanin małorolny jak obszarnik; zarówno dozorca domowy, jak ściąający w pocie czoła lichwiarskie komorne z lokatorów kamienicznik; zarówno wygaszony i matowy urzędnik biurowy, jak rozpływający się i świecący pryncypał, bankier"'.

Przedstawiciele lewicy zdawali sobie sprawę z ogromnego potencjału własnego zaplecza, wynikającego przede wszystkim z uwarunkowań demograficznych i dysproporcji między liczbą osób posiadających środki produkcji — według używanej przez socjalistów nomenklatury marksistowskiej — i nieposiadających ich. Dlatego też naj-

dziły się tłumy na rynkach miast; robotnik, urzędnik porzucał pracę, chłop porzucał rolę i leciał do miasta, na rynek, dowiedzieć się, przekonać się, zobaczyć wojsko polskie, polskie napisy, orły na urzędach, rozczulano się na widok kolejarzy, ba, na widok polskich policjantów i żandarmów. Powstanie II Rzeczypospolitej”; vide Wybór dokumentów 1866-1925, red. H. Janowska, T. Jędruszczak, Warszawa 1981, s. 432.

4 J. Piłsudski, Pisma zbiorowe. Wydanie prac dotychczas drukiem ogłoszonych, t. V, Warszawa 1937, s. $55-56$.

5 W wypowiedziach socjalistów, budujących wizerunek polskiego parlamentu, zwracało uwagę jednoznaczne powiązanie kwestii ustroju przyszłego kraju z hasłami klasowymi. Na łamach „Robotnika” niejednokrotnie stwierdzano, że ,tylko niezawisła Polska może wstapić w fazę socjalistycznej twórczości i tylko Sejm ustawodawczy może być punktem wyjścia dla dalszego rozwoju". Vide inter aliam: I.F., Dyktatura proletariatu a Sejm Ustawodawczy, ,Robotnik” nr 40, wydanie popołudniowe, 25 I 1919, s. 2.

${ }^{6}$ B. Siwik, Pytania i odpowiedzi, „Robotnik” nr 19, 14 I 1919, s. 1. 
większe ugrupowanie lewicowe, jakim pozostawała powstała w 1892 r. Polska Partia Socjalistyczna, od samego początku traktowało kwestię wyborów do SU jako instrument służący historycznym przeobrażeniom i budowie nowego porząadku społecznego. Na niespełna trzy tygodnie przed zbliżającymi się wyborami Zygmunt Zaremba, jeden z liderów PPS, niedwuznacznie wskazywał, że celem partii było na tym etapie wytworzenie takiej sytuacji, w której „cały aparat państwowy powinien służyć polityce ludowej"ᄁ. Wspominany już B. Siwik, stawiając retoryczne pytanie i udzielając na nie odpowiedzi, prowadził do jednoznacznej konkluzji: ,Jaka będzie większość przeważająca w Sejmie? Taka jaką wybiorą włościanie i robotnicy. Jaki będzie ustrój przyszłej Polski? Taki jaki wybiorą przedstawiciele włościan i robotników o ile pójdą ręka w rękę, o ile będą działać społem"8. Na przeszkodzie urzeczywistnienia tego celu stał jasno zdefiniowany wróg, czyli „klasy posiadające - posiadacze fabryk i obszarów ziemi [które - A.A.] jasno powiedziały, że kapitulować nie chcą". Nie był to zresztą jedyny przeciwnik lewicy, która z równą niechęcią co środowiska prawicowe traktowała komunistów, m.in. z tego powodu, że oba środowiska odwoływały się do tej samej grupy odbiorców. Socjaliści starali się przypisać skrajnej lewicy wizerunek siły narodowo antypolskiej, w warstwie politycznej realizującej cele zbliżone do kręgów prawicowych. Jak wskazywał socjalistyczny propagandysta, ,trzeba przyznać, że pod tym względem, i pod wieloma innemi poglądy naszych anarcho-komunistów są bliźniaczo podobne do poglądów naszej burżuazji. Wszak burżuazja nasza również uznaje masy ludowe za ciemne i niewyrobione oraz pragnęłaby ich do sejmu nie dopuścić, i ta tylko zachodzi między naszą burżuazją a anarcho-komunistami różnica, że ta pierwsza chciałaby sfałszować rolę mas ludowych w sejmie, a ci drudzy — poza sejmem. Bo ci ni mniej, ni więcej — tylko ci sami anarcho-komuniści, którzy nie wierzą, aby robotnicy i włościanie potrafili wybrać do sejmu posłów; którzy sądzą że masy ludowe nie są w ogóle w stanie zdać sobie sprawy na czym polegają ich żywotne interesy gospodarcze, społeczne i polityczne, którzy wątpią czy robotnicy razem z włościanami będą mieli większość taka, któraby ustrzegła Polskę od reakcji — ci sami anarcho-komuniści rzucają dziś hasło dyktatury proletariatu" ${ }^{\prime 10}$. Jak można domniemywać, wydanie wizerunkowej wojny komunistom miało również służyć pozyskaniu wyborców żydowskich, zwłaszcza członków Powszechnego Żydowskiego Związku Robotniczego na Litwie, w Polsce i Rosji „Bundu”. Stworzenie pozytywnego wizerunku Sejmu ludowego miało przyciagnąć do PPS zachowawczych członków organizacji, odrzucających wpływy bolszewickie i wizję dyktatury proletariatu ${ }^{11}$.

7 Z. Zaremba, Po jakiej drodze, „Robotnik” nr 11, 9 I 1919, s. 1.

${ }^{8}$ B. Siwik, Pytania i odpowiedzi..., s. 1.

9 Ibidem.

10 Z. Zaremba, Po jakiej drodze, „Robotnik” nr 11, 9 I 1919, s. 1.

11 Należy przy tej okazji zauważyć, że propagandziści PPS atakowali partie żydowskie (w tym Bund), uznając je z jednej strony za ,siedlisko” komunistycznej agitacji; z drugiej zaś wykorzystując hasła antysemickie do stworzenia alternatywy dla potencjalnych zwolenników Narodowego Związku Robotniczego. Świadczyły o tym m.in. próby dyskredytacji Bundu: „,czy Bund jest za Sejmem Ustawodawczym? Ależ naturalnie — przecież kandyduje na prowincji! Czy bojkotuje wybory? Oczywiście — przecież nie wystawił listy w Warszawie”; vide Przegląd list kandydatów do sejmu, „Robotnik” nr 21, 15 I 1919, s. 2. 
Chwila, w której działania wizerunkowe socjalistów przybrały na sile, był moment dymisji rządu Jędrzeja Moraczewskiego. Jak wskazywali propagandziści stronnictwa, upadał rząd ludowy, w którym masy robotnicze i chłopskie pokładały nadzieje na poprawę swojej sytuacji. Mało tego, rząd upadał pod presją prawicy, nieprzyjmującej do wiadomości prawa włościan i mas pracujących do współdecydowania o losach kra$\mathrm{ju}^{12}$. Niewątpliwie socjaliści aprobowali ten fragment oświadczenia rządu, w którym twierdzono, że rząd dążył do stworzenia ideału, tj. ludowej Republiki Polskiej i z tej drogi został zawrócony. Bez wątpienia zgadzali się oni z diagnozą członków gabinetu, którzy stwierdzili, że ,zbiorowy wysiłek może stworzyć tylko wola narodu; wola narodu wypowiedzieć się może w tylko w instytucji wybranej przez cały naród, tylko w Sejmie [...] szybkie zwołanie Sejmu to jedyne wyjście z tych trudności”, a także że „Sejm nie będzie w stanie uspokoić kraju i rozpocząć w nim swej twórczej pracy, jeśli Polska nie będzie miała zapewnionych środków koniecznych dla jej życia państwowego"13. Oczywiście oddanie władzy przez rząd ludowy miało być tylko epizodem. Ten rząd miał powrócić wraz z wygraną wyborczą opcji ludowej i ukonstytuowaniem się ludowego Sejmu ${ }^{14}$. Osiagnięcie tego celu było możliwe jedynie przy pełnej mobilizacji naturalnego zaplecza partii ${ }^{15}$. Stąd też płynące z prasowych łamów zachęty, nie tylko do wzięcia udziału w głosowaniu, ale też do dopełnienia wszystkich formalności związanych $\mathrm{z}$ ewentualnym wpisem na listy wyborców ${ }^{16}$.

W rozważaniach nad wizerunkiem SU należy podkreślić, że już w przededniu wyborów lewicowemu elektoratowi ,zaszczepiono” określenia, które w późniejszym okresie nie mogły nie wpływać na odbiór parlamentu. Socjalistyczni propagandziści wykazywali się przy tej okazji szczególnym talentem, nie ograniczając listy określeń do terminu ,reakcja”, który notabene był zazwyczaj zarezerwowany dla członków i zwolenników partii Romana Dmowskiego. To ugrupowanie zostało zresztą uznane za największego wroga polskiego świata pracy. Jak stwierdzono na łamach ,Robotnika”, ,idzie Dmowski, którego nazwisko wystarcza, aby cały lud pracujący zwrócił się przeciwko tej liście. Jest to lista, którą przede wszystkim zwalczać należy, jako najniebezpieczniejszą dla klasy robotniczej”"17. Nie oznaczało to jednak, że w zależności od zapotrzebowania nie można było tego epitetu użyć w odniesieniu do innych stron-

12 Jak wskazywali socjalistyczni publicyści, ,nie to że rząd socjalistyczno-ludowy zają się przede wszystkim zwołaniem Sejmu Ustawodawczego, aby ogół ludności w drodze najdemokratyczniejszych wyborów wolę swą wyraził i stały rząd ustanowił. Burżuazja poczuła, że jej przywilej panowania i jej prawo do wyzysku jest zagrożone. Znienawidziła więc demokratyczny rząd Moraczewskiego tak, jakby był to najbardziej despotyczny rząd bolszewicki”; vide Nowy rzad, ,Robotnik” nr 26, 17 I 1919, s. 1.

13 Ustapienie Rządu Ludowego. Pismo Prezydenta Rady Ministrów tow. J. Moraczewskiego do Naczelnika Państwa, „Robotnik” nr 29, 19 I 1919, s. 1.

14 Zmiana rzqdu w przededniu wyborów, Robotnik" nr 26, 17 I 1919, s. 2.

15 Jak wskazywał jeden z publicystów „Robotnika”, „,nic bardziej nie ucieszyło burżuazji, jak zejście z drogi zorganizowanej i celowej walki o prawa ludu pracującego na manowce anarchii. Wybory należy wykorzystać w pełni, by porachować się z reakcją. Za zmuszenie rządu ludowego do ustapienia należy wziąć odwet, obalając w dn. 26 stycznia reakcję i niwecząc jej skrytobójcze plany przeciwko Polsce robotniczej i włościańskiej”. Nowy rząd, Robotnik” nr 29, wydanie poranne, 19 I 1919, s. 1.

16 Baczność wyborcy i wyborczynie, ,Robotnik” nr 26, 17 I 1919, s. 1.

17 Przeglad list kandydatów do sejmu, „Robotnik” nr 21, 15 I 1919, s. 2. 
nictw. Generalnie za „reakcję” uznawano wszystkie ugrupowania wyznające wartości konserwatywne i odwołujące się — nawet w minimalnym stopniu — do zasad określonych w nauczaniu społecznym Kościoła katolickiego. Niemniej reakcyjność konserwatystów nie była tak silnie manifestowana, jak ich zaangażowanie w czasach autonomii w zaborze austriackim ${ }^{18}$, natomiast zachowawczość środowisk mieszczańskich, przedstawianych jako kasta kamieniczników i kupców, jednoznacznie określano jako koniunkturalizm i kryptoreakcję. Największą liczbą epitetów obrzucano środowiska robotnicze nieutożsamiające się z ludową wizją przyszłego ustroju Polski, którym z tego powodu odmawiano ideowości. Narodowy Związek Robotniczy, „który przyczepił się do robotników chrześcijańskich”, miał np. „,ienkim głosem prosić o głosy, zapewniając, że jest wszechstronny, bo już ze wszystkich pieców chleb jadł: i z endeckiego, kiedy służył Dmowskiemu, i CKN-owego"19. Natomiast ugrupowania robotników chrześcijańskich, występujące pod szyldem „Narodowego Komitetu Wyborczego Ludu Pracującego”, miały cieszyć się szczególną opieką kleru, a „kapitaliści z całego serca pragnęliby, żeby lud pracujący wybrał takich obywateli”".

W przededniu wyborów do świadomości socjalistów zaczęło jednak docierać, że SU nie będzie parlamentem na miarę ich oczekiwań. Choć do ostatnich chwil starali się oni zaszczepić swoim odbiorcom wizję Sejmu ludowego, a także zmobilizować jak największą liczbę swoich zwolenników do udziału w wyborach, z wypowiedzi publikowanych tuż przed głosowaniem jasno wynikało, iż zaczęli zdawać sobie sprawę, że nie będą w stanie przeforsować swoich politycznych idei. Wymuszało to również zmiany w zakresie kreowania wizerunku nowego parlamentu. Przyszły Sejm z jednoznacznie ludowego zaczął być przedstawiany jako twór przejściowy, który miał stanowić jedynie pierwszy etap budowania robotniczej i włościańskiej reprezentacji ${ }^{20}$. Środowisko polskich socjalistów dało wyraz swoim przekonaniom także w momencie, kiedy poznano pierwsze, rozczarowujące socjalistów, wyniki wyborów. Zygmunt Kisielewski, publikując felieton pod wymownym tytułem „Ich zwycięstwo", prognozował, że w ostatecznym rozrachunku polityczna wygrana i tak stanie się udziałem mas robotniczych. Jednoznacznie stwierdzał: „Krótkie i marne zwycięstwo! Można oszukać lud na miesiąc, na dwa, na pół roku, lecz potem lud zażąda od was czynów. Czy dacie mu ziemie? Czy powstrzymacie zachłanną chciwość paskarza, sklepikarza, obszarnika? Czy zapewnicie masom znękanym wojną i głodem pokój, dobrobyt i pracę? Czy przekonacie ich, że wasza ojczyzna i wasz Bóg, to także ich Bóg i ich ojczyzna? A jeśli tego nie uczynicie wasz wyborca runie na was jak żywioł druzgocący, oblegnie was w waszych okopach św. Trójcy i wymusi

${ }^{18}$ Ibidem. Wymowne było określenie ,upiór z austriackich czasów, który wstał z grobu”.

19 Ibidem.

${ }^{20}$ Dał temu wyraz m.in. Z. Zaremba, stwierdzając w przededniu wyborów, że „26 stycznia [tj. dzień wyborów do SU — A.A.] pokaże nam, ile już sił stoi w szeregu walczących o wyzwolenie ludu pracującego, a szereg ten będzie z dnia na dzień wzrastał i wzrastać też będzie niezależnie od liczby i sił klasy robotniczej w Sejmie. Tylko musimy sobie dobrze uprzytomnić, że decydującym czynnikiem naszego zwycięstwa będzie zorganizowana siła klasy robotniczej”; vide idem, Sejm ustawodawczy a klasa robotnicza, „Robotnik" nr 30, 25 I 1919, s. 2. 
na was prawo, wolność, zwycięstwo!"’21. Podobne treści propagowali m.in. Norbert Barlicki $^{22}$ i Tadeusz Hołówko ${ }^{23}$.

Od pierwszego posiedzenia SU socjaliści starali się budować wizerunek tej Izby zgodnie z zasadą dualizmu, przeciwstawiając siły reakcji siłom postępu. Kreśląc obraz wydarzeń rozgrywających się w trakcie inauguracji, lewicowi komentatorzy przekazywali wymowną narrację: ,Skład poselski w komplecie. Na skrajnej lewicy zasiedli socjaliści, dalej na lewicy enzeterowcy, troszkę ludowców [...] Śmieszne robią wrażenie posłowie ND [Narodowej Demokracji — A.A.] i innych grup reakcyjnych, którzy jak diabeł święconej wody obawiają się należnych im miejsc na prawicy, cała reakcja usadowiła się w centrum. Wskutek tej obawy miejsca na prawicy chwilowo zajęli ludowcy radykalni. W chwili, gdy sala jeszcze falowała i rozbrzmiewała od rozmów, zjawia się na Sali Naczelnik Państwa kom. Piłsudski. Po rogach mównicy stało czterech adjutantów w galowych mundurach. Nastaje cisza. Wszyscy powstają. Jednak kilkunastu posłów próbuje siedzieć. Rozlegają się ostre okrzyki z całej sali: wstać, wstać. Wśród siedzących prowodyrów endeckich, zaskoczonych faktem, że prócz 3-4 rzędów krzeseł wszyscy stoją, nawet ich przyjaciele polityczni, konsternacja. Zaczynają po trochu wstawać. Jedynie posłowi, dr. Rządowi, «sławnemu» ze swego haniebnego przemówienia w Radzie miejskiej w sprawie ulicy hr. Berga, nie zabrakło bezczelności. «Nie na waszą komendę» — rzucił. Była to ostatnia próba oporu. Prowodyrzy endeccy musieli wstać. Naczelnik Państwa rozpoczął przemówienie, którego wysłuchano stojąc. Podczas przemówienia brawom i okrzykom na cześć Piłsudskiego nie było końca. Posłowie ludowi wszelkich odcieni specjalnie gorąco oklaskiwali miejsce orędzia Naczelnika, w którym mówił o potrzebie reformy agrarnej" ${ }^{24}$. Nie bez przyczyny w kontrze do mowy Piłsudskiego wymownie opisano wystapienia marszałka seniora Ferdynanda Radziwiłła: „Książę Radziwiłł rozpoczął przewodnictwo od długiego i nudnego przemówienia, którego treścią były nawoływania od wypełniania obowiązków względem [...] Stolicy Apostolskiej. Mówił też coś długo o kąkolu, tak że z trudnością z tego kąkola się wydobył i przemówienie zakończył. Przemówienie krewnego Hohenzollernów robiło wrażenie głosu z dalekiej, dalekiej przeszłości. Będzie to prawdopodobnie ostatnie tego rodzaju w Sejmie Ustawodawczym"25. Jak bardzo wizerunek SU stanowił po-

${ }^{21}$ Z. Kisielewski, Ich zwycięstwo, „Robotnik” nr 30, 25 I 1919, s. 2.

22 Jak wskazywał N. Barlicki, ideolog PPS: ,cała sytuacja zewnętrzna i wewnętrzna uprawnia do wnioskowania, że zwykła większość sejmowa nie rozstrzygnie przede wszystkim tych zagadnień, które rozstrzygnąć będzie musiało całe społeczeństwo, cały naród. Nie należy zapominać, iż Sejm to nie samodzielna instytucja, która przeciwstawiać się może swemu mocodawcy - Narodowi. Sejm to organ woli narodu, a ta wola to wypadkowa sił historycznych, dająca się dla każdego momentu dziejowego stwierdzić. [...] Co do nas, nie sądzimy aby bieg dziejów wyjątkowo w Polsce miał się wstecz cofnąć"; vide idem, Przedwczesny tryumf, ,Robotnik” nr 44, wydanie popołudniowe, 28 I 1919, s. 1.

${ }^{23}$ T. Hołówko, odnosząc się do osoby marszałka seniora F. Radziwiłła, narzucił narrację, że „mowa Radziwiłła była pożegnaniem umierającej arystokracji, która nic już nie ma do powiedzenia i tylko jeszcze zawadzać może przez pewien czas niepodległej Polsce"; vide T. Hołówko, Wrażenia z pierwszego posiedzenia sejmu, „Robotnik” nr 65, wydanie poranne, 11 II 1919, s. 2.

${ }_{24}$ Otwarcie sejmu, ,Robotnik” nr 65, wydanie poranne, 11 II 1919, s. 2.

${ }^{25}$ Ibidem. 
chodną walki między prawicą i lewicą obrazowała kwestia dokooptowania do składu Sejmu przedstawicieli województwa poznańskiego. Socjalistyczni posłowie jednoznacznie sprzeciwiali się włączeniu do składu Izby „mianowańców” desygnowanych przez Naczelną Radę Ludową w Poznaniu, stawiając jednoznaczną tezę, że SU stałby się przez to parlamentem pozbawionym autorytetu ${ }^{26}$. Prawica natomiast miała pozostawać głucha na potrzebę włączenia do składu Sejmu przedstawicieli Kresów Wschodnich $^{27}$. Oczywiście socjaliści nie ukrywali, że był to akt niezwykle istotny nie tylko w kontekście wizerunku. Jak otwarcie wskazywali, ,wejście 71 ludzi do Sejmu całkowicie zmienia stosunki w Sejmie, bezwzględnie przeważa szalę na stronę prawicy, czyni z tej prawicy znaczną większość. Wybrani z Królestwa i Galicji posłowie byliby zmajoryzowani przez ludzi kooptowanych na zlecenie endecji" ${ }^{28}$. Niemniej to polityka determinowała wizerunek ciała ustawodawczego od momentu jego wyboru przedstawianego jako efekt endeckiej intrygi ,mającej na celu jedynie i wyłącznie partyjny interes narodowej demokracji”, która „,doprowadziłaby do zrobienia z sejmu smutnej karykatury, podkopującej znaczenie i powagę sejmu polskiego"229. Ostateczne ukonstytuowanie się Sejmu sprawiło, że jego odbiór wśród członków, zwolenników i wyborców ugrupowań socjalistycznych pozostał niezmienny niemal do końca jego funkcjonowania.

$\mathrm{Na}$ zmianę wizerunku SU w odbiorze zwolenników polskiej lewicy radykalny wpływ miało ich późniejsze rozczarowanie wywołane niekorzystnym rozwojem wydarzeń politycznych. Położenie, w jakim znaleźli się socjaliści po wypadkach majowych 1926 r., sprawiło, że zaczęli oni postrzegać pierwszy Sejm zwołany po wskrzeszeniu Rzeczypospolitej w pozytywnym świetle. Dał temu wyraz m.in. Ignacy Daszyński, stwierdzając w 10. rocznicę zwołania SU, że Izba ta stała się ,,areną na której spotkali się po raz pierwszy od lat stukilkudziesięciu przedstawiciele wszystkich dzielnic Polski. W trudzie i bólu nieraz zabliźniać zaczęły się głębokie rany zadane kordonami zaborów. Sejm stawał się więzią łączącą Polaków, z których robiono przez cały wiek Prusaków, Austriaków i «prawdziwie rosyjskich ludzi». Wybrawszy Naczelnika Państwa Sejm roz-

${ }^{26}$ Jak jednoznacznie stwierdzał T. Hołówko, „Sejm ma dla nas autorytet tylko wtedy, kiedy jest złożony wyłącznie z posłów wybranych w określony przez demokratyczną ordynację wyborczą sposób. Sejm, którego większość zgodziłaby się na naruszenie podstawowej zasady nowoczesnego przedstawicielstwa, do którego obok posłów wchodziliby «przedstawiciele» dowolnie obrani czy mianowani - nie miałby dla nas żadnego autorytetu (powagi). Niemili nam są w sejmie różni Rządy, Grabscy i inne Gdyki — ale bądź co bądź są to wybrani na podstawie wydanej przez Rząd Ludowy ordynacji posłowie. Ale żadnego autorytetu nie mogą mieć ci, których by do sejmu posłali poznańscy Grabscy, Rządy, Gdyki itp. [...] Dlatego jeśli obecnej większości sejmowej jest drogi autorytet sejmu, jeśli ona chce, aby lewica ten autorytet uznawała, niech własnymi rękoma tego autorytetu nie grzebie. [...] Dlatego też Sejm w imię swego własnego autorytetu, jako ciała powołanego przez bezpośrednią i powszechną wolę narodu, musi pretensję Poznańskiego uchylić. Jeśli chcą być liczniej reprezentowani niech zgodzą się na rozpisanie wyborów w tych okręgach, które zostały już wyzwolone spod panowania pruskiego"; vide T. Hołówko, W sprawie dopuszczenia do Sejmu tzw. , ,przedstawicieli”, „Robotnik” nr 67, wydanie poranne, 12 II 1919, s. 1.

${ }_{27}$ T. Hołówko, W sprawie dopuszczenia do Sejmu tzw. ,przedstawicieli”, cz. II, „,Robotnik” nr 69, wydanie poranne, 13 II 1919, s. 1.

${ }^{28}$ Jeszcze o ,przedstawicielach” Naczelnej Rady Ludowej, „Robotnik” nr 71, wydanie poranne, 14 II 1919, s. 1.

${ }_{29}$ Ibidem. Vide etiam Pan Korfanty i jego większość, „Robotnik” nr 73, wydanie poranne, 15 II 1919, s. 1. 
począł pracę ustawodawczą"30. Jeszcze większą aprobatę wobec dorobku pierwszego Sejmu socjaliści wyrazili na krótko przed klęską wojny obronnej 1939 r. Mało tego, własne ugrupowanie przedstawili jako — obok Naczelnika Państwa — głównego inicjatora zwołania SU w styczniu 1919 r. ${ }^{31}$ Z perspektywy 20 lat wizerunek Sejmu wydawał się im już jednoznacznie pozytywny. Jak stwierdził Adam Próchnik, „Patrząc dziś z pewnej perspektywy historycznej musimy stwierdzić, iż osiagniecia grupy demokratycznej z PPS na czele w tym sejmie o większości politycznie i społecznie zacofanej muszą budzić podziw"32. Główny publicysta obozu M. Niedziałkowski poszedł jeszcze dalej. Uważał, że „ten sejm miał wiele zalet i wiele wad. Zalety górują — według mojego najgłębszego przekonania - tysiąckrotnie nad wadami. [...] Zaletą największą tego sejmu było, że stanowił on pracujaccy nieprzerwanie warsztat zjednoczenia trzech zaborów" 33 .

\section{SEJM USTAWODAWCZY W ODBIORZE ZWOLENNIKÓW RUCHU LUDOWEGO}

Rozpatrując problem wizerunku SU wśród elektoratu ugrupowań ruchu ludowego, należy bezwzględnie zgodzić się z tezą Jana Jachymka, który w kontekście działań PSL ,Wyzwolenie” wskazywał, że stronnictwo to od momentu odzyskania niepodległości „rozwinęło agitację za ludowym obliczem Sejmu Ustawodawczego"34. Tezę tę należy uznać za prawdziwą nie tylko w odniesieniu do partii, która w SU stała się drugą siłą polityczną, uzyskując ponad 800 tys. głosów i 57 mandatów, lecz również do naturalnych konkurentów „Wyzwolenia”, czyli PSL „Piast”. W zasadzie oba stronnictwa wpisywały się w retorykę narzuconą przez socjalistycznych publicystów, aczkolwiek - co zrozumiałe w przypadku środowisk reprezentujących ludność wiejską — większy nacisk kładli oni na oddziaływanie na ludowość włościańską niż na robotniczą ${ }^{35}$. Niemniej ludowcom spod znaku PSL „Piast” również zdarzało się nawoływać do głosowania przeciwko ugrupowaniom socjalistycznym ${ }^{36}$. Przy kreowaniu wizerunku Sejmu w okresie przedwyborczym przywódcy stronnictw ludowych na pierwszy

${ }^{30}$ W obronie demokracji parlamentarnej. Mowa towarzysza Daszyńskiego, marszałka Sejmu wygłoszona wczoraj w Sejmie z powodu dziesięciolecia parlamentaryzmu polskiego, „Robotnik” nr 40, 18 II 1929, s. 1.

31 Jak stwierdził M. Niedziałkowski, ,postawiliśmy sobie jedno zadanie zgodne w świadomości Naczelnika Państwa, Rządu Ludowego i CKR PPS: niech spory polskie rozstrzygnie nasz kraj w swobodnym głosowaniu. I dlatego powstał w lutym roku 1919 ze swobodnego głosowania Sejm Ustawodawczy Rzeczpospolitej Polskiej"; vide idem, Niech spory polskie rozstrzygnie nasz kraj w swobodnym głosowaniu, „Robotnik” nr 43, 12 II 1939, s. 3.

32 A. Próchnik, Oblicze polityczne sejmów w Polsce i charakter ich działalności, „Robotnik” nr 43, 12 II 1939, s. 5.

${ }_{33}$ M. Niedziałkowski, Niech spory polskie...; vide etiam K. Czapliński Pierwszy sejm, „Robotnik” nr 43, 12 II 1939, s. 4.

34 J. Jachymek, Myśl polityczna PSL ,Wyzwolenie” 1918-1931, Lublin 1983, s. 86-87.

35 Jak stwierdził jeden z publicystów „Piasta”, „,niech naprawdę ludową będzie Polska Republika, niech ludową będzie konstytuanta, niech naprawdę będzie przez lud i dla ludu — na czele jej postawiony przyszły prezydent. Niezłomna nasza wola zapewni nam to, że «Piast» będzie chłopskim stronnictwem, «Piast» chłopską gazetą a «Piast» polskim prezydentem”; vide O chtopska konstytuantę, „Piast” nr 2, 12 I 1919, s. 3-4.

${ }_{36}$ Rok próby, „Piast” nr 1, 5 I 1919, s. 2. 
plan w działaniach wizerunkowych wysuwali jednak nie tyle ludowość, co antyszlacheckość przyszłego parlamentu ${ }^{37}$.

Nie ulega wątpliwości, że w przededniu rozstrzygnięć wyborczych oba stronnictwa chłopskie wskazywały na niepowtarzalną szansę rozwoju, jaką stworzyło odzyskanie niepodległości. Na pierwszych stronach noworocznego numeru organu PSL „Wyzwolenie” epatowały swoich zwolenników tezą, zgodnie z którą,,czas zdać sobie sprawę z tego, że odpowiedzialność za losy Polaki na naszych barkach spoczywa. [...] My dziś sięgamy po władzę. My chcemy wydźwignąć Polskę z tego dziejowego przełomu. Na nas spadnie błogosławieństwo bądź przekleństwo tych co po nas przyjdą. Z odmętu nędzy i zniszczenia wyrwać chcemy naszą ziemię, z niewolniczego upodlenia oskrobać duszę narodu, ospalstwo i ciemnotę wygrać precz. Ale wcześniej czeka nas walka"38. Dla przywódców obu stronnictw ludowych nie ulegało również wątpliwości, że od stopnia mobilizacji ich własnych szeregów będzie zależało, czy ludowy będzie nie tylko Sejm, ale również cała Rzeczpospolita. Jak wskazywał S. Thugutt, „od tego czy lud się obudzi, czy wyśle właściwych swoich obrońców do Sejmu, zależy na długie lata jego przyszłość, jego szczęście, jego rozwój i los. I iść do wyborów musimy, nie jako bezładny tłum, ale jako Polskie Stronnictwo Ludowe"39. Przywódcy „Wyzwolenia” sekundowali propagandziści „Piasta”. Ze szpalt organu stronnictwa padały znamienne słowa: ,Zbliżają się wybory do konstytuanty. Niechże każdy Polak i każda Polka pamięta o tym, że od składu pierwszego sejmu zależeć będzie wszystko. [...] Musimy do sejmu wybrać ludzi takich, którym nie będzie chodziło o międzynarodowe mrzonki, ale wyłącznie o dobro polskiego państwa"40. Piszący na łamach „Wyzwolenia” postulowali, aby „lud rządził, lud stanowił o podatkach i innych powinnościach, lud orzekał o wojnie i pokoju. Dla chłopa i robotnika polskiego muszą stać wszystkie drogi otworem i do rządu i do Sejmu i na najwyższe miejsce naczelnika państwa, jeśli będzie dość po temu mądry i zacny"41.

Ludowcy — w przeciwieństwie do socjalistów — równolegle do agitacji wyborczej zaczęli kreować jednoznaczny wizerunek Sejmu nie tylko jako najwyższego przedstawiciela suwerena, ale też jako najwyższy autorytet państwa, usuwając rząd na drugi plan. Wspomniany już S. Thugutt stwierdzał m.in.: „Jedynym prawem będzie to co Sejm powie. Ale to co powie musi być święte i niewzruszone. Kto się woli więk-

37 Z łamów organu PSL „Wyzwolenie” padały jednoznaczne stwierdzenia: „Polska szlachecka na zawsze zginęła. To, co w oczach naszych powstaje, będzie i musi być tylko ludową! To grunt, to zasada nasza!”; vide Budujmy Polskę ludowa, „Wyzwolenie” nr 3, 19 I 1919, s. 1.

38 Bracia! Nowy Rok!, ,Wyzwolenie” nr 1, 5 I 1919, s. 1. W miarę zbliżania się terminu wyborów przeciwnik zagrażający ludowości przyszłego Sejmu stawał się coraz wyraźniejszy. Jak pisano na łamach ,Wyzwolenia”, „,narodowi demokraci wszystkich odcieni nie moga, nie powinni być wybierani na posłów do Sejmu ustawodawczego, to trzeba sobie powiedzieć. Każdy głos chłopa, kobiety, robotnika czy robotnicy oraz uczciwego inteligenta dany na ich listę będzie szkodą dla Polski i będzie zdradą ludu, bo będzie wprowadzeniem do Sejmu fałszu i zaprzaństwa. Każdy chłop co odda głos na endecką listę, daje im do ręki kij na siebie i na swoje dzieci”; vide T. Nocznicki, O Sejmie, „Wyzwolenie” nr 3, 19 I 1919, s. 6.

39 S. Thugutt, Nowy ład, ,Wyzwolenie" nr 1, 5 I 1919, s. 2.

40 Rok próby, „Piast” nr 1, 5 I 1919, s. 2.

41 Z czem idzie Polskie Stronnictwo Ludowe na Sejm, ,Wyzwolenie” nr 3, 19 I 1919, s. 4. 
szości sejmu przeciwstawi, ten będzie nie synem Polski, ale wyrodkiem, ten będzie w stosunku do niej zbrodniarzem-matkobójcą. Z zamętu który się dziś w kraju rozpasał, z bagna fałszu i nienawiści, w jakiem Ojczyzna nasza tonie, nie wyprowadzi jej nic tylko wola Narodu, wyrażona na Sejmie. Kto więc Sejmowi przeszkadza się zebrać, kto woli jego nie uzna, ten nie chce Polski i tego trzeba stawiać za prawem i z kraju precz gonić"42. Niemniej jednak spośród środowisk centrolewicowych to ludowcy spod znaku „Wyzwolenia” kreowali wizerunek Sejmu oparty na realiach, a nie na nadziejach i oczekiwaniach. Jak wskazywał Włodzimierz Wakar, „trudności leżą przed Sejmem ogromne [...] walczyć z trudnościami i zaradzać brakom trzeba nie tylko przez Sejm i w Sejmie”. Dla członków PSL „Wyzwolenie” Sejm stanowił przede wszystkim zbiorowość, która została powołana, aby wyczuć ,,potrzebę i kierunek społecznego rozwoju narodu i na tej swoistej sile opierać działanie"43.

Niezwykle istotnym elementem kształtowania wizerunku pierwszego Sejmu przez przedstawicieli stronnictw ludowych był dzień otwarcia Izby. Polityczni reprezentanci warstwy chłopskiej dokładali wszelkich starań, aby zaakcentować historyczny moment wejścia chłopskiej reprezentacji do parlamentu, a nawet aby wytworzyć wizerunek SU jako „,chłopskiego Sejmu”. Chłopscy posłowie podkreślali swoją odrębność na wszelkie sposoby, przede wszystkim strojem. Jak relacjonował Maciej Rataj, późniejszy marszałek Sejmu, on sam zajmował miejsce ,pośród publiczności, której stroje odbijały się od kożuchów, pasiastych ubrań łowickich, białych sukman itp. chłopskich posłów, którzy w swej masie narzucali się oku" ${ }^{4}$. Staraniom polityków sekundowała prasa. Organy stronnictw ludowych manifestacyjnie podkreślały doniosłość chwili. Jak wskazywali m.in. publicyści Piasta, „Dożyliśmy dnia, który pozostanie w pamięci narodu na wieki. W stolicy polski, w Warszawie, zebrał się dnia 9 lutego 1919 r. pierwszy Sejm zmartwychwstałej Ojczyzny naszej, Polski. Pierwszy Sejm, który ma wybudować fundamenty pod gmach państwowy Polski, ma urządzić państwo jako jego gospodarz, wybrany wolą narodu. Dnia tego oczekiwały pokolenia, krwią sącząc drogę narodu do wolności, oczekiwali wieszcze nasi, każde serce polskie niespodlone niewolą. I wreszcie ten dzień wielki przyszedł" 45 . W ton narzucony przez publicystów „Piasta” wpisywali się propagandziści „Wyzwolenia”, którzy starali się podkreślić, że na przedstawicielstwo chłopskie spadły szczególne zadania „w tym pierwszym po wielu latach Sejmie polskim, najpierwszym Sejmie polskim, w którym zasiądą chłopi. I to jeszcze

42 S. Thugutt, Nowy lad...

43 W. Wakar, O jutro, ,Wyzwolenie” nr 3, 19 I 1919, s. 6.

44 M. Rataj, Pamiętniki 1918-1927, Warszawa 1965, s. 37.

45 Uderzając w pompatyczne tony, „Piastowcy” konsekwentnie budowali wizerunek SU, wskazując, że „trzeba sobie zdać sprawę z tego i uświadomić sobie należycie, że Sejm Polski Konstytucyjny nie jest sejmem zwyczajnym. Niewątpliwie posłowie starać się będą o sprawy swoich powiatów, swoich okręgów wyborczych, ale czynić to będą tylko w wypadkach ogólnych bo całą swą uwagę skierować muszą na ułożenie konstytucyi, która jest jednakowo ważna dla wszystkich obywateli. Od tego jaka będzie ta konstytucyja zależeć będzie los ludu, los wszystkich warstw narodu, los całego państwa. Wszystkie sprawy drobne zejść więc muszą na plan drugi wobec tej wielkiej pracy, jaką jest ułożenie konstytucyi. Oby wszechmogący udzielił temu Sejmowi sił i wytrwania, aby natchnął posłów mądrością i poświęceniem aby praca ich wydała owoce dla Ojczyzny najlepsze”; vide Pierwszy Sejm polski otwarty, „Piast” nr 7, 10 II 1919, s. 1. 
w takim Sejmie, który budować ma Polskę, jako wolna, zjednoczoną Rzeczpospolitą Ludowa” ${ }^{46}$. Wizerunek , ,chłopskiego Sejmu” miały utrwalić relacje z otwarcia konstytuanty, w których skupiano uwagę na chłopskich reprezentantach. Na łamach „Wyzwolenia” podkreślano, że „w poniedziałek 10-go lutego rozpoczął obrady pierwszy ludowy Sejm zmartwychwstałej do nowego życia Polskiej Rzeczypospolitej. Stało się wydarzenie ważne, pamiętne. Rozpoczyna się nowy okres historii narodu polskiego. Rozpoczynają się dzieje Polski Ludowej. Miljony i miljony ludu polskiego z upragnieniem wyczekiwały tej chwili. Sejm ma obmyślać i ustanowić sprawiedliwe prawa, ma usunać wiele, wiele krzywd. Niesłychanie wielka odpowiedzialność ciąży na wszystkich posłach, których lud wybrał do Sejmu. Wśród tych posłów jest gromada nasza: 57 posłów należących do Polskiego Stronnictwa Ludowego. Przyłączą się do niej na pewno niektórzy posłowie z Małopolski. Cały lud przekona się wkrótce, że w tych posłach ma oddanych sobie i wiernych obrońców; że ci posłowie nasi, należący do Polskiego Stronnictwa Ludowego nie zawiodą pokładanych w nich nadziei" ${ }^{\prime 4}$.

W przypadku stronnictw ludowych należy zwrócić uwagę na jeszcze jeden czynnik, który wpływał na wizerunek SU zarówno w okresie jego tworzenia, jak i funkcjonowania. Spory wpływ na odbiór Sejmu przez potencjalnych zwolenników miała rywalizacja o „rząd dusz” na obszarach wiejskich. Podjęte na poziomie deklaratywnym hasło jedności chłopskiej nie doczekało się realizacji w pierwszym polskim Sejmie ${ }^{48}$. Wzajemne obwinianie się stronnictw chłopskich o działanie na szkodę włościan, przy jednoczesnej artykulacji identycznych celów (dążenia do reformy rolnej) ${ }^{49}$ pogłębiało zamęt i nie sprzyjało kreowaniu pozytywnego obrazu przedstawicielstwa narodowego.

${ }^{46}$ T. Nocznicki, Przed nowa era, „Wyzwolenie” nr 6, 9 II 1919, s. 1. Ponadto zwycięskie „Wyzwolenie" na pierwszych stronach swego organu zwracało się do swych zwolenników z patetycznym wezwaniem: „Bracia! Gdy Wy czytać będziecie te słowa - w Warszawie zbierać się będzie pierwszy Sejm wyzwolonej Polski. Nasi przedstawiciele i wybrańcy staną w gromadzie, aby wspólnie podjąć ciężki trud około ustalenia losów Ojczyzny. Oczy nasze i myśli całego ogółu polskiego zwrócone są dziś przy zgromadzeniu, które ma być wyrazem woli naszej, które w imieniu Polski ma powiedzieć całemu światu: Jestem i chcę żyć [...]. Chcę żyć jako wolna republika ludowa, jako państwo oparte na sprawiedliwości i równowadze społecznej, jako kraj rozwijający swobodnie wszystkie swoje zasoby; jako naród mocno na swej ziemi zakorzeniony, co nie chce zdobyczy, ale swego broni, pokój miłuje, zgody z sąsiadami szuka; jako społeczność wolnych i wolność miłujących obywateli”, „Wyzwolenie” nr 6, 9 II 1919, s. 1.

47 Otwarcie sejmu, ,Wyzwolenie” nr 7, 19 I 1919, s. 2.

${ }^{48} \mathrm{Z}$ nawoływaniem do jedności tuż po ukonstytuowaniu się klubu parlamentarnego PSL wystapił T. Dąbal: ,,jeden jest interes chłopski, jedna dola i niedola chłopska, istnieć też winno jedno wielkie i potężne polskie stronnictwo postępowe, a takie musi być PSL, a wtedy my, lud pracujący rządzić będziemy i żaden wróg nas nie zmoże. Dziś skoro zebrał się ten sejm w którym zasiada większość posłów ludowych, nie powinniśmy tej wielkiej chwili zmarnować! Musimy rzucić na bok ambicje jednostek, zapomnijmy drobnych uraz i usterek, wszyscy posłowie ludowcy musimy zjednoczyć się do walki ze wstecznictwem. Dlatego kochani bracia chłopi, wezwijcie wszystkich posłów ludowych, niechaj nie służą pańskim interesom, niech porzucą osobiste ambicje, niechaj złączą się razem, a wtedy Sejm będzie sejmem ludowym i Sejm ten błogosławić będą liczne pokolenia Ludu za jego pracę. Biada jednak tym posłom, którzy daliby się panom opętać i rozbijaliby jedność chłopska, udaremniliby zjednoczenie posłów ludowych i ludu w jedno potężne PSL. Tych posłów bracia piętnujcie jako zdrajców sprawy ludowej"; vide T. Dąbal, Jedność chtopska, „Wyzwolenie” nr 7, 19 I 1919, s. 5.

49 Teraz albo nigdy!, „Piast” nr 2, 12 I 1919, s. 1-2; Precz ze zdrajca sprawy ludowej, „Piast” nr 2, 12 I 1919, s. 4; Klub poselski PSL, „Wyzwolenie” nr 7, 19 I 1919, s. 4. 
Dodatkowo dezorientację elektoratu pogłębiały spory personalne, sięgające korzeniami okresu sprzed I wojny światowej i nasilające się od wyborów do SU. Te spory w społecznym odbiorze nie były traktowane jako konfrontacja odmiennych wizji państwa, ale jako pospolite kłótnie. Wrażenie to pogłębiała niezdolność do załatwienia najbardziej dla chłopów palącej kwestii, czyli zaspokojenia ich „głodu ziemi”. To powodowało, że mieszkańcy wsi, jeśli w ogóle przyjmowali do wiadomości istnienie SU, w znakomitej większości nie odczuwali korzyści płynących z jego funkcjonowania, a tym samym nie mieli powodów, aby obdarzać ten Sejm jakimikolwiek pozytywnymi uczuciami.

\section{WIZERUNEK SEJMU USTAWODAWCZEGO WŚRÓD ZWOLENNIKÓW POLSKIEJ PRAWICY}

Odczucia przedstawicieli prawicy i ich elektoratu trafnie odczytał Juliusz Zdanowski, który napisał: „pierwszy sejm. Tyle myśli marzeń i uczuć. I mimo całą wielkość chwili kontrast między tą szarą rzeszą sejmu, przeważnie z chłopów złożonego, nazwisk złączonych z drobnymi kompromisami mocarstw wiedeńskich itp. a barwnym śnionym wspomnieniem matejkowskich typów wielkiego sejmu i prawdziwie wielkich postaci — jest tak wielki, że człowiek w epokowość chwili obecnej wsłuchać się i wczuć nie może"50.

Nie zaskakiwał fakt, że jeszcze przed zwołaniem SU działacze i publicyści związani z narodową demokracją podjęli wysiłki zmierzające do nadania pierwszemu odrodzonemu parlamentowi wyraźnie narodowego charakteru. Świadomi doniosłości chwili wskazywali oni, że ,,po raz pierwszy cały naród bez żadnej różnicy na równych prawach powołano do wybrania posłów do pierwszego Sejmu odradzającej się Polski. Ten Sejm Konstytucyjny czyli jak go niezbyt prawidłowo nazwany Ustawodawczy, zdecyduje o tem jaka będzie przyszła Polska — wielka, potężna, szczęśliwa czy też słaba mała i uboga. Odbudowywanie wolnej Ojczyzny po wielowiekowej niewoli i wśród czyhających na naszą zgubę wrogów, jest zadaniem bardzo trudnym. Podołać temu zadaniu można tylko wielkim napięciem sił całego narodu, skupieniem wysiłków wszystkich warstw i tylko przy życzliwej pomocy tych państw, które pokonały najgorszych naszych wrogów i przed paroma dniami właśnie rozpoczęły obrady nad przyszłym urządzeniem świata, nad granicami, jakie każdemu narodowi ma wytknąć. Jeżeli w tym pierwszym Sejmie, większość stanowić będą ludzie, którzy tak rozumieją potrzeby chwili obecnej, będziemy mieli Polskę zjednoczoną, z nieuszczuplonymi granicami, z wielkimi kopalniami, z własnym morzem, a więc Polskę, która nie będzie zależna od nikogo [...] Program narodowy, stawiający na pierwszym miejscu wspólne interesy wszystkich, zapewnia zarazem każdej warstwie rozwój i pomyślność. Tylko wolne i silne państwo uchronić może swą ludność od wyzysku obcych, tam tylko dostatnim może być chłop i robotnik, gdzie się rozwija rolnictwo i przemysł"51. Publicyści obozu narodowego jako jedyni próbowali kreować wizerunek SU jako kontynuatora Sejmu Czteroletniego. Podkreślając wagę i znaczenie, a przede wszystkim

\footnotetext{
${ }^{50}$ Dziennik Juliusza Zdanowskiego, t. II: 15 X 1918-23 VI 1919, Szczecin 2013, s. 137-138.

51 Przed wyborami, „Gazeta Warszawska” nr 21, 22 I 1919, s. 3.
} 
tożsamość zadań, stojących zarówno przed Sejmem Wielkim, jak i przed SU, mniej lub bardziej świadomie ustawiali się w roli spadkobierców twórców Konstytucji 3 maja i obozu patriotycznego $0^{52}$.

Niemniej należy podkreślić, że zanim doszło do zwołania przedstawicielstwa narodowego środowisko endeckie zrobiło wiele - często nieświadomie - aby autorytet Sejmu możliwie najbardziej obniżyć. Co charakterystyczne, wizerunek polskiego parlamentaryzmu kształtowany był niejako w kontrze do wysiłków środowisk ówcześnie rządzących, tworzących rząd Jędrzeja Moraczewskiego, względnie zbliżonych do Naczelnika Państwa. Do stałych zabiegów publicystycznych należało bezpośrednie krytykowanie sprawujących władzę ugrupowań, a nawet jednoznacznie formułowanych przez nie zapowiedzi zwołania Sejmu. Deklaracje te miały służyć wyłącznie utrzymaniu władzy przez stronnictwa ludowe, którym nie chodziło o stworzenie ciała ustawodawczego, regulującego za pomocą demokratycznych mechanizmów polski system polityczny zdolny do wypracowania ram prawnych funkcjonowania państwa ${ }^{53}$. Budowaniu pozytywnego wizerunku Sejmu nie sprzyjały również stwierdzenia o braku zdolności sił lewicowych do zgodnego współdziałania w imię dobra powszechne$\mathrm{go}^{54}$ czy wręcz negowanie ich patriotyzmu i zdolności oglądu potrzeb młodego państwa $^{55}$. Zgodzie narodowej nie służyły również nawoływania do stworzenia Sejmu jednolitego narodowościowo oraz odmawianie prawa wyboru swoich reprezentantów mniejszościom narodowym, przede wszystkim Żydom. Przyszły, nie do końca pozytywny wizerunek Sejmu był też kształtowany na poziomie haseł wyborczych, które ujawniały zasadniczy spór między narodowymi demokratami a zwolennikami programu Naczelnika Państwa ${ }^{56}$. Co charakterystyczne, retoryka obozu narodowego nie zmieniła się nawet w momencie, gdy znane już były wstępne wyniki wyborów do konsty-

52 Sejm konstytucyjny, „Gazeta Warszawska” nr 39, 9 II 1919, s. 1.

53 Vide inter aliam Wynurzenia p. Thugutta, „Gazeta Warszawska” nr 7, 8 I 1919, s. 1-2.

${ }^{54}$ Kultura polityczna, „Gazeta Warszawska” nr 8, 9 I 1919, s. 1; Odmowa PPS, „Gazeta Warszawska” nr 9, 10 I 1919, s. 1.

${ }_{55}$ Jak stwierdzał jeden z publicystów środowiska narodowej demokracji już po powołaniu gabinetu I. Paderewskiego, ,powtórzenie rządów socjalistycznych byłoby klęską dla wszystkich, nie wyłączając robotników, których chcą niby specjalnie uszczęśliwić. Powrotu tych rządów pragnać mogą tylko wrogowie nasi lub zaślepieńcy. Sąjednak listy mniej wyraźne, noszące pięknie brzmiące nazwy, w których tylko bliższe wejrzenie odkrywa zakapturzonych socjalistów, tych co albo wchodzili do rządu p. Moraczewskiego, albo gorliwie go popierali. W ich liczbie znajdujemy nazwiska znane skądinąd i zasłużone. Będziemy zawsze chętnie i z pożytkiem czytali powieści Sieroszewskiego np., ale jako polityk byłby on w sejmie tylko szkodnikiem. Nie możemy przecież zapomnieć, że Sieroszewski razem z pp. Thuguttem i Moraczewskim urządzali zamach w Lublinie, który dał początek rządów socjalistów u nas. Są wreszcie listy złożone z samych «aktywistów», to jest z tych co aż do rozgromu Niemiec przez koalicję trzymali z okupantem, co kazali nam łączyć całą naszą przyszłość z Hohenzollernami lub Habsburgami i głosili konieczność wyrzeczenia się Śląska, Wielkopolski i Gdańska. I między nimi są ludzie, którzy pobłądzili w dobrej wierze, którzy z czasem z pożytkiem będą mogli dla Ojczyzny pracować, ale nie powinno być dla nich miejsca w pierwszym polskim Sejmie”; vide Przed wyborami, „Gazeta Warszawska” nr 21, 22 I 1919, s. 3.

56 Spór między zwolennikami programu inkorporacyjnego a federacyjnego na poziomie wizerunkowym obrazowało hasło: „Kto chce Polski zjednoczonej i silnej, kto pragnie skutecznej obrony przed zaborczem prusactwem, bolszewizmem i hajdamaczyzną, komu drogie jest hasło «Bóg i Ojczyzna» niech głosuje na listę nr 10”; „Gazeta Warszawska” nr 23, 24 I 1919, s. 2. 
tuanty ${ }^{57}$. Budowaniu pozytywnego wizerunku nie służyły zapowiedzi o konieczności uregulowania przez nowy Sejm „najżywotniejszych i najbardziej palących podstaw” funkcjonowania armii ${ }^{58}$. Tego typu stwierdzenia uznawano za środki podejmowane w celu odsunięcia Piłsudskiego od decyzji politycznych nie tylko w kwestiach wojskowych, ale - co istotniejsze w warunkach kształtowania się granic odrodzonej Rzeczypospolitej — także w zakresie realizacji jego wizji geopolitycznej. Do niewyrobionego politycznie odbiorcy propagandowych działań endecji mogły trafiać hasła dotyczące potrzeby dokooptowania do SU posłów dzielnicy pruskiej ${ }^{59}$. Niemniej także one miały drugie dno, czyli chęć wzmocnienia nieprzekonującej większości osiągniętej w wyborach. Dodatkowo działanie to pociagało za sobą kolejny kryzys wizerunkowy. Politykami dokooptowanymi do składu Sejmu byli bowiem członkowie i osoby zbliżone ideowo do ruchu narodowego, zasiadające uprzednio w parlamencie w Berlinie. Fakt ten sprawiał, że przeciwnikom politycznym prawicy stosunkowo łatwo przychodziło wskazywanie, że znaczna liczba posłów nie posiada dostatecznej legitymacji do zasiadania w SU.

Należy zauważyć, że w momencie ukonstytuowania się Sejmu również w środowisku narodowym i wśród zwolenników wizji państwa przedstawianych przez obóz Dmowskiego dominowało przeświadczenie o doniosłości tej chwili. W nielicznych publikacjach dawano wyraz dumie z powodu zwołania SU. Jak wskazywał jeden z publicystów związanych z obozem narodowym, ,Z dumą podnosić możemy, że Polska jest pierwszem dźwigającem się z nicości państwem, które choć pozostawione własnym siłom, chociaż nie mające jeszcze nie tylko zabezpieczonych, lecz nawet określonych granic, chociaż rabowane, niszczone, rujnowane przez najeźdźców, potrafiło na drodze najdemokratyczniejszych wyborów wytworzyć normalne przedstawicielstwo narodowe. Jest to wobec świata najwymowniejsze świadectwo naszej tradycji, naszych zdolności, naszego ustroju prawnego, których nie zdołały wytępić upadlająca niewola, ani podciąć szerząca się dookoła anarchia rozkładu"60. Niemniej środowisko narodowe nie ukrywało, że SU to twór tymczasowy, służący jedynie wykreowaniu — wobec mocarstw obradujących w Paryżu — wizerunku ,silnej, zwartej i zgodnej Polski" ${ }^{61}$.

V. KONKLUZJE

Wizerunek SU stwarzany od przełomu 1918 i 1919 r. oscylował między dwoma — jak się później okazało — nieprzystającymi do siebie tendencjami. Z jednej strony funkcjonował jako pokłosie ogólnonarodowej euforii i radości z powodu odzyskania

57 Po wyborach, „Gazeta Warszawska” nr 27, 29 I 1919, s. 1.

58 Sejm i wojsko, „Gazeta Warszawska” nr 29, 30 I 1919, s. 1-2.

59 Jak wskazywał publicysta prawicy, ,Jest rzeczą bądź co bądź pewną, że w Sejmie konstytucyjnym, reprezentowane być winny wszystkie dzielnice polskie i że wszystkie one winny wziąć udział w rozstrzygnięciu losów całego Narodu polskiego. Tego domaga się zgodnie głos powszechny"; vide O Sejm całej Polski, „Gazeta Warszawska” nr 30, 31 I 1919, s. 1.

"60 Sejm konstytucyjny, „Gazeta Warszawska” nr 39, 9 II 1919, s. 1.

${ }^{61}$ Sytuacja sejmowa, „Kurier Poznański” nr 34, 11 II 1919, s. 1. 
utraconej przed ponad 100 laty wolności ${ }^{62}$. Z drugiej zaś obraz SU stanowił pochodną nadziei zarówno tych, którzy chcieli zdobyć (i de facto zdobyli) wpływ na bieg spraw w państwie i ich zwolenników, jak i zwykłych obywateli.

$\mathrm{Na}$ wizerunku Izby bezpośrednio po wyborach zaważyła w znacznej mierze kampania wyborcza, która była czynnikiem stymulującym społeczny odbiór Sejmu bezpośrednio po jego ukonstytuowaniu się. Dla zwolenników lewicy wybrany w styczniu 1919 r. parlament był za mało ludowy. Natomiast dla prawicy narodowej, zwłaszcza kiedy w Izbie zasiedli również przedstawiciele mniejszości, SU był postrzegany jako nie dość odpowiadający narodowym interesom Polaków. Rozczarowani byli przede wszystkim ci, których reprezentanci nie weszli do Sejmu, czyli przedstawiciele radykalnej inteligencji. Choć minorowe odczucia nie były w stanie zniwelować doniosłości chwili, niemniej rozczarowanie wynikami wyborów wpływało na społeczny odbiór wskrzeszonego parlamentu ${ }^{63}$. W zasadniczym stopniu wizerunek ten został utrwalony przez efekt prac Sejmu, czyli kompromisową konstytucję z 1921 r., której przepisy nie do końca zadowalały twórców ustawy zasadniczej. Postrzeganie Sejmu zasadniczo zmieniło się po wypadkach majowych 1926 r. Wówczas ortodoksyjni zwolennicy stronnictw, którym wyraźnie ograniczono wpływ na bieg spraw w państwie, radykalnie przewartościowali swoje poglądy, wypierając poczucie rozczarowania i tworząc w zbiorowej pamięci obraz wyidealizowany. Upadek II RP sprawił, że wizerunek SU, jako niemal idealnego, oczekiwanego, pierwszego Sejmu Niepodległej, ulegał wzmocnieniu, w miarę jak wzrastało uczucie nostalgii za utraconą ojczyzną i zaprzepaszczonymi szansami.

${ }^{62}$ Znalazło to odzwierciedlenie w pamiętnikach A. Szczerbińskiej. Jak zapisała późniejsza małżonka Naczelnika Państwa, ,Zebranie się pierwszego sejmu przygotowane ogromnym wysiłkiem rządu Moraczewskiego nastapiło o trzeciej po południu 10 lutego 1919 roku. [...] Cała Warszawa świętowała ten dzień uroczyście. Choragwie powiewały na wszystkich domach, tłumy bawiły się, śmiano się, śpiewano pieśni patriotyczne, panował powszechny entuzjazm. W dniu tym uświadomiono sobie szczególnie silnie, że nareszcie po tylu latach niewoli Polska była wolna! Galerie dla publiczności zapewnione były na godzinę przed otwarciem sejmu. Tysiące błagały o miejsca. Rząd był w komplecie; zasiadł na podniesieniu przybranym sztandarami. W pewnej chwili przed otwarciem doznałam uczucia, że wśród zebranych są ci, którzy od pokoleń walczyli za tę wymarzoną chwilę otwarcia polskiego sejmu i wolną Polskę; zdawało mi się, że jesteśmy złączeni z tymi patriotami zapomnianymi, zaginionymi, zabitymi w powstaniach, zamęczonymi w śniegach Syberii, a tak gorąco pragnącymi zrealizowania swych snów"; vide A. Piłsudska, Wspomnienia, Warszawa 1989, s. 180.

${ }^{63}$ Jak zapisała w swym dzienniku M. Dąbrowska 12 lutego 1919 r., ,W niedzielę było otwarcie sejmu. Chodziłyśmy z Marysią i Stellą i widziałyśmy wszystko sprzed katedry, z okien ministerstwa i wreszcie sprzed gmachu sejmu". Niemniej tuż po ogłoszeniu wyników wyborów postrzegała wydarzenia polityczne zgoła inaczej: „Lista dziesiąta uzyskała, na ile widać z obliczonych już głosów, olbrzymią większość. Po niej najwięcej głosowało na PPS, potem na żydowskie, na szczęście też rozstrzelone, potem znikomą ilość głosów otrzymały mniejszości. Biorę rozbrat ze wszystkimi inteligencko-postępowymi kierunkami. Co za małe poczucie odpowiedzialności wobec narodu. Wystawić około dziewięciu list, nie będąc rzeczywiście pewnymi mandatów. Jakby umyślne polskich głosów gubienie"; vide M. Dąbrowska, Dzienniki 1914-1945, t. 1, Warszawa 1998, s. 221-222. 
BIBLIOGRAFIA

ŹRÓDŁA

Dokumenty publikowane

Powstanie II Rzeczypospolitej. Wybór dokumentów 1866-1925, red. H. Janowska, T. Jędruszczak, Ludowa Spółdzielnia Wydawnicza, Warszawa 1981.

Pr a s a

„Robotnik” 1919-1939.

„Piast” 1919.

„Wyzwolenie” 1919.

„Gazeta Warszawska” 1919-1939.

Pamięt niki, w s pomnienia

Dąbrowska M., Dzienniki 1914-1945, t. 1, Czytelnik, Warszawa 1998.

Dziennik Juliusza Zdanowskiego, t. II: 15 X 1918-23 VI 1919, Wydawnictwo Naukowe Wydziału Humanistycznego Uniwersytetu Szczecińskiego, Szczecin 2013.

Piłsudska A., Wspomnienia, Instytut Prasy i Wydawnictw „Novum”, Warszawa 1989.

Piłsudski J., Pisma zbiorowe. Wydanie prac dotychczas drukiem ogłoszonych, t. V, Instytut J. Piłsudskiego, Warszawa 1937.

Opracowani e

Cienciałła A., 11 listopada 1918 roku. Józef Piłsudski i niepodległość Polski, „Przegląd Polski” nr 45, 8 XI 2002. 



\title{
WYBORY DO SEJMU USTAWODAWCZEGO W 1919 ROKU. RYSY KAMPANII
}

\author{
ELECTIONS TO THE LEGISLATIVE SEJM IN 1919. \\ AN OUTLINE OF THE CAMPAIGN
}

\begin{abstract}
The article presents the elections to the Legislative Sejm in 1919, along with the rules and conditions of the election. It is focused on the course the election campaign. Political formations taking part in the competition for Deputies' mandates are discussed, as well as their consolidation into two main political camps: the centre-right and the left; electoral strategies and spheres of competition are also analysed. Furthermore, the roles of rallies and the press in the electoral campaign, as well as the substantial content of the competition are discussed. The role of women in the campaign is outlined. Election results are presented, as well as their influence on the efficient functioning of the Legislative Sejm.
\end{abstract}

Słowa kluczowe: centroprawica, formacja, lewica, listy wyborcze, ordynacja wyborcza, prasa, rywalizacja, wiec, strategia wyborcza, związek wyborczy

Key words: central right wing, formation, left wing, electoral register, electoral law, press, competition, rally, election strategy, electoral union

* Dr hab. Zdzisław Ilski, Politechnika Wrocławska, Studium Nauk Humanistycznych i Społecznych, zdzislaw.ilski@pwr.edu.pl

\section{WPROWADZENIE}

R ieg wydarzeń podczas I wojny światowej rozwiną przekonanie o wyzwo-

D leniu Polski. Ugruntowało je wydanie Aktu 5 listopada 1916 r., w którym władcy Niemiec i Austro-Węgier ogłosili, że z odebranych Rosji ziem polskich utworzą samodzielne państwo polskie z dziedziczną monarchią i konstytucyjnym ustrojem $^{1}$. Polacy oczekiwali, że za tą deklaracją pójdą konkretne działania kreujące polską państwowość, w tym przeprowadzone zostaną demokratyczne wybory do sejmu konstytucyjnego. Nie zdołali jednak przełamać oporu państw centralnych, które przekładały to na okres powojenny. Zwołanie konstytuanty stało się realnie możliwe późną jesienią 1918 r. , kiedy restytucji państwa podjęli się sami Polacy. 28 listopada 1918 r. Tymczasowy Naczelnik Państwa Józef Piłsudski wydał dwa dekrety w tej sprawie: dekret o ordynacji wyborczej do Sejmu Ustawodawczego ${ }^{2}$ oraz dekret o wyborach do Sejmu Ustawodawczego ${ }^{3}$, zarządzając ich przeprowadzenie 26 stycznia

${ }^{1}$ Proklamacja z dnia 5 listopada 1916 r., [w:] Historia państwa i prawa Polski. Źródła, wyb. F. Połomski, P. Jurek, Wrocław 1997, s. 303. O genezie i znaczeniu Aktu 5 listopada 1916 r. vide m.in. M. Seyda, Polska na przełomie dziejów. Fakty i dokumenty, Poznań-Warszawa-Wilno-Lublin 1927, s. 327-524; J. Pajewski, Odbudowa państwa polskiego 1914-1918, Warszawa 1978, s. 116-152.

${ }^{2}$ Dekret Naczelnika Państwa z dnia 28 listopada 1918 r. o ordynacji wyborczej do Sejmu Ustawodawczego, „Dziennik Praw Państwa Polskiego” [dalej: Dz.P.P.P.] z 1918 r. nr 18, poz. 46.

${ }_{3}$ Dekret Naczelnika Państwa z dnia 28 listopada 1918 r. o wyborach do Sejmu Ustawodawczego, Dz.P.P.P. z 1918 r. nr 18, poz. 47. 
1919 r. W artykule przeanalizowano wybory do Sejmu Ustawodawczego [dalej: SU]. Kwestie dotyczące ordynacji wyborczej i wyników wyborów do SU są znane, zostały więc tylko ogólnie przypomniane ${ }^{4}$. Uwagę skupiono głównie na kampanii wyborczej, czyli tej fazie procesu wyborczego, która trwała od ogłoszenia wspomnianych dekretów do dnia głosowania. W ramach tego zarysowano obraz kampanii, wskazano konfigurację sił wstępujących w szranki wyborcze, odsłonięto areny, pola i strategie ich rywalizacji, a także omówiono rolę kobiet i znaczenie komunikacji w kampanii wyborczej.

\section{REGULY I WARUNKI}

Zgodnie z postanowieniami ordynacji wybory do SU miały być powszechne. Czynne i bierne prawo wyborcze uzyskali wszyscy obywatele — bez różnicy płci — którzy ukończyli 21 lat. Prawa wybierania nie mieli tylko wojskowi w służbie czynnej i osoby pozbawione praw obywatelskich. Instytucje państwowe były zobowiązane utworzyć spisy wyborców. Wybory miały być też równe, bezpośrednie, z tajnym głosowaniem. Prawo zgłaszania kandydatów na posłów miała grupa 50 wyborców w danym okręgu, a zarejestrowane listy kandydatów mogły tworzyć związek wyborczy. Samo głosowanie miało polegać na wskazaniu numeru listy kandydatów popieranej przez wyborcę. Wybory przeprowadzono zgodnie z formuła proporcjonalna, realizowaną w okręgach wielomandatowych. Na obszarze byłego Królestwa Polskiego, Kresów Wschodnich oraz zaborów austriackiego i pruskiego utworzono 71 nierównych wielomandatowych okręgów wyborczych, liczących od 3 do 16 mandatów (Warszawa), przy czym w większości okręgów miano wybierać od czterech do dziewięciu posłów. Podziału mandatów miano dokonać metodą d'Hondta. Zastosowanie tej metody obliczeniowej wynikało z dodatku nr 5 do ordynacji, zatytułowanego „Szczegóły obliczeń głosowania"s. W wydanym również 28 listopada $1918 \mathrm{r}$. dekrecie o wyborach do SU ustanowiono natomiast, że wybory zostaną przeprowadzone tylko w 46 okręgach dawnego zaboru rosyjskiego i austriackiego wraz z ziemią cieszyńską. Przedstawiciele Kresów Wschodnich i zaboru pruskiego mieli zostać wyłonieni później. Z obszaru Galicji Wschodniej do SU miało wejść 30 dotychczasowych posłów do parlamentu austriackiego, a ponieważ dwóch z nich zmarło, to wybory miały zostać przeprowadzone także w dwóch jednomandatowych okręgach wyborczych we Lwowie (okręgi V i VII) ${ }^{6}$.

Nie kończyło to procedury legislacyjnej i w przepisach regulujących przeprowadzenie wyborów do SU nastapiły dalsze zmiany. Dekretem z 26 grudnia 1918 r. zmieniono przepis ordynacji o kartach do głosowania ${ }^{7}$. Był to efekt krytyki ze strony so-

4 Vide m.in. K. Kacperski, System wyborczy do Sejmu i Senatu u progu Drugiej Rzeczypospolitej, Warszawa 2007, s. 71-142; Z. Ilski, Formula wyborcza u progu niepodległej Polski (do 1922 r.), Toruń 2013, s. 444-459.

5 Dekret Naczelnika Państwa z dnia 28 listopada 1918 r. o ordynacji...; Z. Ilski, op. cit., s. 447.

${ }^{6}$ Dekret Naczelnika Państwa z dnia 28 listopada 1918 r. o wyborach...

7 Dekret Naczelnika Państwa z dnia 26 grudnia 1918 r. o zmianach w ordynacji wyborczej do Sejmu Ustawodawczego, Dz.P.P.P. z 1918 r. nr 21, poz. 74. 
cjalistów i narodowych demokratów, odnoszącej się do pierwotnego zapisu wskazującego, że wyborca, aby oddać głos, powinien wcześniej kupić urzędową kartę do głosowania (za 5 fenigów/10 halerzy). Według „Robotnika”, rozwiązanie to było formą uprzywilejowania ,stronnictw burżuazyjnych”; do krytyki przyłączyła się też „Gazeta Warszawska"8. Interwencja była skuteczna i - zgodnie z nową regulacja — każdy wyborca mógł przynieść do lokalu wyborczego własną kartkę z zaznaczonym na niej numerem listy, na którą oddawał swój głos. Socjaliści podnosili również, że na urzędowych listach wyborców nie ma obywateli powracających do Polski. Skutkowało to wydaniem 11 stycznia 1919 r. dekretu nadającego prawa wyborcze obywatelom, którzy powrócili do kraju po 5 grudnia 1918 r. ${ }^{9}$ Natomiast 14 stycznia 1919 r. ukazały się jeszcze dekrety o przeprowadzeniu wyborów do SU w okręgu nr 2 (powiaty suwalski, sejneński i augustowski) 16 lutego, a w okręgu nr 20 (powiaty bialski, janowski, radzyński i włodawski) 9 marca 1919 r.; w obu przypadkach ,stan okupacyjny uniemożliwił rozpoczęcie we właściwym czasie prac przedwyborczych"10. Po wyborach 26 stycznia 1919 r. wprowadzono kolejne zmiany w prawie wyborczym.

Przy analizowaniu kampanii wyborczej do SU niezbędne jest odniesienie się do sytuacji politycznej odradzającej się Polski. Elekcję przeprowadzano w niezwykle trudnych warunkach, przesłaniających radość z odzyskiwanej niepodległości. W trakcie kampanii zagrożone było bezpieczeństwo wewnętrzne Polski. Młode państwo znalazło się między dwoma silnie promieniującymi ogniskami rewolucyjnymi: rosyjskim, aktywnym już od 1917 r., i niemieckim, rozwijanym niemal równolegle z restytuowaniem państwa polskiego. Recepcji haseł rewolucyjnych na ziemiach polskich sprzyjały zjawiska wynikające z wojny i rozkładu państw zaborczych: bezrobocia, kryzysu aprowizacyjnego, bandytyzmu, paskarstwa, grasowania dezerterów itp. Emanacja wpływów rewolucyjnych zaznaczała się w różny sposób. W Królestwie przybierała formę rozlicznych akcji protestacyjnych i strajkowych, widocznych w zwartych skupiskach robotniczych Warszawy, Łodzi czy Zagłębia Dąbrowskiego, ale też prowadzonych przez robotników folwarcznych. Wyrażała się ona skłonnością do tworzenia struktur parapaństwowych — rad robotniczych, milicji ludowych, Czerwonej Gwardii — dublujących właściwe organy państwa bądź usiłujących je zastapić. Proces rewolucyjny był podsycany przez powstałą w grudniu 1918 r. Komunistyczną Partię Robotniczą Polski [dalej: KPRP]. W styczniu 1919 r. aresztowano setki agitatorów ${ }^{11}$. W Małopolsce proces rewolucyjny charakteryzował się skłonnością do wymiany lokalnych władz oraz do atakowania prywatnych dóbr. Jego epicentrum stanowiła tzw. republika tarnobrze-

8 „Robotnik”, 1 XII 1918, nr 326, s. 1; Handel wyborczy, „Gazeta Warszawska”, 4 XII 1918, nr 19, s. 1.

9 Dekret Naczelnika Państwa z dnia 11 stycznia 1919 r. o nadaniu praw wyborczych obywatelom, którzy po 5 grudnia 1818 r. powrócili do kraju, Dz.P.P.P. z 1919 r. nr 5, poz. 96; „Robotnik”: 3 I 1919, nr 3, s. 1; 14 I 1919 , nr 19, s. 3.

${ }^{10}$ Dekret Naczelnika Państwa z dnia 14 stycznia 1919 r. o przedłużeniu terminu wyborów do Sejmu Ustawodawczego w drugim okręgu wyborczym, Dz.P.P.P. z 1919 r. nr 6, poz. 101; Dekret Naczelnika Państwa z dnia 14 stycznia 1919 r. o przedłużeniu terminu wyborów do Sejmu Ustawodawczego w dwudziestym okręgu wyborczym, Dz.P.P.P. z 1919 r. nr 6, poz. 102; „Robotnik”, 16 I 1919, nr 24, s. 2.

11 „Gazeta Poranna 2 Grosze”: 20 I 1919, nr 19, s. 3; 21 I 1919, nr 20, s. 3. 
ska. Od listopada $1918 \mathrm{r}$. na terenie czterech powiatów stanowiących jeden okręg wyborczy (Tarnobrzeg, Kolbuszowa, Mielec, Nisko) rozwijał się ruch pararewolucyjny. Tworzył go z jednej strony nurt żywiołowy, w którego ramach część chłopów — zwłaszcza dezerterzy z armii austriackiej — atakowała dobra ziemiańskie i żydowskie sklepy, a z drugiej radykalny nurt chłopski - animowany przez ks. Eugeniusza Okonia i Tomasza Dąbala - którego przedstawiciele zmierzali do głębszych zmian społecznych, zwłaszcza nadania chłopom ziemi ${ }^{12}$. W czasie wyborczym Polska była więc poddawana próbom zanarchizowania jej życia wewnętrznego.

Dla przebiegu kampanii wyborczej istotne było również pogarszające się bezpieczeństwo zewnętrzne restytuowanej Polski. Decyzję o przeprowadzeniu wyborów podjęto w sytuacji nieustalonych granic państwa, w trakcie walk z Ukraińcami o panowanie nad obszarem Galicji Wschodniej. W trakcie kampanii pojawiły się nowe fronty walk o granice Polski. W końcu grudnia 1918 r. wybuchło powstanie wielkopolskie, na przełomie 1918/1919 r. oddziały bolszewickie stopniowo zajmowały Białoruś i Litwę, od końca 1918 r. rozwijał się polsko-czeski spór o panowanie nad Spiszem i Orawă a 23 stycznia 1919 r. wojska czeskie zaatakowały Śląsk Cieszyński.

Zagrożenia wewnętrzne i zewnętrzne sprawiły, że wybory do SU były wyjątkowe w polskich dziejach, nigdy później nie przyszło społeczeństwu wyłaniać parlamentu w tak trudnych warunkach. Zagrożenia te wywarły też silny i wieloraki wpływ na całą akcję wyborczą. Z pewnością mobilizowały polskie społeczeństwo do udziału w kampanii i w samych wyborach, ponieważ postrzegano je jako ważny akt państwowotwórczy. Przeprowadzenie wyborów do SU na tle tych zagrożeń stało się jednak tylko jednym z zadań państwowotwórczych, porównywalnym do tworzenia armii i sprawnej administracji, gromadzenia środków finansowych i pozyskiwania międzynarodowego wsparcia. Wybory miały też znaczenie dla organizowania kampanii i kreowania strategii, a zwłaszcza tonowania rywalizacji wyborczej.

\section{ARENY, PODMIOTY I STRATEGIE RYWALIZACJI}

Wybory miały odbywać się na dwóch arenach: w Królestwie oraz w zachodniej części Galicji (Małopolska) wraz ze Śląskiem Cieszyńskim. W Królestwie i w Galicji były to wybory realnie rywalizacyjne ${ }^{13}$. Znaczącym rysem kampanii wyborczej na obu arenach była mnogość podmiotów ubiegających się o mandaty poselskie. Głównym obszarem wyborczym było Królestwo, gdzie w 33 okręgach wyborczych miano wyłonić 241 posłów ( 26 stycznia 1919 r. przeprowadzono wybory w 29 okrę-

12 Vide J. Słomka, Pamiętniki włościanina. Od pańszczyzny do dni dzisiejszych, Warszawa 1983, s. 257-273; J. Rawski, ,Republika Tarnobrzeska” w świetle źródet $i$ wspomnień adiutanta powiatowej komendy wojsk polskich w Tarnobrzegu, Tarnobrzeg 1993, s. 13-90.

${ }_{13}$ Wobec napiętych relacji między Polakami, Niemcami i Czechami żyjącymi na Śląsku Cieszyńskim ugrupowania polskie utworzyły Główny Komitet Zjednoczonych Stronnictw Polskich, obejmujący endecję, Związek Śląskich Katolików, PPSD i PSL, który wystawił wspólną 6-osobową listę polską, noszącą numer 1. Znaleźli się na niej trzej reprezentanci PPSD, dwaj przedstawiciele ZŚK oraz jeden ludowiec. Atak wojsk czeskich uniemożliwił dopełnienie procedury wyborczej, a na prośbę Rady Narodowej Śląska Cieszyńskiego w marcu 1919 r. SU uznał tych sześciu kandydatów ze wspólnej listy za posłów. 
gach). Wiele polskich ugrupowań działało tu jeszcze przed I wojną światowa, a w trakcie jej trwania i w czasie samej kampanii powstawały kolejne formacje. Do ważniejszych ugrupowań, które uczestniczyły w wyborach, należały: Stronnictwo Demokratyczno-Narodowe [dalej: SDN], Narodowy Związek Robotniczy [dalej: NZR], Narodowy Związek Ludowy [dalej: NZL], Zjednoczenie Narodowe [dalej: ZN], Stronnictwo Polityki Realnej [dalej: SPR] Stowarzyszenie Robotników Chrześcijańskich [dalej: SRCh], Stronnictwo Polityczne Demokracji Chrześcijańskiej [dalej: SPDCh], Polskie Zjednoczenie Ludowe [dalej: PZL], Polskie Stronnictwo Ludowe „Piast”, Polska Partia Postępowa [dalej: PPP], Polska Partia Socjalistyczna [dalej: PPS], Stronnictwo Niezawisłości Narodowej [dalej: SNN], Polskie Stronnictwo Ludowe „Wyzwolenie”. Do rywalizacji wyborczej włączyły się organizacje żydowskie: Powszechny Żydowski Związek Robotniczy „Bund”, Żydowska Socjaldemokratyczna Partia Robotnicza „Poalej Syjon”, Żydowska Socjalistyczna Partia Robotnicza „Vereinigte", Żydowska Partia Ludowa [dalej: ŻPL], w okresie wyborczym powstała odrębna Tymczasowa Żydowska Rada Narodowa [dalej: TŻRN]. Osobno w wyborach uczestniczył Związek Zjednoczonych Ortodoksów Żydowskich [dalej: ZZOŻ], jego listy miały różne nazwy, np. „Związek Żydowskich Ortodoksów «Szlome Emune Izrael»". Aspiracje polityczne sygnalizowali też Niemcy: Niemieckie Stronnictwo Ludowe i Ewangelicki Związek Ludowy. Mniejszości słowiańskie oraz KPRP bojkotowały wybory do SU.

Proporcjonalny system wyborczy i minimalna liczba głosów poparcia potrzebnych do zarejestrowania listy wyborczej (50 głosów) przyczyniały się do wystawiania przez różne środowiska społeczne własnych list. Korzystano z tego zwłaszcza w dużych ośrodkach: w Warszawie o 16 mandatów ubiegali się kandydaci z 21 list (dziewięć żydowskich), w Łodzi na 10 mandatów wystawiono 13 list (osiem żydowskich), w okręgu lubelskim o 10 mandatów ubiegali się kandydaci 13 komitetów wyborczych (sześć żydowskich). Dużą liczbę list rejestrowano także poza dużymi ośrodkami miejskimi. Poza formacjami politycznymi tworzyły je bowiem konkretne społeczności, np. mieszkańcy poszczególnych gmin lub miast. Pełną ich identyfikację utrudnia brak źródeł oraz enigmatyczne nazwy list. Listy nazywano na przykład „bezpartyjnymi”, „mieszczańskimi”, ,włościańskimi”, „,chłopsko-robotniczymi”, „,narodowymi”, ,narodowo-ludowymi", sygnowano nazwiskami lokalnych liderów, a czasem tytułowano wręcz zabawnie, np: „Kółko Staszica”, „Lista Skierniewicko-mieszczańska”, „Miejscowi ludowcy”14. Przy tworzeniu list nie brakowało posunięć paradoksalnych, lokujących się na pograniczu manipulacji wyborczej. W ordynacji wyborczej nie umieszczono wymogu, aby osoby ulokowane na liście wyborczej wyraziły zgodę na kandydowanie. W Warszawie zarejestrowano więc listę nr 12 pod nazwą „Orędy Wolnego Zjednoczenia Stronnictwa

${ }_{14}$ Tytułem przykładu: w okręgu nr 23, obejmującym powiaty Biłgoraj, Janów, Krasnystaw i Zamość, zarejestrowano 12 list pod nazwami: 1. Gmina Frampol p. Zamość, 2. Gmina Wilkołaz p. Janów, 3. PPS, 4. Narodowy Komitet Wyborczy Bezpartyjny, 5. Wyborców gm. Janów, 6. Włościan gm. Balice p. Biłgoraj, 7. Gmina Łuków p. Biłgoraj, 8. PSL „Wyzwolenie”, 9. Żydowski Komitet Wyborczy, 10. Związek Ortodoksów, 11. Komitet zwolenników równouprawnienia Żydów, 12. Gmina Annopol p. Janów; vide T. Rzepecki, Sejm Rzeczypospolitej Polskiej 1919 roku, Poznań 1920, s. 156-158. 
Ludowego i Narodowego", na której figurowały nazwiska min. Aleksandra Świętochowskiego, Tytusa Filipowicza, księdza Marcelego Godlewskiego, Andrzeja Niemojewskiego czy księcia Zdzisława Lubomirskiego, umieszczone tam bez ich zgody. W trakcie kampanii wyborczej niektórzy z nich prosili o wykreślenie swoich nazwisk. W wyborach lista otrzymała 15 głosów poparcia, czyli 35 mniej niż liczyła nazwisk w chwili rejestracji ${ }^{15}$.

W Małopolsce miano wybrać 69 posłów w 11 okręgach wielomandatowych, a we Lwowie dwóch posłów w okręgach jednomandatowych. O mandaty walczyły głównie: SDN, Stronnictwo Chrześcijańsko-Ludowe [dalej: SChL], Stronnictwo Katolicko-Ludowe [dalej: SKL], PSL „Piast”, Polskie Stronnictwo Ludowe - Lewica, Polska Partia Socjalno-Demokratyczna Galicji i Śląska Cieszyńskiego [dalej: PPSD]. Zabiegały o nie także mniejsze formacje: konserwatywne Stronnictwo Budowy Zjednoczonej Polski [dalej: SBZP], Chrześcijańsko-Narodowe Stronnictwo Robotnicze [dalej: ChNSR], SNN, ZN oraz Polskie Stronnictwo Republikańskie [dalej: PSR]. Zdarzyło się, że tworzono różne ugrupowania wyłącznie na potrzeby wyborów do SU. Zdiagnozowanym już przypadkiem było PSR. Jego twórcą był Marian Dąbrowski, wydawca „Ilustrowanego Kuriera Codziennego". PSR pojawiło się na początku listopada 1918 r., a w styczniu 1919 r. informowano już o istnieniu 168 kół terenowych, 82 tys. członków i 200 tys. sympatyków ${ }^{16}$. Można było odnieść wrażenie, że w Małopolsce powstało silne ugrupowanie, zdolne do samodzielnych działań politycznych. W rzeczywistości była to mistyfikacja ${ }^{17}$. Utworzenie SPR, a zwłaszcza tworzenie pozoru, że jest to silne ugrupowanie, służyło zajęciu dobrej pozycji przetargowej w procesie tworzenia powiązań przedwyborczych w Małopolsce. Także na tym obszarze, chociaż w mniejszej skali niż w Królestwie, powstawały komitety wyborcze rozmaitych środowisk, a wystawiane przez nie listy nosiły różnorodne nazwy. W grę wyborczą włączyli się także Żydzi, głównie TŻRN. W efekcie w Małopolsce zarejestrowano wiele list wyborczych, z czego najwięcej w okręgu krakowskim, gdzie na 8 mandatów zgłoszono 9 list, w tym 4 żydowskie ${ }^{18}$.

Główna linia podziałów w mozaikowej konfiguracji polskich ugrupowań nie była oparta na kryteriach polityczno-organizacyjnych, lecz aksjologicznych. Ugrupowania operowały odmiennymi wizjami przyszłej Polski, a zwłaszcza różnym rozumieniem demokracji i jej społecznych następstw. W tej optyce można mówić, że wybory SU w znacznym stopniu były dychotomicznym starciem obozów centroprawicy i niepodległościowej lewicy. Podział ten zarysowywał się i nadawał elekcji wymiar plebiscytu. Obóz centroprawicy, budowany przez narodową demokrację, obejmował m.in. jej podstawowe ugrupowanie, czyli SDN, a poza tym: SPR, NZR, NZL, ZN, SPDCh,

15 „Gazeta Warszawska”: 14 I 1919, nr 13, s. 4; 15 I 1919, nr 14, s. 5; 19 I 1919, nr 18, s. 3; 22 I 1919 , nr 21, s. 5; 30 I 1919, nr 29, s. 1; „Gazeta Poranna 2 Grosze”, 1 II 1919, nr 31, s. 5.

16 „Ilustrowany Kurier Codzienny”: 11 XI 1918, nr 218, s. 5-6; 12 XII 1918, nr 249, s. 1; 3 I 1919 , nr 3, s. 2 .

17 C. Brzoza, Polskie Stronnictwo Republikańskie (1918-1919), „Studia Historyczne” 1991, z. 2, s. 276.

18 „Czas”, 19 I 1919, nr 13, s. 3. 
SKL, SChL, PPP, PZL, PSL „Piast”. Pełnoprawną częścią tego obozu był też Kościół katolicki, księża organizowali wiece, byli obecni na listach wyborczych i generalnie wspierali centroprawicę w oddziaływaniu na wyborców. Obóz lewicy obejmował głównie: PPS, PPSD, PSL „Wyzwolenie”, PSL Lewicę, SNN. Tymczasowy Naczelnik Państwa Józef Piłsudski, chociaż był identyfikowany z niepodległościową lewica, to w tym starciu starał się jednak grać rolę arbitra.

Ugrupowania centroprawicy akceptowały demokrację. Rozumiały ją jako porządek emancypacyjno-inkluzywny, równoprawnie respektujący wszystkie grupy społeczne i działający w interesie wspólnego dobra całego społeczeństwa polskiego. Narodowi demokraci odrzucali optykę wyróżniająca jakąkolwiek grupę społeczną. W „Gazecie Warszawskiej” twierdzono: „Demokracja polska nie może uznać dyktatury żadnej warstwy, a we współpracy wszystkich warstw i w równości praw widzi jedyną drogę, która odpowiada polskim tradycjom demokratycznym, jak i właściwościom naszej psychiki narodowej. Dyktatura warstw posiadających czy proletariatu jest obca narodowi polskiemu. Demokracja polska to prawa, równość i prawa dla wszystkich, to harmonijne zespolenie wartości czynników pracy zbiorowej z walorami rywalizacji indywidualnej"19. Podobnie wypowiadano się w pismach krakowskich, chadeckim „Głosie Narodu” i konserwatywnym „Czasie”20. Ugrupowanie PSL „Piast” operowało w kampanii wyborczej konceptem „Polski ludowej”, ale wyraźnie nadawało mu ten emancypacyjno-inkluzywny wymiar.

Lewica odmiennie rozumiała samo pojęcie ,lud”, kojarząc go z biedniejszą częścią społeczeństwa, z chłopami, robotnikami, inteligencją pracującą. W jej odczuciu dobro narodu mogło być pozytywnie realizowane niekoniecznie przez całość, ale właśnie przez tę część narodu. Wywarło to wpływ na przyjęcie wizji demokracji jako porządku ekskluzywnego, gruntującego wpływy warstw ludowych. Taki też wymiar miało dla lewicy hasło „Polski ludowej”. Klasową optykę demokracji bodaj najpełniej wyłożył Józef Sanojca, pisząc: „Polska powinna być niepodległą Rzeczpospolitą ludową. Rząd w Polsce powinien być ludowy, to znaczy złożony z reprezentantów chłopów i robotników"21. Zgodnie z tym stanowiskiem właściwie nie przewidywano udziału warstw i grup dotąd uprzywilejowanych w kreowaniu demokracji. Publicysta PSL Lewicy oznajmił to wprost: „Nadeszły zaś te czasy, że już nie chodzi o równouprawnienie chłopa z panem, a o to, by lud, to jest rzesza chłopska i robotnicza całą władzę nad narodem wzięła w swoje ręce. Dlaczego? Czy to sprawiedliwe? Dla nas to od dawna słuszne i sprawiedliwe"22. Odmienne wizje demokracji wywarły wpływ na organizowanie się formacji politycznych, programy i kampanię wyborcza.

Wobec mnogości podmiotów rywalizujących o mandaty poselskie i ich dychotomicznego uszeregowania potrzebne było operowanie właściwą strategią wyborczą. Wypracowały ją zwłaszcza podstawowe formacje polityczne. Zgodnie z logiką dzia-

19 Polska demokracja, „Gazeta Warszawska”, 25 XI 1918, nr 10, s. 1.

20 „Głos Narodu”, 22 I 1919, nr 14, s. 1; O zgode i siłe narodowa, „Czas”, 17 I 1919, nr 11, s. 1.

21 J. Sanojca, Nasze żadania, „Przyjaciel Ludu”, 29 XII 1918, nr 4, s. 6-7.

${ }_{22}$ Idem, Ludowy rzad, prawo i władza, „Przyjaciel Ludu”, 22 XII 1918, nr 3, s. 3-4. 
łania proporcjonalnego systemu wyborczego, ich strategie były na ogół scentralizowane, ale różniły się w zależności od areny wyborczej. Na obszarze Królestwa najpoważniejszą siłą była Narodowa Demokracja. Formacja ta kierowała się interesem narodowym jako główną wartością swoich praktycznych poczynań. Na tle wskazanych zagrożeń dla bezpieczeństwa Polski w kreowaniu strategii wyborczej odwoływała się ona do solidarności narodowej. Wykorzystywała także swoje dotychczasowe doświadczenia z gry wyborczej do parlamentów Niemiec i Rosji oraz polityki prowadzonej w okresie wojny. Strategia endecji zakładała więc integrowanie w ramach obozu centroprawicy szerokiego wachlarza sił, grup i środowisk ukierunkowanych na realizację potrzeb polskiego narodu ${ }^{23}$.

Siła Narodowej Demokracji sprawiła, że mogła ona w Królestwie efektywnie zastosować strategię integracyjną. Jej postępowanie było pod tym względem elastyczne, uwzględniano w nim zarówno własną siłę endecji, jak i jej sojuszników. Operowano też podejściem kombinacyjnym, skupiając pokrewne sobie siły na trzech poziomach kooperacji. Podstawowy poziom wyznaczało budowanie wspólnych komitetów i bloków wyborczych oraz wystawianie wspólnych list wyborczych i to czasem kilku w okręgu. Najbardziej rozpoznawalną strukturą jaką endecja uruchomiła w analizowanej kampanii, był Narodowy Komitet Wyborczy Stronnictw Demokratycznych [dalej: NKWSD], zawiązany w grudniu 1918 r. w Warszawie. Początkowo w jego składzie znalazły się: SDN, PPP, SPDCh, ZN, Odrodzenie Narodowe [dalej: ON], Narodowa Organizacja Wyborcza Kobiet Polskich [dalej: NOWKP], Koło Polityczne Zrzeszeń Rzemieślniczych ${ }^{24}$. Później pod egidą endecji znalazły się jeszcze: SRCh, Związek Niezależności Gospodarczej, PSD, SPR, Stronnictwo Pracy Narodowej, Konfederacja Zrzeszeń Polskich i Komitet Wyborczy Narodowy Bezpartyjny ${ }^{25}$. W zależności od okręgu wyborczego powiązania budowane przez endecję były różnorodne, a wytworzone porozumienia miały różne nazwy. W Łodzi NKWSD obją: SDN, ZN, SPDCh, NOWKP, Akademicki Narodowy Komitet Wyborczy oraz bezpartyjnych. W Radomiu zawiązano Narodowy Blok Wyborczy obejmujący: NZR, ZN, SPDCh, SRCh, Resursę Rzemieślniczą ${ }^{26}$. W szeregu okręgach blok centroprawicy operował ogólnikową nazwą list „narodowych”.

Drugi poziom realizacji strategii integracyjnej wyznaczyło tworzenie związków wyborczych. Ta forma kooperacji, często niewidoczna dla opinii publicznej, bodaj najwyraźniej pozwalała wyodrębnić obozy centroprawicy i lewicy. Ugrupowania należące do obozu centroprawicy w praktyce nie tworzyły związków wyborczych z partiami i komitetami lewicowymi. Formacje centroprawicowe zawiązywały je często między sobą, a wytworzone przez nie związki wyborcze obejmowały listy endeckie i innych ugrupowań centroprawicowych. Uruchomiano je na terenach, gdzie endecja respektowała formacje pokrewne i lokalne aspiracje wyborcze. W Królestwie w ramach obozu centro-

\footnotetext{
23 Przygotowania przedwyborcze, „Gazeta Warszawska”, 21 XII 1918, nr 36, s. 1.

24 Wybory do Sejmu, ,Gazeta Warszawska”, 22 XII 1918, nr 37, s. 2.

25 „Gazeta Poranna 2 Grosze”, 10 I 1919, nr 9, s. 1.

26 „Gazeta Warszawska”: 3 I 1919, nr 3, s. 3; 10 I 1919, nr 9, s. 4.
} 
prawicy zawarto ponad 20 związków wyborczych. Na przykład w Lublinie (okręg nr 22) zarejestrowano dwie listy narodowe pod zbliżonymi nazwami: Narodowy Komitet Wyborczy Bezpartyjny m. Lublina i Narodowy Komitet Wyborczy Bezpartyjny Ziemi Lubelskiej; obie listy utworzyły wraz z listą PSL „Piast” związek wyborczy, co przyniosło efekt, czyli 3 mandaty poselskie, po jednym dla każdej ${ }^{27}$.

Trzeci poziom realizacji strategii integracyjnej wytyczała współpraca endecji z różnymi środowiskami w zakresie organizacji wieców, wsparcia propagandowego itp., niezależnie od tego, czy współtworzyły ściślejsze związki. Żadna z formacji politycznych nie podjęła tak szerokiej współpracy, jak endecja. Do jej strategii próbowały nawiązać inne środowiska. NZR, który w obozie centroprawicy przejawiał dużą samodzielność, utworzył w Warszawie Narodowy Robotniczy Komitet Wyborczy, który objął również Polskie Zwiazki Zawodowe, Zgromadzenie Rzemieślniczej Czeladzi oraz osoby niezależne. W kilku okręgach NZR wystawił własne lub wspólne listy z PZL i PSL „Piast”, ale generalnie trzymał się centroprawicowych związków wyborczych ${ }^{28}$.

O skupieniu sił myślały także środowiska żydowskie. Od 26 do 30 grudnia $1918 \mathrm{r}$. obradowała w Warszawie Żydowska Konferencja Przedwstępna, na której przedstawiciele wielu środowisk żydowskich rozmawiali na temat koordynacji swoich poczynań. Inicjatywa zakończyła się częściowym powodzeniem. Utworzono wspomnianą już TŻRN, ale Rada grupowała właściwie tylko środowiska syjonistów, poza nią znaleźli się żydowscy socjaliści, ludowcy i ortodoksi ${ }^{29}$. Żydowskie komitety wyborcze, przy wyraźnej skłonności do samodzielnego wystawiania list, potrafiły jednak utrzymać współpracę, co w wielu przypadkach zaowocowało utworzeniem związków wyborczych (w Królestwie utworzono ich 13) 30. $^{30}$

Formacje lewicowe w Królestwie nie stawiały na integrację i tworzenie bloków wyborczych. PSL „Wyzwolenie” i PPS uczestniczyły w wyborach samodzielnie. Ludowcy obawiali się, że demonstrowanie współpracy z PPS przyda prawdziwości rozlicznym zarzutom, że są formacją nibyludową a w gruncie rzeczy socjalistyczną. Tylko więc w okręgu nr 32 (powiaty Kozienice i Radom) PSL „Wyzwolenie” miało wspólną listę ze SNN. Skłonność PPS i PSL „Wyzwolenie” do tego, aby prowadzić wybory — jak wyraził się Aleksander Bogusławski — „pod wyraźną swoją firmą” sprawiła, że niepodległościowa lewica mało odważnie tworzyła też związki wyborcze. W Królestwie formacje lewicy zawiązały je tylko w pięciu okręgach, co późnej raczej

${ }_{27}$ T. Rzepecki, op. cit., s. 100-184; E. Domań, Wybory do Sejmu Ustawodawczego 1919 roku w lubelskim okregu wyborczym, „Annales Universitatis Mariae Curie-Skłodowska Lublin-Polonia” 1983/1984, t. XXXVIII/XXXIX, s. 224, 234.

28 „Gazeta Warszawska”, 31 XII 1918, nr 44, s. 5; T. Rzepecki, op. cit., s. 100-184. Tam, gdzie NZR występował samodzielnie, bywał krytykowany przez pokrewne formacje. W Łodzi NKWSD instruował wyborców w ulotce, aby nie oddawali głosów na listy socjalistów, Niemców, Żydów i właśnie NZR, zarzucając mu, że „do ostatniej chwili wierzył w zwycięstwo Niemców”; vide Ulotki wyborcze do Sejmu Ustawodawczego Rzeczypospolitej Polskiej, Warszawa 1919, Zakład Narodowy im. Ossolińskich, sygn. 409.066 II, nr 5.

${ }_{29}$ L. Halpern, Polityka żydowska w Sejmie i Senacie Rzeczypospolitej Polskiej 1919-1933, Warszawa 1933, s. 5-6.

${ }^{30}$ T. Rzepecki, op. cit., s. 100-184. 
negatywnie zaważyło na rezultatach wyborczych ${ }^{31}$. Ogólnie jednak wspierały się w przedsięwzięciach organizacyjnych.

W Małopolsce podział na obozy centroprawicy i lewicy niepodległościowej istniał, ale był mniej wyrazisty. Rywalizację wyborczą znamionowała względna równowaga sił politycznych. Strategię ścisłej integracji formacji centroprawicowych zastosowano tylko w dwóch okręgach wyborczych. Najpełniej uwidoczniła się w okręgu nr 36 (Kraków-Podgórze-Wieliczka). Na wspólnej liście wyborczej zgrupowano tu 12 podmiotów: SDN, ZN, ChNSR, Koło Polityczne Polek, Klub Polityczny Polek PSR, PSL „Piast”, Polskie Stronnictwo Mieszczańskie, PSR, SBZP, SChL, SKL, Związek Społeczno-Narodowy. Mniejszy blok utworzono też w okręgu nr 37 (Biała-Oświęcim-Chrzanów), a wspólna lista obejmowała: SDN, PSL „Piast”, PSR, SChL. Jeszcze inne było zachowanie sił obu obozów w okręgu nr 44 (Kolbuszowa, Mielec, Nisko, Tarnobrzeg), czyli na obszarze tzw. republiki tarnobrzeskiej. Doszło tu do bezpośredniej konfrontacji obu bloków. PSL Lewica i zwolennicy ks. Eugeniusza Okonia wystawili wspólna, „chłopską” listę wyborcza, a kolejnych siedem list obozu centroprawicy utworzyło związek wyborczy. Nie zapobiegł on porażce: na 6 mandatów 5 zdobyła lewica, a centroprawica tylko jeden. Ogólnie obóz centroprawicy był w Małopolsce mniej spoisty niż ten w Królestwie. Jego ugrupowania zawarły jednak związki wyborcze w sześciu spośród 11 okręgów i chociaż czasem wzajemnie się krytykowały, to jednak generalnie ze sobą współpracowały. Małopolskie ugrupowania lewicowe: PPSD, PSL Lewica i SNN nie zbudowały jednolitego bloku wyborczego, w pięciu okręgach utworzyły jednak związki wyborcze i ogólnie się wspierały ${ }^{32}$.

W konsekwencji zaistniałych podziałów istotnym rysem wyborów w 1919 r. było też to, że rywalizacja między centroprawicą i lewicą na obu arenach wyborczych prowadziła do bratobójczych starć w ramach tych samych środowisk społecznych. W Królestwie o mandaty poselskie wśród chłopów walczyły ze sobą z jednej strony endecja, PZL i PSL „Piast”, a z drugiej PSL „Wyzwolenie”; w Małopolsce endecja, PSL „Piast”, SKL i SChL konfrontowały się na wsi z PSL Lewicą i stronnikami ks. E. Okonia. Wśród robotników PPS rywalizowała z NZR, SChR, ale miała też przeciwnika - KPRP, która kreowała proces rewolucyjny i ścierała się z PPS w staraniach o władzę w radach robotniczych. Podział na dwa rywalizujące ze sobą bloki był na tyle ostry, że prowadził do unieważnienia prób współdziałania między polskimi organizacjami operującymi w tych samych środowiskach społecznych. Na przykład w styczniu 1919 r. PPS zdecydowanie odrzuciła ofertę NZR, aby w Łodzi oba ugrupowania zawarły porozumienie wyborcze ${ }^{33}$. Rywalizacja w ramach tych samych grup społecznych powodowała też, że oba obozy niezbyt chętnie informowały o tworzonych związkach wyborczych.

31 A. Bogusławski, Wspomnienia. Tom II (1916-1919), AZHRL, sygn. P-31, s. 244-249; T. Rzepecki, op. cit., s. 100-184; „Robotnik”, 15 I 1919, nr 21, s. 3.

32 J. Słomka, op. cit., s. 270; T. Rzepecki, op. cit., s. 187-211; „Przyjaciel Ludu”, 29 XII 1918, nr 4, s. 9-10; „Czas”, 14 I 1919, nr 8, s. 1; „Głos Narodu”: 12 I 1919, nr 5, s. 1; 18 I 1919, nr 10, s. 2; „Piast”, 19 I 1919, nr 3, s. 3-5.

33 „Gazeta Warszawska”, 15 I 1919, nr 14, s. 5; „Robotnik”, 14 I 1919, nr 19, s. 3. 
Mechanizm kreowania list wyborczych był na obu arenach wyborów rywalizacyjnych względnie demokratyczny. Listy zgłaszane przez lokalne społeczności powstawały zupełnie demokratycznie. Procedura budowania list przez partie polityczne była już bardziej złożona i scentralizowana. Lokalne struktury stronnictw i lokalne społeczności były zapraszane do wysuwania propozycji personalnych, ale to zarządy partii dokonywały ostatecznych ustaleń w sprawie list kandydatów do SU, ważne były też międzypartyjne uzgodnienia w ramach zawiązywanych bloków wyborczych. Na listach tworzonych przez partie czołowe miejsca na listach zajmowali na ogół ich przywódcy i znaczący działacze. Wyjątkiem było PSL ,Wyzwolenie”, które przyjęło, że na jego listach pierwsze miejsce miał zajmować chłop, znany działacz w lokalnej społeczności. Ogólnie stronnictwa broniły partyjnej formuły wyborów i wzywały swoje elektoraty do zachowania karności ${ }^{34}$.

\section{POLA I TWORZYWA RYWALIZACJI}

Rywalizacja wyborcza widoczna była na wiecach i rozmaitych spotkaniach przedwyborczych, ujawniały ją treści i retoryka zawarte w prasie, ulotkach i na plakatach. Kluczowe znaczenie miały dwa pola rywalizacji: prasa i wiece. Prasa nie wszędzie była dostępna, a ze względu na analfabetyzm nie każdy mógł też do niej sięgnać. W tym stanie rzeczy głównym polem zabiegania o głosy elektoratu oraz rywalizacji między obydwoma obozami politycznymi były wiece i spotkania przedwyborcze. Odgrywały one dużą rolę zwłaszcza w kreowaniu zachowania wyborczego, szczególnie u osób, które nie potrafiły zidentyfikować własnych preferencji wyborczych. W odniesieniu do tej kategorii wyborców wiążąca stawała się właśnie treść stanowiska przyjętego na wiecu: przychylali się do stanowiska większości. Wszystkie siły rywalizujące o mandaty przywiązywały więc wagę do organizowania i obecności na wiecach przedwyborczych. Stąd też jednym z najistotniejszych rysów kampanii wyborczej do SU, mimo stosunkowo krótkiego czasu jej trwania, była znacząca liczba wieców i spotkań przedwyborczych. Na obu arenach wyborczych odbyło się ich kilkaset, a ponadto cechowała je duża frekwencja. Liczba uczestników wieców wahała się od kilkudziesięciu do kilkuset, ale zdarzały się wiece grupujące kilka tysięcy, a nawet kilkadziesiąt tysięcy osób ${ }^{35}$. Tak liczne uczestnictwo samo w sobie świadczyło o poważnym traktowaniu wyborów do SU przez społeczeństwo.

Na obszarze Królestwa w organizacji wieców celowała Narodowa Demokracja i tworzony przez nią obóz. Endecja miała bowiem wpływy, struktury organizacyjne, komitety i biura wyborcze na całym obszarze wyborczym, także w środowisku wiej-

34 W. Witos, F. Bardel, Wskazania przedwyborcze dla ludowców, „Piast”, 15 XII 1918, nr 50, s. 2; Nasi kandydaci na posła do Sejmu, „Piast”, 19 I 1919, nr 3, s. 3-5; S. Thugutt, Nowy ład, „Wyzwolenie”, 5 I 1919 , nr 1, s. 2; „Piast”, 22 XII 1918, nr 51, s. 6; A. Bogusławski, op. cit., s. 243-245; Z. Hemmerling, PSL „,Wyzwolenie" w parlamentach II Rzeczypospolitej 1919-1931, Warszawa 1990, s. 73.

35 Vide: „Gazeta Warszawska”: 18 XII 1918, nr 33, s. 7; 4 I 1919, nr 4, s. 7; 18 I 1919, nr 17, s. 5; ,,Robotnik": 6 XII 1918, nr 336, s. 1-2; 12 I 1919, nr 17, s. 4; 17 I 1919, nr 25, s. 3. 
skim. Dodatkowo na wsi mogła liczyć na wsparcie księży, którzy w szeregu przypadków byli w stanie samodzielnie zwoływać wiece. W efekcie liczbę wieców wyborczych zorganizowanych przez centroprawicę można szacować na 150-200. Przywiązywano też wagę do zwoływania ich w dużych ośrodkach miejskich: Łodzi, Lublinie, a zwłaszcza w Warszawie. Dla endecji wynik wyborów w Warszawie był symbolem woli narodu polskiego. Kampanię wyborczą do SU cechowało więc nasycenie stolicy Polski rozlicznymi wiecami i spotkaniami przedwyborczymi. Zwoływano je na ogół w okresie weekendu, a bywało, że na krótko przed wyborami każdego dnia odbywało się od kilku do kilkunastu tego typu zgromadzeń. Na przykład 19 stycznia 1919 r. NKWSD zorganizował w Warszawie 18 wieców; 20 i 21 stycznia było ich 12, a 23 stycznia odbyło się 11 spotkań $^{36}$. Wiece organizowały także siły sojusznicze endecji: SRCh i NZR ${ }^{37}$. Na podobny wysiłek zdobył się obóz lewicy. 8 grudnia $1918 \mathrm{r}$. duży wiec zwołało w Warszawie PSL „Wyzwolenie”, większą liczbę PPS. Niemniej wieców zwołanych w Warszawie przez lewicę było znacznie mniej niż wieców centroprawicy: np. 18 wiecom NKWSD 19 stycznia 1919 r. PPS przeciwstawiła tylko cztery własne spotkania ${ }^{38}$.

Lewica w Królestwie miała mniejsze możliwości organizowania wieców i akcji wyborczej. Nie wszędzie była obecna, a jej poczynania osłabiały trudności finansowe, a zwłaszcza kadrowe, wynikające z zaangażowania jej aktywistów w POW, tworzenie wojska i administracji. PPS miała bardziej rozwiniętą sieć własnych komitetów i biur wyborczych w miastach i tam przeprowadziła kilkadziesiąt wieców ${ }^{39}$. Sporadycznie organizowała je również na wsi ${ }^{40}$. Sojusznicze PSL „Wyzwolenie” zdołało w pierwszych czterech latach swego istnienia wypracować dobrą pozycję wśród chłopów, ale głównie w austriackiej części Królestwa, zwłaszcza w Kieleckiem i na Lubelszczyźnie. Uruchomiło jednak w całym Królestwie komitety wyborcze, które też przeprowadziły kilkadziesiąt wieców ${ }^{41}$. Małopolska była mniejszą areną wyborczą, ale i tu zorganizowano około 100 wieców przedwyborczych, czasem z wieloma tysiącami uczestników. Ich organizacja była już bardziej równomiernie rozłożona na oba obozy: po stronie centroprawicy wiece zwoływały głównie PSL „Piast”, SKL i SDN, po stronie lewicy PSL Lewica i PPSD ${ }^{42}$.

Z przebiegiem wieców i spotkań przedwyborczych wiąże się istotny problem. Po wyborach do SU pisano, że miał one spokojny przebieg, były uczciwe, wolne od presji

36 „Gazeta Warszawska”: 20 I 1919, nr 19, s. 3; 23 I 1919, nr 22, s. 3; „Gazeta Poranna 2 Grosze”, 23 I 1919, nr 22, s. 1.

37 „Gazeta Poranna 2 Grosze”, 19 I 1919, nr 18, s. 3.

38 „Wyzwolenie”, 15 XII 1918, nr 50, s. 1; „Robotnik”, 16 I 1919, nr 24, s. 1.

39 „Robotnik”: 22 XII 1918, nr 365, s. 6; 1 I 1919, nr 1, s. 6; 5 I 1919, nr 7, s. 6; 13 I 1919, nr 18, s. 3.

40 „Robotnik”, 1 I 1919, nr 1, s. 6.

41 Obszerniej vide: A. Bogusławski, op. cit., s. 238-252; Z. Hemmerling, op. cit., s. 70-79.

42 Informacje o wiecach i frekwencji na nich podawała prasa; vide: „Piast”: 22 XII 1918, nr 51, s. 7; 29 XII 1918, nr 52, s. 7-9; 5 I 1919, nr 1, s. 9-14; 12 I 1919, nr 2, s. 9-13; „Przyjaciel Ludu”: 15 XII 1918, nr 2, s. 9-14; 22 XII 1918, nr 3, s. 10-13; 29 XII 1918, nr 4, s. 9-19; 1 I 1919, nr 1, s. 8-14; 12 I 1919, nr 2, s. 5-12; 19 I 1919, nr 3, s. 25; „Prawo Ludu”: 8 XII 1918, nr 49, s. 3-4; 15 XII 1918, nr 50, s. 2-3; 29 XII 1918 , nr 52, s. 5-6. 
administracji państwowej ${ }^{43}$. Opinie te nie są precyzyjne, nie wiadomo, czy odnoszą się one do kampanii wyborczej, czy do samego dnia głosowania. Nie są też prawdziwe. W kampanii wyborczej idylli nie było. W szeregu przypadkach dochodziło do starć właśnie na wiecach i spotkaniach przedwyborczych albo też w konsekwencji ich przebiegu. Te starcia były trudne do uniknięcia. Wiece często zwoływano w formule otwartej, np. jako wiece ludowe, bez jednoznacznego wskazania formacji politycznej, która je przeprowadzała. Mogli więc w nich uczestniczyć zwolennicy obu obozów — i realnie byli oni tam obecni - co niejako mechanicznie uruchamiało napięcie między nimi. Nie wszystkie stronnictwa miały możliwość organizowania wieców, a zdawały sobie sprawę z ich roli w zakresie formowania preferencji wyborczych. Wówczas decydowały się na uczestnictwo w wiecach organizowanych przez konkurencję. Co więcej, zdarzały się przypadki przejęcia kontroli nad wiecami, które formalnie zwołała konkurencja. Te ,tryumfy” stanowiły tworzywo wykorzystywane później w działaniach propagandowych.

$\mathrm{Na}$ obu terytorialnych arenach wyborczych można wskazać kilka kategorii wieców, na których dochodziło do bezpośredniej konfrontacji:

A. Wiece, na których doszło do starć fizycznych. Wiec zwołany przez PPS 29 grudnia 1918 r. w Warszawie (Praga) został zaatakowany przez bojówkę KPRP, W efekcie czego doszło do walki wręcz. W tym samym dniu doszło do podobnego starcia PPS z komunistami na wiecu w Skierniewicach ${ }^{44}$. Na wiecu centroprawicy, zorganizowanym w Sokołowie 13 stycznia 1919 r., doszło do pobicia Stefana Baranieckiego. Działacz socjalistyczny niefortunnie wdał się w potyczkę słowną ze stronnikami endecji. W oprawie okrzyków: „Zabić Żyda, zabić bolszewika!” został zaatakowany dragami i kijami, a przed linczem uchroniły go strzały oddane przez policję $e^{45}$. W Małopolsce 18 grudnia 1918 r. zwolennicy ks. E. Okonia zaatakowali w Tarnobrzegu uczestników wiecu endecji ${ }^{46}$.

B. Wiece rozbite przez konkurencję, obejmujące spotkania, które zostały przedwcześnie zamknięte, a uczestnicy zmuszeni do ich opuszczenia, na ogół pośpiesznego. 12 stycznia 1919 r. zwolennicy PSL „Wyzwolenie” — z okrzykami „Niech żyje Piłsudski! Niech żyje rząd ludowy!" — rozbili wiec centroprawicy w Karnowie k. Lipna w ziemi dobrzyńskiej. Podobne przypadki odnotowano w Sandomierskiem ${ }^{47}$. W Małopolsce 8 grudnia 1918 r. socjaliści rozbili spotkanie przedwyborcze PSL „Piast” w Wieliczce. Podobnie było w Jaśle ${ }^{48}$. Do tej kategorii należy zaliczyć również wiece, których próba rozbicia zakończyła się fiaskiem ${ }^{49}$.

43 Vide np. Rok 1918 we wspomnieniach mężów stanu, polityków i wojskowych, Warszawa 1987, s. 419; S. Grabski, Pamiętniki, t. 2, Warszawa 1989, s. 107.

44 „Robotnik”: 30 XII 1918, nr 374, s. 1; 1 I 1919, nr 378(1), s. 6.

45 Napad na kandydata PPS w Sokołowie, ,Robotnik”, 23 I 1919, nr 36, s. 1.

46 „Przyjaciel Ludu”, 29 XII 1918, nr 4, s. 9.

47 M. Drewicz, Polskie wybory 1919. Agitacja w pięciu tygodnikach „, Gazeta Świateczna”, ,Zorza”, „,Wyzwolenie”, ,,Rzą i Wojsko”, ,Piast”, Biała Podlaska 2011, s. 30 i 79; ,Gazeta Warszawska”, 24 I 1919, nr 23, s. 4.

${ }^{48}$ Początki socjalistycznego terroru wyborczego, „Ilustrowany Kurier Codzienny”, 16 XII 1918 , nr 253, s. 1; „Piast”, 15 XII 1918, nr 50, s. 3; „Przyjaciel Ludu”, 29 XII 1918, nr 4, s. 9-10.

${ }^{49}$ Np. 22 XII 1918 r. PSL „Piast” usiłowało rozbić wiec PSL Lewicy w Szczucinie; vide „Przyjaciel Ludu", 1 I 1919, nr 1, s. 13. 
C. Wiece, nad którymi kontrolę przejęła konkurencja. Na wiecu ludowym zwołanym 29 grudnia 1918 r. w Grodzisku k. Warszawy zakwestionowano rolę czołowego przywódcy PSL „Wyzwolenie” Tomasza Nocznickiego. Endecy nie dopuścili do zamknięcia wiecu, przejęli nad nim kierownictwo i doprowadzili do przyjęcia uchwały o treści narodowej. Na duży wiec (ok. 1,5 tys. uczestników) zwołany przez endecję 23 stycznia 1919 r. w Warszawie weszła PPS, przejęła nad nim kontrolę i uchwaliła korzystną dla siebie rezolucję ${ }^{50}$. W Małopolsce 15 grudnia 1918 r. PSL „Piast” przejęło kontrolę nad wiecem zwołanym przez PPSD w miejscowości Grabie k. Wieliczki. Natomiast 17 grudnia PSL Lewica przejęło kontrolę nad wiecem zwołanym przez endecję w Wadowicach ${ }^{51}$.

D. Wiece, na których konkurencja została pozbawiona możliwości zabrania głosu. Na szeregu wieców zwołanych przez centroprawicę w pierwszej połowie stycznia 1919 r. w rejonie Jędrzejowa chłopi nie dopuścili przedstawicieli PSL „Wyzwolenie” do głosu. Na wiecu zwołanym w tym czasie przez ludowców w Radomsku postanowiono, że „mówcy kontrowi” będą usuwani z sali, co zmusiło działaczy endeckich do zwołania odrębnego spotkania ${ }^{52}$. W Małopolsce na wiecu centroprawicy 13 stycznia $1919 \mathrm{r}$. w Żabnie nie dopuszczono do głosu Gabriela Dubiela, reprezentanta PSL Lewicy ${ }^{53}$.

E. Wiece, na których doszło do słownej konfrontacji. W Małopolsce na kilku wiecach ludowych w grudniu 1918 i w styczniu 1919 r., w miejscowościach: Biała i Jawiszowice (14 grudnia); Bogumiłowice, Jasło, Oświęcim (15 grudnia); Tarnów (20 grudnia); Pilzno (21 grudnia); Dankowice i Siary (22 grudnia); Dą̧rowa Tarnowska i Czarny Dunajec (23 grudnia); Jordanów (26 grudnia), Szczurowa (29 grudnia), doszło do ostrych starć słownych między zwolennikami PSL „Piast” i zwolennikami PPSD i PSL Lewicy. Na wiecu w Przeworsku 27 grudnia 1918 r. w ferworze emocji przewrócono socjalistę razem z mównicą ${ }^{54}$.

W okresie kampanii wyborczej poza przypadkami niektórych wieców dochodziło także do innych niechlubnych przejawów rywalizacji, których celem było zastraszenie przeciwnika. W nocy z 8 na 9 stycznia 1919 r. milicja ludowa dokonała w Warszawie bezprawnej rewizji drukarni i skonfiskowała 7 tys. plakatów wyborczych NKWSD. W następną noc oddział żołnierzy dokonał najścia na endecki lokal wyborczy przy Nowym Świecie. 13 stycznia milicja ludowa dokonała najazdu na warszawski lokal NOWKP, a także zamknęła lokal „Kuriera Porannego"55. W Małopolsce najgorsza sytuacja panowała w tzw. republice tarnobrzeskiej, gdzie zwolennicy ks. Okonia nie pozwalali na równoprawną rywalizację wyborczą. Atakowali fizycznie uczestników spotkań formacji centroprawicowych, zmuszając ich do zwoływania spotkań po-

${ }^{50}$ Klęska ludowców w Grodzisku, „Gazeta Poranna 2 Grosze”, 3 I 1919, nr 3, s. 7; „Robotnik”: 13 I 1919, nr 18, s. 3; 24 I 1919, nr 39, s. 4.

51 „Piast”, 29 XII 1918, nr 52, s. 8; „Przyjaciel Ludu”, 29 XII 1918, nr 4, s. 11.

52 „Gazeta Warszawska”, 14 I 1919, nr 13, s. 4; „Gazeta Poranna 2 Grosze”, 17 I 1919, nr 16, s. 7.

53 „Piast”, 19 I 1919, nr 3, s. 12.

${ }^{54}$ „Piast”: 22 XII 1918, nr 51, s. 7-8; 29 XII 1918, nr 52, s. 7-9; 19 I 1919, nr 3, s. 12; „Przyjaciel Ludu": 22 XII 1918, nr 3, s. 10-13; 1 I 1919, nr 1, s. 11-14.

55 „Gazeta Warszawska”, 14 I 1919, nr 13, s. 4; „Gazeta Poranna 2 Grosze”, 14 I 1919, nr 13, s. 1. 
ufnych. Przerywali nabożeństwa, na których pojawiły się treści wyborcze: w święto Trzech Króli w Tarnobrzegu część chłopów rzuciła się na ambonę i przerwała odczytywanie listu biskupa w sprawie wyborów ${ }^{56}$. Pacyfikacje z grudnia 1918 r. i stycznia 1919 r. oraz aresztowanie ks. Okonia na wiecu w Baranowie (6 stycznia) pozwoliło opanować sytuację w tym okręgu wyborczym. Groźny incydent wydarzył się także w Krakowie, gdzie po wiecu PPSD 9 stycznia 1919 r. grupa robotników zdemolowała siedzibę „Ilustrowanego Kuriera Codziennego" 57.

Ogólnie można jednak powiedzieć, że skala złych form rywalizacji na obu arenach nie była duża, zakłócono niewielką liczbę wieców.

Rywalizację wyborczą uzewnętrzniała również prasa. Jej zaangażowanie było jednak nierówne. Konserwatywny „Czas” niemal w ogóle nie wikłał się w rozgrywkę wyborczą. Informował jednak o prawie wyborczym, sprawach związanych z organizacją wyborów, uczestnikach i rezultatach rywalizacji wyborczej. Krakowski „Głos Narodu" również drugoplanowo traktował wybory do SU, koncentrując się na przekazywaniu informacji dotyczących organizacji wyborów. Ten chadecki dziennik, doceniając zagrożenia stojące przed Polską, optował jednak za solidarnością narodową i popularyzował zawarcie porozumienie centroprawicowego w Krakowie, a informacyjnie wspierał także poczynania endecji i SKL ${ }^{58}$. Oba wymienione tytuły reprezentowały środowiska, które od rozgrywki wyborczej oczekiwały niewiele. W kampanię wyborczą na obu arenach rywalizacji zaangażowały się natomiast pisma reprezentujące formacje zainteresowane korzystnym dla siebie wynikiem wyborczym. Na terenie Królestwa widoczne to było np. w działaniach „Gazety Warszawskiej”, „Gazety Porannej 2 Grosze”, „Zorzy”, „Robotnika”, „Wyzwolenia”, w Małopolsce: „Piasta”, „Prawa Ludu” i „Przyjaciela Ludu”.

W rywalizacji na wiecach i na łamach prasy odnoszono się do różnych kwestii, ale nie wszystkie miały porównywalne znaczenie. Tworzywem eksploatowanym w zabiegach wokół pozyskiwania elektoratu była oferta programowa. Rekomendowano ją poprzez deklaracje programowe, odezwy wyborcze i ważne teksty publicystyczne ${ }^{59}$. Prezentacja programów wyborczych wykracza poza ramy niniejszego tekstu. W praktyce zresztą częściej operowano zredukowanymi, wyrażanymi hasłowo wersjami programów. W pismach endecji można było na przykład znaleźć taką odezwę: „Kto chce Polski zjednoczonej i silnej, kto pragnie skutecznej obrony przed zaborczym prusactwem, bolszewizmem i hajdamaczyzną, komu drogie jest hasło Bóg i Ojczyzna niech głosuje na listę $\mathrm{Nr} 10^{\prime \prime 60}$. Wręcz szczególny status miało dla obozu centroprawicy ha-

56 „Gazeta Warszawska”, 12 I 1919, nr 11, s. 2; „Piast”, 9 II 1919, nr 6, s. 5; J. Słomka, op. cit., s. 269; J. Rawski, op. cit., s. 74.

57 „Ilustrowany Kurier Codzienny”, 12 I 1919, nr 10, s. 4; Cz. Brzoza, op. cit., s. 273.

58 „Głos Narodu”: 12 I 1919, nr 5, s. 1; 13 I 1919, nr 6, s. 2; 18 I 1919, nr 10, s. 2; 21 I 1919, nr 13, s. 1; 22 I 1919, nr 14, s. 1.

59 T. Hołówko, Nasze postulaty, „Robotnik”, 24 XI 1918, nr 313, s. 1; Z czym idzie Polskie Stronnictwo Ludowe na Sejm, „Wyzwolenie”, 19 I 1919, nr 3, s. 2-3; Deklaracja programowa Stronnictwa Demokratyczno-Narodowego, „Gazeta Warszawska”, 30 XII 1918, nr 43, s. 7-8; J. Bojko, W. Witos, Bracia Ludowcy do walki i zwycięstwa, „Piast”, 22 XII 1918, nr 51, s. 1-2; J. Sanojca, Nasze żądania, „Przyjaciel Ludu", 29 XII 1918, nr 4, s. 6-7.

${ }^{60}$ „Gazeta Warszawska”, 26 I 1919, nr 25, s. 2. Numer 10 miała lista NKWSD w Warszawie. 
sło „Bóg i Ojczyzna”. Natomiast lewica niepodległościowa chętnie odwoływała się do haseł dotyczących sprawiedliwości społecznej i nadania chłopom ziemi. Kandydujący wówczas w okręgu zamojskim Maciej Rataj wspominał: „Punkt główny i bodajże jedyny, który obchodził i animował wyborców włościańskich, to było hasło reformy rolnej, nie w jakiejś formie sprecyzowanej, choćby zarysowanej w konturach, lecz jako «ziemia dla tych, którzy na niej pracują». To wystarczało! O reszcie kandydat nie potrzebował myśleć i mówić, bo go o to nie pytano"61. Tak wyrażona oferta programowa była też łatwa do zastosowania w ulotkach wyborczych i często była tam wykorzystywana.

Na obu głównych polach rywalizacji strony starały się zdyskredytować konkuren$\mathrm{cję}^{62}$. Przybrało to formę bratobójczej konfrontacji stronnictw odwołujących się do tych samych grup społecznych. Najczęściej oskarżano się wzajemnie o sprzeniewierzenie się tym środowiskom, o chęć podporządkowania ich siłom im wrogim: lewica niepodległościowa oskarżała PSL „Piast” i NZR, że służą grupom posiadającym, a centroprawica przekonywała, że lewica chce pozbawić chłopów ziemi, a robotników oddać pod panowanie Żydów. Bratobójczy konflikt wraz z towarzyszącą mu argumentacją był najbardziej widoczny w polemikach „Piasta” z „Przyjacielem Ludu”. W obu periodykach różne oskarżenia dotyczyły wprost Wincentego Witosa i Jana Stapińskiego, a obaj przywódcy osobiście angażowali się w ich wysuwanie ${ }^{63}$.

Główne argumenty, jakich używano w rywalizacji wyborczej, dotyczyły jednak dwóch innych kwestii. W wyborach do SU kluczowe znaczenie miał podział na dwa obozy: centroprawicę i lewicę niepodległościową. Każdy z nich miał różną wizję demokracji i siły podmiotów w niej uczestniczących. Oba obozy przywiązywały więc dużą wagę do uzmysłowienia wyborcom, że elekcja SU będzie momentem decydującym o realizacji danego/własnego projektu demokracji. Tworzywem, które posłużyło im do mobilizowania elektoratów, były trzy aspekty tego historycznego aktu: rozstrzygnięcie kwestii sił władających nową Polska, skład społeczny SU oraz jego znaczenie dla kreowania nowej rzeczywistości. Te aspekty wywarły wpływ na retorykę na obu arenach i polach rywalizacji, a retoryka autonomicznie nadawała wyborom wymiar plebiscytu.

Generalnie lewica podnosiła, że wybory do SU będą historyczną chwila, rozstrzygająca o tym, czy w nowej Polsce wpływy utrzymają stare, czy też nowe siły społeczne: chłopi, robotnicy, inteligencja pracująca. W „Robotniku” akcentowano: „Sprawa jest jasna: albo zwycięży robotnik i chłop, socjalista, ludowiec, garść inteligencji postępowej, albo obszarnik, kapitalista i ich służba" ${ }^{4}$. J. Stapiński pisał, że wybory do

${ }^{61}$ M. Rataj, Pamiętniki 1918-1927, Warszawa 1965, s. 30.

62 Vide M. Drewicz, op. cit., s. 12-289.

${ }^{6}$ Vide Co robili podczas wojny posłowie ludowi, a co robili socjaliści i p. Stapiński, „Piast”, 29 XII 1918, nr 52, s. 2-4; Sąd ludu o p. Stapińskim, „Piast”, 5 I 1919, nr 1, s. 5-6; W. Witos, Teraz albo nigdy, „Piast”, 12 I 1919, nr 2, s. 1-2; J. Czech, Do Braci ludowców w Królestwie!, „Przyjaciel Ludu”, 29 XII 1918, nr 4, s. 5-6; J. Stapiński, Przed sq̨d ludu, „Przyjaciel Ludu”, 26 I 1919, nr 4, s. 3-4.

${ }^{64}$ Przed wyborami, ,Robotnik”, 24 I 1919, nr 37, s. 1. W „Wyzwoleniu” porównywalny argument wysuwali: S. Thugutt (Nowy ład, ,Wyzwolenie”, 5 I 1919, nr 1, s. 2) oraz J. Kaźmierczak (Budujemy Polskę ludowa, ,Wyzwolenie”, 19 I 1919, nr 3, s. 1). 
SU otwierają szansę na przełamanie 1000-letnich rządów szlachty w Polsce ${ }^{65}$. Wskazywano, że grupy dotąd uprzywilejowane będą chciały utrzymać wpływy, aby Polska pozostała „pańska i kapitalistyczna” i lekceważono ich siłę. Młodzi publicyści byli gotowi na wyrost przesądzać o porażce posiadaczy, zwłaszcza o utracie władzy przez szlachtę: „Jest jakby kto umarł. Leży oto staruszka: władza szlachty — panów na katafalku” ${ }^{66}$. Kwestionowano też możliwości twórcze tej grupy społecznej: „Nie masz burżuazji bardziej ślepej, ograniczonej i zarazem niedołężnej jak nasza" ${ }^{67}$. Przyszłość demokratycznego państwa polskiego oraz samego ludu miała zależeć od wejścia nowych sił społecznych do SU. Wszak to nie poszczególne partie, ale właśnie SU miał tworzyć nową Polskę. Socjaldemokratyczne „Prawo Ludu” utrzymywało, że SU „będzie kuźnią ustaw, na których oprze się cała budowa polskiej republiki ludowej”68. W „Robotniku” pisano więc: „My musimy dążyć do tego, aby w tym Sejmie określającym charakter przyszłej Polski, była większość, szczerze reprezentująca interesy pracowitego ludu polskiego" ${ }^{\circ}$. Wezwaniu temu wtórował ludowiec Stanisław Thugutt, podnosząc, że: „Od tego, czy lud się obudzi, czy wyśle właściwych swoich obrońców do Sejmu, zależy na długie lata jego przyszłość, jego rozwój, jego szczęście i los"ᄁo. Lewica roztaczała też wizję sukcesu wyborczego. Źródłem przekonania, że odniosą go warstwy ludowe, był czynnik arytmetyczny. W emitowanej w grudniu 1918 r. odezwie wyborczej PPS głoszono: „Masy pracujące stanowią ogromną większość. Od ich głosowania zależy, czy one będą gospodarzami Polski, czy rządy w Polsce będą zgodne $\mathrm{z}$ ich wolą $\mathrm{i}$ ich interesami" "’1. Lewica wykorzystywała wymienione motywy jako tworzywo mobilizacji różnych środowisk pracy do udziału w wyborach i oddania głosu na listy stronnictw reprezentatywnych dla ludu. W jej retoryce uderzające było to, że nadawała ona wyborom SU wymiar swoistego rewolucyjnego Armagedonu, w ramach którego nowe siły dobra pokonają dawne zło. W odezwie PPS ze stycznia $1919 \mathrm{r}$. kategoryzowano: ,albo nastaną czasy swobody i sprawiedliwości, albo zapanuje jeszcze większy ucisk, niewola i wyzysk pracy"72.

Na przełomowy sens wyborów wskazywał - choć w innej optyce i w stonowany sposób — również obóz centroprawicowy. W „Gazecie Porannej 2 Grosze” pisano: „Od nich zależeć będzie, czy Polska pójdzie po drodze rozwoju sił swoich, będących wynikiem twórczości narodowej, czy też spadnie w otchłań zamętu społecznego"733. Józef Hłasko podkreślał, że odbudowa Polski jest zadaniem niezwykle trudnym, któremu można podołać pod warunkiem solidarnego skupienia wysiłków wszystkich

65 J. Stapiński, Teraz albo nigdy!, „Przyjaciel Ludu”, 12 I 1919, nr 2, s. 1-3.

66 J. Sanojca, Na pogrzebie rzqdów pańskich, „Przyjaciel Ludu”, 19 I 1919, nr 3, s. 2-3.

${ }^{67}$ Przed wyborami, „Robotnik”, 24 I 1919, nr 37, s. 1.

${ }_{68}$ Wybory do Sejmu w Warszawie, „Prawo Ludu”, 1 XII 1918, nr 48, s. 2.

${ }^{69}$ Wybory, „Robotnik”, 16 XII 1918, nr 353, s. 1.

${ }^{70}$ S. Thugutt, Nowy lad, „Wyzwolenie”, 5 I 1919, nr 1, s. 2.

71 „Robotnik”, 19 XII 1918, nr 359, s. 1.

72 „Robotnik”, 1 I 1919, nr 378, s. 2. Na rozstrzygające znaczenie wyborów do SU zwracał także uwagę M. Niedziałkowski (My albo oni, „Robotnik”, 22 XII 1918, nr 365, s. 1) oraz Z. Zaremba (Sejm Ustawodawczy a klasa robotnicza, „Robotnik”, 25 I 1919, nr 39, s. 2).

${ }^{73}$ Przed wyborami, „Gazeta Poranna 2 Grosze”, 10 I 1919, nr 9, s. 1. 
warstw społecznych i międzynarodowego wsparcia ${ }^{74}$. Ten punkt widzenia skłaniał różne pisma tego obozu do wezwania, aby w wyborach SU oddać głos na listy skupiające ludzi najlepszych, gotowych wznieść się ponad partyjne interesy, kierujących się dobrem narodu ${ }^{75}$. Od tej linii rozumowania w pewnym stopniu odbiegała argumentacja autorów publikujących na łamach „Piasta”. Podzielając ogólną dyrektywę centroprawicy, przywiązywali oni jednak wagę do czynnika arytmetycznego i podkreślali, że chłopi stanowią ok. $80 \%$ polskiego społeczeństwa ${ }^{76}$. Wykorzystywali więc ten argument do mobilizowania własnego elektoratu do udziału w wyborach i przewidywania, że przyniosą one duży udział chłopów w SU i w rządach. Maciej Czuła pisał: „Nas chłopów jest najwięcej, nasze stronnictwo jest najliczniejsze, a więc na czele rządu polskiego powinni stać członkowie naszego stronnictwa, a przynajmniej większość członków rządu musi być nasza. Tego domaga się prosta sprawiedliwość" "77. Wybory do SU miały więc urzeczywistnić zawartą w programie PSL „Piast” wizję Polski ludowej, rozumianej jednak w sensie emancypacyjno-inkluzywnym, bez wykluczania innych grup i ze zrozumieniem potrzeby uwzględnienia chłopów jako społecznej podstawy państwa i realnego współgospodarza kraju.

Wyraźną linię podziału między obozami rywalizującymi w wyborach do SU wytyczał ich stosunek do rządu Jędrzeja Moraczewskiego, urzędującego do połowy stycznia 1919 r. Rząd pomyślany jako rząd ogólnonarodowy realnie był rządem lewicowym. Na znaczenie tej kwestii wskazuje los ludowców w Małopolsce. Na początku grudnia 1918 r. doszło do zjednoczenia ugrupowań PSL „Piast” i PSL Lewica, lecz porozumienie to błyskawicznie zostało zerwane. Kwestią, która podzieliła przywódców obu odłamów, był właśnie stosunek do rządu J. Moraczewskiego - jako lewicowego bronił go Stapiński, a Witos optował za jego reorganizacją w kierunku utworzenia rządu ogólnonarodowego ${ }^{78}$. Oba ugrupowania znalazły się w przeciwstawnych obozach i toczyły między sobą bratobójczą walkę, a ujawnienie ich stosunku do rządu stało się kolejnym kluczowym tworzywem, eksploatowanym przez te obozy na obu arenach i polach rywalizacji wyborczej.

Niepodległościowa lewica zgodnie i zdecydowanie broniła rząu J. Moraczewskiego. Dla niej autonomiczną wartością było to, że był to rząd ludowy i jako taki potwierdzał jej wizję Polski ludowej i zdolność ludu do sprawowania w niej władzy. W publicystyce wskazywano, że jest reprezentatywny dla świata pracy, doceniano jego praktyczne poczynania w zakresie restytucji państwa, przypisywano mu autorstwo korzystnego ustawodawstwa, w tym przyjęcie demokratycznej ordynacji wyborczej.

74 J. Hłasko, Przed wyborami, „Gazeta Warszawska”, 22 I 1919, nr 21, s. 3. Podobnie: „Głos Narodu”, 22 I 1919, nr 14, s. 1.

75 Ważna sprawa, „Głos Narodu”, 5 I 1919, nr 4, s. 1; O zgodę i sitę narodowa, „Czas”, 17 I 1919, nr 11, s. 1 .

${ }_{76}$ Baczność ludowcy i ludowczynie!, „Piast”, 15 XII 1918, nr 50, s. 1-2; O chtopska konstytuantę, „Piast”, 12 I 1919, nr 2, s. 3-4.

${ }^{77}$ M. Czuła, Dalej chlopy do roboty, „Piast”, nr 15 XII 1918, nr 50, s. 2-3.

${ }^{78}$ Nowy Zjazd PSL, „Piast”, 22 XII 1918, nr 51, s. 3; Nowe stronnictwo, „Piast”, 29 XII 1918, nr 52, s. 1-2; J. Stapiński, Baczność ludowcy!, „Przyjaciel Ludu”, 22 XII 1918, nr 3, s. 1-2. 
Wręcz eksponowano, że to właśnie jego zasługą było nadanie praw wyborczych kobietom ${ }^{79}$. Formą obrony gabinetu Moraczewskiego było też przyjmowanie na wiecach pochwalnych dla niego uchwał. W rezolucji uchwalonej na wielkim wiecu zorganizowanym przez PSL „Wyzwolenie” 8 grudnia 1918 r. w Warszawie zgromadzeni byli zgodni, że: „Rząd ten uważają za prawdziwego przedstawiciela ludu polskiego i wierza, że potrafi on zaprowadzić niebawem w kraju ład oparty na sprawiedliwości. Rządowi broniącemu interesów ludu polskiego, lud ten okaże najwyższe poparcie, nie skąpiąc ani żołnierza dla obrony granic Ojczyzny, ani mienia swego na jej potrzeby, ani też zaopatrzenia miasta w żywność’" ${ }^{80}$.

Oddziaływanie obozu centroprawicy było w tym aspekcie dwutorowe.

$\mathrm{Z}$ jednej strony kontestował on rząd lewicowy. Publicyści tego obozu podnosili, że jest to rząd prowizoryczny, niereprezentujący większości społeczeństwa, partyjny i złożony głównie z socjalistów. Krytykowali go za nieudolność w rozwiązywaniu problemów tworzącego się państwa, tolerowanie tendencji bolszewickich, złą organizację wyborów i nadużycia komisarzy wyborczych ${ }^{81}$. Ta krytyka była przenoszona na wiece zwoływane przez formacje centroprawicowe i znajdowała odbicie w przyjmowanych na nich uchwałach. Przykładem może być rezolucja ze stycznia 1919 r. z wiecu w Makowie, w której podnoszono, że rząd Moraczewskiego „nie orientuje się w sytuacji międzynarodowej, nie broni kresów, wykazuje nieudolność w rządach wewnętrznych, krępuje wolność słowa i druku", a także obsadza urzędy Żydami ${ }^{82}$.

$\mathrm{Z}$ drugiej strony formacje centroprawicowe zgodnie wzywały do utworzenia rządu ogólnonarodowego, reprezentatywnego dla społeczeństwa i części składowych restytuowanej Polski, zwłaszcza Wielkopolski ${ }^{83}$. Żądanie to przedstawiano i w prasie, i na wiecach. Krytyka wzmogła się po nieudanym zamachu na gabinet Moraczewskiego, zorganizowanym w nocy z 5 na 6 stycznia 1919 r. Jednym z jego skutków było utworzenie rządu przez Ignacego Paderewskiego. Ten rząd zyskał uznanie centroprawicy, ale był też tolerowany przez lewicę ${ }^{84}$.

Kwestia rządu odegrała istotną rolę w kampanii wyborczej. Była podnoszona przez obydwa główne obozy polityczne i pełniła porównywalne funkcje. Bronienie przez lewicę rządu ludowego wzmacniało zarówno pozycję gabinetu, jak i samej lewicy, a hasło obrony rządu ludowego podnoszone w prasie i na wiecach było tworzywem mo-

79 A. Mur, W Rzqdzie Ludowym nasza moc, ,Przyjaciel Ludu”, 15 XII 1918, nr 2, s. 1-2; K. Laskowski, Rzqd ludowy w Warszawie, ,Przyjaciel Ludu”, 1 I 1919, nr 1, s. 1-2; T. Nocznicki, ,Ludu Polski!”, ,Wyzwolenie", 26 I 1919, nr 4, s. 1-2.

${ }^{80}$ „Wyzwolenie”, 15 XII 1918, nr 50, s. 1.

${ }^{81}$ Nowy rzą, „Głos Narodu”, 16 XI 1918, nr 258, s. 1; Partyjny gabinet, „Głos Narodu”, 21 XI 1918, nr 262, s. 1; Partyjny rząd, „Czas”, 28 XI 1918, nr 517, s. 1; O zgodę i sitę narodowa, „Czas”, 17 I 1919 , nr 11, s. 1; Rzqd partyj, „Gazeta Warszawska”, 19 XI 1918, nr 4, s. 3; J. Hłasko, Uchwały tarnowskie, „Gazeta Warszawska”, 5 XII 1918, nr 20, s. 1; J. Łużyc, Na martwym punkcie, „Gazeta Warszawska”, 5 I 1919 , nr 5, s. 1; Nareszcie!, „Gazeta Poranna 2 Grosze”, 18 I 1919, nr 17, s. 2.

${ }^{82}$ „Gazeta Warszawska”, 4 I 1919, nr 4, s. 7.

${ }^{83}$ Rezolucja Zjednoczenia Narodowego, „Gazeta Warszawska”, 19 I 1918, nr 4, s. 4; O rzad narodowy, „Gazeta Warszawska”, 18 XII 1918, nr 33, s. 1;

${ }^{84}$ Po zamachu, „Gazeta Poranna 2 Grosze”, 7 I 1919, nr 6, s. 1-2; Nareszcie!, „Gazeta Poranna 2 Grosze”, 18 I 1919, nr 17, s. 2; „Gazeta Warszawska”, 18 I 1918, nr 17, s. 3; Nareszcie!, „Gwiazdka Cieszyńska”, 21 I 1919, nr 6, s. 1; A. Bogusławski, op. cit., s. 236-237. 
bilizowania opinii publicznej, generowania emocji, a za tym krystalizowania stanowiska wyborczego, zwłaszcza u osób niezdecydowanych. Natomiast obóz centroprawicy zyskiwał na krytyce rządu Moraczewskiego osłabienie jego pozycji, a w kontekście kampanii wyborczej generowanie oporu przeciw niemu, co wraz z hasłem tworzenia rządu narodowego pozwalało skupić siły pod egidą Narodowej Demokracji i kreować korzystną dla centroprawicy preferencję wyborczą. Dymisja rządu generalnie osłabiła też pozycję i morale jej konkurencji. Uczestnik tamtych wydarzeń, A. Bogusławski z PSL „Wyzwolenie” wspominał: „Byliśmy przybici tą nagłą dymisją Rządu Ludowego" "."

\section{ROLA KOBIET}

Przyjmując demokratyczne zasady elekcji SU, Polska znalazła się w gronie pierwszych państw na świecie, które nadały kobietom pełnię praw wyborczych. Kobiety odegrały dużą i wieloaspektową rolę w uruchomieniu naszej konstytuanty. Stanowiły większość elektoratu, co wynikało z naturalnych procesów demograficznych oraz udziału mężczyzn w walkach na frontach I wojny światowej i ponoszonych na nich stratach. Zachowania wyborcze kobiet były więc ważne dla ogólnego wyniku elekcji $^{86}$. Poszczególne formacje zdawały sobie z tego sprawę i zabiegały o kobiece wspar$\mathrm{cie}^{87}$. W konsekwencji kobiety odegrały czynną i widoczną rolę w kreowaniu kampanii wyborczej. Ten rys kampanii został w niniejszym artykule przedstawiony tylko ogólnie, ale z pewnością udział kobiet w wyborach do SU w 1919 r. zasługuje na odrębne i obszerniejsze opracowanie.

Kobiety wzięły udział w kampanii wyborczej w formie zorganizowanej. Tworzyły własne struktury organizacyjne w ramach powstałych obozów politycznych. Najbardziej widoczne było to w przypadku centroprawicy. W Królestwie pod egidą endecji zawiązała się Narodowa Organizacja Wyborcza Kobiet Polskich, czynna w Warszawie i w innych ośrodkach ${ }^{88}$. Animowane przez endecję kobiece ugrupowania wyborcze nosiły następujące nazwy: w Sosnowcu był to Narodowy Komitet Wyborczy Kobiet Polskich, w Lublinie Komitet Narodowy Kobiet Polskich, w Lodzi Narodowa Organizacja Wyborcza Kobiet ${ }^{89}$. Kobiety angażowały się także po stronie obozu centroprawicowego. W Warszawie były to: Katolicki Związek Kobiet Polskich i Narodowy Blok Wyborczy Akademiczek, a w Radomiu Zjednoczenie Polek ${ }^{90}$. Podobnych inicjatyw było na terenie Królestwa więcej, przy czym cechowała je skłon-

85 A. Bogusławski, op. cit., s. 236.

${ }^{86}$ Dostrzegano to wówczas. W „Gazecie Porannej 2 Grosze” oceniano: „W obecnych wszakże czasach wojennych, nienormalnych, przewaga liczebna głosów kobiecych jest tak znaczna, że bez przesady rzec można, iż od nich głównie zależeć będzie przyszłe ukształtowanie się składu posłów Sejmu polskiego" (Polki a sejm, „Gazeta Poranna 2 Grosze”, 23 I 1919, nr 22, s. 1).

87 Baczność ludowcy i ludowczynie!, „Piast”, 15 XII 1918, nr 50, s. 1-2; Wybory do Sejmu a Kobiety, „Robotnik”, 24 XII 1918, nr 368, s. 2; Do Kobiet!, „Robotnik”, 28 XII 1918, nr 371, s. 1.

${ }^{88}$ „Gazeta Warszawska”:19 XII 1918, nr 34, s. 3; 16 I 1919, nr 15, s. 4; „Gazeta Poranna 2 Grosze”, 2 I 1919, nr 2, s. 7.

89 „Gazeta Warszawska”, 18 XII 1918, nr 33, s. 4.

90 „Gazeta Warszawska”: 17 XII 1918, nr 32, s. 4; 3 I 1919, nr 3, s. 3. 
ność do integrowania różnych bytów społecznych ${ }^{91}$. W Małopolsce w obozie centroprawicy lokowały się: Koło Polityczne Kobiet, Klub Polityczny Polek PSR i Polski Związek Niewiast Katolickich. Obóz lewicy miał skromniejszą organizację wyborczą kobiet. W Królestwie bardziej widoczne było to w przypadku PPS, która w ramach swoich struktur miała ,wydziały kobiece” oraz utworzyła Lewicowy Blok Wyborczy Akademiczek $^{92}$. W Małopolsce socjaliści oddziaływali na kobiety poprzez „Głos Kobiet”, który ukazywał się pod redakcją Doroty Kłuszyńskiej, jako miesięczny dodatek do „Prawa Ludu”, organu PPSD. Dodatek ten zawierał szereg treści angażujących kobiety do udziału w wyborach ${ }^{93}$. Natomiast w wielu stronnictwach obu obozów kobiety nie tworzyły własnych form organizacyjnych, ale uczestniczyły wprost w pracy ich głównych struktur.

Niezależnie od formy organizowania się kobiet ich działania w kampanii wyborczej do SU cechowała duża kreatywność. W prasie zachęcały one do udziału w kampanii i w samych wyborach. W apelach nawiązywały do efektywnego wykonywania przez kobiety ról męskich podczas I wojny i na kanwie tego przekonywały o swojej zdolności do wypełniania ról obywatelskich i samodzielnych zachowań wyborczych. Kobiety wzywały też do oddawania głosów na popierane przez nie formacje ${ }^{94}$. Same również animowały kampanię wyborcza, organizując wiece i spotkania ${ }^{95}$. Brały udział w szeregu innych przedsięwzięć podejmowanych przez macierzyste ugrupowania. Większość kobiet angażowała się po stronie konkretnych formacji politycznych i tworzonych przez nie obozów, ale podejmowały też próby samodzielnych wystapień. Przykładem może być inicjatywa znanej feministki Izy Moszczeńskiej, która w Warszawie zainicjowała wystawienie samodzielnej listy kobiecej pod nazwą „Centrum Kobiece”. Inicjatywa ta zakończyła się jednak klęską, na listę oddano bowiem jedynie 51 głosów $^{96}$.

${ }^{91}$ Np. w Łodzi NOWKP była federacją, którą tworzyły: sekcja kobiet w Magistracie, pracownice poczty i sądów, Zrzeszenie Kobiet Pracujących Zawodowo, Stowarzyszenie Ochroniarek, Stowarzyszenie Pielęgniarek, pracownice „Kropli Mleka”, Bractwo „Żywej Róży”, Macierz Szkolna, nauczycielki szkół elementarnych, bałuckie Towarzystwo Gimnastyczne „Sokół”, ewangeliczki z parafii św. Trójcy, Stowarzyszenie Sług Katolickich, Towarzystwo Śpiewacze im. Ignacego Jana Paderewskiego, Towarzystwo Śpiewacze im. Stanisława Moniuszki, Chór Ewangelicki; vide Narodowa organizacja kobiet 1919 w tódzkiem, <http://www.narodowalodz.pl/wojewodztwo>, dostęp 14 II 2018.

92 „Robotnik”: 8 I 1919, nr 9, s. 3; 17 I 1919, nr 25, s. 3.

93 Rozszerzenie prawa wyborczego dla kobiet, „Głos Kobiet”, 7 IV 1918, nr 3, s. 1-2; Bierne i czynne prawo wyborcze, „Głos Kobiet”, 11 VIII 1918, nr 7, s. 1; Kobiety wobec wyborów, „Głos Kobiet”, 15 XII 1918 , nr 10, s. 1.

${ }^{94}$ M. Goczałowa, Do kobiet wiejskich, „Piast”, 5 I 1919, nr 1, s. 6; H. Matuszowa, H. Kaczkowska, Odezwa do Wyborczyń!, „Przyjaciel Ludu”, 19 I 1919, nr 3, s. 1-2; K. Świątek, Do Kobiet Polek włościanek!, „Przyjaciel Ludu”, 26 I 1919, nr 4, s. 6; Kobiety wobec wyborów, „Głos Kobiet”, 15 XII 1918, nr 10, s. 1; Odezwa Narodowego Bloku Akademiczek, „Gazeta Warszawska”, 20 I 1919, nr 19, s. 4; Kobiety Polki!, „Gazeta Poranna 2 Grosze”, 12 I 1919, nr 11, s. 2.

${ }^{5} \mathrm{~Np}$. ,wydział kobiecy” PPS zorganizował na terenie Łodzi 10 wieców, na których było ok. 10 tys. kobiet (Akcja wyborcza PPS wśród kobiet, „Robotnik”, 17 I 1919, nr 25, s. 3). W Warszawie w organizację wieców silnie włączyła się NOWKP, organizująca czasem po kilka wieców dziennie (,Gazeta Poranna 2 Grosze": 10 I 1919, nr 9, s. 5; 19 I 1919, nr 18, s. 3).

96 „Gazeta Warszawska”, 30 I 1919, nr 29, s. 1. 
Co ważne, kobiety występowały też z własnymi propozycjami programowymi. Kobiety występujące po stronie obozu centroprawicowego widziały Polskę zjednoczona, z silnym i sprawiedliwym rządem narodowym, jako kraj wierny tradycji i katolicyzmowi, chciały szkół narodowych i wyznaniowych z nauką praktyczną, żądały formalnego zrównania ich z mężczyznami, ochrony nierozerwalności małżeństwa, opieki nad kobietami skrzywdzonymi moralnie, ochrony kobiet pracujących i sprawiedliwych płac, ochrony macierzyństwa oraz walki z alkoholizmem ${ }^{97}$. W PPS i PSL „Wyzwolenie” zwracały natomiast uwagę na konieczność poprawy sytuacji społecznej kobiet poprzez ich rzeczywiste równouprawnienie, wprowadzenie urlopów macierzyńskich, bezpłatnej pomocy lekarskiej, opieki przedszkolnej i szkolnej oraz zasiłków, wprowadzenie zakazu pracy nocnej, szkodliwej dla zdrowia, zrównanie zarobków kobiet $z$ tymi otrzymywanymi przez mężczyzn oraz eliminacji prostytucji ${ }^{98}$.

Kobiety oczywiście dążyły do uzyskania mandatów w SU. Źródła wskazują jednak na znamienny problem. Poza wspomnianym już przypadkiem listy „Centrum Kobiece" w Warszawie kobiety rzadko były wpisywane na listy wyborcze. Bez względu na podział polityczny w wielu przypadkach listy nie zawierały żadnego nazwiska kobiecego, a jeśli było, to zazwyczaj było to jedno nazwisko i raczej do wyjątków można zaliczyć listy, na których były dwie kandydatury żeńskie. Ważne było i to, na jakich miejscach zostały one ulokowane. Wybory do SU odbywały się według formuły proporcjonalnej, realizowanej w okręgach wielomandatowych. Szansę uzyskania mandatu mieli kandydaci usytuowani na początkowych miejscach list wyborczych. Tymczasem tylko jedno ugrupowanie, PSL ,Wyzwolenie”, zdecydowało się ulokować działaczkę Jadwigę Dziubińską na pierwszym miejscu swojej listy w okręgu nr 7 (Włocławek, Nieszawa). Tylko na kilkunastu listach kobiety zajmowały drugie lub trzecie miejsce. Nazwiska kobiet umieszczano pod koniec list, a nierzadko na ostatnich miejscach. Obecność i usytuowanie nazwisk kobiet na listach wyborczych były wręcz kontrastująco nieadekwatne do dużej roli, jaką odgrywały one w kampanii wyborczej i w samej elekcji. Ze słabej pozycji kobiet zdawano sobie sprawę w obu głównych obozach politycznych. Oceniano, że są,,jakby dla ozdoby listy” i na elekcję ,nie mają niemal zupełnie szans"99. Po wyborach w 1919 r. w SU znalazło się tylko sześć reprezentantek różnych formacji. Wydaje się, że źródłem tego swoistego fenomenu była ówczesna kultura polityczna. Polska wprawdzie nadała kobietom pełnię praw wyborczych, ale jej klasa polityczna nie była jeszcze mentalnie przygotowana na podmiotowe odgrywanie przez kobiety ról politycznych. Ich udział w polityce rozważano raczej w kategorii symbolu. Kiedy na warszawskiej liście NKWSD ulokowano na trzecim miejscu Gabrielę Balicką, żonę zmarłego podczas I wojny współtwórcy ruchu narodowego, Zygmunta Balickiego, to w „Gazecie Warszawskiej” pisano, że komitet „złożył w ten sposób hołd należny kobiecie polskiej, która w długoletnim okresie zma-

97 „Gazeta Warszawska”, 23 XII 1918, nr 38, s. 4; Kobiety a polskie wybory, „Głos Narodu”, 18 I 1919, nr 11, s. 2 (Odezwa Polskiego Związku Niewiast Katolickich).

98 „Robotnik”, 29 XII 1918, nr 373, s. 1; W. Weychert-Szymanowska, Do Kobiet!, „Wyzwolenie”, 19 I 1919, nr 3, s. 13.

99 „Wyzwolenie”, 19 I 1919, nr 3, s. 13; „Czas”, 26 I 1919, nr 20, s. 3. 
gania się z losem i walki o wolność narodu naszego, reprezentowała zawsze jego siłę czynna, wysoko trzymała sztandar ideałów narodowych"100.

\section{KOMUNIKACJA WYBORCZA}

Dla organizacji i rozstrzygnięcia elekcji kapitalne znaczenie miały wszelkie informacje wyborcze. Obowiązek informowania obywateli spoczywał na młodym państwie polskim i jego administracja dokładała starań, aby go właściwie wypełnić. Dekrety dotyczące wyborów były ogłaszane w „Dzienniku Praw Państwa Polskiego”, rozlepiano je też na murach domów. Inne informacje ważne w procedurze wyborczej, zwłaszcza komunikaty o siedzibach komisji wyborczych i usytuowaniu lokali wyborczych, przekazywano wyborcom także $\mathrm{w}$ formie różnych obwieszczeń naklejanych wprost na murach domów. W proces komunikowania włączyły się neutralne instytucje. Powstała w 1917 r. prywatna wówczas warszawska Szkoła Nauk Politycznych organizowała spotkania, na których prawo wyborcze wykładali znakomici uczeni, m.in. Józef Buzek i Julian Makowski ${ }^{101}$. Ciężar przekazania wyborcom najważniejszych informacji brały na siebie również podmioty zainteresowane uzyskaniem poparcia. Przy często ograniczonych zasobach finansowych stworzyły one system komunikacyjny złożony z wielu elementów. Informacje wyborcze przekazywano poprzez: a) działanie komitetów i biur wyborczych oraz biur porad; b) wiece i spotkania przedwyborcze; c) emisję broszur i instrukcji - autorstwa osób związanych z daną formacją - omawiających ordynację wyborczą do $\mathrm{SU}^{102}$; d) kolportaż apeli i odezw, ulotek, plakatów i kartek z numerami list; d) prasę wydawaną w dziesiątkach tysięcy egzemplarzy.

Prasa wydawana przez stronnictwa polityczne odegrała wręcz specjalną rolę w procesie komunikacji wyborczej. Poszczególne tytuły uruchamiały stałe rubryki dotyczące wyborów do SU: w „Czasie” były to rubryki: „Przygotowania do wyborów” i „Przed wyborami”; w „Głosie Narodu”: „Przygotowania wyborcze” i „Z ruchu wyborczego”; w „Piaście”: „Z ruchu wyborczego” „Ruch wyborczy”; w „Gazecie Warszawskiej”: „Ruch przedwyborczy”, „Z ruchu wyborczego” i „Wybory do Sejmu”; w „Gazecie Porannej 2 Grosze”: „Przed wyborami”, „Z prowincji”; w „Przyjacielu Ludu”: „Walka przedwyborcza”; w „Prawie Ludu”: „Ruch wyborczy”; w „Robotniku”: „Akcja wyborcza” i „Na prowincji”, „Z prowincji”. Szereg informacji wyborczych podawano w stałych rubrykach pism, a ważniejsze kwestie omawiano w odrębnych tekstach.

Treść komunikatów wyborczych była bogata. Omawiano prawo wyborcze i zmiany w nim zachodzące, informowano o uprawnieniach i pożądanych zachowaniach wyborców, terminach wyborczych, lokalizacji i terminach dyżurów komisji wyborczych i komitetów oraz biur wyborczych danych partii, informowano o numeracji i kształcie tery-

100 Zygmuntowa Balicka, „Gazeta Warszawska”, 1 II 1919, nr 31, s. 1.

101 „Gazeta Poranna 2 Grosze”, 3 I 1919, nr 3, s. 4. Szkolenia przeprowadzało też Biuro Pracy Społecznej.

102 A. Bogusławski, O ordynacji wyborczej (Objaśnienie ogłoszonej ordynacji wyborczej), Warszawa 1918; L. Nowodworski, O ordynacji wyborczej do pierwszego Sejmu Polskiego. Wyjaśnienia i wskazówki praktyczne, Warszawa 1918; A. Czarski (Z. Zaremba), Jak i kogo wybierać do Sejmu, Warszawa 1918. 
torialnym okręgów wyborczych, numerach list i widniejących na nich kandydaturach, wiecach i spotkaniach przedwyborczych, frekwencji i uchwałach na nich podejmowanych, odsłaniano aktywności własnego elektoratu, przebieg rywalizacji, nieprawidłowości polityczne i organizacyjne, eksponowano rozliczne apele, odezwy i komunikaty ważne dla elekcji, informowano o wynikach wyborów i wielu szczegółowych kwestiach.

Przekazywane informacje nie miały równorzędnego statusu. Podmioty zainteresowane sukcesem przywiązywały szczególną wagę do kilku kwestii.

Po pierwsze, systematycznie przypominano własnym stronnikom o potrzebie sprawdzenia, czy są ulokowani na liście wyborców, bo to był warunek efektywnego poparcia $^{103}$.

Po drugie, informowano o usytuowaniu komisji i lokali wyborczych.

Po trzecie, wskazywano, na jaki numer listy powinni oddać swój głos. Kwestia była istotna, ponieważ — zgodnie z ordynacją wyborczą - listy z kandydatami na posłów otrzymywały w poszczególnych okręgach wyborczych numer zgodny z kolejnością ich zgłaszania. Oznaczało to, że listy tych samych formacji miały w okręgach różne numery ${ }^{104}$.

Po czwarte, instruowano wyborców o sposobie wypełnienia karty wyborczej. W tym przypadku przekazy bywały wręcz precyzyjne. W „Robotniku” pouczano: „Rozmiar, format i kolor tych kart są dowolne. Na karcie wyborca oznaczać winien jedynie numer listy wyborczej, na którą oddaje swój głos. Numer na karcie umieszczony może być drukowany, hektografowany, pisany ołówkiem, piórem lub na maszynie — w formie cyfry arabskiej lub rzymskiej. Przy numerze mogą być umieszczone dodatki, zawierające wyłącznie wskazówki co do samego numeru, na przykład: Nr. 2, lista Nr. 2, na listę Nr. 2, głosuję na listę numer drugi itp. Napisy wszelkiej innej treści są niedopuszczalne i skutkują nieważność karty. Zwłaszcza nie wolno pisać swego nazwiska na karcie”105. Instrukcje bywały też humorystyczne: „Do głosowania trzeba iść już z domu z kartką przysposobioną i nikomu tej kartki po drodze nie pokazywać, gdyż mógłby się trafić przeciwnik, któryby kartkę popsuł, a mogłoby braknąć czystego papieru na nową kartkę"106.

Po piąte, instruowano wyborców o sposobie zachowania się w lokalu wyborczym, a więc że trzeba przyjść z dowodem tożsamości, własną kartę wyborczą włożyć do ostemplowanej koperty. Pełnomocników list pouczano odnośnie ich roli ${ }^{107}$.

${ }^{103}$ L. Nowodworski, Gdzie i kiedy sprawdzać listy wyborcze w Warszawie, „Gazeta Poranna 2 Grosze”, 4 I 1919, nr 4, s. 1; Kobiety Polki!, „Gazeta Poranna 2 Grosze”, 12 I 1919, nr 11, s. 2; Cztery tygodnie do wyborów (Ważne wskazówki wyborcze), „Prawo Ludu”, 29 XII 1918, nr 52, s. 2, Akcja wyborcza, „Robotnik”, 8 I 1919, nr 9, s. 3; „Gwiazdka Cieszyńska”, 21 I 1919, nr 6, s. 1-3.

104 Na jaka listę głosować?, „Gazeta Poranna 2 Grosze”, 25 I 1919, nr 24, s. 1; Nasi kandydaci na posła do Sejmu, „Piast”, 19 I 1919, nr 3, s. 3-5; „Wyzwolenie”, 26 I 1919, nr 4, s. 4-6; „Przyjaciel Ludu”, 19 I 1919, nr 3, s. 11; „Robotnik”, 22 I 1919, nr 33, s. 1.

105 Akcja wyborcza, ,Robotnik”, 15 I 1919, nr 21, s. 3.

106 „Przyjaciel Ludu”, 19 I 1919, nr 3, s. 11.

107 Jak głosować?, „Głos Narodu”, 25 I 1919, nr 17, s. 1; Przed wyborami, „Gazeta Poranna 2 Grosze”, 20 I 1919, nr 19, s. 1; Akcja wyborcza, ,Robotnik”, 22 I 1919, nr 33, s. 2-3; O obowiazkach przedstawicieli grup wyborczych, ,Robotnik”: 22 I 1919, nr 34, s. 1; 25 I 1919, nr 40, s. 4. 


\section{WYNIKI WYBORÓW}

Zmasowana agitacja przyczyniła się do licznego udziału społeczeństwa w elekcji konstytuanty niepodległej Polski. Ze względu na brak źródeł tylko szacunkowo można wskazać, że 26 stycznia 1919 r. do udziału w wyborach uprawnionych było orientacyjnie 5,8 mln osób, w tym ok. 4,6 mln w Królestwie i ok. 1,2 mln w Małopolsce. Łącznie oddało głos 4551283 osób, w tym w 29 okręgach królewiackich — 3567635 , a 11 małopolskich — 983648 osób. Frekwencja wyborcza była więc wysoka: w Królestwie wahała się w poszczególnych okręgach od 56,7\% (okręg nr 21, powiaty: chełmski, hrubieszowski i tomaszowski) do 87,5\% (okręg nr 27, powiaty: pińczowski i stopnicki), a w Małopolsce od 59,5\% (okręg nr 46, powiaty: przemyski, brzozowski i birczański) do 84,5\% (okręg nr 42, powiaty: tarnowski, brzeski, bocheński, dąbrowski i pilzneński) ${ }^{108}$. Społeczeństwo polskie sprostało więc ważnemu państwowotwórczemu obowiązkowi. Jego zachowanie rozwiało też poważną watpliwość związaną z dużą liczbą list wyborczych. Zaniepokojona Maria Dąbrowska wspominała: „Prawdziwy kłopot z głosowaniem do sejmu, gdy na 16 posłów z Warszawy jest 21 list"109. Faktycznie, charakterystycznym rysem wyborów do SU w 1919 r. była znacząca liczba list wyborczych. Liczba mandatów do zdobycia lokowała się we wszystkich okręgach w przedziale od czterech do 16, ale tylko w jednym było ponad 10 mandatów. Natomiast liczba list zarejestrowanych w okręgach wyborczych sytuowała się w przedziale od dwóch do 21. Tylko w sześciu przypadkach liczba list w okręgu wyborczym była mniejsza, w trzech równa, w znakomitej większości była wyższa od liczby przysługujących im mandatów, a zdarzało się, że list było dwa razy więcej niż mandatów do uzyskania. Tymczasem kolejną cechą tych wyborów było to, że społeczeństwo uporało się z dużą liczbą list wyborczych. W poszczególnych okręgach na posłów wybrano przedstawicieli od jednej do sześciu list, a w zdecydowanej większości przypadków reprezentantów dwóch, trzech list ${ }^{110}$. Oznaczało to, że głosy wyborcze zostały skoncentrowane na świadomie wskazanych podmiotach.

Na królewiackiej arenie wyborczej 26 stycznia 1919 r. obsadzono 220 mandatów. Większość z nich, bo 138, przypadła obozowi centroprawicy (89 - NKWSD; 25 - PZL; 15 - NZR; 8 - PSL „Piast”). Lewica objęła 72 mandaty (57 — PSL „Wyzwolenie”; 15 - PPS), 8 mandatów uzyskały listy żydowskie, a 2 Niemcy ${ }^{111}$. Najwięcej mandatów zdobyła więc Narodowa Demokracja i formacje z nią związane. Tryumf odnotowała endecja, zwłaszcza w Warszawie, uzyskując tu 11 z 16 mandatów, co nadało temu zwycięstwu wymiar symbolu preferencji politycznej Polaków ${ }^{112}$. Na ogólny sukces obozu centroprawicy wpłynęła ugruntowana i silna pozycja endecji we wszystkich grupach polskiego społeczeństwa oraz znakomita strategia wyborcza, pozwalająca skoordynować siłę endecji z wpływami sojuszniczych formacji politycznych i środowisk

108 K. Kacperski, op. cit., s. 110-113.

109 Rok 1918 we wspomnieniach mężów stanu..., s. 191.

110 T. Rzepecki, op. cit., s. 100-184.

111 K. Kacperski, op. cit., s. 114-118.

112 „Gazeta Poranna 2 Grosze”, 29 I 1919, nr 28, s. 1. 
społecznych. Trudno jednak uznać samą endecję za zwycięzcę tych wyborów (zwłaszcza w kontekście wcześniejszych wyborów do rosyjskiej Dumy, w których była jednoznacznym zwycięzca). O względności sukcesu endecji przesądziło: pojawienie się w czasie wojny nowych sił, zwłaszcza PSL „Wyzwolenie”, które złamały jej dominację na królewiackiej wsi; pojawienie się radykalizmu społecznego, a także przeprowadzenie wyborów na podstawie proporcjonalnej formuły wyborczej (w wyborach większościowych jej obóz objąłby więcej mandatów). Rezultaty wyborcze NZR i PZL były następstwem ich wpływów we własnych środowiskach społecznych oraz udziału w obozie centroprawicy. Sukces odnotowało PSL „Wyzwolenie”, a przyczyniły się do tego zwłaszcza jego aktywność w okresie wojny, atmosfera radykalizmu i nośność hasła reformy rolnej na wsi. Słabszy wynik PPS wynikał z kilku okoliczności. Partia ta nie miała doświadczeń w prowadzeniu kampanii wyborczej, jej wpływy na wsi były słabe, a wśród robotników redukowane przez NZR i KPRP. W czasie wyborów partia ta była dopiero $\mathrm{w}$ trakcie przeobrażania się z partii kadrowej w masową.

W Małopolsce 26 stycznia 1919 r. obsadzono 71 mandatów: 69 w okręgach wielomandatowych i 2 w jednomandatowych okręgach wyborczych we Lwowie (okręgi V i VII). Większość mandatów, bo 43, objęły tu formacje centroprawicy: 32 PSL — „Piast”, 6 - endecja, 4 - SKL i 1 - demoliberałowie. Lewica uzyskała 27 mandatów: 15 - PPSD, 12 - PSL „Lewica”. 1 mandat przypadł TŻRN. Zwycięzcą wyborów w Małopolsce zostało PSL „Piast”, co było następstwem jego aktywnej postawy w czasie wojny, doświadczeniu w prowadzeniu kampanii wyborczej, w tym świetnemu prowadzeniu akcji organizowania wieców i wręcz wzorowemu oddziaływaniu informacyjnemu tygodnika „Piast”. Sukces odniosła także PPSD. Był on skutkiem umocnienia się tej partii w Małopolsce oraz jej wieloletnich doświadczeń w prowadzeniu akcji wyborczej. Spora liczba mandatów dla PSL „Lewica” wynikała z przywiązania chłopów do osoby jego przywódcy J. Stapińskiego i pisma „Przyjaciel Ludu", obecności w nim dobrych działaczy i publicystów (J. Sanojcy, Józefa Putka) oraz pararewolucyjnej atmosfery panującej w tzw. republice tarnobrzeskiej. Dobre wyniki lewicy wynikały też ogólnie z proporcjonalnego systemu wyborczego; gdyby obowiązywała formuła większościowa, sukces PSL „Piast” byłby większy.

Po wyborach 26 stycznia 1919 r. SU liczył 319 posłów, uwzględniając 28 mandatów posłów do parlamentu wiedeńskiego z Galicji Wschodniej. Później przeprowadzono wybory na obszarach, gdzie wcześniej nie mogły się one odbyć, a więc w kilku okręgach królewieckich ${ }^{113}$ oraz w Wielkopolsce i na Pomorzu. Istotne były zwłaszcza wybory w Wielkopolsce przeprowadzone 1 czerwca 1919 r. Zgodnie z ustawą SU z dnia 5 kwietnia 1919 r., zmieniającej rozstrzygnięcia ordynacji z 28 listopada 1918 r. ${ }^{114}$, Wielkopolska została podzielona na cztery okręgi wyborcze. Rywaliza-

113 W dniu 16 II 1919 r. wybrano czterech posłów w okręgu nr 2 (powiaty suwalski, sejneński i augustowski); 9 III — sześciu posłów w okręgu nr 20 (powiaty bialski, janowski, radzyński i włodawski); 15 VI — siedmiu w okręgu nr 33 (powiaty sokólski i białostocki) i czterech w okręgu nr 34 (powiat bielski).

${ }^{114}$ Ustawa z dnia 5 kwietnia 1919 r. w przedmiocie zmiany niektórych przepisów ordynacji wyborczej objętej dekretami poz. 46 i 47 Nr 18 Dziennika Praw Państwa Polskiego z dnia 6 grudnia 1918 r., celem przeprowadzenia wyborów posłów do Sejmu Ustawodawczego RP z części ziem polskich b. zaboru pruskiego, Dz.P.P.P. z 1919 r. nr 30, poz. 253. 
cja przebiegała zasadniczo między PPS a ugrupowaniami centroprawicy, skupionymi w bloku Zjednoczonych Stronnictw Narodowych [dalej: ZSN], obejmującym Narodowo-Chrześcijański Klub Robotniczy, NZL, Zjednoczenie Mieszczańskie i samą endecję (SDN). Zastosowana przez endecję strategia integrowania sił pronarodowych przyniosła pełny sukces. Blok ZSN przejął wszystkie 42 mandaty poselskie. W pierwszym z okręgów wielkopolskich dokonano tego bez rywalizacji, 10 mandatów objęła jedyna lista wyborcza ZSN. W pozostałych trzech okręgach ZSN zdobył kolejne 32 mandaty, wręcz miażdżąco pokonując konkurencję ${ }^{115}$. Na Pomorzu wybory odbyły się 2 maja 1920 r. Podzielono 20 mandatów: 9 objęło Narodowe Stronnictwo Robotnicze, 4 - endecja, 1 - PSL, a 6 - Niemcy ${ }^{116}$. Do składu SU dołączono też 5 posłów z Górnego Śląska i 6 przedstawicieli ziemi cieszyńskiej, a proces wyłaniania SU zwieńczyło włączenie 24 marca 1922 r. w jego skład 20 przedstawicieli Sejmu Wileńskiego. Ogólnie więc w 1922 r. SU liczył już 433 posłów.

Kombinacyjny tryb wyłaniania, złożona struktura społeczeństwa, znaczna liczba podmiotów politycznych zabiegających o mandaty poselskie oraz proporcjonalny system wyborczy sprawiły, że od początku SU był parlamentem mocno podzielonym. Wywarło to wpływ na jego funkcjonowanie i na ocenę efektów jego działań. Zgodnie z przyjętą 20 lutego 1919 r. tzw. małą konstytucja, w Polsce miał obowiązywać system rządów parlamentarnych. Nadano jednak naszemu parlamentaryzmowi skrajną formę parlamentaryzmu komitetowego z silnym uzależnieniem rządu od Sejmu i jego komisji. Zrodziło to problem efektywnego działania SU jako kluczowego ogniwa władzy w państwie. Trzeba docenić jego dorobek prawodawczy w formie przyjęcia 571 ustaw oraz doniosłą rolę w kreowaniu państwa polskiego, ustanowieniu jego ustroju politycznego, uregulowaniu ważnych kwestii administracyjnych, ekonomicznych i społecznych. Niemniej już ówcześni obserwatorzy poczynań SU wskazywali również na negatywne strony jego działania: bezplanowość i chaos działań, nieprzygotowanie posłów do pracy prawodawczej, preferowanie przez partie partykularnych interesów. Głównie eksponowano jednak to, że SU miał niewielką zdolność kreowania większości potrzebnej do stworzenia stabilnego rządu, dysponującego spójnym programem i koncepcją działania politycznego. Obóz centroprawicy uzyskał w wyborach do SU większość mandatów, ale nie zdołał przetworzyć jej w stabilną większość parlamentarną. Sejm rozpoczął działalność jako parlament podzielony, a z biegiem kadencji rozproszenie sił postępowało: jeżeli po wyborach w styczniu 1919 r. SU liczył 10 klubów, to późniejsze przeobrażenia spowodowały, że w końcu kadencji było już 17 grup poselskich. Uniemożliwiało to stworzenie trwałej większości rządowej i w całej kadencji SU, trwającej do 1922 r., była ona zjawiskiem rzadkim ${ }^{117}$. SU nie zdołał przezwyciężyć tej słabości, co więcej, utrwalił jej podstawę, wprowadzając do tzw. konstytucji marcowej z 1921 r. i do ordynacji wyborczej z 1922 r. przepisy o proporcjonalnym systemie wybierania parlamentu polskiego.

115 T. Rzepecki, op. cit., s. 234-246; K. Kacperski, op. cit., s. 133-136.

116 K. Kacperski, op. cit., s. 136-140.

117 Z. Ilski, op. cit., s. 468-484. 


\section{PODSUMOWANIE}

Wybory do Sejmu Ustawodawczego w 1919 r. przeprowadzono w trudnej sytuacji politycznej, w warunkach oddziaływania procesu rewolucyjnego oraz narastania walk zbrojnych, mających wpływ na granice restytuowanej Polski. W kontekście zagrożenia bezpieczeństwa Polski przeprowadzenie wyborów do konstytuanty stało się ważnym zadaniem państwowotwórczym. Społeczeństwo polskie sprostało temu wyjatkowemu wyzwaniu. Uwidocznił to jego masowy udział w przedsięwzięciach związanych z kampanią wyborczą oraz wysoka frekwencja wyborcza. Do wyborów przystapiło wiele podmiotów politycznych, ale zasadnicza rywalizacja toczyła się między polskimi obozami centroprawicy i lewicy niepodległościowej. Powstały one na podstawie aksjologicznej, ale różniły się wizjami Polski, a zwłaszcza różnym pojmowaniem demokracji i jej następstw. Ten dychotomiczny podział sprawił, że wybory do SU w 1919 r. miały charakter plebiscytarny. Rywalizacja między obydwoma obozami toczyła się na dwóch arenach terytorialnych: w byłym Królestwie Polskim i w Małopolsce. Prowadzono ją też zasadniczo na dwóch polach starcia: na wiecach i w prasie. Dla jej przebiegu i wyników kluczowe znaczenie miały: operowanie odpowiednimi strategiami wyborczymi, utworzenie systemu komunikacji wyborczej, wykorzystanie niezwykłej aktywności kobiet oraz dobór ofert programowej i skutecznej argumentacji. Rywalizacja wyborcza w 1919 r. przyniosła sukces ugrupowaniom obozu centroprawicy, który na obu arenach zdobył większość mandatów. Nie zdołał jednak przełożyć tego sukcesu na utworzenie stabilnej większości parlamentarnej, zdolnej do wyłaniania trwałego i efektywnego rządu. W efekcie stało się to również kluczową słabością samego SU. Miał on poważny dorobek prawodawczy i odegrał pozytywną rolę w restytucji Polski, ale do końca swojego działania w 1922 r. był on przedstawicielstwem mocno podzielonym, niezdolnym do budowania stabilnej większości parlamentarnej.

\section{BIBLIOGRAFIA}

ŹRÓDŁA

Bogusławski A., Wspomnienia. Tom II (1916-1919), AZHRL, Zespół wspomnień i życiorysów, sygn. P-31.

„Czas” 1918-1919.

Dekret Naczelnika Państwa z dnia 28 listopada 1918 r. o ordynacji wyborczej do Sejmu Ustawodawczego, Dz.P.P.P. z 1918 r. nr 18, poz. 46.

Dekret Naczelnika Państwa z dnia 28 listopada 1918 r. o wyborach do Sejmu Ustawodawczego, Dz.P.P.P. z 1918 r. nr 18, poz. 47.

Dekret Naczelnika Państwa z dnia 26 grudnia 1918 r. o zmianach w ordynacji wyborczej do Sejmu Ustawodawczego, Dz.P.P.P. z 1918 r. nr 21, poz. 74.

Dekret Naczelnika Państwa z dnia 11 stycznia 1919 r. o nadaniu praw wyborczych obywatelom, którzy po 5 grudnia 1818 r. powrócili do kraju, Dz.P.P.P. z 1919 r. nr 5, poz. 97.

Dekret Naczelnika Państwa z dnia 14 stycznia 1919 r. o przedłużeniu terminu wyborów do Sejmu Ustawodawczego w drugim okręgu wyborczym, Dz.P.P.P. z 1919 r. nr 6, poz. 101. 
Dekret Naczelnika Państwa z dnia 14 stycznia 1919 r. o przedłużeniu terminu wyborów do Sejmu Ustawodawczego w dwudziestym okręgu wyborczym, Dz.P.P.P. z 1919 r. nr 6, poz. 102.

„Gazeta Poranna 2 Grosze” 1919.

„Gazeta Warszawska” 1918-1919.

„Głos Narodu” 1918-1919.

Grabski S., Pamiętniki, t. 2, Czytelnik, Warszawa 1989.

„Gwiazdka Cieszyńska” 1918-1919.

„Ilustrowany Kurier Codzienny” 1918-1919.

„Piast” 1918-1919.

„Prawo Ludu” 1918.

Proklamacja z dnia 5 listopada 1916 r., [w:] Historia państwa i prawa Polski. Źródla, wyb. F. Połomski, P. Jurek, [b.o.w.] Wrocław 1997, s. 303.

„Przyjaciel Ludu” 1918-1919.

Rataj M., Pamiętniki 1918-1927, Ludowa Spółdzielnia Wydawnicza, Warszawa 1965.

„Robotnik” 1918-1919

Rok 1918 we wspomnieniach mężów stanu, polityków i wojskowych, oprac. J. Borkowski, Państwowy Instytut Wydawniczy, Warszawa 1987.

Rzepecki T., Sejm Rzeczypospolitej Polskiej 1919 roku, Wielkopolska Księgarnia Nakładowa, Poznań 1920.

Słomka J., Pamiętniki włościanina. Od pańszczyzny do dni dzisiejszych, Ludowa Spółdzielnia Wydawnicza, Warszawa 1983.

Ulotki wyborcze do Sejmu Ustawodawczego Rzeczypospolitej Polskiej, Warszawa 1919, Zakład Narodowy im. Ossolińskich, sygn. 409.066 II.

Ustawa z dnia 5 kwietnia 1919 roku w przedmiocie zmiany niektórych przepisów ordynacji wyborczej objętej dekretami poz. 46 i 47 Nr 18 Dziennika Praw Państwa Polskiego z dnia 6 grudnia 1918 r., celem przeprowadzenia wyborów posłów do Sejmu ustawodawczego RP z części ziem polskich b. zaboru pruskiego, Dz.P.P.P. z 1919 r. nr 30, poz. 253.

„Wyzwolenie” 1918-1919.

PIŚMIENNICTWO

Brzoza Cz., Polskie Stronnictwo Republikańskie (1918-1919), „Studia Historyczne” 1991, z. 2.

Domań E., Wybory do Sejmu Ustawodawczego 1919 roku w lubelskim okregu wyborczym, „Annales Universitatis Mariae Curie-Skłodowska Lublin-Polonia", 1983/1984, t.. XXXVIII/ XXXIX.

Drewicz M., Polskie wybory 1919. Agitacja w pięciu tygodnikach „, Gazeta Świateczna”, „Zorza”, ,Wyzwolenie”, , Rzad i Wojsko”, „Piast”, Arte Klub Zachowawczo-Monarchiczny, Biała Podlaska 2011.

Halpern L., Polityka żydowska w Sejmie i Senacie Rzeczypospolitej Polskiej 1919-1933, Instytut Badań Spraw Narodowościowych, Warszawa 1933.

Hemmerling Z., PSL „, Wyzwolenie” w parlamentach II Rzeczypospolitej 1919-1931, Uniwersytet Warszawski, Warszawa 1990.

Ilski Z., Formuła wyborcza u progu niepodległej Polski (do 1922 r.), Wydawnictwo Adam Marszałek, Toruń 2013.

Kacperski K., System wyborczy do Sejmu i Senatu u progu drugiej Rzeczypospolitej, Wydawnictwo Sejmowe, Warszawa 2007. 
Pajewski J., Odbudowa państwa polskiego 1914-1918, Państwowe Wydawnictwo Naukowe, Warszawa 1978.

Rawski J., „Republika Tarnobrzeska” w świetle źródet $i$ wspomnień adiutanta powiatowej komendy wojsk polskich w Tarnobrzegu, Oficyna Wydawnicza Witek-Druk, Tarnobrzeg 1993.

Seyda M., Polska na przełomie dziejów. Fakty i dokumenty, Poznań-Warszawa-Wilno-Lublin 1927. 


\title{
PRAWO WYBORCZE DO SEJMU USTAWODAWCZEGO
}

\author{
ELECTORAL LAW TO THE LEGISLATIVE SEJM
}

The legislative works conducted by Jędrzej Moraczewski's government were a key element of the process begun in the fall of 1918, aimed at establishing a democratic electoral law to the constituent assembly, including both women and men. Between 18 and 27 November 1918 its members prepared two drafts regulating the matter in detail. Both decrees were signed by Chief of State Józef Piłsudski on 28 November 1918. The elections effected on the basis of provisions contained therein were held on 26 January 1919. As a result, political representation of Poland reborn after decades of partitions was established. However, opening of the debates of the Legislative Sejm did not terminate activities related to electing Deputies, as the legal status of the lands, which were to be a part of the re-established state according to J. Piłsudski and subsequent cabinets, had still not been determined. Actions in this sphere were continued by Polish authorities on the basis of various normative solutions until March 1922. Indubitably, those efforts - taking into consideration both their systemic and social significance - had gone down in history of the Second Republic of Poland.

Słowa kluczowe: wybory, prawo wyborcze, projekt, ordynacja wyborcza, dekret, ustawa, rząd Jędrzeja Moraczewskiego, Sejm Ustawodawczy, Naczelnik Państwa Józef Piłsudski

Key words: elections, electoral law, draft, electoral ordinance, decree, act, Jędrzej Moraczewski’s government, Legislative Sejm, Chief of State Józef Piłsudski

* Dr Kamil Kacperski, Polskie Towarzystwo Stosunków Międzynarodowych, k.kacperski@onet.eu

I. ZAGADNIENIE PRAWA WYBORCZEGO DO KONSTYTUANTY W ŚWIETLE DECYZJI USTROJOTWÓRCZYCH PODJĘTYCH PRZEZ RZĄDY IGNACEGO DASZYŃSKIEGO I JĘDRZEJA MORACZEWSKIEGO ORAZ NACZELNIKA PAŃSTWA JÓZEFA PILSUDSKIEGO

$U_{d}^{h}$ konstytuowanie się w nocy z 6 na 7 listopada 1918 r. Tymczasowego Rządu Ludowego Republiki Polskiej otworzyło nowy rozdział w ramach zainicjowanego pięć miesięcy wcześniej procesu formowania prawa wyborczego do jednoizbowego organu przedstawicielskiego ${ }^{1}$. Gabinet pod przywództwem Ignacego Daszyńskiego z Polskiej Partii Socjalno-Demokratycznej Galicji i Śląska Cieszyńskiego [dalej: PPSD] w proklamowanym tej samej nocy manifeście Do Ludu Polskiego zapowiedział, że: „Sejm Ustawodawczy zwołany będzie przez nas jeszcze w roku bieżącym na podstawie powszechnego, bez różnicy płci, równego, bezpo-

1 Mowa tu o czynnościach jurydycznych, jakie podjęła Komisja Administracyjna Biura Pracy Społecznej jeszcze w okresie okupacji terenów Królestwa Polskiego przez Niemcy i Austro-Węgry. Vide K. Kacperski, Koncepcje systemu wyborczego do Sejmu na ziemiach Królestwa Polskiego w latach 1917-1918, Warszawa 2018, s. 233 i n. 
średniego, tajnego i proporcjonalnego głosowania. Ordynacja wyborcza będzie ogłoszona w ciagu kilku najbliższych dni. Czynne i bierne prawo wyborcze będzie przysługiwało każdemu obywatelowi i obywatelce mającym 21 lat skończonych"”. W ten sposób członkowie utworzonego w Lublinie rządu, mimo że reprezentowali głównie stronnictwa lewicy niepodległościowej z Królestwa Polskiego i Galicji, znacząco wpłynęli na zakres prowadzonej wtedy - nie tylko na forum publicznym, ale i w wymiarze urzędowym - debaty ustrojowej, której istota dotyczyła mechanizmów kreacji pierwszego parlamentu w dziejach II RP³. W dniu 11 listopada $1918 \mathrm{r}$. Rząd Ludowy podporządkował się zwolnionemu z niemieckiej niewoli Józefowi Piłsudskiemu4 $u^{4}$ Trzy dni później wydał on dekret formalnie mianujący I. Daszyńskiego premierem $^{5}$. W treści tego dokumentu podkreślono, że gabinet Daszyńskiego — z racji przejściowego charakteru - ma za zadanie jedynie administrowanie wolnymi ziemiami polskimi. Deklaracja ta stanowiła odwzorowanie poglądów J. Piłsudskiego, który w owym czasie twierdził, że najważniejsze decyzje w odradzającym się państwie może podejmować wyłącznie Sejm Ustawodawczy [dalej: SU] ${ }^{6}$.

W dniu 17 listopada 1918 r. I. Daszyński został zastapiony na stanowisku premiera przez Jędrzeja Moraczewskiego (PPSD) 7 . Działalność nowego gabinetu, w skład którego wchodziło także kilku ministrów zasiadających uprzednio w Rządzie Ludowym, zgodnie z zamysłem wyrażonym przez J. Piłsudskiego, miała przede wszystkim koncentrować się na wypracowaniu prawa wyborczego do konstytuan-

2 K.W. Kumaniecki, Odbudowa państwowości polskiej. Najważniejsze dokumenty: 1912-styczeń 1924, Kraków 1924, s. 130-132. Temat ten poruszono także w „Jedności Robotniczej”: „Jesteśmy świadkami faktu, że zarówno w różnych zrzeszeniach społecznych, jak i organizacjach wypracowujących projekty ustaw wyborczych do ciał przedstawicielskich, przyjmuje się zasada przyznania kobietom biernego i czynnego prawa wyborczego. Idzie teraz o to, by kobiety same zrozumiały, jak żywotnym jest ich interes w uzyskiwaniu wpływu na tok spraw politycznych, by kobieta zdolną była do zerwania z kompromisem i jako człowiek pracujący i obywatelka stanęła obok męskiego swego towarzysza do twórczej pracy dla jutra". Vide Kobiety a Sejm, ,Jedność Robotnicza” z 17 XI 1918 r., nr 46, s. 6.

3 S. Thugutt (PSL ,Wyzwolenie”), pełniący w tym rządzie funkcję ministra spraw wewnętrznych, odnosząc się wówczas do problematyki wyłonienia parlamentu napisał: „Musi być powołany Sejm. Tylko z tego Sejmu wytryśnie żywy zdrój siły, tylko ten Sejm będzie Polską, będzie mógł w jej imieniu ostatnie słowo powiedzieć”. Vide Czego żądać od rządu, „Wyzwolenie” z 10 XI 1918 r., nr 45, s. 397.

4 A. Ajnenkiel, Spór o model parlamentaryzmu polskiego do roku 1926, Warszawa 1972, s. 168. Natomiast trzy dni później rozwiązała się Rada Regencyjna. J. Pajewski, Odbudowa państwa polskiego 1914-1918, Warszawa 1978, s. 298.

${ }^{5}$ Dekret naczelnego dowódcy Józefa Piłsudskiego z dnia 14 listopada 1918 r., Dziennik Praw Państwa Polskiego [dalej: Dz.P.P.P.] z 1918 r. nr 17, poz. 40. Vide też B. Hełczyński, Józef Piłsudski jako Naczelnik Państwa (listopad 1918-grudzień 1922), „Niepodległość”, t. 9, Londyn-Nowy York 1974, s. 290.

${ }^{6}$ Należy zaznaczyć, że Rząd Ludowy podjął działania, których istota ogniskowała się wokół przygotowania przepisów prawa wyborczego do konstytuanty. I. Daszyński, omawiając tę kwestię, stwierdził: „W późną noc siedzieliśmy z panem Thuguttem nad przyszłą sejmową ordynacją wyborczą, ale zdaje mi się, żeśmy jej całkowicie nie skończyli, bo już czasu zabrakło". Rok 1918 we wspomnieniach mężów stanu, polityków i wojskowych, wybrał i opracował J. Borkowski, Warszawa 1987, s. 89.

7 Monitor Polski [dalej: M.P.] z 1918 r. nr 206. A. Garlicki, analizując te wydarzenia, zauważył: „Z punktu widzenia celów Piłsudskiego rząd Moraczewskiego był ową przykrą koniecznością, był ustępstwem na rzecz wymogów chwili i rezultatem krótkowzroczności prawicy. Dlatego traktował go jako swoiste prowizorium, poszukując jednocześnie możliwości rozszerzenia jego oparcia na prawo". A. Garlicki, Józef Pitsudski 1867-1935, Warszawa 1988, s. 205. 
ty ${ }^{8}$. W tej sytuacji rząd problematyką wyborczą zajął się już na pierwszym posiedzeniu (pkt 4 obrad). Odbyło się ono 18 listopada 1918 r. ${ }^{9}$ Premier Moraczewski zapowiedział wówczas uwzględnienie w porządku „najbliższych posiedzeń Rady Ministrów, jako bardzo pilnej, sprawy ordynacji wyborczej do Sejmu Ustawodawczego" ${ }^{10}$. Przytoczona enuncjacja znalazła swoje odzwierciedlenie w postaci projektu normującego tę kwestię ${ }^{11}$ napisanego w niespełna dwie doby przez ministra spraw wewnętrznych Stanisława Thugutta z Polskiego Stronnictwa Ludowego [dalej: PSL] „Wyzwolenie”, Naczelnika Wydziału Sejmowego w Ministerstwie Spraw Wewnętrznych [dalej: MSW] Mieczysława Niedziałkowskiego z Polskiej Partii Socjalistycznej [dalej: PPS] i dyrektora Głównego Urzędu Statystycznego prof. Józefa Buzka. Jego podstawą były regulacje zawarte w przedłożeniach sporządzonych w latach 1917-1918 przez Komisję Sejmowo-Konstytucyjną Tymczasowej Rady Stanu [dalej: KS-K TRS], rządy pod przywództwem Jana Kantego Steczkowskiego i Józefa Świeżyńskiego, Komisję Administracyjną Biura Pracy Społecznej [dalej: KA BPS] oraz prof. Józefa Siemieńskiego ${ }^{12}$.

Przywołany wniosek stał się przedmiotem obrad gabinetu w okresie od 19 do 27 listopada 1918 r. $^{13}$ Prowadzone w tych dniach postępowanie legislacyjne można podzielić na dwa etapy ${ }^{14}$. Pierwsza odsłona analizowanego procesu ogniskowała się zarówno wokół uregulowania naczelnych zasad prawa wyborczego, jak i zredagowania poszczególnych przepisów zamieszczonych w przedłożeniu. Mechanizmy normatywne, które zostały zawarte w projekcie, nie wzbudziły wśród ministrów większych kontrowersji. W dniu 19 listopada (3. posiedzenie, pkt 5 obrad) rząd przegłosował zatem artykuły od 1 do 22, 20 listopada (4. posiedzenie, pkt 2 obrad)

${ }^{8}$ Po latach ukazała się relacja J. Piłsudskiego ze spotkania, w trakcie którego przekazał on swoje oczekiwania J. Moraczewskiemu: „Kazałem mu stanąć na baczność, potem mu powiedziałem: Panie kapitanie, ma Pan zostać Prezesem Ministrów, ale pod dwoma warunkami: 1) by Pan nie wkraczał swymi zarządzeniami w jakiekolwiek stosunki społeczne, 2) wypracuje Pan w ciagu jednego tygodnia ustawę wyborczą i to tak, jak gdyby miał Pan budować okopy”. B. Hełczyński, Józef Piłsudski..., s. 291.

9 Archiwum Akt Nowych [dalej: AAN], Prezydium Rady Ministrów [dalej: PRM], Protokoły z posiedzeń Rady Ministrów 18 XI-31 XII 1918 r., t. 4, k. 317, sygn. 20048.

10 Zagadnienie to zostało wprowadzone także do porządku dziennego, wyznaczonego na 19 listopada 1918 r., 2. posiedzenia rządu (pkt 2 obrad). Ibidem, k. 317 i 328. Confer Kronika polityczna, „Robotnik” z 19 XI 1918 r., nr 303, s. 2.

11 AAN, PRM, t. 4, k. 335-348.

12 Vide K. Kacperski, Koncepcje systemu..., s. 21 i n.

${ }_{13}$ Ministrowie w proklamowanym 20 listopada 1918 r. manifeście Do Narodu Polskiego napisali: „Sejm Ustawodawczy, oparty na powszechnym, równym, bezpośrednim, tajnym i proporcjonalnym głosowaniu wszystkich obywateli i obywatelek, mających 21 lat skończonych, zdecydowani jesteśmy zwołać w początku roku przyszłego, ustalając dzień wyborów na ostatnią niedzielę stycznia. Przygotowania do tego aktu rozpoczynamy niezwłocznie, zaś ordynacja wyborcza zostanie przez nas ogłoszona w dniach najbliższych”. M.P. z 1918 r. nr 208.

${ }^{14}$ Ciekawą uwagę w tym względzie poczynił publicysta A. Trzaska-Chrząszczewski: „Gabinet Moraczewskiego zbierał się na posiedzenia [...] późnym wieczorem i odbywał swoje narady przeważnie nocą. Niekiedy przed posiedzeniem przyjeżdżał Piłsudski i odbywał krótką naradę z Moraczewskim. W posiedzeniach Rady Ministrów udziału nie brał. Było jednak widoczne, że udzielał swoich dyrektyw premierowi, które miały charakter hamujący ferwor reformatorski gabinetu”. A. Trzaska-Chrząszczewski, Wspomnienia i rozważania z lat 1887-1957, t. 1, 1887-1922, k. 145-146, sygn. 14098/II. 
przyjął artykuły od 23 do 59, zaś 21 listopada (5. posiedzenie, pkt 11 obrad) zatwierdził artykuły od 60 do 107 ordynacji ${ }^{15}$. Ostateczny kształt przepisy tego aktu prawnego uzyskały 26 listopada (9. posiedzenie, pkt 6 obrad) ${ }^{16}$. Druga faza omawianych czynności jurydycznych dotyczyła natomiast wytyczenia granic okręgów wybor$\mathrm{czych}^{17}$. Zagadnienie to było rozpatrywane przez gabinet podczas czterech spotkań: 23 listopada (7. posiedzenie, pkt 2 obrad), 25 listopada (8. posiedzenie, pkt 3 obrad), 26 listopada (9. posiedzenie, pkt 6 i 8 obrad) i 27 listopada (10. posiedzenie, pkt 13 obrad) ${ }^{18}$. Minister Thugutt $\mathrm{w}$ trakcie zainicjowanej 23 listopada dyskusji na ten temat zaproponował, aby tereny Królestwa Polskiego zostały podzielone albo na okręgi trzymandatowe, albo na okręgi liczące od 5 do 8 mandatów. Rozwiązania te miały znaleźć zastosowanie również w Galicji (bez wschodniej jej części) i na Śląsku Cieszyńskim, z tym że w przypadku drugiego wariantu dopuścił on możliwość utworzenia nie tylko okręgów wielomandatowych, ale i jednomandatowych ${ }^{19}$. Rząd nie poparł żadnej z przedstawionych wtedy koncepcji. Większość jego członków uznała bowiem, że wybory powinny odbyć się na wszystkich ziemiach polskich, jednak ich rozpisanie miało nastapić wyłącznie ,tam, gdzie urzędują władze polskie”"20. Co więcej, gabinet — obawiając się deformacji wyniku głosowania — odrzucił zasadność wykorzystania, oprócz proporcjonalnego systemu wyborczego, także formuły większościowej. W konsekwencji podjętych wówczas decyzji urzędnicy zatrudnieni w MSW, których działalność koordynował J. Buzek, ukształtowali nowe rozstrzygnięcia w tej materii ${ }^{21}$. Poprawiona mapa okręgów wyborczych została zaprezentowana przez ministra Thugutta na plenum Rady Ministrów 25 listopada $^{22}$. Tego samego dnia nastapiło też jej zatwierdzenie ${ }^{23}$. W ostatniej kolejności gabinet w dniach 25, 26 i 27 listopada rozpatrzył kwestię zorganizowania wyborów na terenach dawnego zaboru pruskiego ${ }^{24}$. W myśl rozwiązań opracowanych w MSW planowano utworzyć tam 11 okręgów. Warto zaznaczyć, że legislatorzy objęli spisem okręgów nie tylko terytoria znajdujące się we władaniu Prusaków, na mocy uchwał Kongresu Wiedeńskiego z 1815 r., ale również Górny Śląsk i Mazury. Pomysł ten, którego referentem był M. Niedziałkowski, rząd zaaprobował 27 listopada ${ }^{25}$. Ostatecznie dobę później Naczelnik Państwa J. Piłsudski podpisał dwa - przedstawio-

${ }^{15} \mathrm{~W}$ trakcie tych czynności wykreślił on z procedowanego projektu sześć artykułów. AAN, PRM, t. 4, k. 326,349 i 361 .

${ }^{16}$ Legislatorzy dokonali wówczas punktowych korekt w ramach 11 przepisów tego przedłożenia. Ibidem, k. 410.

${ }^{17}$ Pierwotnie wniosek wypracowany w MSW stanowił, że wybory odbędą się jedynie na ziemiach Królestwa Polskiego. Tereny te miały zostać podzielone na 30 okręgów, w których można było uzyskać łącznie 185 mandatów. Ibidem, k. 344.

18 Ibidem, k. 379, 394, 410 i 423.

19 Ibidem, k. 362 i 379.

${ }^{20}$ Ibidem, k. 379.

${ }^{21}$ Ibidem, k. 362.

22 Ibidem, k. 394 i 397-399.

${ }^{23}$ Ibidem, k. 394.

${ }^{24}$ Ibidem, k. 394, 410 i 423.

25 Ibidem, k. 423 i 429. 
ne przez gabinet - dekrety systematyzujące problematykę wyborów do Sejmu Ustawodawczego ${ }^{26}$.

Prawo wyborcze do konstytuanty zostało przygotowane przez rząd Moraczewskiego w następstwie presji, jaką w tej sprawie wywierał J. Piłsudski, w trakcie niespełna dwóch tygodni. Osiągnięcie tego celu w tak krótkim czasie było możliwe dzięki wykorzystaniu przez Radę Ministrów przedłożeń będących rezultatem wysiłków instytucjonalnych przedsięwziętych przez KS-K, KA, rządy Steczkowskiego i Świeżyńskiego oraz J. Siemieńskiego ${ }^{27}$. Wbrew pozorom nie oznaczało to jednak, że sporządzone przez nią akty prawne stanowiły kopię wypracowanych wcześniej wniosków. Owszem, gabinet Moraczewskiego w ramach upublicznionych wtedy dekretów zamieścił dużą liczbę uformowanych w latach 1917-1918 mechanizmów kreacji parlamentu. Jednocześnie zawarł w nich, co należy podkreślić, wiele autorskich rozwiązań jurydycznych, które w zasadniczy sposób wpłynęły na proces kształtowania fundamentów demokratycznego, gwarantującego jednakowy status kobiet i mężczyzn, prawa wyborczego do organów przedstawicielskich na ziemiach polskich w XX w.

\section{PRAWO WYBORCZE DO KONSTYTUANTY - ANALIZA DEKRETÓW Z 28 LISTOPADA 1918 R.}

Ordynacja wyborcza do Sejmu Ustawodawczego liczyła 101 artykułów ${ }^{28}$. W jej skład wchodziło też pięć dodatków, za pośrednictwem których legislatorzy usystematyzowali spis okręgów wyborczych, określili liczbę mandatów przypadających na

${ }^{26}$ M. Niedziałkowski na ten temat napisał: „Gorączkowo, w dzień i w noc, przygotowywano i przerabiano w Ministerstwie Spraw Wewnętrznych — w związku z żądaniami delegacji dzielnic, prowincji i grup ludności — te dwa dokumenty. I gdy ujrzały one wreszcie światło dzienne, zdawało się, że ciężar olbrzymi spadł z serc i z myśli ówczesnych kierowników młodziuteńkiego państwa". M. Śliwa, Myśl polityczna Mieczysława Niedzialkowskiego (1893-1940), Warszawa 1980, s. 60. S. Thugutt z kolei zanotował: „O szóstej trzeba już być w pałacu Namiestnikowskim, gdzie się codziennie odbywała Rada Ministrów, trwająca czasami do pierwszej w nocy. Potem jeździłem często sam lub z Moraczewskim do Belwederu i o bardzo późnej godzinie mogłem dopiero zabrać się w łóżku do przeglądania najważniejszych chociażby papierów". S. Thugutt, Autobiografia, przedmowa A. Więzikowa, T. Janczak, Warszawa 1984, s. 116. Vide też Dekret Naczelnika Państwa z dnia 22 listopada 1918 r. o najwyższej władzy reprezentacyjnej Republiki Polskiej, Dz.P.P.P. z 1918 r. nr 17, poz. 41.

${ }^{27}$ Działania te wzbudziły w „Gazecie Warszawskiej” liczne zastrzeżenia: „Wiemy, że rząd dotychczas zadowolił się przeczytaniem i przyjęciem ordynacji wyborczej, ongi przez Biuro Pracy Społecznej zaprojektowanej. To chyba nie wystarcza, bo powyższa ordynacja stosuje się tylko do Królestwa Kongresowego. Trzeba zatem pomyśleć o czymś szerszym odpowiadającym wymaganiom doby obecnej i potrzebom narodu”. Vide J. Bartoszewicz, Zasada wyborcza dla Sejmu Konstytucyjnego, „Gazeta Warszawska” z 29 XI 1918 r., nr 14, s. 1. W odpowiedzi na zarzuty w tej materii S. Thugutt powiedział: „Krytykują ustawę wyborczą? Myśmy przecież przyjęli tę, jaką nam zostawili nasi poprzednicy, wprowadzając kilka zaledwie zmian. Być może ustawa jest niedoskonała. Przyszły Sejm może ją poprawić, zmienić. Teraz nie było na to czasu. Lepszy Sejm na niedoskonałej nawet ustawie wyborczej oparty, niż dalsza zwłoka, niż ta pokątna walka wszystkich ze wszystkimi”. Vide Rozmowa z ministrem spraw wewnętrznych, „Kurier Polski” z 11 XII 1918 r., nr 309, s. 3.

${ }^{28}$ Dekret z dnia 28 listopada 1918 r. o ordynacji wyborczej do Sejmu Ustawodawczego, Dz.P.P.P. z 1918 r. nr 18, poz. 46. Należy podkreślić, że konstytuanta nie była ograniczona wymogiem kadencyjności. O wygaśnięciu jej pełnomocnictw nie decydował bowiem upływ czasu, a moment ukończenia prac nad konstytucją. W. Komarnicki, Polskie prawo polityczne (geneza i system), Warszawa 1922, s. 55. 
poszczególne okręgi wyborcze, ustalili wzory — listy wyborców, karty do głosowania i formularza protokołu głosowania oraz wyjaśnili mechanizmy przeliczania głosów na mandaty.

Na podstawie art. 1 czynnym prawem wyborczym dysponowali obywatele państwa, którzy do dnia ogłoszenia wyborów ukończyli 21 lat ${ }^{29}$. Przepis ten obejmował każdego obywatela państwa polskiego bez względu na jego płeć ${ }^{30}$. Dzięki temu kobiety po raz pierwszy w historii Polski formalnie uzyskały możliwość wzięcia udziału w wyborach do Sejmu ${ }^{31}$. W tym kontekście należy jednak zaznaczyć, że przytoczony artykuł - warunkujący obowiązywanie w praktyce zasady powszechności prawa wyborczego - został sformułowany niestarannie w wymiarze stylistycznym. Analizujący ówcześnie tę kwestię prof. J. Siemieński stwierdził nawet, że zamieszczone w nim postanowienia były zrozumiałe „głównie dla osób znających język rosyjski, jako że w zdaniu: «który do dnia ogłoszenia wyborów ukończył 21 lat», wyraz «do» użyty został w znaczeniu «przed» zgoła nie po polsku. [...] Widocznie redaktor ostateczny ustawy powziął płonną obawę, że tekst w dniu oznaczałby wyłącznie tych, co w sam dzień zarządzenia wyborów osiagnną wiek wyborczy, tak że wszyscy pozostali obywatele, liczący w dniu zarządzenia wyborów ukończonych 21 lat z najmniejszym choćby okładem - byliby pozbawieni praw wyborczych" ${ }^{\prime 32}$. Co więcej, regulacje zawarte w art. 1 stają się jeszcze mniej klarowne, gdy skonfrontuje się je z treścią następnego przepisu. Art. 2 stanowił bowiem, że wyborcy musieli być mieszkańcami obwodu głosowania, w którym głosuja, przynajmniej od przedednia zarządzenia wyborów. Tymczasem w art. 1 legislatorzy posłużyli się wyrażeniem „ogłoszenie wyborów”33. Rozbieżność ta, wynikająca z nieuwagi normodawców, mogła skutkować niespójnością terminów prekluzyjnych zapisanych w kalendarzu wyborczym ${ }^{34}$. Finalnie niebezpieczeństwo,

${ }^{29} \mathrm{~W}$ dniach 10, 20 i 27 listopada 1918 r. odbyły się w Warszawie manifestacje zorganizowane przez kobiety. W ich trakcie domagały się one przyznania praw wyborczych w wyborach do Sejmu. Vide Polityczny wiec kobiet polskich, „Nowa Gazeta” z 13 XI 1918 r., nr 47, s. 1; Wiec kobiet polskich, „Bluszcz” z 30 XI 1918 r., nr 48, s. 359.

${ }^{30}$ Czołowa polska sufrażystka I. Moszczeńska na ten temat napisała: „Niechaj kobiety idą do urny wyborczej z tą świadomością, że nowe przyjęły na siebie obowiązki, że są wezwane do służby politycznej, z której sumiennie wedle swego najlepszego rozumienia wywiązać się powinny, że prawo wyborcze posiadają nie po to, by siebie, swoje stronnictwo lub klasę społeczną broniły przed możliwą krzywdą, lecz by troskliwą i czujną rozciaggały opiekę nad dolą ojczyzny”. Vide I. Moszczeńska, Kobiety na arenie politycznej, „Głos” z 27 XI 1918 r., nr 383, s. 2.

31 Rozwiązania, o których mowa, zyskały poparcie na łamach ,Zorzy”: „,Dobrze się więc stało, że ustawa o wyborach do pierwszego Sejmu polskiego nadaje kobietom takie same prawa wyborcze, jak mężczyznom. Zasługują one na to. Jest to nowość. Jest to bardzo doniosła zmiana. Wszak dotychczas kobiety nie brały u nas udziału ani w wyborach do Dumy, ani nawet w samorządzie gminnym, i nie zawsze były dopuszczane do narad o sprawach ogólnych, politycznych i społecznych. Stąd też wiele kobiet mniej się interesowała tymi sprawami, zajmując się prawie wyłącznie sprawami domowymi i gospodarczymi. Dziś wszystko to musi się zmienić”. Vide Kobiety a wybory do Sejmu, ,Zorza” z 19 I 1919 r., nr 3, s. 35-36.

32 J. Siemieński, Rozbiór krytyczny ordynacji wyborczej do Sejmu Ustawodawczego, Warszawa 1919, s. 10.

33 Wydaje się, że wyrażenie to powinno zostać zastapione określeniem ,zarządzenie wyborów”.

${ }_{34}$ Co więcej, 19 grudnia 1918 r. prawodawcy zdecydowali o przedłużeniu — o 10 dni — terminów prekluzyjnych zawartych w art. 43, 47, 51 i 54 ordynacji. Dekret z dnia 19 grudnia 1918 r. o przedłużeniu niektórych terminów prekluzyjnych przy wyborach do Sejmu Ustawodawczego, Dz.P.P.P. z 1918 r. nr 20, poz. 63. 
o którym mowa, dostrzegli także autorzy dekretu. Stąd też opublikowana przez nich w grudniu 1918 r. Instrukcja do ordynacji wyborczej do Sejmu Ustawodawczego nakazywała słowa „ogłoszenie wyborów” rozpatrywać jedynie w kontekście ostatniego zdania art. $15^{35}$. Zgodnie z art. 3 każdy wyborca mógł głosować tylko w jednym obwodzie głosowania ${ }^{36}$. W art. 4 zakazano wojskowym w służbie czynnej udziału w głosowaniu, art. 5 wyłączał natomiast z tego aktu osoby sądownie pozbawione praw obywatelskich. W myśl wieńczącego rozdział I art. 6 prawo głosowania miało być wykonywane osobiście.

Na mocy art. 7 bierne prawo wyborcze uzyskali wszyscy obywatele państwa polskiego bez względu na płeć, dysponujący czynnym prawem wyborczym, niezależnie od miejsca zamieszkania, jak również wojskowi ${ }^{37}$. Artykuł ten, zamieszczony w rozdziale II, został sformułowany w sposób budzący wątpliwości natury jurydycznej. W świetle zawartych w nim rozwiązań, aby mieć prawo wybieralności trzeba było posiadać czynne prawo wyborcze, a jak wcześniej zaznaczono, jego uzyskanie legislatorzy uzależnili od cenzusu domicylu. Z tego też powodu można przyjać, że prawem tym nie mogły legitymować się osoby niemające stałego, przynajmniej od przedednia zarządzenia wyborów, miejsca zamieszkania. Co oczywiste, z biernego prawa wyborczego nie mogli korzystać także Polacy, którzy zamieszkiwali tereny znajdujące się poza granicami wymienionych w dekrecie okręgów wyborczych. Art. 8 zabraniał wybierać urzędników państwowych władz administracyjnych, skarbowych i sądowych w okręgu, na który rozciagała się ich działalność służbowa ${ }^{38}$. Obostrzenie to nie obejmowało urzędników i wojskowych władz centralnych. Art. 9 odnosił się do wojskowych i płatnych urzędników państwowych, którzy zostali wybrani do Sejmu ${ }^{39}$. Nakazywał on zwolnienie takich osób z czynności służbowych na czas trwania mandatu ${ }^{40}$.

35 Biblioteka Szkoły Głównej Handlowej [dalej: BSGH], Instrukcja do ordynacji wyborczej do Sejmu Ustawodawczego, sygn. 167071.

${ }^{36}$ Dekret z 11 stycznia 1919 r. stanowił, że obywatelom spełniającym wymogi zapisane w art. 1 ordynacji, powracającym do Polski po 5 grudnia 1918 r., również przysługiwały prawa wyborcze. Dekret z dnia 11 stycznia 1919 r. o nadaniu praw wyborczych obywatelom, którzy po 5 grudnia 1918 r. powrócili do kraju, Dz.P.P.P. z 1919 r. nr 5, poz. 97.

37 Przepis, na podstawie którego żołnierze otrzymali prawo wybieralności, stał się przedmiotem rozważań ze strony adwokata L. Nowodworskiego. Jego zdaniem, zamieszczone w nim rozwiązanie było ze wszech miar korzystne, ponieważ nie pozwalało przenieść agitacji politycznej do armii, umożliwiając jednocześnie wybór do Sejmu osób, których wiedza wojskowa mogła zostać spożytkowana w zakresie obronności państwa polskiego. L. Nowodworski, O ordynacji wyborczej do pierwszego Sejmu Polskiego: wyjaśnienie i wskazówki praktyczne, Warszawa 1918, s. 10.

38 Wprowadzenie obostrzeń w tej materii rekomendował też Z. Cybichowski. Wskazywał bowiem, że zapobiegały one ,wykorzystywaniu wpływów, zdobytych przez urzędowanie, na korzyść uzyskania mandatu parlamentarnego". Z. Cybichowski, Polskie prawo państwowe, t. I, Warszawa 1929, s. 130.

${ }^{39}$ Na mocy dekretu z 8 lutego 1919 r. prawodawcy usunęli z art. 9 ordynacji słowo ,wojskowych”. Jednocześnie dopisali do niego drugi ustęp: „Przynależni do wojska w razie wyboru na posła zwalniają się zupełnie z armii polskiej na czas trwania mandatu poselskiego". Dekret z dnia 8 lutego 1919 r. w sprawie zmiany art. 9 dekretu o ordynacji wyborczej do Sejmu Ustawodawczego, Dz.P.P.P. z 1919 r. nr 14, poz. 198.

${ }^{40}$ W ocenie A. Bogusławskiego (PSL ,Wyzwolenie”) postanowienia te pozwalały posłowi być ,,człowiekiem swobodnym, niezależnym, ażeby każde nadużycie mógł wykryć i w Sejmie przedstawić, bez względu na to, czy to zrobi niższy, czy wyższy od niego urzędnik państwowy”. A. Bogusławski, O ordynacji wyborczej (objaśnienie ogłoszonej ordynacji wyborczej), Warszawa 1918, s. 13. 
Na podstawie art. 10 poseł powołany do płatnej służby państwowej przestawał być członkiem Izby. Przytoczony przepis nie dotyczył — podobnie jak artykuł poprzedni - ministrów, podsekretarzy stanu i profesorów wyższych uczelni ${ }^{41}$.

W myśl art. 11, którego postanowienia rozpoczynały rozdział III, wykaz okręgów wyborczych został wyszczególniony w dodatku $\mathrm{nr} 1^{42}$. Dodatek ten dzielił terytorium państwa polskiego na 71 okręgów, w których można było uzyskać w sumie 527 mandatów ${ }^{43}$. Królestwo Polskie wraz z Ziemią Białostocką podzielono na 34 okręgi wyborcze. Ich wielkość wahała się w granicach od 4 (nr 2 Suwałki, nr 5 Lipno i nr 34 Bielsk) do 16 (nr 16 Warszawa) mandatów ${ }^{44}$. Najwięcej utworzono okręgów sześcioi siedmiomandatowych: odpowiednio 9 i 7. Były one usytuowane w województwach warszawskim, kieleckim, łódzkim, lubelskim i białostockim. Czterem okręgom przyznano po 9 mandatów. Należały one do województw białostockiego i kieleckiego. Po 10 mandatów liczyły 4 okręgi wchodzące w skład województw lubelskiego i łódzkiego. Wytyczono także trzy okręgi ośmiomandatowe. Dwa z nich położone były w województwie warszawskim, a jeden w kieleckim. Trzy okręgi czteromandatowe wyodrębniono z kolei w województwach białostockim i warszawskim. W województwach warszawskim i łódzkim usytuowano też 2 okręgi pięciomandatowe. Łącznie na tych terenach repartycji podlegało 241 mandatów.

Galicja została podzielona na 24 okręgi wyborcze, a wraz ze Śląskiem Cieszyńskim liczyła ich $26^{45}$. W sumie agregowały one 174 mandaty ${ }^{46}$. Największy okręg — nr 52 (Kołomyja, woj. stanisławowskie) — obejmował 10 mandatów, w czterech

${ }^{41}$ Zdaniem W. Zwolińskiego dopuszczenie do udziału w wyborach ministrów i podsekretarzy stanu było słuszne, gdyż: „Urzędnicy władz głównych nie mają bezpośredniej styczności z ludnością; wpływy ich w wielkim mieście nie mogą być stosunkowo tak wielkie, jak na przykład wpływy komisarza powiatowego w obrębie jego powiatu”. W. Zwoliński, Polski Sejm Konstytucyjny, czyli , konstytuanta”, Warszawa 1918, s. 11.

42 Analizując tę kwestię, Z. Ilski trafnie zauważył: „Ten podział na okręgi był nowością; nie zawierał go żaden z wcześniejszych projektów”. Z. Ilski, Formuła wyborcza u progu niepodległej Polski (do $1922 \mathrm{r}$.), Torun 2013, s. 447.

${ }^{43}$ Koncepcję tę popierał W. Jodko-Narkiewicz (PPS): „Im więcej okręgów wyborczych, tym bardziej skład parlamentu odpowiada rzeczywistemu politycznemu obliczu kraju, tym większe jest zatem u wszystkich poczucie, że nikomu nie dzieje się krzywda". W. Jodko-Narkiewicz, Jaka powinna być ordynacja wyborcza do przyszłego Sejmu polskiego?, Warszawa 1918, s. 28. Odmienną opinię na ten temat wyraził z kolei J. Siemieński: „Jeżeli stan rzeczy jest taki, że ludzie z odległych okolic nie znają się wzajemnie i nie znają w ogóle nikogo, nawet najwybitniejszych obywateli, niezamieszkałych pośród nich, a nie umieją też dochodzić z obcymi do porozumienia - wybory w wielkich okręgach nie są w stanie dać wyrazu rzeczywistej woli politycznej takiego społeczeństwa”. J. Siemieński, Rozbiór krytyczny..., s. 26-27.

${ }^{44} \mathrm{~W}$ okręgu $\mathrm{nr}$ 1, obejmującym powiaty: kalwaryjski, wołkowyski, mariampolski i władysławowski, rząd - wobec wątpliwości dotyczących statusu państwowego tych ziem — nie określił liczby mandatów, które miały zostać rozdzielone w wyborach.

${ }^{45}$ Należy zauważyć, że na mocy dekretu o wyborach do Sejmu Ustawodawczego okręgi nr 35 (Cieszyn) i nr 35A (Frydek), które były usytuowane na Śląsku Cieszyńskim, połączono w jeden, ośmiomandatowy okręg wyborczy. Dekret z dnia 28 listopada 1918 r. o wyborach do Sejmu Ustawodawczego, Dz.P.P.P. z 1918 r. nr 18, poz. 47.

${ }^{46}$ Pierwotnie w okręgu nr 39 (Nowy Targ) repartycji miało podlegać 7 mandatów. Faktycznie ich liczba powinna być o jeden mandat większa. Błąd ten został spowodowany niewłaściwym zsumowaniem ludności, która zamieszkiwała wchodzące w jego skład powiaty. W wyborach wybrano 8 posłów, a pomyłkę tę sprostowano w Dz.P.P.P. z 1919 r. nr 40, [brak poz.]. 
najmniejszych wybierano zaś po pięciu posłów — nr 37 (Oświęcim), nr 38 (Wadowice), nr 40 (Nowy Sącz) i nr 46 (Przemyśl). Okręgi te znajdowały się w województwach krakowskim i lwowskim. Najwięcej - 10 - ukształtowano okręgów sześciomandatowych. Były one położone w województwach lwowskim i tarnopolskim. Wytyczono również cztery okręgi dziewięciomandatowe. Usytuowano je w województwach krakowskim, lwowskim, stanisławowskim i tarnopolskim. Przewidziano także istnienie sześciu okręgów, po trzy, siedmio- i ośmiomandatowych. Umiejscowiono je w województwach lwowskim, stanisławowskim, tarnopolskim, krakowskim i na Śląsku Cieszyńskim. Ziemie byłego zaboru pruskiego podzielono natomiast na 11 okręgów wyborczych, w których do zdobycia było 112 mandatów ${ }^{47}$. Najmniejszy okręg liczył trzy mandaty — nr 70 (Nysa), największe dwa zaś po 13 mandatów — nr 63 (Poznań) i nr 65 (Opole). Najwięcej — cztery — uformowano okręgów dwunastomandatowych. Ponadto utworzono po jednym okręgu siedmio-, ośmio-, dziewięcio- i jedenastomandatowym.

Na mocy art. 12 jeden poseł przypadał na 50 tys. mieszkańców okręgu, przy czym ułamki tej liczby większe niż 25 tys. osób, także powodowały przyznanie następnego mandatu. Przyjęcie tego rozstrzygnięcia oznaczało, że do polskiego prawa wyborczego po raz pierwszy formalnie wprowadzono, stosowaną również obecnie, zasadę jednolitej normy przedstawicielstwa ${ }^{48}$. Dzięki temu legislatorzy potwierdzili też obowiązywanie $\mathrm{w}$ ramach przepisów ordynacji zasady równości prawa wyborczego w aspekcie materialnym. W myśl art. 13 główna komisja wyborcza dzieliła okręg wyborczy na obwody głosowania ${ }^{49}$.

W rozdziale IV prawodawcy zamieścili szczegółowe rozwiązania w zakresie wyboru członków Izby. W świetle art. 14 wybory te miały być zarządzone przez Naczelnika Państwa. Na podstawie art. 15 wydane przez niego zarządzenie zawierało dzień głosowania, na który należało wybrać niedzielę lub święto ${ }^{50}$. Głosowanie to powinno zostać przeprowadzone jednego dnia na terenie całego państwa. Było ono wyznaczane najpóźniej na 60. dzień po dniu zarządzenia wyborów. Zarządzenie wyborów musiało zostać ogłoszone w Dzienniku Praw Państwa Polskiego oraz w dziennikach politycznych. Zgodnie z treścią ostatniego zdania tego artykułu, dzień ogłoszenia wyborów w Dzienniku Praw uważano za dzień zarządzenia wyborów. W art. 18 ustanowiono, że w każdym okręgu miała ukonstytuować się główna komisja wyborcza, zaś w każdym obwodzie głosowania - miejscowa komisja wyborcza. Ich powstanie

47 Vide też J. Pietrzak, O reprezentację byłego zaboru pruskiego w Sejmie Ustawodawczym w 1919 r., „Dzieje Najnowsze”, Wrocław-Warszawa 1976, nr 4, s. 7-14.

${ }^{48}$ Confer J. Buczkowski, Podstawowe zasady prawa wyborczego III Rzeczypospolitej, Lublin 1998, s. 146.

49 Zgodnie z treścią Instrukcji liczba mieszkańców obwodu głosowania, poza Galicją i Śląskiem Cieszyńskim, nie mogła przekroczyć 3 tys., a w miastach z populacją powyżej 10 tys. - 2 tys. BSGH, Instrukcja..., sygn. 167071 .

50 Rozwiązanie to skrytykowano na szpaltach „Czasu”: „Wybory muszą być koniecznie w niedzielę, nie wiemy czy dlatego, że przeciwko obraniu soboty protestowaliby niewątpliwie wyborcy żydowscy, czy też dlatego, by zerwać ostentacyjnie z burżuazyjnym przesądem święcenia dnia świętego". Vide Program Moraczewskiego, „Czas” z 22 XII 1918 r., nr 511, s. 1. 
i funkcjonowanie kontrolował minister spraw wewnętrznych, od którego decyzji przysługiwało komisjom odwołanie do Sądu Najwyższego [dalej: SN]. Nad przestrzeganiem przepisów w danym okręgu nadzór pełnił ponadto okręgowy komisarz wyborczy mianowany przez ministra spraw wewnętrznych ${ }^{51}$. Komisarze pozostawali pod zwierzchnictwem Generalnego Komisarza Wyborczego [dalej: GKW], mianowanego przez Naczelnika Państwa na wniosek rządu ${ }^{52}$. W art. 19 przewidziano, że przewodniczącym głównej komisji wyborczej był prezes sądu okręgowego lub sędzia przez niego powołany. Zgodnie z art. 20 funkcję jego zastępcy sprawował sędzia powołany przez prezesa sądu okręgowego. Na mocy art. 21 pozostałych trzech członków komisji wybierały ze swego grona zarówno rady miejskie — wybór jednego członka, jak i zgromadzenia wójtów powiatu - wybór dwóch członków. W okręgach obejmujących wyłącznie miasto, wyboru dwóch członków komisji dokonywały rady miejskie, jednego wybierały natomiast związki zawodowe. W myśl art. 25 miejscowe komisje wyborcze składały się z przewodniczącego, jego zastępcy i trzech członków. Byli oni powoływani przez główną komisję wyborczą. Przyjęcie przez legislatorów zaprezentowanych regulacji oznaczało, że nie tylko struktura komisji wyborczych, ale również relacje między nimi miały charakter zdecentralizowany. Główne komisje wyborcze działały bowiem niezależnie od siebie, a powzięte przez nie decyzje cechowała duża samodzielność. Częściowe zmiany w ramach przywołanych rozwiązań normatywnych nastapiły w II RP dopiero na podstawie ordynacji wyborczej do Sejmu i Senatu z 28 lipca 1922 r. Były one skutkiem utworzenia wspólnej dla całego kraju Państwowej Komisji Wyborczej. Należy jednak pamiętać, że kompetencje Komisji odnosiły się przede wszystkim do problematyki nowej instytucji prawa wyborczego, jaką były listy państwowe.

Na podstawie art. 31 sprawdzenie praw wyborczych rozpoczynało się od sporządzenia przez naczelnika gminy spisu obywateli, zamieszkujących w poszczególnych miejscowościach gminy, którzy w dniu ogłoszenia wyborów mieli ukończone 21 lat. Do tego spisu obowiązkowo dołączał on spis osób, które nie posiadały praw wyborczych w myśl art. 5 ordynacji. Zgodnie z art. 33 po otrzymaniu spisów od naczelnika gminy, względnie burmistrza, miejscowa komisja badała je, a następnie podejmowała decyzję o ich zatwierdzeniu. To wszystko powodowało, że listę wyborców trzeba było dopiero ułożyć. Dokonywano tego albo przez odpisanie ze spisu ogólnego wszystkich nazwisk z wyjątkiem zamieszczonych w spisie negatywnym, albo przez wykreślenie tych nazwisk ze spisu ogólnego. Na mocy art. 34 komisja miejscowa miała prawo żądać od naczelnika gminy okazania materiałów, na bazie których opracował on spisy mieszkańców. Miała także prawo żądać od niego wyjaśnień w tej sprawie. Zgodnie $\mathrm{z}$ art. 35 komisja ta była zobowiązana najpóźniej do 25. dnia od dnia ogłoszenia

51 Należy zauważyć, że przyjęte przepisy — co odróżnia omawiane przedłożenie od projektów wcześniejszych — wprowadzały przedstawicieli rządu do procesu wyborczego. Regulacje te były jednak zgodne z obowiązującymi wtedy na Starym Kontynencie kanonami prawa konstytucyjnego.

52 Generalnym Komisarzem Wyborczym w okresie wyborów do konstytuanty został B. Sobolewski — prezes Sądu Apelacyjnego w Warszawie (M.P. z 1918 r. nr 217), jego zastępcą był W. Wolter — prezydent Krajowego Sądu Wyższego w Krakowie (M.P. z 1918 r. nr 223). 
wyborów przesłać zaakceptowaną przez siebie listę wyborców do głównej komisji wyborczej i jednocześnie drugi egzemplarz tej listy wyłożyć do wglądu obywateli na osiem godzin dziennie przez pięć dni ${ }^{53}$. W świetle art. 36 każdy obywatel miał prawo przedłożyć reklamację przeciwko liście wyborców. Zgodnie z art. 38 komisja miejscowa — najpóźniej nazajutrz — pisemnie zawiadamiała osoby, wobec których wniesiono reklamację mającą na celu usunięcie ich z listy wyborców. Na podstawie art. 39 osoby, których prawo wybierania podano w wattpliwość, mogły przedkładać dowody na swoją obronę do komisji miejscowej w czasie trzech dni od dnia doręczenia im zawiadomienia. W art. 40 zobligowano komisję miejscowa, aby reklamację w tej kwestii rozstrzygnęła w ciagu trzech dni. Od jej postanowień przysługiwało odwołanie do komisji głównej za pomocą reklamacji złożonej do komisji miejscowej w trakcie 48 godzin od daty doręczenia orzeczenia. Przepis ten dopuszczał też możliwość zgłoszenia kontrreklamacji, ale w przeciwieństwie do reklamacji nie precyzował, w jakim terminie należało to zrobić. Na mocy art. 41 główna komisja wyborcza badała spisy, listy, protesty, reklamacje i kontrreklamacje. W dalszej kolejności ustalała ostateczne listy wyborców i rozsyłała je do komisji miejscowych najpóźniej w 32. dniu od dnia ogłoszenia wyborów. W myśl art. 42 orzeczenia głównej komisji wyborczej mogły zostać zaskarżone do SN, ale tylko ze względu na przekroczenie prawa ${ }^{54}$. Nie budzi wątpliwości, że przyjęcie transparentnych mechanizmów formowania list wyborców, które legislatorzy zawarli w dekrecie, było ważnym elementem procedur normujących przebieg procesu wyborczego ${ }^{55}$. Ich prawidłowe przygotowanie stanowiło bowiem prawną gwarancję realizacji w praktyce zasady równości prawa wyborczego $\mathrm{w}$ aspekcie formalnym.

W świetle art. 43 zgłoszenie kandydatury poselskiej do głównej komisji wyborczej musiało nastapić pisemnie nie później niż 24. dnia od dnia ogłoszenia wyborów, wymagano też, aby było ono podpisane przez 50 wyborców, zamieszkałych w danym okręgu wyborczym (art. 44) ${ }^{56}$. Przytoczony przepis nie nakazywał jednak, by podpisy te były poświadczone przez sąd, notariusza czy urząd gminy ${ }^{57}$. To de facto czyniło ten warunek niemal bezprzedmiotowym. Na mocy art. 45 zgłoszenia były rejestrowane

53 W tym kontekście w „Kurierze Warszawskim” napisano: „Wyborcy! Przypominamy wam, że pilnym waszym obowiązkiem narodowym jest dopilnować swoich praw wyborczych i wziąc udział w wyborze posłów do pierwszego polskiego sejmu ustawodawczego. Macie już tylko cztery dni na sprawdzenie w biurach obwodowych wyborczych, czy wciagnięto was do spisu wyborców, czy nie jesteście pozbawieni należnych wam praw obywatelskich”. Vide Przed wyborami, „Kurier Warszawski” z 9 I 1919 r., nr 9, s. 3.

54 Skargi na orzeczenia w tych sprawach na terenie okręgów wytyczonych w Galicji rozpoznawał Krajowy Sąd Wyższy. Dekret z dnia 19 grudnia 1918 r. o przekazaniu Krajowemu Sądowi Wyższemu w Krakowie niektórych funkcji Sądu Najwyższego, Dz.P.P.P. z 1918 r. nr 20, poz. 64.

55 J. Makowski, omawiając tę kwestię, zauważył: „Należy wszystko uczynić, żeby te listy wyborców odzwierciedlały dokładnie to, co publicystyka francuska zwykła określać wyrażeniem payslégal, winny one więc być sporządzane uczciwie i dokładnie, bez opuszczeń, błędów i fałszerstw". J. Makowski, Zarys prawa wyborczego, Warszawa 1918, s. 26.

56 Vide też S. Kutrzeba, Proporcyonalne głosowanie, Warszawa-Lublin-Łódź-Kraków [b.d.w.], s. 60.

57 Art. 48 projektu przygotowanego w MSW wprowadzał tego rodzaju obostrzenie. Został on jednak wykreślony przez rząd z rozpatrywanego przedłożenia 20 listopada 1918 r. AAN, PRM, t. 4, k. 349, sygn. 20048. 
przez komisję według kolejności ich składania. Numer zgłoszenia automatycznie stawał się numerem listy kandydatów. Przepisy ordynacji nie określały natomiast ani minimalnej, ani maksymalnej liczby kandydatów, których można było umieścić na liście ${ }^{58}$. W myśl art. 47 grupy, które zgłosiły listy kandydatów mogły — najpóźniej 27. dnia od dnia ogłoszenia wyborów - poinformować, że tworzą związek wybor$\mathrm{czy}^{59}$. Omawiany artykuł przewidywał również, że takim związkom przysługiwały prawa jednej grupy ${ }^{60}$. Zgodnie z art. 48 zgłoszenie powinno szeregować kandydatów w porządku pierwszeństwa, w jakim mieli wchodzić do Sejmu. Na podstawie art. 49 należało podać w nim imię i nazwisko, zawód, wiek i miejsce zamieszkania każdego $\mathrm{z}$ nich. Poważnym błędem wydaje się pominięcie $\mathrm{w}$ dekrecie — co nie zdarzało się we wcześniejszych przedłożeniach - obostrzenia dotyczącego wyrażenia zgody przez kandydata, aby zamieścić jego nazwisko na liście ${ }^{61}$. W praktyce oznaczało to, że można było na nią wpisać dowolną osobę nawet wbrew jej woli ${ }^{62}$. Zgodnie z art. 50 ten sam kandydat mógł ubiegać się o mandat „w wielu” okręgach wyborczych. W świetle art. $53 \mathrm{w}$ przypadku zgłoszenia tylko jednej listy kandydatów lub zgłoszenia kilku list, ale obejmujących tyle nazwisk, ile było mandatów do rozdzielenia w danym okręgu, wybory nie odbywały się. Główna komisja wyborcza ogłaszała wówczas, że każda z tych osób uzyskiwała mandat poselski. Art. 54 stanowił z kolei, że w razie zgłoszenia więcej niż jednej listy, o łącznej liczbie kandydatów większej od liczby posłów, którzy mieli zostać wybrani w tym okręgu, główna komisja wyborcza ogłaszała, najpóźniej 32. dnia od dnia ogłoszenia wyborów, wszystkie listy kandydatów.

Głosowanie rozpoczynało się o godzinie ósmej i trwało nieprzerwanie do godziny 22. W myśl art. 69 odbywało się ono za pomocą kart urzędowych. Karty te, zawierające wydrukowane numery list kandydatów, miały być sprzedawane w ciagu pięciu dni przed wyborami po pięć fenigów sztuka (10 halerzy). Nie budzi wątpliwości, że

${ }^{58}$ Wydaje się, że wymiernym skutkiem przyjętego rozwiązania mogła być sytuacja, w której na liście umieszczono by jedynie tylu kandydatów, ile było mandatów do obsadzenia w okręgu lub nawet liczby mniejszej niż wynikająca z regulacji zawartych w dodatku nr 1. Zagrożenie to nasilało się szczególnie w najmniejszych okręgach, gdzie w razie śmierci posła, unieważnienia lub wygaśnięcia jego mandatu, przy założeniu zgłoszenia tylko jednej listy kandydatów, fotel poselski mógł zostać trwale opróżniony. Ostatecznie prawodawcy na mocy Instrukcji umożliwili zgłaszanie większej liczby kandydatów na posłów niż było mandatów do rozdzielenia w danym okręgu. BSGH, Instrukcja..., sygn. 167071.

${ }^{59}$ Legislatorzy nie wskazali natomiast reguł, na podstawie których komisje miały dokonywać repartycji mandatów między listy tworzące ten związek. Uchybienie to zostało przez nich naprawione w Instrukcji. Mandaty na bazie zapisanych w niej postanowien, w takim przypadku, nakazali oni rozdzielać według metody d'Hondta. Ibidem.

${ }^{60}$ M. Rostworowski analizując to zagadnienie stwierdził: „Zgłoszenie związku wyborczego nie jest połączeniem stronnictw, czyli ich koalicją gdyż ta polega na wystawieniu wspólnej listy przez dwa lub kilka stronnictw, przy czym kolejność kandydatów zależy od liczebności stronnictw. Tymczasem związek wystawia tyle list, ile jest stronnictw i nie wyklucza bynajmniej ich konkurencji między sobą". M. Rostworowski, Geneza państwa polskiego, Kraków 1921, s. 184-185.

${ }^{61}$ Ułomność rozpatrywanego rozstrzygnięcia była skutkiem niezrozumiałej decyzji podjętej przez gabinet. W dniu 20 listopada 1918 r. postanowił on bowiem wykreślić z projektu wypracowanego w MSW art. 54, który zawierał takie zastrzeżenie. AAN, PRM, t. 4, k. 349, sygn. 20048.

${ }^{62}$ Postępowanie, o którym mowa, odnotowano choćby w okręgu nr 16 (Warszawa). Vide Przed wyborami, „Kurier Warszawski” z 21 I 1919 r., nr 21, s. 4. 
wprowadzenie tej opłaty godziło w zasadę powszechności prawa wyborczego, ponieważ wyborca mógł nie dysponować kwotą umożliwiającą zakup karty do głosowania. Tak więc, mimo że formalnie miał on prawo wybierania, tracił możliwość oddania głosu. Finalnie ułomność przyjętego rozstrzygnięcia dostrzegli także legislatorzy. Na mocy dekretu z 26 grudnia 1918 r. o zmianach w ordynacji wyborczej do Sejmu Ustawodawczego znieśli zatem kartę urzędową, sankcjonując jednocześnie głosowanie kartami prywatnymi ${ }^{63}$. Głosowanie — regulował to art. 70 - odbywało się w następujący sposób: wyborca podchodził do stołu, przy którym siedziała komisja wyborcza i wymieniał swoje nazwisko. Po sprawdzeniu, czy znajdowało się ono na liście wyborców, otrzymywał kopertę urzędowa, do której wkładał kartę do głosowania ${ }^{64}$. Zakleiwszy kopertę, wręczał ją przewodniczącemu komisji. Przewodniczący, po zweryfikowaniu stempla urzędowego na kopercie, wrzucał ją do urny wyborczej. Równolegle członek komisji prowadzący protokół dokonywał stosownej adnotacji w jego treści. Należy podkreślić, że niezamieszczenie w omawianym przedłożeniu rozwiązań warunkujących wydzielenie osłoniętych miejsc, w obrębie których wyborca mógłby włożyć kartę do koperty, było przykładem wadliwego unormowania zasady tajności głosowania ${ }^{65}$. Pominięcie tego wymogu powodowało bowiem, że wyborca, który nie napisał (ewentualnie nie wydrukował) wcześniej numeru listy kandydatów na karcie do głosowania, musiał to uczynić w obecności wszystkich osób znajdujących się w danym lokalu wyborczym ${ }^{66}$.

Stwierdzenie wyniku głosowania następowało w dwóch etapach. Najpierw prace podejmowała miejscowa komisja wyborcza. Na mocy art. 75 i 76 obliczała, weryfikując jednocześnie ważność kart do głosowania, liczbę głosów oddanych na konkretne listy kandydatów. Następnie komisja sporządzała protokół dokumentujący przedsięwzięte przez nią działania. Protokół ten - po podpisaniu przez członków komisji - był przekazywany wraz z kartami do głosowania oraz listami wyborców do głównej komisji wyborczej. Zgodnie $\mathrm{z}$ art. 80 jej posiedzenie rozpoczynające drugi etap procesu musiało odbyć się najpóźniej na trzeci dzień po głosowaniu. W ordynacji nie wspomniano natomiast, że mandaty miały być rozdzielane między listy kandydatów proporcjonalnie $^{67}$. Co więcej, w przepisach dekretu nie ma informacji, według jakiej

${ }^{63} \mathrm{Na}$ podstawie tego dekretu art. 69 ordynacji uzyskał następujące brzmienie: „Głosowanie odbywa się za pomocą kart do głosowania. Karta ma zawierać jedynie numer listy kandydatów, na którą wyborca oddaje swój głos. Numer może być drukowany, albo pisany". Dekret z dnia 26 grudnia 1918 r. o zmianach w ordynacji wyborczej do Sejmu Ustawodawczego, Dz.P.P.P. z 1918 r. nr 21, poz. 74.

${ }_{64}$ Pierwotnie, zgodnie $\mathrm{z}$ art. 71 ordynacji, wyborca oddawał głos poprzez podkreślenie na karcie numeru listy. Ostatecznie jednak rozwiązanie to - na mocy przeprowadzonej w grudniu 1918 r. nowelizacji przepisów — prawodawcy usunęli z przedłożenia. Ibidem.

${ }_{65}$ Wada ta stanowiła pokłosie decyzji podjętej przez rząd 21 listopada $1918 \mathrm{r}$. Wówczas to bowiem jego członkowie wykreślili z projektu przygotowanego w MSW fragment art. 75. Usunięte przez nich obostrzenie warunkowało istnienie ,osobnego pokoju lub też należycie osłoniętego stołu”. AAN, PRM, t. 4, k. 341 i 361, sygn. 20048.

${ }_{66}$ Adwokat A. Bogucki zalecał zatem, aby wyborcy przynosili wypełnione już karty do głosowania. A. Bogucki, Ordynacja wyborcza do Sejmu Ustawodawczego, Warszawa 1919, s. 18.

${ }^{67}$ Zastosowanie proporcjonalności popierał S. Kutrzeba: „Specjalnie zaś nadaje się ona dla Polski, a to ze względu na jej skład nie jednonarodowy; zabezpieczy prawa reprezentacji mniejszości narodowych obcych: Niemców, Żydów itd., którzy nie będą mogli czynić nam żadnych zarzutów, iż ich upośledzamy, gdy 
metody przeliczania głosów na mandaty komisje miały dokonywać tej operacji. Art. 81 stanowił tylko, że główna komisja wyborcza po obliczeniu głosów oddanych na poszczególne listy przystępowała do repartycji mandatów poselskich wykorzystując przy tym metodę zaprezentowaną w dodatku $\mathrm{nr} 5^{68}$. Na podstawie symulacji matematycznej zamieszczonej we wskazanym dodatku można orzec, że chodziło o metodę d'Hondta $^{69}$. W myśl art. 82 z czynności głównej komisji wyborczej spisywano protokół. Po ustaleniu jego zawartości przewodniczący głównej komisji wyborczej ogłaszał wynik głosowania, a następnie podawał go do publicznej wiadomości (art. 83). Potem, zgodnie $z$ art. 84, wystawiał on dla posłów wybranych w danym okręgu listy wierzytelne ${ }^{70}$. Zgodnie z art. 85 protokół był podpisywany przez członków komisji. Na mocy art. 86 protokół ten wraz z aktami wyborczymi miejscowych komisji wyborczych i kartami do głosowania przesyłano do pierwszego prezesa SN.

Rozdział V normował zagadnienie ważności wyborów. W świetle art. 88 w ciągu 14 dni po ogłoszeniu wyniku głosowania przez główną komisję wyborczą każdy obywatel mógł wnieść protest przeciwko wyborowi konkretnej osoby na posła. Zgodnie z art. 89 przewodniczący tej komisji po otrzymaniu skargi ogłaszał w dzienniku urzędowym państwa i w dzienniku miejscowym, że została ona formalnie przedłożona. Jednocześnie wyznaczał dziesięciodniowy okres, w trakcie którego można było przedkładać zarzuty wobec jej treści. Na mocy art. 90 i 94 o ważności wyborów oprotestowanych decydował na publicznym posiedzeniu SN. Miał na to sześć miesięcy od dnia wyborów. Zgodnie z art. $91 \mathrm{SN}$ - działając w charakterze trybunału wyborczego orzekał w składzie trzech sędziów ${ }^{71}$. Jeśli chodzi natomiast o ważność wyborów nieoprotestowanych, to kwestię tę na podstawie art. 96 rozstrzygał Sejm, najpóźniej w terminie dwóch miesięcy.

Rozdział VI regulował zarówno mechanizmy wygaśnięcia mandatu poselskiego, jak i uzupełnienia składu Sejmu. Mandat zostawał unieważniony (art. 97), jeżeli okazało się, że poseł nie był wybieralny według art. 7 i 8, albo później prawo to utracił. W myśl art. 98 SN mógł unieważnić wybór gdy: zostało stwierdzone, że w danym okręgu mandat poselski uzyskano przy użyciu przekupstwa, wymuszenia, fałszu lub

dostaną tyle mandatów, ile im przypadnie w stosunku do siły liczebnej ich wyborców, zabezpieczy jednak także bez sztucznych kombinacji i prawa reprezentacji mniejszości polskich, np. na Rusi”. S. Kutrzeba, Proporcyonalne głosowanie..., s. 40.

${ }^{68}$ Nie budzi wattpliwości, że problematykę tę — z racji jej znaczenia — legislatorzy powinni uregulować w konkretnym artykule dekretu.

${ }^{69} \mathrm{Na}$ temat tej metody vide A. Esmein, Prawo konstytucyjne, nota biograficzna K.M. Ujazdowski, Warszawa 2013 (reprint wydania z 1921 r.), s. 263.

${ }^{70}$ Oryginalny dokument potwierdzający wybór na posła S. Osieckiego znajduje się w Muzeum Historii Polskiego Ruchu Ludowego, S. Osiecki i F. Kamiński, [brak jednolitej paginacji kart], sygn. 4645.

71 W. Komarnicki chwalił przytoczone rozwiązania: „Cechą charakterystyczną tej ordynacji wyborczej jest wybitny udział w organizacji wyborów organów sądowych, co objaśnia się poza względami bezstronności i autorytetu tych organów, tym także, że w momencie owym organy sądowe, jako istniejące dawniej, działały sprawniej, niż organy dopiero tworzącej się administracji. Zupełnie zresztą słusznie wprowadzono ingerencję sądową do rozstrzygania protestów przeciwko ważności wyborów, oraz zakwestionowania wyborów przez Sejm, właściwie bowiem jest to funkcja z natury swej sądowa”. W. Komarnicki, Polskie prawo..., s. 62. 
jakichkolwiek innych działań zabronionych przez prawo, albo jeżeli w postępowaniu wyborczym przepisy ordynacji nie były przestrzegane. W art. 99 zapisano, że w wypadku, gdy ten sam kandydat został wybrany w więcej niż w jednym okręgu, musiał on — najpóźniej na pierwszym posiedzeniu Izby — podjać decyzję, z którego z nich obejmował mandat. W przeciwnym razie rozstrzygało o tym losowanie dokonywane przez marszałka Sejmu. Zgodnie z art. $100 \mathrm{w}$ sytuacji unieważnienia wyboru posła według art. 98, o ile SN orzekł, że nie mogły być wykorzystane procedury zapisane $\mathrm{w}$ art. 101, minister spraw wewnętrznych zarządzał wybory ponowne w okręgu lub obwodzie, gdzie prawo zostało przekroczone, w okresie 15 dni od ich unieważnienia. Z kolei art. 101 miał zastosowanie we wszystkich pozostałych przypadkach unieważnienia lub ustania mandatu. Na jego mocy główna komisja wyborcza informowała o wstapieniu na miejsce posła, którego mandat wygasł lub został unieważniony, następnego kandydata $\mathrm{z}$ tej samej listy i wystawiała mu list wierzytelny.

W dniu 28 listopada 1918 r., wraz z dekretem o ordynacji wyborczej, J. Piłsudski podpisał również dekret o wyborach do Sejmu Ustawodawczego ${ }^{72}$. Wybory na jego podstawie wyznaczono na dzień 26 stycznia 1919 r. Dekret ten wskazywał także ziemie, na których miały one zostać przeprowadzone. Przyjęcie postanowień, o których mowa, było podyktowane koniecznością dostosowania wykazu terenów objętych procedurami wyborczymi do realiów politycznych ${ }^{73}$. Oczywiste było bowiem, że dodatek nr 1 uwzględniał listę okręgów, która została ułożona bardziej podług oczekiwań normodawców niż faktycznych możliwości prawnych czy też decyzyjnych otwierających się w tej kwestii przed II RP.

W dekrecie zapisano, że wybory odbędą się na większości ziem dawnego zaboru rosyjskiego ${ }^{74}$. Elekcja na tych terenach miała zostać zarządzona we wszystkich okręgach wymienionych $\mathrm{w}$ dodatku $\mathrm{nr} 1$, $\mathrm{z}$ wyjątkiem okręgu $\mathrm{nr} 1$. W przypadku terytorium byłego zaboru austriackiego wybory miały odbyć się w okręgach od $\mathrm{nr} 36$ do nr 46. Na pozostałych obszarach Galicji, które wyszczególniono w ordynacji — chodzi tu o okręgi od $\mathrm{nr} 47$ do $\mathrm{nr} 59$ - na skutek toczących się tam zmagań zbrojnych nie można było ich zorganizować. W związku z tym w miejsce kandydatów, których planowano wybrać w przywołanych okręgach, mieli wejść polscy posłowie reprezentu-

${ }^{72}$ Dekret z dnia 28 listopada 1918 r. o wyborach do Sejmu Ustawodawczego, Dz.P.P.P. z 1918 r. nr 18, poz. 47

${ }^{73}$ Dziennikarze „Głosu” analizując tę kwestię napisali: „W okręgach Galicji Wschodniej pozostaną w mocy dawne mandaty polskie do austriackiej Rady Państwa; przedstawicielstwo zaboru pruskiego ma być ustalone po porozumieniu z przedstawicielami społeczeństwa polskiego w tym zaborze, a więc zapewne wobec oczywistej niemożebności przeprowadzenia tam obecnie wyborów — wypadnie również zachować dawne mandaty, uzupełniając je co do niektórych okręgów niemających przedstawicielstwa polskiego. Sześcioprzymiotnikowy zatem system zostanie zastosowany tylko do ziem byłej Kongresówki i do Galicji Zachodniej. Zastosowanym zostanie tam, gdzie ludność najmniej jest przystosowaną do tak szerokiego korzystania ze swych praw obywatelskich. Niejednolitość systemu przedstawicielstwa zapewne niejednokrotnie będzie w Sejmie lub poza Sejmem użytkowana, jako argument w tych wypadkach, gdy co jest zupełnie możliwe, podział przy głosowaniach nad wieloma wnioskami nastapi według dzielnic”. Vide Zwołanie Sejmu, „Głos” z 30 XI 1918 r., nr 386, s. 1.

74 Poszczególne rozwiązania, które zostały zawarte w tym przedłożeniu ministrowie omówili w dniach 23, 25, 26 i 27 listopada 1918 r. AAN, PRM, t. 4, k. 362, 379 i 394, sygn. 20048. 
jący te ziemie w Izbie Posłów Rady Państwa monarchii austriackiej ${ }^{75}$. Wybory rozpisano też na Śląsku Cieszyńskim, ale nie w dwóch, jak stanowiły przepisy ordynacji, lecz w jednym okręgu wyborczym (nr 35 Cieszyn). Przedstawiciele z dawnego zaboru pruskiego - okręgi od $\mathrm{nr} 60$ do $\mathrm{nr} 70$ - mieli zostać wyłonieni na mocy porozumienia zawartego między władzami odrodzonej RP a zamieszkującą ten region polską społecznością. Legislatorzy zdawali sobie bowiem sprawę, że zadaniem niewykonalnym będzie - przy braku dostatecznie silnej armii — pokonanie na tym terytorium wojsk niemieckich. Na koniec należy zauważyć, że w skład konstytuanty mieli zostać powołani, choć przedłożenie nie precyzowało daty rozpoczęcia tego procesu, także reprezentanci Polaków na Litwie i Rusi.

W dniu 8 stycznia 1919 r. J. Piłsudski podpisał dekret o postanowieniach karnych za przeciwdziałanie wyborom do Sejmu i wykonywaniu obowiązków poselskich ${ }^{76}$. Był to ostatni akt prawny dotyczący kwestii wyborczych, który został przygotowany przez rząd Moraczewskiego. Stało się tak, ponieważ 16 stycznia 1919 r. J. Moraczewskiego na stanowisku premiera zastapił Ignacy Jan Paderewski (bezpartyjny) ${ }^{77}$. Wydarzenia te, mimo że spowodowały znaczące przetasowania na scenie politycznej, nie wpłynęły na zmianę charakteru wyzwań, z którymi musiała zmierzyć się nowa Rada Ministrów. Najważniejsze z nich nadal ogniskowało się wokół problemu przeprowadzenia wyborów do konstytuanty ${ }^{78}$. To niełatwe zadanie przypadło w udziale mianowanemu przez I.J. Paderewskiego na urząd ministra spraw wewnętrznych Stanisławowi Wojciechowskiemu (bezpartyjny) ${ }^{79}$. Ostatecznie pierwsze wybory parlamentarne w II RP zostały uznane zarówno przez liderów poszczególnych stronnictw, jak i opinię publiczną za w pełni uczciwe ${ }^{80}$. Anonimowy autor na łamach „Naprzód” stwierdził: „Wczo-

75 Ostatecznie w okręgu nr 47 (Lwów — miasto), w konsekwencji śmierci posłów reprezentujących dawne okręgi nr V i nr VII, ich granice pokrywały się z obszarem przywołanego okręgu, rozpisano wybory uzupełniające. Odbyły się one 26 stycznia 1919 r. na podstawie przepisów ordynacji do Izby Posłów Rady Państwa.

${ }^{76} \mathrm{Na}$ mocy tego dekretu sądy, w zależności od istoty popełnionego przestępstwa, mogły wymierzyć oskarżonemu nie tylko karę aresztu, ale i więzienia. Dekret z dnia 8 stycznia 1919 r. o postanowieniach karnych za przeciwdziałanie wyborom do Sejmu i wykonywaniu obowiązków poselskich, Dz.P.P.P. z 1919 r. nr 5, poz. 96.

77 M.P. z 1919 r. nr 13. Premier Paderewski oświadczył wówczas: „Pierwszym zadaniem nowego rządu będzie przeprowadzenie wyborów i zwołanie Sejmu, na którym niewątpliwie wypowie się zbiorowa wola naszego narodu”. Vide Deklaracja Paderewskiego, „Kurier Polski” z 17 I 1919 r., nr 13, s. 3.

${ }^{78}$ Członkowie rządu Moraczewskiego podsumowując swoje dokonania w tej materii napisali: ,W bardzo krótkim czasie przygotowaliśmy w zupełności zwołanie Sejmu. Wybory rozpisano na najdemokratyczniejszej podstawie, rozstrzygną one w dniu 26 stycznia 1919 r. walkę o władzę w Polsce. Pierwsze posiedzenie Sejmu może się odbyć przed upływem połowy lutego. Najważniejsze więc nasze zadanie spełnione". Vide Pismo ustępujacego gabinetu do Naczelnika Państwa, ibidem, s. 4.

${ }^{79}$ Minister Wojciechowski w okólniku adresowanym do komisarzy wyborczych stwierdził: „Zadaniem administracji państwa jest dopilnowanie, aby wszyscy wyborcy mogli spełnić swój obywatelski obowiązek w dniu 26 stycznia. Wyznaczam Pana do podjęcia, z bezwzględną bezstronnością, wszystkich środków zabezpieczających spokój i bezpieczeństwo głosujących i całość dokumentów. Należy wszystko tak przeprowadzić, aby zarzut stronniczości czy niedołęstwa nie spadł na administrację państwa i jej funkcjonariuszy". Biblioteka Narodowa, S. Wojciechowski, Moje wspomnienia, t. II, 1918-1922, k. 4, akc. 10398.

${ }^{80}$ Na temat wyniku tych wyborów vide K. Kacperski, System wyborczy do Sejmu i Senatu u progu Drugiej Rzeczypospolitej, Warszawa 2007, s. 107-126. 
rajszy dzień historyczny miał w sobie jakiś odmienny nastrój — czy może robił takie wrażenie w tych dziesiątkach tysięcy, które czuły, że dokonuje się wielkie uroczyste dzieło, że w tych godzinach buduje się wielki gmach - Sejmu polskiego. Zrozumienie doniosłości tej chwili przejawiało się w thumnym udziale ludności, jak też w niezakłóconym spokoju, z jakim we wszystkich lokalach odbywały się wybory"

Ordynacja wyborcza do konstytuanty, którą na polecenie Naczelnika Państwa J. Piłsudskiego wypracował rząd J. Moraczewskiego, nie była wzorcowym aktem prawnym. Nie budzi wątpliwości, że niektóre zawarte w niej regulacje zostały przez legislatorów sformułowane niestarannie. Niejednokrotnie też na skutek pośpiechu, jaki towarzyszył kopiowaniu rozwiązań jurydycznych zamieszczonych w przedłożeniach stanowiących dla nich punkt odniesienia, były one niespójne wewnętrznie, a w kilku przypadkach nawet błędne merytorycznie. Piętno, jakie dokument ten odcisnął na systemie politycznym RP, jest jednak znacznie głębsze niż wynikałoby to jedynie z analizy jego niedoskonałych przepisów. Należy bowiem pamiętać, że zorganizowane na ich podstawie 26 stycznia 1919 r. wybory umożliwiły ukonstytuowanie się Sejmu Ustawodawczego, który skupiał reprezentantów wszystkich warstw i grup społecznych osiadłych na terenach wskrzeszonego państwa. Rozpatrując tę kwestię, trzeba także zaznaczyć, że zasady prawa wyborczego, które zostały wtedy zdefiniowane na forum Rady Ministrów, weszły do kanonu reguł ustrojowych obowiązujących na terytorium Polski nie tylko w latach międzywojnia, ale przede wszystkim, po dostosowaniu ich do wymogów współczesnej demokracji, również w XXI w.

\section{PROBLEMATYKA PRAWA WYBORCZEGO DO KONSTYTUANTY \\ W LATACH 1919-1922}

Oficjalne ogłoszenie wyniku wyborów przeprowadzonych w styczniu 1919 r., wobec nierozstrzygniętego statusu państwowego poszczególnych regionów, które według zamierzeń J. Piłsudskiego, a także kolejnych gabinetów miały wchodzić w skład II RP, nie zakończyło procesu kształtowania się konstytuanty ${ }^{82}$. Co więcej, okoliczności towarzyszące wyłanianiu posłów na obszarach, które były odzyskiwane w latach 1919-1922, wespół ze specyfiką relacji, jakie łączyły zamieszkujące je społeczności z odrodzoną Polską, częstokroć wymuszały zarówno na członkach Izby, jak i istniejących wówczas rządach uchwalenie nowych bądź nowelizację już obowiązujących przepisów prawa.

W pierwszej kolejności wybory, po zakończeniu okupacji tych ziem przez wojska niemieckie, odbyły się 16 lutego 1919 r. w okręgu nr 2 (Suwałki) i 9 marca 1919 r.

${ }^{81}$ Vide Wybory w Krakowie, „Naprzód” z 28 I 1919 r., nr 24, s. 1.

${ }^{82}$ Konstytuanta, po doliczeniu do 291 posłów wybranych w wyborach 28 członków byłej Izby Posłów Rady Państwa, składała się z 319 przedstawicieli II RP. W tym kontekście należy przypomnieć, że posłów $\mathrm{z}$ dawnego zaboru austriackiego wyłoniono na podstawie dekretu o wyborach do Sejmu Ustawodawczego. Inaczej rzecz miała się z 16 parlamentarzystami, którzy wywodzili się z byłego zaboru pruskiego ( 5 z Górnego Ślasska, 9 z Poznańskiego i 2 z Pomorza). W ich przypadku został bowiem wydany w dniu 7 lutego 1919 r. dekret w przedmiocie powołania do Sejmu Ustawodawczego Polaków, którzy w 1918 r. posiadali mandat poselski do parlamentu Rzeszy Niemieckiej, Dz.P.P.P. z 1919 r. nr 14, poz. 193. 
w okręgu nr 20 (Biała Podlaska) ${ }^{83}$. W okręgu nr 2 wszystkie 4 mandaty przypadły w udziale Związkowi Ludowo-Narodowemu [dalej: ZLN] ${ }^{84}$. W okręgu nr 20 po 2 mandaty uzyskały natomiast PSL „Piast” i ZLN, po jednym zaś Polskie Zjednoczenie Ludowe [dalej: PZL] i mniejszość żydowska ${ }^{85}$. W dniu 15 czerwca 1919 r. wybory zorganizowano też w okręgach nr 33 (Białystok) i nr 34 (Bielsk). W przeciwieństwie do wcześniejszych elekcji zostały one rozpisane nie tylko na podstawie stosowanych dotychczas regulacji prawnych, ale także na mocy ustawy w sprawie zmiany niektórych przepisów ordynacji wyborczej z 28 listopada $1918 \mathrm{r} .{ }^{86}$ Ustawę tę opublikowano, po jednomyślnym zaakceptowaniu przez posłów, 15 maja $1919 \mathrm{r} .{ }^{87}$ Artykuł 1 tego przedłożenia stanowił, że w okręgach nr 33 i nr 34 przewodniczących i ich zastępców w ramach głównych komisji wyborczych powoływał prezes sądu okręgowego w Warszawie. Zgodnie $\mathrm{z}$ art. 3 kandydatury poselskie miały być zgłaszane do głównych komisji wyborczych najpóźniej 11. dnia od dnia zarządzenia wyborów. W świetle art. 4 za dzień zarząazzenia wyborów należało uznać datę wydania rozporządzenia przez ministra spraw wewnętrznych ${ }^{88}$. W okręgu nr 33 po 2 mandaty uzyskały ZLN i Narodowe Zjednoczenie Ludowe [dalej: NZL], po jednym natomiast Zjednoczenie Mieszczańskie [dalej: ZM] oraz listy — Chrześcijańsko-Narodowa i mniejszości żydowskiej. W okręgu nr 34 czterema mandatami - po 2 - podzieliły się ZLN i ZM ${ }^{89}$.

Wybory do konstytuanty, mimo że przygotowania związane z ich przeprowadzeniem były zaawansowane, nie odbyły się na Ziemi Cieszyńskiej. Stało się tak na skutek niespodziewanego zajęcia tych terenów przez wojska czechosłowackie ${ }^{90}$. W tej sytuacji poseł Emil Bobrowski (PPS) na 2. posiedzeniu SU 14 lutego 1919 r. złożył wniosek o powołanie w jego skład 7 kandydatów, którzy mieli zostać wybrani w okręgach $\mathrm{nr} 35$ (Cieszyn) i nr 35A (Frydek) ${ }^{91}$. Projektodawca zaproponował, aby za po-

${ }^{83}$ Dekret z dnia 14 stycznia 1919 r. o przedłużeniu terminu wyborów do Sejmu Ustawodawczego w drugim okręgu wyborczym, Dz.P.P.P. z 1919 r. nr 6, poz. 101; dekret z dnia 14 stycznia 1919 r. o przedłużeniu terminu wyborów do Sejmu Ustawodawczego w dwudziestym okręgu wyborczym, Dz.P.P.P. z 1919 r. nr 6, poz. 102.

${ }^{84}$ K. Kacperski, System wyborczy..., s. 126.

85 Ibidem.

${ }^{86}$ Ustawa z dnia 10 maja 1919 r. w sprawie zmiany niektórych przepisów ordynacji wyborczej z dnia 28 XI 1918 r., celem przeprowadzenia wyborów w okręgach 33 i 34, Dz.P.P.P. z 1919 r. nr 40, poz. 294.

${ }^{87} \mathrm{Na}$ mocy decyzji podjętych przez marszałka trzy czytania tej ustawy odbyły się podczas 36 . posiedzenia Izby 10 maja 1919 r.; SU, sprawozdanie stenograficzne [dalej: spr. sten.], ł. XXXVI/58.

${ }^{88}$ Minister Wojciechowski rozporządzenie to wydał 15 maja 1919 r. Rozporządzenie Ministra Spraw Wewnętrznych z dnia 15 maja 1919 r. o wyborach poselskich do Sejmu Ustawodawczego RP w 33 (białostockim) i 34 (bielskim) okręgach wyborczych, Dz.P.P.P. z 1919 r. nr 40, poz. 295.

${ }^{89}$ K. Kacperski, System wyborczy..., s. 126-127.

${ }^{90} \mathrm{~W}$ tym miejscu warto przypomnieć, że 5 listopada 1918 r. PRNKC zawarła umowę z czeskim Komitetem Narodowym. Na podstawie jej treści dokonano prowizorycznego rozgraniczenia przywołanych ziem. Poczynione wówczas ustalenia miały obowiązywać do momentu rozstrzygnięcia statusu państwowego tych terenów przez mocarstwa. Porozumienie, o którym mowa, zostało zaakceptowane przez Główny Komitet Narodowy w Pradze. Druk nr 162.

91 Należy podkreślić, że przedłożona propozycja była sprzeczna z regulacjami zamieszczonymi w dekrecie o wyborach do SU. Zgodnie z jego postanowieniami okręgi te bowiem scalono. SU, spr. sten., 1. II $/ 38-42$. 
słów uznać 6 kandydatów - 3 z PPSD, 2 ze Związku Katolików Śląskich i 1 z PSL „Piast” — zgłoszonych na wspólnej liście przez partie zrzeszające Polaków w okręgu nr 35. Siódmy mandat na gruncie decyzji podjętej przez Polską Radę Narodową dla Księstwa Cieszyńskiego [dalej: PRNKC] miała uzyskać Dorota Kłuszyńska (PPS) w okręgu nr 35 ${ }^{92}$. Wniosek ten marszałek przesłał do Komisji Konstytucyjnej [dalej: KK $]^{93}$. Miesiąc później, 14 marca 1919 r., sprawozdanie z jej prac na 14. posiedzeniu SU przedstawił poseł M. Niedziałkowski (PPS) ${ }^{94}$. W pierwszym rzędzie przeanalizował on możliwość wyłonienia nowych parlamentarzystów bez konieczności organizowania wyborów. W dalszej kolejności rozważył natomiast zasadność zaaprobowania kandydatury D. Kłuszyńskiej jako reprezentantki okręgu nr 35A. Poseł Niedziałkowski stwierdził, że pierwsza z rozpatrywanych kwestii nie wzbudziła na forum KK żadnych obiekcji ani w aspekcie prawnym, ani moralnym. W opinii całej Komisji wszystkie czynności proceduralne w okręgu nr 35 przeprowadzono bowiem zgodnie $\mathrm{z}$ kalendarzem wyborczym. Co więcej, tryumf w wyborach listy kompromisowej, wobec znaczącej przewagi ludności polskiej nad pozostałymi nacjami, był pewny ${ }^{95}$. Wątpliwości w KK, jak zauważył referent, zrodziła za to sprawa przekazania okręgowi $\mathrm{nr} 35 \mathrm{~A}$ mandatu z okręgu nr 35. Ostatecznie jej członkowie zdecydowali, że na ten temat wypowiedzą się dopiero, gdy ententa ureguluje status państwowy spornego terytorium. W tej sytuacji poseł sprawozdawca złożył wniosek o uznanie za posłów Tadeusza Regera, ks. Józefa Londzina, Jerzego Kantora, Ryszarda Kunickiego, Pawła Bobka i Karola Junga. Jednocześnie zaapelował, aby Izba odrzuciła tę część przedłożenia, która dotyczyła okręgu nr $35 \mathrm{~A}^{96}$. Następnie głos zabrali posłowie: Konstanty Kowalewski (ZLN), Bolesław Fichna (Narodowy Związek Robotniczy, NZR), Maciej Rataj (PSL), Jan Załuska (ZLN), Stanisław Osiecki (PSL „Wyzwolenie”) i Władysław Kiernik (PSL „Piast”) ${ }^{97}$. Wszyscy mówcy poparli rozwiązania uformowane na plenum KK. W związku z tym marszałek zarządził głosowanie procedowanego wniosku. Został on jednomyślnie zaakceptowany przez konstytuantę ${ }^{98}$.

W przypadku terenów byłego zaboru pruskiego Sejm Ustawodawczy, biorąc pod uwagę specyfikę okoliczności towarzyszących ich wejściu w skład II RP, postanowił przyjąć zbiór odrębnych przepisów normujących opisywaną problematykę. Dyskusja w tym zakresie została zapoczątkowana wnioskami, które posłowie I. Daszyński (PPS) oraz Wojciech Korfanty (ZLN) wnieśli w trakcie 2. posiedzenia SU w dniu 14 lutego 1919 r. ${ }^{99}$ Poseł Daszyński w forsowanej wówczas uchwale wezwał rząd, ,aby bezzwłocznie po ustaniu przeszkód, wywołanych operacjami wojennymi” ogłosił wybo-

92 Podobny wniosek zgłosił wtedy również poseł W. Korfanty. Ibidem, ł. II/42-43.

93 Ibidem, 1. II/38 i 45.

94 Ibidem, ł. XIV/696.

$95 \mathrm{~W}$ okręgu nr 35 jeden mandat miał też uzyskać kandydat mniejszości niemieckiej. Ibidem, 1. XIV/ 697-699.

\footnotetext{
96 Ibidem, 1. XIV/700.

97 Ibidem, 1. XIV/700-708.

98 Ibidem, 1. XIV/710.

99 Ibidem, 1. II/37 i 43-44.
} 
ry na obszarze dawnego zaboru pruskiego ${ }^{100}$. Poseł Korfanty zaproponował z kolei, aby z tych ziem weszło do konstytuanty, oprócz 16 posłów do parlamentu Rzeszy Niemieckiej, którzy uzyskali mandaty na mocy dekretu z 8 lutego 1919 r., jak też 71 członków Naczelnej Rady Ludowej [dalej: NRL] i Komisariatu NRL, wybranych 5 grudnia 1918 r. przez Sejm Dzielnicowy w Poznaniu ${ }^{101}$. Jego zdaniem wybory posłów miały odbyć się natomiast „W przeciagu czterech tygodni po przyłączeniu tej dzielnicy" do Polski ${ }^{102}$. Przedłożenia te marszałek skierował do KK ${ }^{103}$.

Dysputa na ten temat była kontynuowana podczas 26. posiedzenia SU 5 kwietnia 1919 r. ${ }^{104}$ Konkluzje w tej sprawie jako referent sprawozdania KK zaprezentował poseł W. Kiernik (PSL „Piast”). W pierwszym rzędzie odniósł się do projektów, które zgłosili posłowie Daszyński i Korfanty. Relacjonując przebieg debaty, która wywiązała się na kanwie ich treści, przyznał, że jej uczestnikom nie udało się wypracować rozwiązania unifikującego obie przedstawione koncepcje. Jednocześnie zauważył, że w toku obrad Komisji większość posłów, chcąc przełamać rodzący się w tym względzie impas, opowiedziała się za szybkim rozpisaniem wyborów na terytorium Księstwa Poznańskiego. W dalszej części wystapienia skoncentrował się on na kwestii zorganizowania wyborów na tych terenach. Analizując tę materię, stwierdził, że KK przygotowała projekt ustawy modyfikujący niektóre przepisy ordynacji. Korekta zawartych w niej norm miała objąc zarówno prawo wybierania, strukturę wewnętrzną komisji wyborczych, mechanizmy formowania list wyborców, jak i spis okręgów wyborczych. W dyskusji na forum Izby udział wzięli posłowie: M. Niedziałowski (PPS), Antoni Stychel (ZLN) i Stanisław Nowicki (NZR) ${ }^{105}$. Wszyscy mówcy poparli założenia rozpatrywanego aktu prawnego. Marszałek zarządził zatem najpierw drugie, a potem trzecie czytanie tego projektu. Ostatecznie posłowie jednomyślnie zaaprobowali wniosek autorstwa $\mathrm{KK}^{106}$.

Artykuł 1 ustawy stanowił, że jej przepisy obowiązywały wyłącznie na wolnych od okupacji niemieckiej ziemiach polskich wchodzących w skład dawnego zaboru pruskiego, w tym zwłaszcza na terenach Księstwa Poznańskiego. W świetle art. 2 terytorium, na którym planowano przeprowadzić wybory, podzielono na 4 okręgi wyborcze: nr I (Mogilno) - 10 mandatów $^{107}$, nr II (Gniezno) - 11 mandatów, nr III (Poznań) - 12 mandatów i nr IV (Ostrów) - 9 mandatów. W dalszej kolejności prawodawcy

100 Ibidem, 1. II/37.

101 Ibidem, 1. II/43-44.

102 Ibidem.

103 Ibidem, 1. II/45.

104 Ibidem, 1. XXVI/3-8.

105 Ibidem, 1. XXVI/8-13. Druk nr 305.

106 Ustawa z dnia 5 kwietnia 1919 r. w przedmiocie zmiany niektórych przepisów ordynacji wyborczej objętej dekretami poz. 46 i 47 nr 18 Dziennika Praw Państwa Polskiego z dnia 6 grudnia 1918 r., w celu przeprowadzenia wyborów posłów do Sejmu Ustawodawczego RP z części ziem polskich byłego zaboru pruskiego, Dz.P.P.P. z 1919 r. nr 30, poz. 253.

107 Ostatecznie wybory w tym okręgu nie odbyły się. Stało się tak, ponieważ Niemcy wciąż zajmowali położone w jego granicach miasta. Oficjalnie polskie władze jako powód odstapienia od aktu głosowania podały jednak zarejestrowanie tylko jednej listy kandydatów. Mowa tu o liście Zjednoczenia Stronnictw Narodowych. Vide Do urny wyborczej, „,Dziennik Poznański” z 31 V 1919 r., nr 124, s. 1. 
zmienili regulacje zapisane w art. 4 ordynacji. Dzięki temu wojskowi w służbie czynnej mogli wziąć udział w głosowaniu, jeśli nie znajdowali się poza obszarem wyborów, który został wskazany w art. $2^{108}$. Następnie legislatorzy znowelizowali art. 8 ordynacji. Na mocy art. 5 zdecydowali, że nie będzie on obejmował członków i urzędników Komisariatu oraz Podkomisariatów NRL zaboru pruskiego. Co więcej, postanowienia zamieszczone w art. 9 i 10 ordynacji nie miały zastosowania wobec komisarzy i podkomisarzy NRL oraz profesorów wyższych uczelni. Zgodnie z art. 6 główne komisje wyborcze składały się z 5 członków, z których 2 wybierali delegaci rad miejskich miast powiatowych, 3 zaś delegaci wszystkich innych gmin okręgu. W świetle art. 7 dzień wyborów miał być wyznaczony najpóźniej na 40. dzień po dniu zarządzenia i ogłoszenia wyborów. Według art. 8 ukonstytuowanie się głównych komisji wyborczych odbywało się maksymalnie w piątym dniu po dniu zarządzenia wyborów. Na podstawie art. 9 spisy obywateli naczelnicy gmin sporządzali do 10. dnia od dnia zarządzenia wyborów i najpóźniej 11. dnia, dostarczali je do miejscowych komisji wyborczych. Komisje te musiały w ciagu kolejnych trzech dni zbadać ich zawartość, a potem ułożyć listę wyborców. W trakcie dalszych 24 godzin jeden egzemplarz zatwierdzonej listy przesyłały do głównej komisji wyborczej, drugi natomiast wykładały do wglądu obywateli na trzy dni, aby mogli oni w tym czasie wnosić ewentualne reklamacje dotyczące jej treści. W art. 10 nakazano, aby główna komisja wyborcza najpóźniej 30. dnia od dnia ogłoszenia wyborów zwróciła ustaloną ostatecznie listę wyborców miejscowym komisjom wyborczym. W myśl art. 11 kandydatury poselskie mogły być zgłaszane do głównej komisji wyborczej najpóźniej 20. dnia od dnia ogłoszenia wyborów. Zgodnie z art. 12 komisja ta ogłaszała najpóźniej 30. dnia od dnia ogłoszenia wyborów listy kandydatów pod warunkiem, że nie zachodziły tu przesłanki wymienione w art. 53 ordynacji. Art. 13 stanowił, że z chwilą wystawienia wybranym posłom listów wierzytelnych wygasały mandaty tych członków Izby, a dawnych posłów do parlamentu Rzeszy Niemieckiej z terytorium Księstwa Poznańskiego, którzy zostali powołani w jej skład na mocy dekretu z 8 lutego 1919 r. Zgodnie z art. 14 pozostałe przepisy zapisane w ordynacji z 28 listopada obowiązywały podczas przygotowywanej wtedy elekcji. Wybory w Wielkopolsce odbyły się 1 czerwca 1919 r. ${ }^{109} \mathrm{~W}$ ich rezultacie wszystkie 42 mandaty uzyskała lista Zjednoczenia Stronnictw Narodowych ${ }^{110}$.

108 Zgodnie z art. 4 rozporządzenia ministra spraw wewnętrznych wojskowi w służbie czynnej mogli głosować w tym obwodzie głosowania, w którym znajdowali się od przedednia złożenia list. Rozporządzenie Ministra Spraw Wewnętrznych z dnia 18 kwietnia 1919 r. o wyborach poselskich do Sejmu Ustawodawczego z części ziem polskich b. zaboru pruskiego, Dz.P.P.P. z 1919 r. nr 33, poz. 270.

109 Ibidem. Wybory te zostały zbojkotowane przez partie reprezentujące Niemców. Ich decyzja miała pokazać, że do momentu formalnego rozstrzygnięcia przez mocarstwa statusu państwowego Wielkopolski nie zaaprobują oni przekazania tych ziem pod zwierzchnictwo Polski. Vide Wybory do Sejmu, „Dziennik Poznański” z 5 VI 1919 r., nr 128, s. 1.

${ }^{110}$ W jej skład weszli kandydaci: Centrum Obywatelskiego, Narodowego Stronnictwa Robotników, Stronnictwa Demokratyczno-Narodowego, Stronnictwa Mieszczańskiego i Narodowego Stronnictwa Ludowego. Vide Zawarcie kompromisu wyborczego, „Kurier Poznański” z 14 V 1919 r., nr 110, s. 1. W następstwie tych wyborów wygasły mandaty dziewięciu posłów. T. Rzepecki, Sejm Rzeczypospolitej Polskiej 1919 roku, Poznań 1920, s. 234-246. 
W dniu 21 lipca 1919 r. w trakcie 74. posiedzenia konstytuanty poseł ks. Kazimierz Lutosławski (ZLN) złożył do laski marszałkowskiej, będący dopełnieniem ustawy z 5 kwietnia 1919 r., projekt ustawy o uzupełniających wyborach do Sejmu Ustawodawczego z dalszych części byłego zaboru pruskiego ${ }^{111}$. Wniosek ten marszałek przekazał do $\mathrm{KK}^{112}$. Sprawozdanie z jej prac na 83. posiedzeniu SU 1 sierpnia $1919 \mathrm{r}$. zaprezentował poseł Władysław Seyda $(Z L N)^{113}$. Referent stwierdził, że Komisja jednogłośnie poparła propozycję kontynuacji procesu wyborczego na mocy postanowień ordynacji z 28 listopada. Jednocześnie, chcąc zrealizować postulaty przedstawione przez posłów podczas omawianych obrad, zarekomendował zmianę niektórych jej przepisów. Zgodnie z art. 2 rozpatrywanego przedłożenia okręgi wyborcze na terenach oswobadzanych spod okupacji niemieckiej miały być tworzone dekretem rządu, wydawanym na wniosek zastępcy Generalnego Komisarza Wyborczego [dalej: ZGKW], przy zachowaniu zasadniczego stosunku jeden poseł na 50 tys. osób. Okręgi te, zgodnie z procedowanym aktem prawnym, liczyły od 7 do 13 mandatów. W myśl art. 3 główne komisje wyborcze należało formować zależnie od warunków miejscowych uchwałą Rady Ministrów wydawaną na wniosek ZGKW. W świetle art. 4 obostrzenia zawarte w art. 8 ordynacji nie dotyczyły, identycznie jak w przypadku Księstwa Poznańskiego, członków i urzędników Komisariatu oraz Podkomisariatów NRL. Na bazie tego samego przepisu ograniczenia zamieszczone w art. 9 i 10 ordynacji nie obejmowały komisarzy i podkomisarzy NRL oraz profesorów wyższych uczelni. W art. 5 zapisano, że wybory miały być zarządzane w danym okręgu niezwłocznie po zakończeniu okupacji jego ziem, zaś dzień głosowania powinien być wyznaczony nie później niż w ciągu 80 dni po ustapieniu zarządu niemieckiego. $\mathrm{Na}$ podstawie art. 6 funkcję GKW powierzono mianowanemu przez rząd ZGKW ${ }^{114}$. Art. 7 przewidywał, że z chwilą wystawienia wybranym posłom listów wierzytelnych wygasały mandaty tych członków Izby, a dawnych posłów do parlamentu Rzeszy Niemieckiej, którzy zostali powołani w jej skład na mocy dekretu z 8 lutego 1919 r. Projekt ten nie wzbudził w Izbie kontrowersji. W związku z tym marszałek zarządził jego drugie i trzecie czytanie. Finalnie został on zaakceptowany przez wszystkich uczestników głosowania115.

Kolejna odsłona postępowania wyborczego nastapiła rok później. Rada Ministrów pod przywództwem Leopolda Skulskiego (NZL) 1 marca 1920 r. wydała rozporządzenie, na kartach którego dokonała podziału województwa pomorskiego na okręgi wyborcze $^{116}$. Przepisy zawarte $\mathrm{w}$ tym rozporządzeniu dzieliły wskazane terytorium na

111 SU, spr. sten., ł. LXXIV/20.

112 Ibidem.

113 Ibidem, ł. LXXXIII/121-124, druk nr 954.

114 Został nim członek NRL W. Wyczyński. C. Demel, Uzupetniajace wybory do Sejmu w Wielkopolsce 1 czerwca 1919 r., „Studia i materiały do Dziejów Wielkopolski i Pomorza”, Warszawa-Poznań 1976, z. 1, s. 159.

115 SU, spr. sten., ł. LXXXIII/124. Ustawa z dnia 1 sierpnia 1919 r. o uzupełniających wyborach do Sejmu Ustawodawczego z dalszych części b. zaboru pruskiego, Dz.P.P.P. z 1919 r. nr 65, poz. 393.

116 Rozporządzenie Rady Ministrów z dnia 1 marca 1920 r. w przedmiocie podziału Województwa Pomorskiego na okręgi wyborcze, Dz.U. z 1920 r. nr 20, poz. 111. 
2 okręgi: nr I (Kościerzyna) — 9 mandatów i nr II (Grudziądz) — 11 mandatów. Tego samego dnia minister spraw wewnętrznych $\mathrm{S}$. Wojciechowski podpisał też rozporządzenie o uzupełniających wyborach do Sejmu Ustawodawczego z dalszych części byłego zaboru pruskiego ${ }^{117}$. Zgodnie $\mathrm{z}$ jego postanowieniami zarządził on na tych terenach wybory poselskie na dzień 2 maja 1920 r. ${ }^{118}$ Wybory na Pomorzu odbyły się bez żadnych komplikacji ${ }^{119}$. W ich rezultacie 9 mandatów uzyskało Narodowe Stronnictwo Robotników [dalej: NSR], 6 mniejszość niemiecka, 4 ZLN, jeden zaś PSL ${ }^{120}$.

Należy przypomnieć, że w okresie pełnomocnictw Izby wybory nie zostały przeprowadzone na Kresach Wschodnich. Stało się tak, mimo że pierwsze wnioski zawierające postulat uregulowania tego zagadnienia posłowie Daszyński (PPS) i ks. Lutosławski (ZLN) wnieśli już na 2. posiedzeniu SU 14 lutego 1919 r. ${ }^{121}$ Poseł Daszyński w zgłoszonej wtedy uchwale wezwał rząd, ,,aby bezzwłocznie przedłożył Sejmowi projekt ustawy wyborczej, mocą której wschodnie ziemie polskie, nieobjęte dotychczasową ustawą wyborcza, mają wybrać posłów na Sejm"122. Poseł ks. Lutosławski zaprezentował z kolei następujący wniosek: „Sejm Rzeczypospolitej poleca Komisji Konstytucyjnej opracować i przedstawić Izbie do uchwalenia projekt ustawy o uzupełnieniu składu osobistego Sejmu Ustawodawczego przedstawicielami ludności polskiej Kresów Wschodnich" "23. Obie uchwały marszałek odesłał do $\mathrm{KK}^{124}$. W dniu 8 kwietnia 1919 r. w trakcie 28. posiedzenia SU posłowie zapoznali się ze sprawozdaniem, jakie w tej kwestii przygotowała Komisja ${ }^{125}$. Poseł S. Osiecki (PSL „Wyzwolenie”) najpierw odczytał uchwały, których treść została uformowana na plenum KK. Pierwsza z nich, którą zaaprobowała większość członków tego gremium, brzmiała: „Wzywa się rząd, aby najdalej do końca kwietnia r.b. w porozumieniu z przedstawicielstwem społeczeństwa polskiego na Litwie i Rusi przedłożył Sejmowi do zatwierdzenia projekt składu osobistego tymczasowego sejmowego

117 Rozporządzenie Ministra Spraw Wewnętrznych z dnia 1 marca 1920 r. o uzupełniających wyborach do Sejmu Ustawodawczego z dalszych części b. zaboru pruskiego, Dz.U. z 1920 r. nr 20, poz. 112.

118 Ibidem. Do rozporządzenia została dołączona Instrukcja do ordynacji wyborczej do Sejmu Ustawodawczego. Zawarte w niej regulacje odnosiły się do 37 przepisów ordynacji. Instrukcja z 1 marca 1920 r. do ordynacji wyborczej do Sejmu Ustawodawczego z dnia 28 listopada 1918 r. (Dz.Pr. nr 18 p. 46) ze zmianami wynikającymi z dekretów z dn. 19 i 26 grudnia 1918 r. (Dz.Pr. nr 20 p. 63 i nr 21 p. 74) oraz z ustawy z dnia 1 sierpnia 1919 r. o uzupełniających wyborach z dalszych części b. zaboru pruskiego (Dz.Pr. nr 65 p. 393), Dz.U. z 1920 r. nr 20, poz. 113.

119 W okręgu nr I (Kościerzyna) zgłoszono 7 list kandydatów, w okręgu nr II (Grudziądz) zarejestrowano ich 9; mowa o listach: Stronnictwa Chrześcijańsko-Ludowego, Narodowo-Chrześcijańskiego Stronnictwa Robotników, NSR, PSL, ZLN, PPS i mniejszości niemieckiej (jedna w okręgu nr I i dwie w okręgu nr II). Vide Wybory do Sejmu na Pomorzu, „Dziennik Bydgoski” z 30 IV 1920 r., nr 98, s. 1.

${ }^{120} \mathrm{~W}$ następstwie tych wyborów wygasły mandaty 2 posłów. Vide Ostateczny wynik wyborów na Pomorzu, „Dziennik Bydgoski” z 15 V 1920 r., nr 109, s. 1. Należy zauważyć, że Śląsk w Izbie przez cały okres jej pełnomocnictw reprezentowali Polacy legitymujący się mandatem do parlamentu Rzeszy Niemieckiej. Vide W. Musialik, Górnoślazacy w parlamentach II Rzeczypospolitej (1919-1939), Opole 2004.

121 SU, spr. sten., 1 . II/37-38 i 44.

122 Ibidem, 1. II/37-38.

123 Ibidem, ł. II/44.

124 Ibidem.

${ }^{125}$ Ibidem, 1. XXVIII/19, druk nr 322. 
przedstawicielstwa ludności polskiej z ziem wschodnich w ilości 16 przedstawicieli”"126. Druga natomiast — wniesiona jako wniosek mniejszości — stanowiła, że: „Sejm Ustawodawczy, nie widząc możliwości powoływania posłów do Sejmu na podstawach innych, niż powszechne głosowanie całej ludności miejscowej, wypowiada się za koniecznością przeprowadzenia wyborów sejmowych według zasad ordynacji wyborczej z dnia 28 listopada 1918 r. z tych ziem na wschodzie, które zgodnie z wolą mieszkańców zostaną przyłączone do Rzeczypospolitej Polskiej" ${ }^{127}$. W dalszej części przemowy poseł Osiecki opowiedział się za przyjęciem drugiego z procedowanych rozwiązań. Poseł Władysław Jabłonowski (ZLN) stwierdził, że reprezentanci Kresów musząjak najszybciej znaleźć się w parlamencie. Dlatego też zachęcał posłów do poparcia uchwały zaakceptowanej przez $\mathrm{KK}^{128}$. Poseł Kazimierz Czapiński (PPS), będąc zwolennikiem wypracowanych już wzorców partycypacji politycznej, podzielił stanowisko wyrażone przez S. Osieckiego ${ }^{129}$. Icchak Grünbaum (Tymczasowa Żydowska Rada Narodowa) postulował, aby w głosowaniu na terenach Litwy i Rusi mogła wziać udział także ludność niepolska, która uznawała się za obywateli II RP ${ }^{130}$. Poseł ks. Lutosławski (ZLN) przypomniał, że posłowie wyłonieni na mocy pierwszego projektu zasiadaliby w ławach Izby tylko do momentu ogłoszenia wyniku wyborów ${ }^{131}$. Poseł Niedziałkowski (PPS) zaapelował z kolei o przestrzeganie, wytyczonych normami ordynacji, standardów jurydycznych ${ }^{132}$. Poseł referent Witold Kamieniecki (PZL) przekonywał natomiast, że mechanizm prawny zamieszczony w tekście uchwały forsowanej przez kluby prawicy i centrum nie był obarczony błędami rzeczowymi. Finalnie jednak, w obliczu wątpliwości proceduralnych, poprosił marszałka o odesłanie tego przedłożenia do $\mathrm{KK}^{133}$. Sejm w głosowaniu usankcjonował tę propozycję ${ }^{134}$. Wniosek ten nie został ponownie uwzględniony w porządku obrad Izby ${ }^{135}$.

Ostatecznie omawiana kwestia została rozstrzygnięta wyłącznie w przypadku Ziemi Wileńskiej. Jednak stało się to nie na mocy przepisów prawa wyborczego, lecz na podstawie decyzji politycznych powziętych zarówno przez wybrany 8 stycznia $1922 \mathrm{r}$. Sejm Wileński, jak i Sejm Ustawodawczy ${ }^{136}$. W odpowiedzi na przegłosowaną 20 lu-

${ }^{126}$ Wniosek ten popierali posłowie prawicy i centrum. SU, spr. sten., ł. XXVIII/20.

127 Uchwałę tę zgłosili posłowie lewicy. Ibidem.

128 Ibidem, 1. XXVIII/22-23.

129 Ibidem, 1. XXVIII/26-31.

130 Ibidem, 1. XXVIII/32.

131 Ibidem, 1. XXVIII/37.

132 Ibidem, 1. XXVIII/39-40.

133 Ibidem, 1. XXVIII/41-42.

134 Ibidem, ł. XXVIII/43.

135 W drugiej połowie 1919 r. posłowie prowadzili też dyskusję, której istota dotyczyła wyłonienia specjalnego organu stanowiącego zinstytucjonalizowane przedstawicielstwo ziem byłego Księstwa Litewskiego. Członkowie tego ciała mieli według zamysłu zwolenników omawianego pomysłu, którzy wywodzili się z klubów prawicy i centrum, formalnie zdecydować o przyszłości prawnej tych terenów. SU, spr. sten., ł. LX/77-78, ł. LXXXII/102-120, ł. LXXXIII/5-13, ł. XCIII/39, ł. CII/51-61 i ł. CIII/3-40. Druki numer: $746,900,1126$ i 1176.

136 SU, spr. sten., ł. CCLX/46-76 ił. CCLXI/4-34. Vide też A. Srebrakowski, Sejm Wileński 1922 roku: idea i jej realizacja, „Acta Universitatis Wratislaviensis”, „Historia”, t. XCIX, Wrocław 1995. 
tego 1922 r. przez Sejm Wileński uchwałę o przyłączeniu Ziemi Wileńskiej do Polski posłowie na 292. posiedzeniu konstytuanty 24 marca 1922 r. jednogłośnie zaaprobowali dwie uchwały: o objęciu władzy państwowej w Ziemi Wileńskiej przez Rząd Rzeczypospolitej Polskiej oraz w sprawie przyjęcia w skład Sejmu Ustawodawczego delegacji Sejmu Wileńskiego. Zgodnie z postanowieniami zawartymi w drugiej z tych uchwał liczba członków Sejmu Ustawodawczego powiększyła o 20 przedstawicieli Sejmu Wileńskiego ${ }^{137}$.

Inicjatywy prawodawcze, które były realizowane na przestrzeni lat 1918-1922 w zakresie problematyki wyborczej, umożliwiły wyłonienie pierwszego parlamentu w dziejach II RP ${ }^{138}$. Analizując przebieg tego procesu, należy podkreślić, że istotne różnice dotyczące mechanizmów kreacji najważniejszych instytucji politycznych, które uwidoczniły się w ramach prowadzonej w tym okresie dysputy ustrojowej, nie wpływały na decyzje podejmowane przez reprezentantów poszczególnych partii uczestniczących w obradach organów formujących zasady regulujące elekcję posłów. W trakcie dyskusji odbywających się czy to na forum rządu, czy też na plenum Sejmu lub w KK, kierowali się oni bowiem nie tyle doraźnymi interesami danego stronnictwa, ile znajomością procedowanych zagadnień, ewentualnie specyfiką konkretnych terenów, które w kolejnych kwartałach miały zostać objęte procedurami wyborczymi. Dzięki temu posiedzenia ciał kształtujących prawo wyborcze do konstytuanty charakteryzowały się wysokim, nastawionym na znalezienie koncyliacyjnych konkluzji normatywnych, poziomem rozważań jurydycznych. Nie budzi wątpliwości, że działania te, biorąc pod uwagę nie tylko ich znaczenie państwowotwórcze, ale i społeczne, zapisały się w historii Polski.

BIBLIOGRAFIA

ŹRÓDŁA

Archiw um Akt Nowy ch w Warszawie

Prezydium Rady Ministrów. Protokoły z posiedzeń Rady Ministrów 18 XI-31 XII 1918 r., t. 4 (maszynopis).

B ibli oteka Narodowa w W a s zawie

Wojciechowski S., Moje wspomnienia, t. II, 1918-1922 (rękopis).

${ }_{137}$ Uchwała Sejmu Wileńskiego z 20 lutego 1922 r. w przedmiocie przynależności państwowej Ziemi Wileńskiej, Dziennik Urzędowy Tymczasowej Komisji Rządzącej z 9 III 1922 r., nr 7, nr 486; SU, spr. sten., 1. CCXC/69-70 i ł. CCXCII/3-13; uchwała Sejmu Ustawodawczego z dnia 24 marca 1922 r. o objęciu władzy państwowej w Ziemi Wileńskiej przez Rząd Rzeczypospolitej Polskiej, Dz.U. z 1922 r. nr 20, poz. 162; uchwała Sejmu Ustawodawczego z dnia 24 marca 1922 r. w sprawie przyjęcia w skład Sejmu Ustawodawczego delegacji Sejmu Wileńskiego, Dz.U. z 1922 r. nr 20, poz. 163.

${ }^{138}$ W dniu otwarcia obrad przez konstytuantę poseł M. Rataj napisał: „Niezapomniana chwila. Jest Polska, jest Sejm — jej przedstawicielstwo. Wtłoczony w masę, czułem się jednak dumny i szczęśliwy, iż jestem jednym z tych, którzy mają budować odrodzone państwo". M. Rataj, Pamiętniki (1918-1927), do druku przygotował J. Dębski, Warszawa 1965, s. 37. 
B iblioteka Sejmowa W W a s zawie

Druki urzędowe Sejmu Ustawodawczego 1919-1922 (maszynopis).

Dziennik Praw Państwa Polskiego 1918-1919 (maszynopis).

Dziennik Urzędowy Tymczasowej Komisji Rządzącej 1922 (maszynopis).

Dziennik Ustaw Rzeczypospolitej Polskiej 1919-1939 (maszynopis).

Monitor Polski. Dziennik Urzędowy Rzeczypospolitej Polskiej 1918-1919 (maszynopis).

Sprawozdania stenograficzne z posiedzeń Sejmu Ustawodawczego 1919-1922 (maszynopis).

B ibli oteka Szkoły Głównej Handlowej w Warszawie

Instrukcja do ordynacji wyborczej do Sejmu Ustawodawczego (maszynopis).

Muzeum Historii Polskiego Ruchu Ludowegow Warszawie

Stanisław Osiecki i Franciszek Kamiński (częściowo rękopis, częściowo maszynopis).

Z a kład Narodowy im. Os s olińs kich we Wrocławiu

Trzaska-Chrząszczewski A., Wspomnienia i rozważania z lat 1887-1957, t. 1, 1887-1922 (maszynopis).

\section{PIŚMIENNICTWO}

Ajnenkiel A., Spór o model parlamentaryzmu polskiego do roku 1926, Książka i Wiedza, Warszawa 1972.

Bartoszewicz J., Zasada wyborcza dla Sejmu Konstytucyjnego, „Gazeta Warszawska” z 29 XI 1918 r., nr 14.

Bogucki A., Ordynacja wyborcza do Sejmu Ustawodawczego, Księgarnia E. Wende i Spółka, Warszawa 1919.

Bogusławski A., O ordynacji wyborczej (objaśnienie ogłoszonej ordynacji wyborczej), Drukarnia Jana Buriana, Warszawa 1918.

Buczkowski J., Podstawowe zasady prawa wyborczego III Rzeczypospolitej, Wydawnictwo UMCS, Lublin 1998.

Cybichowski Z., Polskie prawo państwowe, t. I, Seminarium Prawa Publicznego Uniwersytetu Warszawskiego, Warszawa 1929.

Czego żądać od rzqdu, „Wyzwolenie” z 10 XI 1918 r., nr 45.

Deklaracja Paderewskiego, „Kurier Polski” z 17 I 1919 r., nr 13.

Demel C., Uzupetniajace wybory do Sejmu w Wielkopolsce 1 czerwca 1919 r., „Studia i materiały do dziejów Wielkopolski i Pomorza”, Polskie Towarzystwo Historyczne, Warszawa-Poznań 1976, nr 1.

Do urny wyborczej, „Dziennik Poznański” z 31 V 1919 r., nr 124.

Esmein A., Prawo konstytucyjne, nota biograficzna K.M. Ujazdowski, Wydawnictwo Sejmowe, Warszawa 2013 (reprint wydania z 1921 r.).

Garlicki A., Józef Pitsudski 1867-1935, Czytelnik, Warszawa 1988.

Hełczyński B., Józef Pitsudski jako Naczelnik Państwa (listopad 1918-grudzień 1922), „Niepodległość”, t. 9, Instytut Józefa Piłsudskiego, Londyn-Nowy York 1974.

Ilski Z., Formuła wyborcza u progu niepodległej Polski (do 1922 r.), Wydawnictwo Adam Marszałek, Toruń 2013.

Jodko-Narkiewicz W., Jaka powinna być ordynacja wyborcza do przyszłego Sejmu polskiego?, Drukarnia Towarzystwa Akcyjnego S. Orgelbranda Synów, Warszawa 1918. 
Kacperski K., Koncepcje systemu wyborczego do Sejmu na ziemiach Królestwa Polskiego w latach 1917-1918, Wydawnictwo Sejmowe, Warszawa 2018.

Kacperski K., System wyborczy do Sejmu i Senatu u progu Drugiej Rzeczypospolitej, Wydawnictwo Sejmowe, Warszawa 2007.

Kobiety a Sejm, „Jedność Robotnicza” z 17 XI 1918 r., nr 46.

Kobiety a wybory do Sejmu, „Zorza” z 19 I 1919 r., nr 3.

Komarnicki W., Polskie prawo polityczne (geneza i system), Księgarnia F. Hoesicka, Warszawa 1922.

Kronika polityczna, „Robotnik” z 19 XI 1918 r., nr 303.

Kumaniecki K.W., Odbudowa państwowości polskiej. Najważniejsze dokumenty: 1912-styczeń 1924, Księgarnia J. Czerneckiego, Kraków 1924.

Kutrzeba S., Proporcyonalne głosowanie, Gebethner i Wolff, Warszawa-Lublin-Łódź-Kraków [b.d.w.].

Makowski J., Zarys prawa wyborczego, Księgarnia F. Hoesicka, Warszawa 1918.

Moszczeńska I., Kobiety na arenie politycznej, „Głos” z 27 XI 1918 r., nr 383.

Musialik W., Górnoślazacy w parlamentach II Rzeczypospolitej (1919-1939), Instytut Śląski, Opole 2004.

Nowodworski L., O ordynacji wyborczej do pierwszego Sejmu Polskiego: wyjaśnienie i wskazówki praktyczne, Drukarnia Jana Buriana, Warszawa 1918.

Ostateczny wynik wyborów na Pomorzu, „Dziennik Bydgoski” z 15 V 1920 r., nr 109.

Pajewski J., Odbudowa państwa polskiego 1914-1918, Państwowe Wydawnictwo Naukowe, Warszawa 1978.

Pietrzak J., O reprezentację bytego zaboru pruskiego w Sejmie Ustawodawczym w 1919 r., „Dzieje Najnowsze”, Zakład Narodowy im. Ossolińskich, Wydawnictwo Polskiej Akademii Nauk, Wrocław-Warszawa 1976, nr 4.

Pismo ustepujacego gabinetu do Naczelnika Państwa, „Kurier Polski” z 17 I 1919 r., nr 13.

Polityczny wiec kobiet polskich, „Nowa Gazeta” z 13 XI 1918 r., nr 47.

Program Moraczewskiego, „Czas” z 22 XII 1918 r., nr 511.

Przed wyborami, „Kurier Warszawski” z 9 I 1919 r., nr 9.

Przed wyborami, „Kurier Warszawski” z 21 I 1919 r., nr 21.

Rataj M., Pamiętniki (1918-1927), do druku przygotował J. Dębski, Ludowa Spółdzielnia Wydawnicza, Warszawa 1965.

Rok 1918 we wspomnieniach mężów stanu, polityków $i$ wojskowych, wybrał i opracował J. Borkowski, Państwowy Instytut Wydawniczy, Warszawa 1987.

Rostworowski M., Geneza państwa polskiego, Towarzystwo Biblioteki Słuchaczy Prawa Uniwersytetu Jagiellońskiego, Kraków 1921.

Rozmowa z ministrem spraw wewnętrznych, „Kurier Polski” z 11 XII 1918 r., nr 309.

Rzepecki T., Sejm Rzeczypospolitej Polskiej 1919 roku, Wielkopolska Księgarnia Narodowa, Poznań 1920.

Siemieński J., Rozbiór krytyczny ordynacji wyborczej do Sejmu Ustawodawczego, Księgarnia F. Hoesicka, Warszawa 1919.

Srebrakowski A., Sejm Wileński 1922 roku: idea i jej realizacja, „Acta Universitatis Wratislaviensis”, „Historia”, t. XCIX, Uniwersytet Wrocławski, Wrocław 1995. 
Śliwa M., Myśl polityczna Mieczysława Niedziałkowskiego (1893-1940), Państwowe Wydawnictwo Naukowe, Warszawa 1980.

Thugutt S., Autobiografia, przedmowa A. Więzikowa, T. Janczak, Ludowa Spółdzielnia Wydawnicza, Warszawa 1984.

Wiec kobiet polskich, „Bluszcz” z 30 XI 1918 r., nr 48.

Wybory do Sejmu, „Dziennik Poznański” z 5 VI 1919 r., nr 128.

Wybory do Sejmu na Pomorzu, „Dziennik Bydgoski” z 30 IV 1920 r., nr 98.

Wybory w Krakowie, „Naprzód” z 28 I 1919 r., nr 24.

Zawarcie kompromisu wyborczego, „Kurier Poznański” z 14 V 1919 r., nr 110.

Zwoliński W., Polski Sejm Konstytucyjny, czyli „,konstytuanta”, Skład Główny Redakcji „Zorzy", Warszawa 1918.

Zwołanie Sejmu, „Głos” z 30 XI 1918 r., nr 386. 


\title{
MIĘDZY JEDNOLITOŚCIĄ A PODZIALEM WLADZY: POZYCJA USTROJOWA SEJMU USTAWODAWCZEGO
}

\author{
BETWEEN UNIFORMITY AND SEPARATION OF POWERS: \\ THE SYSTEMIC POSITION OF THE LEGISLATIVE SEJM
}

The purpose of the article is to determine the systemic position of the Legislative Sejm functioning between 1919 and 1922. The Sejm's output is considered significant due to the fact that the terminated continuity of Polish systemic institutions was tantamount to cessation of the natural evolution of earlier solutions, which had become useless. Hence, constructing the new statehood proved the earlier legal regulations inadequate in the new circumstances. The author seeks to justify the opinion that the Legislative Sejm operated under the circumstances favouring the establishment of the principle of uniformity of power with certain elements typical for the principle of separation of powers. The choice was not incidental - it was not only a result of the prompt adoption of the little constitution, but also an expression of a broader European tendency to concentrate the supreme ("sovereign") power in the parliament, which — as it turned out — served to emphasise the role of the Legislative Sejm in establishing the constitutional foundation of the renascent state in the form of the constitution passed on 17 March 1921.

Słowa kluczowe: Sejm Ustawodawczy, pozycja ustrojowa, nadrzędność, podział władzy, jednolitość władzy

Key words: Legislative Sejm, systemic position, primacy, separation of powers, uniformity of power

* Dr hab. Grzegorz Kuca, Uniwersytet Jagielloński, Wydział Prawa i Administracji, Katedra Prawa Ustrojowego Porównawczego,g.kuca@uj.edu.pl

\section{UWAGI WPROWADZAJĄCE}

S ejm Ustawodawczy (1919-1922) uznawany jest za głównego architekta ustroju odrodzonego po 123 latach zaborów państwa polskiego. Wynikało to nie tylko z uznania, że istotą parlamentu czy szerzej — władzy ustawodawczej — jest stanowienie prawa, ale także z konieczności przyznania parlamentowi, będącemu organem przedstawicielskim pochodzącym z wyborów, legitymacji do rządzenia pozwalającej na przeniesienie władzy z istniejących już podmiotów. Dorobek Sejmu Ustawodawczego [dalej: SU] obejmujący określenie zasad ustroju w okresie przejściowym, tzw. małej konstytucji z 20 lutego 1919 r. ${ }^{1}$, zorganizowanie aparatu państwowego, odbudowę kraju i rozstrzygniecie wielu istotnych zagadnień społecznych i prawnych, a przede wszystkim uchwalenie konstytucji z 17 marca 1921 r. $^{2}$ musi budzić uznanie ${ }^{3}$ zważyw-

1 Vide uchwała Sejmu z dnia 20 lutego 1919 r. o powierzeniu Józefowi Piłsudskiemu dalszego sprawowania urzędu Naczelnika Państwa, Dz.P.P.P. nr 19, poz. 226 [dalej: mała konstytucja].

2 Vide ustawa z dnia 17 marca 1921 r. — Konstytucja Rzeczypospolitej Polskiej, Dz.U. nr 44, poz. 267 [dalej: konstytucja marcowa lub konstytucja z 1921 r.].

${ }^{3}$ D. Malec, Sejm Ustawodawczy 1919-1922. W 90. rocznicę pierwszego posiedzenia, „Przegląd Sejmowy" 2009, nr 1, s. 9. 
szy na fakt, że przerwana ciagłość polskich instytucji ustrojowych oznaczała kres naturalnej ewolucji wcześniejszych rozwiązań, które przez to stały się w dużej mierze nieprzydatne ${ }^{4}$. Dlatego też budowanie nowej państwowości przesądziło o niezdatności dawniej obowiązujących regulacji prawnych w nowych okolicznościach ${ }^{5}$. Decydował o tym anachronizm i nieprzystawalność do istniejących, jak i rodzących się warunków społeczno-politycznych oraz problemów ustrojowo-prawnych mających swój byt w systemach trzech zaborów. Wyraźny brak własnego, adekwatnego i aktualnego wzorca ustrojowego oznaczał spore wyzwanie dla twórców ustroju, niosące konieczność stworzenia nowego systemu lub sięgnięcia po obce wzorce ustrojowe. Europejska kultura prawno-polityczna dostarczała w tej mierze wzorców o zróżnicowanym charakterze i niejednoznacznych ocenach. $Z$ jednej strony postabsolutystyczne monarchie konstytucyjne ujawniały swój anachronizm, z drugiej strony - dokonująca się zmiana czy to w formie rewolucyjnego, czy też implozyjno-rewolucyjnego demontażu czyniła dostarczane przez nie wzorce wątpliwymi do zastosowania w warunkach stopniowo rodzącej się niepodległości ${ }^{6}$. W tych warunkach SU podjął wysiłek na rzecz stworzenia nowego modelu, który w pierwszej kolejności miał zapewnić połączenie trzech odrębnych systemów, a w dalszej - nadania im jednolitych podstaw prawnych. Wymagało to odbycia, w ciagu czteroletniej kadencji, aż 342 posiedzeń plenarnych oraz kilku tysięcy posiedzeń komisji sejmowych.

\section{POWSTANIE SEJMU USTAWODAWCZEgo}

Pierwsza formalna zapowiedź utworzenia SU pojawiła się w manifeście Tymczasowego Rządu Ludowego Republiki Polskiej ogłoszonym 7 listopada 1918 r. ${ }^{7}$ Dokument ten, opracowany przez Stanisława Thugutta oraz Tadeusza Hołówkę, zawierał zapowiedź szybkiego zwołania Sejmu Ustawodawczego. Charakterystyczne, że manifest nazywał Sejm, który miał powstać „ustawodawczym”, co było niezbyt fortunnym określeniem z prawnego (normatywnego) punktu widzenia, zwłaszcza jeśli uznać, że każdy parlament niezależnie od jego nazwy własnej jest organem ustawodawczym ${ }^{8}$. Na usprawiedliwienie można stwierdzić, że intencją autorów manifestu była chęć zaakcentowania różnic między sejmem „zwykłym”, a sejmem będącym „konstytuantą”, a taką właśnie funkcję miał sprawować projektowany organ. Niemniej lepszym roz-

${ }^{4}$ Istotne znaczenie odegrał też fakt, że akty konstytucyjne okresu zaborów były oktrojowane przez czynniki zewnętrzne, a przez to nie były ustawami zasadniczymi państwa suwerennego. Vide S. Krukowski Mała Konstytucja z 1919 r., [w:] Konstytucje Polski. Studia monograficzne z dziejów polskiego konstytucjonalizmu, t. II, red. M. Kallas, Warszawa 1990, s. 7.

${ }_{5}^{5}$ W.W. Wołpiuk, Naczelnik Państwa 1918-1922. Przedprezydencka forma władzy państwowej, „Przegląd Sejmowy" 2005, nr 5, s. 26.

6 Vide A. Kulig, Ksztaltowanie formy rzq̨ów u progu niepodległej Polski (1917-1926), Warszawa 2013, s. 115-117.

7 Vide Manifest Tymczasowego Rządu Ludowej Republiki Polskiej z 7 listopada 1918 r., Kraków-Warszawa 1920 .

${ }^{8}$ Vide W. Komarnicki, Polskie prawo polityczne, Reprint wydania z 1922 r., Warszawa 2008, s. 55. 
wiązaniem było nawiązanie do Konstytucji 3 maja 1791 r. i stosowanego w jej art. VI pojęcia „Sejmu Konstytucyjnego"9.

Zgodnie z zapowiedzią SU miał być wybrany ,na podstawie powszechnego bez różnicy płci, równego, bezpośredniego, tajnego i proporcjonalnego głosowania. Ordynacja wyborcza będzie ogłoszona w ciagu najbliższych kilku dni. Czynne i bierne prawo wyborcze będzie przysługiwało każdemu obywatelowi i obywatelce, mającym 21 lat skończonych". W pierwszej kolejności SU miał rozpatrzeć wniesione projekty reform społecznych dotyczących: a) przymusowego wywłaszczenia i zniesienie wielkiej i średniej własności ziemskiej i oddania jej w ręce ludu pracującego pod kontrolą państwowa; b) upaństwowienia kopalń, salin, przemysłu naftowego, dróg komunikacyjnych oraz innych działów przemysłu, gdzie się to da od razu uczynić; c) udziału robotników w administracji tych zakładów przemysłowych, które nie zostaną od razu upaństwowione; d) prawa o ochronie pracy, ubezpieczeniu od bezrobocia, chorób i na starość; e) konfiskaty kapitałów powstałych w czasie wojny ze zbrodniczej spekulacji artykułami pierwszej potrzeby i dostaw dla wojska; f) wprowadzenia powszechnego, obowiązkowego i bezpłatnego świeckiego nauczania szkolnego.

Po przejęciu władzy przez Józefa Piłsudskiego od Rady Regencyjnej i podporządkowania sobie Tymczasowego Rządu wydano pierwszy akt o charakterze konstytucyjnym, dekret z dnia 14 listopada 1918 r. ${ }^{10}$, potwierdzający utworzenie ,w możliwie krótkim, kilkumiesięcznym terminie" Sejmu Ustawodawczego, który jako jedyny może być „twórcą praw narodu”. Było to możliwe dzięki autorytetowi Piłsudskiego i jego zaangażowaniu w odbudowę państwowości polskiej, co wyrażało się także poprzez uznanie jego kierowniczej roli przez powstające ad hoc ośrodki władzy ${ }^{11}$. Mimo znaczących różnic politycznych dzielących środowiska i stronnictwa aspirujące do władzy, wyraźna aprobata państwotwórczej roli Piłsudskiego została także niewiele później zatwierdzona aktami wybranego w powszechnych wyborach SU, który akceptował ten stan rzeczy. W tak zróżnicowanym środowisku politycznym i wyraźnie słabszym otoczeniu instytucjonalnym Piłsudski równolegle przystapił do wielostronnych wysiłków na rzecz odbudowy państwowości polskiej, zrywając jednocześnie z próbami budowania porządku ustrojowego z pomocą władz okupacyjnych ${ }^{12}$. Dobitnie wyrażały to jego słowa ujęte w dekrecie: ,lud polski sam musi wykazać swoją zdolność organizacyjna, bo żadna siła z zewnątrz nie może mu jej narzucić" "13, które pośrednio mogły być odczytywane jako wezwanie do próby stworzenia własnego modelu, w którym obce wzorce będą co najwyżej materiałem do dyskusji. Akt ten nazwany dekretem

9 Art. VI ustawy rządowej z 3 maja 1791 r. in fine stanowił: „Zapobiegając z jednej strony gwałtownym i częstym odmianom konstytucyi narodowej, z drugiej uznając potrzebę wydoskonalenia onej, po doświadczeniu jej skutków, co do pomyślności publicznej porę i czas rewizyi i poprawy konstytucyi, co lat dwadzieścia pięć naznaczamy, chcąc mieć takowy sejm konstytucyjny ekstra-ordynaryjnym, podług osobnego o nim prawa opisu".

${ }^{10}$ Dekret naczelnego dowódcy Józefa Piłsudskiego z 14 listopada 1918, Dz.P.P.P. nr 17, poz. 40.

11 A. Kulig, Ksztaltowanie formy rząów..., s. 137.

12 Ibidem.

13 Vide akapit 1 dekretu z dnia 14 listopada $1918 \mathrm{r}$. 
w istocie rzeczy nie przypominał strukturą i formą aktu normatywnego, stąd przypisywany mu charakter orędzia do narodu ${ }^{14}$, oświadczenia publicznego ${ }^{15}$ lub programu ${ }^{16}$, trafnie $\mathrm{w}$ ten syntetyczny sposób charakteryzując jego formę. Po nieudanej próbie stworzenia rządu przez Ignacego Daszyńskiego funkcję premiera powierzono Jędrzejowi Moraczewskiemu. Nowy rząd w orędziu z 20 listopada 1918 r. nawiązał do manifestu lubelskiego, wskazując kierunek prac zmierzającym do utworzenia SU. Wyznaczał też zasady prawa wyborczego odwołując się do pięcioprzymiotnikowych wyborów, w których mieli wziąć udział wszyscy „obywatele i obywatelki, mający 21 lat skończonych". Wyznaczono również przybliżony termin zwołania Sejmu, który miał nastapić ,w początku roku przyszłego".

Dekret z 22 listopada 1918 r. o najwyższej władzy reprezentacyjnej Republiki Polskiej ${ }^{17}$ określił prowizoryczny porządek ustrojowy państwa do czasu zwołania SU. Brak organu przedstawicielskiego wymusił konieczność powierzenia najwyższej władzy Tymczasowemu Naczelnikowi Państwa, który miał ją sprawować do czasu zwołania SU. Rząd stanowili mianowani przez Naczelnika Państwa i odpowiedzialni przed nim, aż do zebrania się Sejmu, prezydent Ministrów i ministrowie. Projekty ustawodawcze uchwalone przez Radę Ministrów ulegały zatwierdzeniu przez Naczelnika Państwa i uzyskiwały moc obowiązująca, jeśli sama ustawa inaczej nie stanowiła, z chwilą ogłoszenia w Dzienniku Praw Państwa Polskiego. Akty te traciły moc obowiązująca, jeśli nie będą przedstawione na pierwszym posiedzeniu SU do jego zatwierdzenia. Również budżet miał uchwalać rząd Republiki Polskiej na pierwszy okres budżetowy i przedłożyć Naczelnikowi Państwa do zatwierdzenia.

Charakterystyczne, że założeniem wskazanych wcześniej aktów było odejście od koncepcji kompromisu feudalno-mieszczańskiego rozumianego jako rozdzielenie politycznego wpływu na władzę. Zarówno w manifeście, jak i obu dekretach używano bowiem określeń generalizujących, unikając zarówno odniesień do odrębności wytworzonych granicami dawnych zaborów, jak i podziałów klasowych. Wskazują na to określenia: „lud polski”, „prawa narodu”, „lud wiejski i miejski” czy „położenie narodu". Takie ujęcie zbiorowości społecznej przesądza o jednoznacznym zerwaniu z rozdzieleniem politycznego wpływu na władzę między parlament reprezentujący szlachtę i mieszczaństwo w legislatywie, monarchę wraz z ministrami reprezentującego interesy arystokracji i wyższego duchowieństwa w egzekutywie oraz władzę sądową „odejmującą” głowie państwa dyskrecjonalny wpływ na sądy i czyniącą z sędziów politycznie zneutralizowane „usta ustawy”.

W dniu 28 listopada 1918 r. Naczelnik Państwa wydał dwa dekrety: o ordynacji wyborczej do Sejmu Ustawodawczego oraz o wyborach do Sejmu Ustawodawczego ${ }^{18}$.

${ }^{14}$ Vide W.T. Kulesza, Uchwała Sejmu Ustawodawczego z dnia 20 lutego 1920 r. o powierzeniu Józefowi Pitsudskiemu dalszego sprawowania urzędu Naczelnika Państwa, „Przegląd Sejmowy” 2007, nr 5, s. 33.

${ }_{15}$ Vide Z. Cybichowski, Polskie prawo państwowe: na tle uwag z dziedziny nauki o państwie i porównawczego prawa państwowego, Warszawa 1925, t. I, s. 205.

16 Vide J. Piłsudski, Pisma zbiorowe, t. V, Warszawa 1937, s. 18.

17 Dz.P.P.P. nr 17, poz. 41.

${ }^{18}$ Dz.P.P.P. nr 18, poz. 46 i 47. 
Kwestia organizacji parlamentu i związany z nią wybór między jedno- lub dwuizbową jego strukturą nie budził już żadnych wattpliwości. W tym okresie dwuizbowość parlamentu była negowana w kręgach demokratycznych, a ewentualne jego przywrócenie było niecelowe, gdyż mogło niepotrzebnie przedłużać prace nad podstawami nowego ustroju ${ }^{19}$. Dekret o ordynacji wyborczej opierał prawo wyborcze na pięcioprzymiotnikowych wyborach, tj. głosowaniu powszechnym, bezpośrednim, równym, tajnym i proporcjonalnym. Prawo wyborcze otrzymali wszyscy obywatele bez różnicy płci, którzy do dnia ogłoszenia wyborów ukończyli 21 lat (art. 1) i mieszkali na terenie danego obwodu do głosowania (art. 2). Praw wyborczych zostali pozbawieni wojskowi wszystkich stopni i rodzajów broni w służbie czynnej oraz osoby sądownie pozbawione praw obywatelskich (art. 4) ${ }^{20}$. W tych okręgach wyborczych, na które rozciagała się działalność służbowa, nie mogli być również wybrani urzędnicy państwowych władz administracyjnych, skarbowych i sądowych (art. 8 zd. 1), ale przepis ten nie dotyczył urzędników i wojskowych władz centralnych (art. 8 zd. 2). Jeden poseł miał przypadać przeciętnie na 50 tys. ludności okręgu; na ułamki tej liczby wynoszące powyżej 25 tys. przypadał jeden poseł (art. 12). Wybory zarządzał Naczelnika Państwa (art. 14).

Dekret o wyborach do Sejmu Ustawodawczego wyznaczał dzień wyborów na 26 stycznia 1919 r. Terytorium państwa podzielono na 70 okręgów, w których miano wybrać 524 posłów. Na obszarze dawnego zaboru rosyjskiego miano wybrać 241 posłów, zaboru pruskiego — 112 posłów, w Galicji Wschodniej — 94 posłów, w Galicji Zachodniej i na Śląsku Cieszyńskim — 77 posłów. W praktyce okazało się, że wybory mogą odbyć się w okręgach wyborczych dawnego Królestwa Polskiego oraz Galicji Zachodniej. Wybory miały być przeprowadzone przez ministra spraw wewnętrznych. W praktyce dekret o wyborach podlegał kilkakrotnie zmianom i uzupełnieniom. Na mocy dekretów Naczelnika Państwa: z 19 grudnia 1918 r. zmianie uległy niektóre terminy prekluzyjne ${ }^{21}$; z 26 grudnia 1918 r. zmodyfikowano zasady sporządzania kart wyborczych $^{22}$; z 11 stycznia 1919 r. powierzono prawa wyborcze obywatelom spełniającym kryteria określone w art. 1 ordynacji wyborczej, którzy powrócili do kraju po 5 grudnia $1918 \mathrm{r}^{23}$

Osobnym dekretem regulowano zagadnienie odpowiedzialności karnej za akty przeciwdziałające wyborom i wykonywaniu mandatu poselskiego ${ }^{24}$, natomiast zapewnienie właściwego przebiegu wyborów odbyło się na mocy okólników wydawanych

19 W. Maliniak, Prawo konstytucyjne, Warszawa 1928, s. 69.

${ }_{20}$ M. Adamczyk, S. Pastuszka, Konstytucje polskie w rozwoju dziejowym 1791-1982, Warszawa 1985, S. 188.

${ }^{21}$ Dekret z dnia 19 grudnia 1918 r. o przedłużeniu niektórych terminów prekluzyjnych przy wyborach do Sejmu Ustawodawczego, Dz.P.P.P. nr 20, poz. 63.

${ }^{22}$ Dekret z dnia 26 grudnia 1918 r. o zmianach w ordynacji wyborczej do Sejmu Ustawodawczego, Dz.P.P.P. nr 21, poz. 74 .

${ }^{23}$ Dekret z dnia 11 stycznia 1919 r. o nadaniu praw wyborczych obywatelom, którzy po dniu 5 grudnia 1918 r. powrócili do kraju, Dz.P.P.P. nr 5, poz. 97.

${ }^{24}$ Dekret z dnia 8 stycznia 1919 r. o postanowieniach karnych za przeciwdziałanie wyborom do Sejmu i wykonywaniu obowiązków poselskich, Dz.P.P.P. nr 5, poz. 96. 
przez ówczesnego ministra spraw wewnętrznych, który wzywał komisarzy wyborczych, aby przeciwdziałać jakimkolwiek formom nacisku ze strony organów rządowych i samorządowych na wyborców, tak aby wybory odbyły się „w warunkach zupełnej wolności obywatelskiej, by istotnie wola narodu mogła znaleźć swój wyraz bez najmniejszego skrępowania" ${ }^{25}$. W ten sposób SU został wybrany w powszechnych wyborach przeprowadzonych $\mathrm{w}$ trudnych okolicznościach, bo w dobie tworzenia państwa i wśród zamętu wywołanego wojną światową, budowa zaś państwa została oparta na podstawie demokratycznej ${ }^{26}$.

\section{SEJM USTAWODAWCZY A NACZELNIK PAŃSTWA I RZĄD}

Podjęta 20 lutego 1919 r. uchwała Sejmu o powierzeniu Józefowi Piłsudskiemu dalszego sprawowania urzędu Naczelnika Państwa, nazywana małą konstytucją składała się z dwóch części. W pierwszej Sejm przyjął „oświadczenie Józefa Piłsudskiego, że składa w ręce Sejmu urząd Naczelnika Państwa do wiadomości i wyraża Mu podziękowanie za pełne trudów sprawowanie urzędu w służbie dla Ojczyzny”. W drugiej części określił podstawy ustroju w okresie przejściowym, odnawiając Piłsudskiemu urząd Naczelnika Państwa aż do ustawowego uchwalenia tej treści konstytucji, która określi zasadniczo przepisy o organizacji naczelnych władz w Państwie Polskim. Mała konstytucja z 1919 r. była skrótowym, pozostawiającym znaczną swobodę ustawodawcy zwykłemu, aktem prawnym, który miał stworzyć ramy ustrojowe odrodzonego państwa do momentu wejścia w życie pełnej konstytucji. Na usprawiedliwienie tej formy podaje się, że miała obowiązywać bardzo krótko, ale w praktyce okazało się, że trwało to aż do jesieni 1922 r. Formą prawną małej konstytucji była uchwała SU, a nie jak by się mogło wydawać, ustawa. $Z$ jednej strony świadczyło to o sporym pośpiechu w jej przygotowywaniu, a z drugiej strony o tym, że była ona zaprojektowana jako akt tymczasowy ${ }^{27}$.

Zawarte w uchwale Sejmu z 20 lutego 1919 r. postanowienia jednoznacznie określały pozycję ustrojową SU, który był samodzielnym organem państwowym, co było intencją wcześniejszych postanowień obu dekretów. To właśnie w nich jednoznacznie oparto ustrój na zasadzie suwerenności narodu, jednocześnie organem jego reprezentacji czyniąc Sejm Ustawodawczy. W konsekwencji SU będący wyłącznym reprezentantem suwerena musiał zając pozycję samodzielnego organu państwowego. Co więcej, rodzaj posiadanej legitymacji i jej wyjątkowość w konfrontacji z jej brakiem po stronie pozostałych naczelnych organów państwa czyniły pozycję Sejmu unikalną ${ }^{28}$. Stąd niezbyt precyzyjny w znaczeniu prawnym (normatywnym), ale jednoznaczny w znaczeniu politycznym zwrot użyty na wstępie punktu pierwszego części drugiej

25 S. Krukowski, Sejm Ustawodawczy 1919-1922, „Czasopismo Prawno-Historyczne” 1986, z. 1, S. 96.

${ }^{26}$ W. Komarnicki, Ustrój państwowy Polski współczesnej. Geneza i system, reprint opublikowany w Wilnie w 1937, Kraków 2006, s. 25.

27 A. Kulig, Ksztaltowanie formy rzadów..., s. 151.

${ }^{28}$ Ibidem, s. 154. 
małej konstytucji, w którym SU został określony mianem „władzy suwerennej”29. Charakterystyczny brak rozstrzygnięcia czy wskazane pojęcie „,władzy suwerennej” dotyczy wewnętrznego aspektu suwerenności (tj. zwierzchnictwa,) czy może zewnętrznego (tj. niezależności). Było to ważne dlatego, że suwerenność to nie cała władza w państwie, ale jedynie władza najwyższa. Władza suwerenna przysługuje tylko ludowi (narodowi), natomiast władza państwowa zostaje powierzona przez naród organom państwowym. Niemniej wobec obiektywnej niemożności bezpośredniego sprawowania władzy przez suwerena, wykonawcą jego zwierzchnictwa uczyniono SU. Prowadziło to do jednoznacznej stratyfikacji naczelnych organów państwowych, wobec których SU zachowuje nadrzędność.

W małej konstytucji z 1919 r. położono akcent na podmiotowy (organizacyjny) rozdział aparatu państwowego, stanowiąc, że „władzą [...] ustawodawczą w Państwie Polskim jest Sejm Ustawodawczy" odsuwając jednocześnie na dalszy plan przedmiotowy (funkcjonalny) rozdział aparatu państwowego polegający na uznaniu, że czynności podejmowane przez SU są sprawowane przez władzę ustawodawczą. Miało to charakter symboliczny i służyło podkreśleniu roli Sejmu w kształtowaniu podstaw ustroju politycznego i społeczno-gospodarczego odrodzonego państwa, będącego uosobieniem zbiorowego podmiotu suwerenności. Stąd też wynikała formalna nadrzędność SU potwierdzona w tak krótkim, niespełna półstronicowym akcie prawnym. Jej cechą charakterystyczną był rzeczywisty monopol SU na stanowienie prawa, z jednoczesnym pozbawieniem organów władzy wykonawczej jakiejkolwiek wpływu na proces stanowienia prawa ${ }^{30}$. Nadrzędność ta wynikała z faktu, że SU nie tylko językiem prawa rozstrzygał o funkcjonowaniu wszystkich pozostałych organów państwa, ale także z tego, że czynił to na zasadzie samodzielności bezwzględnej, gdyż żaden inny organ nie uczestniczył w procesie stanowienia prawa bądź jego kontroli. W konsekwencji postępowanie ustawodawcze odbywało się wyłącznie w obrębie SU, a udział organów egzekutywy sprowadzał się jedynie do kontrasygnaty prezydenta Ministrów i właściwego ministra aktu marszałka Sejmu w sprawie ogłoszenia ustawy. Zbliżało to system polityczny do reguł jednolitości władzy, nie było bowiem mowy ani o hamowaniu, ani tym bardziej o kształtowaniu więzi zapewniających równowagę w relacjach organów. Tym samym wszelkie elementy ograniczające przewagę zaliczane do arsenału checks and balances SU, jak np. weto ustawodawcze, sądowa kontrola konstytucyjności ustaw, zostały uznane za bezprzedmiotowe. Formalną gwarancją nadrzędności SU była daleko idąca autonomia, permanentny tryb pracy, decydowanie o terminach posiedzeń, a zwłaszcza brak możliwości odroczenia posiedzeń czy skrócenia jego kadencji przez głowę państwa lub rząd.

${ }^{29}$ Podkreśla się przy tym, że takiego ujęcia nie należy traktować w rozumieniu brytyjskiego parlamentaryzmu, tj. że suwerenność prawna skupiona jest w parlamencie. Normy stanowione przez parlament, teoretycznie rzecz ujmując, są nieograniczone zakresowo z uwagi na brak konstytucji w znaczeniu formalnym. Więcej na temat brytyjskiej zasady suwerenności parlamentu vide P. Mikuli, Wielka Brytania, [w:] S. Bożyk, M. Grzybowski, Systemy ustrojowe państw współczesnych, Białystok 2012, s. 18-20.

${ }^{30}$ Monopol ten został przełamany dopiero w drodze praktyki ustrojowej. 
Istotne znaczenie dla wzmocnienia pozycji ustrojowej SU miało podjęcie przez niego uchwały 13 lutego 1920 r. ${ }^{31}$ rozszerzającej jego kompetencje o sferę finansów publicznych. Do punktu 1 ust. 2 uchwały z 20 lutego 1919 r. dodano bowiem wyłączne prawo udzielania zezwolenia na emisję biletów Polskiej Krajowej Kasy Pożyczkowej lub innych biletów obciążających Skarb Państwa, zaciagania pożyczek państwowych oraz przyjmowania przez państwo gwarancji finansowych. Było to konsekwencją likwidacji Banku Polskiego, którego namiastkę stanowiła Polska Krajowa Kasa Pożyczkowa. Kasa dokonała unifikacji systemu pieniężnego na ziemiach polskich poprzez wprowadzenie, w miejsce wycofywanych z obiegu rubli rosyjskich i koron austriackich, jednolitej jednostki pieniężnej — marki polskiej ${ }^{32}$.

Ukształtowanie składu SU, jak na ówczesne warunki, w demokratycznych wyborach z jednej strony legitymizowało ten organ do rządzenia, z drugiej zaś strony pozwalało na przeniesienie na organ przedstawicielski władzy z istniejących już podmiotów, a zwłaszcza z Naczelnika Państwa. Było to szczególnie ważne w kontekście dużego autorytetu J. Piłsudskiego, którego nie sposób było lekceważyć, a także jego dystansu do istniejących wówczas partii politycznych, które musiały ukształtować między sobą relacje pozwalające na decydujący lub współdecydujący wpływ na państwo ${ }^{33}$. W rezultacie relacje między SU a Naczelnikiem Państwa odzwierciedlały wytworzony wówczas układ sił politycznych, ale także intencje ugrupowań parlamentarnych. Trudno bowiem nie wziąć pod uwagę systemu partyjnego rodzącego się państwa, w obrębie którego działały swoiste subsystemy partyjne właściwe dla obszarów wyznaczonych granicami dawnych zaborów. W jakiejś mierze zapewniały one sobie wpływ na władzę, co mogłoby być odczytywane jako element społecznego podziału władzy między stronnictwa polityczne działające na obszarze trzech zaborów. Należy przy tym podkreślić, że pozycja ustrojowa SU i czas trwania mandatów poselskich pozostały nieokreślone. Z tego powodu W. Komarnicki zwracał uwagę, że „władza zatem Konstytuanty Polskiej w całym tym okresie pozostała formalnie nieograniczoną" "34. Słuszność tego twierdzenia wymaga jednak uwzględnienia wielu formalnych ograniczeń właściwych systemowi podziału władzy. Do takich ograniczeń należała utworzona we wskazanej wcześniej ordynacji wyborczej sądowa weryfikacja ważności wyborów (art. 90), czy niepołączalność formalna mandatu parlamentarnego z inną płatną służbą państwowa. Zakaz ten nie dotyczył ministrów, podsekretarzy stanu i profesorów wyższych uczelni (art. 10).

Wyeksponowanie pozycji ustrojowej SU następowało poprzez określenie pozycji ustrojowej Naczelnika Państwa i rządu. Te dwa ostatnie organy mogły przesądzać o dualizmie egzekutywy, w ramach której Naczelnik Państwa zyskał miano ,najwyższego wykonawcy uchwał Sejmu”. Oczywiście użyte tu określenie odnosiło się do formal-

31 Dz.U. z 1920 r. nr 17, poz. 84.

32 W. Baka, Bankowość centralna, funkcje - metody - organizacja, Warszawa 2001, s. 91.

33 Vide A. Kulig, Dwie prowizoryczne Konstytucje lutowe z 1919 roku: polska i niemiecka, [w:] Ustroje. Historia i wspótczesność. Polska - Europa-Ameryka Łacińska. Księga jubileuszowa dedykowana profesorowi Jackowi Czajowskiemu, red. M. Grzybowski, G. Kuca, P. Mikuli, Kraków 2013, s. 188-213.

${ }^{34}$ W. Komarnicki, Ustrój państwowy Polski współczesnej..., s. 27. 
noprawnej formy stanowienia aktów przez SU jako organu kolegialnego, obejmując także inne akty prawne stanowione przez Sejm. Tym samym Naczelnik Państwa nie otrzymał w sposób skonkretyzowany pozycji organu władzy wykonawczej w znaczeniu nadanym jej zasadą podziału władzy, co mogło być odczytywane jako intencja twórców małej konstytucji polegająca na dążeniu do ograniczenia jego samodzielności funkcjonalnej ${ }^{35}$. Obok funkcji wykonawczej Naczelnik Państwa był traktowany jako głowa państwa, co zostało wyrażone w lapidarnym sformułowaniu, że jest on „przedstawicielem państwa”. W praktyce ustrojowej korzystał z wielu kompetencji właściwych głowie państwa, tj. prawo łaski, powoływanie sędziów, udział w audiencjach akredytacyjnych przedstawicieli dyplomatycznych państw obcych i przyjmowanie listów uwierzytelniających. Biorąc to pod uwagę, należy uznać, że pozycja ustrojowa SU jednoznacznie przesądzała o odejściu od wcześniej zarysowanej zasady podziału władzy, zaprowadzała rządy sejmowe ${ }^{36}$ właściwe modelowi rządów zgromadzenia $^{37}$, nazywanych także systemem rządów komitetowych ${ }^{38}$. Warto podkreślić, że przyjęte założenia były wyrazem szerszej tendencji spotykanej w ówczesnej Europie, gdzie koncentracja władzy w parlamencie, wypływająca z nieufności do władzy wykonawczej, była charakterystyczna dla społeczeństw wyzwolonych spod nacisku politycznego ${ }^{39}$. W warunkach polskich było to usprawiedliwione względami praktycznymi, w których przyszło funkcjonować SU działającemu z pomocą stronnictw politycznych wywodzących się z obszaru trzech różnych zaborów.

Sejm Ustawodawczy dysponował prawem udziału w procesie tworzenia rządu, powołanego przez Naczelnika Państwa „w pełnym składzie na podstawie porozumienia z Sejmem" ${ }^{40}$. Nie określano jednak zasad, na jakich miało to następować. Lukę wypełniła praktyka ustrojowa, która w początkowym okresie nie wywoływała zastrzeżeń. Przyjęto bowiem założenie, że to nie Sejm in pleno, a Konwent Seniorów, będący $\mathrm{w}$ istocie pozaregulaminowym organem ukształtowanym w drodze praktyki, był właściwy do ustalenia kandydatów na premiera zgłoszonych przez Naczelnika, marszałka Sejmu lub przedstawicieli klubów. Kandydat taki musiał uzyskać poparcie większości członków Konwentu, co warunkowało możliwość przejścia do kolejnego etapu polegającego na utworzeniu rządu ,,w porozumieniu z Sejmem w osobie jego marszałka”. Kandydat prowadził rozmowy ze stronnictwami politycznymi na temat obsady resortów, a po ich przeprowadzeniu przedstawiał Naczelnikowi Państwa skład rządu w celu dokonania oficjalnej nominacji. Następnie prezentował w SU program swojego rządu.

Ukształtowana w drodze praktyki ustrojowej procedura została zakwestionowana w 1922 r. w związku ze sporem na tle podania się do dymisji dysponującego poparciem większości sejmowej A. Ponikowskiego, krytycznie ocenianego przez J. Piłsud-

35 A. Kulig, Ksztaltowanie formy rząów..., s. 156.

36 W. Komarnicki, Ustrój państwowy Polski współczesnej..., s. 26.

37 Vide A. Kulig, Ksztaltowanie formy rząów..., s. 156.

38 Vide A. Ajnenkiel, Konstytucje Polskie w rozwoju dziejowym 1791-1997, Warszawa 2001, s. 161.

${ }_{39}$ Podobne rozwiązania można odnaleźć w konstytucjach: bawarskiej z 14 sierpnia 1919 r., pruskiej z 30 listopada 1920 r., austriackiej z 1 października 1920 r.

${ }^{40}$ Przewidywał to ust. 2 pkt 3 małej konstytucji. 
skiego. Doszło wówczas do naruszenia reguł, zgodnie z którymi głowa państwa nie może dymisjonować rządu popieranego przez parlament ${ }^{41}$. W tej sytuacji Naczelnik Państwa zakwestionował prawo Konwentu Seniorów do reprezentowania Sejmu, a główny zarzut dotyczył tego, że był to organ niemający podstaw w regulaminie Sejmu. Piłsudski domagał się wyjaśnienia, do kogo należy głos decydujący w razie niemożności osiagnięcia porozumienia ${ }^{42}$. Sejm 16 czerwca 1922 r. podjął uchwałę, ustalającą autentyczną wykładnię art. 3 małej konstytucji, która osłabiała pozycję Naczelnika Państwa przy wyznaczaniu kandydata na szefa rządu. Na mocy uchwały Naczelnik Państwa dysponował jedynie prawem wskazania kandydata na premiera, ale dopiero po uzyskaniu poparcia sejmowej większości kandydat mógł otrzymać misję tworzenia rządu. Naczelnik Państwa uznał, że wbrew konstytucji został pozbawiony prawa do wskazania premiera i odmówił desygnowania kandydata. W tej sytuacji większość parlamentarna desygnowała na premiera Wojciecha Korfantego, który jednak nie otrzymał od Piłsudskiego oficjalnej misji tworzenia rządu. $Z$ tego powodu wysunięto przeciwko Piłsudskiemu wotum nieufności, które nie uzyskało wymaganego poparcia. Nowym kandydatem stał się wskazany przez Naczelnika Julian Nowak, który uzyskał poparcie Sejmu, co oznaczało zwycięstwo koncepcji, że kandydat na premiera musi mieć poparcie zarówno Naczelnika, jak i Sejmu. W tym samym czasie utworzono nowy organ SU Komisję Główna, składającą się z przedstawicieli klubów poselskich, którzy mieli taką liczbą głosów, jaką miał w Sejmie ich klub ${ }^{43}$.

\section{SEJM USTAWODAWCZY A SĄDY}

Kształtowaniu się relacji między SU a Naczelnikiem Państwa i rządem towarzyszyły prace wokół pozycji ustrojowej sądów. W związku ze zróżnicowaniem prawnym trzech zaborów konieczne było podjęcie prac unifikacyjnych, a następnie kodyfikacja różnych działów prawa ${ }^{44}$. Jeszcze przed odzyskaniem niepodległości, na mocy przepisów o tymczasowej organizacji sądów ${ }^{45}$, utworzono Sąd Najwyższy. Sądy i urzędy wymiaru sprawiedliwości otrzymały nazwę królewsko-polskich i sprawowały swoją działalność w imieniu Korony Polskiej. Struktura sądownictwa obejmowała sądy: po-

${ }^{41}$ D. Malec, op. cit., s. 26-27.

${ }^{42}$ S. Krukowski, Mała Konstytucja z 1919 r., [w:] Konstytucje Polski. Studia monograficzne z dziejów polskiego konstytucjonalizmu, red. M. Kallas, Warszawa 1990, t. II, s. 16-17.

${ }_{43}^{4}$ D. Malec, op. cit., s. 27.

${ }^{44}$ W. Ćwik, Druga Rzeczpospolita, [w:] W. Ćwik, T. Opas, Prawo sadowe w Polsce do 1939 r., Rzeszów 1999, s. 118.

${ }^{45}$ Były to przepisy rozporządzenia Tymczasowej Rady Stanu opublikowane w pierwszym numerze „Dziennika Urzędowego” Departamentu Sprawiedliwości: 1) przepisy tymczasowe o urządzeniu sądownictwa w Królestwie Polskim; 2) przepisy tymczasowe o dyslokacji sądów królewsko-polskich; 3) przepisy tymczasowe o wynagrodzeniu urzędników wymiaru sprawiedliwości w Polsce; 4) przepisy przechodnie do ustawy postępowania karnego; 5) przepisy przechodnie do ustawy postępowania cywilnego; 6) przepisy przechodnie do kodeksu karnego; 7) przepisy tymczasowe o kosztach sądowych; 8) tymczasowe przepisy kasowe sądownictwa w Królestwie Polskim; 9) dyslokacja sądów królewsko-polskich, Dz.Urz. Dep. Spr. TRS z 26 sierpnia 1917 r., nr 2. Podaję za: M. Materniak-Pawłowska, Zawód sędziego w Polsce w latach 1918-1939, „Czasopismo Prawno-Historyczne” 2011, t. LXIII, s. 67. 
koju, okręgowe, apelacyjne oraz Sąd Najwyższy, który miał się składać z dwóch izb: Cywilnej i Karnej ${ }^{46}$. Na czele każdej z izb stał prezes, zaś na czele całego SN pierwszy prezes ${ }^{47}$. Sędziowie i prezesi SN mianowani byli przez ówczesne tymczasowe władze polskie spośród kandydatów wybranych na zgromadzeniach prawników. Sąd Najwyższy był sądem kasacyjnym, uprawnionym do wyjaśniania obowiązującego prawa, nie był organem kontroli konstytucyjności prawa ${ }^{48}$. Sąd Najwyższy był również sądem dyscyplinarnym dla funkcyjnych sędziów i prokuratorów. Mimo planów nie udało się zrealizować propozycji powołania trzeciej izby administracyjnej, która pełniłaby rolę sądu administracyjnego, dopiero w 1922 r. w Polsce powołano odrębny system sądownictwa administracyjnego.

Dekret z dnia 22 listopada 1918 r. o najwyższej władzy reprezentacyjnej Republiki Polskiej ${ }^{49}$ podkreślał znaczenie sądów, które miały wydawać wyroki w imieniu Republiki Polskiej, ale nie rozstrzygał o podstawowych gwarancjach niezależności sądów ani niezawisłości sędziów. Jeszcze przed uchwaleniem małej konstytucji, 8 lutego 1919 r. Naczelnik Państwa wydał dekret określający organizację oraz kompetencje Sądu Najwyższego ${ }^{50}$, który stopniowo przejmował kompetencje swoich odpowiedników działających na obszarze trzech zaborów. Przejęcie obowiązków sądów najwyższych państw zaborczych (Niemiec i Austrii) pociagnęło za sobą reorganizację struktury wewnętrznej, tj. konieczność powołania trzech dalszych izb (razem było pięć), w tym izbę dla spraw administracyjnych (do 1922 r.). Sąd Najwyższy orzekał w składzie trzyosobowym, ale mógł również orzekać w składzie całej izby, a nawet Zgromadzenia Ogólnego sędziów Sądu Najwyższego. Przy Sądzie Najwyższym powołani zostali prokuratorzy SN z pierwszym prokuratorem SN na czele. Na przełomie lat 1918 i 1919 zorganizowane zostało odrębne sądownictwo wojskowe, w strukturach którego znajdował się Najwyższy Sąd Wojskowy ${ }^{51}$.

Jeśli chodzi o relacje SU z sądami, to w pierwszej kolejności należy wskazać, że Sąd Najwyższy, działający w charakterze trybunału wyborczego, rozstrzygał o ważności wyborów do $\mathrm{SU}^{52}$. Do jego właściwości należało też rozpatrywanie protestów wyborczych; prawo ich wniesienia przysługiwało każdemu obywatelowi w ciagu 14 dni od ogłoszenia wyborów ${ }^{53}$. Sąd Najwyższy mógł unieważnić wybór jeżeli zostało stwierdzone, że w danym okręgu wyborczym mandat poselski został uzyskany przy użyciu przekupstw, wymuszeń, fałszu lub jakichkolwiek podejść; jeżeli uzyska-

46 R. Jastrzębski, O stu latach Sądu Najwyższego, „Palestra” 2017, nr 4, s. 70.

${ }_{47}$ Na stanowisko pierwszego prezesa Sądu Najwyższego został mianowany Stanisław Pomian-Śrzednicki, jedyny Polak w byłym zaborze rosyjskim, który pełnił funkcję wiceprezesa sądu.

${ }_{48}$ Zagadnienie kontroli konstytucyjności prawo pojawiło się dopiero w pierwszych projektach pełnej konstytucji. Vide B. Szmulik, M. Żmigrodzki, Kwestia kontroli konstytucyjności prawa w latach 1918-1982, „Annales UMCS”, cz. K, „Politologia” 1998, t. 5, s. 152 i n.

49 Dz.P.P.P. nr 17, poz. 41.

${ }^{50}$ Dekret z dnia 8 lutego 1919 r. w przedmiocie ustroju Sądu Najwyższego, Dz.P.P.P. nr 15, poz. 199.

51 Vide M. Materniak-Pawłowska, Struktura polskich sąów powszechnych w latach 1917-1928, „Czasopismo Prawno-Historyczne" 2001, t. LIII, z. 1.

52 Przewidywały to art. 90 i 91 dekretu o ordynacji wyborczej.

53 SN był sądem wyłącznie orzekającym o przekroczeniu prawa przy badaniu protestów wyborczych. 
ny w postępowaniu wyborczym przepisy ordynacji wyborczej nie były przestrzega$n \mathrm{e}^{54}$. Sąd Najwyższy rozpatrywał też odwołania od postanowień ministra spraw wewnętrznych w zakresie, w jakim dotyczyły one działalności komisji wyborczych oraz odwołania od orzeczeń głównej komisji wyborczej ${ }^{55}$. W procesie wyborczym uczestniczyły ponadto sądy niższego szczebla. W szczególności prezes sądu okręgowego lub sędzia przez niego powołany pełnił funkcję przewodniczącego głównej komisji wyborczej działającej na obszarze okręgu wyborczego ${ }^{56}$.

Mimo że mała konstytucja stanowiła, że „Naczelnik Państwa oraz Rząd są odpowiedzialni przed Sejmem za sprawowanie swego urzędu" to nie do końca jest jasne, czy intencją ustrojodawcy było wprowadzenie odpowiedzialności parlamentarnej czy też odpowiedzialności konstytucyjnej ${ }^{57}$, zwłaszcza że bez uregulowania trybu odpowiedzialności konstytucyjnej trudno mówić o jej istnieniu. W przeciwieństwie bowiem do procedury uchwalania wotum nieufności, realizacja odpowiedzialności konstytucyjnej wymaga skonkretyzowania jej zasad, w szczególności określenia zakresu przedmiotowego, zakresu podmiotowego oraz wskazania organu właściwego do jej egzekwowania ${ }^{58}$. Nie było zatem wiadomo, czy w kwestii ewentualnego pociagania do odpowiedzialności konstytucyjnej za właściwy organ można uznać SU działający samodzielnie lub wraz z sądem, w tym w szczególności z Sądem Najwyższym. Brakowało też rozwiązań proceduralnych zawartych w konkretyzujących małą konstytucję aktach prawnych. Dowodzi to, że udział sądów w relacjach z SU był znacznie ograniczony i w zasadzie poza kwestiami wyborów nie występował. Było to przynajmniej w jakiejś mierze efektem traktowania sądów jako organów odrębnych (apolitycznych) od innych władz, w tym także nie uczestniczących w relacjach między dwiema pierwszymi — z natury rzeczy politycznymi — władzami.

\section{UWAGI KOŃCOWE}

Pozycja ustrojowa SU przesądzała o jego znaczącej przewadze, preponderancji czy supremacji w systemie organów państwowych. Brak oparcia tego systemu na zasadzie podziału władzy, która nie wynikała, ale i nie musiała wynikać explicite z przepisów prawa, oznaczał w konsekwencji przyjęcie zasady jednolitości władzy. Jest tak nawet po uwzględnieniu słusznej opinii, że system organów państwowych musi być konstruowany na kanwie gotyckiego łuku, w którym zasada podziału władzy jest nierozłącznie związana z zasada jej jedności, a reguły te leżą u podstaw każdego należycie zbudowanego aparatu państwowego, niezależnie od woli jego architektów ${ }^{59}$.

${ }^{54}$ Stanowił o tym art. 98 dekretu o ordynacji wyborczej (art. 92 ordynacji wyborczej).

${ }^{55}$ Wynikało to odpowiednio z art. 18 i 42 ordynacji wyborczej.

56 Vide art. 19 dekretu o ordynacji wyborczej.

${ }^{57}$ Przykładowo M. Pietrzak stwierdził, że mała konstytucja dawała podstawę do odpowiedzialności konstytucyjnej. Vide M. Pietrzak, Rzady parlamentarne w Polsce w latach 1919-1926, Warszawa 1969, s. 50.

${ }_{58}$ S. Krukowski, Mała Konstytucja z 1919 r., [w:] Konstytucje Polski. Studia monograficzne z dziejów polskiego konstytucjonalizmu, red. M. Kallas, Warszawa 1990, t. II, s. 13-14.

${ }^{59}$ R.M. Małajny, Doktryna podziału władzy „Ojców Konstytucji” USA, Katowice 1985, s. 20. 
Wyeksponowanie pozycji ustrojowej SU prowadziło do jednoznacznej stratyfikacji pozostałych naczelnych organów państwowych, wobec których Sejm zachowywał nadrzędność, co w praktyce ustrojowej zostało utrwalone w systemie zależności właściwym dla zasady jednolitości władzy. Charakterystyczny był też brak konstytucyjnego wydzielenia trzech władz bądź przynajmniej organów je tworzących, oparcia systemu organów państwowych na koncepcji domniemań kompetencyjnych znanej ówczesnej doktrynie prawa ${ }^{60}$ czy wreszcie ukształtowania relacji z uwzględnieniem arsenału hamulców ustrojowych.

Przyjęcie takiego systemu było wyrazem nie tylko pośpiechu, jaki towarzyszył uchwaleniu małej konstytucji, ale także szerszej tendencji europejskiej sprzyjającej koncentracji władzy najwyższej (,suwerennej”) w parlamencie. To drugie miało posłużyć i posłużyło podkreśleniu roli Sejmu Ustawodawczego, jaką odegrał on w zakresie kształtowania podstaw konstytucyjnych odrodzonego państwa. Było to też przynajmniej w pewnej mierze konsekwencją krytycznego stanowisko doktryny wobec zasady podziału władzy ${ }^{61}$, która współcześnie jest traktowana za jeden z elementów państwa prawnego.

\section{BIBLIOGRAFIA}

\section{PIŚMIENNICTWO}

Adamczyk M., Pastuszka S., Konstytucje polskie w rozwoju dziejowym 1791-1982, Warszawa 1985.

Ajnenkiel A., Konstytucje Polskie w rozwoju dziejowym 1791-1997, Warszawa 2001.

Baka W., Bankowość centralna, funkcje - metody - organizacja, Warszawa 2001.

Cybichowski Z., Polskie prawo państwowe: na tle uwag z dziedziny nauki o państwie i porównawczego prawa państwowego, t. I, Warszawa 1925.

Ćwik W., Druga Rzeczpospolita, [w:] W. Ćwik, T. Opas, Prawo sqqdowe w Polsce do 1939 r., Rzeszów 1999.

Gumplowicz L., Geschichte der Staatstheorien, Innsbruck 1905.

Jastrzębski R., O stu latach Saqu Najwyższego, „Palestra” 2017, nr 4.

Kasparek F., Prawo polityczne ogólne z uwzględnieniem austriackiego razem ze wstępna nauka ogólna o państwie, t. II, Kraków 1877.

Komarnicki W., Polskie prawo polityczne, Reprint wydania z 1922 r., Warszawa 2008.

Komarnicki W., Ustrój państwowy Polski współczesnej. Geneza i system, reprint dzieła opublikowanego w Wilnie w 1937, Kraków 2006.

Krukowski S., Mała Konstytucja z 1919 r., [w:] Konstytucje Polski. Studia monograficzne z dziejów polskiego konstytucjonalizmu, t. II, red. M. Kallas, Warszawa 1990.

${ }^{60}$ Pisał o niej W. Komarnicki: ,zasada ta [podziału władzy - G.K.] polega na istnieniu domniemania kompetencyjnego na rzecz odpowiedniej władzy, które jedynie przez wyraźny przepis może być uchylone", Zob. W. Komarnicki, Polskie prawo polityczne..., s. 219.

${ }_{61}$ Tytułem przykładu F. Kasparek zarzucał że ,taki szorstki rozdział i rozerwanie jednolitej władzy państwa jest błędnym i organicznej naturze państwa przeciwnym”. F. Kasparek, Prawo polityczne ogólne z uwzględnieniem austriackiego razem ze wstępna naukq ogólna o państwie, Kraków 1877, t. II, s. 612. W nieco łagodniejszym aczkolwiek krytycznym też tonie wypowiadał się L. Gumplowicz. Vide Gumplowicz, Geschichte der Staatstheorien, Innsbruck 1905, s. 235 i n. 
Krukowski S., Sejm Ustawodawczy 1919-1922, „Czasopismo Prawno-Historyczne” 1986, z. 1.

Kulesza W.T., Uchwała Sejmu Ustawodawczego z dnia 20 lutego 1920 r. o powierzeniu Józefowi Piłsudskiemu dalszego sprawowania urzędu Naczelnika Państwa, „Przegląd Sejmowy" 2007, nr 5.

Kulig A., Dwie prowizoryczne Konstytucje lutowe z 1919 roku: polska i niemiecka, [w:] Ustroje. Historia i wspótczesność. Polska - Europa - Ameryka Łacińska. Księa jubileuszowa dedykowana profesorowi Jackowi Czajowskiemu, red. M. Grzybowski, G. Kuca, P. Mikuli, Kraków 2013.

Kulig A., Kształtowanie formy rząów u progu niepodległej Polski (1917-1926), Warszawa 2013.

Malec D., Sejm Ustawodawczy 1919-1922. W 90. rocznicę pierwszego posiedzenia, „Przegląd Sejmowy" 2009, nr 1.

Maliniak W., Prawo konstytucyjne, Warszawa 1928.

Małajny R.M., Doktryna podziału władzy „,Ojców Konstytucji” USA, Katowice 1985.

Materniak-Pawłowska M., Zawód sędziego w Polsce w latach 1918-1939, „Czasopismo Prawno-Historyczne" 2011, t. LXIII.

Mikuli P., Wielka Brytania, [w:] Systemy ustrojowe państw współczesnych, red. S. Bożyk, M. Grzybowski, Białystok 2012.

Pietrzak M., Rzady parlamentarne w Polsce w latach 1919-1926, Warszawa 1969.

Piłsudski J., Pisma zbiorowe, t. V, Warszawa 1937.

Szmulik B., Żmigrodzki M., Kwestia kontroli konstytucyjności prawa w latach 1918-1982, „Annales UMCS” 1998, t. 5.

Wołpiuk W.W., Naczelnik Państwa 1918-1922. Przedprezydencka forma władzy państwowej, „Przegląd Sejmowy” 2005, nr 5. 


\title{
RELACJE SEJMU USTAWODAWCZEGO Z RZĄDEM I NACZELNIKIEM PAŃSTWA: SYSTEM RZACDÓW W LATACH 1919-1922
}

\author{
RELATIONS BETWEEN THE LEGISLATIVE SEJM, \\ THE GOVERNMENT AND THE CHIEF OF STATE: \\ SYSTEM OF GOVERNANCE BETWEEN 1919 AND 1921
}

Constructing the Polish State after the First World War required establishing a system of governance enabling consolidation of the state and its authorities. Initially, the burden of establishing a provisional system of governance fell on Józef Piłsudski, who founded it on the principle of uniformity of power. In accordance with the decree of 22 November 1918, the state in statu nascendi was headed by J. Piłsudski as Provisional Chief of State, with the government subordinated to him. Piłsudski combined his office with the function of the Commander in Chief, which - in the circumstances of military conflicts accompanying the renascent Poland - strengthened his competences. The domination of the one-person organ was emphasised by the absence of a representative organ. The second stage of establishing the system of governance began with the summoning of the Legislative Sejm, which adopted the small constitution on 20 February 1919. The form of governance specified therein was also based on the principle of uniformity of power. However, it differed fundamentally from the previous one. It implemented into its structure a highly representative, but also strongly pluralised government, where no party had the majority of mandates. The Legislative Sejm had the supremacy among state organs: the government, formally subordinated to it, and the Chief of State. Because of its potentially infinite influence on the government, including co-deciding about its appointment, the Council of Ministers was made reliant on the changeable party coalitions within the Sejm. Political instability caused the works of both the Sejm and the Council of Ministers to be ineffective. The Chief of State, equipped with the competences of the Commander in Chief, politically supported by the Sejm, permanent in his opinions and consequently realizing them, steadily gained influence on shaping the policy of the state - including foreign and defence policy, as well as matters of the security of the state - taking advantage of intra-parliamentary and ministerial antagonisms. As a result, the system of governance formally based on parliament's hegemony was transformed into a more parliamentary form, with conceivable balance between the Sejm, the government subordinated to it and Chief of State. Hence, the system of governance adopted in the small constitution, although formally close to assembly governance, was distinguished with features typical for parliamentary system from before its rationalisation.

Słowa kluczowe: forma rządów, Mała Konstytucja, Sejm Ustawodawczy, Naczelnik Państwa, rząd

Key words: system of governance, small constitution, Legislative Sejm, Chief of State, government

* Dr hab. Andrzej Kulig, prof. Uniwersytetu Jagiellońskiego, andrzej.kulig@uj.edu.pl 


\section{WPROWADZENIE}

Dolska odradzająca się po ponad 100 latach niewoli stawała niemal przed samymi niewiadomymi. Odnosiły się one do tak fundamentalnych dla każdego państwa elementów jak jego terytorium, skład ludnościowy czy granice. Z nieznaną konsystencją terytorialno-ludnościową współgrała próżnia ustrojowa, w jakiej znalazło się wskrzeszone państwo. Dotychczasowe dogmaty ustrojowe, jakich nosicielami był konstytucjonalizm monarchiczny państw zaborczych, szybko się dezaktualizowały. Proponowany jeszcze w lipcu 1917 r. przez Komisję Sejmowo-Konstytucyjną Tymczasowej Rady Stanu projekt konstytucji, wzorowany na tym modelu i przygotowany z udziałem najwybitniejszych prawników polskich, dewaluował się raptownie. Jego wartość spadała wraz z postępującą klęską państw zaborczych i nadchodzącym zwycięstwem państw o ustrojach demokratycznych oraz obserwowaną radykalizacją społeczną. Kiedy w październiku i listopadzie 1918 r. pojawiły się wyraźne oznaki upadku władzy zaborczej, szybko traciły swój — i tak nikły — autorytet struktury quasi-państwowe powołane z woli okupantów. Rada Stanu rozwiązana została 7 października 1918 r. przez Radę Regencyjna, podobnie jak niecały miesiąc później Rada Ministrów pod kierunkiem Józefa Świeżyńskiego. Podjęto też próby uchwycenia suwerennej władzy na obszarze wyzwalającej się Polski. Miały one charakter z reguły lokalny, nigdy nie obejmowały nawet całości ziem poszczególnych zaborów ${ }^{1}$.

Ostateczny upadek systemu organów o charakterze quasi-państwowym działających z woli okupantów nastapił 14 listopada 1918 r., gdy Rada Regencyjna rozwiązała się, składając — jak nazwała w swym orędziu — „obowiązki i odpowiedzialność względem narodu polskiego" Józefowi Piłsudskiemu jako Naczelnemu Dowódcy, w celu przekazania rządowi narodowemu. W ten sposób stan faktycznej próżni ustrojowej został symbolicznie potwierdzony, a jednocześnie rozpoczął się proces kondensacji władzy państwowej na ziemiach polskich wokół J. Piłsudskiego². Ten moment często wskazywany jest w literaturze jako rozpoczęcie okresu dyktatury Piłsudskie$\mathrm{go}^{3}$. Pogląd ten wydaje się dyskusyjny, jeśli jednak go przyjąć, to warto wskazać na kilka okoliczności pozwalających dostrzec jej pełny kontekst ${ }^{4}$. Po pierwsze, objęcie

${ }^{1}$ Szerzej J. Pajewski, Budowa Drugiej Rzeczypospolitej 1918-1926, Poznań 2007, s. 38.

${ }^{2}$ Znamienne jest, że Rada Regencyjna w pierwszych zdaniach swego orędzia stwierdziła, że „stan przejściowy podziału zwierzchniej władzy państwowej, ustanowiony odezwą z dnia 11 listopada 1918 roku, nie może trwać bez szkody dla powstającego Państwa Polskiego. Władza ta powinna być jednolita". Choć zarówno sama Rada, jak i jej akty miały już symboliczne znaczenie polityczne, dostrzec w tym stwierdzeniu można uznanie formującego się nowego ośrodka realnej władzy.

${ }^{3}$ W. Komarnicki, Polskie prawo polityczne, Warszawa 1922, s. 52, który choć konsekwentnie używa tego określenia, to jednak wraz z wydaniem przez Tymczasowego Naczelnika Państwa dekretu z 28 listopada 1918 r. - ordynacja wyborcza do Sejmu Ustawodawczego oraz dekretu o wyborach do Sejmu Ustawodawczego, uznał, że stworzone w ten sposób podstawy organizacyjne wyborów oraz skonkretyzowany krąg obywateli uprawnionych do głosowania odjęły Polsce ,cechy państwa o ustroju tymczasowo absolutystycznym”. Confer Z. Witkowski, Prezydent Rzeczypospolitej Polskiej 1921-1935, Warszawa-Poznań 1987, s. 17.

${ }^{4}$ Confer A. Ajnenkiel, Spór o model parlamentaryzmu polskiego do roku 1926, Warszawa 1972, s. 176, idem, Parlamentaryzm II Rzeczypospolitej, Warszawa 1975, s. 106. Z kolei M. Bobrzyński w pracy Wskrze- 
władzy przez J. Piłsudskiego nastapiło wtedy, gdy brakowało ośrodka mającego zdolność objęcia władzy na całym obszarze odradzającego się państwa. Ani Polska Komisja Likwidacyjna, ani rząd lubelski, ani Rada Regencyjna i znajdujący się w faktycznej rozsypce rząd warszawski ${ }^{5}$, ale też inne podmioty tworzące się w wymiarze lokalnym nie spotykały się z ogólnonarodowym uznaniem i albo nie przejawiły ambicji do podjęcia działań na skalę odradzającego się państwa, albo spotykały się z odmową współpracy, a niekiedy wręcz były zwalczane. Na tym tle J. Piłsudski nie rysował się jako całkowicie neutralny i powszechnie akceptowany formator centralnego ośrodka władzy ${ }^{6}$. Jednak przemawiała za nim nie tylko legenda pierwszego, który przystapił do czynnej walki o niepodległość oraz więźnia niemieckiego zaborcy, ale także opinia dowódcy wojskowego, który w istniejących okolicznościach walki o wszystkie granice i wobec obecności armii niemieckiej na ziemiach polskich mógł jako jedyny wziąć na siebie ciężar zadań najpilniejszych z punktu widzenia egzystencji państwa — zapewnienia jego bezpieczeństwa zewnętrznego i wewnętrznego ${ }^{7}$. Świadomość tej roli Piłsudskiego będzie towarzyszyć kręgom politycznym, ale przede wszystkim opinii publicznej w następnych latach, a przejawiać się będzie prawnie wiążąco również w uchwałach Sejmu Ustawodawczego [dalej: SU] ${ }^{8}$. Mimo zróżnicowania społecznego w skali akceptacji dla osoby J. Piłsudskiego, licząca się jego część miała świadomość, że w najbliższym trudnym do konkretyzacji czasie sprawowanie przez niego władzy państwowej jest ultima ratio odradzającej się Polski.

Po drugie, przejmowanie władzy przez Tymczasowego Naczelnika Państwa odbywało się w warunkach władzy „leżącej na ulicy”, której los mógł pod wpływem radykalizacji społecznej przerodzić się w chaos lub zamieszki.

Po trzecie, wraz z ustapieniem Rady Regencyjnej, podporządkowaniem się innych ośrodków lub ich atrofią, Piłsudski jeszcze 14 listopada 1918 r. publicznie poddał swą władzę samoograniczeniu w zakresie podmiotowym, przedmiotowym i czasowym. W wydanym zaraz po ustapieniu Rady Regencyjnej dekrecie z dnia 14 listopada

szenie państwa polskiego. Szkic historyczny, t. II, Kraków 1920, s. 22 wskazał: „Organizacja naczelnej władzy, krótka i jasna, nadawała jej formę dyktatury powierzonej Piłsudskiemu do czasu zebrania się Sejmu, ale nie nadała jej treści”. W dalszej zaś części (s. 36) ten sam autor stwierdził: „Naczelnik Państwa dzierżył nad krajem władzę, oparty na społeczeństwie".

${ }^{5}$ Ostatnie posiedzenie rządu J. Świeżyńskiego o składzie zdominowanym przez przedstawicieli endecji, powołanego przez Radę Regencyjna, odbyło się 3 listopada 1918 r., ale po próbie obalenia Rady Regencyjnej został przez nią zdymisjonowany. Od tej pory funkcjonowało już tylko ciało noszące nazwę Rady Kierowników Ministerstw, które nie podjęło szerszej aktywności.

${ }^{6}$ Confer A. Ajnenkiel, Sejm jako czynnik integracji narodu i państwa, [w:] Sejmy Drugiej Rzeczypospolitej, red. A. Zakrzewski, Warszawa 1990, s. 25. Inaczej D. Górecki, Powstanie władz naczelnych w odradzajacej się Polsce (1914-1919), „Acta Universitatis Lodziensis. Folia Iuridica” 1983, nr 13, s. 151 i n. i cyt. tam literatura.

7 W dekrecie z dnia 14 listopada 1918 r., pierwszym akcie wydanym po rezygnacji Rady Regencyjnej, J. Piłsudski, jeszcze jako Naczelny Dowódca, stwierdził m.in.: ,Wyszedłszy z niemieckiej niewoli, zastałem wyzwalającą się Polskę w najbardziej chaotycznych stosunkach wewnętrznych i zewnętrznych, wobec zadań niezmiernie trudnych, w których lud polski sam musi wykazać swoją zdolność organizacyjną, bo żadna siła z zewnątrz nie może mu jej narzucić. Uważałem za swój obowiązek ułatwić ludowi pracę organizowania się [...]".

${ }^{8}$ J. Pajewski, op. cit., s. 36 i n. 
1918 r., ujętym w formie odezwy, a nie aktu normatywnego — co metaforycznie korelowało z państwem, znajdującym się in statu nascendi — podtrzymał wcześniej artykułowaną publicznie wolę szybkiego zwołania SU, w którym upatrywał ,jedynego twórcę praw narodu” i zaznaczał konieczność jego zwołania „w możliwie krótkim, kilkumiesięcznym terminie", co rzeczywiście nastapiło w niecałe trzy miesiące. Ponadto wskazywał, że „,z natury położenia Polski” nowy rząd będzie miał przejściowy charakter, ograniczając jego egzystencję do momentu zwołania posiedzenia Sejmu. Akcentując „prowizoryczny” charakter gabinetu, podkreślał brak zarówno jego, jak i własnej szerokiej legitymacji demokratycznej do sprawowania władzy. Z tego też względu w dekrecie (odezwie) przesądzał, że sytuacja ta ,nie dozwala na przeprowadzenie głębokich zmian społecznych, które uchwalić może tylko Sejm Ustawodawczy". Jest oczywiste, że do przyjęcia tego stanowiska skłaniały J. Piłsudskiego motywy polityczne wyrastające z przekonania, że nie powinien wiązać się z żadnym ugrupowaniem politycznym (szczególnie, że ich faktyczne wpływy polityczne były niewiadoma), a raczej stać ponad nimi. Jednak w przekonaniu tym równie wyraźnie można dostrzec samoograniczenie zakresu rodzącej się pod jego auspicjami tymczasowej władzy, że kluczowe decyzje odnoszące się także do ustroju społecznego powinny być wynikiem prac podjętych przez reprezentację narodu.

Zobowiązując prezydenta Ministrów, aby „przedłożył projekt utworzenia najwyższej władzy reprezentacyjnej Republiki Polskiej, aż do czasu zwołania Sejmu Ustawodawczego, obejmującej wszystkie trzy zabory" Piłsudski wskazał, że regulacja ta będzie miała charakter prowizoryczny, obowiązujący do czasu zwołania SU. Gabinetowi przekazał „liczne uwagi i programowe żądania otrzymane od stronnictw politycznych", których przedstawiciele intensywnie wizytowali go od powrotu z Magdeburga. Wydaje się, że już wtedy zaznaczał się wyraźny podział priorytetów J. Piłsudskiego, który z bezpośredniego, systematycznego udziału w procesie rządzenia wybrał dla siebie kluczowe zakresy: wykuwanie obszaru terytorialnego tworzącego się państwa, obronę jego egzystencji oraz wpływanie na politykę zagraniczną przy jednoczesnej rezygnacji z bezpośredniego wpływu na szereg innych dziedzin życia, jak choćby odbudowa administracji, gospodarki czy stabilizacja finansów.

Zgodnie z tą zapowiedzią 22 listopada 1918 r. rząd pod kierunkiem Jędrzeja Moraczewskiego przedłożył J. Piłsudskiemu projekt dekretu „,o najwyższej władzy reprezentacyjnej Republiki Polskiej”, który został przez niego zatwierdzony. Ze względu na fakt, że była to pierwsza, wolna od ingerencji zaborców regulacja zawierająca podstawowe normy ustrojowe tworzącego się państwa polskiego, przydaje się jej rangę konstytucyjna. Przejściowy charakter tej regulacji wyraźnie zaznaczono we wstępie, przypominając, że kresem jej obowiązywania będzie zwołanie SU. W dekrecie tym J. Piłsudski oznajmiał, że objął najwyższą władzę państwową jako Tymczasowy Naczelnik Państwa. Dekret określał kompetencje tymczasowej głowy państwa w zakresie ustawodawstwa oraz wobec rządu i tworzącego się aparatu państwowego. W pierwszym obszarze do jego kompetencji należało zatwierdzanie aktów ustawodawczych uchwalanych przez Radę Ministrów, które - co do zasady — miały obowiązywać po 
ich publikacji, jeśli w przyjętych aktach nie proponowano innego terminu ich wejścia. Jednocześnie ustalał, że akty te - podpisywane przez Naczelnika za kontrasygnatą prezydenta Ministrów — zostaną przedłożone Sejmowi na pierwszym posiedzeniu pod groźbą utraty ich mocy.

W sferze odnoszącej się do rządu i innych organów Tymczasowy Naczelnik miał zagwarantowane uprawnienia do powoływania Rady Ministrów, a tym samym i jego poszczególnych członków, a praktyka dodała w tym względzie także kompetencję do ich odwoływania. Podobnie rzecz miała się z mianowaniem wyższych urzędników państwowych, zastrzeżonych „w myśl przepisów dotychczasowych Głowie Państwa”, których Naczelnik powoływał na podstawie propozycji prezydenta Ministrów i właściwego ministra9. W dekrecie z 22 listopada 1918 r. poświęcono także uwagę Radzie Ministrów, nazywanej w tym akcie również rządem, składającej się z ministrów wraz z ich prezydentem. Wszyscy członkowie rządu ponosili odpowiedzialność przed Tymczasowym Naczelnikiem Państwa do czasu zebrania się Sejmu. Rząd dysponował kompetencją do uchwalania projektów ustawodawczych i ich przedkładania J. Piłsudskiemu do zatwierdzenia. Objęło to też budżet, który po uchwaleniu przez rząd na pierwszy okres budżetowy podlegał jego zatwierdzeniu. Dekret nie ingerował w zasady organizacji polskiego sądownictwa, które stopniowo kształtowało się jeszcze w końcowym okresie zaborów. Jedyną, acz symboliczną korektą, był nakaz wyrokowania przez sądy w imieniu Republiki Polskiej.

Pozycja Tymczasowego Naczelnika Państwa z formalno-prawnego punktu widzenia była normatywną kontynuacją stanu faktycznie wytworzonego co najmniej od 14 listopada 1918 r., a w istocie rzeczy klarującego się od powrotu J. Piłsudskiego do Warszawy, gdy na różne sposoby ujawniała się jego przywódcza rola. O ile dekret (orędzie) z 14 listopada miało charakter ad personam, to w świetle dekretu z 22 listopada jego autor ujawnił się jako Tymczasowy Naczelnik Państwa, na którego drogą faktów dokonujących się od powrotu z Magdeburga wyrastał wraz z ustępowaniem innych ośrodków ${ }^{10}$. Fakt, że w dekrecie nie wspomniano ani słowem o sile zbrojnej, skupiając się na organizacji - co prawda w szczątkowej formie - centralnego aparatu państwa, oznaczał, że nastapiło rozdzielenie dwóch ról ustrojowych J. Piłsudskiego — zwierzchnika państwa oraz naczelnego dowódcy (którego zakres kompetencji i relacje z władzą cywilną zostały pominięte). Dualizm tu normatywnie zapoczątkowany będzie kontynuowany przez kilka następnych lat, mimo istotnie zmienionych uwarunkowań ustrojowych.

We wprowadzonym systemie organów państwowych można dostrzec kilka cech charakterystycznych. Po pierwsze, wyraźna jest tymczasowość wytworzonego układu. Wskazywał na to fakt, że dekret ściśle wiązał się z osobą J. Piłsudskiego, personi-

${ }_{9}$ W istocie było to zakamuflowane odwołanie się do art. 31 dekretu Rady Regencyjnej z 3 stycznia 1918 r. o tymczasowej organizacji Władz Naczelnych w Królestwie Polskiem (Dziennik Praw Królestwa Polskiego z 1918 r. nr 5, poz. 8), określającego uprawnienia w tym zakresie Rady Regencyjnej.

${ }^{10}$ Stąd też zasadne jest stwierdzenie, że dla ukonstytuowania władzy J. Piłsudskiego dekret z 22 listopada 1918 r. miał charakter deklaratoryjny. Inaczej T. Ciświcki, O Naczelniku Państwa i Prezydencie Rzeczypospolitej Polskiej. Studium prawno-polityczne, Poznań 1922, s. 14. 
fikując w jego postaci urząd Tymczasowego Naczelnika Państwa. Wyrażało się to także w zwrotach językowych w nim zawartych, przede wszystkim pisanych w trybie oznajmującym, w pierwszej osobie liczby pojedynczej (np. stanowię, co następuje, obejmuję) lub w dopełnieniu wyrażonym zaimkiem przymiotnym „mój” (ulegają mojemu zatwierdzeniu ). Dekret limituje czasowo jego władzę nie tylko poprzez pierwszy człon nazwy organu, ale również wskazanie, że jej kres wyznacza zwołanie SU. Oznaczało to, że z tą chwilą może się zmienić zarówno forma rządów, jak i pozycja Tymczasowego Naczelnika Państwa i podporządkowanego mu rządu. Było to wysoce prawdopodobne, zważywszy, że większość sił politycznych od wielu miesięcy wyrażała konieczność zwołania pierwszej ogólnonarodowej reprezentacji parlamentarnej, wiążąc $\mathrm{z}$ tym organem zasadnicze decyzje ustrojowe ${ }^{11}$. W odniesieniu do rządu potwierdzało to orędzie J. Moraczewskiego z 20 listopada 1919 r., które stanowiło, że rząd ma charakter tymczasowy, a jego misja zakończy się wraz ze zwołaniem SU.

Po drugie, cechą rodzącego się systemu organów państwowych jest fragmentaryczność jego regulacji normami o charakterze konstytucyjnym. Tworzące go organy zostały zarysowane cząstkowo i niepełnie (pominięto przede wszystkim sądownictwo), co odnosi się także do określenia zakresu ich działania. Brakuje jakiegokolwiek odniesienia się do kwestii budowy pozostałego aparatu państwa, jego relacji z rządem lub Naczelnikiem, natomiast zakres kompetencji obu organów ujęty był niezwykle wąsko, w dużym stopniu skupiając się na wzajemnym stosunku oraz ich udziale w ustawodawstwie. Jest to zrozumiałe, gdyż mimo wyraźnej intencji objęcia rodzącą się władzą państwową ogółu ziem polskich ${ }^{12}$, zakres zadań i kompetencji do ich realizacji przyznanych organom tworzącego się państwa ulegał dopiero stopniowej krystalizacji w nadchodzących latach, gdy uświadamiano sobie skalę różnych problemów koniecznych do rozwiązania w nowo tworzącym się państwie. Ponadto w praktyce ustrojowej okazało się, że niektóre regulacje pochodzące $\mathrm{z}$ okresu rządów Rady Regencyjnej będą miały zastosowanie nadal, stając się techniczno-wykonawczym rozwinięciem reguł generalnie określonych $\mathrm{w}$ dekrecie czy aktach konstytucyjnych powstałych w następnych latach. Dotyczyło to m.in. organizacji prac rządu i ministrów, a także zakresu ich właściwości czy tworzenia nowych organów i instytucji publicznych, określonych m.in. w dekrecie Rady Regencyjnej z 3 stycznia 1918 r.

Mimo szczątkowego charakteru regulacji, można wskazać, że pierwsze unormowanie o charakterze konstytucyjnym pozwalało potraktować zarówno Tymczasowego Naczelnika Państwa, jak i Radę Ministrów jako dwa odrębne organy państwowe. Przemawiają za tym - określone w sposób dalece niepełny z perspektywy współczesnych standardów — zawarte w dekrecie z 22 listopada 1918 r. postanowienia odnoszące się do kompetencji i zadań obu tych organów, jak i określenie ich obsady perso-

${ }^{11}$ Jedyną, choć istotna, siłą polityczną niechętnie nastawioną do zwołania Sejmu była endecja, co czyniła głównie ze względów taktycznych, obawiając się (jak się miało okazać, niesłusznie), że na kanwie radykalizacji społecznej jej reprezentacja parlamentarna może w niewystarczającym stopniu odzwierciedlać wpływy społeczne.

${ }^{12}$ Dekret z 14 listopada 1918 r. Naczelnego Dowódcy wskazywał na obszar trzech zaborów, co tworzyło szerokie ramy dla określenia przyszłych granic państwa polskiego. 
nalnej. Co interesujące, o ile w okresie rządów Rady Regencyjnej istniała wspólna formuła działania Rady i Rady Ministrów w postaci Rady Koronnej, to brak takiej instytucji w dekrecie z 22 listopada 1918 r. podkreślał tę odrębność. Piłsudski zrezygnował z zajmowania stanowiska ministra spraw wojskowych w kolejnych rządach i co znamienne - nie powołując nikogo na to stanowisko, co podkreślało zarówno rozdzielność obu organów, jak i wyraźną autonomizację problematyki dowodzenia wobec prac rządowych.

Po trzecie, nie budzi wattpliwości zwierzchnia pozycja Tymczasowego Naczelnika Państwa. Jest to zwierzchność w rodzącym się systemie organów państwowych, a wspomniana w dekrecie „najwyższa władza”, powinna być odnoszona do usytuowania Tymczasowego Naczelnika względem pozostałych organów. Zwierzchność ta jednak napotykała ograniczenia. W pierwszej kolejności była ona ograniczona odrębnością sądownictwa, którego niezależność nie była modelowa, lecz pozostawała poza bezpośrednim wpływem Tymczasowego Naczelnika Państwa. W stosunku do Rady Ministrów jego pozycję wyznaczała odpowiedzialność polityczna ponoszona przez rząd przed Naczelnikiem, a w konsekwencji swoboda kształtowania jego składu. Jednak jak się szybko okazało, zarówno ostatecznie niepowołany rząd Ignacego Daszyńskiego, jak i rządy J. Moraczewskiego oraz Ignacego J. Paderewskiego powstawały pod wpływem układu politycznego kształtującego się u zarania II RP w różnym, ale zwiększającym się stopniu systematycznie uwzględnianym przez Piłsudskiego. Tymczasowy Naczelnik Państwa dysponował możliwością zablokowania projektów ustawodawczych przygotowanych przez Radę Ministrów bez względu na to, czy stały za tym racje polityczne, prawne czy też innej proweniencji. Zwierzchność Naczelnika Państwa, choć wyraźna i ujawniająca się w praktyce politycznej tego okresu, nie oznaczała jednak braku samodzielności Rady Ministrów ${ }^{13}$. W praktyce kolejne rządy podejmowały większość decyzji bez ingerencji Tymczasowego Naczelnika, a nawet poza jego świadomością, oczywiście jeśli były podejmowane w formie prawnej innej niż dekrety ${ }^{14}$. Działalność kolejnych rządów pokazała, że większość ich zadań związanych była z mozołem permanentnego zarządzania kryzysowego, skupiającego się na podstawowych potrzebach egzystencjalnych obywateli i państwa, które pozostając w generalnej optyce J. Piłsudskiego nie zdominowały jego

13 Podobnie P. Sarnecki, Zasady ustrojowe odradzajacej się Polski, „Przegląd Sejmowy” 1998, nr 5, s. $35-36$.

14 Jest rzeczą ciekawa, że dekrety przedstawione na pierwszym posiedzeniu SU zostały podzielone na grupy zgodnie z zakresem przedmiotowym działania danego ministra (np. Ministerstwo Spraw Wewnętrznych przedłożyło 34 dekrety, Ministerstwo Skarbu - 22 dekrety), a nie en bloc przez rząd lub szefa rządu. Prezydent Ministrów przedstawił 10 dekretów, w tym dwa ustanowione przez Radę Regencyjną. Dekrety te miały z reguły charakter generalny, dotycząc powołania urzędów (np. utworzenia kancelarii cywilnej Naczelnika Państwa, Ministerstwa Sztuki i Kultury), czy ustrojowy (np. dekret o najwyższej władzy reprezentacyjnej Republiki Polskiej czy dotyczący nadania statutu Komisji Rządzącej dla Galicji i Śląska Cieszyńskiego oraz Górnej Orawy i Spiżu). Podział dekretów przedstawiony SU nie był zawsze konsekwentny, gdyż dekret o ordynacji wyborczej do SU, choć miał ogólnoustrojowe znaczenie, znalazł się w puli dekretów przekazanych przez Ministerstwo Spraw Wewnętrznych ze względu na fakt, że został przygotowany przez to ministerstwo. Łącznie przedłożono w trakcie pierwszego posiedzenia konstytuanty 210 dekretów. Confer także S. Krukowski, Mała Konstytucja z 1919 r., [w:] Konstytucje Polski, red. M. Kallas, Warszawa 1990, s. 8-9. 
wysiłków na rzecz utrzymania niepodległości państwa na drodze dyplomatycznej, jak i militarnej ${ }^{15}$.

Józef Piłsudski jako Tymczasowy Naczelnik Państwa nie predestynował do roli suwerena. O ile był organem zwierzchnim (z zastrzeżeniem faktycznej pozycji sądownictwa) wobec innych organów, także sił zbrojnych, o tyle uznawał w sposób oczywisty suwerenność narodu ${ }^{16}$, traktując wytworzony stan jako przejściowy — fazę pośrednią w prawnej materializacji zasady suwerenności narodu via wybory i ukonstytuowanie się SU. Potwierdziło to także orędzie J. Moraczewskiego z 20 listopada 1918 r. i to zarówno gdy chodzi o jego formę, jak i samą treść. Wystosowane przed ogłoszeniem dekretu o najwyższej władzy reprezentacyjnej było swoistym exposé programowym ${ }^{17}$, które w zwykłych okolicznościach rząd parlamentarny — w różnej postaci — przedkłada reprezentacji narodu na początku swej drogi. Wobec braku tej reprezentacji orędzie to pod tytułem „Do narodu polskiego” kierowano bezpośrednio do suwerena, tym samym uznając go za pierwotne źródło władzy państwowej. Nie budziło wątpliwości, że organy państwa wskazane $\mathrm{w}$ dekrecie z 22 listopada $1918 \mathrm{r}$. funkcjonowały z przeświadczeniem ograniczonego charakteru swej legitymacji oraz zakładając związanie zasadą suwerenności narodu ${ }^{18}$.

Próbując odpowiedzieć na pytanie o system rządów, którego ucieleśnieniem był układ wytworzony w pierwszych miesiącach niepodległości Polski, należy uwzględnić kontekst historyczny jego formowania się. Niepodległość została dana Polsce w warunkach przez większość nieoczekiwanych. Jeszcze w pierwszych latach wojny duża część sił politycznych wiązała się współpracą z zaborcami, licząc raczej na ograniczoną zmianę statusu ziem polskich niż na pełną suwerenność państwową. Skala i przebieg wojny czyniły z upływem czasu wizję niepodległości państwa polskiego coraz bardziej realna, ale jej kształt ustrojowy był nadal nieskonkretyzowany. Formujący się prowizoryczny system rządów był wypadkową lawiny nieprzewidywalnych wydarzeń oraz okoliczności, których planowanie nie było możliwe. Stąd należy ocenić to rozwiązanie jako przynoszące minimalny ład organizacyjny, pozwalający uniknać chaosu i anarchii. Wytworzony pod presją chwili i bez wcześniej wypracowanych założeń, przyjęty został z intencją możliwe sprawnego sprostania najważniejszym zadaniom stojącym przed formującym się państwem. Stąd też zwierzchnia wobec innych tworzacych się form organizacyjnych rola organu jednoosobowego (co prima facie może przypominać dyktaturę) i koncentracja na organach o charakterze zarządzającym, działającym na podstawie samodzielnie tworzonego, lecz tymczasowego ustawodawstwa. Był to więc z konieczności prowizoryczny model oparty na systemie jed-

${ }^{15}$ Confer J. Goclon, Rzad Jędrzeja Moraczewskiego 17 XI 1918-16 I 1919 (struktura, funkcjonowanie, dekrety), „Przegląd Nauk Historycznych” 2009, nr 2, s. 99 i n.; idem, Rzad Ignacego Jana Paderewskiego. Geneza, skład osobowy i dzialalność (16 stycznia 1919-9 grudnia 1919 r.), „Acta Universitatis Lodziensis. Folia Historica" 2011, nr 86, s. 93 i n.

${ }^{16}$ Confer Z. Cybichowski, Polskie prawo państwowe, cz. I, Warszawa 1925, s. 205.

17 Pisano w nim m.in.: , ,...] poczuwamy się do obowiązku wyłuszczenia przed narodem naszego stanowiska, do wskazania mu dróg, któremi pójdziemy i celów jakie sobie stawiamy".

18 Confer P. Sarnecki, op. cit., s. 32. 
nolitości władzy, dla którego zwieńczeniem, a w tych okolicznościach i punktem krystalizacji był Tymczasowy Naczelnik Państwa. Jednak dojmującym jego brakiem była absencja organu przedstawicielstwa narodowego.

\section{NARODZINY NOWEGO SYSTEMU RZĄDÓW}

Wraz z zebraniem się Sejmu Ustawodawczego 10 lutego 1919 r. rozpoczął się nowy etap ewolucji ustrojowej. Formalnie z tym dniem wygasła tymczasowa regulacja ustrojowa, wprowadzona dekretem przez J. Piłsudskiego. Dominującym problemem w tych dniach było określenie pozycji ustrojowej organu przedstawicielstwa narodowego i bezpośrednio z tym powiązana konieczność odniesienia się do roli ustrojowej pozostałych organów naczelnych, tworzących prowizoryczną formę rządów. Mimo daleko zaawansowanego zróżnicowania politycznego SU, panowała w nim zgoda co do jego nadrzędnego stanowiska w systemie ustrojowym państwa ${ }^{19}$. Przyczyn takiego nastawienia było kilka, należy jednak przypomnieć, że przyznanie reprezentacji narodu zwierzchniego charakteru było pewną reguła, charakterystyczną dla państw znajdujących się w fazie gwałtownych przemian społecznych i politycznych ${ }^{20}$. Dzieje państw europejskich pokazały, że radykalizacja społeczna dla sił lewicowych i prawicowych jest silnym impulsem do formowania przedstawicielstwa narodowego o szczególnej pozycji. Oczywiście motywacje poszczególnych środowisk politycznych były z reguły odmienne, zarówno ideowe jak i czysto taktyczne, i nie inaczej było u zarania SU.

W odradzającej się Polsce idea zwołania Sejmu jako zasadniczej inauguracji jej państwowości od dłuższego czasu stała się głównym postulatem powielanym w licznych deklaracjach różnych sił politycznych i innych podmiotów ${ }^{21}$. Nawet powstały u kresu działalności Rady Regencyjnej rząd J. Świeżyńskiego, zdominowany przez endeków, punktem swego programu uczynił postulat niezwłocznego zwołania Sejmu. A gdy siły polityczne, reprezentowane w tym rządzie, za kilkanaście dni zmieniły radykalnie swój pogląd, lansując zamiast zwołania Sejmu powołanie Naczelnej Rady

${ }^{19}$ Zdawał sobie z tego sprawę J. Piłsudski, który otwierając pierwsze posiedzenie SU 10 lutego 1919 r., stwierdził m.in.: ,[...] przypadł mi zaszczyt otwierać sejm, który znowu będzie domu swego ojczystego jedynym panem i gospodarzem [...]". W tym samym wystapieniu wśród głównych zadań parlamentu wskazywał: „Obdarzeni dziś zaufaniem narodu dać mu macie podstawy dla jego niepodległego życia w postaci prawa konstytucyjnego Rzeczypospolitej Polskiej”, sprawozdanie stenograficzne z posiedzenia Sejmu Ustawodawczego" [dalej: spr. sten. z SU] z 1. posiedzenia SU, 10 lutego 1919 r., ł. 2-3.

${ }^{20}$ Podobnie Z. Witkowski, op. cit., s. 19.

${ }_{21}$ Już 17 listopada 1916 r., na zjeździe obywatelskim Ligi Państwowości Polskiej w Piotrkowie, przyjęta została rezolucja, głosząca m.in.: „Źródłem rządu i twórcą armii może być jedynie powstały na zasadzie ogólnych wyborów Sejm Polski”. W tym samym czasie podobnie wypowiedziała się PPS — Frakcja Rewolucyjna, która w swojej odezwie stwierdziła, że „O budowie wewnętrznej naszego państwa, o jego ustroju społecznym i politycznym stanowić może jedynie Sejm ustawodawczy, czyli konstytuanta wybrana przez powszechne, równe, tajne, bezpośrednie i proporcjonalne głosowanie". Jak łatwo dostrzec, echa tego sformułowania są wyraźne w stanowisku J. Piłsudskiego, zajmowanym u narodzin niepodległości. Od końca 1916 r. postulat zwołania Sejmu i zajęcia przez niego szczególnego stanowiska ustrojowego był głoszony — choć z różną motywacją — przez niemal wszystkie ugrupowania polityczne. Confer L. Hass, Do genezy złudzeń parlamentarnych w Polsce międzywojennej (Sejm i glosowanie powszechne w propagandzie politycznej Królestwa 1915-1918), „Kwartalnik Historyczny” 1972, LXXIX, z. 1, s. 56 i n. 
Narodu Polskiego, składającej się z delegatów partii politycznych z trzech zaborów, to także ten organ w planach jej twórców miał stać się zwierzchni wobec innych, likwidując przy okazji urząd Tymczasowego Naczelnika Państwa22 ${ }^{22}$ Poza jasnymi przyczynami politycznymi tego rozwiązania, zwraca uwagę fakt, że Rada, choć o wątpliwej reprezentacyjności, została wysunięta jako wiodąca w systemie rządów, co pokazuje, jak silne było przekonanie o tym, że organy traktowane jako przedstawicielskie powinny zajmować uprzywilejowaną pozycję ${ }^{23}$.

Upadek Rzeczypospolitej na skutek rozbiorów przynosił Polakom utratę ich podmiotowości politycznej, a w konsekwencji poddanie się polityce zaborców systematycznego redukowania wpływu politycznego i ekonomicznego Polaków na zamieszkiwane przez nich terytorium. Wskrzeszenie Polski przynosiło jej obywatelom odzyskanie pełni podmiotowości politycznej, w tym uzyskanie praw wyborczych w celu wyłonienia własnego przedstawicielstwa parlamentarnego ${ }^{24}$. Skoro wśród powstających centralnych organów państwowych parlament jako jedyny miał tak szczególną legitymację, naturalną rzeczą było jego wysforowanie. W ten sposób można było oznajmić powstanie nowego ładu politycznego, dla którego kluczowym spoiwem była zasada suwerenności narodu, a w konsekwencji praktyczna forma jej realizacji przez obywateli w postaci wyborów powszechnych i pochodzącego z nich najwyższego organu państwowego ${ }^{25}$. Rzeczą naturalną w ówczesnym myśleniu o roli parlamentu było, że skoro źródłem władzy jest naród, to parlament jako jego emanacja powinien mieć zagwarantowaną adekwatną pozycję w państwie. O ile w pierwszych miesiącach odzyskiwania niepodległości można uznać za dość powszechny głos opinii publicznej upatrujący w J. Piłsudskim jedyną osobę właściwą do sprawowania pełni władzy, jako nieformalnie wyrażone stanowisko suwerena, o tyle wraz z przeprowadzeniem wyborów jedynym organem czerpiącym swą władzę z wyraźnie objawionej woli suwerena stał się SU. Konstytuanta - z chwila jej wyłonienia - stała się jedynym bezpośrednim organem państwowym, kładąc kres dotychczasowej ludowej, ale domniemanej legitymacji J. Piłsudskiego. Zmieniało to diametralnie relacje w rodzącym się systemie rządów, wynosząc SU na miejsce dotąd zajmowane przez Tymczasowego Naczelnika Państwa, tego zaś przesuwając do roli, która miała zostać określona przez konstytuantę.

22 Confer M. Bobrzyński, op. cit., s. 46 i n.; A. Ajnenkiel, op. cit., s. 187 i n.

${ }^{23}$ W tym kontekście przywoływany jest przykład czechosłowackiego Narodnego Vyboru, który powołany został w drodze nominacji partii politycznych wedle klucza, jakim była liczba mandatów obsadzonych przez nie w ostatnich przedwojennych wyborach do parlamentu austriackiego w 1911 r., confer A. Ajnenkiel, op. cit., s. 187 i n.

${ }^{24}$ Problematyka kształtu wyborów do konstytuanty, w różnych wariantach, pojawiała się w dyskursie politycznym co najmniej od 1916 r., a wraz ze zbliżającym się końcem wojny światowej przechodziła fazę radykalizacji postulatów, lakonicznie ujmowanych jak wybory demokratyczne. W istocie takie się stały na mocy ordynacji z 28 listopada 1918 r., przygotowanej przez rząd J. Moraczewskiego i zatwierdzonej przez Tymczasowego Naczelnika Państwa. To sprawiło, że pierwsze w historii Polski wybory powszechne, poza walorem autentyczności wyłonionej reprezentacji, wywołały duże nadzieje związane z efektami pracy konstytuanty.

${ }_{25}$ Por. M. Pietrzak, Parlament w systemie organów państwowych, [w:] Sejmy Drugiej..., s. 57. 
Dla dużej części posłów, głównie z ugrupowań centroprawicowych, nadrzędne stanowisko Sejmu w systemie organów państwowych rozwiązywało uwierający i nie do zaakceptowania na dłuższą metę, status Naczelnika Państwa. Zmiana istniejącej konfiguracji, przy dużym autorytecie społecznym J. Piłsudskiego, mogła być uzasadniona jedynie wtedy, kiedy jego miejsce zajęło przedstawicielstwo narodowe, pochodzące $\mathrm{z}$ wyborów powszechnych i materializujące wielkie nadzieje z nim związane, wyrażane przez większość wyborców. Nie znosiło to oczywiście problemu znalezienia właściwej formuły dalszej egzystencji ustrojowej Naczelnika, ale było satysfakcjonującym dla obozu centroprawicowego, ograniczeniem jego dotychczasowego statusu i barierą dla jego emancypacji kompetencyjnej.

Dla obozu lewicy sejmowej, z reguły przyjaznej J. Piłsudskiemu, oparcie rodzącego się ustroju politycznego na zasadzie suwerenności narodu i wynikającej stąd uprzywilejowanej pozycji parlamentu było od dawna postulatem programowym ${ }^{26}$. System z pierwszoplanową pozycją parlamentu był radykalnym odcięciem się od dotąd obowiązujących na ziemiach polskich mechanizmów monarchii konstytucyjnej, dla której parlament niemal do samego końca ich istnienia nie odgrywał kluczowej roli ustrojowej. Większość polityków tego obozu, ale i sam J. Piłsudski, dostrzegała zalety deliberatywnej i integracyjnej funkcji SU, w którego pracach można było skonfrontować różne nurty polityczne i ich programy, tworząc parlamentarną większośćc ${ }^{27}$. Misja SU jako organu tworzącego nowy ład prawny, w tym konstytucję niepodległego państwa, po raz pierwszy od blisko 130 lat w sposób wolny od dyktatu państw obcych i - w założeniu — zgodny z wolą narodu, przemawiała oczywiście za nieskrępowaną, wolną od ograniczeń, pozycją reprezentacji narodowej ${ }^{28}$.

${ }^{26}$ M. Bobrzyński, op. cit., s. 50 odnosząc się do genezy małej konstytucji, uważał, że ,złożyło się na nią dążenie posłów i stronnictw ultrademokratycznych do wszechwładzy Sejmu z nieufnością narodowych demokratów do Piłsudskiego, która im podyktowała ograniczenie władzy Naczelnika Państwa”.

${ }^{27}$ W trakcie swojej przemowy w SU, składając urząd, J. Piłsudski stwierdził m.in.: „Wśród olbrzymiej zawieruchy, w której miliony ludzi rozstrzyga sprawy jedynie gwałtem i przemoca, dążyłem, by właśnie w naszej Ojczyźnie konieczne i nieuniknione tarcie społeczne były rozstrzygane w sposób jedynie demokratyczny: za pomocą praw, stanowionych przez wybrańców narodu". Z tą konstatacją dobrze koreluje instrukcja przekazana polskiej delegacji na rozmowy z Komitetem Narodowym Polskim w Paryżu i przedstawicielami państw Ententy, w której zawarto następujące tezy: „Państwo Polskie buduje się zupełnie na nowo i nie ma w nim żadnej tradycji, żadnego zwyczajowego i prawnego oparcia. Państwo nie posiada prawnych podstaw swej egzystencji i poszczególne formy jego organizacji są to właściwie ciagle stany ex lex. W tych warunkach: a) konstytuanta da krajowi pierwsze poczucie prawa dokonanego bez udziału obcych, b) konstytuanta jedynie zaważyć może przeciwko bolszewizmowi, będącemu niczym innym jak dyktaturą mniejszości, niemożliwemu zatem tam, gdzie panuje ukonstytuowana większość. Obawy nadmiernego zradykalizowania konstytuanty i przez konstytuantę kraju są z gruntu fałszywe. Konstytuantę w Polsce będzie wybierać ogromna większość chłopska, c) konstytuanta będzie jedyną formą złączenia dzielnic w jedno, wyrównania różnic między dzielnicami, faktycznego zjednoczenia Polski”, cyt. za: A. Ajnenkiel, Sejm jako czynnik..., s. 23.

${ }_{28}$ Znamienne jest tu sformułowanie zawarte w wystapieniu Tymczasowego Naczelnika Państwa na posiedzeniu SU 20 lutego 1919 r., gdy składając swój urząd, stwierdził m.in., że: ,w Polsce XX wieku źródłem praw może być jedynie Sejm, wybrany na podstawach demokratycznych". Confer także A. Ajnenkiel, Spór o model..., s. 194-195, R. Kraczkowski, Mała Konstytucja z 20 lutego 1919 r., [w:] Małe Konstytucje. Ustawy zasadnicze okresów przejściowych 1919-1947-1992, red. R. Jastrzębski. M. Zubik, Warszawa 2014. 
Wreszcie — paradoksalnie — za ważne należy uznać doświadczenie mijających miesięcy obowiązywania modelu jednolitości władzy, a w nim nadrzędności jednego organu państwowego nad pozostałymi. Zewnętrzna obserwacja działania tego modelu choć niejednoznaczna i spotykająca się z krytyką zarówno Naczelnika Państwa, jak i podporządkowanego mu rządu miała jednak dwa istotne walory. Była pierwszą doświadczoną na wyzwalającym się obszarze Polski formą rządów, poznaną - co prawda - dość powierzchownie, nierozwiniętą w pełnym zakresie ze względu na skrajnie trudne warunki, jednak konsolidującą władzę państwową. Usytuowanie Sejmu w miejscu zajmowanym dotąd przez Naczelnika Państwa mogło być uważane za udoskonalenie dotychczasowej formy rządów, gdyż zastępowało jednoosobowość — kolegialnością, wyrażającą przy tym wielopartyjność właściwą parlamentarnemu przedstawicielstwu. Dawało to podstawy do przypuszczeń, że poszczególne ugrupowania reprezentowane w Sejmie uzyskają wpływ na dalszy rozwój wypadków, w tym znajdujące się na porządku dziennym kwestie ustrojowe, społeczne czy gospodarcze, dotyczące m.in. reformy rolnej, relacji między pracodawcą a pracownikami, problemów narodowościowych i szeregu innych palących kwestii.

Wielu stronnictwom towarzyszyła nadzieja, że możliwe jest stworzenie większości parlamentarnej, która uzyska dzięki pozycji SU dominujący wpływ na kluczowe rozstrzygnięcia polityczne i ustrojowe. Sejm przy swojej zwierzchniej pozycji jawił się jako arena rywalizacji o zdobycie pełnej władzy w państwie i podporządkowanie sobie innych organów państwowych. Inna rzecz, że to co u początków konstytuanty wydawało się całkiem realne, $\mathrm{z}$ biegiem czasu okazało się jedynie mirażem. W tym stanie rzeczy, mimo różnicy generalnych zapatrywań na przyszły kształt ustrojowy Polski oraz docelowy system rządów, występująca między ugrupowaniami parlamentarnymi kwestia nowej formy rządów została zdecydowana sprawnie, choć w sposób stosunkowo oryginalny. Wobec świadomości wszystkich ugrupowań, że przyjęcie nowej konstytucji może trwać dłużej (choć nikt nie przewidywał, że zajmie to ponad dwa lata ${ }^{29}$, zdecydowano się na rozwiązanie przejściowe, podobnie jak w listopadzie 1918 r. uczynił to J. Piłsudski.

\section{FORMA RZĄDÓW WEDLUG MALEJ KONSTYTUCJI}

Projekt kolejnego prowizorium był przedmiotem krótkotrwałych obrad Konwentu Seniorów. Organ ten powstał samorzutnie, jeszcze przed przyjęciem Tymczasowe-

${ }^{29} \mathrm{~W}$ protokole z posiedzenia Konwentu Seniorów stwierdzono, że m.in. ,[...] ze względu na anormalny stan jaki wytwarza łączenie w rękach jednej osoby najwyższej władzy cywilnej i wojskowej [co było oczywistym dostrzeżeniem ról pełnionych przez J. Piłsudskiego - uwaga A.K.] postanowiono protokólarnie stwierdzić, że projekty konstytucji po pierwszym czytaniu, które może się ciaggnąć najdalej przez trzy posiedzenia, będą odesłane do Komisji Konstytucyjnej z poleceniem przedłożenia sprawozdania o organizacji naczelnych władz w Państwie Polskim najdalej w ciagu trzech tygodni, tak iżby powyższe tymczasowe zasady Konstytucji mogły być uchwalone najdalej w ciagu czterech tygodni.”, cyt. za: S. Krukowski, op. cit., s. 12. Jak wiadomo, był to przejaw katatymii dającej się usprawiedliwić szczególnym momentem historycznym. W praktyce prace nad konstytucją rozpoczęły się w połowie 1919 r., zakończyły 17 marca 1921 r., zaś sama konstytucja wchodziła w życie do grudnia $1922 \mathrm{r}$. 
go Regulaminu obrad Sejmu ${ }^{30}$. Stanowił reprezentację klubów sejmowych liczących co najmniej 12 posłów, a w jego skład wchodzili przedstawiciele każdego klubu w liczbie wynikającej z wielokrotności liczby 12, mieszczącej się w ogólnej liczbie posłów tego klubu. Podstawą prac tego wąskiego gremium stał się wniosek przedstawiony formalnie 19 lutego 1919 r. przez Franciszka Bardla, posła PSL „Piast”, a który nie stał się nawet oficjalnym drukiem sejmowym. Po krótkiej dyskusji wniosek ten przyjął formę projektu uchwały SU i uzyskał niemal jednomyślne poparcie, które wyraziło się już w oficjalnym wniosku złożonym następnego dnia na posiedzeniu Sejmu, podpisanym przez ponad stu kilkudziesięciu posłów, w tym liderów wszystkich klubów sejmowych, jak posłowie: Wojciech Korfanty, Wincenty Witos, Ignacy Daszyński, Błażej Stolarski, Józef Ostachowski, Bolesław Fichna i Stanisław Chaniewski ${ }^{31}$.

Nim to jednak nastapiło, 20 lutego 1919 r. przed Sejmem wystapił J. Piłsudski, który powołując się na prowizoryczny charakter rządów dotąd sprawowanych oraz dopełniając zobowiązanie zawarte w dekrecie z 22 listopada 1918 r., złożył swój urząd. Następnie został przedstawiony przez marszałka Sejmu Wojciecha Trąmpczyńskiego jako nagły, wspomniany wniosek poselski i zgodnie z jego sugestia, uchwała ta została niezwłocznie przyjęta, bez dyskusji i przez aklamację, otrzymując tytuł o powierzeniu Józefowi Piłsudskiemu dalszego sprawowania urzędu Naczelnika Państwa ${ }^{32}$. Ze względu na swoje fundamentalne znaczenie ustrojowe zyskała miano małej konstytucji, choć ani forma tego aktu prawnego, ani jej tytuł nie skłaniały do tego - uchwała Sejmu z dnia 20 lutego 1919 r. o powierzeniu Józefowi Piłsudskiemu dalszego sprawowania urzędu Naczelnika Państwa [dalej: mała konstytucja] ${ }^{33}$. Przyjęcie projektu przez nieformalne ciało parlamentarne, a następnie jego uchwalenie nastapiło również, jak na akt konstytucyjny, w sposób wyjątkowy. Jednak stała się ona zasadniczym aktem dla określenia formy rządów w państwie polskim na — jak się okazało — blisko cztery lata.

Mała konstytucja od strony konstrukcyjnej składała się z dwóch części. Pierwsza była swego rodzaju bilansem dotychczasowej aktywności J. Piłsudskiego, rozliczającym okres sprawowania przez niego władzy. Dokonało się to w formule jednoczesnego przyjęcia jego oświadczenia o złożeniu urzędu oraz ponownym mu go powierzeniem (to rozstrzygniecie obwieszczono już w II części uchwały). Wacław Komarnicki nazywa to wprost udzieleniem J. Piłsudskiemu przez SU wotum zaufania za okres poprzednich rządów, choć w samej uchwale takie pojęcie nie padło ${ }^{34}$. Sam Piłsudski bowiem ustalił kres swego urzędu w obu wspomnianych dekretach listopadowych na moment zebrania się SU i pomijał w nich swoją odpowiedzialność polityczną (w formie

${ }^{30}$ A. Ajnenkiel, Historia sejmu polskiego, Warszawa 1989, t. II, cz. 2, s. 35.

31 Szerzej na ten temat W.T. Kulesza, Uchwała Sejmu Ustawodawczego z dnia 20 lutego 1919 r. o powierzeniu Józefowi Piłsudskiemu dalszego sprawowania urzędu Naczelnika Państwa, „Przegląd Sejmowy” 2007, nr 5, s. 38 i n. i cyt. tam literatura.

32 Dz.P.P.P. z 1919 nr 19, poz. 226.

33 Warto jednak pamiętać, że w tym okresie terminologia stosowana dla nazwania aktów normatywnych uchwalanych przez SU nie była jeszcze ostatecznie ukształtowana. Pojawiały się m.in. określenia: ustawa tymczasowa (z dnia 2 sierpnia 1919 r. o organizacji władz administracyjnych II instancji), ustawa zasadnicza (zasadnicza ustawa sanitarna z dnia 19 lipca 1919 r.).

34 W. Komarnicki, op. cit., s. 65. 
parlamentarnej) za ten okres. Zamknięcie tego epizodu ustrojowego miało się dokonać wedle Naczelnika Państwa na drodze czysto mechanicznej, bez jakiejkolwiek prawnej formy jego rozliczenia ${ }^{35}$. Jedynym podmiotem ponoszącym odpowiedzialność parlamentarną za jego działania był rząd, przejmujący ją w drodze kontrasygnaty, co czyniło ją bezprzedmiotową w stosunku do Piłsudskiego. Przy przyjęciu koncepcji W. Komarnickiego, że działania naczelnych organów państwowych sprzed ukonstytuowania się SU również podlegały odpowiedzialności parlamentarnej, to właśnie podstawę prawną do tego rodzaju działań — i tylko wobec Rady Ministrów — stanowiła instytucja kontrasygnaty, przewidziana w dekrecie z 22 listopada $1918 \mathrm{r}^{36}$ Jednak ten sam autor stwierdził, że instytucja ta nie stanowiła ,istotnej gwarancji prawnopolitycznej” i nie odgrywała tej roli, ,co przy systemie wyłącznej odpowiedzialności rządu, lub nawet wspólnej odpowiedzialności obu czynników (Naczelnika Państwa i rządu)"37. Jeśli zgodzić się z opinią W. Komarnickiego, że jednym ze skutków małej konstytucji było swoiste wotum zaufania, to należy w nim dostrzegać działanie SU pro futuro jako inaugurację nowego systemu rządów, w którym obowiązuje zasada, uzależniająca powołanie i działalność Naczelnika Państwa oraz Rady Ministrów od woli ciała parlamentarnego. W tym znaczeniu wspomniane przez W. Komarnickiego wotum zaufania było nadaniem przez SU inwestytury Naczelnikowi Państwa, dla którego źródłem sprawowanej władzy — inaczej niż do tej pory — była wola wyrażona przez parlament.

Niewatpliwie jednak kluczowa dla budowy nowej formy rządów była II część małej konstytucji. Istniejący dotąd zespół naczelnych organów państwowych poszerzony został o SU, ale ta zmiana pociagała za sobą przede wszystkim całkowitą rekonfigurację istniejącego systemu. Wynikała ona nie tyle z konieczności uwzględnienia organu przedstawicielskiego, ile zasadniczego przekierunkowania relacji między podmiotami nowej formy rządów i dokonanego przewrotu kompetencyjnego. W świetle II części małej konstytucji użyte zarówno w tytule samej uchwały, jak i jej treści sformułowanie „o powierzeniu Józefowi Piłsudskiemu dalszego sprawowania urzędu Naczelnika Państwa" okazało się nieco mistyfikujące. O ile bowiem urząd nosił formalnie tę samą nazwę, jak przed 20 lutego 1919 r., o tyle jego materialna treść uległa fundamentalnej zmianie. Gdy w dekrecie z 22 listopada 1918 r. obwieszczono, że Naczelnik Państwa objął najwyższą władzę w państwie, to nowa regulacja przesądziła, że odtąd organem tym stał się SU. Dla ukształtowania charakteru ustrojowego organu reprezentacji narodowej posłużono się określeniem: władza suwerenna i ustawodawcza, co wywołało krytyczny komentarz ze względu na niespójność terminologiczną. Jak wskazał W. Komarnicki, użyte w małej konstytucji pojęcie władzy suwerennej

${ }^{35}$ Co więcej, o jakimkolwiek rozliczeniu J. Piłsudskiego z tego tytułu nie wspomniano nie tylko w małej konstytucji, ale jakimkolwiek akcie SU odnoszącym się do okresu sprzed jego zebrania się.

${ }^{36}$ Przepis określający, że dekrety ustanowione przed zebraniem się SU miały być mu przedłożone na 1. posiedzeniu dawał podstawy do dalszych spekulacji na temat potencjalnych czynności, które mogły być wobec nich i ich twórców (Rada Ministrów) podjęte.

37 W. Komarnicki, op. cit., s. 53. 
jako zakresowo najszersze obejmowało także władzę ustawodawczą a tym samym jej wskazanie było zbędne.

Wydaje się jednak, że należy na użyte określenia spojrzeć także z perspektywy jego bezpośrednich twórców. Wyrośli oni w ustrojach, w których pojęcie suwerena było zawarowane dla monarchów, stąd upadek ustrojów monarchicznych był dla nich przejawem zrzucenia jarzma obcej władzy, ale także wyzwoleniem jednoczącego się narodu do sprawowania pełnej, najwyższej i niegraniczonej władzy. Mając świadomość, że suwerenność narodu objawia się na drodze prawnej — jak to pojmowano ówcześnie - jedynie poprzez wybory parlamentarne, wyrażono w uchwale wolę, aby reprezentacja suwerena na czas, gdy ten formalnie „milczy”, została uznana za sprawującą delegowaną jej władzę najwyższą i nieograniczoną. Niewątpliwie dla części posłów sprawowanie jej przejściowo przez J. Piłsudskiego w poprzednim systemie rządów było sygnałem potencjalnego zagrożenia wynikającego z legitymizowania się wolą suwerena przez inny, konkurencyjny względem parlamentu, podmiot ${ }^{38}$. W użytym w małej konstytucji wobec Sejmu pojęciu ,władza suwerenna” nie należy dostrzegać samokreacji nowego podmiotu władzy państwowej, a odwołanie się do kluczowej dla konstytuanty legitymacji sprawowania władzy ${ }^{39}$. Użyte wobec konstytuanty określenie władzy suwerennej nie czyniło z niej suwerena, lecz podkreślało jej charakter jako jedynego organu legitymowanego wolą suwerena - organu bezpośredniego ${ }^{40}$.

Określenie władza suwerenna niosło za sobą także inne treści. Niewątpliwie było wskazaniem, że w stratyfikacji wszystkich organów państwowych SU zajmuje pozycję nadrzędną wobec zarówno Naczelnika Państwa, jak i rządu. Oznaczało to, że odrzucona została po raz kolejny zasada podziału władzy jako klucz do organizacji aparatu państwowego, przy czym gdy uczynił to po raz pierwszy Piłsudski, brakowało realnych podstaw do oparcia się o nią choćby ze względu na brak jakiejkolwiek formy zbiorowego przedstawicielstwa narodu czy kształtowanie się pozostałych władz. Ponownie więc, mimo pojawienia się już realnych możliwości implementacji tej zasady, wybrano ideę koncentracji władzy tym razem w formie rządów zgromadzenia. To zaś w konsekwencji czyniło wtórnym kwestię precyzyjnego określenia roli ustrojowej pozostałych organów państwowych. W istocie bowiem za określeniem konstytuanty władzą suwerenną kryło się prawo swobodnego charakteryzowania misji pozostałych organów, będących adresatami przyszłych zadań państwowych ${ }^{41}$. Inną

38 Problem ten objawił się w następnych miesiącach, gdy projekty przyszłej ustawy zasadniczej, przewidujące powszechny wybór głowy państwa wpłynęły do konstytuanty. A w latach następnych problem suwerenności narodu stał się kluczowym zagadnieniem wynikłym na kanwie dyskusji prowadzonej przed uchwaleniem konstytucji kwietniowej.

39 Podobnie R. Kraczkowski, op. cit., s. 15. Odmiennie S. Krukowski, op. cit., s. 13.

${ }^{40}$ Notabene, o ile zasada suwerenności narodu nie była podważana na początku lat dwudziestych XX w. przez główne siły polityczne (inna rzecz na ile wyrażało to ugruntowane przekonania, a na ile było manewrem taktycznym), o tyle w latach następnych zarówno w Europie, jak i w Polsce podjęto próby jej wyraźnej deprecjacji, czego doskonałym przykładem były prace nad polską konstytucją kwietniową z 1935 r.

${ }^{41}$ Przykładem o znaczeniu fundamentalnym takiego podejścia była kwestia przyszłej ustawy zasadniczej. Początkowo wyrażano pogląd, że podstawą prac nad konstytucją będą projekty poselskie. Jednak już 
konsekwencją przyjęcia formuły zwierzchniej władzy konstytuanty była, jak słusznie zauważył Zbigniew Witkowski, deprecjacja położenia pozostałych organów czyli Naczelnika Państwa i rządu ${ }^{42}$. Objawiała się nie tylko w utracie dotychczasowej pozycji, ale też w nieograniczonej swobodzie konstytuanty do modelowania pozostałych organów. Skoro bowiem wprowadzono zasadę nadrzędności SU w systemie organów państwowych, pozostałe podmioty systemu rządów nie miały po swej stronie żadnych argumentów ustrojowych, mogących chronić je przed hegemonią konstytuanty ${ }^{43}$.

Innym powodem zastosowania pojęcia władzy suwerennej jako formy charakterystyki SU był brak pełnej świadomości głównych sił politycznych co do realnego kształtu kompetencyjnego tego organu. Najbardziej skonkretyzowana została funkcja ustawodawcza jako oczywista i w praktyce politycznej okresu zaborów zapoznana przez wielu posłów do SU, którzy wcześniej zasiadali w parlamentach państw zaborczych. Stąd też jej wyraźne wskazanie, w sposób dostosowany do szczególnej pozycji konstytuanty. Charakterystyczne jest potraktowanie funkcji ustawodawczej jako w całości kompetencyjnie zawłaszczonej przez konstytuantę i nieograniczonej przedmiotowo. Dominacja kompetencyjna wyrażała się w pominięciu milczeniem w małej konstytucji prawa inicjatywy ustawodawczej (nie przypisano jej zarówno Naczelnikowi Państwa, jak i Radzie Ministrów, działającym razem lub osobno), co przy deklarowanej nadrzędności Sejmu mogło sugerować pozbawienie obu organów tego uprawnienia. Dopiero kompetencja ta, definiowana jako prawo Rady Ministrów do składania pisemnych wniosków, została przyjęta w art. 15 tymczasowego regulaminu obrad.

Równie znamienne było pozbawienie Naczelnika Państwa kompetencji do podpisywania przyjętych przez SU ustaw i jej scedowanie na marszałka Sejmu za kontrasygnatą prezydenta Ministrów i właściwego ministra. Za tym symbolicznym podkreśleniem pełni praw Sejmu do kształtowania ustawodawstwa szło pozbawienie wpływu na nie innych organów. Zniknęło prawo sankcji, żaden z pozostałych organów nie uzyskał możliwości zastosowania weta ustawodawczego, choćby w formie zawieszającej, a nawet wpływu na przebieg postępowania ustawodawczego, np. poprzez wniosek o jego przyspieszenie, co w tymczasowym regulaminie było uprawnieniem grupy co najmniej 15 posłów. Nieograniczonemu przedmiotowo zakresowi uchwalanych ustaw towarzyszył wyraźny brak podziału materii podległej prawodawczemu normowaniu przez organy państwa. W ten sposób ustawa stawała się dogodnym regulatorem problematyki zarówno w kwestiach o charakterze generalnym i o wymiernym znaczeniu

12 marca 1919 r. Komisja Konstytucyjna wezwała rząd I.J. Paderewskiego do przedstawienia własnego projektu ustawy zasadniczej, a gdy on okazał się niedostateczny, główne prace rozpoczęły się 1 grudnia 1919 r. po przedstawieniu kolejnego projektu, tym razem przez rząd L. Skulskiego Confer szerzej S. Krukowski, Geneza konstytucji z 17 marca 1921 r., Warszawa 1977.

42 Confer Z. Witkowski, op. cit., s. 20. Podobnie uważał czołowy poseł endecji S. Głąbiński, Wspomnienia polityczne, Pelplin 1939, s. 422 i n.

${ }^{43}$ Dobitnie scharakteryzował powstały ten system rządów poseł S. Głąbiński, ,Polska bowiem nie jest państwem monarchicznym, w którem możliwe są konflikty między reprezentacją narodu a monarchą, ale jest państwem demokratycznym, w którym zarówno rząd jak i Naczelnik Państwa są wykonawcami woli Sejmu Ustawodawczego"; spr. sten. z 324. posiedzenia SU, 5 lipca 1922 r., 1. 19. 
ustrojowym $^{44}$, jak w kwestiach wzbudzających zainteresowanie jedynie pewnych grup posłów, często o wymiarze indywidualnym ${ }^{45}$. Co więcej, ustawa często była traktowana jako instrument zlecania rządowi konkretnych zadañ ${ }^{46}$, podkreślając wyraźnie, że kreatorem polityki państwa stała się konstytuanta.

Inne obszary władczej dominacji SU zostały już określone bardziej ogólnie, co przy braku hamulców ustrojowych lub środków inicjatywnych, leżących po stronie innych organów państwowych, a nade wszystko przy ukształtowaniu konstytuanty jako organu najwyższego, dawało podstawę do traktowania tego rozwiązania jako swoistego domniemania kompetencji na jej rzecz ${ }^{47}$. W małej konstytucji nie wspomniano o konkretnych instrumentach kontroli parlamentarnej wobec Naczelnika Państwa i rządu, choć pewne z nich znalazły się wcześniej w tymczasowym regulaminie obrad, jak choćby interpelacje czy prawo żądania obecności na posiedzeniach komisji. Wszystko to miało ulegać twórczemu rozwinięciu w drodze praktyki, a obok „suwerennego" charakteru władzy konstytuanty, zachęcała do tego szeroko rozciagnięta odpowiedzialność parlamentarna Naczelnika Państwa i rządu. Odpowiedzialność ta nie została bezpośrednio scharakteryzowana w małej konstytucji, co prowadziło W. Komarnickiego do przyjęcia stanowiska, zgodnie z którym obie jej formy (polityczna i prawna) były dopuszczalne ${ }^{48}$. Oponował przeciwko temu S. Krukowski, wskazując, że ze względu na charakter odpowiedzialności prawnej powinny zostać choćby w rudymentarnym zakresie rozstrzygnięte takie zagadnienia jak prawo inicjowania postępowania, forma jego prowadzenia, podmiot rozstrzygający w kwestii odpowiedzialności, nie wspominając o określeniu sankcji nałożonych na osobę uznaną winną naruszenia prawa ${ }^{49}$. O ile

${ }^{44}$ Przykładowo: ustawa z dnia 28 marca 1919 r. o załatwianiu zatargów zbiorowych pomiędzy pracodawcami a pracownikami rolnymi; ustawa z dnia 11 kwietnia 1919 r. o utworzeniu Głównego Urzędu Zaopatrywania Armii; ustawa z dnia 24 lipca 1919 r. o policji państwowej; ustawa z dnia 1 sierpnia 1919 r. o tymczasowej organizacji zarządu b. dzielnicy pruskiej; ustawa z dnia 20 stycznia 1920 r. o obywatelstwie Państwa Polskiego; ustawa z dnia 30 kwietnia 1920 r. o biletach skarbowych.

45 Przykładowo: ustawa z dnia 28 lutego 1919 r. w przedmiocie zaopatrzenia ludności w drzewo budulcowe i opałowe; trzy ustawy z dnia 11 kwietnia 1919 r. o budowie linii kolejowej Łódź-Kutno-Płock, o budowie linii kolejowej Kutno-Strzałków i o budowie linii kolejowej Płock-Sierpc, oraz o przebudowie wąskotorowej linii Nasielsk-Sierpc; ustawa z dnia 29 kwietnia 1919 r. o obwałowaniu lewego brzegu Wisły od ujścia Potoku Kościelnickiego do Zawichostu; ustawa z dnia 18 listopada 1919 o obrocie ziemiopłodami w roku gospodarczym 1919/1920; ustawa z dnia 9 lipca 1920 r. o zasiłku w kwocie 4,5 mln koron dla szkół Głównego Zarządu Towarzystwa Szkoły Ludowej w Krakowie, prowadzonych dla mniejszości polskich w Galicji Wschodniej.

46 Przykładowo w każdej z trzech wspomnianych ustaw „kolejowych” z 11 kwietnia 1919 r. zawarto w art. 1 każdej z nich imperatywny zwrot „Poleca się Ministrowi Kolei przystapić do budowy [...]”. Zasadą było, że każda ustawa w przepisach końcowych zawierała polecenie jej wykonania adresowane szczegółowo zarówno do Rady Ministrów, jak i konkretnych ministrów, a także innych organów państwowych. Innym przykładem zlecania zadań ministrom z pominięciem rządu były uchwały określające ich konkretne zadania ustawodawcze do wykonania, np. na 13. posiedzeniu SU 11 marca 1919 r. podjęto uchwałę następującej treści: „Poleca się Komisji Ochrony Pracy jak najszybsze nawiązanie kontaktu z odnośnym ministerstwem w celu opracowania omówionych ustaw" (mowa o ustawach ubezpieczeniowych dla robotników od kalectwa, bezrobocia i emerytalnych).

${ }^{47}$ Zwracał na to uwagę już w maju 1919 r. M. Rostworowski, Wytyczne konstytucji polskiej, Kraków 1919, s. 6.

${ }^{48}$ W. Komarnicki, op. cit., s. 67. Podobny pogląd wyraził M. Pietrzak, op. cit., s. 50.

${ }^{49}$ S. Krukowski, op. cit., s. 13-14. 
argumenty te jednoznacznie przesądzałyby wspomnianą kwestię w państwie działającym z utrwalonym porządkiem prawnym i wierną legalizmowi klasą polityczna, o tyle w przypadku państwa znajdującego się w fazie stopniowego krzepnięcia, z brakiem reguł odnoszących się do prawotwórstwa i o niewyrobionym poczuciu praworządności u klasy politycznej, zastrzeżenia S. Krukowskiego tracą na znaczeniu. Pozycja SU i związane z tym poczucie jego omnipotencji podzielane przez większość posłów pozwalały zakładać zarówno zlekceważenie zasady lex retro non agit, jak i ukształtowanie pełnej procedury tej odpowiedzialności ad causum. Było to możliwe, ponieważ ponoszenie odpowiedzialności prawnej przed parlamentem nie było abstrakcją w innych ustrojach państwowych, a pozycja zajmowana przez Sejm pozwalała na podjęcie także tej aktywności. Jednak w praktyce politycznej kwestia odpowiedzialności prawnej Naczelnika Państwa i ministrów nie była na tyle istotna, aby podjęto się jej materializacji. Co więcej, gdy podejmowano się egzekwowania odpowiedzialności Naczelnika Państwa i rządu, to zawsze to czyniono w trybie odpowiedzialności politycznej bez próby zainicjowania innej formy odpowiedzialności, być może także ze względu na dużo większą swobodę jej stosowania niż w przypadku odpowiedzialności konstytucyjnej czy prawnej.

Zgodnie z przyjętą w małej konstytucji konstrukcją dualnej odpowiedzialności parlamentarnej, ponosiły ją rząd i Naczelnik Państwa. Zakresy przedmiotowe odpowiedzialności obu organów nie zostały przy tym precyzyjnie określone, ograniczając się do stwierdzenia, że każdy z organów ponosi ją za „sprawowanie swego urzędu”. Wobec jednak mgławicowego określenia zakresu działania Rady Ministrów i tylko nieco wyraźniejszej charakterystyki tego obszaru w odniesieniu do głowy państwa, prowadziło to często do elastycznego interpretowania owej klauzuli przy krytyce obu organów.

Naczelnik Państwa mimo odpowiedzialności parlamentarnej został też zobligowany do uzyskania kontrasygnaty każdego swego aktu państwowego przez właściwego ministra. Teoretycznie oznaczało to, że wszelkie rozstrzygnięcia głowy państwa wymagały akceptacji przedstawiciela rządu, co stwarzało podstawy do hamowania działalności Naczelnika Państwa, szczególnie przy założeniu, że rząd będzie emanacją większości sejmowej, niechętnej lub wręcz wrogiej J. Piłsudskiemu. Ale w sytuacji, gdy uzyskana kontrasygnata nie zwalniała Naczelnika Państwa z odpowiedzialności parlamentarnej, obarczając nią także członka rządu, paradoksalnie głowa państwa czuła się tym wymogiem mniej związana, skoro nadal miała ponosić odpowiedzialność za podjęte przez siebie akty państwowe. System dualnej odpowiedzialności parlamentarnej, choć podkreślał nadrzędne stanowisko SU wobec obu organów, nie mógł przynieść zamierzonego efektu w postaci powstrzymywania Naczelnika Państwa ${ }^{50}$. Skoro mała konstytucja nie wiązała explicite z uzyskaniem kontrasygnaty właściwego ministra dla aktu państwowego Naczelnika przymiotu jego ważności, nadawało to pozycji głowy państwa większą swobodę w kreowaniu tych aktów ${ }^{51}$. Formy egzekwowania odpowiedzialności parlamentarnej Naczelnika Państwa oraz rządu nie zostały w małej konstytucji

${ }^{50}$ Odmiennie M. Pietrzak, op. cit., s. 49 i n. oraz W.T. Kulesza, op. cit., s. 41.

${ }^{51}$ Odmiennie W. Komarnicki, op. cit., s. 67, natomiast podobnie S. Krukowski, op. cit. 
określone, co na tle przyjętych w tym okresie rozwiązań w wielu państwach europejskich, nie było niczym zaskakującym, ale w oczywisty sposób dawało konstytuancie swobodę w wyborze środka wyrażania swego stanowiska w tym obszarze.

Ukształtowanie pozycji Naczelnika Państwa było efektem panujących w konstytuancie relacji międzypartyjnych, dla których jednym z wyznaczników był stosunek do J. Piłsudskiego, ale przede wszystkim wynikało z konieczności jasnego usytuowania Naczelnika Państwa w nowym systemie rządów. Jak bowiem trafnie zauważyła Dorota Malec, forma rządów przyjęta w małej konstytucji była antytezą rządów ustalonych dekretem z 22 października 1918 r., a łącznikiem między nimi był Piłsudski, tyle że jego rola uległa istotnej transpozycji52. Skoro utracił dotychczasową pozycję na rzecz Sejmu, należało znaleźć formułę, która odzwierciedlając położenie ustrojowe konstytuanty plasowała Naczelnika Państwa w sposób niestwarzający ryzyka restytucji poprzedniego jego umiejscowienia. Nowy status Naczelnika Państwa w systemie rządów kreowanym przez małą konstytucję był refleksem i konsekwencją zajęcia jego dotychczasowego miejsca przez konstytuantę ${ }^{53}$.

Z tą myśla, w małej konstytucji określono rolę Naczelnika Państwa w pierwszej kolejności jako „przedstawiciela państwa”, a więc przyznając mu atrybut głowy państwa. W charakterystyce tej zwraca jednak uwagę brak przymiotnika „najwyższy”, który jasno stratyfikowałby Naczelnika Państwa wobec innych potencjalnych podmiotów reprezentacji państwowej. Chociaż przymiotem reprezentanta nie został obdarzony w małej konstytucji żaden inny z organów, to w praktyce - np. w dyplomatycznej, ale też wewnątrzkrajowej - określenie to używane było również na niższych poziomach władzy. Wydaje się, że taka charakterystyka Naczelnika Państwa miała prowadzić do zachowania równowagi, a może nawet do powstrzymywania Naczelnika Państwa w sferze aktywności, w tym także międzynarodowej, poprzez rolę równolegle i faktycznie odgrywaną przez rząd, prezydenta Ministrów i ministrów. W istocie bowiem funkcję reprezentanta państwa konstytuanta pojmowała w dwóch płaszczyznach: czysto symbolicznej (jako forma ucieleśnienia państwa w czynnościach podejmowanych przez Naczelnika Państwa) oraz wyraźnie wtórnej (jako realizująca wolę konstytuanty poprzez konkretne akty działania wynikające bezpośrednio lub pośrednio z dyspozycji SU) ${ }^{54}$. Takiemu odczytaniu reprezentacji w stosunkach wewnętrznych i zewnętrznych sprzyjała pozostała część konstytucyjnej charakterystyki Naczelnika Państwa jako „najwyższego wykonawcy uchwał Sejmu Ustawodawczego w sprawach cywilnych i wojskowych". Zgodnie z nią nie pojawiała się więc żadna wolna przestrzeń, pozwalająca na poszukiwanie zakotwiczenia dla jakiegokolwiek wpływu Naczelnika Państwa na politykę państwa. Tak uszczuplona formuła reprezentacji nie dawała też pola do interpreta-

52 D. Malec, Sejm Ustawodawczy 1919-1922. W 90. rocznice pierwszego posiedzenia, „Przegląd Sejmowy" 2009, nr 1, s. 25.

53 A. Próchnik, Pierwsze piętnastolecie Polski niepodleglej, Warszawa 1983, s. 54 i n.

${ }^{54}$ K.W. Kumaniecki w komentarzu do małej konstytucji uważał, że „Naczelnik Państwa jest przedstawicielem państwa naprawdę właściwie tylko w zakresie reprezentacyjnym, poza tem treści władzy nie posiada." Idem, Odbudowa państwowości polskiej. Najważniejsze dokumenty 1912-styczeń 1924, Warszawa-Kraków 1924, s. 167. 
cji dopuszczającej istnienie jakiejś sfery, w której głowa państwa ma silniejsza, pierwszoplanową możliwość działania nawet o charakterze symbolicznym.

Ta część charakterystyki Naczelnika Państwa jeszcze dobitniej sytuowała jego relacje z SU. W małej konstytucji określając go „najwyższym wykonawcą uchwał Sejmu", położono kres dotychczasowej jego roli jako inicjatora i kreatora polityki państwa oraz podmiotu dysponującego możliwością samodzielnego określania środków i metod jej wdrażania. Tym samym wykonawstwo wpisane w rolę ustrojową Naczelnika Państwa sprowadzono do czystego egzekwowania ustaleń podjętych poza nim przez SU, bez względu na formę ich przyjęcia. Była to więc zasadnicza różnica między pojęciem władzy wykonawczej w układzie wyznaczonym przez zasadę podziału władzy, z wyraźnie zaznaczoną odrębnością organizacyjna, zadaniową i funkcjonalna, a wykonawstwem rozumianym jako techniczne wdrażanie dyrektyw kształtowanych przez Sejm, w układzie jego nadrzędności i warunkach braku autonomii decyzyjnej organów wykonawczych. Zwraca uwagę szerokie ujęcie formy prawnej dyspozycji wydawanych Naczelnikowi Państwa. Uchwały, o których mowa we wspomnianym postanowieniu małej konstytucji, to jedynie naturalna formuła wypowiadania się organu kolegialnego. Obejmowała ona wszelkie stosowane przez konstytuantę akty o charakterze dyrektywnym, które mogły być skierowane do pozostałych organów państwowych, w tym — rzecz jasna - Naczelnika Państwa. W praktyce akty te - o różnej formie prawnej i podejmowane nie tylko przez izbę in pleno, ale też jej organy - kierowano z reguły do rządu ${ }^{55}$.

Choć przymiotnik ,tymczasowy” zniknął z nazwy urzędu piastowanego przez J. Piłsudskiego, to jednak przejściowy charakter rozwiązań prawnych odnoszących się do głowy państwa uległ podtrzymaniu w świetle postanowień małej konstytucji. Jednoznacznie na zamiar szybkiej zmiany stanu prawnego wskazują postanowienia konstytucyjne wyznaczające czas ich obowiązywania ,[...] do ustawowego uchwalenia tej treści Konstytucji, która określi zasadniczo przepisy o organizacji Państwa”. Łatwo dostrzec, że w tej dyspozycji mieściła się przyszła ustawa zasadnicza, ale także ewentualność uchwalenia odrębnej ustawy, regulującej jedynie fragmentarycznie wskazany wcześniej wycinek pełnej konstytucji. Dalsza prowizoryczność regulacji odnoszącej się do Naczelnika Państwa wytwarzała wrażenie niestabilności jego pozycji, co widoczne było na tle braku postanowień wyznaczających czasowy horyzont działania $\mathrm{SU}^{56}$. Brakowało zarówno norm pozwalających ustalić kadencję konstytuanty,

${ }_{55} \mathrm{~Np}$. na posiedzeniu 11 marca 1919 r. skierowane do rządu wezwanie w sprawie odbudowy mostu na Sanie w Przemyślu, a 14 marca 1919 r. wezwanie, aby „,...] rząd w ciągu 15 dni przedstawił Komisji Administracyjnej szczegółowy schemat organizacji poszczególnych ministerstw, jak również wykazy poszczególnych urzędników, przepisów wykonawczych, regulaminów itd. w celu ich uzgodnienia i wprowadzenia potrzebnych zmian, a przede wszystkim śpiesznego i należytego rozgraniczenia kompetencji Ministerstw". Zapewne było to spowodowane względami praktycznymi (wszak rząd dysponował aparatem administracyjnym), ale też politycznymi, gdyż w praktyce politycznej było jasne, że to rząd, a nie Naczelnik Państwa jest ściśle uzależniony od Sejmu.

${ }^{56}$ Po części mogło wynikać z powiązania czasu pracy konstytuanty z naczelnym zadaniem, czyli przyjęciem nowej ustawy zasadniczej. W praktyce jednak okazało się, że dopełnienie tego obowiązku nie zdeterminowało końca działalności SU, który funkcjonował jeszcze blisko dwa lata. 
ale także instrumentów leżących poza parlamentem, pozwalających organom wykonawczym oddziaływać na okres pracy SU; nie dysponowały one możliwością rozwiązania parlamentu, a z racji przyjęcia przez konstytuantę systemu permanencji obrad, nie mogły tym samym wpływać na sesję parlamentarną i terminy zwoływania posiedzeń konstytuanty. Tym samym na tle SU z normatywnego punktu widzenia Naczelnik Państwa rysował się jako organ o dużym ryzyku nietrwałości, ale w równym stopniu wpływało to na pozycję Piłsudskiego jako dzierżyciela tego urzędu. Wszak wraz z kolejnym zapowiadanym w małej konstytucji posadowieniem ustrojowym głowy państwa, zaszłaby potrzeba jej obsadzenia, tak jak stało się to w wyniku przyjęcia małej konstytucji. Jak się wydaje, wkomponowanie z góry w urząd Naczelnika Państwa niestabilności nie było przypadkowe. W głowach znacznej części posłów tliło się — stale podsycane — przekonanie, że Piłsudski może stanowić wyraźne zagrożenie dla dominacji SU, stąd wprowadzenie elementów podważających definitywność rozwiązań ustrojowych odnoszących się do głowy państwa miało pozbawić atrakcyjności politycznej próby budowania wokół niego przeciwwagi dla konstytuanty.

Domknięciem formy rządów wytworzonej w małej konstytucji były niezwykle skromne postanowienia odnoszące się do rządu, wyrażające ducha rządów komitetowych. Rząd został pozbawiony osłony normatywnej dla swej koniecznej — choćby minimalnej - autonomii kompetencyjnej, funkcjonalnej i organizacyjnej. Pominięto charakterystykę roli ustrojowej pełnionej przez Radę Ministrów, co mogło prowadzić do wniosku, że Naczelnik Państwa jako najwyższy wykonawca wspierany przez rząd będzie tworzyć zespół wykonawców woli SU. Taki związek funkcjonalny nie został jednak uwzględniony w prowizorycznej konstytucji, wręcz założono daleko idącą odrębność obu organów. Istniejące regulacje wiązały rząd dużo ściślej z SU niż Naczelnikiem Państwa, wyraźnie likwidując układ wytworzony między głową państwa i rządem przed wejściem w życie małej konstytucji. Po pierwsze, już u swej genezy każdy formujący się gabinet musiał być wyrazem porozumienia między Naczelnikiem Państwa a SU. Porozumienie to dotyczyło pełnego składu rządu, co miało dobitnie wskazywać, że nie uczyniono wyjątku dla żadnego z ministrów (obawiano się bowiem autonomizacji ministra spraw wojskowych), który mógłby być powoływany z pominięciem SU. Po drugie, odpowiedzialnością parlamentarną objęto zarówno cały rząd (odpowiedzialność solidarna), jak i poszczególnych jego członków (odpowiedzialność indywidualna). Tym samym znana z poprzednio obowiązującego systemu rządów odpowiedzialność przed Naczelnikiem Państwa przeszła do historii. Przy braku jakiegokolwiek mechanizmu osłonowego, który mógłby być wsparciem ze strony głowy państwa udzielonym rządowi w przypadku zagrożenia pociagnięciem do odpowiedzialności parlamentarnej, a nadto uwzględniając, że głowa państwa także ponosiła ją przed konstytuanta, relacje głowy państwa z rządem zastapiono ścisłym związkiem rządu z konstytuantą. Głowa państwa nie miała bowiem instrumentu budującego jej wpływ na rząd, nie mówiąc o możliwości tworzenia równowagi między parlamentem a pozostałymi organami wykonawczymi. O ile zdolność konstytuanty do pociagnięcia do odpowiedzialności politycznej Naczelnika Państwa była raczej umiarkowana, choć- 
by ze względu na jego osobisty autorytet, ale też wierność polityczną części posłów, o tyle w przypadku rządu w praktyce nie występowały w SU zahamowania przed silnym, dyspozycyjnym oddziaływaniem na rząd, włącznie z gotowością do wymuszenia ustapienia rządu i jego poszczególnych członków.

Organizacji Rady Ministrów czy jej relacjom z pozostałymi organami państwowymi, w tym administracją nie poświęcono w małej konstytucji miejsca. Pominięto rolę prezydenta Rady Ministrów, co dobrze wpisywało się w trend osłabiania wszelkich jednoosobowych form działalności państwowej. Jego pominięcie kompetencyjne, przy jednoczesnym wskazaniu jako organu kontrasygnującego akty ogłaszane przez marszałka Sejmu dawało jednak podstawę do wskazania, że — z jednej strony — stoi on na czele rządu (a w takim przypadku kierowanie rządem bezpośrednio przez Naczelnika Państwa nie jest możliwe $)^{57}$, z drugiej zaś - to rząd z prezydentem na czele jest faktycznym ,technicznym” wykonawcą woli SU.

System rządów określony w małej konstytucji był poddany wielokrotnie analizie. W jego ocenie powtarza się często pogląd, że w ten sposób w Polsce został zaprowadzony system parlamentarny w skrajnej postaci ${ }^{58}$. Wydaje się jednak, że opinia ta opiera się nie tyle na ocenie normatywnej, co uwzględnia praktykę ustrojową tego okresu, która złagodziła cechy projektowanego w małej konstytucji systemu bliskiego rządom zgromadzenia czy też rządom komitetowym ${ }^{59}$. Analiza nadanych mu cech prowadzi do wniosku, że czynniki określające pozycję samego parlamentu (jedyny organ o charakterze pierwotnym, a jednocześnie organ najwyższy, określający politykę państwa, brak jakichkolwiek ograniczeń w materialnym i proceduralnym kształtowaniu własnych rozstrzygnięć, w tym ustawodawstwa, a nawet norm konstytucyjnych, domniemanie kompetencji na rzecz parlamentu i system permanencji jego obrad, nieograniczona kontrola nad organami wykonawczymi), jak i relacje konstytuanty z organami wykonawczymi (całkowite uzależnienie powoływania organów wykonawczych od konstytuanty i ich nieograniczona podległość konstytuancie, obowiązek realizowania zadań określonych przez Sejm, brak konstytucyjnie określonego zakresu właściwości, zadań i kompetencji) oddalały — przynajmniej w założeniu — z grubsza zarysowaną w małej konstytucji formę rządu od rozwiązań właściwych systemowi parlamentarnemu.

\section{SYSTEM RZĄDÓW PRAKTYKOWANY W OKRESIE OBOWIĄZYWANIA MALEJ KONSTYTUCJI}

Jeżeli jednak uznaje się okres obowiązywania małej konstytucji za wprowadzenie do systemu parlamentarnego, formalnie istniejącego od wejścia w życie konstytucji marcowej, to przede wszystkim ze względu na fakt, że założenia systemu rządów zgromadzenia okazały się nierealne. Utrzymanie tego założenia stało się niemożliwe głównie ze względu na stan systemu partyjnego, który miał charakter nieskonsolidowany,

${ }^{57}$ Co zresztą odzwierciedlało występujący stan rzeczy zarówno pod rządami dekretu z 22 listopada 1918 r., jak i po przyjęciu małej konstytucji.

${ }^{58}$ Confer M. Pietrzak, op. cit., s. 50, S. Krukowski, op. cit., s. 13.

${ }^{59}$ Confer W. Komarnicki, op. cit., s. 73 i n. 
charakteryzujący się dużą i stale postępującą fragmentaryzacją stronnictw parlamentarnych wynikającą z różnorodności programowej, ale też silnych podziałów socjopolitycznych i porozbiorowych wzmagających antagonizmy międzypartyjne i wewnątrzpartyjne. Partie - z reguły o słabym poziomie instytucjonalizacji, szczególnie $\mathrm{w}$ wymiarze pozaparlamentarnym, z niską dyscypliną organizacyjna, z silnie zaznaczającymi ruchami odśrodkowymi, często motywowanymi osobistymi animozjami i ambicjami - nie były w stanie wytworzyć stałych, przewidywalnych reguł współistnienia w systemie partyjnym, co również znajdowało swoje odzwierciedlenie w niezwykle rzadkim i krótkotrwałym funkcjonowaniu koalicji parlamentarnych i rządowych ${ }^{60}$. Zasadniczym fundamentem ich tworzenia było zaspokojenie ambicji uczestnictwa w rządzie najbardziej wpływowych w danym momencie członków poszczególnych ugrupowań parlamentarnych ${ }^{61}$. Przykładowo, w trakcie debaty nad exposé premiera W. Witosa, poseł I. Daszyński podniósł pod adresem jednego z posłów: „Pan Głąbiński, z przeproszeniem, rozpęd bierze ku ławie ministerialnej jeszcze od lata 1920 r. kiedy przyszedł w imieniu swego klubu siebie na ministra finansów zaproponować i kiedy odszedł z tem gorzkiem przekonaniem, że jego przyjaciel p. Grabski zostanie ministrem finansów, co mu też odpłacono w najbliższej przyszłości" ${ }^{62}$. Podstawy programowe koalicyjnych większości parlamentarnych i rządowych były z reguły ogólne, niekiedy o krótkim horyzoncie czasowym, rzadko z trwalszą wizją rozwiązywania głównych problemów społecznych czy gospodarczych państwa ${ }^{63}$, niekiedy budowane i utrzymywane w celu niedopuszczenia do władzy innych stronnictw.

Od zebrania się SU rzeczą oczywistą było, że stanowi on patchwork ugrupowań politycznych, podlegających stałemu rozdrobnieniu ${ }^{64}$. Kondycja partii i systemu par-

${ }^{60}$ Confer R. Kraczkowski, op. cit., s. 21, M. Pietrzak, Rzady parlamentarne w Polsce w latach 1919-1926, Warszawa 1969, s. 142 i n.

${ }^{61}$ Obrazowo przedstawił to W. Witos, Moje wspomnienia, t. II, Paryż 1964, s. 264 i n.

62 Spr. sten. z 248. posiedzenia SU, 30 września 1921 r., 1. 38.

${ }^{63}$ Przykładowo, wystapienie programowe I.J. Paderewskiego, przedstawione w formie sprawozdania z dotychczasowej pracy oraz planów na przyszłość, było w istocie wezwaniem do kontynuacji dotychczasowych działań, pełnym patetycznych odniesień o charakterze historiozoficznym, lecz poza kwestiami związanymi z konferencją pokojową nie zawierało istotnych konkretów; spr. sten. z 3. posiedzenia SU, 20 lutego 1919 r., 1. 59 i n. Z kolei wystapienie programowe W. Grabskiego, choć następowało w dramatycznym momencie ofensywy rosyjskiej i temu głównie było poświęcone, zawierało stwierdzenie, że 70 projektów ustaw, które zastał po rządzie L. Skulskiego jest już pewną częścią programu jego gabinetu; spr. sten. z 156. posiedzenia SU, 30 czerwca 1920 r., ł. 8. Z kolei exposé W. Witosa składane w sytuacji tworzenia rządu obrony narodowej skupiało się obronie państwa i zawarciu pokoju. Ponowne exposé z 24 września 1920 r. obok podkreślenia dotychczasowych dokonań gabinetu zawierało ogólnie zarysowane cele programowe: reforma rolna, poprawa aprowizacji, odbudowanie zniszczeń po najeździe rosyjskim, likwidacja odrębności dzielnicowych i budowa sprawnego aparatu administracyjnego; spr. sten. z 167. posiedzenia SU, 24 września 1920 r., 1. 11-20. Natomiast A. Ponikowski prezentując program swojego gabinetu wyraźnie zastrzegł, że choć gabinet jego ma charakter pozaparlamentarny i złoży dymisję z chwilą wytworzenia się warunków dla działalności rządu parlamentarnego, to jego intencją nie jest, ,[...] aby zadania i program swego gabinetu dostosował na czas krótki i ograniczony”, spr. sten. z 247. posiedzenia SU, 27 września 1921 r., ł. 6.

${ }^{64}$ Przykładowo, już w 1919 r. w SU ukonstytuowało się 10 klubów, z których największy (Związek Sejmowy Ludowo-Narodowy) liczył 109 posłów na 335 ogółem. W roku 1920 liczba klubów wzrosła do 15, a na koniec kadencji, w 1922 było ich 19. Od 1920 r. żaden z klubów nie zrzeszał więcej niż 100 posłów, dominowały natomiast kluby liczące od 10 do 91 posłów, dane za: A. Ajnenkiel, Historia..., s. 285-287. 
tyjnego czyniła je trudnym budulcem do tworzenia większości, nieodzownej do sformowania koalicji parlamentarnych i rządowych. W istocie poza efektownym początkiem prac SU, gdzie przez aklamację przyjęto kolejno tymczasowy regulamin obrad oraz małą konstytucję, chcąc zamanifestować jedność polityczną, w konstytuancie z reguły dominowały działania dezintegracyjne. Wyjątkowo, gdy sytuacja była krytyczna dla państwa, latem 1920 r. z powodu wojny z Rosją Radziecką udało się przy szerokim konsensie uchwalić np. ustawę o Radzie Obrony Państwa ${ }^{65}$.

Wewnętrzny potencjał konstytuanty — na który obok słabości partii politycznych wpływał też poziom poszczególnych posłów, z których tylko niewielu miało obycie parlamentarne w legislatywach państw zaborczych oraz wyrobienie w aktywności publicznej — musiał także ujawnić się w jej niezdolności do wykonywania swych funkcji. Tymczasem szeroko zakrojone ambicje — aby stać się centralnym ośrodkiem dyspozycji politycznej, co odzwierciedlałoby zawarty w małej konstytucji model rządów zgromadzenia - wymagały jednak spełnienia licznych warunków.

W pierwszej kolejności była to zdolność do konsolidacji politycznej, pozwalającej uformować większość o spójnym programie politycznym, zawierającym określenie celów i zadań powierzonych do realizacji przez organy wykonawcze. Tymczasem przypadki, w których udało się osiagnąć szerszą współpracę, miały z reguły charakter jednostkowy lub krótkotrwały ${ }^{66}$. W kadencji SU utworzono jedynie dwa rządy oparte na większościowej koalicji parlamentarnej — Leopolda Skulskiego i Wincentego Witosa. W obu jednak przypadkach, w trakcie ich funkcjonowania, większość parlamentarną i rządową opuszczali stopniowo poszczególni parlamentarzyści i kluby, a w ślad za tym i członkowie rządu ${ }^{67}$. W znaczącym stopniu implikowało to pogorszeniem się pozycji politycznej rządu, spadkiem efektywności prac Sejmu i rządu, koncentrowaniem się gabinetu na obronie przed wzmagającą się krytyką parlamentarną i upadkiem. Istniejące podziały nie tylko uniemożliwiały stworzenie spójnego programu działania

${ }^{65}$ Ustawa o utworzeniu Rady Obrony Państwa, Dz.U. z 1920 r. nr 53, poz. 327.

${ }^{66} \mathrm{~W}$ trakcie debaty nad exposé A. Ponikowskiego 1 października 1921 r. poseł J. Woźnicki zauważył retrospektywnie m.in.: „Już wówczas, kiedyśmy tu w tym Sejmie uchwalili reformę rolną, pokazało się Sejm ten w najważniejszych zagadnieniach nie ma większości. Ile razy chodziło o wyłonienie rządu, to Sejm był w położeniu zupełnie bezradnem. [...] Sejm ten jest nie tylko niezdolny do rządzenia, ale ma skład taki, że obali każdego, kto przyjdzie do niego z jakimkolwiek śmielszym programem, z jakimikolwiek śmielszymi zamiarami”; spr. sten. z 249. posiedzenia SU z 1 października 1921 r., 1.4 i 6. Z innych pozycji, ale z podobnymi wnioskami wystapił też poseł S. Głąbińskiego, spr. sten. z 248. posiedzenia SU, 30 września 1921 r., 1. 20-21.

${ }^{67}$ Pozycja gabinetu L. Skulskiego zaczęła słabnąć zaledwie po niecałych pięciu miesiącach od jego uformowania w grudniu 1919 r., a ostateczny upadek nastapił po upływie blisko sześciu miesięcy działalności, w wyniku ustapienia najsilniejszej partii koalicyjnej PSL, Piast”. W przypadku rządu W. Witosa już po niecałym półroczu jego działalności z poparcia dla rządu wycofały się endecja, chadecja, PPS i PSL Wyzwolenie, zaś rok 1921 do ostatecznego ustąpienia gabinetu we wrześniu przebiegał głównie pod znakiem nieustających prób budowania poparcia dla rządu, m.in. poprzez sięganie do takich metod jak unikanie głosowania przez posłów partii opozycyjnych; confer szerzej A. Wątor, Gabinet Leopolda Skulskiego; tegoż, Gabinet Wincentego Witosa, [w:] Gabinety Drugiej Rzeczypospolitej, red. J. Pajewski, Szczecin-Poznań 1991, s. 58 i n. oraz s. 76 i n.; A. Próchnik, op. cit., s. 72 i n. oraz 96 i n.; J. Goclon, Rzad Leopolda Skulskiego (13 XII 1919 r.-9 VI 1920 r.) skład, funkcjonowanie i jego polityka wschodnia, ,Acta Universitatis Lodziensis. Folia Historica” 2012, nr 88, s. 196. 
SU i jego organów, ale też wykonania zasadniczego obowiązku organu kierowniczego, jakim było kreowanie polityki państwa. W tym stanie rzeczy dokonywało się to tylko odcinkowo, np. w kwestiach polityki zagranicznej czy reformy rolnej i to w drodze tarć i kompromisów między poszczególnymi ugrupowaniami konstytuanty a rządem, a w pierwszym przypadku z dużym i pierwszoplanowym udziałem Naczelnika Państwa. Na tę sytuację zwracał uwagę minister Stanisław Wojciechowski w swoim wystapieniu sejmowym 1 października 1919 r., mówiąc m.in.: „Niejeden przedstawia je sobie tak, że zbiera się zgromadzenie, radzi nad sprawą i powiada: Ma być tak a tak, a ten organ powinien to wykonać. [...] Skoro mam postępować w ten sposób: «powiedzcie mi czego chcecie, a wszystko czego chcecie, zrobię», [...] staję się ślepym narzędziem tego, co przypadek w tem zgromadzeniu przyniesie, w tem zgromadzeniu, które zresztą kieruje się, nie patrząc w przyszłość, nie rozwagą, nie rozumem, ale nastrojem chwili”" ${ }^{6}$. To zaś prowadziło go do wniosku: „rząd musi wziąć w swoje ręce kierownictwo polityczne, a to jest możliwe tylko przy poparciu Sejmu".

Brak konsolidacji SU choćby w kwestii programu legislacyjnego, wyraźnie wpływał na doraźność i wybiorczość wysiłków ustawodawczych. W trakcie jednej z debat nad przyspieszeniem prac konstytucyjnych w Sejmie w dniu 7 maja 1920 r. poseł Eustachy Rudziński tak scharakteryzował działalność Sejmu w tym zakresie: „Sejm pogrążył się w pracy, powiedziałbym mrówczej, nad opracowaniem całego mnóstwa, całej powodzi wniosków nagłych i nienagłych [chodzi o inicjatywy ustawodawcze — uwaga A.K.], Sejm zaczął tworzyć większe i mniejsze ustawy, mniejszej i większej wagi dla których stworzenia i opracowania przyniosło hasła i pobudki życie, które taranem niejako uderzyło w ten Sejm i zapanowało nad Sejmem. Nie widzimy zaś w pracach Wysokiego Sejmu jakiejś pewnej planowości, która by zapanowała nad tym chaotycznym biegiem wypadków. Życie uderza taranem, życie pewne konieczności i te konieczności doraźnie Wysoka Izba załatwia.[...] Wszystkie te ustawy, albo prawie wszystkie noszą na sobie piętno dorywczości, mają charakter tymczasowości. [...] widzi się pewne istotne niezharmonizowanie tych praw" ${ }^{\prime 9}$.

Przy założeniu kierowniczej roli Sejmu w systemie organów państwowych konieczne było wyraźne rozgraniczenie funkcji konstytuanty od funkcji organów wykonawczych. Tymczasem w praktyce działania SU nigdy nie doszło do ustalenia linii demarkacyjnej rozdzielającej zakresy aktywności konstytuanty i organów wykonawczych, a wręcz często się one krzyżowały ${ }^{70}$. Przywództwo legislacyjne SU szybko okazało się pozorne. Co prawda formalnie monopol ustawodawczy należał do konstytuanty, jednak w praktyce zasadnicze projekty ustaw przygotowywał rząd, choć nieraz nie z własnej inicjatywy, lecz na żądanie Sejmu, wyrażane w licznych rezolucjach, często

68 Spr. sten. z 85. posiedzenia SU, 1 października 1919 r., 1. 20-21.

69 Spr. sten. z 145. posiedzenia SU, 7 maja 1920 r., 1. 35-36.

${ }^{70}$ Niekiedy posłowie wprost przyznawali, że poprzez swe akty SU wkracza w sferę działania organów wykonawczych, np. poseł R. Wasilewski, referując jeden z projektów rezolucji skierowanych do ministra aprowizacji, stwierdzał, że wkracza ona w tę sferę bardzo głęboko, lecz uzasadniał to nieuwzględnianiem przez tego ministra w swej pracy słusznych żądań stowarzyszeń skupionych przy kółkach rolniczych; spr. sten. z 149. posiedzenia SU, 19 maja 1920 r., ł. 23. 
bardzo szczegółowych ${ }^{71}$. Inna rzecz, że posłowie dbali o to, by projekt był traktowany jedynie jako punkt wyjścia do prac parlamentarnych, których ostateczny kształt zależał wyłącznie od woli powstałej w tej kwestii większości posłów. Natomiast rząd nie dysponował instrumentami równoważącymi wpływ posłów na kształt ustawy, poza słownymi próbami perswazji. Często też członkowie rządu w trakcie prac ustawodawczych w komisji sejmowej, ale i na posiedzeniach Sejmu nie zabierali głosu, biernie obserwując bieg wydarzeń ${ }^{72}$.

Ogólna liczba uchwalonych przez SU ustaw wyniosła co prawda 571, ale wśród istotnych regulacji o charakterze generalnym i koncentrujących się na ważnych społecznie i politycznie zagadnieniach, jak choćby dotyczących organizacji administracji, sądownictwa, Prokuratorii Generalnej, szkolnictwa, kontroli państwowej, czasie pracy i urlopach w przemyśle i handlu czy obligatoryjnych ubezpieczeniach na wypadek choroby, znajdowały się regulacje o zakresie wybitnie indywidualnym, interwencyjnym, podyktowane interesem partykularnym, jak np. ustawa o przebudowie węzła kolejowego warszawskiego czy ustawa o przyznawaniu nagród za pomoc w zwalczaniu przemytnictwa. Ustawy tworzone w warunkach targów międzypartyjnych, głównie w komisjach sejmowych, miały z reguły charakter połowiczny, aby zadowolić oczekiwania różnych interesariuszy projektu. W efekcie powstały kompromisowy akt miał często charakter blankietowy, był pełen luk i niejasności terminologicznych, co prowadziło do konieczności konkretyzacji ustawy w drodze aktów wykonawczych, nie zawsze zgodnych z intencją ustawodawcy ${ }^{73}$. Jednak niezdolność Sejmu do regulacji niektórych obszarów prowadziła do wyposażania gabinetu w prawo stanowienia aktów o mocy ustawy ${ }^{74}$. Często też wraz z przyjęciem ustawy równolegle uchwalano rezolucje, które były wytycznymi działania administracji w zakresie wykonywania takiej ustawy ${ }^{75}$. Niekiedy wręcz rezolucje uchwalano w trakcie debat nad preliminarzem budżetowym, instruując rząd lub właściwego ministra nie tylko w kwestii polityki wydatkowej, ale i organizacji pracy resortu ${ }^{76}$.

Szczególnie dojmującą cechą działalności ustawodawczej i uchwałodawczej było nieliczenie się ze skutkami finansowymi podejmowanych inicjatyw i rozstrzygnięć. Jak

${ }^{71}$ Przykładowo: rezolucja z 20 listopada 1919 r. wzywała rząd, ,[...] aby jak najrychlej przedłożył Sejmowi ustawę o dniach świątecznych, która by zmniejszyła ich liczbę do liczby, przyjętej w najbardziej uprzemysłowionych krajach zachodniej Europy, po porozumieniu się ze zwierzchnością duchowną".

72 Confer M. Pietrzak, Rzady parlamentarne w Polsce w latach 1919-1926, Warszawa 1969, s. 240 i n., Z. Wasik, Pozycja komisji parlamentarnych pod rzadami Konstytucji marcowej, Toruń 1981, s. 51.

${ }^{73}$ Confer M. Bobrzyński, op. cit., s. 103 zauważał: „Ustawy pisane tak, że decyzję w najważniejszych dla jednostek sprawach pozostawiały swobodnemu uznaniu urzędnika, otwierały drogę protekcji i korupcji".

${ }^{74}$ Np. ustawa z dnia 2 sierpnia 1919 r. o upoważnieniu Rządu do wydania rozporządzenia, normującego przenoszenie własności nieruchomości ziemskiej.

${ }^{75}$ Np. ustawa z dnia 27 listopada 1919 r. o obowiązku zarządów gmin miejskich dostarczenia pomieszczeń (Dz.U. z 1919 r. nr 92, poz. 498) towarzyszyły trzy rezolucje, w tym m.in. jedna z nich wzywała rząd, „aby ustawę stosował w najoględniejszy sposób i tylko w koniecznej potrzebie”.

${ }^{76} \mathrm{~Np}$. w trakcie debaty nad wykonaniem preliminarza wydatków za okres 1 stycznia-30 czerwca 1919 r., odbytym na początku 1920 r. w części wykonywanej przez Ministerstwo Wyznań Religijnych i Oświecenia Publicznego przyjęto dziewięć rezolucji, a w odniesieniu do Ministerstwu Zdrowia Publicznego - osiem rezolucji. 
trafnie wskazał Michał Pietrzak ${ }^{77}$, SU koncentrował się wyłącznie na wydatkach, czyniąc to zresztą rozrzutnie, zobowiązując wielokrotnie różnych członków rządu do ponoszenia wydatków na cele wskazane przez konstytuantę ${ }^{78}$. Sejm nie określał polityki budżetowej, a rząd nie był w stanie zarówno z przyczyn obiektywnych (stan państwa w organizacji oraz prowadzona wojna nie pozwalały na rzetelne oszacowanie dochodów i wydatków państwa, szczególnie przy zwiększającej się inflacji), jak i subiektywnych (brak koordynacji polityki budżetowej przez szefa rządu, Radę Ministrów lub ministra skarbu, stała skłonność Sejmu do swobodnego decydowania o wydatkach itp.) kreować ani tym bardziej nadzorować wykonywania polityki budżetowej. Dopiero pod koniec 1921 r., po wysłuchaniu wystapienia ministra skarbu Jerzego Michalskiego, przyjęto jednomyślnie rezolucję, zgodnie z którą postanowiono, że Komisja Skarbowo-Finansowa każdy wniosek i projekt ustawy jej przekazany będzie badać pod kątem wydatków z nich wynikających i zbilansowania środkami na ich realizację ${ }^{79}$.

Zmieniające się większości parlamentarne coraz bardziej koncentrujące się na indywidualnych zagadnieniach dzielących poszczególne kluby, np. stosunek do reformy rolnej czy innych działań w tym zakresie jak kontrola państwa nad rynkiem rolnym i polityka sekwestru, warunki życia ludności wiejskiej, czy też takie zagadnienia konstytucyjne jak powołanie drugiej izby, kompetencje i tryb wyboru prezydenta RP sprawiały, że SU nie był w stanie wypracować jednolitego podejścia do systematycznego kontrolowania stanu realizacji wytyczonych celów i powierzonych zadań. W praktyce parlamentarnej kontrola miała charakter przypadkowy i niesystematyczny. Zapewne w pewnym stopniu miał rację minister skarbu Steczkowski, że brak budżetu uniemożliwiał też — przynajmniej częściowo — „,...] wykonywanie konstytucyjnego zarówno prawa jak i obowiązku kontroli władzy wykonawczej, kontroli bez której odpowiedzialność rządu stałaby się fikcją, a czynność prawodawcza Wysokiej Izby w sprawach pociagających za sobą wydatki państwowe, funkcją bezprogramowa, na łaskę przypadku zdaną"80.

Sejm Ustawodawczy mimo niemal codziennych posiedzeń nie był w stanie zaproponować racjonalnego mechanizmu kontroli sprawowanego przez całą izbę. Dominowały działania pobieżne, często inspirowane potrzebą chwili, równie gwałtownie wybuchające, co zamierające. To w efekcie prowadziło do przejęcia działań kontrolnych przez komisje sejmowe. Działania te łączyły się nierozerwalnie z ciagłą ingerencją w zakres działania organów rządowych, przede wszystkim ministrów, często sprowadzając się do wymuszania konkretnych czynności pod groźbą odmowy zaufania dla indagowanych funkcjonariuszy ${ }^{81}$. Najlepszym wyrazem siły komisji sejmowej było

77 M. Pietrzak, Parlament w systemie organów..., s. 63.

${ }^{78} \mathrm{~Np}$. na 67. posiedzeniu SU 10 lipca 1919 r. podjęto rezolucję wzywającą rząd do podjęcia budowy rurociagów, m.in. na rachunek skarbu.

79 Spr. sten. z 250. posiedzenia SU, 4 października 1921 r., ł. 33-35.

${ }^{80}$ Spr. sten. z 243. posiedzenia SU, 28 lipca 1921 r., 1. 9. Podobną refleksję miał poseł S. Rottermund w trakcie wystapienia na 123. posiedzeniu Sejmu, stwierdzając, że „Sejm nie może korzystać z zasadniczego swego prawa konstytucyjnego: kontroli nad wydatkami”; confer spr. sten. ze 123. posiedzenia SU, 24 lutego 1920 r., 1. 4-5.

${ }^{81} \mathrm{~W}$ trakcie debaty nad exposé premiera W. Witosa, poseł A. de Rosset odniósł się do praktyki komisyjnej: „Komisje, które częstokroć przekraczają granice kompetencji sejmowych i wkraczają w dziedzinę 
przybycie na posiedzenie Komisji Skarbowo-Budżetowej premiera W. Witosa, który na jej posiedzeniu bronił zarówno preliminarza budżetowego, jak i jej autora, ministra skarbu Jana K. Steczkowskiego - rozważano wotum nieufności dla niego. Z kolei Komisja Spraw Zagranicznych, wielokrotnie odpytując premierów i ministrów spraw zagranicznych, była czynnikiem współkształtującym politykę zagraniczną, z silną tendencją do kurateli nad ministrem, doprowadzając do dymisji jednego z nich ${ }^{82}$. Szeroko rozwinięta została działalność komisji specjalnych, odpowiednika późniejszych komisji śledczych, których SU powołał ok. 20, często w sprawach o charakterze szczegółowym (np. na skutek zajść w poszczególnych miejscowościach), ale także w sprawach o doniosłym charakterze, np. w sprawie stanu administracji publicznej na Kresach Wschodnich. Warto zauważyć, że zakres ich kompetencji, każdorazowo ustalany, był z reguły szeroki, korespondujący z pozycją $\mathrm{SU}^{83}$.

Realizację funkcji kontrolnej przez SU osłabiał brak systematyczności oraz stabilnych reguł i kryteriów określających postępowania wewnątrzparlamentarne zmierzające do weryfikacji aktywności rządu i ministrów w zakresie wykonywania woli parlamentu. Sprzyjał temu zarówno brak trwałej większości parlamentarnej, potrafiącej w sposób względnie stabilny i przewidywalny określić oczekiwania wobec rządu w dłuższym horyzoncie czasowym, ale też ciagła zmienność gabinetów i jeszcze częstsze zmiany na stanowiskach ministerialnych ${ }^{84}$.

Systemowa wada SU polegająca na chronicznym braku stabilnej większości parlamentarnej w naturalny sposób oddziaływała na relacje z organami wykonawczymi w sferze odpowiedzialności politycznej. Relacje z rządem i Naczelnikiem Państwa uległy wypaczeniu ${ }^{85}$. W odniesieniu do głowy państwa, jego autorytet społeczny, łącze-

bezpośredniego rządzenia, nie tylko sprawom nie dopomagaja, ale sprawy utrudniaja, sprawy prowadzą do zadrażnień, które nie prowadzą do żadnego celu. Przeciążenie naszych komisji sprawami do nich nie należącymi, wcale nie przyczynia się do utrwalenia silnego rządu, ale przeciwnie rząd ten osłabia"; spr. sten. z 209. posiedzenia SU, 11 lutego 1921 r., ł. 52.

${ }^{82}$ Confer szerzej P.A. Tusiński Komisja Spraw Zagranicznych Sejmu Ustawodawczego 1919-1922 jako podmiot polityki zagranicznej w pierwszych latach II Rzeczypospolitej, „Wschodni Rocznik Humanistyczny", 2015, t. XII.

${ }^{83} \mathrm{~W}$ uchwale z dnia 7 listopada 1919 r. o powołaniu komisji dla zbadania stanu rzeczy w więzieniach i obozach koncentracyjnych na całym obszarze Rzeczypospolitej Polskiej i terenach wojennych znalazło się postanowienie: „Komisja ma prawo wstępu w każdej porze do więzień i obozów koncentracyjnych, do cel pojedynczych i zbiorowych. Komisja ma prawo zapoznawać się z papierami uwięzionych, żądać wyjaśnień od władz administracyjnych, cywilnych i wojskowych, od władz sądowych i od administracji więziennej”.

${ }^{84}$ Przykładowo: w rządzie I.J. Paderewskiego m.in. minister skarbu, odpowiedzialny w dużej mierze za pozyskiwanie podatków i finanse państwa, zmieniał się trzykrotnie, minister aprowizacji również trzykrotnie, a minister sprawiedliwości dwukrotnie. W rządzie W. Witosa m.in. ministrowie spraw zagranicznych, skarbu, ochrony pracy zmieniali się trzykrotnie, minister aprowizacji pięciokrotnie, a ministrowie sprawiedliwości, przemysłu i handlu, spraw wewnętrznych, spraw wojskowych — dwukrotnie.

${ }^{85}$ Jak głęboko postrzegano więzi z rządem w sferze odpowiedzialności politycznej obrazują słowa posła H. Diamanda wypowiedziane w trakcie debaty dotyczącej objęcia przez ministra skarbu administracji skarbowej na obszarze Polski, który dawniej zajęty był przez monarchię austro-węgierską. W trakcie prac sejmowych nad tą ustawą zmienił się minister skarbu — miejsce J. Englicha zajął S. Karpiński — poseł Diamand stwierdził wtedy m.in.: „Pan Minister Skarbu nie cieszy się zaufaniem całej izby. Na konferencji przewodniczących klubów podnoszono co do osoby Pana Ministra wątpliwości. Mimo to Rząd zamianował Ministra, a Sejm, Suwerenny Sejm nie wie kto został ministrem Skarbu, kto — w tem znaczeniu, że nie znamy 
nie funkcji cywilnej z dowodzeniem wojskiem i to w czasie konfliktów zbrojnych, silna grupa jego zwolenników usytuowanych w różnych klubach sejmowych, w tym w zasadzie stałe poparcie partii lewicy parlamentarnej, uniemożliwiały pociagnięcie go do odpowiedzialności parlamentarnej. Dopiero stabilizacja polityczna państwa związana z zakończeniem wojny z Rosją Radziecka, okrojenie kompetencji Naczelnika związanych z prowadzoną wojna, ale też ostry konflikt z Sejmem na tle wymuszenia upadku rządu Antoniego Ponikowskiego, doprowadził do nieudanej próby odwołania J. Piłsudskiego przez Sejm Ustawodawczy ${ }^{86}$.

Nie oznacza to jednak, żeby relacje między SU a Naczelnikiem Państwa nie były z reguły napięte, szczególnie gdy chodzi o zachowanie prawicowego, wyraźnie niechętnego Piłsudskiemu, skrzydła konstytuanty ${ }^{87}$. Animozje dotyczyły nie tylko kwestii znajdujących się stale w obszarze zainteresowania Naczelnika Państwa, ale także dziedzin, w których co prawda jego udział był znikomy czy wręcz symboliczny, ale dla jego przeciwników politycznych stanowił dogodny przyczynek do ataków ${ }^{88}$.

Odpowiedzialność parlamentarna Rady Ministrów ujawniała się w różnych postaciach. Jednym z rozwiązań, praktykowanym w zasadzie od początku obowiązywania małej konstytucji stanowiło przedkładanie przez prezydenta Ministrów exposé programowego. $Z$ reguły poprzedzała je informacja Naczelnika Państwa lub prezydenta Ministrów, odczytywana przez marszałka Sejmu, o dymisji poprzedniego rządu i powołaniu nowego gabinetu. Początkowo exposé podlegało jedynie konfrontacji z wystapieniami klubowymi, jednak bez głosowania formalnego wotum zaufania. Uważano bowiem, że skoro w Konwencie Seniorów zapadała decyzja o kandydaturze szefa rządu i całym składzie gabinetu, wykazując formalne poparcie lub neutralność większości klubów, to głosowanie takie jest zbędne ${ }^{89}$. Dopiero 16 czerwca 1922 r. na tle konfliktu z Naczelnikiem Państwa związanym z dymisją drugiego rządu A. Ponikowskiego została przesądzona kwestia udzielania inwestytury sejmowej poprzez przyjmowanie w Sejmie wotum zaufania dla nowo powstałego rządu. Pierwszym rządem,

ani poglądów, ani planów Pana Karpińskiego - a to zdaje mi się, jest rzeczą której Sejm spokojnie ścierpieć nie może". Spr. sten. z 28. posiedzenia SU, 8 kwietnia 1919 r., 1. 5-6.

${ }^{86}$ Szeroko na ten temat J. Faryś, Konflikt Naczelnika Państwa z Sejmem Ustawodawczym w 1922 roku, „Dzieje Najnowsze” 1975, nr 3; K.W. Kumaniecki, op. cit., s. 621 i n.; A. Ajnenkiel, Historia..., s. 48 i n.

${ }^{87}$ Szczególnie zajadłym krytykiem Naczelnika był poseł ks. K. Lutosławski.

${ }^{88} \mathrm{~Np}$. w trakcie debaty nad ustawą o ubezpieczeniach państwowych i Państwowej Dyrekcji Ubezpieczeń poseł A. Wierzbicki krytykował rozwiązanie zaproponowane przez sejmową Komisję Administracyjna, przewidujące, że prezes Zarządu Dyrekcji Ubezpieczeń będzie powoływany przez Naczelnika Państwa na wniosek ministra skarbu, uznając, że daje to mu swoistą nietykalność, uniemożliwiającą jego odwołanie w przypadku wykazania mu niekompetencji; spr. sten. z 209. posiedzenia SU, 11 lutego 1921 r., ł. 40. Podobny charakter miała debata nad broszurą posła J. Zamorskiego, atakującą J. Piłsudskiego; confer rezolucję z 30 listopada 1921 r. i spr. sten. z 266. posiedzenia SU z tego dnia, 1. 20-48.

89 Jednak posiadanie zaufania przez cały okres działalności rządu i poszczególnych jego członków było traktowane jako warunek sine qua non. W efekcie tego niemal przez cały okres ich działalności byli narażeni na systematyczne ,sprawdzanie” spełnienia tego warunku, poprzez różnorodne środki parlamentarne, niekoniecznie ukierunkowane wprost na weryfikację zaufania izby, ale mające weryfikować, na ile każde z konkretnych działań rządu i ministrów ma poparcie większości parlamentarnej. To zaś powodowało, że rząd i jego członkowie byli zmuszeni do kalkulowania swoich działań pod kątem ewentualnej utraty zaufania. 
który formalnie wystapił w takiej sytuacji o wotum zaufania, był gabinet A. Śliwińskiego, któremu zresztą go odmówiono.

Formalne głosowanie nad wotum nieufności było rzadkością, gdyż kres rządu następował w wyniku nie tyle głosowania, co w drodze kalkulacji głosów popierających gabinet, głosów neutralnych oraz jego przeciwników. W przypadku wyraźnej mniejszości tych pierwszych, gabinet był podawany do dymisji. Tak wydarzyło się w przypadku rządu I.J. Paderewskiego, L. Skulskiego, W. Grabskiego, W. Witosa, pierwszego i drugiego gabinetu A. Ponikowskiego. Z reguły jednak prawdziwą przyczyną upadku gabinetu był rozpad koalicji, ujawniający się niekiedy przy okazji upadku istotnego projektu rządowego w Sejmie. Przykładowo, rząd L. Skulskiego za próbnik dla swej dalszej egzystencji uznał uchwalenie ustawy o sekwestrze, a gdy została ona odrzucona przez większość domagającą się wolnego obrotu handlowego produktami rolnymi, podał się do dymisji. Z kolei pierwszy rząd A. Ponikowskiego podał się do dymisji na skutek sporu między prawicą a lewicą sejmową oraz wobec zachodnich nacisków dyplomatycznych i Naczelnika Państwa w kwestii statusu Wileńszczyzny i formuły jej włączenia do Polski. Brak zaufania wobec członków rządu był często manifestowany w innych formach. Jedną z nich był brak poparcia dla polityki ministra, wyraźnie okazywany przez komisję sejmowa, organ z reguły kluczowy dla wytworzenia dobrych relacji między konstytuantą a ministrem. Manifestowane odrzucanie rekomendowanej przez danego ministra polityki lub popieranego projektu ustawy kończył się ustępstwem członka rządu lub jego dymisją ${ }^{90}$, jak zdarzyło się w przypadku ministra Eustachego Sapiehy. Inną formą dezawuowania członka gabinetu było odrzucenie przez komisję lub Sejm przedłożonego sprawozdania lub odpowiedzi na interpelację ${ }^{91}$.

Rządy w okresie obowiązywania małej konstytucji nie były w stanie wytworzyć spójni ideowo-programowej zarówno ze względu na oparcie ich na kruchych koalicjach parlamentarnych, jak i konieczność formowania rządów o genezie pozaparlamentarnej, np. Władysława Grabskiego, dwa gabinety A. Ponikowskiego, Artura Śliwińskiego czy Juliana Nowaka. Z oczywistych względów zarówno te gabinety, jak i rządy koalicyjnej większości, które jednak z biegiem czasu stawały się gabinetami mniejszościowymi, spotykały się w SU z wachlarzem postaw — najczęściej dwie mniejszościowe grupy zwolenników i przeciwników rządu oraz pewna część ugrupowań zaledwie tolerujących rząd, zazwyczaj ze względów taktycznych, aby nie doszło do przesilenia, a w jego efekcie utworzenia gabinetu sformowanego przez przeciwników politycznych ${ }^{92}$. Rządy te z reguły dość szybko poddawane były zmasowanej kry-

${ }^{90}$ Znany był przypadek ministra spraw zagranicznych E. Sapiehy, któremu członkowie Komisji Spraw Zagranicznych odmówili zaufania, powiadamiając o tym premiera W. Witosa; szerzej Ministrowie spraw zagranicznych II Rzeczypospolitej, red. J. Pajewski, Szczecin 1992, s. 77 i n.

${ }_{91}$ Tak wydarzyło się w związku z rozpatrywaniem sprawy Dojlid, gdy prezes Urzędu Ziemskiego i członek gabinetu A. Ponikowskiego W. Kiernik podał się do dymisji na skutek odrzucenia przez Sejm jego odpowiedzi na interpelację posłów Związku Ludowo-Narodowego; vide szerzej spr. sten. z 296. posiedzenia SU, 4 kwietnia 1922 r., 1.72 i n.

${ }_{92}$ M. Bobrzyński, op. cit., s. 101 i n., opisując formowanie rządów w tym czasie, napisał: „Szukano chwilowych kompromisów. Rząd taki nie złączony ze sobą naprawdę programem wspólnym, nie miał wa- 
tyce, wychodzącej także od partii wspierających rząd, np. gdy nie zgadzały się z propozycją wysuwaną przez członka rządu popieranego przez inną partię koalicyjną. Inna rzecz, że rządy pozaparlamentarne nie podejmowały projektów, które mogły go antagonizować z Sejmem, prowadząc politykę kunktatorską ${ }^{93}$.

Na niekomfortowe położenie rządów wobec SU zwracał uwagę m.in. poseł I. Daszyński: „Spytacie dlaczego wszystkie gabinety zrażone waszą wrzawa, krzykami i obelgami rzucają te rządy? Dlatego, bo powiadają: Nie chcemy wiecznie stać pod pręgierzem u swoich i u obcych; nie możemy nic zrobić, bo każdy plan jest w tej chwili pokiereszowany, opluty przez was, przez waszą prasę, wasze zgromadzenia i waszych ludzi" ${ }^{94}$. Wsparcie lub zaledwie tolerancja dla rządów z reguły wynikała z faktu ulokowania w nich osób, które odpowiadały za sprawy bliskie danemu stronnictwu, ale udzielanie wsparcia dla konkretnego ministra nie przenosiło się na poparcie dla całego gabinetu, np. w rządzie I.J. Paderewskiego człowiekiem zaufania endecji był sam prezydent Ministrów czy minister skarbu Leon Biliński ${ }^{95}$, a w gabinecie L. Skulskiego reprezentantem Narodowego Zjednoczenia Ludowego był sam premier oraz ministrowie Władysław Seyda i W. Grabski, gdy Andrzej Kędzior i F. Bardel reprezentowali PSL „Piast”. Następstwem tego było atomizowanie się rządu, brak solidarności gabinetowej oraz konflikty między ministrami. Stosunkowo szybko dostrzegł to poseł. W. Witos, który w trakcie posiedzenia Sejmu mówił: „Na różnych komisjach [...] widzieliśmy, że przedstawiciele poszczególnych ministerstw występowali przeciwko sobie, [...] że rząd nie idzie razem, że nie ma programu, że nie panuje tam jednolitość poglądów, czyli że robota musi być chaotyczna" ${ }^{\prime 66}$. W sytuacji państwa wymagającego długoletnich programów odbudowy szeregu dziedzin życia publicznego oraz konsekwencji w ich realizacji, przynosiło to zgubne efekty, które poseł Edward Dubanowicz, wybitny konstytucjonalista nazwał rządzeniem „od wypadku do wypadku”97.

Wielokrotnie zwracano uwagę na niewykonywanie ustaw przez rząd. Słynne były problemy z wdrożeniem reformy rolnej, co wzbudzało aktywność (choć idącą w różnych kierunkach) zarówno stronnictw chłopskich, jak i obozu prawicowego. Innym przykładem było niewykonywanie ustawy inwalidzkiej z 18 marca 1921 r., co w świetle ustaleń komisji sejmowej było m.in. wynikiem nieuzgodnienia stanowisk właści-

runków trwałości, bo każda ważniejsza sprawa, wywołując sprzeczne żądania stronnictw wchodzących w skład koalicji, osłabiała i rozkładała rząd. Pokusa dostania się do władzy i uzyskania choćby na krótki czas wpływu na administrację i różnych korzyści dla stronnictwa i dla jego wyborców była jednak tak silna, że próby tworzenia takiego rządu i kompromisów programowych pojawiały się nieustannie".

${ }_{93} \mathrm{~Np}$. poseł W. Witos, krytykując rząd A. Ponikowskiego, zauważył, że jego gabinet kierował się zasada, że ,[...] w najważniejszych sprawach nie powinien zajmować żadnego stanowiska i że może usunać się od rozwiązywania wszelkich trudności. To zrodziło chwiejność, niezdecydowanie, brak myśli i wyraźnego kierunku"; spr. sten. z 302. posiedzenia SU, 4 maja 1922 r., 1. 12.

${ }_{94}$ Spr. sten. z 248. posiedzenia SU, 30 września 1921 r., ł. 46.

${ }_{95}$ Symptomatyczne było jego pierwsze wystapienie sejmowe 3 października 1919 r., kiedy wprost stwierdził, że członkostwo w rządzie ma ,do zawdzięczenia szanownym stronnictwom tego Sejmu, które wyraziły życzenie, ażebym objął urząd Ministra Skarbu"; spr. sten. z 86. posiedzenia SU z tego dnia, ł. 6.

${ }_{96}$ Spr. sten. ze 103. posiedzenia SU, 25 listopada 1919 r., 1. 41. Podobnie na tym samym posiedzeniu podsumowujący dokonania rządu I.J. Paderewskiego wypowiadał się poseł L. Skulski, ł. 53-54.

${ }^{97}$ Spr. sten. z 248. posiedzenia SU, 30 września 1921 r., ł. 32. 
wych ministerstw ${ }^{98}$. Jednak przyczyny tego stanu były różne, tkwiące zarówno po stronie gabinetu, jak i poza nim. Kolejni ministrowie zainteresowani byli własnymi projektami, nie zaś kontynuowaniem kierunków zainicjowanych przez poprzedników, czego zresztą często od nich oczekiwały siły wspierające rząd. Niekiedy taka postawa wynikała z faktu, że większość opowiadająca się za uchwaleniem ustawy szybko się rozpadała, co sprawiało, że tracono zainteresowanie dla realizacji tejże.

Rezolucje SU, choć licznie podejmowane, były traktowane wybiórczo przez rząd i poszczególnych ministrów ${ }^{99}$. Określały zadania indywidualne poszczególnych członków rządu ${ }^{100}$. Odnosiły się one często do spraw z zakresu zwykłego kierownictwa podległej administracji ${ }^{101}$, interwencji w sprawach jednostkowych ${ }^{102}$. Często też SU, mimo swej formalnie kreatorskiej roli względem polityki państwa, wzywał gabinety i ministrów do przedstawiania programów działania w wybranych obszarach polityki państwa ${ }^{103}$.

Mała konstytucja nie stała się też impulsem dla racjonalizacji organizacji rządu i administracji rządowej. Stosunkowo często podnoszono zarzut rozbudowania ponad miarę różnych agend rządowych ${ }^{104}$, ich niewydolności wynikającej często z braku środków finansowych ${ }^{105} \mathrm{i}$ wspomnianej walki wewnętrznej w rządzie. Dekret wydany przez Radę Regencyjną 3 stycznia 1918 r. o tymczasowej organizacji władz naczelnych w Królestwie Polskim w efekcie praktyki ustrojowej stawał się coraz bardziej zawodnym narzędziem regulującym pracę gabinetu. W wyniku konfliktów politycznych w rządzie, ale też niesprzyjających warunków parlamentarnych, funkcjonowanie gabinetu oddalało się od dekretowego wzorca. Koalicyjna struktura partyjna części gabinetów lub pozaparlamentarny charakter pozostałych sprawiały, że ministrowie często dochodzili do porozumienia z poszczególnymi klubami poselskimi, a nawet ich częścia, poza świadomością rządu. To dodatkowo atomizowało gabinet i osłabiało po-

98 Spr. sten. z 262. posiedzenia SU, 18 listopada 1921 r., ł. 43-70.

99 Na jednym z posiedzeń Sejmu poseł ks. K. Sobolewski stwierdził: „Komisja Administracyjna wie ze smutnego trzyletniego doświadczenia Wysokiego Sejmu, że większość rezolucji uchwalonych przez Sejm, stała się przysłowiowym grochem o ścianę Rządu, ale niechaj i Polska wie, że Sejm spełnia swój obowiązek"; spr. sten. z 255. posiedzenia SU, 18 października 1921 r., 1. 10. Na 123. posiedzeniu Sejmu 24 lutego 1920 r. poseł S. Rottermund zwrócił uwagę na niewykonanie rezolucji z maja 1919 r. w sprawie rozgraniczenia kompetencji dwóch ministerstw.

${ }_{100}$ Np. rezolucja z 18 listopada 1921 r. wzywająca do przedstawienia Sejmowi projektu ustawy dotyczącej szpitalnictwa, rezolucje z 2 grudnia 1921 r. w sprawie aktywizacji w województwach i powiatach komitetów wałowych oraz skierowania do Sejmu projektu ustawy o Szkole Nauk Politycznych.

$101 \mathrm{~Np}$. rezolucja z 18 października 1921 r. wzywająca rząd do skutecznej ochrony granic celnych, czy cykl 7 rezolucji z 20 stycznia 1922 r. dotyczących organizacji służby celnej, w tym jej podległości.

$102 \mathrm{~Np}$. cykl rezolucji z 21 października 1921 r. odnoszących się do Muzeum w Rapperswilu, rezolucja z 25 listopada 1921 r. w sprawie sprzedaży drutu kolczastego.

${ }_{103} \mathrm{~Np}$. na 275. posiedzeniu SU 17 grudnia 1921 r. przyjęto rezolucję wzywającą ,rząd do przestawienia planu racjonalnego i celowego działania w kierunku popierania twórczości naukowej i środowisk nauki, jej twórców i krzewicieli”.

104 Np. w dniu 27 stycznia 1920 r. SU podjął rezolucję: „Wzywa się rząd, aby w ciagu 2 miesięcy przedstawił Sejmowi projekt reorganizacji urzędów państwowych celem zmniejszenia liczby urzędników do norm koniecznych". Confer M. Bobrzyński, op. cit., s. 131 i n.

$105 \mathrm{~Np}$. istnienie równolegle dwóch dublujących swe funkcje urzędów, jak urząd melioracji i urząd torfowy, spr. sten. z 109. posiedzenia SU, 22 lipca 1925 r., ł. 16. 
zycję jego szefa. Niekiedy konstytuanta wyrażała oczekiwania względem struktury rządu i administracji, poparte raczej wiedzą ogólną niż rzetelnymi badaniami ${ }^{106}$. Próba uporządkowania tego stanu rzeczy została podjęta przez rząd L. Skulskiego, który przedłożył projekt ustawy o zakresie działania władz naczelnych. Stało się to jednak w przededniu upadku jego rządu, i choć projekt trafił do sejmowej Komisji Konstytucyjnej, nigdy nie został uchwalony. Warto jednak wskazać, że próbował on w formie normatywnej zaradzić dysfunkcjonalności ówczesnych rządów. Wprowadzał nowe — w świetle wspomnianego dekretu Rady Regencyjnej — zasady głoszące, że prezydent Ministrów czuwa nad jednolitością ogólnej polityki rządu, sprawuje nadzór nad działalnością poszczególnych ministrów oraz przestrzega granic ich kompetencji.

Szczególną pozycję w faktycznym systemie rządów istniejącym w okresie obowiązywania małej konstytucji zajmował Naczelnik Państwa. Niewatpliwie wyłamał się z ciasnych ram nałożonych przez uchwałę Sejmu, na co złożyło się wiele przyczyn. Dla sporej części społeczeństwa oraz klasy politycznej J. Piłsudski był postacią charyzmatyczną, owianą nimbem chwały za rolę, jaką odegrał w trakcie I wojny światowej i odzyskiwania niepodległości, a z biegiem czasu za zasługi w wojnie polsko-bolszewickiej. Towarzyszył temu twardy charakter ${ }^{107}$, przekonanie do własnych racji oraz oddane grono współpracowników, w tym także adherentów politycznych usytuowanych w różnych klubach parlamentarnych. Był konsekwentny w działaniu przy sprawowaniu urzędu, co po części było skutkiem jego natury, ale też wynikało z przewagi, jaką posiadał organ jednoosobowy nad kolegialnymi, silnie uwikłanymi w skomplikowany wewnętrzny proces decyzyjny. Należy pamiętać, że Naczelnik Państwa był jednocześnie Naczelnym Wodzem, odpowiadającym za działania wojenne na znacznym obszarze państwa, a tym samym za zarząd tą częścią terytorium ${ }^{108}$. Implikowało to zawężenie terytorialne oddziaływania SU, co zresztą prowadziło do licznych prób tego kontestowania w pracach Sejmu. Skupienie się Piłsudskiego na kwestiach obronności i ścisły związek z siłami zbrojnymi nie ustały wraz z formalnym zakończeniem działań wojennych, gdyż na początku 1921 r. powołał Ścisłą Radę Wojenną, która w istocie autonomizowała problematykę obronną i wojenną względem rządu, podporządkowując przy tym ministra spraw wojskowych jako jej organ wykonawczy ${ }^{109}$. Sam Piłsudski był niemal bezustannie przedmiotem sporów politycznych w SU ${ }^{110}$, jednak skala poparcia dla niego wśród ugrupowań parlamentarnych, choć zmienna i uzależniona zarówno od przedmiotu ocen, jak

${ }^{106}$ Wystapienie i wniosek posła Suligowskiego i innych posłów w sprawie reformy administracji państwowej, spr. sten. z 249. posiedzenia SU, 1 października 1921 r., 1. 51 i n.

107 Zwracał na to uwagę także polityczny przeciwnik Naczelnika, poseł S. Głąbiński, op. cit., s. 452.

108 Problem ten ujawnił się w trakcie ekspresowych prac nad małą konstytucja, gdyż Piłsudski kontestował jej postanowienia przyznające mu rolę wykonawcy uchwał Sejmu w sprawach wojskowych. Wobec powyższego wszystkie ugrupowania zasiadające w Konwencie Seniorów przyjęły w protokole ze swego posiedzenia uzgodnienie - formalnie pozbawione mocy prawnej, gdyż niemieszczące się w samym akcie - głoszace, że pod ten punkt nie podpadają wojskowe rozporządzenia strategiczne lub taktyczne; szerzej M. Pietrzak, op. cit., s. 45 i n.

109 Confer J. Wołpiuk, Naczelnik Państwa 1918-1922. Przedprezydencka forma władzy państwowej, „Przegląd Sejmowy” 2006, nr 6, s. 36 i n.

110 Por. W. Wołpiuk, op. cit., s. 37 i n. i cyt. tam literatura 
i konkretnych okoliczności, uniemożliwiała podjęcie silniejszych środków działania wobec niego. Wspomniany wcześniej konflikt z Sejmem na tle interpretacji uprawnień Naczelnika Państwa w zakresie powoływania rządu, szeroko opisywany w literaturze, również nie doprowadził do przesilenia. Potwierdził raczej istnienie pewnej równowagi sił między silną pozycją i kompetencjami, lecz słabą zdolnością do ich egzekucji Sejmem Ustawodawczym, a formalnie drugorzędnie usytuowanym Naczelnikiem Państwa, czerpiącym jednak swą siłę zarówno z poparcia społecznego, jak i kręgów politycznych i wojskowych. Często równoważące się oddziaływania między Sejmem a Naczelnikiem Państwa, występujące od początku obowiązywania małej konstytucji sprawiły, że J. Piłsudski zachowywał faktyczny wpływ na kształt rządu. Choć formalnie kluczem poszukiwania przez Sejm nowego szefa rządu było sondowanie poparcia parlamentarnego gabinetu $^{111}$, to stanowisko Belwederu było istotną wskazówką, często niewyrażoną wprost przy poszukiwaniu optymalnego kandydata, gwarantującego możliwą współpracę z Naczelnikiem. Uwzględnianie stanowiska J. Piłsudskiego przychodziło nolens volens łatwiej, gdy ugrupowania sejmowe nie osiagały porozumienia w tej kwestii, a argument poparcia lub jego braku ze strony Belwederu urastał do roli przesłanki przesądzającej o sformowaniu gabinetu lub poniechania tego. Jest charakterystyczne, że nawet dwaj szefowie rządów parlamentarnych (L. Skulski, W. Witos) uważani byli za dobrze współpracujących z głową państwa, za co czyniono im zarzuty. W efekcie nieraz udawało się wywrzeć wpływ na powołanie w skład rządu oddanych mu ministrów, np. S. Wojciechowski został ministrem spraw wewnętrznych w rządach I.J. Paderewskiego i L. Skulskiego, a K. Bartel ministrem kolei w rządach L. Skulskiego i W. Witosa.

Szczególny, choć także nieformalny wpływ uzyskał J. Piłsudski na obsadę stanowiska ministra spraw wojskowych ${ }^{112}$, co było mu pomocne w sprawowaniu funkcji Naczelnego Wodza i umacnianiu wpływów w wojsku. Równie nieformalnie, choć wyraźnie dla opinii publicznej Naczelnik Państwa oddziaływał na obsadę stanowiska ministra spraw zagranicznych ${ }^{113}$. Jego wpływ na priorytety polityki zagranicznej wynikał po części z prowadzonych działań wojennych, ale też koniecznego budowania relacji międzynarodowych, wzmacniających pozycję Polski w sferze ekonomicznej, bezpieczeństwa i obrony, a więc wyraźnie wykraczał poza wymagania związane ze wsparciem głowy państwa ${ }^{114}$. W tych dwóch obszarach można po części zgodzić się

111 Szeroko na ten temat M. Pietrzak, op. cit., s. 135 i n.

112 Powołany na to stanowisko w lutym 1919 r. gen. J. Leśniewski sprawował je do sierpnia 1920 r. w kolejnych czterech gabinetach (I.J. Paderewskiego, L. Skulskiego, W. Grabskiego i W. Witosa), a jego zastępcą (osobą faktycznie kierującą resortem) był najbliższy współpracownik Naczelnika gen. K. Sosnkowski, który został w sierpniu 1920 r. jego następcą i kierował nieprzerwanie resortem w kolejnych gabinetach do 1924 r.

113 Do ministrów związanych z Naczelnikiem należeli S. Patek i E. Sapieha, którzy kolejno kierowali resortem od grudnia 1919 r. do maja 1921 r. oraz G. Narutowicz (czerwiec-grudzień 1922 r.). Jego antagonistą politycznym, a jednocześnie ministrem osłabiającym wpływ J. Piłsudskiego na politykę zagraniczną był K. Skirmunt, z którym ostry konflikt doprowadził do wymuszenia upadku rządu A. Ponikowskiego. Confer Ministrowie..., Szczecin 1992.

114 Przewodniczący Komisji Spraw Zagranicznych S. Grabski przyznał, że odbywał regularne spotkania z Naczelnikiem Państwa w celu omówienia kwestii stojących w jej porządku dziennym, często ustalając z nim wcześniej problematykę prac komisji, confer S. Grabski, Pamiętniki, t. II, Warszawa 1989, s. 114. 
z opinią S. Rogowskiego o wielotorowości polityki prowadzonej przez zasadnicze organy naczelne RP. Dolegliwa i nieustanna kontrola polityki zagranicznej dokonywana przez komisję sejmowa, liczne próby ingerencji Sejmu w tej sferze, odbywane niekiedy przy okazji ratyfikacji umów międzynarodowych, wreszcie usiłowanie — z reguły nieudane, ze względu na postawę J. Piłsudskiego — ingerencji w kierowanie siłami zbrojnymi stanowiły codzienność działania najwyższego organu państwowego. Z kolei polityka rządu, z reguły meandryczna, była pochodną realnych potrzeb i możliwości działania państwa z próbą zaspokojenia politycznych ambicji stronnictw sejmowych oraz uwzględniania z reguły twardo stawianych oczekiwań Naczelnika Państwa. Opisana wcześniej słabość wewnętrzna Sejmu, niezdolność do wypracowania konsekwentnej polityki państwa w obszarze obronności, bezpieczeństwa i stosunków zagranicznych, przenosząca się na kolejne rządy, była wykorzystywana przez głowę państwa dzięki stałości jego poglądów, konsekwencji realizacji swych planów i umiejętnościom taktycznym wykazywanym w relacjach z pozostałymi organami. W efekcie mimo formalnego braku konstytucyjnych uprawnień do kształtowania polityki zagranicznej, obronnej i bezpieczeństwa, Naczelnikowi Państwa udało się w tym zakresie równoważyć wpływy pozostałych organów naczelnych ${ }^{115}$.

\section{PODSUMOWANIE}

W czasie jednego z posiedzeń SU, ponad rok od przyjęcia małej konstytucji poseł endecki S. Głąbiński zauważył: „Sądzę, że Sejm nie korzysta z tych praw jakie ma i jakie sam sobie nadał uchwałą z 20 lutego, ogłosiwszy się sejmem suwerennym. Można by wskazać na postępowanie Sejmu w ostatnich czasach, z którego się okazuje, że znaczną część suwerenności Sejm sam ustępuje i nie korzysta z tych praw, jakie posiada sejm konstytucyjny" "116. W efekcie bowiem przyjęta w małej konstytucji forma rządów, bliska rządom zgromadzenia ${ }^{117}$, uległa ewolucji w kierunku rządów parlamentarnych sprzed ery ich racjonalizacji. Wytworzone elementy równowagi między SU a Naczelnikiem Państwa, niepełne podporządkowanie Rady Ministrów konstytuancie i uległość rządu w pewnym zakresie wobec Naczelnika Państwa to elementy praktyki ustrojowej, które rozwinęły się wbrew zamierzeniom twórców małej konstytucji. Niezdolność SU do egzekwowania swej pozycji ustrojowej dezorganizowała pracę rządu, co w efekcie sprawiło, że oba te organy nie były zdolne do wykonania ról ustrojowych, powierzonych im przez małą konstytucję. Słabości obu organów wykorzystał J. Piłsudski, zachowując dzięki temu liczącą się, wcale niedrugorzędną pozycję ustrojową.

115 Confer S. Rogowski, Praktyka konstytucyjna w okresie obowiazywania Matej Konstytucji z 1919 r., [w:] Mate Konstytucje..., s. 42 i n.

${ }_{116}$ Parlamentaryzm II Rzeczypospolitej, Warszawa 1975; spr. sten. z 145. posiedzenia SU, 7 maja 1920 r., 1. 45.

${ }^{117}$ Charakterystyka tej formy rządów zawierała się także w zwięzłej formule rządów sejmowych użytej przez W. Komarnickiego, op. cit., s. 73 i n. Formuła ta, odpowiednik rządów zgromadzenia, wskazywała, że nie był to system rządów parlamentarnych, nawet w „,skrajnej postaci”, choćby ze względu na kluczowe założenie ustrojowe, czyli odrzucenie zasady podziału władz. Confer także P. Sarnecki, Założenia ,rzqdów zgromadzenia" i możliwości ich adaptacji do przyszłej konstytucji RP, [w:] Konstytucyjne systemy rzq̨ów. Możliwości adaptacji do warunków polskich, red. M. Domagała, Warszawa 1997, s. 138 i n. 
Na taki kształt relacji między SU, Naczelnikiem Państwa i rządem złożyło się wiele przyczyn. Podobnie jak w wielu wspomnianych wcześniej państwach przekonanie o tym, że stan podwyższonej aktywności politycznej obywateli będzie stałym elementem pejzażu politycznego odradzającego się państwa, znajdowało - naturalny w tych warunkach - wyraz w postaci uprzywilejowanej pozycji konstytuanty. Jednak warunki zarówno zewnętrzne, jak i wewnętrzne jej funkcjonowania uniemożliwiły w praktyce spełnienie roli, do jakiej predestynowała. Jej wewnętrzne podziały i coraz bardziej agresywny sposób ich artykułowania oraz niezdolność do konsolidacji nastawionych z reguły konfrontacyjnie ugrupowań sejmowych, silnie osłabiały jej zdolność do determinowania działalności pozostałych organów systemu rządów. W efekcie ramy prawne małej konstytucji, otwierające drogę do niczym nieskrępowanej dominacji SU, zostały wykorzystane głównie przez Naczelnika Państwa, po stronie którego obok osobistych zdolności i predyspozycji, stała też wierna i ciągle zwiększająca się grupa zwolenników, w tym także wśród parlamentarzystów. Silnie motywowany do działania Naczelnik Państwa w konfrontacji z niezdolnym do wykorzystania swej pozycji SU, uzyskiwał na tyle istotny wpływ na bieg spraw państwowych, że wielokrotnie potrafił równoważyć oddziaływania konstytuanty. Niemal chroniczny brak większości parlamentarnej i stan niezorganizowanego pluralizmu partyjnego w SU pozbawiał rząd silnego w nim oparcia. W tej sytuacji oddziaływanie Naczelnika Państwa wzmocnionego dodatkowo pozycją Naczelnego Dowódcy, biorącego na siebie ciężar rozwiązania najtrudniejszego zadania stojącego przed państwem, jakim była obrona jego niepodległości, dodatkowo krępowało swobodę działalności rządu.

Wraz z odzyskaniem niepodległości Polska poznawała funkcjonowanie systemu rządów, odległego od dotychczasowej praktyki znanej państwom zaborczym. Brakowało w nim czynnika nadrzędnego, porządkującego działanie innych podmiotów reżimu politycznego, a konieczne stawało się zaakceptowanie pluralizmu społecznego i politycznego i oparcie systemu rządów na cierpliwie osiaganym kompromisie.

\section{BIBLIOGRAFIA}

\section{ŹRÓDŁA}

Dekret Rady Regencyjnej z dnia 3 stycznia 1918 r. o tymczasowej organizacji Władz Naczelnych w Królestwie Polskiem, Dz.P.P.P. z 1918 r. nr 1, poz. 1.

Dekret Józefa Piłsudskiego z dnia 14 listopada 1918 r., Dz.U. z 1918 r. nr 17, poz. 40.

Dekret Tymczasowego Naczelnika Państwa o najwyższej władzy reprezentacyjnej Republiki Polskiej z dnia 22 listopada 1918 r., Dz.U. z 1918 r. nr 17, poz. 41.

Uchwała Sejmu z dnia 20 lutego 1919 r. o powierzeniu Józefowi Piłsudskiemu dalszego sprawowania urzędu Naczelnika Państwa, Dz.U. z 1919 r. nr 19, poz. 226.

Sprawozdania stenograficzne Sejmu Ustawodawczego z posiedzeń w latach 1919-1922, $1-342$.

\section{PIŚMIENNICTWO}

Ajnenkiel A., Spór o model parlamentaryzmu polskiego do roku 1926, Książka i Wiedza, Warszawa 1972. 
Ajnenkiel A., Parlamentaryzm II Rzeczypospolitej, Wiedza Powszechna, Warszawa 1975.

Ajnenkiel A., Historia sejmu polskiego, t. II, cz. 2, PWN, Warszawa 1989.

Ajnenkiel A., Sejm jako czynnik integracji narodu i państwa, [w:] Sejmy Drugiej Rzeczypospolitej, red. A. Zakrzewski, Ludowa Spółdzielnia Wydawnicza, Warszawa 1990.

Bobrzyński M., Wskrzeszenie państwa polskiego. Szkic historyczny, t. II, Krakowska Spółka Wydawnicza, Kraków 1920.

Ciświcki T., O Naczelniku Państwa i Prezydencie Rzeczypospolitej Polskiej. Studium prawnopolityczne, Wydawnictwo Fiszer i Majewski, Poznań 1922.

Cybichowski Z., Polskie prawo państwowe, cz. I, Wydawnictwo Seminarium Prawa Publicznego Uniwersytetu Warszawskiego, Warszawa 1925.

Faryś J., Konflikt Naczelnika Państwa z Sejmem Ustawodawczym w 1922 roku, „Dzieje Najnowsze" 1975, nr 3.

Głąbiński S., Wspomnienia polityczne, Drukarnia i Księgarnia, Pelpin 1939.

Goclon J., Rzad Ignacego Jana Paderewskiego. Geneza, skład osobowy i działalność (16 stycznia 1919-9 grudnia 1919), „Acta Universitatis Lodziensis. Folia Historica” 2011, nr 86.

Goclon J., Rząd Jędrzeja Moraczewskiego 17 XI 1918-16 I 1919 (struktura, funkcjonowanie, dekrety), „Przegląd Nauk Historycznych” 2009, t. VIII, nr 2.

Goclon J., Rzqd Leopolda Skulskiego (13 XII 1919 r.-9 VI 1920 r.) sktad, funkcjonowanie i jego polityka wschodnia, „Acta Universitatis Lodziensis. Folia Historica” 2012, nr 88.

Grabski S., Pamiętniki, t. II, Czytelnik, Warszawa 1989.

Górecki D., Powstanie władz naczelnych w odradzajacej się Polsce (1914-1919), „Acta Universitatis Lodziensis. Folia Iuridica" 1983, nr 13.

Hass L., Do genezy złudzeń parlamentarnych w Polsce międzywojennej (Sejm i głosowanie powszechne w propagandzie politycznej Królestwa 1915-1918), „Kwartalnik Historyczny” 1972, t. LXXIX, nr 1.

Komarnicki W., Polskie prawo polityczne, Księgarnia F. Hoesicka, Warszawa 1922.

Kraczkowski R., Mała Konstytucja z 20 lutego 1919 r., [w:] Małe Konstytucje. Ustawy zasadnicze okresów przejściowych 1919-1947-1992, red. R. Jastrzębski. M. Zubik, Wydawnictwo Sejmowe, Warszawa 2014.

Krukowski S., Mała Konstytucja z 1919 r., [w:] Konstytucje Polski, red. M. Kallas, PWN, Warszawa 1990.

Krukowski S., Geneza konstytucji z 17 marca 1921 r., Ludowa Spółdzielnia Wydawnicza, Warszawa 1977.

Kulesza W.T., Uchwała Sejmu Ustawodawczego z dnia 20 lutego 1919 r. o powierzeniu Józefowi Pitsudskiemu dalszego sprawowania urzędu Naczelnika Państwa, „Przegląd Sejmowy" 2007, nr 5.

Kumaniecki K.W., Odbudowa państwowości polskiej. Najważniejsze dokumenty 1912-styczeń 1924, Księgarnia J. Czerneckiego, Warszawa-Kraków 1924.

Malec D., Sejm Ustawodawczy 1919-1922. W 90. rocznice pierwszego posiedzenia, „Przegląd Sejmowy" 2009, nr 1.

Ministrowie spraw zagranicznych II Rzeczypospolitej, red. J. Pajewski, Polskie Pismo i Książki, Szczecin 1992.

Pajewski J., Budowa Drugiej Rzeczypospolitej 1918-1926, Wydawnictwo Poznańskie, Poznań 2007.

Pietrzak M., Parlament w systemie organów państwowych, [w:] Sejmy Drugiej Rzeczypospolitej, red. A. Zakrzewski, Ludowa Spółdzielnia Wydawnicza, Warszawa 1990. 
Próchnik A., Pierwsze piętnastolecie Polski niepodległej, Państwowe Wydawnictwo Naukowe, Warszawa 1983.

Rogowski S., Praktyka konstytucyjna w okresie obowiazywania Małej Konstytucji z 1919 r., [w:] Małe Konstytucje. Ustawy zasadnicze okresów przejściowych 1919-1947-1992, red. R. Jastrzębski, M. Zubik, Wydawnictwo Sejmowe, Warszawa 2014.

Rostworowski M., Wytyczne konstytucji polskiej, Krakowska Spółka Wydawnicza, Kraków 1919.

Sarnecki P., Założenia , rządów zgromadzenia” i możliwości ich adaptacji do przyszłej konstytucji RP, [w:] Konstytucyjne systemy rząów. Możliwości adaptacji do warunków polskich, red. M. Domagała, Wydawnictwo Sejmowe, Warszawa 1997.

Sarnecki P., Zasady ustrojowe odradzającej się Polski, „Przegląd Sejmowy” 1998, nr 5.

Tusiński P.A., Komisja Spraw Zagranicznych Sejmu Ustawodawczego 1919-1922 jako podmiot polityki zagranicznej w pierwszych latach II Rzeczypospolitej, „Wschodni Rocznik Humanistyczny" 2015, t. XII.

Wasik Z., Pozycja komisji parlamentarnych pod rzadami Konstytucji marcowej, Wydawnictwo Uniwersytetu Mikołaja Kopernika, Torun 1981.

Wątor A., Gabinet Leopolda Skulskiego, tenże: Gabinet Wincentego Witosa, [w:] Gabinety Drugiej Rzeczypospolitej, red. J. Pajewski, Likon, Szczecin-Poznań 1991.

Witkowski Z., Prezydent Rzeczypospolitej Polskiej 1921-1935, PWN, Warszawa-Poznań 1987.

Witos W., Moje wspomnienia, t. II, Instytut Literacki, Paryż 1964.

Wołpiuk J., Naczelnik Państwa 1918-1922. Przedprezydencka forma władzy państwowej, „Przegląd Sejmowy" 2005, nr 6. 


\section{SEJM USTAWODAWCZY W HISTORIOGRAFII POLSKIEGO PARLAMENTARYZMU

\author{
THE LEGISLATIVE SEJM IN THE HISTORIOGRAPHY \\ OF POLISH PARLIAMENTARISM
}

The article deals with issues from the sphere of research on the history of Polish parliamentarism in the interwar period and the position of the Legislative Sejm in the historiography of Polish parliamentarism. On the one hand, they are a part of broader research on the history of historiography in the $20^{\text {th }}$ century, and on the other - on the history of law and system, as well as socio-political history and the political thought of the Second Republic of Poland. Such approach to research problems allows not only to review the main historiographic strategies represented by researchers of Polish parliamentarism over the last few decades, but also to raise numerous research questions related to the position and significance of the research into the history of the Legislative Sejm in Polish historiography in the interwar period, in the People's Republic of Poland and nowadays. The article presents a dozen or so main historians, law historians and constitutionalists dealing with the history of the Legislative Sejm, its political, social and systemic functions, as well as the significance and position in the history of Polish parliamentarism, i.a. Stanisław Starzyński, Wacław Komarnicki, Maciej Starzewski, Władysław Konopczyński, Stanisław Kutrzeba, Tadeusz Rzepecki, Andrzej Ajnenkiel, Michał Pietrzak, Konstanty Grzybowski, Bogusław Leśnodorski.

Słowa kluczowe: Sejm Ustawodawczy 1919 r., konstytucja marcowa, parlamentaryzm II Rzeczypospolitej, historia historiografii XX w., historia prawnoustrojowa w XX w.

Key words: Legislative Sejm 1919, March Constitution, parliamentarism of the Second Republic of Poland, history of historiography of the $20^{\text {th }}$ century, legal and systemic history in the $20^{\text {th }}$ century

* Dr hab. Lidia Michalska-Bracha, Uniwersytet Jana Kochanowskiego w Kielcach, Instytut Historii; lmbracha@interia.pl

Droblematyka dziejów parlamentaryzmu w II Rzeczypospolitej posiada bogatą literaturę przedmiotu, od studiów szczegółowych po ujęcia syntetyzujące i podręcznikowe ${ }^{1}$. Istotne miejsce zajmują w niej prace dotyczące funkcjonowania Sejmu Ustawodawczego [dalej: SU], jego uprawnień określonych w uchwale z dnia 20 lutego 1919 r. o powierzeniu Józefowi Piłsudskiemu dalszego sprawowania urzędu Naczelnika Państwa [dalej: mała konstytucja] ${ }^{2}$, miejsca parlamentu w systemie ustrojowym konstytucji z 17 marca $1921 \mathrm{r}^{3}$ oraz jego rola w praktyce ustrojowej lat 1919-1922 w warunkach wielopartyjnego systemu politycznego. Idea zwołania SU,

${ }^{1}$ Jedynie tytułem przykładu można się odwołać do częściowych zestawień bibliograficznych z tego zakresu: Dzieje parlamentaryzmu w Polsce XV-XX wieku. Materiały Bibliograficzne, oprac. K. Zieliński, Warszawa 1985; A. Ajnenkiel, Historia Sejmu polskiego, t. II, II Rzeczpospolita, Warszawa 1989 (bibliografia).

${ }^{2}$ Uchwała Sejmu Ustawodawczego z dnia 20 lutego 1920 r., Dz.P.P.P., nr 19, poz. 226.

${ }^{3}$ Ustawa z dnia 17 marca 1921 r. Konstytucja Rzeczypospolitej Polskiej, Dz.U. nr 44, poz. 267. 
którego zasadniczym celem miało być określenie zasad ustroju politycznego odrodzonego państwa, znajdowała odbicie w programach większości środowisk politycznych u progu II RP. Uznanie w konsekwencji toczących się dyskusji zasady demokratycznego parlamentu, z przeważająca pozycją SU, przesądzało o przyszłym ustroju politycznym odrodzonego państwa polskiego $0^{4}$.

Tematyka niniejszego artykułu dotyczy szerokiego spektrum zagadnień wkraczających w obszar badań nad dziejami polskiego parlamentaryzmu w okresie międzywojennym i miejscem problematyki SU w historiografii polskiego parlamentaryzmu. Wpisują się one z jednej strony w szersze studia nad historiografią XX w., z drugiej zaś nad historią prawa i ustroju oraz nad dziejami społeczno-politycznymi i myślą polityczną II RP ${ }^{5}$. Zaprezentowana w takim ujęciu problematyka badawcza pozwala nie tylko na przegląd głównych stanowisk historiograficznych reprezentowanych przez badaczy dziejów polskiego parlamentaryzmu na przestrzeni kilku dziesięcioleci, ale także na postawienie pytań badawczych dotyczących miejsca i znaczenia badań nad dziejami SU w polskiej historiografii lat międzywojennych, okresu PRL oraz czasów współczesnych.

Początki zainteresowania problematyką SU, jego politycznych, społecznych i ustrojowych funkcji sięgają lat dwudziestych XX w. i - z jednej strony - mają w głównej mierze wymiar polityczny i publicystyczny oraz stanowią istotny składnik międzywojennej myśli politycznej. Natomiast z drugiej strony stają się integralną częścią myśli konstytucyjnej i przedmiotem zainteresowania ze strony czołowych polskich konstytucjonalistów. W konsekwencji wpisują się w przypadający na okres międzywojenny rozwój samodzielnej subdyscypliny historycznej, jaką była historia państwa i prawa, ale także na coraz prężniej rozwijające się badania z zakresu dziejów najnowszych. Te ostatnie coraz częściej podejmowali nie tylko publicyści czy działacze polityczni, ale przede wszystkim profesjonalni historycy, z uwagi na naturalną wręcz tendencję do poszerzenia chronologicznego zakresu zainteresowań historycznych ${ }^{6}$.

Na okres międzywojenny przypadł także rozwój pierwszej z wymienionych subdyscyplin historycznych, a mianowicie historii państwa i prawa, która miała w polskiej historiografii bogate tradycje sięgające XIX w. Tylko dla okresu międzywojennego w samym ośrodku lwowskim historią prawnoustrojowa, jako głównym obszarem

4 Vide szerzej M. Pietrzak, Parlament w systemie organów państwowych, [w:] Sejmy Drugiej Rzeczypospolitej, red. A. Zakrzewski, Warszawa 1990, s. 54-57.

${ }^{5}$ K. Kawalec, Spadkobiercy niepokornych. Dzieje polskiej myśli politycznej 1918-1939, Wrocław-Warszawa-Kraków 2000; idem, Wizje ustroju państwa w polskiej myśli politycznej lat 1918-1939. Ze studiów nad dziejami polskiej myśli politycznej, Wrocław 1995.

${ }^{6}$ O rosnącym w okresie międzywojennym zainteresowaniu historyków dziejami najnowszymi i historią współczesną świadczą dane statystyczne, z których wynika, że historią współczesną we Lwowie zajmowało się aż 61 historyków (16,4\% zbiorowości), w Krakowie — 58 (19\% zbiorowości), a w Warszawie 85 (26,1\%). Vide szerzej J. Pisulińska, Lwowskie środowisko historyczne w okresie międzywojennym (1918-1939), Rzeszów 2012, s. 193; W. Marmon, Krakowskie środowisko historyczne w latach 1918-1939, Kraków 1995, s. 111; J. Maternicki, Warszawskie środowisko historyczne w okresie II Rzeczypospolitej, Rzeszów 1999, s. 103. 
badań, zajmowało się 40 historyków (tj. 10,5\% całej zbiorowości) i tym samym dziedzina ta zajmowała czwartą pozycję spośród wszystkich kierunków zainteresowań twórczych historyków lwowskich w latach 1918-19397. Lwów był w tym czasie silnym ośrodkiem badań nad historią państwa i prawa oraz dominował pod względem badań historycznoprawnych w porównaniu z pozostałymi ośrodkami uniwersyteckimi ${ }^{8}$, $\mathrm{np}$. w środowisku warszawskim badania historycznoprawne prowadziło w tym czasie 39 historyków (9,2\% zbiorowości), w Krakowie zaś 30 (9,8\% zbiorowości). Historia prawa i państwa zajmowała więc w Warszawie trzecią pozycję w zestawieniu z innymi kierunkami badań historycznych, podobnie w Krakowie ${ }^{9}$. Historia państwa i prawa czerpała wówczas z koncepcyjnych, badawczych i metodologicznych osiagnięć co najmniej kilku wybitnych historyków prawa, np. Oswalda Balzera (1858-1953) i jego szkoły oraz Stanisława Kutrzeby (1876-1946), z którymi wiążą się kolejne okresy w rozwoju historii państwa i prawa na przestrzeni od końca XIX w. do 1939 r. ${ }^{10}$

Istotny był tu również wpływ myśli prawnoustrojowej rozwijanej m.in. przez takich prawników i uczonych, jak Stanisław Starzyński (1853-1935), Maciej Starzewski (1891-1944) czy Wacław Komarnicki (1891-1954) ${ }^{11}$. W efekcie czego można zaobserwować w dwudziestoleciu międzywojennym wyraźny rozwój myśli konstytucyjnej, a także wzrost literatury prawniczej, pośród której powstały ważne studia dotyczące zagadnień konstytucyjnych, w tym zgłaszanych wówczas projektów konstytucyjnych oraz konstytucji marcowej, która została poddana krytyce i dyskusji przez

7 J. Pisulińska, Lwowskie środowisko historyczne..., s. 216, 227.

${ }^{8}$ A. Redzik, O naukach historycznoprawnych w Uniwersytecie Jana Kazimierza we Lwowie, [w:] Nauki historycznoprawne w polskich uniwersytetach w II Rzeczypospolitej, red. M. Pyter, Lublin 2008, s. 131-183; Academia Militans. Uniwersytet Jana Kazimierza we Lwowie, red. A. Redzik, Kraków 2015, passim.

9 J. Maternicki, Warszawskie środowisko historyczne..., s. 112-113; W. Marmon, Krakowskie środowisko historyczne..., s. 126, 130-131. Confer Profesorowie Wydziału Prawa i Administracji Uniwersytetu Warszawskiego 1808-2008, red. G. Bałtruszajtys, Warszawa 2008; Złota księga Wydziału Prawa i Administracji Uniwersytetu Jagiellońskiego, red. J. Stelmach, W. Uruszczak, Kraków 2000.

${ }_{10}$ J. Maternicki, Historiografia polska XX wieku, Wrocław-Warszawa-Kraków 1982, s. 112-129; M. Patkaniowski, Rozkwit nauk historycznoprawnych w Uniwersytecie Jagiellońskim, [w:] Studia z dziejów Wydziału Prawa Uniwersytetu Jagiellońskiego, red. M. Patkaniowski, Kraków 1964; A. Redzik, O naukach historycznoprawnych w Uniwersytecie Jana Kazimierza we Lwowie, [w:] Nauki historycznoprawne w polskich uniwersytetach w II Rzeczypospolitej, red. M. Pyter, Lublin 2008, s. 131-183; M. Pyter, Oswald Balzer i lwowska szkoła historycznoprawna, Lublin 2010; A. Supruniuk, M.A. Supruniuk, Nauki prawne w Uniwersytecie Stefana Batorego w Wilnie w latach 1919-1944, [w:] Nauki historycznoprawne w polskich..., s. 217-275; K. Sikorska-Dzięgielewska, Historia prawa i jej przedstawiciele na Wydziale Prawno-Ekonomicznym Uniwersytetu Poznańskiego w okresie II RP, [w:] Nauki historycznoprawne w polskich ..., s. 389-423.

${ }_{11}$ M. Tarkowski, Wileńscy prawnicy wobec wybranych koncepcji ustrojowo-politycznych oraz kodyfikacji prawa w okresie dwudziestolecia międzywojennego, [w:] Tendencje rozwojowe myśli politycznej i prawnej, red. M. Maciejewski, M. Marszal, M. Sadowski, Wrocław 2014, s. 495-11; Komarnicki Wacław, [w:] Postowie i senatorowie Rzeczypospolitej Polskiej 1919-1939. Stownik biograficzny, t. III: K-L, oprac. Piotr Majewski, red. G. Mazur, Warszawa 2005, s. 155-156; P. Sarnecki, A. Wiekłuk, Starzewski Maciej, [w:] Polski stownik biograficzny, t. 42, Warszawa-Kraków 2003-2004, s. 436-38; A. Redzik, Stanisław Starzyński (1853-1935) a rozwój polskiej nauki prawa konstytucyjnego, Warszawa-Kraków 2012; A. Zoll, Makarewicz Juliusz, [w:] Polski słownik biograficzny, t. XIX, Wrocław-Warszawa-Kraków 1974, s. 211-213. 
liczne środowiska polityczne i prawnicze ${ }^{12}$. Jednym z przykładów takiej debaty wpływającej na rozwój myśli konstytucyjnej był zorganizowany w 1921 r. pod auspicjami profesorów Uniwersytetu Jagiellońskiego cykl wykładów w Szkole Nauk Politycznych w Krakowie. Wzięli w nich udział znani ówcześnie historycy krakowscy i prawnicy, m.in. Michał Rostworowski, Stanisław Kutrzeba, Stanisław Estreicher, którym przyświecał zasadniczy cel bezstronnej oceny ustawy zasadniczej, a tym samym „zbadania i poznania" konstytucji ,w oderwaniu od ludzi, którzy ją uchwalali i od warunków, wśród których powstała"'3. Michał Rostworowski (1864-1940), badacz prawa narodów i prawa politycznego na Uniwersytecie Jagiellońskim, w swoich pracach wiele miejsca poświęcił konstytucji marcowej ${ }^{14}$.

Zagadnienia dotyczące konstytucji marcowej poddawane wnikliwej analizie zawartych w niej zasad prawnych znalazły swoją ugruntowaną pozycję w ówczesnej myśli konstytucyjnej, czego przykładem mogą być prace wybitnego lwowskiego konstytucjonalisty Stanisława Starzyńskiego. Starzyński, prawnik i profesor prawa politycznego na Uniwersytecie Lwowskim, przez wiele lat związany z tą uczelnia, pełnił w niej funkcje dziekana i prodziekana Wydziału Prawa oraz rektora. Za swoje osiagnięcia naukowe w 1925 r. został mianowany na Uniwersytecie Jana Kazimierza profesorem honorowym prawa politycznego przez Prezydenta RP. Wychował spore grono uczniów, pośród których znajdowali się znani prawnicy: Wacław Komarnicki, Edward Ignacy Dubanowicz oraz Ludwik Ehrlich ${ }^{15}$. Starzyński jako znawca zasad prawnych konstytucji marcowej oraz współczesnych zagadnień ustrojowych był autorem kilku wydanych w latach dwudziestych prac na ten temat, m.in.: Konstytucja państwa polskiego (1921) i Współczesny ustrój prawno-polityczny Polski i innych państw stowiańskich (1928) ${ }^{16}$. Jak słusznie napisał Adam Redzik, Starzyński był ,pierwszoplanową osobistością polskiej nauki prawa konstytucyjnego końca XIX w. i pierwszych 35 lat dwudziestego wieku"17.

W gronie znanych lwowskich badaczy prawa znalazł się konstytucjonalista Edward Dubanowicz (1881-1943), referent i współtwórca znacznej części projektu konstytucji marcowej ${ }^{18}$. Istotną rolę w lwowskiej szkole historycznoprawnej odegrał też Ludwik

12 Vide m.in.: Projekty Konstytucji Rzeczypospolitej Polskiej. Projekt Komisji Konstytucyjnej Sejmu Ustawodawczego, Warszawa 1920; Nasza Konstytucja. Cykl odczytów urządzonych staraniem Dyrekcji Szkoły Nauk Politycznych w Krakowie od 12-25 maja 1921 r., Kraków 1922; S. Car, Z zagadnień konstytucyjnych Polski, Warszawa 1924; J.K. Malicki, Marszałek Pitsudski a Sejm. Historia rozwoju parlamentu polskiego 1919-1936, Warszawa 1936.

13 M.R. [M. Rostworowski], Wstęp, [w:] Nasza Konstytucja. Cykl odczytów, nlb.

14 P. Sarnecki, Nauka prawa konstytucyjnego na Uniwersytecie Jagiellońskim w okresie międzywojennym, [w:] Prawo konstytucyjne II Rzeczypospolitej. Nauka i instytucje, red. P. Sarnecki, Kraków 2006, s. 59-60.

15 A. Redzik, Stanisław Starzyński (1853-1935) a rozwój polskiej..., passim.

16 S. Starzyński, Kilka uwag o Konstytucji Rzeczypospolitej Polskiej, „,Ruch Prawniczy i Ekonomiczny” 1921, s. 413-424; idem, Konstytucja Rzeczypospolitej Polskiej z dnia 17. marca 1921, „Przegląd Prawa i Administracji”' 1921, s. 94-115; idem, Konstytucja państwa polskiego, Lwów 1921; idem, Wspótczesny ustrój prawno-polityczny Polski i innych państw stowiańskich, Lwów 1928 (reprint Warszawa 2010).

${ }_{17}$ A. Redzik, Stanisław Starzyński - nestor polskich konstytucjonalistów z okresu Drugiej Rzeczypospolitej, [w:] S. Starzyński, Współczesny ustrój prawno-polityczny Polski i innych państw słowiańskich, Warszawa 2010, s. VII.

18 A. Ławniczak, M. Masternak-Kubiak, A. Preisner, Prawo konstytucyjne na Uniwersytecie Lwowskim wokresie międzywojennym, [w:] Prawo konstytucyjne II Rzeczypospolitej. Nauka i instytucje, red. P. Sarnecki, Kraków 2006, s. 22-33. 
Ehrlich, badacz dziejów prawa politycznego i prawa narodów, autor Zarysu historii nauki prawa politycznego $w$ Polsce (1949) ${ }^{19}$. Ehrlich był profesorem Uniwersytetu Lwowskiego, kierownikiem Katedry Prawa Narodów w latach 1924-1939 i dziekanem tamtejszego Wydziału Prawa w latach 1932-1934. Z zakresu prawa państwowego opublikował mniej znaną pracę Kilka uwag o interpretacji konstytucji $(1925)^{20}$.

Zagadnienia konstytucji marcowej i zasad ustrojowych II RP znalazły trwałe miejsce w działalności naukowej Wacława Komarnickiego, znawcy prawa konstytucyjnego. Komarnicki studiował prawo i filozofię na Uniwersytecie Lwowskim oraz w Dorpacie, doktorat uzyskał na Uniwersytecie Jagiellońskim, ale na stałe związał się z wileńskim środowiskiem uniwersyteckim, gdzie w latach 1921-1939 już jako profesor wykładał naukę o państwie i prawie państwowym. W latach 1924-1927 był dziekanem Wydziału Prawa i Nauk Społecznych Uniwersytetu Stefana Batorego. Politycznie związany ze Stronnictwem Narodowym w latach 1928-1935 zasiadał w Sejmie i prowadził z jego ramienia kampanię na rzecz rewizji konstytucji marcowej ${ }^{21}$. Komarnicki w swoim dorobku naukowym wiele miejsca poświęcił zagadnieniom ustroju politycznego pierwszych lat II RP z perspektywy uchwalonej w 1921 r. konstytucji. Jego poglądy oparte były na krytyce ustawy zasadniczej, a to ze względu na wynikającą z jej postanowień dominację Sejmu w systemie władz państwowych II RP. Komarnicki charakterystyce poddawał nie tylko zasady prawne konstytucji, ale również ustrój polityczny państwa w tzw. okresie przejściowym, za który, podobnie jak czynili to inni ówcześni badacze ustroju II RP, uznawał okres funkcjonowania SU i małej konstytucji. Co istotne, Komarnicki miał w tym zakresie spore doświadczenie praktyczne, albowiem nadzorował prace nad projektem małej konstytucji22.

Swoje poglądy na zagadnienia konstytucyjne i zasady ustrojowe pierwszych lat II RP zawarł w kilku zasadniczych pracach o syntetycznym charakterze, niektóre z nich, jak podkreśla się w literaturze przedmiotu, weszły do kanonu uniwersyteckiego kształcenia. Ugruntowały one zresztą pozycję Komarnickiego w nauce prawa państwowe$\mathrm{go}^{23}$. Pośród nich szczególne miejsce przypisać należy klasycznej już dziś monografii:

19 L. Ehrlich, Zarys historii nauki prawa politycznego w Polsce, [w:] L. Ehrlich, J.S. Langrod, Zarys historii prawa narodów, prawa politycznego i administracyjnego w Polsce, Kraków 1949.

${ }_{20}$ Vide A. Ławniczak, M. Masternak-Kubiak, A. Preisner, Prawo konstytucyjne na Uniwersytecie Lwowskim..., s. 21-22.

${ }^{21}$ Komarnicki Wacław, [w:] Postowie i senatorowie Rzeczypospolitej Polskiej 1919-1939. Słownik biograficzny, t. III, K-L, oprac. P. Majewski, red. G. Mazur, Warszawa 2005, s. 155-156; Kto byt kim w Drugiej Rzeczypospolitej, red. J. Majchrowski przy współpracy G. Mazura, K. Stepana, Warszawa 1994, s. 321322; Wacław Komarnicki (1891-1954), uczony, polityk, specjalista prawa państwowego i administracyjnego, działacz społeczny i polityczny, [w:] K. Pol, Poczet prawników polskich, Warszawa 2000, s. 1227-1242; M. Tarkowski, Wileńscy prawnicy wobec wybranych koncepcji ustrojowo-politycznych oraz kodyfikacji prawa $w$ okresie dwudziestolecia międzywojennego, [w:] Tendencje rozwojowe myśli politycznej i prawnej, red. M. Maciejewski, M. Marszal, M. Sadowski, Wrocław 2014, s. 498; A. Cieszyński, Dorobek nauki prawa konstytucyjnego na Uniwersytecie Stefana Batorego w Wilnie, [w:] Prawo konstytucyjne II Rzeczypospolitej. Nauka i instytucje, red. P. Sarnecki, Kraków 2006, s. 56-57.

${ }^{22}$ M. Mohyluk, Wacław Komarnicki o Konstytucji marcowej, ,Miscellanea Historico-Iuridica” 2015, t. XIV, z. 2, s. 145.

${ }^{23}$ W. Komarnicki, Zarys ustroju państwowego Rzeczypospolitej Polskiej, Warszawa 1923; idem, Ustrój państwowy Rzeczypospolitej Polskiej, Warszawa 1934. 
Polskie prawo polityczne. Geneza i system (1922), w której właściwie jako pierwszy w tak szerokim zakresie przeprowadził wnikliwą analizę i krytykę konstytucji marco$w^{2}{ }^{24}$. Jej charakterystykę poprzedził szczegółowymi studiami zagranicznej literatury prawniczej oraz akt prawnych państw zaborczych, co pozwoliło mu na zaprezentowanie systematycznego wykładu prawa politycznego na podstawie analizy ustawy zasadniczej w ujęciu porównawczym. Komarnicki zwracał uwagę, że: „Konstytucja marcowa kodyfikuje zasady parlamentaryzmu wraz ze wszystkimi konsekwencjami prawno-politycznymi, ale precyzując ten system $\mathrm{w}$ określeniach prawnych na podobieństwo współcześnie uchwalonych konstytucji, posuwa się nasza konstytucja od nich dalej w przeprowadzeniu tej zasady, usuwając z przyjętych przez nią instytucji wszystko to, co mogłoby zasadę rządów parlamentarnych w jakikolwiek sposób osłabić” ${ }^{25}$.

Swoje uwagi i przemyślenia zawarte w dziele: Polskie prawo polityczne. Geneza i system, Komarnicki formułował niemal na bieżąco, poddając wnikliwej obserwacji system ustrojowy pierwszych lat odrodzonego państwa. Przedstawiony w nim wykład prawa politycznego, ale już w wersji popularnej, opublikował rok później w kolejnej swojej pracy: Zarys ustroju państwowego Rzeczypospolitej Polskiej (1923). Do kwestii tych nawiązywał również inny z uczniów Starzyńskiego, Ludwik Ehrlich (1889-1968), profesor Uniwersytetu Lwowskiego, w latach trzydziestych dziekan Wydziału Prawa, autor m.in.: Zarys historii nauki prawa politycznego w Polsce (1949) ${ }^{26}$.

W gronie uznanych konstytucjonalistów znajdował się także Zygmunt Klemens Cybichowski (1879-1946), od 1916 r. profesor Uniwersytetu Warszawskiego, na którym kierował Katedrą Prawa Państwowego i Międzynarodowego oraz wykładał prawo państwowe w latach 1917-1933. Brał udział w pracach nad konstytucją marco$w_{a}^{27}$. Jest autorem kilku znaczących opracowań z tego zakresu, w których analizie poddawał prawo konstytucyjne państw współczesnych, koncentrując się na sześciu wiodących zasadach (zasada demokratyczna, podziału władz, parlamentu dwuizbowego, rządów parlamentarnych, niezawisłości sądów, praw człowieka i obywatela), które wszystkie „uświęcała”, jego zdaniem, konstytucja marcowa z 1921 r. $^{28}$

$\mathrm{Na}$ osłabienie, a nawet upadek autorytetu władzy wykonawczej w okresie funkcjonowania SU zwracał uwagę Stanisław Car (1882-1938), prawnik, polityk, publicysta. Zaangażowany politycznie pełnił funkcję szefa Kancelarii Cywilnej przy Naczelniku Państwa (1918-1922) oraz przy Prezydencie Rzeczypospolitej (1922-1923, 1926), brał udział w pracach ustawodawczych nad małą konstytucją, był posłem na

${ }^{24}$ W. Komarnicki, Polskie prawo polityczne. Geneza i system, Warszawa 1922 (vide również reprint Warszawa 2008, z przedmową P. Sarneckiego).

25 Cytat za: Wacław Komarnicki (1891-1954), uczony, polityk, s. 1233.

${ }^{26}$ L. Ehrlich, Zarys historii nauki prawa politycznego w Polsce, [w:] L. Ehrlich, J.S. Langrod, Zarys historii prawa narodów, prawa politycznego i administracyjnego w Polsce, Kraków 1949.

${ }_{27}$ M. Żabicka-Kłopotek, Zygmunt Klemens Cybichowski (1879-1946), [w:] Konstytucjonaliści polscy 1918-2011, red. A. Szmyt, P. Sarnecki, R. Mojak, Warszawa 2012; Z. Jarosz, Prawo konstytucyjne na Uniwersytecie Warszawskim, [w:] Prawo konstytucyjne II Rzeczypospolitej. Nauka i instytucje, red. P. Sarnecki, Kraków 2006, s. 65-68.

${ }_{28}$ Z. Cybichowski, Polskie prawo państwowe na tle uwag z dziedziny nauki o państwie i porównawczego prawa państwowego, t. 2, Warszawa 1933, s. 7-8. 
Sejm w latach 1930-1938, marszałkiem Sejmu III kadencji (1935-1938) oraz współautorem konstytucji kwietniowej i jej referentem w Sejmie ${ }^{29}$. Jako autor pracy zatytułowanej Z zagadnień konstytucyjnych Polski (1924) zgłosił postulat rewizji zasad ustrojowych określonych w konstytucją z 17 marca 1921 r. ${ }^{30}$ Odwołując się do znajomości praktyki ustrojowej państw europejskich, krytyce poddawał zasady ustroju parlamentarnego w Polsce. Zwracał przy tym uwagę na dominująca pozycję Sejmu wobec władzy wykonawczej. Podkreślał, że „poddanie rewizji zasad współczesnego ustroju parlamentarnego jest koniecznością, która wymaga poważnego zastanowienia się, jeśli chcemy uniknąć rzeczywistego kryzysu" ${ }^{\prime 1}$.

Okres funkcjonowania Sejmu Ustawodawczego w latach 1919-1922, nazywany często sejmowładztwem w międzywojennej literaturze prawniczej czy historycznej, szerszej charakterystyce poddał Maciej Starzewski, prawnik i przedstawiciel krakowskiego środowiska uniwersyteckiego oraz poseł na Sejm w latach 1938-193932. Zajmując się szerzej prawem konstytucyjnym, historią konstytucjonalizmu i doktryn ustrojowych, zagadnieniom praktyki ustrojowej w II RP poświęcił opublikowane w latach trzydziestych dzieło: Od sejmowładztwa do rzadów gabinetowych (20 lutego 1919-16 stycznia 1934) ${ }^{33}$.

Wydaje się, że równoważne znaczenie w rozwoju ówczesnych zainteresowań problematyką SU można przypisać szeroko rozwiniętej w okresie II Rzeczypospolitej publicystyce politycznej i dziełom, które powstawały w kręgu działaczy politycznych i parlamentarnych. Znakomitym przykładem mogą być w tej mierze poglądy prawnoustrojowe Mieczysława Niedziałkowskiego (1893-1940) i klasyczna już dzisiaj praca jego autorstwa: Demokracja parlamentarna w Polsce (1930) ${ }^{34}$. Choć należy podkreślić, że Niedziałkowski na temat funkcjonowania SU wypowiadał się niemal na bieżąco, co spowodowane było podejmowaną w końcu 1919 r. krytyką ustroju republikańsko-demokratycznego. Swoim poglądom dał wówczas wyraz w artykule: „Rządy parlamentarne”, zamieszczonym w końcu 1919 r. na łamach „Trybuny”, w którym pisał o politycznych wrogach SU wskazując na: „komunistów, socjalistów, skrajną prawicę społeczną i tzw. przeciętną opinię publiczną̧" ${ }^{35}$.

${ }^{29}$ Car Stanisław Henryk, [w:] Postowie i senatorowie Rzeczypospolitej Polskiej 1919-1939. Stownik biograficzny, t. 1: A-D, oprac. M. Smogorzewska, red. A.K. Kunert, Warszawa 1998, s. 242-243; Kto byt kim..., s. 33-34; Stanisław Car (1882-1938), adwokat, polityk, organizator wymiaru sprawiedliwości, pisarz i publicysta prawniczy, działacz państwowy i społeczny, [w:] K. Pol, Poczet prawników polskich, s. $1097-1126$.

${ }^{30}$ S. Car, Z zagadnień konstytucyjnych Polski. Istota i zakres władzy prezydenta Rzeczypospolitej Polskiej. Państwowość polska w jej rozwoju historycznym, Warszawa 1924; idem, Konstytucja 17 marca 1921 roku a polska rzeczywistość. Odczyt wygłoszony w dn. 24.11.1929 r. w sali Teatru Starego w Krakowie, Warszawa 1930.

31 S. Car, Z zagadnień konstytucyjnych, s. 12.

32 P. Sarnecki, A. Wiekłuk, Starzewski Maciej, [w:] Polski słownik biograficzny, t. XLII, Warszawa-Kraków 2003-2004, s. 436-438. ków 1934.

${ }_{3}^{3}$ M. Starzewski, Od sejmowładztwa do rząów gabinetowych (20 lutego 1919-16 stycznia 1934), Kra-

${ }^{34}$ M. Niedziałkowski, Demokracja parlamentarna w Polsce, Warszawa 1930.

${ }^{35}$ Idem, Rzady parlamentarne, [w:] Mieczysław Niedziałkowski o demokracji i parlamentaryzmie, wstęp, wybór i opracowanie M. Śliwa, Warszawa 1996, s. 56-64. 
Niedziałkowski, czołowy przedstawiciel Polskiej Partii Socjalistycznej, działacz parlamentarny, znawca problematyki ustrojowej i prawa konstytucyjnego był współautorem ordynacji wyborczej do Sejmu Ustawodawczego, a od stycznia 1919 r. kierownikiem Biura Konstytucyjnego Prezydium Rady Ministrów. W SU pełnił funkcję sekretarza tymczasowego i zasiadał jako poseł w Sejmach kolejnych kadencji w latach 1922-1935 $5^{36}$. Miał spore doświadczenie praktyczne, jeśli chodzi o zagadnienia konstytucyjne, w SU brał udział w pracach Komisji Konstytucyjnej, podobnie jak w Sejmach kolejnych kadencji. Z ramienia PPS dwukrotnie zgłaszał oparty na zasadach demokracji politycznej projekt konstrukcji ustroju politycznego, tj. „Tymczasowa Ustawę Konstytucyjną Rzeczypospolitej Polskiej"37.

Niedziałkowski, poddając analizie zagadnienia prawnoustrojowe okresu funkcjonowania SU i zasady prawne określone w konstytucji marcowej, daleki był od idealizowania ustroju demokracji parlamentarnej. Chociaż w zestawieniu tej formy ustrojowej państwa z systemem monarchicznym czy prezydialnym zyskiwała ona, w jego opinii, na całościowej ocenie i w ostatecznych jego poglądach była najwłaściwszą formą ustrojową. Stawał się też obrońcą zasad konstytucji marcowej przed próbami jej zmian w latach dwudziestych ${ }^{38}$. Wśród pozytywnych cech demokracji parlamentarnej wskazywał na tzw. ,elastyczność” ustroju państwowego ${ }^{39}$. W Demokracji parlamentarnej w Polsce szczegółowo omówił kluczowe dla funkcjonowania systemu parlamentarnego w latach 1919-1922 zagadnienia, w tym problem genezy konstytucji z 17 marca 1921 r., kwestię kryzysu ustawy zasadniczej z lat 1921-1926 i jej krytykę, projekty naprawy i obronę demokracji parlamentarnej. Twierdził, że ten dziesięcioletni okres systemu parlamentarnego można nazwać „okresem niestałej równowagi społeczno-gospodarczej, politycznej i kulturalnej, albo okresem przejściowym, jeżeli ujać go pod kątem widzenia stałości danych form bytowania zbiorowego ludzi"40. Jego zdaniem, system demokracji parlamentarnej sprzyjał realizacji „ogólnonarodowych funkcji państwa" ${ }^{41}$. Dzieło Niedziałkowskiego podsumowywało dziesięcioletni okres funkcjonowania parlamentaryzmu w II RP i pod tym względem stało się ważnym głosem w toczącej się wówczas szerszej debacie na temat zagadnień ustrojowych i politycznych.

Kolejnym przykładem pracy poruszającej problematykę funkcjonowania SU, ale pozostającej w nurcie publicystyki politycznej, jest dzieło Juliana K. Malickiego, warszawskiego publicysty i dziennikarza, pt.: Marszałek Piłsudski a Sejm. Historia roz-

${ }^{36}$ Niedziałkowski Mieczysław, [w:] Posłowie i senatorowie Rzeczypospolitej Polskiej 1919-1939. Stownik biograficzny, t. IV: M-P, oprac. P. Majewski, red. G. Mazur, Warszawa 2009, s. 226-228; Kto byt kim..., s. 963.

37 Tymczasowa Ustawa Konstytucyjna Rzeczypospolitej Polskiej, [w:] Mieczysław Niedziałkowski o demokracji i parlamentaryzmie, wstęp, wybór i opracowanie M. Śliwa, Warszawa 1996, s. 25-45.

38 M. Śliwa, Uwagi Mieczysława Niedziałkowskiego o tzw. kryzysie parlamentaryzmu, „Dzieje Najnowsze", R. XI, 1979, z. 1, s. 53-66; idem, Ludowcy i socjaliści w parlamencie II Rzeczypospolitej, Warszawa 1995 .

${ }^{39}$ M. Niedziałkowski, Demokracja parlamentarna..., s. 52-53.

40 Ibidem, s. 46-47.

${ }^{41}$ Mieczysław Niedziałkowski o demokracji i parlamentaryzmie, wstęp, wybór i opracowanie M. Śliwa, Warszawa 1996, s. 11-12. 
woju parlamentu polskiego 1919-1936 (1936). Poddając szerszej charakterystyce stosunek Józefa Piłsudskiego do parlamentu w II RP, Malicki ścisłej problematyce działalności SU i jego krytyce poświęcił pierwszą część pracy: , Sejmowładztwo”. Sejm konstytucyjny 1919-1922, swoje rozważania opierając na propiłsudczykowskiej deklaracji ideowej ${ }^{42}$.

Podobny publicystyczny charakter miały dwie kolejne prace. Autorem pierwszej, wydanej w początkach lat trzydziestych, zatytułowanej: Sejmowładztwo. Sejm ustawodawczy 1919-1922 $r^{43}$ był Walenty Miklaszewski (1868-1950) ${ }^{44}$. Autorem drugiej był Feliks Honowski, sędzia sądu okręgowego w Warszawie, który charakterystykę SU przedstawił z perspektywy czasowej już lat trzydziestych. Jego praca: Parlament i rzad w Polsce niepodleglej (1938) dotyczyła zagadnień politycznoprawnych i budowy odrodzonego państwa ${ }^{45}$. Honowski, wydając z perspektywy mijającego dwudziestolecia międzywojennego opinię na temat dziejów polskiego parlamentaryzmu, odniósł się do okresu sejmowładztwa i partyjnictwa z lat 1919-1926. Podkreślał w pracy, że: „Od roku 1919 do 1926 upłynęło 7 lat zmagania się patriotyzmu o Polskę z partyjnictwem lokalnym w sensie politycznym, z zadziwiająca jednością przeciwnych sobie u podstaw, a nawet skądinąd wrogich sobie stronnictw politycznych i klubów sejmowych, solidarnych, jeśli chodziło o powzięcie i utrzymanie uchwały o suwerenności Sejmu Ustawodawczego i zachowanie z pewnym zamaskowaniem tej ważkiej i brzemiennej w skutki przewagi politycznej w Konstytucji marcowej" ${ }^{\prime 4}$.

Problematyka SU stała się w okresie międzywojennym przedmiotem zainteresowania również ze strony środowiska historyków profesjonalistów. Nie miały one jednak jeszcze w tym czasie charakteru systematycznych studiów naukowych i nie zaowocowały większymi pracami z tego zakresu. Tematykę tę jeśli podejmowano, to wyłącznie przy okazji syntez dziejów ojczystych, prac o szerszym chronologicznym i problemowym zakresie, badań dotyczących budowy zrębów polskiej państwowości po odzyskaniu niepodległości oraz zagadnień prawno-ustrojowych. Znakomitym przykładem są w tej mierze prace dwóch wybitnych przedstawicieli krakowskiego środowiska historycznego o zainteresowaniach badawczych wkraczających w obszar historii państwa i prawa. Chodzi w tym przypadku o Władysława Konopczyńskiego (1880-1952), historyka dziejów nowożytnych ${ }^{47}$ i Stanisława Kutrzebę (1876-1946),

42 J. Malicki, Marszałek Pitsudski a Sejm. Historia rozwoju parlamentu polskiego 1919-1936, przedmowa A. Boguckiego wicemarszałka Senatu RP, Warszawa 1936, s. 7-120.

${ }^{43}$ W. Miklaszewski, Sejmowładztwo. Sejm ustawodawczy 1919-1922 r., Warszawa 1931.

${ }^{44}$ B. Zielińska, Miklaszewski Walenty Eukasz, [w:] Polski slownik biograficzny, t. XXI, Wrocław-Warszawa-Kraków 1976, s. 68-70. W.Ł. Miklaszewski był synem prawnika Walentego Piotra. Vide Walenty Piotr Miklaszewski (1839-1924), uczony, karnista, procesualista, penitencjarysta, organizator nauki, pisarz i publicysta prawniczy, działacz oświatowy, społeczny i kulturalny, [w:] K. Pol, Poczet prawników polskich, s. 323-336.

${ }^{45}$ F. Honowski, Parlament i rzqd w Polsce niepodleglej, Warszawa 1938. Confer W. Grzankowski, Na marginesie pracy Feliksa Honowskiego, „Palestra” 1938, nr 4, s. 403-407.

${ }^{46}$ F. Honowski, Parlament ..., s. XIII.

47 Konopczyński Władysław, [w:] Postowie i senatorowie Rzeczypospolitej Polskiej 1919-1939. Stownik biograficzny, t. III: $K-E$, oprac. P. Majewski, red. G. Mazur, Warszawa 2005, s. 161-163; P. Biliński, Władysław Konopczyński 1880-1952. Człowiek i dzieło, Kraków 2017. 
historyka dziejów średniowiecznych i doby nowożytnej oraz prawa i ustroju Polski ${ }^{48}$. Konopczyński, zdeklarowany przeciwnik Piłsudskiego, do tematyki SU odniósł się szerzej w swojej Historii politycznej Polski 1914-1939 (1947), której tekst powstał na bazie jego wcześniejszych, uniwersyteckich wykładów $w^{49}$. Charakterystyce poddając okres „sejmowładztwa” z lat 1919-1922, konkludował: „Sejm [Wojciecha - L.M.B.] Trąmpczyńskiego, blisko czteroletni, nie doczekał się dotąd sprawiedliwego porównania ze swym sławnym poprzednikiem. Piłsudski i stańczycy postarają się go owszem, poniżyć. Chociaż mu społeczeństwo nie dało mocnej większości, choć przeważali w nim ludzie niedoświadczeni, o niewyrobionych poglądach, sprostał swemu zadaniu nie najgorzej. Dał konstytucję, powściagnął samowolę, uchwalił niemało reform, stworzył armię i umożliwił jej zwycięstwo, ustalił wreszcie granice Rzeczpospolitej”50.

Kolejny z historyków, Stanisław Kutrzeba do kwestii małej konstytucji z 20 lutego 1919 r., ustawy zasadniczej i wzajemnych tarć pomiędzy Naczelnikiem a Sejmem odnosił się w swojej syntezie opublikowanej w 1921 r., która uzupełniana sukcesywnie przez niego doczekała się kolejnych wydań ${ }^{51}$.

Inaczej przedstawiała się sprawa zainteresowania dziejami SU w badaniach Adama Feliksa Próchnika (1892-1942), publicysty i historyka, działacza politycznego PPS, posła na Sejm w latach 1928-193052. Zajmując się problematyką odbudowy państwa polskiego w 1918 r. i okresem od odzyskania niepodległości do uchwalenia ustawy zasadniczej w 1921 r., szerzej odniósł się do ustawodawczej działalności Sejmu, pierwszych reform oraz konstytucji marcowej. Jego praca, Pierwsze piętnastolecie Polski niepodleglej (1918-1932). Zarys dziejów politycznych (1933), utrwaliła się w historiografii i do dzisiaj jest wykorzystywana w badaniach nad dziejami parlamentary$\mathrm{zmu}^{53}$. Doczekała się też kolejnych wydań w 1957 i 1983 r.

Podsumowując przegląd międzywojennej historiografii, należy zwrócić uwagę na jeszcze dwie ważne kwestie. W pierwszym rzędzie na miejsce w historiografii polskiego parlamentaryzmu opracowania dokumentacyjnego: Sejm Rzeczypospolitej Polskiej 1919 roku (1920) autorstwa Tadeusza Rzepeckiego, które do dzisiaj nie straciło swojego znaczenia źródłowego w badaniach historycznych ${ }^{54}$. Opracowanie to miało być

48 Stanisław Kutrzeba (1876-1946), uczony, polityk, historyk prawa i ustroju Polski, historyk kultury, wydawca źródel, organizator nauki, pisarz i publicysta prawniczy, działacz społeczny i kulturalny, [w:] K. Pol, Poczet prawników polskich ..., s. 929-948; Biogramy uczonych polskich, cz. I, Nauki społeczne, z. 2, K-O, red. A. Śródka, P. Szczawiński, Wrocław 1984.

49 W. Konopczyński, Historia polityczna Polski 1914-1939, Warszawa 1995, s. 81-96 (Sejmowładztwo).

50 Ibidem, s. 90-91.

51 S. Kutrzeba, Polska Odrodzona 1914-1921, Warszawa-Kraków 1921.

${ }^{52}$ Kto byl kim..., s. 403; Próchnik Adam Feliks, [w:] Postowie i senatorowie Rzeczypospolitej Polskiej 1919-1939. Stownik biograficzny, t. IV: M-P, oprac. P. Majewski, red. G. Mazur, Warszawa 2009, s. 435-437; S.S. Nicieja, Adam Próchnik — historyk — polityk - publicysta, Warszawa 1986.

53 A. Próchnik, Pierwsze piętnastolecie Polski niepodległej (1918-1932). Zarys dziejów politycznych, Warszawa 1933, s. 13-93.

${ }^{54}$ T. Rzepecki był synem Jana Rzepeckiego, brata Karola Rzepeckiego (1865-1931), poznańskiego wydawcy i księgarza, założyciela Wielkopolskiej Księgarni Nakładowej (1913), członka ND, posła na Sejm w 1922 i 1928 r. Rzepecki Karol, [w:] Kto byt kim..., s. 419. 
w swoim założeniu pierwszym kompendium wiedzy na temat działalności SU. Rzepecki, współautor również późniejszych kompendiów o Sejmie i Senacie z lat 1922$-1933^{55}$, opracował je na podstawie danych statystycznych Głównych Komisji Wyborczych oraz na pozyskiwanych na bieżąco kwestionariuszach osobowych posłów. Chcąc wypełnić lukę w stanie wiedzy na temat działalności Sejmu, w przedmowie do dzieła zwrócił uwagę, że „Od roku blisko obraduje już Sejm Niepodległej i Zjednoczonej Polski. Publiczność, interesująca się Jego obradami nie miała dotąd podręcznika, który by w zwięzłej formie mógł ją poinformować o dotychczasowej działalności Sejmu, o jego składzie, posłach i wynikach wyborów z dnia 28 stycznia 1919 r. Pragnąc temu zaradzić, puszczam w świat tę skromną książkę"

W drugiej kolejności uwagę należy skoncentrować na pomnikowym wręcz dziele: Parlament Rzeczypospolitej Polskiej 1919-1927 (1928), opracowanym przez Henryka Mościckiego i Włodzimierza Dzwonkowskiego. Inicjatywa ta zrodziła się w końcu 1927 r., w środowisku historyków XIX w. i dziejów najnowszych ${ }^{57}$. Jego idea zbiegła się z rocznicą dziesięciolecia odzyskania niepodległości, z okazji której wydawano drukiem dzieła pamiątkowe podsumowujące dokonania II RP w wielu obszarach życia państwowego, społecznego, naukowego. Dzieło oprócz części opisowej, zawierającej szkic z dziejów polskiego parlamentaryzmu do odzyskania niepodległości (m.in. na podstawie prac Kutrzeby i Komarnickiego), obejmowało także sporzadzone na bieżąco biogramy posłów i senatorów z lat 1919-1927 oraz zarys dziejów Sejmu z lat 1919-192758. Zbliżony charakter jubileuszowy miała także wydana w tym samym czasie księga pamiątkowa na dziesięciolecie odrodzonej Polski, w której omówione zostały zagadnienia dotyczące konstytucji marcowej i działalności SU, w opracowaniu Wacława Makowskiego, prawnika i współautora rządowego projektu zmian w konstytucji, tzw. noweli sierpniowej 1926 r. oraz Mariana Grzegorczyka ${ }^{59}$.

Kolejny okres rozwoju badań historycznych nad dziejami parlamentaryzmu w II RP przypadł na czasy PRL, wraz z wewnętrznymi cezurami w dziejach polskiej nauki historycznej tego okresu ${ }^{60}$. Prowadzone po 1945 r. badania historycznoprawne dotyczace zagadnień międzywojennych wpisywały się w obserwowaną w tym czasie, a szczegól-

55 T. i W. Rzepeccy, Sejm i Senat 1922-1927. Podręcznik dla wyborców, zawierajacy wyniki wyborów w powiatach, okręgach, województwach, podobizny senatorów i posłów sejmowych oraz mapy poglądowe, Poznań 1923; T. i K. Rzepeccy, Sejm i Senat 1928-1933, Podręcznik zawierający wyniki wyborów w województwach, okręgach i powiatach, podobizny posłów sejmowych i senatorów, statystyki i mapy poglądowe, Poznań 1928.

56 T. Rzepecki, Sejm Rzeczypospolitej Polskiej 1919 roku, Poznań 1920.

${ }_{57}$ Mościcki Henryk, [w:] Biogramy uczonych polskich, cz. I, z. 2: K-O, red. A. Śródka i P. Szczawiński, Wrocław 1984; Dzwonkowski Włodzimierz, [w:] Słownik historyków polskich, red. M. Prosińska-Jackl, Warszawa 1994, s. 124.

58 Parlament Rzeczypospolitej Polskiej 1919-1927, red. H. Mościcki i W. Dzwonkowski, Warszawa 1928, s. VII-VIII.

59 W. Makowski, Konstytucja, zwierzchnicy państwa, Sejm, Senat i Rząd, [w:] Dziesięciolecie Polski Odrodzonej. Księga Pamiatkowa 1918-1928, Kraków-Warszawa 1928, s. 175-180; M. Grzegorczyk, Sejm i Senat, [w:] ibidem, s. 183-187.

${ }^{60}$ R. Stobiecki, Historiografia PRL. Ani dobra, ani mądra, ani piękna ... ale skomplikowana. Studia i szkice, Warszawa 2007, s. 119 i nn. 
nie w okresie stalinizacji nauki historycznej, reinterpretację dziejów II RP ${ }^{61}$. Przejawiała się ona w krytyce ustroju „państwa burżuazyjno-obszarniczego" i zapoczątkowanej wówczas, jak podkreśla Rafał Stobiecki, tzw. czarnej legendzie tego okresu, co zakwestionowano, jego zdaniem, dopiero w drugiej połowie lat sześćdziesiątych ${ }^{62}$.

Podjęta w latach pięćdziesiątych inicjatywa całościowego opracowania historii państwa i prawa Polski, w tym okresu obejmującego zagadnienia prawnoustrojowe II RP, podlegała tym samym tendencjom, jakie oddziaływały na powstające w okresie PRL syntezy dziejów ojczystych, które choć w różnym stopniu, to jednak pozostawały pod wpływem stalinowskiej teorii formacji ekonomiczno-społecznych. Jak zauważył R. Stobiecki, „Stalinowska unifikacja polskiej nauki historycznej znalazła swoje odzwierciedlenie także w postaci zmian dokonujących się w dotychczasowym obrazie dziejów narodowych. Konstrukcję nowego obrazu wyznaczały zarówno nowe dyrektywy metodologiczne, jak i ideologiczne cele partii-państwa" ${ }^{63}$. Odejście od takiej interpretacji zauważalne jest w syntezach dziejów ojczystych dopiero w latach osiemdziesiatych $^{64}$. Badania historyczne prowadzone na podstawie marksistowskiej wykładni dziejów zbiegły się w czasie z instytucjonalną przebudową historiografii, w tym historii państwa i prawa ${ }^{65}$. Na ten okres przypadła także inicjatywa opracowania pierwszej w polskiej historiografii syntezy historii państwa i prawa Polski, czego podjęło się środowisko naukowe skupione wokół nowo powołanego w $1956 \mathrm{r}$. Instytutu Nauk Prawnych PAN i funkcjonującego w jego strukturach Działu Historii Państwa i Prawa ${ }^{66}$.

W efekcie podjętych prac badawczych już w 1957 r. ukazały się pierwsze dwa tomy, oparte na założeniach marksistowskich, wielotomowej historii państwa i pra$\mathrm{wa}^{67}$. Wszystko to miało niewątpliwie istotny wpływ na dalszy rozwój badań historycznoprawnych w zakresie studiów nad dziejami parlamentaryzmu w II RP, w tym badań nad Sejmem Ustawodawczym. Prace nad kolejnym tomem syntezy, dotyczącym historii prawa i państwa lat międzywojennych, przypadły już na drugą połowę lat pięćdziesiątych, a ściślej — rozpoczęły się w 1956 r. w środowisku Instytutu Nauk Prawnych PAN i Instytutu Historyczno-Prawnego Uniwersytetu Warszawskiego. W ogólnej charakterystyce historiografii tego okresu uwagę zwracają zachodzące

${ }^{61}$ S. Salmonowicz, Historia prawa wobec II RP. Uwagi o stanie badań, „Studia Iuridica Toruniensia” 2016, t. XVIII, s. 13.

${ }^{62}$ R. Stobiecki, Najnowsze dzieje polski w syntezach historycznych okresu PRL, „Przegląd Zachodni”" 1994, z. 4, s. 118; M. Tyrchan, Nauki prawnohistoryczne 1945-1956 w Polsce, „Przegląd Historyczny” 2012, z. 1, s. 151-174.

${ }^{63}$ R. Stobiecki, Stalinowska unifikacja nauki historycznej (przykład Polski), „Acta Universitatis Lodziensis. Folia Historica" 1996, t. 55, s. 34.

${ }^{64} \mathrm{Na}$ ten temat szerzej R. Stobiecki, Najnowsze dzieje polski w syntezach historycznych..., s. 114-116.

65 M. Tyrchan, Nauki prawnohistoryczne 1945-1956 w Polsce..., s. 151-174; idem, Nauki historycznoprawne w latach 60. XX wieku - organizacja badań, „Krakowskie Studia z Historii Państwa i Prawa” 2012, z. 5, s. 358.

${ }^{66}$ M. Tyrchan, Nauki historycznoprawne w latach 60. XX wieku ..., s. 355-373.

${ }^{67}$ J. Bardach, Historia państwa i prawa Polski, t. I, Do połowy XV wieku, Warszawa 1957; Z. Kaczmarczyk, B. Leśnodorski, Historia państwa i prawa Polski, t. II, Od połowy XV wieku do r. 1795, Warszawa 1957. 
w niej przewartościowania, które były skutkiem zmian politycznych wywołanych „przełomem październikowym”. Przejawem tego stanu było z pewnością powolne odchodzenie w nauce historycznej od stalinowskiego dogmatyzmu naukowego. Tym samym tendencjom podlegały badania historycznoprawne ${ }^{68}$.

Kolejny tom syntezy, Historia państwa i prawa Polski 1918-1939 (1962) ${ }^{69}$, wydany już w zmieniających się warunkach i postępującej ideologizacji historiografii, miał w warstwie dokumentacyjnej charakter rzeczowego studium. Niemniej w warstwie interpretacyjnej utrzymany został w nurcie krytyki czasów „Polski burżuazyjno-obszarniczej (1918-1939)"’70. W gronie autorów znaleźli się: Andrzej Ajnenkiel, Cezary Berezowski, Andrzej Gwiżdż, Jan Jończyk, Romuald Klimowiecki, Karol Ostrowski, Michał Pietrzak i Franciszek Ryszka. W przedmowie dzieła autorzy odnosząc się do oceny systemu ustrojowego lat 1918-1939 podkreślili, że „Cechą systemu państwa i prawa doby międzywojennej jest jego połowiczność: «Od niepełnej demokracji (mieszczańskiej) do niepełnego faszyzmu»" "11. Problematyce SU, małej konstytucji i ustawie zasadniczej poświęcono w syntezie odrębną część charakteryzująca tzw. okres przejściowy w systemie ustrojowym II RP ${ }^{72}$.

Omawiane dzieło było pierwszą syntetyczną próbą całościowego opracowania okresu międzywojennego i — co istotne - podsumowaniem dotychczasowego stanu badań, z wykorzystaniem literatury przedwojennej, ale także prac powstałych już po 1945 r. na emigracji i w Polsce. Jeśli chodzi o zagadnienia dotyczące SU i myśli konstytucyjnej tego okresu, to ich podstawą stała się m.in. wydana w 1956 r., a więc już w czasie prac nad synteza, praca A. Gwiżdża, Burżuazyjno-obszarnicza konstytucja z 1921 roku w praktyce, którą cechowała wyraźna jednostronność interpretacyjna i metodologia oparta na wykładni marksistowskiej ${ }^{73}$. Kiedy po kilkunastu latach do tej pracy odwoływał się A. Ajnenkiel, zwracał uwagę na stan ówczesnej historiografii i poglądy autorów, które — jak zauważył — aktualnie ulegały zmianie, ale wypowiadanych wówczas sądów nie można, w jego ocenie, ,wyłącznie szukać w postawach badaczy" "74. W czasie przygotowywania syntezy ukazał się również syntetyczny szkic Konstantego Grzybowskiego na temat parlamentaryzmu II RP ${ }^{75}$.

Autorzy syntezy w charakterystyce stanu badań zwrócili uwagę na znaczenie metodologicznych i historiograficznych inicjatyw podejmowanych w okresie PRL, w tym „owocnych prób przedstawienia z pozycji marksistowskich niektórych węzłowych za-

${ }^{68}$ R. Stobiecki, Historia i historycy w latach przełomu październikowego 1956, „Tygiel Kultury” 1996, nr 10-11; idem, Historiografia PRL..., s. 128-129; M. Tyrchan, Nauki historycznoprawne w latach 60. XX wieku..., s. 358.

${ }^{69}$ Historia państwa i prawa Polski 1918-1939, cz. 1, red. F. Ryszka, Warszawa 1962.

${ }^{70}$ S. Salmonowicz, Historia prawa wobec II RP..., s. 15; M. Tyrchan, Nauki historycznoprawne w latach 60. XX wieku ..., s. 365-366.

${ }^{71}$ Historia państwa i prawa Polski 1918-1939..., cz. I, s. 5.

${ }^{72}$ Ibidem, s. 97-131.

${ }^{73}$ A. Gwiżdż, Burżuazyjno-obszarnicza konstytucja z 1921 roku w praktyce, Warszawa 1956.

${ }^{74}$ A. Ajnenkiel, Spór o model parlamentaryzmu polskiego do 1926 roku, Warszawa 1972, s. 13.

${ }^{75}$ K. Grzybowski, Parlamentaryzm polski w dwudziestoleciu międzywojennym 1918-1939, [w:] Historia najnowsza Polski, red. I. Pietrzak-Pawłowska, K. Piwarski, Warszawa 1960. 
gadnień dwudziestolecia" ${ }^{76}$. Odwołano się tym samym do znaczenia konferencji metodologicznej w Otwocku (28 grudnia 1951 r.-12 stycznia 1952 r.), ale także do obrad VIII Powszechnego Zjazdu Historyków Polskich w Krakowie w 1958 r. ${ }^{77}$ Ten ostatni, odbywający się w atmosferze rozliczania się z nauką stalinowska, miał szczególne znaczenie dla dalszej dyskusji na temat badań historycznych nad dziejami parlamentaryzmu w II RP. Wydaje się też, że w tym zakresie odegrał on rolę przełomową. Wpisywało się to w ogólną tendencję obserwowaną w ówczesnej polskiej historiografii, którą po zmianach w latach 1956-1958 cechowało osłabienie krytycznego tonu wobec oceny dziejów II RP ${ }^{78}$.

Przechodząc do charakterystyki dyskusji zjazdowej, w której uczestniczyli historycy prawa - autorzy syntezy historii państwa i prawa Polski, należy zwrócić uwage na referat K. Grzybowskiego, który wystapił w obronie polskiego parlamentaryzmu II RP i chciał go rozpatrywać ,„... [ na tle rozwoju ustroju konstytucyjnego na ziemiach polskich przed r. 1918 i na tle rozwoju konstytucjonalizmu i parlamentaryzmu burżuazyjnego lat 1918-1939”. Za „,naukowo bezpłodną” uznał zaś metodę jego konfrontacji z socjalistycznymi modelami ustrojowymi ${ }^{79}$. Dowodził dalej, że sytuacja, w jakiej powstała konstytucja marcowa, przesądzała z góry o jej podstawowych zasadach, a te znalazły już wyraz - w jego ocenie — przy powoływaniu SU. Odnosząc się do zasad ustrojowych określonych w konstytucji marcowej, stawiał pytanie: „Czy system rządów parlamentarnych stworzony przez Konstytucję Marcową, funkcjonujący zaledwie cztery lata, zawiódł"so.

Odmienne stanowisko w kwestii oceny parlamentaryzmu przedstawił drugi z dyskutantów, A. Ajnenkiel, który poruszył problem suwerenności SU. Uważał inaczej niż czynił to Grzybowski, że SU nie miał żadnego wpływu na kształtowanie się pierwszych instytucji państwowych w momencie, kiedy „,władza dyktatorska” znajdowała się w rękach Naczelnika Państwa. W jego ocenie, Sejm po uchwaleniu małej konstytucji nie był władzą suwerenna, jak wskazywał na to w swoim wystapieniu zjazdowym Grzybowski ${ }^{81}$. W obronie konstytucji marcowej wystapił także Michał Pietrzak, źródeł słabości polskiego parlamentaryzmu w II RP upatrując nie w modelu ustrojowym ustawy zasadniczej, a raczej w wewnętrznym układzie sił politycznych w parlamencie ${ }^{82}$.

${ }^{76}$ Historia państwa i prawa Polski 1918-1939, cz. I..., s. 12-13. R. Stobiecki, Pierwsza Konferencja Metodologiczna Historyków Polskich, [w:] Skryte oblicze systemu komunistycznego. U źródel zła..., red. R. Bäcker, P. Hübner, Warszawa 1997, s. 193-211.

77 Historia państwa i prawa Polski 1918-1939, cz. I..., s. 13.

78 T. Jędruszczak, O kryteriach oceny dziejów Polski w okresie międzywojennym (1918-1939), „Kwartalnik Historyczny" 1958, nr 2, s. 484-496; A. Garlicki, T. Nałęcz, W. Władyka, II Rzeczpospolita w powojennych badaniach historyków polskich, „Przegląd Historyczny” 1978, nr 3, s. 396-397; R. Stobiecki, Najnowsze dzieje polski w syntezach historycznych, s. 119.

${ }^{79}$ K. Grzybowski, Parlamentaryzm polski w Dwudziestoleciu (1918-1939), [w:] Pamiętnik VIII Powszechnego Zjazdu Historyków Polskich w Krakowie 14-17 września 1958 roku. Referaty i dyskusja, t. 1, Warszawa 1958, s. 229.

80 Ibidem, s. 231, 236.

${ }^{81}$ Pamiętnik VIII Powszechnego Zjazdu Historyków Polskich ..., s. 248.

${ }^{82}$ Ibidem, s. 256. 
Dyskusja na VIII Powszechnym Zjeździe Historyków Polskich była jedną z istotniejszych debat w polskiej historiografii tego okresu na temat parlamentaryzmu II RP, a przy tym na temat oceny funkcjonowania Sejmu Ustawodawczego. Kolejnym czynnikiem, który wpłynął na rozwój zainteresowań badawczych dziejami parlamentaryzmu do 1926 r. była dyskusja na temat dziedzictwa II RP, opublikowana na łamach „Kwartalnika Historycznego” w 1968 r. Do kwestii tych odniósł się wówczas Bogusław Leśnodorski, twierdząc, że system demokracji parlamentarnej przyczynił się do rozbudzenia życia politycznego w kraju oraz A. Ajnenkiel, którego zdaniem wprowadzenie tego ustroju i utrwalenie go w konstytucji marcowej było wynikiem autentycznych dążeń, a nie mechanicznym zapożyczeniem wzoru francuskiego. Tym samym podkreślał znaczenie konstytucji marcowej w walce o władzę i system ustrojowy w Polsce w okresie do 1926 r. ${ }^{83}$ Rozwijające się od tego momentu badania nad dziejami parlamentaryzmu II RP, szczególnie do 1926 r., i konstytucjonalizmu były ściśle związane z działalnością naukową M. Pietrzaka, historyka zagadnień prawnoustrojowych oraz wspominanego już wielokrotnie A. Ajnenkiela (1931-2015), historyka dziejów najnowszych, znawcy prawa i ustroju ${ }^{84}$. Obaj związani z profesorem Juliuszem Bardachem i warszawskim środowiskiem historycznoprawnym, byli autorami wydanych drukiem na przełomie lat sześćdziesiątych i siedemdziesiątych istotnych monografii, szeroko odwołujących się do zagadnienia funkcjonowania systemu rządów parlamentarnych do przewrotu majowego i noweli sierpniowej z 1926 r.

Pierwszy z wymienionych, M. Pietrzak w Rzadach parlamentarnych $w$ Polsce w latach 1919-1926 (1969) szczegółowej analizie poddawał ,burżuazyjny ustrój polityczny" tego okresu, charakteryzując system rządów parlamentarnych i strukturę polityczną SU ${ }^{85}$. Omawiając jego funkcjonowanie, podkreślał, że „Wprowadzając system rządów parlamentarnych i nadając mu określone kształty instytucjonalne, Sejm Ustawodawczy niedostatecznie interesował się jego stroną funkcjonalną"86.

W przypadku dorobku naukowego A. Ajnenkiela, chodzi o wydane na przełomie lat sześćdziesiątych i siedemdziesiątych monograficzne opracowania dziejów parlamentaryzmu do 1926 r., pokazane na szerszym tle rozwijających się od końca XIX w. koncepcji politycznych ${ }^{87}$. Szczególne znaczenie miała z pewnością rozprawa habilitacyjna $\mathrm{Aj-}$ nenkiela, Spór o model parlamentaryzmu polskiego do 1926 roku (1972), w której podsumowując dotychczasowy stan badań, zwracał uwagę na niedostatek opracowań $\mathrm{z}$ tego zakresu ${ }^{88}$. Z krytyczną oceną odniósł się przede wszystkim do dorobku polskiej

${ }^{83}$ B. Leśnodorski, Przełom roku 1918, „Kwartalnik Historyczny” 1968, nr 3, s. 531-532; Przełom roku 1918. Dyskusja, „Kwartalnik Historyczny” 1968, nr 3, s. 536.

${ }^{84}$ Pro bono Reipublicae. Księga jubileuszowa Profesora Michała Pietrzaka, red. P. Borecki, A. Czohara, T.J. Zieliński, Warszawa 2009, s. 19-20; U. Olech, T. Panecki, Profesor Andrzej Ajnenkiel (1931-2015), „Przegląd Historyczno-Wojskowy” 2015, t. 16, s. 235-238.

${ }^{85}$ M. Pietrzak, Rzady parlamentarne $w$ Polsce w latach 1919-1926, Warszawa 1969, s. 15.

${ }^{86}$ Ibidem, s. 312-315.

${ }^{87}$ A. Ajnenkiel, Od rzqdów ludowych do przewrotu majowego. Zarys dziejów politycznych Polski 1918-1926, Warszawa 1968; idem, Spór o model parlamentaryzmu polskiego do 1926 roku, Warszawa 1972; idem, Parlamentaryzm II Rzeczypospolitej, Warszawa 1975.

${ }^{88}$ A. Ajnenkiel, Spór o model parlamentaryzmu..., s. 9. 
historiografii lat pięćdziesiątych. Podkreślał, że ówczesne interpretacje historyków były często ,jednostronnym, schematycznym spojrzeniem, traktującym dzieje państwa i jego ustrój w jednolitej konwencji, sprowadzającej się do poszukiwania w każdym dążeniu do usprawnienia funkcjonowania aparatu państwowego, tendencji faszyzujących czy wręcz faszystowskich" ". Znaczącą część swojej monografii poświęcił analizie „sporów o kształt i rolę parlamentu w dobie Sejmu Ustawodawczego”, zwracając uwagę na cezurę uchwalenia konstytucji marcowej, która zamykała — jego zdaniem - tzw. okres przejściowy, a rozpoczynała funkcjonowanie parlamentaryzmu polskiego już w ramach określonych przez tę konstytucję $e^{90}$.

W wydanej kilka lat później kolejnej swojej pracy: Parlamentaryzm II Rzeczypospolitej (1975), odnosząc się do stanu badań nad okresem narodzin polskiego parlamentaryzmu do 1926 r., stwierdził jednoznacznie, że w porównaniu z parlamentaryzmem lat 1926-1939 posiada on o wiele większy dorobek historyczny. Wypowiadając się na temat SU, podkreślał, że jego działalność przypadła na trudny okres budowy zrębów polskiej państwowości i scalania państwa. Mimo tego dziedzictwo SU, jego funkcje administracyjne, polityczne, społeczne poddawał wysokiej ocenie, widząc w nich ,najbardziej widoczny symbol integracji” i ,,szkołę myślenia politycznego ${ }^{91}$. $\mathrm{Z}$ nazwiskiem Ajnenkiela łączy się dalszy rozwój badań historycznoprawnych nad parlamentaryzmem II RP i konstytucjonalizmem, które zaowocowały szeregiem znaczących prac z tego zakresu. Przy wyłącznie pobieżnym przeglądzie stanu badań uwagę zwraca przede wszystkim wydana w 1989 r. Historia Sejmu polskiego, której tom drugi obejmujący czasy II RP stanowił istotną część większej całości ${ }^{92}$.

Nie bez znaczenia dla rozwoju tych zainteresowań były także ówczesne badania nad polską myślą polityczną II RP, które w polskiej historiografii po pracach Andrzeja Micewskiego czy J. Holzera nabrały tempa od przełomu lat siedemdziesiątych i osiemdziesiątych, czego przejawem były m.in. opracowania Michała Śliwy, Romana Wapińskiego a wreszcie też wrocławska seria wydawnicza: Polska Myśl Polityczna XIX i XX wiek ${ }^{93}$.

Od lat dziewięćdziesiątych obserwujemy prawdziwy renesans w zainteresowaniach badawczych historycznych i historycznoprawnych problematyką SU i konstytucjonalizmu. Przy wyłącznie pobieżnym przeglądzie stanu badań z tego zakresu w hi-

89 Ibidem, s. 13.

90 Ibidem, s. 165-253.

91 A. Ajnenkiel, Parlamentaryzm II Rzeczypospolitej..., s. 174-176.

92 A. Ajnenkiel, Historia Sejmu polskiego, t. II, cz. II, II Rzeczpospolita, Warszawa 1989, s. 5-63; idem, Konstytucje Polski w rozwoju dziejowym 1791-1997, Warszawa 2001.

93 A. Micewski, Z geografii politycznej II Rzeczypospolitej. Szkice, Kraków 1964; J. Holzer, Mozaika polityczna Drugiej Rzeczypospolitej, Warszawa 1974; M. Śliwa, Polska myśl polityczna w I połowie XX wieku, Wrocław 1993; R. Wapiński, Historia polskiej myśli politycznej XIX i XX wieku, Gdańsk 1997; Polska Myśl Polityczna XIX i XX wieku, t. 1-11, Wrocław 1975-2001; K. Kawalec, Wizje ustroju państwa w polskiej myśli politycznej lat 1918-1939. Ze studiów nad dziejami polskiej myśli politycznej, Wrocław 1995; idem, Spadkobiercy niepokornych. Dzieje polskiej myśli politycznej 1918-1939, Wrocław-Warszawa-Kraków 2000; Więcej niż niepodległość. Polska myśl polityczna 1918-1939, red. J. Jachymek, W. Paruch, Lublin 2005 . 
storiografii współczesnej w pierwszym rzędzie uwagę zwraca wielokierunkowość prowadzonych badań i poszerzenie ich problemowego zakresu. Jedynie tytułem przykładu można się odwołać do badań monograficznych poświęconych koncepcjom parlamentarnym, działalności ugrupowań politycznych w SU, mniejszości narodowych, a także niezwykle istotnym i prężnie rozwijającym się studiom biograficznym ${ }^{94}$. W tym zakresie należy zwrócić uwagę m.in. na projekt badawczy nad słownikiem biograficznym posłów i senatorów, który prowadzony jest od 1993 r. pod auspicjami Biblioteki Sejmowej, a jego pokłosiem jest aktualnie wydawany wielotomowy słownik biograficzny, obejmujący noty biograficzne posłów i senatorów wszystkim kadencji parlamentu II Rzeczypospolitej ${ }^{95}$.

Zaprezentowany w niniejszym studium przegląd głównych kierunków badań historycznych i historycznoprawnych poświęconych problematyce Sejmu Ustawodawczego, jakie rozwijały się od lat dwudziestych XX w. do czasów współczesnych, nie wyczerpuje z pewnością w całości tego zagadnienia. Pozwala jednak, przynajmniej w jakiejś części, na przeprowadzenie systematyzacji zainteresowań badawczych wybranych postaci historyków, historyków prawa i ustroju oraz konstytucjonalistów zajmujących się rolą i miejscem Sejmu Ustawodawczego w historiografii polskiego parlamentaryzmu na przestrzeni XX w.

\section{BIBLIOGRAFIA}

ŹRÓDŁA

Car S., Konstytucja 17 marca 1921 roku a polska rzeczywistość. Odczyt wygloszony $w$ dn. 24.11.1929 r. w sali Teatru Starego w Krakowie, Nakładem Księgarni F. Hoesicka, Warszawa 1930.

Uchwała Sejmu Ustawodawczego z dnia 20 lutego 1919 r., Dz.P.P.P. nr 19, poz. 226.

Ustawa z dnia 17 marca 1921 r. Konstytucja Rzeczypospolitej Polskiej, Dz.U. nr 44, poz. 267.

Nasza Konstytucja. Cykl odczytów urządzonych staraniem Dyrekcji Szkoły Nauk Politycznych w Krakowie od 12-25 maja 1921 r., Kraków 1922.

Projekty Konstytucji Rzeczypospolitej Polskiej. Projekt Komisji Konstytucyjnej Sejmu Ustawodawczego, Warszawa 1920.

Rzepeccy T. i K., Sejm i Senat 1928-1933. Podręcznik zawierajacy wyniki wyborów w województwach, okręgach i powiatach, podobizny postów sejmowych i senatorów, statystyki i mapy pogladowe, Wielkopolska Księgarnia Nakładem K. Rzepeckiego, Poznań 1928.

94 Sejmy Drugiej Rzeczypospolitej, red. A. Zakrzewski, Warszawa 1990; Z. Zaporowski, Sejm Rzeczypospolitej Polskiej 1919-1939: działalność postów, parlamentarne koncepcje Józefa Pitsudskiego, mniejszości narodowe, Lublin 1992; M. Śliwa, Ludowcy i socjaliści w parlamencie II Rzeczypospolitej, Warszawa 1995; B. Gałka, Ziemianie w parlamencie II Rzeczypospolitej, Toruń 1999; J. Fałowski, Parlamentarzyści mniejszości niemieckiej w Drugiej Rzeczypospolitej, Częstochowa 2000; idem, Posłowie żydowscy w Sejmie Ustawodawczym 1919-1922, Częstochowa 2000; S. Rudnicki, Żydzi w parlamencie II Rzeczypospolitej, Warszawa 2004.

${ }_{95}$ Posłowie i senatorowie Rzeczypospolitej Polskiej 1919-1939. Słownik biograficzny, t. I-IV, Warszawa 1998-2009. 
Rzepeccy T. i W., Sejm i Senat 1922-1927. Podręcznik dla wyborców, zawierajacy wyniki wyborów w powiatach, okręgach, województwach, podobizny senatorów i postów sejmowych oraz mapy pogladowe, Wielkopolska Księgarnia Nakładowa, Poznań 1923.

Rzepecki T., Sejm Rzeczypospolitej Polskiej 1919 roku, Wielkopolska Księgarnia Nakładowa, Poznań 1920.

Tymczasowa Ustawa Konstytucyjna Rzeczypospolitej Polskiej, [w:] Mieczysław Niedziałkowski o demokracji i parlamentaryzmie, wstęp, wybór i opracowanie M. Śliwa, Kancelaria Sejmu, Warszawa 1996.

\section{PIŚMIENNICTWO}

Academia Militans. Uniwersytet Jana Kazimierza we Lwowie, red. A. Redzik, Wydawnictwo Wysoki Zamek, Instytut Pamięci Narodowej, Kraków 2015.

Ajnenkiel A., Od rzadów ludowych do przewrotu majowego. Zarys dziejów politycznych Polski 1918-1926, Wiedza Powszechna, Warszawa 1968.

Ajnenkiel A., Spór o model parlamentaryzmu polskiego do 1926 roku, Książka i Wiedza, Warszawa 1972.

Ajnenkiel A., Parlamentaryzm II Rzeczypospolitej, Wiedza Powszechna, Warszawa 1975.

Ajnenkiel A., Historia Sejmu polskiego, t. 2, cz. II, II Rzeczpospolita, Państwowe Wydawnictwo Naukowe, Warszawa 1989 (bibliografia).

Ajnenkiel A., Konstytucje Polski w rozwoju dziejowym 1791-1997, Oficyna Wydawnicza Rytm, Warszawa 2001.

Bardach J., Historia państwa i prawa Polski, t. I, Do połowy XV wieku, Państwowe Wydawnictwo Naukowe, Warszawa 1957.

Biliński P., Władysław Konopczyński 1880-1952. Człowiek i dzieło, Ośrodek Myśli Politycznej, Kraków 2017.

Biogramy uczonych polskich, cz. I, Nauki społeczne, z. 2, K-O, red. A. Śródka, P. Szczawiński, Zakład Narodowy im. Ossolińskich, Wrocław 1984.

Car S., Z zagadnień konstytucyjnych Polski. Istota i zakres władzy prezydenta Rzeczypospolitej Polskiej. Państwowość polska w jej rozwoju historycznym, Drukarnia Policyjna, Warszawa 1924.

Car Stanisław Henryk, [w:] Posłowie i senatorowie Rzeczypospolitej Polskiej 1919-1939. Stownik biograficzny, t. 1: A-D, oprac. M. Smogorzewska, red. A.K. Kunert, Wydawnictwo Sejmowe, Warszawa 1998.

Cieszyński A., Dorobek nauki prawa konstytucyjnego na Uniwersytecie Stefana Batorego w Wilnie, [w:] Prawo konstytucyjne II Rzeczypospolitej. Nauka i instytucje, red. P. Sarnecki, Wydawnictwo Uniwersytetu Jagiellońskiego, Kraków 2006.

Cybichowski Z., Polskie prawo państwowe na tle uwag z dziedziny nauki o państwie i porównawczego prawa państwowego, t. 2, Wydawnictwo Seminarium Prawa Publicznego Uniwersytetu Warszawskiego, Warszawa 1933.

Dzieje parlamentaryzmu w Polsce XV-XX wieku. Materiaty Bibliograficzne, oprac. K. Zieliński, Centralna Biblioteka Wojskowa, Warszawa 1985.

Dzwonkowski Włodzimierz, [w:] Słownik historyków polskich, red. M. Prosińska-Jackl, Wiedza Powszechna, Warszawa 1994.

Ehrlich L., Zarys historii nauki prawa politycznego w Polsce, [w:] L. Ehrlich, J.S. Langrod, Zarys historii prawa narodów, prawa politycznego i administracyjnego w Polsce, Polska Akademia Umiejętności, Kraków 1949.

Fałowski J., Parlamentarzyści mniejszości niemieckiej w Drugiej Rzeczypospolitej, Wyższa Szkoła Pedagogiczna w Częstochowie, Częstochowa 2000. 
Fałowski J., Posłowie żydowscy w Sejmie Ustawodawczym 1919-1922, Wyższa Szkoła Pedagogiczna w Częstochowie, Częstochowa 2000.

Gałka B., Ziemianie w parlamencie II Rzeczypospolitej, Wydawnictwo Adam Marszałek, Toruń 1999.

Grzankowski W., Na marginesie pracy Feliksa Honowskiego, „Palestra” 1938, nr 4.

Grzegorczyk M., Sejm i Senat, [w:] Dziesięciolecie Polski Odrodzonej. Księga Pamiatkowa 1918-1928, Nakładem Ilustrowanego Kuriera Codziennego, Kraków-Warszawa 1928.

Grzybowski K., Parlamentaryzm polski w Dwudziestoleciu (1918-1939), [w:] Pamiętnik VIII Powszechnego Zjazdu Historyków Polskich w Krakowie 14-17 września 1958 r. Referaty i dyskusja, t. 1, Polskie Towarzystwo Historyczne, Warszawa 1958.

Grzybowski K., Parlamentaryzm polski w dwudziestoleciu międzywojennym 1918-1939, [w:] Historia najnowsza Polski, red. I. Pietrzak-Pawłowska i K. Piwarski, Polskie Towarzystwo Historyczne, Warszawa 1960.

Gwiżdż A., Burżuazyjno-obszarnicza konstytucja z 1921 roku w praktyce, Wydawnictwo Prawnicze, Warszawa 1956.

Historia państwa i prawa Polski 1918-1939, cz. 1, red. F. Ryszka, Państwowe Wydawnictwo Naukowe, Warszawa 1962.

Holzer J., Mozaika polityczna Drugiej Rzeczypospolitej, Książka i Wiedza, Warszawa 1974.

Honowski F., Parlament i rzqd w Polsce niepodlegtej, Polskie Wydawnictwo Naukowe, Warszawa 1938.

Jarosz Z., Prawo konstytucyjne na Uniwersytecie Warszawskim, [w:] Prawo konstytucyjne II Rzeczypospolitej. Nauka i instytucje, red. P. Sarnecki, Wydawnictwo Uniwersytetu Jagiellońskiego, Kraków 2006

Kaczmarczyk Z., Leśnodorski B., Historia państwa i prawa Polski, t. II, Od połowy XV wieku do r. 1795, PWN, Warszawa 1957.

Kawalec K., Spadkobiercy niepokornych. Dzieje polskiej myśli politycznej 1918-1939, Zakład Narodowy im. Ossolińskich, Wrocław-Warszawa-Kraków 2000.

Kawalec K., Wizje ustroju państwa w polskiej myśli politycznej lat 1918-1939. Ze studiów nad dziejami polskiej myśli politycznej, Wydawnictwo Uniwersytetu Wrocławskiego, Wrocław 1995.

Komarnicki W., Polskie prawo polityczne. Geneza i system, Nakładem Księgarni F. Hoesicka, Warszawa 1922.

Komarnicki W., Zarys ustroju państwowego Rzeczypospolitej Polskiej, Nakładem Księgarni F. Hoesicka, Warszawa 1923.

Komarnicki W., Ustrój państwowy Rzeczypospolitej Polskiej, Nakładem Księgarni F. Hoesicka, Warszawa 1934.

Komarnicki Wacław, [w:] Postowie i senatorowie Rzeczypospolitej Polskiej 1919-1939. Stownik biograficzny, t. III: $K-\ell$, oprac. Piotr Majewski, red. G. Mazur, Wydawnictwo Sejmowe, Warszawa 2005.

Konopczyński W., Historia polityczna Polski 1914-1939, Inicjatywa Wydawnicza ad astra, Warszawa 1995.

Konopczyński Władysław, [w:] Posłowie i senatorowie Rzeczypospolitej Polskiej 1919-1939. Słownik biograficzny, t. III: $K-\ell$, oprac. P. Majewski, red. G. Mazur, Wydawnictwo Sejmowe, Warszawa 2005.

Konstytucjonaliści polscy 1918-2011, red. A. Szmyt, P. Sarnecki, R. Mojak, Wydawnictwo Sejmowe, Warszawa 2012.

Kto byt kim w Drugiej Rzeczypospolitej, red. J. Majchrowski, G. Mazur, K. Stepan, Polska Oficyna Wydawnicza „BGW”, Warszawa 1994. 
Kutrzeba S., Polska Odrodzona 1914-1921, Gebethner i Wolff, Warszawa-Kraków 1921.

Leśnodorski B., Przełom roku 1918, „Kwartalnik Historyczny” 1968, nr 3.

Ławniczak A., Masternak-Kubiak M., Preisner A., Prawo konstytucyjne na Uniwersytecie Lwowskim w okresie międzywojennym, [w:] Prawo konstytucyjne II Rzeczypospolitej. Nauka i instytucje, red. P. Sarnecki, Wydawnictwo Uniwersytetu Jagiellońskiego, Kraków 2006.

Makowski W., Konstytucja, zwierzchnicy państwa, Sejm, Senat i Rzą, [w:] Dziesięciolecie Polski Odrodzonej. Księga Pamiatkowa 1918-1928, Nakładem Ilustrowanego Kuriera Codziennego, Kraków-Warszawa 1928.

Malicki J.K., Marszałek Pitsudski a Sejm. Historia rozwoju parlamentu polskiego 1919-1936, Dom Książki Polskiej, Warszawa 1936.

Marmon W., Krakowskie środowisko historyczne w latach 1918-1939, Wydawnictwo Naukowe WSP, Kraków 1995.

Maternicki J., Historiografia polska XX wieku, Zakład Narodowy im. Ossolińskich, Wrocław-Warszawa-Kraków 1982.

Maternicki J., Warszawskie środowisko historyczne w okresie II Rzeczypospolitej, Wydawnictwo Wyższej Szkoły Pedagogicznej, Rzeszów 1999.

Micewski A., Z geografii politycznej II Rzeczypospolitej. Szkice, Wydawnictwo „ZNAK”, Kraków 1964.

Mieczysław Niedziałkowski o demokracji i parlamentaryzmie, wstęp, wybór i opracowanie M. Śliwa, Wydawnictwo Sejmowe, Warszawa 1996.

Miklaszewski W., Sejmowładztwo. Sejm ustawodawczy 1919-1922 r., „Siła”, Warszawa 1931.

Mohyluk M., Wacław Komarnicki o Konstytucji marcowej, „Miscellanea Historico-Iuridica” 2015, t. XIV, z. 2.

Mościcki Henryk, [w:] Biogramy uczonych polskich, cz. I, z. 2, $K-O$, red. A. Śródka i P. Szczawiński, Zakład Narodowy im. Ossolińskich, Wrocław 1984.

Nicieja S.S., Adam Próchnik — historyk - polityk - publicysta, PWN, Warszawa 1986.

Niedziałkowski M., Demokracja parlamentarna w Polsce, Księgarnia Robotnicza, Warszawa 1930.

Niedziałkowski M., Rzqdy parlamentarne, [w:] Mieczysław Niedziałkowski o demokracji i parlamentaryzmie, wstęp, wybór i oprac. M. Śliwa, Wydawnictwo Sejmowe, Warszawa 1996.

Niedziałkowski Mieczysław, [w:] Posłowie i senatorowie Rzeczypospolitej Polskiej 1919-1939. Stownik biograficzny, t. IV: $M-P$, oprac. P. Majewski, red. G. Mazur, Wydawnictwo Sejmowe, Warszawa 2009.

Olech U., Panecki T., Profesor Andrzej Ajnenkiel (1931-2015), „Przegląd Historyczno-Wojskowy" 2015, t. 16.

Parlament Rzeczypospolitej Polskiej 1919-1927, red. H. Mościcki i W. Dzwonkowski, Nakładem Lucjana Złotnickiego, Warszawa 1928.

Patkaniowski M., Rozkwit nauk historycznoprawnych w Uniwersytecie Jagiellońskim, [w:] Studia z dziejów Wydziału Prawa Uniwersytetu Jagiellońskiego, red. M. Patkaniowski, Uniwersytet Jagielloński, Kraków 1964.

Pietrzak M., Parlament w systemie organów państwowych, [w:] Sejmy Drugiej Rzeczypospolitej, red. A. Zakrzewski, Ludowa Spółdzielnia Wydawnicza, Warszawa 1990.

Pietrzak M., Rzady parlamentarne w Polsce w latach 1919-1926, Książka i Wiedza, Warszawa 1969.

Pisulińska J., Lwowskie środowisko historyczne w okresie międzywojennym (1918-1939), Wydawnictwo Uniwersytetu Rzeszowskiego, Rzeszów 2012. 
Polska Myśl Polityczna XIX i XX wieku, t. 1-11, Zakład Narodowy im. Ossolińskich, Wrocław 1975-2001.

Pro bono Reipublicae. Księga jubileuszowa Profesora Michała Pietrzaka, red. P. Borecki, A. Czohara, T.J. Zieliński, Wydawnictwo Prawnicze LexisNexis, Warszawa 2009.

Profesorowie Wydzialu Prawa i Administracji Uniwersytetu Warszawskiego 1808-2008, red. G. Bałtruszajtys, Wydawnictwo Prawnicze LexisNexis, Warszawa 2008.

Próchnik A., Pierwsze piętnastolecie Polski niepodległej (1918-1932). Zarys dziejów politycznych, „Robotnik”, Warszawa 1933.

Próchnik Adam Feliks, [w:] Posłowie i senatorowie Rzeczypospolitej Polskiej 1919-1939. Słownik biograficzny, t. IV: $M-P$, oprac. P. Majewski, red. G. Mazur, Wydawnictwo Sejmowe, Warszawa 2009.

Przełom roku 1918. Dyskusja, „Kwartalnik Historyczny” 1968.

Pyter M., Oswald Balzer i lwowska szkoła historycznoprawna, Wydawnictwo KUL, Lublin 2010.

Redzik A., O naukach historycznoprawnych w Uniwersytecie Jana Kazimierza we Lwowie, [w:] Nauki historycznoprawne w polskich uniwersytetach w II Rzeczypospolitej, red. M. Pyter, Wydawnictwo KUL, Lublin 2008.

Redzik A., Stanisław Starzyński (1853-1935) a rozwój polskiej nauki prawa konstytucyjnego, Wydawnictwo Wysoki Zamek, Warszawa-Kraków 2012.

Rudnicki S., Żydzi w parlamencie II Rzeczypospolitej, Kancelaria Sejmu, Warszawa 2004.

Salmonowicz S., Historia prawa wobec II RP. Uwagi o stanie badań, „Studia Iuridica Toruniensia" 2016, t. XVIII, http://dx.doi.org/10.12775/SIT.2016.001.

Sarnecki P., Nauka prawa konstytucyjnego na Uniwersytecie Jagiellońskim w okresie międzywojennym, [w:] Prawo konstytucyjne II Rzeczypospolitej. Nauka i instytucje, red. P. Sarnecki, Wydawnictwo Uniwersytetu Jagiellońskiego, Kraków 2006.

Sarnecki P., Wiekłuk A., Starzewski Maciej, [w:] Polski słownik biograficzny, t. XLII, Warszawa-Kraków 2003-2004.

Sejmy Drugiej Rzeczypospolitej, red. A. Zakrzewski, Ludowa Spółdzielnia Wydawnicza, Warszawa 1990.

Sikorska-Dzięgielewska K., Historia prawa i jej przedstawiciele na Wydziale Prawno-Ekonomicznym Uniwersytetu Poznańskiego w okresie II RP, [w:] Nauki historycznoprawne w polskich uniwersytetach $w$ II Rzeczypospolitej, red. M. Pyter, Wydawnictwo KUL, Lublin 2008.

Stanisław Kutrzeba (1876-1946), uczony, polityk, historyk prawa i ustroju Polski, historyk kultury, wydawca źródel, organizator nauki, pisarz i publicysta prawniczy, działacz społeczny i kulturalny, [w:] K. Pol, Poczet prawników polskich, C.H. Beck, Warszawa 2000.

Starzewski M., Od sejmowładztwa do rządów gabinetowych (20 lutego 1919-16 stycznia 1934), Kraków 1934.

Starzyński S., Konstytucja państwa polskiego, Towarzystwo Naukowe, Lwów 1921.

Starzyński S., Kilka uwag o Konstytucji Rzeczypospolitej Polskiej, „Ruch Prawniczy, Ekonomiczny i Socjologiczny" 1921.

Starzyński S., Konstytucja Rzeczypospolitej Polskiej z dnia 17. marca 1921, „Przegląd Prawa i Administracji” 1921.

Starzyński S., Współczesny ustrój prawno-polityczny Polski i innych państw słowiańskich, K.S. Jakubowski, Lwów 1928 (reprint Wydawnictwo Sejmowe, Warszawa 2010).

Stobiecki R., Najnowsze dzieje polski w syntezach historycznych okresu PRL, „Przegląd Zachodni" 1994, z. 4. 
Stobiecki R., Historia i historycy w latach przełomu październikowego 1956, „Tygiel Kultury” 1996, nr 10-11.

Stobiecki R., Stalinowska unifikacja nauki historycznej (przykład Polski), „Acta Universitatis Lodziensis. Folia Historica" 1996, t. 55.

Stobiecki R., Pierwsza Konferencja Metodologiczna Historyków Polskich, [w:] Skryte oblicze systemu komunistycznego. U źródet zła..., red. R. Bäcker, P. Hübner, Wydawnictwo DiG, Warszawa 1997.

Stobiecki R., Historiografia PRL. Ani dobra, ani madra, ani piękna ... ale skomplikowana. Studia i szkice, Wydawnictwo Trio, Warszawa 2007.

Supruniuk A., Supruniuk M.A., Nauki prawne w Uniwersytecie Stefana Batorego w Wilnie w latach 1919-1944, [w:] Nauki historycznoprawne w polskich uniwersytetach w II Rzeczypospolitej, red. M. Pyter, Wydawnictwo KUL, Lublin 2008.

Śliwa M., Uwagi Mieczysława Niedziałkowskiego o tzw. kryzysie parlamentaryzmu, „Dzieje Najnowsze", R. XI, 1979, z. 1.

Śliwa M., Polska myśl polityczna w I połowie XX wieku, Zakład Narodowy im. Ossolińskich, Wrocław 1993.

Śliwa M., Ludowcy i socjaliści w parlamencie II Rzeczypospolitej, Kancelaria Sejmu, Warszawa 1995.

Tarkowski M., Wileńscy prawnicy wobec wybranych koncepcji ustrojowo-politycznych oraz kodyfikacji prawa w okresie dwudziestolecia międzywojennego, [w]: Tendencje rozwojowe myśli politycznej i prawnej, red. M. Maciejewski, M. Marszal, M. Sadowski, E-Wydawnictwo. Prawnicza i Ekonomiczna Biblioteka Cyfrowa. Wydział Prawa, Administracji i Ekonomii Uniwersytetu Wrocławskiego, Wrocław 2014.

Tyrchan M., Nauki historycznoprawne w latach 60. XX wieku - organizacja badań, „Krakowskie Studia z Historii Państwa i Prawa" 2012, z. 5.

Tyrchan M., Nauki prawnohistoryczne 1945-1956 w Polsce, „Przegląd Historyczny” 2012, z. 1.

Wacław Komarnicki (1891-1954), uczony, polityk, specjalista prawa państwowego i administracyjnego, działacz społeczny i polityczny, [w:] K. Pol, Poczet prawników polskich, C.H. Beck, Warszawa 2000.

Wapiński R., Historia polskiej myśli politycznej XIX i XX wieku, „Arche”, Gdańsk 1997.

Więcej niż niepodległość. Polska myśl polityczna 1918-1939, red. J. Jachymek, W. Paruch, Wydawnictwo Uniwersytetu Marii Curie-Skłodowskiej, Lublin 2005.

Zaporowski Z., Sejm Rzeczypospolitej Polskiej 1919-1939: działalność postów, parlamentarne koncepcje Józefa Pitsudskiego, mniejszości narodowe, Wydawnictwo Uniwersytetu Marii Curie-Skłodowskiej, Lublin 1992.

Zielińska B., Miklaszewski Walenty Lukasz, [w:] Polski stownik biograficzny, t. XXI, Wrocław-Warszawa-Kraków 1976.

Złota ksiega Wydziału Prawa i Administracji Uniwersytetu Jagiellońskiego, red. J. Stelmach, W. Uruszczak, Wydawnictwo Uniwersytetu Jagiellońskiego, Kraków 2000.

Zoll A., Makarewicz Juliusz, [w:] Polski słownik biograficzny, t. XIX, Wrocław-Warszawa-Kraków 1974.

Żabicka-Kłopotek M., Zygmunt Klemens Cybichowski (1879-1946), [w:] Konstytucjonaliści polscy 1918-2011, red. A. Szmyt, P. Sarnecki, R. Mojak, Wydawnictwo Sejmowe, Warszawa 2012. 


\title{
PROCEDURY USTAWODAWCZE W PIERWSZYM SEJMIE ODRODZONEJ RZECZYPOSPOLITEJ POLSKIEJ (1919-1922). REGULACJA PRAWNA I PRAKTYKA PARLAMENTARNA
}

\author{
LEGISLATIVE PROCEDURES IN THE FIRST SEJM \\ OF THE RENASCENT REPUBLIC OF POLAND (1919-1922). \\ LEGAL REGULATIONS AND PARLIAMENTARY PRACTICE
}

From its onset, the Legislative Sejm 1919-1922 took on all the fundamental functions of a parliament in a constitutional state, the most important of which was the legislative competence. The constituent assembly was forced to establish the legal rules of the functioning of the state as a whole, and to lay down the procedures of its own work. The legal-positive foundation of those procedures was rather modest. It comprised fragmentary regulations in the so-called small constitution of 20 February 1919, several ordinary statutes delegating competences to pass acts in the form of decrees and extraordinary legislation to the executive power, as well the most complex but incomplete norms included in the provisional regulations of the Legislative Sejm of 14 February 1919. The deficiency of legal-positive regulation, apparent in numerous situations, had to be overcome by parliamentary practice referring to solutions applied in regulations and parliamentary customs of the Western states, particularly partitioning powers, in representations previously peopled by some Deputies of the constituent assembly, but also France and, incidentally, other countries. The chamber established its own solutions and customs relatively quickly and some of them lasted until the end of the interwar period. The legislative proceedings included numerous procedures: general, applied to pass ordinary statutes, and particular, i.e. legislative procedures to pass the constitution and the budget. The latter also included proceedings comprising elements of oversight and legislative procedure, such as the procedure of granting the consent to ratify international agreements and the procedure of approving the decree legislation passed by the executive. All procedures could be shortened (shortened proceedings) or accelerated (urgency clause), just as all comprised distinguished stages: the first reading of a bill held at a plenary session (Deputies' bills preferred); committee works on the bill; second reading before the whole chamber, beginning with a committee report, followed by a general, then a detailed debate, and partial, then general vote; third reading, sometimes preceded by an additional stage of committee works, and often automatically commenced immediately after the second reading; promulgation of an act by the Marshal of the Sejm and ordering its publication in the official gazette.

Słowa kluczowe: czytania projektu ustawy, inicjatywa ustawodawcza, komisje sejmowe, konstytuanta, mała konstytucja z 1919 r., marszałek Sejmu, ogólna procedura ustawodawcza, poseł sprawozdawca, postępowanie ustawodawcze, praktyka parlamentarna, prawo pozytywne, prawo zwyczajowe, procedura budżetowa, procedura skrócona, tryb ustawodawczy, tymczasowy regulamin obrad Sejmu Ustawodawczego, uchwalanie konstytucji, ustawodawstwo dekretowe, wniosek nagły, wniosek poselski, zgoda na ratyfikację umów międzynarodowych, źródła prawa

Key words: reading of a bill, legislative initiative, Sejm committees, constituent assembly, small constitution of 1919, Marshal of the Sejm, general legislative procedure, Deputy-Rapporteur, parliamentary practice, positive law, custom law, budget procedure, shortened proceedings, legislative procedure, provisional regulations of the Legislative Sejm, passing of a constitution, decree legislation, urgent motion, Deputy's motion, consent to ratify an international agreement, sources of law

* Dr hab. Piotr A. Tusiński, prof. Uniwersytetu Pedagogicznego im. KEN w Krakowie, Instytut Prawa, Administracji i Ekonomii, ptusinski@up.krakow.pl 


\section{WPROWADZENIE}

Darlament działający w ramach systemu odpowiedzialności rządu (casus

1 III Republiki Francuskiej), jak również w warunkach jego odmiany zracjonalizowanej po I wojnie światowej (w republikach: weimarskiej i austriackiej oraz szeregu państw Europy Środkowo-Wschodniej, w tym w Polsce) ${ }^{1}$ pełnił szereg funkcji ustrojowych, z których najistotniejsze były kompetencje: ustawodawcza, kontrolna i kreacyjna ${ }^{2}$. Funkcje te, charakterystyczne dla parlamentu mieszczącego się w ramach pouvoir constitué, a więc związanego przepisami konstytucji i usytuowanego obok innych organów konstytucyjnych, cechowały parlament wywindowany do roli suwerena, a więc konstytuantę. Dla każdej ze wspomnianych funkcji ustrojowych charakterystyczne było działanie zgodne z określonym trybem postępowania (procedury parlamentarnej), rozumianego jako regulowany normami prawa i zwyczajami zbiór czynności, układających się w sukcesywny (sekwencyjny, etapowy) łańcuch decyzyjny i podejmowanych wyłącznie przez podmioty wskazane normami kompetencyjnymi, w kolejności wyznaczonej normami formalnymi i organizacyjnymi, prowadzący do załatwienia (rozstrzygnięcia) jakiejś sprawy mieszczącej się w uprawnieniach parlamentu ${ }^{3}$.

W ramach funkcji ustawodawczej Sejm Ustawodawczy Rzeczypospolitej Polskiej [dalej: SU] stosował kilka procedur parlamentarnych — procedurę ustawodawcza ogólną (w zakresie uchwalania ustaw zwykłych) oraz procedury szczególne: ustawodawczą w sprawie uchwalenia konstytucji (część doktryny wyróżnia nawet w związku z tym osobną funkcję parlamentu bądź procedurę parlamentarna, procedurę ustrojodawcza) i procedurę budżetową ${ }^{4}$. Do grupy procedur szczególnych należy również zaliczyć procedury łączące w sobie elementy postępowania kontrolnego sensu stricto z elementami postępowania ustawodawczego, do których można zaliczyć procedurę wyrażania zgody na ratyfikację umów międzynarodowych i procedurę zatwierdzania ustawodawstwa dekretowego stanowionego przez egzekutywę.

\section{KONSTYTUCYJNE ŹRÓDLA PRAWA PROCEDUR USTAWODAWCZYCH}

Procedury parlamentarne stosowane w SU w latach 1919-1922 były regulowane aktami normatywnymi rangi konstytucyjnej, ustawami zwykłymi, aktem wewnętrznego prawa parlamentarnego (regulaminem izby) oraz normami prawa zwyczajowego. Charakterystyczną cechą regulacji pozytywnoprawnych z tego zakresu prawa było łączenie w jednym akcie norm formalnoprawnych z przepisami materialnoprawnymi

1 J. Stembrowicz, Rzad w systemie parlamentarnym, Warszawa 1982, s. 60 i n.

2 B. Banaszak, Prawo konstytucyjne, Warszawa 2012, s. 435-438.

3 Vide m.in.: Stownik języka polskiego, t. 2: L-P, Warszawa 1979, s. 926; E. Kustra, Proces ustawodawczy jako proces decyzyjny, „Acta Universitatis Nicolai Copernici. Prawo XII. Nauki Humanistyczno-Społeczne" 1973, z. 56, s. 110; P.A. Tusiński, Postępowanie ustawodawcze w Sejmie i w Senacie II Rzeczypospolitej 1919-1939. Prawo - zwyczaje — praktyka parlamentarna, Radom 2008, s. 25.

4 Confer P.A. Tusiński, op. cit., s. 257-259. 
w każdym z wymienionych typów prawodawstwa. Postępowanie ustawodawcze z racji wiodącej kompetencji ustrojowej izby, jaką była funkcja ustawodawcza, podlegało najszerszej regulacji normatywnej. W okresie bezpośrednio poprzedzającym zebranie się SU oraz w trakcie jego kadencji obowiązywały trzy akty prawne pełniące rolę prowizorycznej (tymczasowej) konstytucji. Pierwszym był wydany 3 stycznia $1918 \mathrm{r}$. przez Radę Regencyjną dekret o tymczasowej organizacji władz naczelnych w Królestwie Polskim 5 . Drugim ustanowiony przez Radę Ministrów i Tymczasowego Naczelnika Państwa dekret z dnia 22 listopada 1918 r. o najwyższej władzy reprezentacyjnej Republiki Polskiej ${ }^{6}$. Trzecim uchwała Sejmu z dnia 20 lutego 1919 r. o powierzeniu Józefowi Piłsudskiemu dalszego sprawowania urzędu Naczelnika Państwa [dalej: mała konstytucja z 20 lutego 1919 r.] $]^{7}$.

Dekret z 3 stycznia 1918 r. o tymczasowej organizacji władz naczelnych w Królestwie Polskim miał fundamentalne znaczenie dla kształtu ustrojowego rządu do czasu wejścia w życie ustawy zasadniczej z 17 marca 1921 r. ${ }^{8}$, a częściowo — jako podstawa prawna działalności szeregu ministerstw - zachował aktualność nawet do końca międzywojnia. Dekretem powierzono władzę zwierzchnią w Królestwie Radzie Regencyjnej [dalej: RR], która miała ją sprawować za pośrednictwem prezydenta Rady Ministrów (premiera) oraz poszczególnych ministrów. Wszelkie akty RR musiały być kontrasygnowane przez prezydenta ministrów.

Problematykę ,ustawodawstwa zwykłego" uregulowano w art. 3 dekretu z dnia 22 listopada 1918 r. o najwyższej władzy reprezentacyjnej Republiki Polskiej. Dekrety, zwane projektami ustawodawczymi oraz ustawami, były uchwalane przez Radę Ministrów i zatwierdzane przez Tymczasowego Naczelnika Państwa9. Uzyskiwały one moc obowiązującą z chwilą ogłoszenia ich w „Dzienniku Praw Państwa Polskiego", chyba że same stanowiły inaczej. Moc tę uzyskiwały tymczasowo, pod rygorem jej utraty, na okres do dnia pierwszego posiedzenia SU, na którym miały być mu przedstawione do zatwierdzenia. Notabene przepis ten został dokładnie powtórzony za dekretem RR z dnia 15 października 1918 r., dotyczącym ustawodawstwa tymczasowego, w którym ta ogłosiła się organem władzy uprawnionym do stanowienia rozporządzeń z mocą ustawy ${ }^{10}$. Przepis obligujący do przedstawienia dekretów Sejmowi do zatwierdzenia na pierwszym jego posiedzeniu miał, jak się wkrótce okazało, charakter głównie proceduralny, ponieważ SU na swoim pierwszym posiedzeniu ograniczył się tylko do odczytania przez tymczasowego sekretarza obrad, posła Mieczysława Niedziałkowskiego, spisu przedłożonych przez rząd 216 dekretów RR

5 „Dziennik Praw Królestwa Polskiego” [dalej: Dz.P.K.P.] z 1918 r. nr 1, poz. 1. Treść dekretu omawia: W. Komarnicki, Polskie prawo polityczne (Geneza i system), Warszawa 1922, s. 44-47.

6 „Dziennik Praw Państwa Polskiego” [dalej: Dz.P.P.P.] z 1918 r. nr 17, poz. 41.

7 Uchwała Sejmu z dnia 20 lutego 1919 roku o powierzeniu Józefowi Piłsudskiemu dalszego sprawowania urzędu Naczelnika Państwa, Dz.P.P.P. nr 19, poz. 226.

${ }^{8}$ Ustawa z dnia 17 marca 1921 roku Konstytucja Rzeczypospolitej Polskiej, Dz.U. nr 44, poz. 267.

9 Confer R. Kraczkowski, Dekretowanie ustaw w Polsce w latach 1918-1926, Warszawa 1994, s. $32-33$.

${ }^{10}$ Dekret z dnia 15 października $1918 \mathrm{r}$. w przedmiocie tymczasowego wykonywania władzy ustawodawczej, Dz.P.K.P. nr 12, poz. 24; R. Kraczkowski, op. cit., s. 29 i 33. 
i Tymczasowego Naczelnika Państwa oraz przyją je „do ustawowego traktowania”, czyli zatwierdzenia w trybie ustawodawczym, a nie kontrolnym. Na 3. posiedzeniu Sejm skierował wszystkie te dekrety do świeżo powołanej ze swego grona Komisji Prawniczej, która miała je ewentualnie przesłać dalej do innych komisji wedle ich właściwości przedmiotowej ${ }^{11}$. Praca nad tymi dekretami trwała w następnych tygodniach i miesiącach funkcjonowania konstytuanty, co oznaczało rozciagnięcie ich mocy obowiązującej poza dzień 10 lutego 1919 r., kiedy SU zainaugurował swe obrady. Więcej o aspektach procedury rozpatrywania tych dekretów przez konstytuantę będzie dalej.

Uchwalona przez SU 20 lutego 1919 r. mała konstytucja była w sprawach ustawodawstwa niemal równie enigmatyczna jak dekret z 22 listopada 1918 r. W jej artykule II, w zadaniu pierwszym, zapowiadano uchwalenie konstytucji w sposób „ustawowy”, a w konstytucji miano zawrzeć ,zasadniczo przepisy o organizacji naczelnych władz w Państwie Polskim”. W 1. punkcie powołanego artykułu określono SU jako władzę ,suwerenną i ustawodawczą" oraz ustanowiono, że uchwalane przez Sejm „ustawy” ogłasza marszałek Sejmu. Jak zauważono w literaturze, „Mała konstytucja nie określała zakresu przedmiotowego ustawodawstwa ani przypadków wyłączności ustawy. Sejm Ustawodawczy był suwerenny: mając nieoznaczone kompetencje mógł zastrzec do swej decyzji każdą sprawę. Konsekwencją utrzymania w mocy dotychczasowego porządku prawnego była jednak konieczność sięgania po formę ustawy w tych wszystkich sprawach, które zostały uregulowane aktami ustawodawczymi zaborców. Drugą grupę stanowiły materie, które stały się już przedmiotem ustawodawstwa Sejmu bądź zostały uregulowane dekretami Tymczasowego Naczelnika Państwa lub Rady Regencyjnej. Trzecią natomiast były te, które zgodnie z panującymi poglądami winny być uregulowane ustawowo"12. W niewielkim tylko zakresie deficyt regulacji materii ustawodawczej w małej konstytucji usunięto jej nowelizacją z 13 lutego 1920 r. ${ }^{13}$, w której postanowiono, że: „Emisja biletów Polskiej Krajowej Kasy Pożyczkowej lub innych biletów, obciążających Skarb Państwa, nie mniej zaciaganie pożyczek państwowych, tudzież przyjmowanie przez Państwo gwarancji finansowych nie może nastapić bez uprzedniego zezwolenia Sejmu".

Uchwała SU z 20 lutego 1919 r. formalnie nie miała rangi ustawy, ale zarówno w ówczesnej doktrynie, jak i w praktyce ustrojowej nie podważano jej rangi konstytucyjnej. Częściowo ten formalny mankament małej konstytucji usunięto ustawą przechodnią z dnia 18 maja $1921 \mathrm{r} .{ }^{14}$, uchwaloną w związku z zamierzonym vacatio legis dla konstytucji z 17 marca 1921 r. Ustawa ta ze względu na jej treść normatywną niewątpliwie miała charakter ustawy konstytucyjnej. W art. 1 powołanej ustawy stano-

${ }_{11}$ R. Kraczkowski, op. cit., s. 34.

${ }^{12}$ Ibidem, s. 45.

${ }^{13}$ Uchwała Sejmu z dnia 13 lutego 1920 r. uzupełniająca uchwałę Sejmu z dnia 20 lutego 1919 r. o powierzeniu Józefowi Piłsudskiemu dalszego sprawowania urzędu Naczelnika Państwa, Dz.U. nr 17, poz. 84.

${ }^{14}$ Ustawa przechodnia z dnia 18 maja 1921 r. do ustawy konstytucyjnej z dnia 17 marca 1921 r. w sprawie tymczasowej organizacji władzy zwierzchniej Rzeczypospolitej, Dz.U. nr 44, poz. 268. 
wiono, że: „Sejm Ustawodawczy sprawuje swą władzę w dotychczasowym zakresie do chwili ukonstytuowania się władzy ustawodawczej na zasadach ustawy konstytucyjnej z dnia 17 marca 1921 roku", przez co pośrednio nadano sankcję ustawy konstytucyjnej tym przepisom uchwały z 20 lutego 1919 r., które określały kompetencje konstytuanty ${ }^{15}$.

\section{USTAWOWE ŹRÓDLA PRAWA PROCEDUR PARLAMENTARNYCH}

Deficyt unormowań ustroju państwa określonego w przepisach małej konstytucji z 20 lutego 1919 r. wypełniały w pewnej mierze, choć w zakresie dalekim od wyczerpującego, przepisy niektórych ustaw zwykłych — zarówno utrzymanych w mocy z poprzednich okresów ustrojowych, jak i uchwalanych przez konstytuantę - oraz przede wszystkim przepisy tymczasowego regulaminu obrad Sejmu Ustawodawczego Rzeczypospolitej Polskiej, uchwalonego 14 lutego 1919 r. ${ }^{16}$

Ustawy zwykłe okresu konstytuanty o materii ustawodawstwa traktowały jedynie w odniesieniu do tzw. ustawodawstwa delegowanego, zwanego też dekretowym. Z jednej strony przepisy te upoważniały organy władzy wykonawczej do dekretowania ustaw, zawężając tym samym przedmiotowo i czasowo kompetencję ustawodawczą parlamentu bądź lokując ją niejako konkurencyjnie w rękach egzekutywy, z drugiej zaś nakładały na te organy obowiązki związane z przedstawianiem dekretów do wiadomości bądź zatwierdzenia przez Sejm. Ta ostatnia kwestia implikowała uprawnienia Sejmu do uchylania tych dekretów w odpowiedniej formie i procedurze.

W okresie obowiazzywania małej konstytucji z 20 lutego 1919 r. SU uchwalił w sumie 10 ustaw upoważniających rząd (Radę Ministrów i poszczególnych ministrów) do stanowienia ustawodawstwa dekretowego (mówiąc ściśle, jedna z nich dotyczyła nadania ministrowi przemysłu i handlu uprawnień do regulowania w rozporządzeniach spraw opałowych, które to pełnomocnictwo, funkcjonujące 21 miesięcy, zaliczono w literaturze do prawodawstwa wyjattkowego, a nie delegowanego), a czterokrotnie uchwalenia takiej delegacji odmówił ${ }^{17}$. Częściowo podobny do delegacji ustawodawczej ustanowionej we wspomnianych ustawach pod rządami małej konstytucji charakter - przynajmniej w zakresie czasowego ograniczenia kompetencji ustawodawczej Sejmu - miały tzw. akty prawotwórstwa wyjątkowego, stanowione przez Radę Obro-

15 W czerwcu 1922 r. o włączeniu przepisów małej konstytucji do ,wielkiej konstytucji” na mocy ustawy przechodniej z 18 maja 1921 r. był przekonany poseł H. Lieberman: vide sprawozdanie stenograficzne z posiedzenia Sejmu Ustawodawczego [dalej: spr. sten. SU] z 321. posiedzenia z 23 czerwca 1922 r., ł. 6.

16 Tymczasowy regulamin obrad Sejmu Ustawodawczego Rzeczypospolitej Polskiej, Sejm Ustawodawczy Rzeczypospolitej Polskiej 1919-1922, druk nr 1; ,Tymczasowy regulamin obrad Sejmu Ustawodawczego Rzeczypospolitej Polskiej z uwzględnieniem zmian...”, Sejm Ustawodawczy RP, druk nr 1, Warszawa 15 września 1921 r. Pierwotny tekst regulaminu opublikował też T. Rzepecki: Sejm Rzeczypospolitej Polskiej 1919 roku, Poznań 1920, s. 40-48. Tekst regulaminu wraz z wykazem jego nowelizacji — notabene w ujęciu nierzetelnym, z błędami i pominięciami — w opracowaniu T. Koperskiej opublikowano też w „Przeglądzie Sejmowym” 1993, nr 1, s. 99-110.

${ }_{17}$ Regulacje te, jak również przedłożenia odrzucone przez Sejm oraz pełnomocnictwa opałowe omawia R. Kraczkowski, op. cit., s. 46-56, 78-80. 
ny Państwa [dalej: ROP] ${ }^{18}$. Na mocy ustawy z dnia 1 lipca 1920 r. o utworzeniu Rady Obrony Państwa ${ }^{19}$ stała się ona tymczasowym organem władzy ustawodawczej i wykonawczej, któremu podlegała Rada Ministrów. Rada, wykonując funkcje ustawodawcze, miała prawo do wydawania rozporządzeń z tymczasową mocą ustaw. Tymczasowa, ponieważ rozporządzenia te wymagały następczego zatwierdzenia przez SU i miały mu być w tym celu przedstawiane na najbliższym posiedzeniu po ich wyda$\mathrm{niu}^{20}$. Podstawowe aspekty postępowania sejmowego w tym zakresie omówiono dalej. Należy również zauważyć, że SU — niezależnie od wspomnianych ustaw — niepublikowaną w „Dzienniku Ustaw” uchwała (sic!) z dnia 1 sierpnia 1919 r. upoważnił ministra skarbu do tymczasowego regulowania stosunków celnych w drodze rozporządzeń (z obowiązkiem ich publikacji w „Dzienniku Ustaw”), a więc udzielił mu faktycznie pełnomocnictw dekretowych ${ }^{21}$.

\section{POSTĘPOWANIE USTAWODAWCZE W PRZEPISACH TYMCZASOWEGO REGULAMINU OBRAD SU ORAZ PRAKTYKI PARLAMENTARNEJ}

Wobec znaczącego deficytu regulacji kwestii ustroju państwa w przepisach małej konstytucji z 20 lutego 1919 r. oraz incydentalnego podejmowania materii dotyczącej ustawodawstwa i kontroli rządu w ustawach zwykłych podstawowe zadanie reglamentacji prawnej ich aspektów formalnych (a częściowo również materialnoprawnych) spoczęło na tymczasowym regulaminie obrad SU. Brak regulacji odnoszących się do postępowania ustawodawczego w małej konstytucji z 20 lutego 1919 r. sprawił, że pod jej rządami jedynym źródłem pozytywnego prawa parlamentarnego, normującego niektóre kwestie materialnoprawne dotyczące ustawodawstwa oraz przebieg procedury ustawodawczej w SU, był regulamin izby. Tymczasowy regulamin obrad SU do chwili wejścia w życie konstytucji marcowej pozostawał w zasadzie jedynym aktem normującym szczegółowe kompetencje, strukturę wewnętrzną i procedury pracy SU. Charakterystyczne, że regulamin ten dotyczył nie tylko obrad Sejmu, ale również wielu innych istotnych kwestii ustrojowych oraz że — mimo zaznaczonej w tytule ,tymczasowości" - stanowił on podstawę funkcjonowania konstytuanty do końca jej działania $^{22}$. Tymczasowy regulamin obrad był w zakresie postępowania ustawodawczego

${ }^{18}$ Formalnie natomiast nie miały charakteru aktów ustawodawczych (dekretów), lecz rozporządzeń wykonawczych, wspomniane rozporządzenia ministra przemysłu i handlu wydawane w ramach nadzwyczajnych pełnomocnictw opałowych, na podstawie ustawy z dnia 14 lipca 1920 r. w sprawie udzielenia Ministrowi Przemysłu i Handlu nadzwyczajnych pełnomocnictw do uregulowania spraw opałowych, Dz.U. nr 75, poz. 508 , ze zm.).

19 Dz.U. nr 53, poz. 327.

${ }^{20}$ Confer R. Kraczkowski (op. cit., s. 58-59); P.K. Marszałek, Rada Obrony Państwa z 1920 roku. Studium prawnohistoryczne, „Acta Universitatis Wratislaviensis” 1995, Prawo CCXXVIII, passim.

${ }_{21}$ Vide spr. sten. z 83. posiedzenia SU, 1 sierpnia 1919 r., ł. 15-39.

${ }^{22}$ Zgodnie z art. 1 tymczasowego regulaminu miał on obowiązywać do chwili uchwalenia przez Sejm ostatecznego regulaminu na wniosek Komisji Regulaminowej. Nie nastapiło to jednak do końca funkcjonowania konstytuanty. Już 4 sierpnia 1919 r. posłowie Związku Ludowo-Narodowego [dalej: ZLN] zgłosili wniosek w sprawie uchwalenia stałego regulaminu Sejmu w formie ustawy, z załączonym do niego projektem (druk nr 969). Wniosek nie doczekał się jednak rozpatrzenia. 
trzykrotnie (w niewielkim stosunkowo zakresie) nowelizowany uchwałami izby podjętymi w dniach 24 marca 1920 r., 21 stycznia i 1 marca 1921 r. ${ }^{23}$

Mimo relatywnie rozbudowanej i szczegółowej — w porównaniu z innymi procedurami parlamentarnymi - reglamentacji prawnej postępowania ustawodawczego okresu konstytuanty w przepisach pozytywnego prawa parlamentarnego (głównie w regulaminie sejmowym) trudno uznać ją za wyczerpująca. Tu i ówdzie w tym niewątpliwie złożonym trybie procedowania występowały znaczące luki regulacyjne oraz sformułowania nieostre, z których tylko niewielka część doczekała się do końca kadencji SU uściśleń poprzez nowelizację regulaminu. Zasadniczą większość tych niedostatków musiano przezwyciężyć w praktyce parlamentarnej wypracowywanej ad hoc na rodzimym gruncie bądź sięgając do zapożyczeń z norm zwyczajowego prawa parlamentarnego państw wzorcowych dla odradzającego się parlamentaryzmu polskiego (głównie Prus i II Rzeszy Niemieckiej, Austrii i autonomicznej Galicji oraz Francji).

Obserwacja praktyki parlamentarnej w okresie konstytuanty pozwala na sformułowanie spostrzeżenia, że postępowanie ustawodawcze przebiegało w trzech fazach: przygotowawczej, obejmującej czynności sporządzenia projektu ustawy ${ }^{24}$ oraz wykonania inicjatywy ustawodawczej; głównej, obejmującej trzy czytania projektu na forum plenarnym i rozdzielające czytania plenarne prace $\mathrm{w}$ komisji/komisjach sejmowych; oraz w kończącej bieg postępowania fazie promulgacji i ogłoszenia ustawy, obejmującej podpisanie projektu przez marszałka Sejmu i zarządzenie jego ogłoszenia w „Dzienniku Ustaw” przez prezydenta Rady Ministrów ${ }^{25}$.

Warto podkreślić, że pewna część przepisów tymczasowego regulaminu obrad SU, odnoszących się do ustawodawstwa, w warunkach sygnalizowanej wcześniej zwięzłości regulacyjnej małej konstytucji miała de facto i de iure charakter przepisów materialnoprawnych i wkraczała w obszar normowany zwykle ustawą zasadniczą. Niewątpliwie taki charakter miały przepisy art. 15 i 16 regulaminu, normujące zagadnienie podmiotów inicjatywy, sensu largo wnioskodawczej, a sensu stricto ustawodawczej. Rozróżnienie obu zakresów przedmiotowych inicjatywy jest o tyle istotne, że w regulaminie tego nie zrobiono. Ustanowiono tylko $\mathrm{w}$ jego art. 15, że przedmiotem obrad Sejmu mógł być „,wniosek” rządu, komisji sejmowej, ewentualnie większości lub mniejszości komisji oraz posła. Natomiast w art. 38 regulaminu ustanowiono, że „projekty ustaw podlegają trzem czytaniom”, pozostałe wnioski więc, a contrario, nie musiały im podlegać, co potwierdziła w całej rozciagłości praktyka parlamentarna okresu konstytuanty. Jest przy tym oczywiste (dowodem na to są druki SU), że tylko część z wniosków, które wpływały do laski marszałkowskiej, zawierała w załączeniu projekty ustaw. Zgodnie z art. 15 i 16 tymczasowego regulaminu obrad SU inicjatywa wnioskodawcza (w tym ustawodawcza) przysługiwała:

${ }^{23}$ A. Gwiżdż, Formy pracy sejmów Drugiej Rzeczypospolitej, [w:] Sejmy Drugiej Rzeczypospolitej, red. A. Zakrzewski, Warszawa 1990, s. 126.

${ }^{24} \mathrm{~W}$ praktyce parlamentarnej już od zarania prac konstytuanty przyjmowano, że projekt ustawy musi być sformułowany normatywnie.

${ }^{25}$ Szczegółowo o całym przebiegu postępowania ustawodawczego w SU oraz w izbach parlamentarnych następnych kadencji vide P.A. Tusiński, op. cit., passim. 
rządowi ${ }^{26}$, komisji sejmowej, większości komisji sejmowejj ${ }^{27}$, mniejszości komisji oraz grupie co najmniej 15 posłów ${ }^{28}$. Projekt musiał być zgłoszony na piśmie (w tym przypadku był to już wymóg odnoszący się tylko do formy projektu). Poselskie przedłożenie ustawodawcze musiało być zaopatrzone w podpisy popierających je posłów ${ }^{29}$.

Odnośnie do samej instytucji wniosku parlamentarnego (w tym ustawodawczego) w okresie konstytuanty należy podkreślić, że zwiększeniu siły jego oddziaływania, ale przede wszystkim przyspieszeniu uchwalenia, służyła przewidziana w art. 35 regulaminu instytucja trybu nagłego (nadawanego na przedstawiony marszałkowi, na piśmie wraz z załączeniem motywów, wniosek rządu lub 30 posłów), wyraźnie wzorowana na parlamentaryzmie austriackim ${ }^{30}$. W pierwszych tygodniach obrad konstytuanty zgłoszone w takim trybie wnioski marszałek poddawał pod głosowanie na forum plenarnym, w celu nadania im klauzuli nagłości ${ }^{31}$, ale odstępował od wymogu głosowania i ograniczał się do podania stosownej informacji o przesłaniu wniosku w trybie nagłym wprost do komisji, jeśli został on podpisany przez posłów z kilku dużych klubów wraz z ich przywódcami, co niewątpliwie rokowało poparcie wniosku ${ }^{32}$. Już pierwsze dni działalności SU przyniosły bardzo dużą liczbę wniosków uznanych przez ich inicjatorów za nagłe ${ }^{33}$. W następstwie tego w praktyce nastapiła zmiana wykładni przepisu art. 35 regulaminu stosowanej przez Konwent Seniorów ${ }^{34}$. W nowej wykładni (wyraźnie praeter legem) przyjęto, że zaopatrzenie wniosku w 30 podpisów jest wystarczającym i automatycznym wymogiem upoważniającym do nadania mu klauzuli nagłości, bez konieczności zatwierdzenia jej przez izbę. Stanowiło też upoważnienie do przesłania wniosku przez marszałka bezpośrednio do komisji, po poinformowaniu o tym posłów na posiedzeniu plenarnym izby ${ }^{35}$. W pierwszym roku funk-

${ }^{26}$ Rząd w opisywanym okresie korzystał z niej zasadniczo (ale, jak się okazało, z licznymi wyjątkami) in collegio; vide P.A. Tusiński, op. cit., s. 87-109.

${ }^{27}$ Użyte w cytowanym przepisie zwroty „komisji” i ,większości komisji” na oznaczenie dwóch różnych podmiotów inicjatywy ustawodawczej były w praktyce rozróżnieniem pozornym. W gruncie rzeczy mógł to być wyłącznie jeden i ten sam podmiot, bowiem komisja mogła zająć stanowisko tylko większością głosów swych członków.

${ }^{28}$ Było to wyraźne nawiązanie do niemieckiej tradycji parlamentarnej, gdzie przyjęto dokładnie taki sam wymóg. Różnica dotyczyła jednak możliwości wnoszenia poprawek do projektu ustawy, ponieważ w Niemczech mógł to uczynić nawet pojedynczy poseł, podczas gdy w SU co najmniej 15; confer H.J. Schreiner, Procedury w niemieckiej tradycji parlamentarnej, „Przegląd Sejmowy” 1994, nr 4, s. 50-51.

${ }^{29}$ Na temat inicjatywy ustawodawczej łącznie z jej obrazem statystycznym vide P.A. Tusiński, op. cit., s. $87-114$.

${ }^{30}$ Confer S. Głąbiński, Wspomnienia polityczne, Pelplin 1939, s. 123; W. Witos, Moje wspomnienia, Warszawa 1978, s. 288.

31 Np. spr. sten. z 4. posiedzenia SU, 22 lutego 1919 r., ł. 97-98, 100, 151.

32 Spr. sten. z: 17. posiedzenia SU, 21 marca 1919 r., ł. 915-916; z 23. posiedzenia SU, 1 kwietnia 1919 r., ł. 53; z 85. posiedzenia SU, 1 października 1919 r., 1. 29.

${ }_{33}$ Zwracał na to zjawisko uwagę marszałek W. Trąmpczyński, apelując do posłów o umiar; vide spr. sten. z 6. posiedzenia SU, 25 lutego 1919 r., ł. 202.

34 Szerzej o konwencie vide P.A. Tusiński, Norma prawna i obyczaj jako podstawa wyłaniania i funkcjonowania organów kierowniczych parlamentu II Rzeczypospolitej, „Prace Naukowe Politechniki Radomskiej im. Kazimierza Pułaskiego: Ekonomika" 1999, nr 1, s. 94-99.

35 Spr. sten. z 40. posiedzenia SU, 22 maja 1919 r., ł. 67-68 oraz z 42. posiedzenia SU, 27 maja 1919 r., 1. 65 . 
cjonowania SU utarł się zwyczaj, że tryb nagły zatwierdzano na plenum tylko w przypadku wniosków o charakterze stricte politycznym, a o postawieniu sprawy na porządku dziennym decydował dyskrecjonalnie marszałek Sejmu ${ }^{36}$, ale już wiosną 1920 r. zwyczaj ten rozszerzono również na wnioski o charakterze ekonomicznym ${ }^{37}$. Zgodnie ze stanowiskiem Konwentu Seniorów z lata 1920 r., jeśli wnioskodawcy domagali się dyskusji nad trybem nagłym na forum plenarnym, to uprawnienie do nadania tego trybu przechodziło z marszałka na izbę. W październiku tego roku Konwent postanowił dodatkowo, że nad trybem nagłym miano dyskutować na plenum izby dopiero po uprzednim przedstawieniu wniosku przedstawicielom poszczególnych klubów w celu zapoznania się z nim$^{38}$. Natomiast w przypadku wniosków nieroztrząsanych na plenum, konwent - aby uniknąć niespodzianek — postanowił sam nadawać klauzulę nagłości ${ }^{39}$. Zebranie pod wnioskiem 30 podpisów w celu uznania trybu nagłego wcale nie było trudne, zważywszy na zasadę wzajemności. W ten sposób z formy kwalifikowanej, jaką niewątpliwie chcieli mu nadać twórcy regulaminu, wniosek nagły stał się instytucją stosowaną na co dzień. Posłowie wobec nawału wniosków nagłych doskonale zdawali sobie sprawę, że brak zgody Sejmu na nadanie wnioskowi trybu nagłego i traktowanie go jak zwykłego wniosku praktycznie oznaczało jego ,pogrzebanie”. Stąd większość spośród ponad 2 tys. wniosków zgłaszanych w konstytuancie uznawano nie całkiem formalnie - za wnioski zgłaszane w trybie nagłym ${ }^{40}$. Główny cel zgłaszających taki wniosek, czyli przyspieszenie procedowania, wobec równoczesnego niewyznaczenia komisji terminu na przedstawienie sprawozdania $\mathrm{w}$ jego sprawie, nie był osiagany. W praktyce nadanie trybu nagłego najczęściej nie wpływało bowiem na przyspieszenie uchwalenia ustaw $\mathrm{y}^{41}$. Podejmowane w SU próby ograniczenia tego zjawiska nie przynosiły jednak zadowalających rezultatów do końca jego funkcjonowania ${ }^{42}$.

W regulaminie SU w ogóle nie unormowano zagadnienia związanego z wykonaniem inicjatywy ustawodawczej, pozostawiając tę materię — jak zresztą wiele innych

${ }^{36}$ Konwent Seniorów postanowił nawet 23 marca 1920 r., że klauzula nagłości może przysługiwać tylko wnioskom dotyczącym zagadnień ogólnopolitycznych i tylko takie miały być umieszczane w porządku dziennym obrad Sejmu; vide „Kurier Polski” nr 83, 24 III 1920 r. Marszałek Trąmpczyński dopuszczał apelację od swojej decyzji o nieumieszczeniu dyskusji w sprawie klauzuli nagłości wniosku na forum plenarnym do Konwentu Seniorów. Przyznawał też, że omawiana kompetencja doskwiera mu i postulował przeniesienie jej na Sejm; vide spr. sten. SU ze 163. posiedzenia, 14 lipca 1920 r., 1. 80 oraz spr. sten. z 238. posiedzenia SU, 23 czerwiec 1921 r., 1. 64.

${ }_{37}$ Spr. sten. ze 139. posiedzenia SU, 23 kwietnia 1920 r., 1. 68.

38 Spr. sten. ze 170. posiedzenia SU, 7 października 1920 r., ł. 48.

39 Spr. sten. z 48. posiedzenia SU, 12 czerwca 1919 r., ł. 60; z 49. posiedzenia, 13 czerwca 1919 r., ł. 56; „Kurier Polski” nr 192, 16 VII 1920, oraz nr 263, 25 IX 1920.

40 Sejm Ustawodawczy Rzeczypospolitej Polskiej. Skorowidz rzeczowy do sprawozdań stenograficznych z posiedzeń plenarnych Sejmu pos. 1 (10.II.1919)_pos. 342 (27.XI.1922), Kancelaria Sejmu PRL, Warszawa 1972, maszynopis w Bibliotece Sejmowej [dalej: Skorowidz], s. XXVII-XXVIII.

${ }^{41}$ Zwrócił na to zjawisko uwagę sprawozdawca Komisji Regulaminowej Sejmu I kadencji, przedstawiając projekt regulaminu Sejmu w lutym 1923 r. i podkreślając, że posłowie konstytuanty zdawali sobie sprawę z problematycznej klauzuli nagłości wniosków tak określanych, a składali je mimo to w celach demonstracyjnych; spr. sten z 16. posiedzenia Sejmu I kad., 16 lutego 1923 r., 1. 10. Confer też: L. Zieleniewski, Regulaminy Sejmu i Senatu, „Nowe Państwo” 1936, t. IV, z. 2, s. 47.

${ }^{42}$ Z. Kaczmarek, Wojciech Trampczyński, Poznań 1993, s. 128. 
szczegółowych aspektów procedury ustawodawczej — praktyce parlamentarnej ${ }^{43}$. Nie uwzględniono też możliwości wycofania projektu ustawy przez wnioskodawcę i jego ewentualnych dalszych losów, np. wskutek podtrzymania wniosku przez inny podmiot wyposażony w prawo inicjatywy ustawodawczej.

Szczątkowe tylko materiały źródłowe SU, obrazujące jego prace wewnętrzne, ale też inne źródła pośrednio dotyczące tego zagadnienia nie pozwalają na prześledzenie całości działań marszałka i ewentualnie Komisji Regulaminowej i Nietykalności Poselskiej, składających się na wykonanie inicjatywy ustawodawczej. Na etap ten składały się takie czynności, jak: wniesienie projektu do laski marszałkowskiej; badanie zgodności projektu z konstytucją przez marszałka (i ewentualnie Komisję Regulaminowa); badanie projektu w aspekcie jego poprawności formalno-legislacyjnej (wniesienie na piśmie, sformułowanie normatywne, załączenie odpowiedniej liczby odpisów projektu, załączenie uzasadnienia, opatrzenie projektu odpowiednią liczbą podpisów posłów w przypadku inicjatywy poselskiej lub promowanie projektu przez właściwego ministra, powołującego się na stosowną uchwałę Rady Ministrów o wystapieniu z rządowym projektem ustawy; promowanie projektu przez przewodniczącego komisji, powołującego się na stosowną uchwałę komisji o wystapieniu z własnym projektem ustawy itp.); ewentualna korespondencja i bezpośrednie spotkania marszałka z wymienionymi podmiotami inicjatywy ustawodawczej w celu wyjaśnienia wątpliwości powstających na tym etapie procedury.

W odniesieniu do wykonania inicjatywy ustawodawczej w okresie prac SU udało się natrafić jedynie na wątek dotyczący badania konstytucyjności zgłaszanych projektów ustaw. W tym względzie precedensowa była rezolucja Komisji Skarbowo-Budżetowej SU z 4 października 1921 r., dotycząca kontroli projektów ustaw na etapie prac komisyjnych po pierwszym czytaniu na posiedzeniu plenarnym. Sprawa dotyczyła badania zgodności projektów ustaw z art. 10 konstytucji marcowej. Tekst rezolucji był następujący: „,Komisja Skarbowo-Budżetowa powinna każdy wniosek i projekty ustaw jej przedkładane zbadać przede wszystkim czy są zgodne z art. 10 Konstytucji i w tym wypadku, jeżeli wnioski te lub ustawy pociaggają za sobą wydatki ze Skarbu Państwa, lecz nie podają sposobu ich pokrycia, odsyłać je inicjatorom dla ich uzupełnienia w myśl żądań Konstytucji”"44. Jednomyślne uchwalenie tej rezolucji przez Sejm ${ }^{45}$ dzisiaj budzi poważne wątpliwości prawne, wówczas jednak ich nie dostrzeżono. Stosowanie rezolucji w praktyce oznaczałoby wydłużenie jednej z czynności etapu wykonania inicjatywy ustawodawczej do fazy już po przyjęciu ustawy w pierwszym czytaniu, wkraczałoby w kompetencje przyznane regulaminem Sejmu (co prawda expressis verbis dopiero od lutego 1923 r.) jego marszałkowi i przyznawałoby komisji uprawnienie do eliminowania pro-

${ }^{43} \mathrm{~W}$ projekcie regulaminu SU Związek Ludowo-Narodowy proponował nowe przepisy materialnoprawne rangi konstytucyjnej, np. zakładał wymóg formy ustawowej dla każdego wniosku, ,którego przyjęcie przez Sejm powoduje normę prawną dla postępowania rządu, lub obywateli, albo pociagga za sobą wydatek ze Skarbu Państwa przekraczający sto tysięcy złotych w stosunku rocznym” (art. 53).

44 A. Wierzbicki, Wspomnienia, t. II, s. 256-257, maszynopis w Bibliotece Instytutu Historii Polskiej Akademii Nauk w Warszawie.

${ }^{45}$ Spr. sten z 250. posiedzenia SU, 4 października 1921 r., 1. 33-35. 
jektów ustaw, która to kompetencja przysługiwała tylko izbie. Nie jest też jasne, czy tej procedurze miały podlegać także rządowe projekty ustaw, czy tylko poselskie. Nie bez znaczenia pozostaje wreszcie antycypowanie w rezolucji mocy obowiązującej konstytucji marcowej, wbrew przepisom ustawy przechodniej z 18 marca $1921 \mathrm{r}$.

Przepisy odnoszące się do szeroko pojętej procedury ustawodawczej wypełniały zasadniczą część tymczasowego regulaminu obrad. Były one treścią aż 43 spośród 65 artykułów zamieszczonych w rozdziałach: „Posiedzenia”; „Prezydium urzędujące”, „Porządek dzienny”, „Wnioski nagłe”, „Ustawy”, „Głosowanie”, „Komisje”, „Protokoły i stenogramy posiedzeń". Większość z tych 43 artykułów dotyczyła unormowania postępowania ustawodawczego sensu stricto oraz procedowania pozostałych różnorakich wniosków, niemających charakteru ustawodawczego, a także spraw wynikających z pozostałych funkcji konstytuanty, a więc: interpelacji, rezolucji, wystąpień przedstawicieli rządu, wniosków w sprawie wotum nieufności, wniosków w sprawach personalnych itp.

Wspólne przepisy normowały zagadnienia dotyczące:

— jawności (tajności) posiedzeń (art. 4), przy czym w regulaminie postanowiono, że w trybie tajnym nie można było przeprowadzać głosowania „nad żadną ustawa”;

- języka rozpraw, którym był język polski (art. 5);

- sposobu ustalania porządku dziennego posiedzenia i jego przedmiotu (art. 11 i 15), przy czym zgodnie z pierwszym z powołanych przepisów porządek dzienny ustalał marszałek i przedstawiał go Sejmowi do zatwierdzenia bądź zmiany, w drugim zaś mówiąc o przedmiocie obrad, określano enumeratywnie podmioty inicjatywy wnioskodawczej (ustawodawczej), o czym już była mowa;

- udzielania głosu poza porządkiem dziennym (art. 13 i 29) na najwyżej 5 minut w sprawie formalnej, w celu sprostowania i złożenia oświadczenia osobistego;

- kworum (art. 14), które wynosiło przynajmniej 100 posłów;

- poselskiej inicjatywy wnioskodawczej (art. 16), która przysługiwała co najmniej 15 posłom;

- zapisywania się do głosu, listy mówców, kolejności i sposobu przemawiania (art. 17-25 i 28);

- zgłaszania poprawek (art. 26-27), które mogły być zgłaszane „w ten sam sposób, co i wnioski samodzielne", czyli przez minimum 15 posłów;

- wniosków formalnych (art. 30-34) o: zamknięcie dyskusji, przejście do punktu porządku dziennego, przerwanie dyskusji, odesłanie do komisji, odroczenie dyskusji, głosowanie bez dyskusji, głosowanie w całości (en bloc), zmianę porządku dziennego, przywołanie do porządku i wnioski „do prowadzenia obrad”, oraz sposobu procedowania w ich sprawie;

- wniosków w trybie nagłym (art. 35-36);

- techniki głosowania (art. 46-48), czyli głosowania: ,przez powstanie z miejsc”, obliczenie przez sekretarzy ${ }^{46}$ oraz głosowanie imienne;

${ }^{46} \mathrm{~W}$ praktyce sejmowej ustalanie wyniku głosowania przez obliczenie odbywało się metodą,,przez drzwi”, polegającej na wyjściu wszystkich posłów z sali plenarnej i wchodzeniu na nią przez dwoje drzwi z napisami ,tak” i ,nie”. 
— organizacji i regulacji obrad komisji sejmowych (art. 49-53);

— a także protokołów i stenogramów posiedzeń (art. 65), z nakazem ich sporządzania oraz po nowelizacji regulaminu opatrywania ich w załączeniu tekstami wniosków i interpelacji poselskich.

Do przebiegu procesu ustawodawczego odnosił się wprost tylko jeden rozdział regulaminu, zatytułowany „Ustawy”, obejmujący art. 38-44. W powołanych przepisach ustanowiono dwie procedury postępowania ustawodawczego w Sejmie: zwykłą i skrócona. Obydwie obejmowały trzy czytania projektu ustawy, ale procedura skrócona dawała możliwości przyspieszania biegu postępowania przez rezygnację z niektórych działań podejmowanych podczas procedowania w trybie zwykłym, ustanawiania terminów dla komisji lub skracania biegu niektórych terminów.

Skutkiem prawnym (pozytywnym) wykonania inicjatywy ustawodawczej było uruchomienie następnego stadium postępowania ustawodawczego w Sejmie — fazy głównej. Pierwszą czynnością fazy głównej było zlecenie przez marszałka druku projektu ustawy i doręczenie go posłom ,,co najmniej na 24 godziny przed postawieniem jej na porządku dziennym” (art. 39 in medio regulaminu). Oczywiście dotyczyło to wszystkich podmiotowo wyróżnionych typów inicjatywy ustawodawczej, z wyjątkiem posiłkowej (związanej) inicjatywy komisyjnej, w której debata nad wnioskiem wzywającym do przygotowania projektu ustawy zastępowała pierwsze czytanie, a właściwy projekt powstawał na etapie prac w komisji. Po tej pierwszej czynności fazy głównej postępowanie ustawodawcze w sprawie danego projektu mogło biec dalej wskutek wyznaczenia daty pierwszego czytania i przystapienia do niego. Do pierwszego czytania projektu mogło jednak nie dojść, jeśli został on wycofany przez wnioskodawcę. Niestety nie udało się potwierdzić w źródłach występowania takich przypadków w czasie prac konstytuanty.

Pierwsze czytanie projektu ustawy na posiedzeniu plenarnym obejmowało rozprawę „nad całością ustawy” (,bez rozpraw co do szczegółów ustawy”) i kończyło się jego odrzuceniem ${ }^{47}$ albo przesłaniem do określonej komisji (art. 38-39) ${ }^{48}$. W ujęciu przedstawiciela przedwojennej doktryny pierwsze czytanie projektu ustawy miało dać odpowiedź na pytanie, ,czy parlament chce się w ogóle projektem zająć”49. Przepisy regulaminu dotyczące pierwszego czytania były bardzo nieprecyzyjne. Deficyt ten szybko przezwyciężono, ponieważ już pod koniec funkcjonowania konstytuanty zaczęto wyraźnie różnicować pierwsze czytanie rządowego projektu ustawy od czytania

${ }^{47} \mathrm{~W}$ art. 39 regulaminu oraz innych jego przepisach w rozdziale „Ustawy” nie posłużono się jednak terminem ,projekt ustawy”, lecz ,ustawa”. Tymczasem akt prawny stawał się ustawą w znaczeniu formalnym dopiero wówczas, gdy przeszedł pełną ścieżkę legislacyjną i został, zgodnie z dyspozycją art. II pkt 1 zd. 2 małej konstytucji, ogłoszony przez marszałka Sejmu.

${ }^{48} \mathrm{~W}$ projekcie regulaminu SU, zgłoszonym przez ZLN, postulowano obowiązek przesłania projektu ustawy przyjętego w pierwszym czytaniu prezydentowi ministrów „dla zakomunikowania Rządowi, który powinien swoje wobec niej stanowisko określić w komisji i wyłuszczyć Izbie przed drugim czytaniem. Żadna ustawa nie może być w drugim czytaniu uchwalona bez wysłuchania przez Sejm opinii o niej Rządu" (art. 56). Każdy projekt ustawy, której wykonanie miało pociągnąć za sobą wydatek ze Skarbu Państwa, musiał być przesyłany dodatkowo do — oprócz właściwej komisji — Komisji Skarbowo-Budżetowej, której opinia była niezbędna, aby przejść do głosowania w drugim czytaniu (art. 55).

49 Z. Cybichowski, Polskie prawo państwowe na tle uwag z dziedziny nauki o państwie i porównawczego prawa państwowego, t. II, Warszawa 1933, s. 108. 
projektu poselskiego. W praktyce znacząco uprzywilejowywano wnioski poselskie, które na forum plenarnym były poddawane tylko pewnym formalnym czynnościom, bardzo uproszczonym, wręcz rutynowym, o wybitnie informacyjnym charakterze. Warto też podkreślić, że w procedurze pierwszych czynności postępowania z wnioskami poselskimi nie rozróżniano wniosków zawierających projekty ustaw od tych, w których tylko wzywano do przedłożenia projektu przez rząd lub komisję czy też wniosków służących innym celom. Rządowe projekty ustaw podlegały natomiast, co najmniej od 1922 r., typowym — przynajmniej w kontekście przepisów regulaminu - czynnościom charakterystycznym dla pierwszego czytania.

Pierwsze czytanie wniosku poselskiego, z nielicznymi tylko przykładami odstępstw od tej reguly, w latach prac konstytuanty odbywało się na końcu plenarnego posiedzenia izby i było przedostatnim lub jednym z ostatnich punktów porządku dziennego. Polegało na odczytaniu przez marszałka (sekretarza obrad) samego tytułu wniosku i poinformowaniu, do której komisji sejmowej został on skierowany ${ }^{50}$. W odniesieniu do wniosków nagłych w regulaminie (art. 36) przewidziano możliwość uzasadnienia tego trybu prac przez wnioskodawcę w 5-minutowym wystapieniu oraz, w takim samym czasie, ewentualne wystapienie mówcy, który opowiadał się przeciwko temu trybowi. Wnioskodawca mógł - i robiono to stosunkowo często - oprócz samego uzasadniania nagłego trybu procedowania poruszyć także aspekty zasadności merytorycznej projektu. Podobnie jego adwersarz. Obaj mówcy nie mogli jednak wchodzić w szczegóły projektu ${ }^{51}$. Ta krótka debata kończyła się głosowaniem, ale tylko dotyczącym nadania klauzuli nagłości, a nie meritum projektu. Nad meritum głosowano czasami bezpośrednio po zatwierdzeniu trybu nagłego, ale tylko jeśli wniosek nie zawierał załączonego projektu ustawy. Na koniec marszałek oznajmiał, że wniosek, jako nagły lub zwykły (gdy Sejm nie nadał mu klauzuli nagłości) został skierowany do danej komisji. Oznaczało to, że wniosek poselski, a tym samym załączony do niego poselski projekt ustawy, nie mógł zostać odrzucony przez izbę w pierwszym czytaniu, czyli zawsze przechodził do etapu prac komisyjnych. $\mathrm{Na}$ tym właśnie polegało uprzywilejowanie poselskich projektów ustaw w stosunku do projektów rządowych. Dostrzegając to, rząd również zaczął podążać tą drogą. Niektóre projekty ustaw gabinet przedkładał jako wnioski nagłe, przez co mogły być one poddawane pierwszemu czytaniu już na tym posiedzeniu plenarnym, na którym zostały wniesione. Wnoszonych w tym trybie rządowych projektów ustaw nie poddawano debacie, lecz marszałek odsyłał je bezpośrednio do właściwej komisji, po poinformowaniu o tym Sejmu. Niektórzy posłowie próbowali przeciw temu protestować, ale praktyka ta szybko się przyjęła, a marszałek zaczął się nawet powoływać na ten zwyczaj. Trzeba jednak podkreślić, że przedkładanie rządowych projektów ustaw

50 Confer Skorowidz, s. XXVII.

51 Już na początku obrad konstytuanty zwracał na to uwagę marszałek: „Muszę P. Posłom przypomnieć, żeby w swoich przemówieniach nie zapominali o koniecznej pewnej celowości, zatem w sprawach, które odsyła się do komisji nie powinni Panowie Posłowie zanadto wchodzić w szczegóły"; vide spr. sten. z 14. posiedzenia SU, 14 marca 1919 r., 1. 731. 
w formie wniosków w trybie nagłym ograniczano do projektów pilnych, a przez to wyjątkowych i relatywnie rzadkich ${ }^{52}$.

W pierwszym roku funkcjonowania SU rządowe projekty ustaw były poddawane pierwszemu czytaniu zazwyczaj na końcu posiedzenia plenarnego. Po roku zaczęła się kształtować praktyka, wyraźnie już ugruntowana na początku 1921 r., umieszczania pierwszego czytania rządowych projektów ustaw na początku posiedzenia plenarnego, w zasadzie w pierwszym punkcie merytorycznych obrad. Natomiast terminu dostarczenia posłom druków projektów ustaw na 24 godziny przed pierwszym czytaniem dotrzymywano rzadko, rozdając stosowne druki tuż przed otwarciem posiedzenia lub nawet $\mathrm{w}$ jego trakcie. Pierwsze czytanie rządowego projektu (zgłoszonego w trybie zwykłym, a nie nagłym) w znakomitej większości przypadków polegało na odczytaniu przez marszałka tytułu projektu ustawy i poinformowaniu, do której komisji jest on kierowany. Brak wystapień posłów na etapie pierwszego czytania rządowego projektu ustawy, a tym samym debaty, najczęściej oznaczał brak głosowania za odrzuceniem $^{53}$ bądź odesłaniem projektu do właściwej komisji. Wobec braku głosów sprzeciwu marszałek decydował nie tylko o formalnym przejściu projektu przez etap pierwszego czytania, ale również o wyznaczeniu właściwej — jego zdaniem — komisji w celu jego dalszego procedowania ${ }^{54}$. Sam marszałek już w marcu 1920 r. powoływał się na stosowny zwyczaj w tym zakresie.

Zwyczaj ograniczania pierwszego czytania rządowego projektu ustawy do informacji o jej tytule i odesłaniu do komisji - wykształcony w początkach konstytuanty i naruszany niezwykle rzadko — zaczęto jednak zmieniać w końcowym okresie funkcjonowania SU. Wówczas coraz więcej rządowych projektów ustaw budziło poważne zainteresowanie posłów, którzy zapisywali się u sekretarza obrad do głosu. Zapisy te były sygnałem, że nad projektem, a ściślej nad jego zasadami ogólnymi i celowością, odbędzie się debata. Już od początków prac konstytuanty debaty te często wynikały z życzenia ministra, który zawczasu chciał poznać opinię Sejmu na temat projektu ${ }^{55}$.

52 Confer: spr. sten. z 53. posiedzenia SU, 18 czerwca 1919 r., 1. 58; spr. sten. z 63. posiedzenia SU, 4 lipca 1919 r., ł. 66; spr. sten. z 69. posiedzenia SU, 15 lipca 1919 r., ł. 58; spr. sten. z 75. posiedzenia SU, 22 lipca 1919 r., ł. 2; spr. sten. z 88. posiedzenia SU, 14 października 1919 r., ł. 33; spr. sten. z 91. posiedzenia SU, 24 października 1919 r., 1. 9; spr. sten. z 243. posiedzenia SU, 28 lipca 1921 r., 1. 8.

53 Sporadycznie pojawiały się jednak wnioski poselskie o odrzucenie rządowego projektu ustawy w pierwszym czytaniu, ale zazwyczaj nie znajdowały one poparcia większości, np.: spr. sten. z 215. posiedzenia SU, 4 marca 1921 r., ł. 13; spr. sten. z 260. posiedzenia SU, 15 listopada 1921 r., ł. 39; spr. sten. z 263. posiedzenia SU, 22 listopada 1921 r., 1. 30-31. Jedyny odnotowany w stenogramie SU przypadek odrzucenia rządowego projektu ustawy zdarzył się w lutym 1922 r. i spowodował podanie się do dymisji ministra robót publicznych G. Narutowicza; spr. sten. z 284. posiedzenia SU, 10 lutego 1922 r., 1. 13-14; „Kurier Polski” nr 42, 11 II 1922 r.

54 Spr. sten. z 39. posiedzenia SU, 16 maja 1919 r., 1. 9; spr. sten. z 50. posiedzenia SU, 14 czerwca 1919 r., ł. 4; spr. sten. z 74. posiedzenia SU, 21 lipca 1919 r., ł. 24. Precedensowym rozwiązaniem było również odesłanie przez marszałka projektu ustawy do komisji bez stawiania sprawy na forum plenarnym, na pisemny wniosek złożony w tej sprawie przez kluby reprezentujące większość izby; vide spr. sten. z 185. posiedzenia SU, 16 listopada 1920 r., 1. 65. Stosunkowo często marszałek wyznaczał komisję wiodąca, odpowiadającą za opracowanie sprawozdania o projekcie ustawy, i komisję, która miała współpracować z komisją wiodącą przy wykonaniu tego zadania.

55 Spr. sten. z 37. posiedzenia SU, 13 maja 1919 r., ł. 55. 
Treść debaty była też wskazówką dla prac komisji na następnym etapie procesu ustawodawczego ${ }^{56}$. Debata taka zajmowała niekiedy większą część posiedzenia plenarnego, z bardzo długimi, godzinnymi lub nawet dłuższymi mowami zainteresowanych posłów, którzy przemawiali w imieniu swoich klubów bądź własnym. Dla przykładu można tu przywołać całodzienną debatę z 10 stycznia 1922 r., podczas pierwszego czytaniu rządowego projektu ustawy o powszechnym obowiązku służby wojskowej ${ }^{57}$.

Skutkiem prawnym pierwszego czytania projektu ustawy na posiedzeniu plenarnym Sejmu było skierowanie go do komisji. Zgodnie z przepisami regulaminu dotyczącymi komisji (art. 49-53), komisje szczegółowo rozpatrywały przedłożenia i opracowywały referaty (sprawozdania o projekcie) ${ }^{58}$. Odtworzenie spójnego obrazu przebiegu tego etapu ustawodawczej procedury parlamentarnej w okresie prac konstytuanty napotyka na zasadnicze trudności, tak ze względu na pobieżność przepisów regulaminowych, jak i z uwagi na brak zachowanych źródeł sejmowych obrazujących etap postępowań komisyjnych. O jego przebiegu można więc wnioskować tylko na podstawie przekazów pośrednich. Wobec dyrektywy nakazującej stosowanie do obrad komisji odpowiednio regulaminu sejmowego (przepisów dotyczących obrad plenarnych, art. 51) należy zakładać, że etap prac komisyjnych w ramach postępowania ustawodawczego (przypadający między pierwszym a drugim czytaniem projektu ustawy na posiedzeniu plenarnym) składał się z następującego ciągu czynności:

- wpłynięcie projektu ustawy do komisji i wyznaczenie daty jego pierwszego czytania w komisji;

- pierwsze czytanie, czyli prezentacja projektu, ustalenie właściwości komisji, wybór referenta/ów (sprawozdawcy/ów) projektu, opracowanie referatu przez sprawozdawcę i wyznaczenie daty drugiego czytania w komisji;

- drugie czytanie, czyli debata ogólna i szczegółowa nad projektem, przegłosowanie poprawek, ewentualna praca sprawozdawcy nad zintegrowaniem poprawek $\mathrm{z}$ wersją pierwotną projektu; trzecie czytanie projektu w komisji;

- opracowanie sprawozdania komisji dla Sejmu przez referenta i przekazanie go marszałkowi izby ${ }^{59}$.

56 Ibidem.

57 „Kurier Polski” nr 11, 11 I 1922.

${ }^{58}$ Ibidem.

59 Komisja była zatem „niejako parlamentem w miniaturze”; vide Z. Cybichowski, op. cit., s. 108. W kontekście instytucji sprawozdawcy komisji warto również zaznaczyć, że w przypadkach kontrowersyjnych projektów ustaw w komisjach powoływano też — razem z referentem — koreferenta projektu, reprezentującego inny niż sprawozdawca większości komisji klub poselski, który — jak się wydaje — pełnił na etapie drugiego czytania projektu na forum plenarnym rolę rzecznika mniejszości komisji. W przypadku projektów obszernych istniała też praktyka wyłaniania przez komisję kilku referentów (sprawozdawców), przy czym jeden z nich był koordynatorem całości projektu, a pozostali odpowiadali za poszczególne części projektu. Praktyka funkcjonowania instytucji sprawozdawcy komisyjnego w Sejmie II RP wskazuje ponadto, że najczęściej poseł pełniący tę funkcję na etapie prac komisyjnych kontynuował swą rolę jako referent projektu ustawy w imieniu komisji na posiedzeniu plenarnym izby w trakcie drugiego czytania oraz w ewentualnej dodatkowej fazie prac komisyjnych między drugim a trzecim czytaniem. Referent był związany wynikiem debaty komisyjnej i stanowiskiem większości komisji, które powinien — przedstawiając sprawozdanie — prezentować lojalnie, obiektywnie i bezstronnie na posiedzeniu plenarnym, nawet wbrew swoim osobistym poglądom. 
W przypadku obrad komisji sejmowej kworum wynosiło połowę składu członkowskiego, a uchwały zapadały zwykłą większością głosów (art. 51 regulaminu). Poza członkami komisji w jej obradach mogli brać udział — jednak bez prawa głosu — posłowie niewchodzący w jej skład, a ponadto marszałek lub wyznaczony przez niego zastępca oraz przedstawiciele rządu, ale „bez prawa głosowania” (art. 52 regulaminu). W posiedzeniach komisji mogli również uczestniczyć wezwani przez nią posłowie niezasiadający w komisji, przedstawiciele rządu oraz rzeczoznawcy (art. 53 regulaminu), którzy mieli głos doradczy. Członkowie komisji na etapie prac komisji mogli wnosić poprawki i przedstawiać wnioski odnoszące się do całości projektu. Posłowie, w domyśle niebędący członkami komisji, mogli zgłaszać do marszałka Sejmu poprawki do projektu ustawy przesłanego do komisji. Marszałek „,ogłaszał” je wówczas „w Sejmie” i odsyłał do komisji (art. 42). W przepisach regulaminu nie określono terminu na opracowanie projektu ustawy w komisji, chyba że było to postępowanie skrócone ${ }^{60}$. Na zakończenie obowiązkiem komisji było przygotowanie drukowanego sprawozdania z prac nad projektem (art. 50 in fine regulaminu). Istotną częścią sprawozdania był wniosek komisji o odrzucenie lub przyjęcie projektu ustawy w „brzmieniu proponowanem” przez komisję (art. 40 ab initio regulaminu). Zatem w sprawozdaniu komisja mogła opowiedzieć się - i rekomendować to stanowisko Sejmowi — za odrzuceniem projektu ustawy w całości, przyjęciem go bez poprawek lub za przyjęciem go z poprawkami uchwalonymi przez komisję. Sprawozdanie musiało zostać posłom doręczone w druku najpóźniej w przeddzień drugiego czytania na forum plenarnym izby (art. 40 in medio regulaminu).

Na etapie prac komisyjnych nad projektem ustawy wykształciła się praktyka zwracania się komisji, do której skierowano projekt, do innej komisji o współpracę w jego opracowaniu. Zjawisko to, a w ślad za tym współdziałanie dwóch, a nawet trzech komisji w dziele opracowywania projektu ustawy było stosunkowo częste ${ }^{61}$. Niekiedy współdziałające komisje powoływały wspólne podkomisje, innym razem zbierały się na wspólne posiedzenia, najczęściej jednak przywołana do współdziałania komisja przedstawiała tylko swoją opinię komisji wiodącej ${ }^{62}$. Zdarzało się również, że już na posiedzeniu plenarnym marszałek, informując o skierowaniu projektu ustawy po pierw-

Przyjęło się również, że sprawozdawca był rzecznikiem rządowego projektu ustawy i jego obrońcą przed atakami ze strony opozycji ; vide m.in.: spr. sten. z 9. posiedzenia SU, 28 lutego 1919 r., ł. 357; spr. sten. z 173. posiedzenia SU, 15 października 1920 r., 1. 43; spr. sten. z 242. posiedzenia SU, 8 lipca 1921 r., 1. 64 i 66; spr. sten. z 285. posiedzenia SU, 14 lutego 1922 r., ł. 4-5, 21; „Kurier Polski” nr 87, 11 IV 1919; nr 284, 16 X 1920; M. Rataj, Wskazania obywatelskie i polityczne, Warszawa 1987, s. 159 i 207.

${ }^{60}$ Inaczej było w III Republice Francuskiej, gdzie w maju 1920 r. do regulaminów izb parlamentarnych wprowadzono przepis ograniczający ten czas do czterech miesięcy „,w celu zwalczenia jednej z najbardziej dokuczliwych plag francuskiego parlamentaryzmu, tzn. przetrzymywania projektów w komisjach"; vide B. Radziewanowska, Ewolucja francuskiego systemu komisji parlamentarnych na tle porównawczym, s. 43, praca doktorska: Wydział Prawa i Administracji UJ, sygn. 81/71, Archiwum Biblioteki Jagiellońskiej w Krakowie.

${ }^{61}$ Confer L. Zieleniewski, Regulamin Senatu na tle regulaminów oraz praktyki izb ustawodawczych w Polsce i innych państwach, t. II, Warszawa 1933, s. 18-21; „Kurier Polski” nr 27, 27 I 1922.

${ }^{62}$ „Kurier Polski” nr 133, 29 V 1919; nr 148, 4 VI 1921; nr 181, 7 VII 1921; nr 322, 26 XI 1921; nr 339, 13 XII 1921; R. Wojdaliński, Relacje posła na Sejm Ustawodawczy (1919-1922), t. I, s. 186, 196, 1999; t. II, s. 47, 52, maszynopis w Bibliotece Zakładu Narodowego im. Ossolińskich we Wrocławiu [dalej: Ossolineum], sygn. 14108/II; A. Wierzbicki, Wspomnienia i dokumenty (1877-1920), Warszawa 1957, s. 434-435. 
szym czytaniu do komisji, sugerował zajęcie się projektem przez dwie komisje i pozostawiał im według „,dotychczasowego zwyczaju” swobodę w jego rozpatrzeniu ${ }^{63}$. Osobliwym zjawiskiem było współdziałanie Komisji Konstytucyjnej z Konwentem Seniorów, który w maju 1922 r., w czasie prac nad ordynacją wyborczą do Sejmu wspomagał ją w uzgadnianiu szczegółowych rozwiązań projektu ${ }^{64}$. Precedensem było postępowanie na 223. posiedzeniu w dniu 14 kwietnia $1921 \mathrm{r}$. w sprawie zgody na ratyfikację traktatu ryskiego. Procedura pierwszego czytania stosownego projektu ustawy rozpoczęła się od wystapienia premiera Wincentego Witosa, następnie od razu, bez dyskusji, przystapiono do drugiego czytania. W imieniu Komisji Spraw Zagranicznych wygłosił uprzednio przygotowane sprawozdanie poseł Władysław Kiernik, po czym wywiązała się obszerna dyskusja, zakończona głosowaniem projektu ustawy w drugim i — niezwłocznie po nim — trzecim czytaniu. Do ustawy wyrażającej zgodę na ratyfikację, krótkiej i formalnej, do której załącznikiem był sam traktat, nie można było zgłaszać poprawek, ponieważ oznaczałoby to jednostronne ingerowanie w treść umowy międzynarodowej. Ustawę taką można było zatem tylko przyjąć bądź odrzucić. W omawianym przypadku Sejm uchwalił wspomnianą ustawę tylko przy jednym głosie sprzeciwu $^{65}$. Osobliwością omawianego postępowania były nie tylko trzy czytania przeprowadzone jednego dnia, ale również uruchomienie prac komisji jeszcze przed pierwszym czytaniem projektu ustawy na forum plenarnym.

Efektem finalnym fazy prac komisyjnych nad projektem ustawy było, jak już wspomniano, sprawozdanie, którego załącznikiem był projekt ustawy. W II Rzeczypospolitej, tak jak w III Republice Francuskiej, na której się niewątpliwie wzorowano, projekt ustawy wychodzący z komisji miał formę nadaną mu przez komisję $e^{66}$. Ponadto godzi się podkreślić, że jeżeli Sejm skierował do komisji więcej niż jeden projekt ustawy dotyczący tej samej materii, autonomicznym uprawnieniem komisji było stworzenie z nich projektu zintegrowanego bądź odrzucenie projektów nieakceptowanych przez większość i wybranie jako podstawy dalszych prac tylko jednego z nich. Zatem rola komisji nie polegała tylko na wydaniu generalnej opinii dla Sejmu, rekomendującej projekt bądź rekomendacji tej odmawiającej, oraz na zaproponowaniu poprawek do projektu, lecz — co należy podkreślić — na uprawnieniu do eliminowania projektów, do dokonywania w tych projektach zmian i nadawania im nowego, integralnego brzmienia, zgodnego ze stanowiskiem większości danej komisji ${ }^{67}$. Przegłosowana mniejszość nie stała ze swymi propozycjami na całkiem straconej pozycji, ponieważ jej stanowisko było zazwyczaj opisane w sprawozdaniu komisji, co dawało szansę na

${ }^{63}$ Na przykład spr. sten. ze 159. posiedzenia SU, 6 lipca 1920 r., ł. 6.

${ }^{64}$ A. Wątor, Działalność Zwiqzku Ludowo-Narodowego w latach 1919-1922, Szczecin 1992, s. 81.

${ }^{65}$ Spr. sten. z 223. posiedzenia SU, 14 kwietnia 1921 r., ł. 10; R. Wojdaliński, op. cit., t. III, s. 47-48; ustawa z dnia 15 kwietnia 1921 r. o ratyfikacji Traktatu Pokoju miedzy Polską a Rosją i Ukrainą podpisanego w Rydze dnia 18 marca 1921 r., Dz.U. nr 49, poz. 299; Traktat Pokoju między Polską a Rosją i Ukrainą podpisany w Rydze dnia 18 marca 1921 r., Dz.U. nr 49, poz. 300.

${ }^{66}$ Confer J. Stembrowicz, Parlament V Republiki Francuskiej, Warszawa 1963, s. 139.

${ }^{67}$ Przykładów dokonywania przez komisje zmian w projektach ustaw są setki. Jako zupełnie pierwszy z rzędu można przywołać rządowy projekt ustawy o dzierżawie odłogów, rozpatrywany w 1920 r., poważnie zmieniony przez Komisję Rolną; vide R. Wojdaliński, op. cit., t. II, s. 48-49. 
dotarcie ze swymi racjami do wszystkich parlamentarzystów i podjęcie próby przekonania większości z nich. Stałą praktyką, podobnie jak we Francji, było też wybieranie przez mniejszość komisji własnego sprawozdawcy, który przemawiał na posiedzeniu plenarnym w trakcie drugiego czytania na początku debaty, tuż po wystapieniu sprawozdawcy większości. Jak zauważono w literaturze, „Był to jeden $\mathrm{z}$ wielu parlamentarnych zwyczajów tego okresu, praktykowanych w celu ochrony mniejszości i tendencji do zaznajomienia izby z możliwie najszerszym wachlarzem opinii”'68.

W praktyce parlamentarnej okresu konstytuanty komisje zasadniczo nie rekomendowały Sejmowi odrzucenia projektu ustawy, choć zdarzył się wyjątek ${ }^{69}$. Warto podkreślić, że jeżeli większość w komisji miała poważne zastrzeżenia lub negatywny stosunek do projektu, to zazwyczaj nie prowadziła nad nim prac, pozostawiając projekt niejako bez rozpatrzenia ${ }^{70}$ i pozwalając, aby wskutek upływu kadencji izby objęła go zasada dyskontynuacji. W SU z różnych powodów „utonęło” w komisjach aż 315 projektów ustaw ${ }^{71}$, czyli 27,7\% ogółu zgłoszonych.

Drugie czytanie projektu ustawy na posiedzeniu plenarnym Sejmu stanowiło kulminacyjny etap całego postępowania ustawodawczego. To wówczas w większości przypadków decydował się los projektu w ogóle oraz zasadniczy kształt merytoryczny przyszłej ustawy. Drugie czytanie, jak wynika z obserwacji praktyki parlamentarnej, pochłaniało gros czasu przeznaczonego na debaty plenarne i skupiało największą uwagę opinii publicznej. Pomyślne przebrnięcie projektu ustawy przez tę fazę procesu ustawodawczego praktycznie przesądzało o jej uchwaleniu.

Drugie czytanie projektu ustawy na forum plenarnym nie mogło — co do zasady — odbyć się tego samego dnia co pierwsze (art. 43 ab initio regulaminu) ${ }^{72}$. Na wniosek marszałka mogło być ono jednak przeprowadzone tego samego dnia co pierwsze, jeśli nie sprzeciwiło się temu co najmniej 10 posłów (art. $43 \mathrm{zd} .2$ regulaminu) ${ }^{73}$. Drugie czytanie obejmowało rozprawę nad szczegółami projektu ustawy (art. 38 in fine regulaminu $)^{74}$. Debatę w drugim czytaniu rozpoczynało sprawozdanie i kończący je

${ }^{68}$ B. Radziewanowska, op. cit., s. 19-20.

${ }^{69}$ Wiosną 1922 r. Komisja Prawnicza rekomendowała izbie odrzucenie jednego z rządowych projektów ustaw. Notabene Sejm nie przychylił się do tego wniosku; vide spr. sten. z 301. posiedzenia SU, 28 kwietnia 1922 r., 1. 3.

70 Tak było na przykład z rządowym projektem ustawy o samorządzie gminnym, który był zwalczany przez posłów chłopskich z dawnej Galicji oraz byłego zaboru pruskiego za lansowanie koncepcji gminy zbiorowej; vide J. Sudoł, Wspomnienia z lat 1882-1945, t. V, s. 85, maszynopis Ossolineum, sygn. 15329/I, II.

71 Skorowidz, s. 478-479.

${ }^{72} \mathrm{~W}$ pierwotnym brzmieniu regulaminu nie mogło ono ,być zwyczajnie przedsięwzięte tego samego dnia co pierwsze", a po nowelizacji art. 43 z 24 marca 1920 r. nie mogło się odbyć ,z reguły” tego samego dnia, co pierwsze. Decyzję o wyznaczeniu daty drugiego czytania podejmował Konwent Seniorów.

${ }^{73}$ Było to oczywiście możliwe w odniesieniu do projektów ustaw nieodsyłanych do komisji lub takich, nad którymi komisja (prowadząc obrady równolegle do posiedzenia plenarnego, co było wyjątkowo dopuszczane przez marszałka; vide np.: spr. sten. z 49. posiedzenia SU, 13 czerwca 1919 r., ł. 2; spr. sten. z 205. posiedzenia SU, 3 lutego 1921 r., ł. 56-58; „Kurier Polski” nr 312, 16 XI 1921) zakończyła prace przed zamknięciem posiedzenia plenarnego.

${ }^{74}$ Z. Cybichowski, op. cit., s. 108. W projekcie regulaminu SU zgłoszonym przez ZLN zakładano, że w drugim czytaniu, przy dyskusji nad pierwszym artykułem, miały być dopuszczalne ,,wywody ogólne, całości ustawy dotyczące" (art. 52). 
wniosek komisji, przedstawiane przez posła sprawozdawcę/referenta (art. 19 ab initio regulaminu $)^{75}$. Z powodu luki w regulaminie w praktyce - o ile mniejszość komisji zawarła w sprawozdaniu swoje stanowisko - marszałek zaraz po referencie większości udzielał również głosu posłowi, który był sprawozdawcą wniosków mniejszości. Sprawozdawca mniejszości korzystał z dwóch przywilejów przewidzianych dla referenta większości: nieograniczonego czasu na wystapienie oraz prawa zabrania głosu na końcu debaty, ale przed wystapieniem referenta większości komisji ${ }^{76}$. Przed dopuszczeniem do głosu posłów z sali zdarzały się też wystapienia przedstawicieli rządu (zazwyczaj przy rozważaniu rządowych projektów ustaw), którzy na podstawie normy regulaminowej również mieli nieograniczony czas na wystapienie. Brak przedstawiciela rządu na sali był wystarczającym powodem do zdjęcia danego punktu z porządku obrad i przełożenia go na inny termin ${ }^{77}$.

Po wystapieniach sprawozdawcy (sprawozdawców) oraz ewentualnie przedstawiciela rządu ${ }^{78}$ rozpoczynała się seria wystąpień poselskich. Posłowie chcący zabrać głos w debacie powinni to zgłosić sekretarzowi obrad prowadzącemu listę mówców z równoczesnym oświadczeniem, czy będą przemawiać „za” czy „przeciw” projektowi, przy czym każdy wnoszący poprawkę był uważany za przemawiającego przeciw wnioskowi głównemu (art. 17 regulaminu). Po wystapieniu sprawozdawcy komisji marszałek był zobowiązany zarządzić odczytanie listy mówców w podziale na deklarujących się ,za" i ,przeciw” (art. 18 zd. 1 regulaminu), ale tego nie praktykowano. Ponadto marszałek kolejno udzielał głosu osobom zapisanym do dyskusji, zaczynając od deklarujących się ,przeciw” wnioskowi (art. 19 ab initio regulaminu). W czasie drugiego czytania posłowie niebędący członkami komisji, która opracowywała projekt, a także posłowie należący do mniejszości komisji lub pojedynczy posłowie mogli zgłaszać wnioski odnoszące się do projektu oraz szczegółowe popraw-

75 W przypadku nieobecności sprawozdawcy komisji na sali obrad, co było dosyć częstym zjawiskiem, wobec braku reguły regulaminowej marszałek — zgodnie z utartą praktyką — wzywał do złożenia sprawozdania w zastępstwie nieobecnego przez przewodniczącego komisji lub w drugiej kolejności jej wiceprzewodniczącego, sekretarza albo też wyznaczonego przez przewodniczącego innego członka komisji, która rozpatrywała projekt ustawy; np. spr. sten z 45. posiedzenia SU, 4 czerwca 1919 r., ł. 10; spr. sten. ze 127. posiedzenia SU, 5 marca 1920 r., ł. 44; spr. sten. z 238. posiedzenia SU, 23 czerwca 1921 r., ł. 46. Zdarzył się nawet odosobniony przypadek, że jeden z projektów referował w takiej sytuacji sprawozdawca mniejszości komisji; vide spr. sten. z 32. posiedzenia SU, 2 maja 1919 r., ł. 4-6 i 16-17. Gdy zastapienie sprawozdawcy nie było możliwe, marszałek przesuwał w czasie bądź zdejmował dany punkt z porządku dziennego obrad; vide spr. sten. ze 127. posiedzenia SU, 5 marca 1920 r., 1. 21; spr. sten. z 202. posiedzenia SU, 25 stycznia 1921 r., ł. 61; spr. sten. z 281. posiedzenia SU, 27 stycznia 1922 r., 1. 15.

${ }^{76}$ Confer L. Zieleniewski, Regulamin Senatu..., t. II, s. 57; spr. sten. z 38. posiedzenia SU, 15 maja 1919 r., ł. 12; spr. sten. z 41. posiedzenia SU, 23 maja 1919 r., ł. 75-78; spr. sten. ze 103. posiedzenia SU, 25 października 1919 r., ł. 31 i 36.

77 Vide np. spr. sten. z 91. posiedzenia SU, 24 października 1919 r., ł. 4.

78 Jeśli przedstawiciel rządu zabrał głos w debacie w trakcie czytania (przedstawicielom rządu, na podstawie przepisu art. 22 regulaminu, przysługiwało prawo wystapień poza kolejnościa), norma prawa zwyczajowego nakazywała rozpoczynanie debaty od początku (z otwieraniem listy mówców od nowa); vide spr. sten. z 30. posiedzenia SU, 11 kwietnia 1919 r., ł. 63; spr. sten. z 71. posiedzenia SU, 17 czerwca 1919 r., 1. 34; spr. sten. ze 127. posiedzenia SU, 5 marca 1920 r., 1. 26-27. Za przedstawiciela rządu uważano również zasiadającego w Sejmie w ławach rządowych prezesa Najwyższej Izby Kontroli Państwa. 
ki do poszczególnych artykułów ${ }^{79}$. Poprawki miały być składane „w ten sam sposób, co i wnioski samodzielne" (art. 26 zd. 1 w zw. z art. 15-16 regulaminu), a więc na piśmie i podpisane przez co najmniej 15 posłów. Poprawki, zgodnie z art. 27 regulaminu, mogły mieć jedynie formę wniosku o: „wykreślenie”, „dopisanie” lub „Zastąpienie określonych wyrazów". Debatę drugiego czytania, w którym zabierali głos posłowie zgłaszający się do dyskusji, kończyło wystąpienie referenta komisji, który miał ponadto przywilej zabierania głosu po każdej ze zgłoszonych poprawek ${ }^{80}$. Następnie marszałek ogłaszał przystapienie do głosowania, co oznaczało, że od tego momentu ,już nikomu głos do rozpraw nad przedmiotem udzielony być nie może" (art. 19 zd. 2 i art. 28 regulaminu) ${ }^{81}$.

Zgodnie z przywołaną już normą regulaminową (art. 38), drugie czytanie projektu ustawy na posiedzeniu plenarnym polegało na przeprowadzeniu debaty szczegółowej. Praktyka w tym względzie była jednak od początku obrad konstytuanty wyraźnie contra legem, ponieważ przy omawianiu art. 1 projektu ustawy wykształcił się zwyczaj przeprowadzania debaty ogólnej przed dyskusją szczegółową ${ }^{82}$. Przesłanką jego pojawienia się było prawdopodobnie nieprecyzyjne sformułowanie cytowanego wcześniej przepisu art. $40 \mathrm{zd}$. 1 regulaminu, ale też lansowanie przez marszałka izby sto-

${ }^{79} \mathrm{~W}$ konstytuancie funkcjonował zwyczaj niepowtarzania w debacie na forum plenarnym treści przemówień wygłoszonych uprzednio w komisji; vide spr. sten. ze 110. posiedzenia SU, 14 stycznia 1920 r., 1. $42-43$.

${ }^{80}$ Należy również zaznaczyć, że izba mogła w każdym stadium drugiego czytania, czyli przed ostatecznym przegłosowaniem projektu ustawy, uchwalić — zgodnie z art. 30 regulaminu — wniosek formalny o odesłanie go na powrót do komisji (wniosek taki miał pierwszeństwo przed innymi i był zazwyczaj niezwłocznie poddawany pod głosowanie przez marszałka), co oznaczało przerwanie i odroczenie drugiego czytania w oczekiwaniu na wynik uzupełniających prac (uzgodnień) komisji. Na posiedzeniu plenarnym można było też przyjąć inny wniosek formalny: o zamknięcie dyskusji, o przerwanie dyskusji (rozprawy), o odroczenie dyskusji, o głosowanie bez dyskusji, o głosowanie w całości (en bloc) i o skrócenie postępowania formalnego (a więc o zastosowanie trybu skróconego); vide Skorowidz, s. XXXVII. Najczęściej uchwalano wnioski formalne o przerwanie dyskusji. Po ich przegłosowaniu marszałek udzielał głosu już tylko przedstawicielowi rządu, jeżeli procedowano projekt ustawy przedłożony przez gabinet, oraz w celu wygłoszenia „ostatniego słowa” sprawozdawcy komisyjnemu; vide spr. sten. z 43. posiedzenia SU, 30 maja 1919 r., 1. 57-59. W początkach obrad konstytuanty na plenum toczono zaciekłe spory o wykładnię przepisów regulaminu dotyczących zamykania debaty; vide np. spr. sten. z 10. posiedzenia SU, 5 marca 1919 r., ł. 426-433. Po roku, wobec ciagłych kontrowersji na ten temat, marszałek dopuścił możliwość składania przez zainteresowanych posłów i kluby oświadczeń przed poddaniem pod głosowanie wniosku o zamknięcie dyskusji; vide spr. sten. ze 142. posiedzenia SU, 29 kwietnia 1920 r., ł. 48.

${ }^{81}$ Regulamin zawierał również przepisy normujące szczegółowo przebieg debaty (w istocie w każdym z trzech czytań, jak i nad wnioskami niemającymi charakteru ustawodawczego), odnoszące się do: kolejności, czasu, wielokrotności i miejsca przemówień, a także odczytywania przemówień, które było zasadniczo zakazane. Wyjątki ustanowiono dla sprawozdawców komisyjnych, przedstawicieli rządu oraz — za zgodą marszałka - odczytujących „,dokumenty lub akty, na których [poseł — P.A.T.] wywód opiera” (art. 18, 20-26).

${ }^{82}$ Confer spr. sten. z 9. posiedzenia SU, 28 lutego 1919 r., ł. 354; spr. sten. z 11. posiedzenia SU, 7 marca 1919 r., ł. 476. Na dowód istnienia omawianego zwyczaju można przywołać następującą wypowiedź marszałka: „Dyskusja szczegółowa otwarta. Jesteśmy przy art. 1. Według jednak przyjętego zwyczaju podczas szczegółowej dyskusji nad art. 1 wolno ogólnie mówić i o innych artykułach"; vide spr. sten. ze 112. posiedzenia SU, 20 stycznia 1920 r., ł. Vide także spr. sten. z 278. posiedzenia SU, 17 stycznia 1922 r., 1. 46-47; spr. sten. z 300. posiedzenia SU, 27 kwietnia 1922 r., 1. 15-16. Omawiany zwyczaj był zatem wyraźnie zbieżny z odnośną normą nieuchwalonego projektu regulaminu sejmowego autorstwa klubu ZLN. 
sownego wzorca niemieckiego. Zatem debatowanie nad odrzuceniem lub przyjęciem ustawy było siłą rzeczy rozważaniem zagadnienia ogólnego, a więc np. przydatności i celowości ustanowienia danej regulacji ustawowej. Zwyczaj ten wynikał więc z pragmatyzmu i z negatywnej weryfikacji nieżyciowego i nieodpowiadającego praktyce wskazanego przepisu regulaminu. Wolno również wysunąć przypuszczenie, że praktyka odbywania debaty ogólnej na początku drugiego czytania na posiedzeniu plenarnym mogła być podyktowana i tym, że w okresie konstytuanty wiele projektów ustaw (aż 222) było komisyjnymi inicjatywami ustawodawczymi, które po raz pierwszy pojawiały się na posiedzeniu plenarnym dopiero przy drugim czytaniu. Również zwyczaj nieprzeprowadzania w pierwszych latach działania SU debaty nad rządowymi projektami ustaw oraz zasada jej nieodbywania nad poselskimi nie dawały posłom niebędącym członkami komisji rozpatrującej projekt po pierwszym czytaniu okazji do wypowiedzi ogólnych odnoszących się do jego zasad i założeń legislacyjnych. Deficyt ten, spowodowany zarówno lukami regulaminowymi, jak i częstym pomijaniem debaty przy pierwszym czytaniu, musiał zatem zostać uzupełniony przez praktykę, która przybrała formę normy prawa zwyczajowego ${ }^{83}$.

Wynik drugiego czytania projektu ustawy na forum plenarnym Sejmu i jego ewentualne dalsze procedowanie uzależnione były od tego, czy do projektu zgłoszono poprawki, czy też nie. Jeżeli nie zgłoszono ${ }^{84}$, referent projektu lub inny poseł mogli zgłosić na podstawie art. 41 regulaminu wniosek o głosowanie nad projektem ustawy w całości (en bloc $)^{85}$. Wskutek zgłoszenia takiego wniosku projekt ustawy mógł zo-

${ }^{83}$ Uruchamianie debaty ogólnej nad zasadami projektu przy rozpatrywaniu art. 1 projektu ustawy $\mathrm{w}$ drugim czytaniu powodowało nie tylko skutek proceduralny $\mathrm{w}$ formie wydłużenia rozprawy, ale również inny, o doniosłym znaczeniu materialnoprawnym. Precedensowa sytuacja wytworzyła się w maju 1922 r., $\mathrm{w}$ trakcie procedowania na forum plenarnym projektu ustawy o monopolu spirytusowym. Otóż bez stosownego wniosku o odrzucenie nie uzyskał poparcia większości w trakcie głosowania w drugim czytaniu art. 1 projektu, który był osią całego projektu, ponieważ w nim ogólnie określono przedmiot regulacji ustawowej. Jak zanotował poseł A. Wierzbicki, „Zdawałoby się, że jest to jednoznaczne z odrzuceniem całej ustawy. Jednak marszałek Trąmpczyński (w myśl regulaminu Sejmu w sprawach dotyczących sposobu prowadzenia obrad, niewskazanych wyraźnie w regulaminie, marszałek Sejmu rozstrzygał ostatecznie), idąc na rękę rządowi, który oświadczył, że nie wycofuje ustawy, zdecydował inaczej. Powołał się na precedensy w parlamentach w Berlinie i Wiedniu, iż w drugim czytaniu wychodziły czasem ustawy z artykułami zupełnie sprzecznymi ze sobą i dopiero trzecie czytanie przesądzało sprawę ostatecznie. Poddał więc głosowaniu wszystkie artykuły po kolei, po czym w trzecim czytaniu poprawka posła Osieckiego o przywrócenie art. 1 została uchwalona 193 głosami przeciwko 186, a cała ustawa 185 głosami przeciwko 178”; A. Wierzbicki, Wspomnienia..., s. 353. Cytowany autor myli się, podając, że nie złożono wniosku o skreślenie art. 1 projektu ustawy. W istocie wniosek taki wpłynął i w głosowaniu nad nim głosy rozłożyły się po równo, 183 za i tyle samo przeciw; vide spr. sten. z 314. posiedzenia SU, 29 maja 1922 r., 1. 39-42; spr. sten. z 315. posiedzenia SU, 31 maja 1922 r., ł. 10-11; spr. sten. z 316. posiedzenia SU, 1 czerwca 1922 r., ł. 69.

${ }^{84}$ Przepis art. 41 regulaminu był niejasny, jeśli chodzi o niezgłoszeniu poprawek ,przed rozprawą nad drugim czytaniem". Tymczasem należy domniemywać, zresztą wykazała to praktyka, że poprawki zgłaszano właśnie w trakcie rozprawy. Formalnie oznaczało to, że poprawki powinny być wniesione na piśmie przed udzieleniem głosu pierwszemu z mówców zapisanemu na liście. Zatem wystapienia w rozprawie mogły dotyczyć: uzasadnienia zgłaszanych poprawek, polemiki ze zgłoszonymi poprawkami lub stawiania wniosków całościowych odnoszących się do projektu.

${ }^{85}$ Miało się to odbywać na stosowny wniosek porządkowy (formalny). W praktyce wniosek taki był zwyczajowo stawiany ex praesidio i przyjmowany przez izbę poprzez brak sprzeciwu (tacite). 
stać w wyniku głosowania całej izby uchwalony lub odrzucony. Odrzucenie projektu kończyło prace nad nim. Uchwalenie zaś projektu w całości otwierało możliwość dalszego biegu postępowania ustawodawczego, polegającego na przystapieniu do trzeciego czytania. Jeżeli w trakcie drugiego czytania projektu ustawy zgłoszono do niego na posiedzeniu plenarnym poprawki, marszałek zarządzał głosowanie. Przyjęcie poprawek oznaczało, że Sejm mógł ponownie odesłać projekt do tej samej komisji, która sprawozdawała (w przeważającej liczbie przypadków takiego odesłania) lub do innej, nawet specjalnej, powołanej ad hoc w tym celu (art. $40 \mathrm{zd}$. 3 regulaminu). Ponowne odesłanie projektu do komisji służyło uzgodnieniu poprawek, przyjętych $\mathrm{w}$ trakcie drugiego czytania, $\mathrm{z}$ innymi postanowieniami projektu ${ }^{86}$. Użycie w omawianym przepisie funktora „może” oznaczało fakultatywność tej czynności. Równie dobrze Sejm mógł się zachować przeciwnie i projektu po drugim czytaniu do komisji nie odsyłać. Jeżeli projekt w drugim czytaniu odesłano do komisji, to - wobec braku przepisów regulaminu na ten temat — należy domniemywać, że komisja przygotowywała (na piśmie) dodatkowe sprawozdanie o projekcie w związku poprawkami z przyjętymi na posiedzeniu plenarnym ${ }^{87}$. Można też przypuszczać, że musiało zostać ono dostarczone posłom w druku co najmniej w przeddzień trzeciego czytania. W regulaminie nie unormowano jednak również tej i następnych czynności do końca drugiego czytania, z wyjątkiem wspomnianej regulacji w art. 41. Zatem i w tym zakresie zawierał on istotną lukę prawną, którą starano się usunąć w praktyce parlamentarnej. Po dodatkowym sprawozdaniu komisji izba rozpoczynała głosowanie projektu od nowa. W dodatkowym sprawozdaniu komisja mogła wnioskować o przywrócenie artykułu skreślonego na posiedzeniu plenarnym w przerwanym drugim czytaniu projektu, przeciwko czemu protestowała jednak część posłów ${ }^{88}$.

Analiza stenogramów posiedzeń konstytuanty pozwala skonstatować, że głosowanie kończące fazę drugiego czytania projektu ustawy na forum plenarnym miało zasadniczo charakter szczegółowy. Przechodzono po kolei od artykułu do artykułu, odczytywano jego treść w wersji zaproponowanej przez komisję oraz odczytywano zgłoszone do niego poprawki. Następnie marszałek wzywał posłów, aby opowiedzieli się za lub przeciw poprawce bądź artykułowi ${ }^{89}$. Na końcu debatowano nad tytułem

${ }^{86}$ Z. Cybichowski, op. cit., s. 108.

${ }^{87} \mathrm{~W}$ art. 61 projektu regulaminu zgłoszonego przez ZLN zakładano przygotowanie przez komisję ponownego sprawozdania, które „,będzie stanowiło przedmiot powtórnego drugiego czytania”. Ponadto zgodnie z art. 63 tego projektu zakładano, że: „Marszałek może, jeśli uzna ustawę za niewłaściwie sformułowaną albo jeśli tak orzeknie izba, odesłać ją dla właściwego ostatecznego sformułowania do Komisji Prawniczej przed trzecim czytaniem".

88 Vide spr. sten. z 73. posiedzenia SU, 19 lipca 1919 r., ł. 8; spr. sten. z 75. posiedzenia SU, 22 lipca 1919 r., 1. 3-5, 7-9.

${ }^{89}$ Głosowanie szczegółowe przebiegało zazwyczaj według następującego schematu. Najpierw wniosek o wykreślenie całego artykułu (wniosek najdalej idący), przy czym istniał zwyczaj głosowania najpierw brzmienia artykułu w wersji przedstawionej przez komisję. Jeśli nie uzyskało ono większości, dopiero wówczas poddawano pod głosowanie wszystkie pozostałe poprawki zgłoszone do danego artykułu, począwszy od wniosku o jego wykreślenie (np. spr. sten. ze 183. posiedzenia SU, 10 listopada 1920 r., 1. 41; spr. sten. z 234. posiedzenia SU, 14 czerwca 1921 r., ł. 51-52). Ale bywało również na odwrót (vide np. spr. sten. z 206. posiedzenia SU, 4 lutego 1921 r., ł. 27). W drugiej kolejności Sejm przystępował do głosowania wnio- 
ustawy. W miarę nabywania doświadczeń, aby zaoszczędzić na czasie, rezygnowano z odczytywania artykułów w wersji proponowanej przez komisję, ponieważ posłowie znali ich treść z rozdawanych im druków ze sprawozdaniami. Jeżeli do artykułu nie zgłoszono żadnych poprawek, to przy braku sprzeciwów posłów marszałek traktował go jako przyjęty bez potrzeby przeprowadzania głosowania ${ }^{90}$. Po przegłosowaniu w opisany sposób wszystkich artykułów projektu ustawy marszałek zarządzał niekiedy głosowanie końcowe nad całym projektem ustawy. Nie było to jednak reguła.

Po uchwaleniu wszystkich przepisów projektu ustawy w drugim czytaniu Sejm głosował ewentualne rezolucje pod adresem rządu związane ze sposobem wykonania ustawy, zgłoszone przez komisję, mniejszość w komisji lub posłów na posiedzeniu plenarnym w trakcie tego czytania ${ }^{91}$.

Zgodnie z przepisem art. $40 \mathrm{zd}$. 3 regulaminu projekt ustawy po drugim czytaniu izba mogła odesłać ponownie do tej samej lub do innej komisji. Wobec braku wskazania w powołanym przepisie przesłanek ponownego odesłania, należy domniemywać, że mogło to nastapić w przypadku, jeśli w drugim czytaniu na forum plenarnym uchwalono poprawki do poszczególnych artykułów. Praktyka parlamentarna okresu konstytuanty dowodzi trafności tego domniemania i dostarcza na to stosunkowo wielu przykładów. Odesłanie następowało z wniosku marszałka ex praesidio, przy braku sprzeciwu ze strony posłów, albo uchwałą izby na wniosek zgłoszony z sali. Przyjęło się — w wykładni marszałka Sejmu — że prawo do zgłoszenia wniosku o odesłanie projektu ustawy do komisji po drugim czytaniu nie przysługiwało rządowi ${ }^{22}$. Komisja była zobowiązana, na podstawie dyspozycji wydanej jej przez marszałka oraz przyjętej w tym zakresie praktyki (regulamin nie zawierał przepisów na ten temat) rozważyć, czy wobec przyjęcia w drugim czytaniu poprawek nie ma sprzeczności między poszczególnymi postanowieniami projektu ustawy oraz opracować odpowiednie wnioski. Komisja wobec ponownego skierowania do niej projektu ustawy przed trzecim czytaniem była zobowiązana przygotować dodatkowe sprawozdanie na posiedzenie plenarne. Sprawozdanie zazwyczaj było drukowane ${ }^{93} \mathrm{i}$ warunkowało przystapienie do trzeciego czytania projektu ustawy w Sejmie. W regulaminie nie ustanowiono terminu dla komisji na wywiązanie się z wymienionych obowiązków. Jeżeli się on pojawiał, to tylko jako wykonanie dyspozycji przepisu regulaminu, stanowiącego o możliwości skrócenia przez izbę postępowania ustawodawczego (art. 44).

Instytucja trzeciego czytania projektu ustawy na posiedzeniu plenarnym Sejmu podlegała najskromniejszej - w porównaniu z poprzedzającymi ją fazami postępowa-

sku o wykreślenie fragmentu artykułu, a następnie wniosku o dopisanie passusu w artykule oraz wniosku o dodanie całego nowego artykułu. W okresie działania konstytuanty zdarzało się, że głosowano nad poszczególnymi artykułami tuż po zakończeniu nad nimi dyskusji, co oznaczało przeplatanie dyskusji z głosowaniami. Praktykę tę następnie zarzucono, przeprowadzając głosowanie szczegółowe po zakończeniu debaty nad wszystkimi artykułami projektu.

90 Vide spr. sten. z 315. posiedzenia SU, 31 maja 1922 r., 1. 5.

${ }^{91} \mathrm{Na}$ temat rezolucji uchwalanych w trakcie postępowania ustawodawczego w II Rzeczypospolitej vide więcej P.A. Tusiński, Postępowanie..., s. 170 i 185-190.

92 Vide spr. sten. z 82. posiedzenia SU, 31 lipca 1919 r., ł. 83.

${ }^{93}$ Obowiązek przygotowania sprawozdania można wyinterpretować z przepisu art. 50 regulaminu. 
nia ustawodawczego - reglamentacji regulaminowej. Zgodnie z pierwotnym brzmieniem przepisu art. 43 in medio mogło być ono otwarte ,zaraz po drugim”. Należy domniemywać, że mogło to nastapić, tylko jeśli nie odesłano projektu do komisji albo kiedy komisja przygotowała dodatkowe sprawozdanie jeszcze tego samego dnia. Użycie w przepisie funktora „może” oznaczało fakultatywność takiego rozwiązania. Równie dobrze trzecie czytanie projektu mogło być umieszczone w porządku dziennym jednego z następnych posiedzeń plenarnych izby. Konstytuanta po roku pracy, na wniosek Konwentu Seniorów, na 135. posiedzeniu plenarnym 24 marca 1920 r. ten przepis regulaminu jednak jednomyślnie zmieniła i sformułowała zasadniczy zakaz przeprowadzania drugiego i trzeciego czytania tego samego dnia ${ }^{94}$. Niezwłoczne przystapienie do trzeciego czytania po drugim było możliwe na zasadzie wyjątku, jeśli stosowny wniosek w tej sprawie poparło co najmniej 30 posłów. Zgodnie z art. 38 regulaminu trzecie czytanie projektu ustawy obejmowało rozprawę „nad całością” projektu ${ }^{95}$. W przepisie tym nie określono ani formy rozprawy na tym etapie postępowania ustawodawczego, ani tego, czym się ono miało kończyć. Oznaczało to, że do procedury trzeciego czytania stosowano przepisy ogólne dotyczące prowadzenia debaty i głosowań oraz reguły wypracowane w praktyce parlamentarnej. W głosowaniu zarówno poszczególne przepisy projektu, jak i jego całość mogły zostać uchwalone bądź odrzucone. Trzecie czytanie definitywnie kończyło procedowanie nad ustawą w Sejmie.

Jeżeli projekt ustawy został uchwalony w drugim czytaniu bez poprawek, co było zwyczajowo-prawną regułą $\mathrm{w}$ odniesieniu do ustaw wyrażających zgodę na ratyfikację umów międzynarodowych, to zgodnie z pierwotnym brzmieniem art. 43 regulaminu trzecie czytanie mogło nastapić ,zaraz po drugim”. W regulaminie nie sformułowano też zakazu niezwłocznego przystępowania do trzeciego czytania, gdy w drugim zostały uchwalone poprawki do projektu. Wniosek w sprawie niezwłocznego przystapienia do trzeciego czytania zgłaszał z reguły sprawozdawca komisji, ale zdarzało się również, że czynił to dowolny poseł ,z sali” lub nawet ex praesidio marszałek, oznajmiając o przystapieniu do tego czytania i zwracając się do posłów z pytaniem, kto jest przeciw. Pytanie o sprzeciw padało często, ale nie zawsze, nawet jeśli wniosek zgło-

94 „Marszałek [...] Jeżeli trzecie czytanie nie ma być czczą formalnością to i co do tego regulamin powinien zawierać jakiś wyraźny przepis, a nie rzucać sprawy na fale przypadkowej większości, co może mieć nie tylko fatalne skutki dla poszczególnych ustaw, ale może być źródłem bardzo znacznych niesnasek w Sejmie"; vide spr. sten. ze 135. posiedzenia SU, 24 marca 1920 r., 1. 4. Vide też: R. Wojdaliński, op. cit., t. IV, s. 164. W intencji inicjatorów zmiana ta miała służyć przede wszystkim wydłużeniu tych postępowań ustawodawczych, w których Sejm uchwalił poprawki do projektu w drugim czytaniu. Znowelizowany przepis zaowocował częściowo pożądaną praktyka, ponieważ okazało się, że stosunkowo często znajdowała się odtąd wymagana grupa co najmniej 30 posłów, którzy skutecznie mogli powodować odroczenie trzeciego czytania (przegłosowanie ich przez większość nie wchodziło przy takim sformułowaniu omawianego przepisu w rachubę). Niezależnie od słusznych intencji, klauzula ta była wykorzystywana często przez opozycję w celach obstrukcyjnych.

95 Z. Cybichowski zauważył, że w trzecim czytaniu ,dopuszczalne powinny być tylko poprawki stylistyczne, co jest zasadą w Anglii. Trzecie czytanie powinno być formalne; otworzenie obrad merytorycznych może wywołać skutki szkodliwe, gdy np. w ostatniej chwili przechodzi poprawka, która jest sprzeczna z podstawami ustawy. Mimo to wiele parlamentów pozwala na zgłaszanie w trzecim czytaniu poprawek merytorycznych"; vide Z. Cybichowski, op. cit., s. 108. 
sił inny poseł niż marszałek. Jeżeli sprzeciwu nie było, rozpoczynano procedurę trzeciego czytania. Działanie to mogło być nawet czysto symboliczne i sprowadzać się do wypowiedzenia przez marszałka dwu-, trzyzdaniowej formuły, która zarazem otwierała i kończyła trzecie czytanie ${ }^{96}$. Ze stenogramów z pierwszego roku funkcjonowania SU wynika, że izba - mimo formalnego istnienia instytucji trzech czytań — znakomitą większość ustaw faktycznie uchwalała w dwóch czytaniach. Praktyka była bowiem taka, że tuż po drugim czytaniu, o ile nie zgłoszono i nie przyjęto wniosku o odesłanie projektu ustawy z powrotem do komisji ${ }^{97}$, wniosek o rozpoczęcie trzeciego padał prawie zawsze i był milcząco akceptowany. Działo się tak dlatego, że w Sejmie — i nie tylko - wywierano swoistą presję, jeśli chodzi o szybkie stanowienie prawa wobec różnorakich problemów, przed jakimi stało odbudowujące się państwo polskie i które musiały być rozwiązywane niemal niezwłocznie ${ }^{98}$. Zatem trzecie czytanie sprowadzano najczęściej do podjęcia niezwłocznej uchwały o przegłosowaniu całego projektu. Przy czym uchwała ta bardzo często była przyjmowana tacite, bez przeprowadzania formalnego głosowania99. Czynność ta nie tylko kończyła szybkie i traktowane czysto formalnie trzecie czytanie, ale również całe postępowanie ustawodawcze w izbie. Do ogłoszenia drukiem ustawy brakowało jeszcze tylko podpisu marszałka

${ }^{9}$ Można przytoczyć np. jedną z wypowiedzi marszałka z początków 1920 r.: „Proponuję przystapić do 3 czytania. Nikt nie protestuje, głosu nikt nie żąda. Mogę przypuścić na mocy poprzedniego głosowania, że ustawa i w trzecim czytaniu jest przyjęta. Nie słyszę protestu”; vide spr. sten. ze 122. posiedzenia SU, 20 lutego 1920 r., 1. 24.

${ }^{97}$ Jeżeli projekt z powrotem odesłano do komisji, to przygotowywała ona dodatkowe, drukowane sprawozdanie, które przed trzecim czytaniem rozdawano posłom. Bywało jednak i tak, że formalnie nie odsyłano projektu ustawy do komisji, a mimo to do trzeciego czytania nie dochodziło niezwłocznie. Co ciekawe, odkładano trzecie czytanie nawet wówczas, gdy w drugim Sejm nie uchwalił do projektu żadnych poprawek. Rozwiązanie to znalazło następnie potwierdzenie w decyzji Konwentu Seniorów, który w lipcu 1919 r. postanowił, że sporne projekty ustaw (we wszystkich czytaniach) nie będą rozważane na posiedzeniach przypadających w poniedziałki i soboty, kiedy w izbie była obniżona frekwencja ze względu na wyjazdy posłów do domów; vide spr. sten. z 72. posiedzenia SU, 18 lipca 1919 r., 1. 85-86; spr. sten. z 73. posiedzenia SU, 19 lipca 1919 r., ł. 10.

98 Niezmiernie ciekawa była w tym względzie — i wielce problematyczna w kontekście zasady praworządności — sytuacja z początku lutego 1921 r. Otóż 4 lutego Sejm przyjął w drugim czytaniu projekt ustawy o ustanowieniu orderu Orła Białego. Rząd, jako inicjator ustawy, oraz popierający go w izbie posłowie liczyli na niezwłoczne trzecie czytanie projektu tego samego dnia. Tymczasem poseł H. Diamand, poparty przez więcej niż 30 posłów, sprzeciwił się temu i trzecie czytanie odłożono. Sprawa była jednak pilna, ponieważ ordery już wybito i 5 lutego — mimo nieuchwalenia ustawy w trzecim czytaniu — dwa z nich zostały wręczone w czasie wizyty J. Piłsudskiego we Francji prezydentowi A. Millerandowi oraz ministrowi L. Barthou. Ustawa została ostatecznie uchwalona przez Sejm dopiero kilka dni później, ale została antydatowana na 4 lutego 1921 r., a opublikowano ją dopiero 15 marca 1921 r., Dz.U. nr 24, poz. 136; vide „Kurier Polski” nr 35, 37-38, II 1921 r.

99 Jako ilustrację takiej uproszczonej i przyspieszonej procedury można przytoczyć następujący cytat ze stenogramu posiedzenia Sejmu: „Marszałek: [...] Proszę tych posłów, którzy są za przyjęciem projektu ustawy $[. .$.$] aby powstali z miejsc. (Większość). Ustawa jest przyjęta w drugim czytaniu. (P. Steinhaus [po-$ seł sprawozdawca — P.A.T]: Proszę o przystapienie do trzeciego czytania). Referent stawia wniosek o trzecie czytanie. Nikt nie protestuje, a ponieważ była tak znaczna większość przy głosowaniu w drugim czytaniu, zatem i teraz mogę przyjąć, że i w trzecim czytaniu, o ile nie usłyszę protestu, ustawa jest przyjęta. Nie ma protestu, zatem ustawa przyjęta i w trzecim czytaniu"; vide spr. sten. z 56. posiedzenia SU, 26 czerwca 1919 r., 1. 8. 
Sejmu. Stan taki powodował, że ustawy uchwalane „na gorąco”, niezwłocznie po drugim czytaniu, miały wiele wad wewnętrznych, zarówno w formie luk (po wykreśleniach), sprzeczności i niespójności (wskutek przyjętych poprawek), jak i sformułowań, które odbiegały od wymogów poprawnej techniki legislacyjnej i spójności systemowej. Uproszczenie procedury trzeciego czytania nie było stosowane konsekwentnie, bywało bowiem również i tak, że marszałek przeprowadzał formalne głosowanie w trzecim czytaniu, wzywając posłów do powstania z miejsc w celu wyrażenia poparcia dla uchwalanego projektu ustawy ${ }^{100}$. Wspomniana częściowa zmiana procedury trzeciego czytania - mimo jej pewnych pozytywnych rezultatów — nie wpłynęła zasadniczo na spowolnienie tempa procedowania ustaw w dalszym okresie funkcjonowania konstytuanty.

Zatem w SU trzecie czytanie bardzo często sprowadzało się tylko do milczącego powtórzenia wyniku głosowania z drugiego czytania. Niemniej jednak konstytuanta prowadziła również relatywnie wiele postępowań ustawodawczych, które dostarczają przykładów rozbudowanego przebiegu procedury trzeciego czytania. Jak zaznaczono wcześniej, zgodnie z regulaminem i początkową praktyką trzecie czytanie miało obejmować dyskusję ogólną nad całością ustawy. Stosunkowo szybko zaczęto jednak od tej formuły odchodzić i zmierzać do modelu charakterystycznego dla drugiego czytania, ponieważ trzecie czytanie, o ile otwierano w nim debatę, zaczęło obejmować nie tylko dyskusję ogólna, lecz koncentrować się na rozprawie szczegółowej, ze zgłaszaniem i uchwalaniem poprawek do poszczególnych artykułów projektu ustawy. Już w początkach funkcjonowania konstytuanty - wbrew przepisom regulaminu i rozwiązaniom przyjętym w parlamencie wiedeńskim oraz galicyjskim Sejmie Krajowym, przełamując opór części posłów, a za wzorem Reichstagu i pruskiego Landtagu (z wyraźnym poparciem marszałka Wojciecha Trąmpczyńskiego) - zaczęto dopuszczać możliwość wnoszenia w trzecim czytaniu nie tylko poprawek stylistycznych, ale także merytorycznych, nawet tych, które zostały odrzucone w drugim czytaniu ${ }^{101}$. Zatem debata w trzecim czytaniu koncentrowała się na uzasadnianiu zgłaszanych poprawek. Poważne i ciągle powracające spory budziła również kwestia terminu zgłaszania poprawek do trzeciego czytania. Zasadniczo od początku zgadzano się z tym, że poprawki powinny być wydrukowane i rozdane posłom przed głosowaniem. Niemniej w praktyce część poprawek posłowie dostawali tuż przed posiedzeniem, na którym miało zostać przeprowadzone trzecie czytanie, część była rozdawana w powielonym maszynopisie już w trakcie posiedzenia, część już w trakcie trzeciego czytania, a część była zgłaszana nawet ustnie $\mathrm{w}$ trakcie debaty, tuż przed samym głosowaniem. Wynikający z tego chaos budził krytyczne uwagi wielu posłów i negatywnie wpływał na jakość stanowionego prawa. W tej sytuacji Konwent Seniorów postanowił w czerwcu 1921 r.,

100 Vide np.: spr. sten. z 295. posiedzenia SU, 31 marca 1922 r., 1. 31; spr. sten. z 296. posiedzenia SU, 4 kwietnia 1922 r., 1. 34; spr. sten. z 297. posiedzenia SU, 6 kwietnia 1922 r., 1. 53 i 60.

101 Vide spr. sten. z 32. posiedzenia SU, 2 maja 1919 r., ł. 47; spr. sten. z 76. posiedzenia SU, 24 lipca 1919 r., 1. 25; spr. sten. z 83. posiedzenia SU, 1 sierpnia 1919 r., 1. 113-118; spr. sten. ze 122. posiedzenia SU, 20 lutego 1920 r., ł. 5; spr. sten. z 328. posiedzenia SU, 18 lipca 1922 r., 1. 14-16. 
że poprawki do trzeciego czytania powinny być zgłaszane i rozdane posłom przed rozpoczęciem dyskusji (praktycznie za spełnienie tego wymogu uważano dostarczenie ich przynajmniej w jednym egzemplarzu samym tylko klubom parlamentarnym). Od tej pory starano się konsekwentnie trzymać tej zasady, a marszałek powoływał się nawet w tym względzie na ",prawo zwyczajowe"102.

Trzecie czytanie projektu ustawy zazwyczaj kończyło się formalnym głosowaniem. Najpierw głosowano poprawki, a następnie cały projekt ustawy ${ }^{103}$. Warto zauważyć, że niektórzy posłowie traktowali trzecie czytanie jako ostatnią szansę na wyeliminowanie projektu ustawy w całości. Jednak już latem 1919 r. w marszałek uznał wniosek formalny o przejście do porządku dziennego nad projektem ustawy, zgłoszony w trakcie trzeciego czytania, za niedopuszczalny i zauważył, że posłowie, którzy chcą głosować przeciw projektowi, mogą w kończącym trzecie czytanie głosowaniu en bloc opowiedzieć się przeciw niemu ${ }^{104}$. Pod koniec obrad konstytuanty pojawił się też praktyczny problem związany z dopuszczalnością reasumpcji głosowania nad uchwalonym już przez Sejm w głosowaniu szczegółowym artykułem projektu ustawy. W regulaminie brakowało przepisu na ten temat, natomiast w przywołanych przez marszałka regulaminach parlamentarnych innych państw dopuszczano reasumpcję tylko przy braku sprzeciwu. Rozstrzygnięcie tej precedensowej sytuacji pozostawiono izbie, która wypowiedziała się w głosowaniu przeciw dopuszczalności reasumpcji głosowania $\mathrm{w}$ trzecim czytaniu ${ }^{105}$.

Na koniec omawianego zagadnienia godzi się też zauważyć, że w okresie działania SU wykształciła się praktyka wieńczenia etapu trzeciego czytania niezwykle ważnych projektów ustaw okolicznościowym przemówieniem marszałka izby, w którym zazwyczaj podkreślał on rangę ustanowionego prawa i wyrażał podziękowania posłom i komisjom, które przyczyniły się do jego uchwalenia ${ }^{106}$.

Skrócona procedura postępowania ustawodawczego, przewidziana w przepisach art. 44 regulaminu, mogła być zastosowana na wniosek poparty przez co najmniej 15 posłów (w domniemaniu również na wniosek przedstawiciela rządu). W postępowaniu skróconym przewidziano:

- zwolnienie z obowiązku drukowania wniosku (projektu ustawy) lub sprawozdania komisji;

— dopuszczenie natychmiastowej rozprawy nad projektem bez odesłania go do komisji;

- dopuszczenie rozprawy zaraz po rozdaniu drukowanego sprawozdania komisji, co oznaczało przyspieszenie drugiego i trzeciego czytania, bez zachowania wymo-

102 Vide spr. sten. z 238. posiedzenia SU, 23 czerwca 1921 r., ł. 23-24; spr. sten. z 295. posiedzenia SU, 31 marca 1922 r., ł. 4 i 24; spr. sten. z 232. posiedzenia SU, 28 czerwca 1922 r., 1. 4; spr. sten. z 331. posiedzenia SU, 27 lipca 1922 r., ł. 17-20.

103 Vide spr. sten. z 84. posiedzenia SU, 2 sierpnia 1919 r., 1. 61-62; spr. sten. z 219. posiedzenia SU, 15 marca 1921 r., ł. 51-52.

104 Vide spr. sten. z 84. posiedzenia SU, 2 sierpnia 1919 r., 1. 60.

105 Vide spr. sten. z 332. posiedzenia SU, 28 lipca 1922 r., 1. 18-21.

106 Vide np. spr. sten. z 82. posiedzenia SU, 31 lipca1919 r., 1. 52-53. 
gu dotrzymania terminu jednego dnia na zapoznanie się posłów z drukiem sprawozdania komisji;

- wyznaczenie komisji terminu na przedłożenie sprawozdania. Wobec braku stosownego przepisu należy sądzić, że ten termin powinien zostać określony we wniosku o jego wyznaczenie.

\section{SZCZEGÓLNE POSTĘPOWANIA USTAWODAWCZE}

Zespół szczególnych procedur ustawodawczych stanowiły w praktyce funkcjonowania SU dwie procedury: konstytucyjna i budżetowa, a także mieszczące się formalnie w ramach funkcji kontrolnej parlamentu procedura postępowania w sprawach wyrażenia przez Sejm zgody na ratyfikację umowy międzynarodowej przez Naczelnika Państwa oraz procedura postępowania w sprawach zatwierdzania przez Sejm ustawodawstwa dekretowego.

Zgodnie z przepisem art. II ab initio małej konstytucji głównym zadaniem SU było przygotowanie i uchwalenie konstytucji. W tymczasowym regulaminie obrad nie przewidziano odrębnej procedury w zakresie prac nad projektem (projektami) konstytucji, stąd przepisy odnoszące się do ogólnego trybu prac nad wnioskami (w przypadku małej konstytucji) oraz ogólnego (zwykłego) trybu postępowania ustawodawczego (w przypadku konstytucji marcowej) musiały zostać — co rozstrzygnięto w praktyce parlamentarnej — zastosowane w pełnym zakresie do procedowania w sprawach wydawania aktów rangi ustrojowej. Tryby uchwalenia obydwu wymienionych ustaw zasadniczych przez konstytuantę, łącznie z komentarzem do przepisów stanowiących ich podstawę normatywna, zostały wyczerpująco przedstawione w literaturze przedmio$\mathrm{tu}^{107}$, co zwalnia autora niniejszego tekstu od ich ponownego podejmowania.

Drugie ze szczególnych postępowań ustawodawczych w latach prac konstytuanty, czyli procedura budżetowa, nie znajdowała żadnego umocowania w przepisach prawa pozytywnego, co oznaczało, że do jej biegu stosowały się przepisy ogólne normujące postępowanie ustawodawcze, uzupełniane stosownymi normami prawa zwyczajowego i doraźnie kształtowaną praktyką parlamentarną ${ }^{108}$. Już w okresie funkcjonowania konstytuanty wykształciła się norma prawa zwyczajowego ograniczająca krag podmiotów

107 Vide m.in.: S. Krukowski, Geneza konstytucji z 17 marca 1921 r., Warszawa 1977; idem, Konstytucja Rzeczypospolitej Polskiej z 1921 r., [w:] Konstytucje Polski. Studia monograficzne z dziejów polskiego konstytucjonalizmu, t. II, red. M. Kallas, Warszawa 1990, s. 19-70; W. Komarnicki, op. cit., s. 133-206; idem, Ustrój państwowy Polski współczesnej. Geneza i system, Wilno 1937, s. 30-34; A. Gwiżdż, Burżuazyjno-obszarnicza Konstytucja z 1921 roku w praktyce, Warszawa 1956, s. 47-72; A. Ajnenkiel, Spór o model parlamentaryzmu polskiego do roku 1926, Warszawa 1972, s. 207-241; M. Pietrzak, Tryb uchwalenia konstytucji marcowej (17 marca 1921 r.), [w:] Tryby uchwalania polskich konstytucji, red. M. Wyrzykowski, Warszawa 1998, s. 43-52; F. Siemieński, Uchwalanie konstytucji polskich, [w:] Przeobrażenia we współczesnym prawie konstytucyjnym, red. K. Działocha, „Acta Universitatis Wratislaviensis” 1995, Prawo CCXLVII; W.T. Kulesza, Uchwała Sejmu Ustawodawczego z dnia 20 lutego 1919 r. o powierzeniu Józefowi Pitsudskiemu dalszego sprawowania urzędu Naczelnika Państwa, „Przegląd Sejmowy” 2007, nr 5, s. 33-56; P.A. Tusiński, Postępowanie..., s. 355-375.

${ }^{108} \mathrm{Na}$ temat procedury budżetowej w Sejmie i Senacie okresu II RP vide szerzej P.A. Tusiński, Postępowanie..., s. 295-353. 
uprawnionych do inicjatywy budżetowej (w zakresie przedkładania stosownego projektu ustawy skarbowej wraz z załączonym preliminarzem budżetowym) wyłącznie do rządu. Norma zwyczajowa została następnie podniesiona do rangi prawnopozytywnej w konstytucji marcowej. Ograniczenie inicjatywy budżetowej tylko do rządu wynikało ze szczególnego charakteru budżetu, którego przygotowanie wymagało specjalistycznych zabiegów fachowych ${ }^{109}$. W latach 1919-1922 rząd złożył w Sejmie za pośrednictwem ministra skarbu sześć projektów ustaw skarbowych z załączonym preliminarzem budżetowym lub prowizorium budżetowym bądź wnioskiem o udzielenie dodatkowych kredytów. Pierwszy z projektów obejmował okres I półrocza 1919 r., dwa następne dotyczyły okresów 9-miesięcznych, a dwa ostatnie objęły okresy roczne lat 1921 i $1922^{110}$. W tym czasie Sejm trzykrotnie wzywał rząd - we wnioskach nagłych — do wniesienia projektu budżetu. Pierwszy raz w odniesieniu do projektu budżetu na rok 1921, którego przedłożenia izba zażyczyła sobie najpierw do dnia 15 czerwca, a gdy to nie nastąpiło, wezwała rząd „do jak najszybszego przedłożenia”, już bez wyznaczania konkretnego terminu ${ }^{111}$. W trzeciej rezolucji zażądano uzupełnienia projektu budżetu na rok 1922. Izba procedowała nad ustawami skarbowymi w trybie przyjętym dla uchwalania ustaw. Sejm tylko dwukrotnie przystapił do drugiego czytania przedłożonych projektów ustaw budżetowych (na podstawie sprawozdań przygotowanych przez Komisję Skarbowo-Budżetowa) na posiedzeniu plenarnym, ale ani razu ich nie ukończył i nie przystapił do trzeciego czytania. Tak więc SU w całym okresie swego funkcjonowania ani razu nie zdołał uchwalić budżetu państwa ${ }^{112}$.

Mieszczace się formalnie w ramach funkcji kontrolnej postępowanie w sprawie wyrażenia zgody Sejmu na ratyfikację umowy międzynarodowej toczyło się w okresie działania konstytuanty zasadniczo w ramach ogólnego postępowania ustawodawczego. Co najwyżej w takiej sytuacji relatywnie częściej niż w przypadku rozpatrywania projektów innych aktów sięgano do instrumentów postępowania skróconego ${ }^{113}$.

Szczególna procedura zatwierdzania przez konstytuantę ustawodawstwa dekretowego wykazywała w części zastosowań cechy typowego postępowania ustawodawczego, w innych zaś cechy standardowych zasad postępowania kontrolnego. Obydwa sposoby znajdowały umocowanie prawne w omówionych wcześniej aktach prawa pozytywnego, normach prawa zwyczajowego oraz praktyce parlamentarnej. Stosunek konstytuanty do ustawodawstwa dekretowego został opisany w literaturze przedmiotu $^{114}$, wobec czego nie wymaga ponownej eksplikacji. Spośród poczynionych

109 Vide szerzej: T. Grodyński, Zasady gospodarstwa budżetowego w Polsce na tle porównawczem, Kraków 1932, s. 229-230.

${ }^{110}$ T. Grodyński (op. cit., s. 30-32) wylicza tylko pięć projektów; Sejm Ustawodawczy RP, druki nr: 402, 692, 966, 2049, 2463, 3223.

111 Vide spr. sten. z 232. posiedzenia SU, 7 czerwca 1921 r., ł. 66-67; „Kurier Polski”, nr 182, 8 VII 1921.

112 Confer T. Grodyński, op. cit., s. 30-32.

113 Vide P.A. Tusiński, Postępowanie..., passim w obrębie rozdz. II (s. 85-202); M. Kijowski, Udział Sejmu i Senatu w ratyfikacji umów międzynarodowych (1919-2003), Rzeszów 2004, s. 41-57. Drugi z autorów nie zajmuje się jednak analizą i egzegezą aspektów prawno-proceduralnych postępowania ustawodawczego w zakresie uchwalania przez SU ustaw wyrażających zgodę na ratyfikację umów międzynarodowych.

114 Vide R. Kraczkowski, op. cit., s. 29-86; P.A. Tusiński, Postępowanie..., s. 259-266. 
w powołanych opracowaniach ustaleń należy przywołać tylko te, które sumarycznie obrazują to zagadnienie. Dyspozycja, jak określano to w SU, „konstytucyjnego zatwierdzenia" ustawodawstwa tymczasowego (dekretowego), delegowanego i wyjątkowego odnosiła się do dziewięciu dekretów Rady Regencyjnej, 210 dekretów zatwierdzonych przez Tymczasowego Naczelnika Państwa, 10 dekretów Rady Ministrów oraz 63 rozporządzeń ROP. Spośród dekretów Rady Regencyjnej konstytuancie przedstawiono na wspomnianym wcześniej 1. posiedzeniu siedem dekretów, ponieważ dwa utraciły aktualność. Z dekretów Naczelnika Państwa nie przedstawiono Sejmowi jednego (z 8 lutego 1919 r.) ${ }^{115}$, a jeden ze zgłoszonych został wycofany. Natomiast dekrety Rady Ministrów oraz rozporządzenia ROP przedstawiono izbie w całości.

We wspomnianych aktach konstytucyjnych Rady Regencyjnej z 15 października 1918 r. i Naczelnika Państwa z 22 listopada 1918 r., nakładających na rząd obowiązek - pod rygorem utraty mocy — przedstawienia SU na 1. posiedzeniu do zatwierdzenia nie wyznaczono Sejmowi terminów na rozpatrzenie i zatwierdzenie przedstawionych ustaw tymczasowych wydanych przed jego zebraniem się. Problemu tego nie podjęto również w małej konstytucji. W tej sytuacji może się wydawać, że kwestia ta, jak również szczegółowe określenie procedury rozpatrywania przedłożonych dekretów miały zostać unormowane w szczególnych przepisach tymczasowego regulaminu obrad. Niestety tak się nie stało i tryb postępowania w tym zakresie wynikał z norm określających ogólne postępowanie w sprawach wniosków i projektów ustaw oraz z praktyki parlamentarnej, która — co należy wyraźnie podkreślić — nie budziła w konstytuancie żadnych sporów natury proceduralnej. Odnośnie do samej kwestii tymczasowości obowiązywania ustawodawstwa dekretowego poprzedzającego zebranie się SU, godzi się zauważyć, że (wskutek enigmatyczności wspomnianych dekretów konstytucyjnych, na podstawie których je ustanowiono) nie było jasne, czy utrata mocy obowiązującej dekretów nieprzedstawionych do zatwierdzenia Sejmowi miała nastapić z mocy samego faktu braku przedłożenia (ex lege), czy też powinna zostać stwierdzona np. specjalną uchwałą konstatującą brak przedłożenia.

Wspomniano już, że dekrety ustawodawcze Rady Regencyjnej i Naczelnika Państwa zostały odesłane na 1. posiedzeniu konstytuanty do Komisji Prawniczej i innych komisji według ich właściwości resortowych. Działając w trybie ustawodawczym, komisje przygotowywały sprawozdania na posiedzenia plenarne Sejmu. Konkluzja takiego sprawozdania sprowadzała się do zaproponowania jednego z trzech wariantów możliwych rozwiązań: zatwierdzenia dekretu, wprowadzenia do niego zmian lub odrzucenia go w całości. Jak ustalił R. Kraczkowski, w odniesieniu do 24 dekretów wydanych przed 10 lutego 1919 r. komisje SU wniosły o ich zatwierdzenie, co izba przyjmowała w formie zwykłej uchwały, na ogół bez dyskusji, ale czasami opatrywała rezolucjami skierowanymi do rządu (a więc w trybie kontrolnym). W stosunku do 33 dekretów komisje wnioskowały o wprowadzenie do nich

115 Mimo że nie został opublikowany w „Dzienniku Praw”, obowiązywał kilka lat i został zastapiony dopiero ustawą uchwaloną przez Sejm. 
zmian, co zawsze odbywało się przez przygotowanie przez nie nowego kompleksowego projektu ustawy, łączącego pozostawiane w mocy przepisy dekretu oraz wprowadzane nowe regulacje (tak więc postępowanie nosiło wszelkie cechy postępowania ustawodawczego). Ustawa taka po uchwaleniu zastępowała dekret, bez względu na zakres proponowanych zmian. Na początku 1920 r. rozwiązanie to uważano w Sejmie za utarty zwyczaj wprowadzania zmian do dekretów ${ }^{116}$. Sprawozdanie komisji $\mathrm{z}$ wnioskiem o wprowadzenie do rozpatrywanego dekretu zmian, wraz z załączonym stosownym projektem ustawy, traktowano jako drugie czytanie projektu, ponieważ przedstawienie tytułu dekretu na pierwszym posiedzeniu izby było równoznaczne z pierwszym czytaniem projektu ustawy. Również w takich przypadkach rzadko dochodziło do debaty w trakcie drugiego czytania, a Sejm uchwalał stosowny projekt ustawy tylko po wystapieniu komisyjnego sprawozdawcy i zazwyczaj niezwłocznie w trzecim czytaniu. Komisje SU zgłosiły sześć wniosków o uchylenie dekretów w całości, z czego izba zdołała rozpatrzyć i zaaprobować tylko trzy. Uchylenie dekretu następowało poprzez uchwałę Sejmu opublikowaną w „Dzienniku Ustaw” (a więc również w trybie kontrolnym). W sumie więc SU w trybie przyjętym dla „konstytucyjnego zatwierdzania" dekretów, zdołał rozpatrzyć w pełni tylko 60 spośród 215 ostatecznie przedstawionych przez rząd do zatwierdzenia dekretów, czyli niespełna $28 \%$. Komisje zdołały przygotować sprawozdania jeszcze w sprawie kilku kolejnych dekretów, ale do ich rozpatrzenia na forum plenarnym nie doszło. Jak zauważył badacz problemu, rozpatrywanie przez konstytuantę dekretów wydanych przed 10 lutego 1919 r. praktycznie zakończyło się w styczniu 1920 r., ponieważ po tej dacie jeszcze tylko w grudniu tego roku stanęła na plenum sprawa jednego dekretu. Nieuchylone w całości bądź zmienione stosowną ustawą (formalnie nowelizującą dekret) akty ustawodawstwa tymczasowego sprzed 10 lutego 1919 r. obowiązywały zatem nadal, nierzadko jeszcze przez wiele następnych lat, po czym były sukcesywnie znoszone ustawami uchwalanymi przez parlament w zwykłym trybie ustawodawczym bądź derogowane po zamachu majowym rozporządzeniami Prezydenta RP z mocą ustawy.

W odniesieniu do ustawodawstwa delegowanego przez konstytuantę na Radę Ministrów w dwóch ustawach je ustanawiających określono termin — trzy miesiące na wydanie dekretów oraz przedstawienie ich izbie do zatwierdzenia. W tym trybie wpłynęło do Sejmu 10 dekretów, ale z analizy stenogramów posiedzeń plenarnych wynika, że utknęły one w komisjach i nie stały się przedmiotem stosownych sprawozdań na forum plenarnym. Ponadto — zgodnie z ustawą o ROP — wszystkie wydawane rozporządzenia i zarządzenia, które wymagały zatwierdzającej uchwały Sejmu, miały być mu przedkładane do zatwierdzenia za pośrednictwem premiera na najbliższym posiedzeniu (art. 4 ust. 2). W praktyce, aprobowanej przez doktrynę, tylko rozporządzenia ustanawiały normy ogólne, a więc miały charakter ustaw tymczasowych ${ }^{117}$. W całym okresie swojej działalności Rada Regencyjna wydała 63 rozpo-

116 Tak twierdził poseł M. Rataj; vide spr. sten. ze 109. posiedzenia SU, 13 stycznia 1920 r., 1. 5.

117 R. Kraczkowski, op. cit., s. 58-59. 
rządzenia, z czego sześciu nie opublikowano ${ }^{118}$. Rząd przekazał Sejmowi do zatwierdzenia 59 rozporządzeń, które trafiły do właściwych komisji w celu rozpatrzenia ${ }^{119}$. W odniesieniu do zatwierdzania rozporządzeń ROP Sejm przyjął zasadniczo tryb postępowania stosowany wcześniej do zatwierdzania dekretów wydawanych przed 10 lutego 1919 r. ${ }^{120}$ Jak ustalił R. Kraczkowski, przedmiotem sprawozdań komisji stało się tylko 10 rozporządzeń ROP, a więc niespełna $17 \%$ ze zgłoszonych izbie. Spośród nich konstytuanta na wniosek komisji zatwierdziła sześć, co nastapiło w formie uchwał Sejmu, ogłoszonych w „Monitorze Polskim” jako obwieszczenia marszałka izby (a więc w trybie kontrolnym). Jedno rozporządzenie Sejm zatwierdził ze zmiana, a więc ustawą uchwaloną 26 listopada 1920 r. Trzy rozporządzenia zostały zaś uchylone, przy czym jedno 29 października 1920 r. uchwałą Sejmu (w trybie kontrolnym), a dwa ustawami z 9 i 17 grudnia $1920 \mathrm{r}^{121} \mathrm{~W}$ porównaniu z procedurą stosowaną do zatwierdzania dekretów Rady Regencyjnej i Tymczasowego Naczelnika Państwa widać niekonsekwencję Sejmu w zakresie stosowanej formy prawnej uchylania rozporządzeń ROP. Niekonsekwencję tę cytowany autor próbuje wytłumaczyć twierdzeniem, że izba wypowiadała się w formie ustawy dopiero po ustaniu mandatu ROP, czyli najpóźniej z końcem listopada $1920 \mathrm{r}$. (co było raczej działaniem politycznym, ponieważ nigdy nie zostało potwierdzone formalnym aktem). Ustanie mandatu ROP i udzielenie jej absolutorium, choć znów nieformalne, było też — zdaniem R. Kraczkowskiego — sumarycznym zatwierdzeniem pozostałych wydanych przez nia, a nierozpatrzonych jeszcze przez Sejm rozporządzeń. Tak więc rozporządzenia ROP od grudnia 1920 r. można było uchylać wyłącznie ustawa, ponieważ nie można było sprawować kontroli nad organem, który już nie istniał ${ }^{122}$. Ponadto należy zauważyć, że po ustaniu mandatu ROP jej rozporządzenia, nierozpatrzone przez Sejm, stawały się (z ustaw tymczasowych) aktami o nieograniczonej czasowo mocy prawnej i jako takie mogły być derogowane tylko aktem prawnym co najmniej tej samej rangi.

\section{UWAGI KOŃCOWE}

Pierwszy parlament odrodzonej Rzeczypospolitej był fenomenem dziejowym tworzącym podwaliny ustrojowo-prawne systemu rządów parlamentarno-gabineto-

${ }^{118}$ R. Kraczkowski (ibidem, s. 72) podaje, że nie opublikowano czterech rozporządzeń ROP. Tymczasem analiza treści „Dziennika Ustaw” z 1920 r. pozwala doliczyć się tylko 57 rozporządzeń ROP opublikowanych na jego łamach. Sejmowi przedłożono 59 rozporządzeń, co oznaczałoby, że nie opublikowano nie czterech, lecz sześciu rozporządzeń ROP. Liczba 59 rozporządzeń przedłożonych Sejmowi przez premiera znajduje również potwierdzenie w Skorowidzu, s. 606-614.

119 Vide spr. sten. ze 166. posiedzenia SU, 24 lipca 1920 r., ł. 5-6.

${ }^{120}$ R. Kraczkowski, op. cit., s. 74.

121 Ibidem, s. 74-75. Z zestawienia losów rozporządzeń ROP sporządzonego w Skorowidzu, s. 607-614, wynika, że w komisjach zaległo 46 rozporządzeń; izba uchyliła nie trzy lecz cztery spośród nich oraz poddała częściowej zmianie nie jedno lecz trzy rozporządzenia. W sumie więc izba rozpatrzyła 13 rozporządzeń ROP, a nie 10, jak podaje R. Kraczkowski. Autor ten nie wskazuje wyraźnie podstawy źródłowej swoich obliczeń, nie powołuje się też na cytowany tu Skorowidz, który wydaje się wiarygodny.

${ }^{122}$ R. Kraczkowski, op. cit., s. 75-78. 
wych w Polsce. Wiele jego dokonań zachowywało aktualność - mimo istotnie zmienionych warunków ustrojowych — nawet do końca międzywojnia i weszło do kanonu polskiej tradycji parlamentarnej. SU zasadniczo nie mógł odwoływać się do dorobku ustrojowego I Rzeczypospolitej, z racji jego historycznej dezaktualizacji. Trzeba było zatem stworzyć nowy kształt przedstawicielstwa narodowego, niejako na surowym korzeniu, korzystając co najwyżej z wiedzy w zakresie problematyki prawno-ustrojowej posiadanej przez zasiadających w jego ławach prawników (dotyczącej porządków konstytucyjnych państw zachodnioeuropejskich) oraz doświadczeń wyniesionych przez nich oraz posłów nieposiadających przygotowania prawniczego z parlamentów państw zaborczych ${ }^{123}$. Ten kapitał społeczny okazał się bezcenny, jeśli chodzi o potrzebę nadawania kształtu normatywnego i praktycznego omówionych procedur parlamentarnych. Należy jednak zauważyć, że znaczący wkład w to dzieło wniósł również rząd Ignacego Paderewskiego, który przedłożył projekt regulaminu obrad izby (uchwalony przez nią z niewielkimi poprawkami), pracownicy Biura Sejmu oraz ci spośród posłów niezaliczonych do wymienionych grup, którzy czynnie angażowali się w prace komisji oraz postępowania sejmowe, szybko uczyli się nowych ról społecznych i wykazywali się wielką pracowitością, spędzając np. dziesiątki godzin tygodniowo w Bibliotece Sejmowej.

Sejm Ustawodawczy od samego początku swojego istnienia podjął się wykonywania wszystkich klasycznych funkcji parlamentarnych państwa konstytucyjnego, zaadaptował i twórczo przeszczepił na polski grunt szeroki zasób istotnych procedur parlamentarnych, a nawet dopracował się w tym zakresie rozwiązań bezprecedensowych na skalę europejska, jak np. w odniesieniu do przebiegu i usprawniania obrad plenarnych oraz podnoszenia efektywności prac całej izby i jej komisji ${ }^{124}$. Wszystko to na podstawie niezwykle skromnego umocowania w normach pozytywnego prawa parlamentarnego, praktycznie ograniczonego do przepisów niezbyt obszernego regulaminu. Wymagało to od organów kierowniczych izby, komisji i klubów poselskich znajomości ich odpowiedników w parlamentaryzmie zachodnioeuropejskim oraz subtelnych niekiedy tamtejszych zwyczajów i konwenansów bądź podjęcia — jak się okazało, z dużym powodzeniem - trudu stopniowego dopracowywania się rodzimych reguł proceduralnych.

123 Przez ławy konstytuanty w całym okresie jej funkcjonowania przewinęło się ogółem 451 osób pełniących mandat poselski, z czego 52 (11,5\% ogółu) z nich odbyły studia prawnicze (ponad 1/3 z nich uprawiała zawód prawniczy). W tej grupie 37 posłów miało doświadczenie parlamentarne z przedstawicielstw państw zaborców Polski (20 zasiadało uprzednio w wiedeńskiej Radzie Państwa, 10 w Sejmie Krajowym we Lwowie, czterech w Reichstagu Rzeszy, a trzech w pruskim Sejmie Krajowym). Spośród posłów reprezentujących zawody nieprawnicze doświadczenia parlamentarne posiadało 51 posłów konstytuanty (11,3\% ogółu posłów), z czego: 21 w parlamencie wiedeńskim, 17 w Sejmie Krajowym galicyjskim, po 13 w Reichstagu i rosyjskiej Dumie Państwowej oraz pięciu w Landtagu pruskim [obliczenia własne — P.A.T.].

124 Sejm w trakcie 45 miesięcy działalności odbył 342 posiedzenia plenarne (średni czas trwania posiedzenia wynosił ok. 4,5 godziny), uchwalił 606 ustaw (53,3\% ogółu zgłoszonych projektów ustaw) i blisko 1,5 tysiąca innych wniosków i rezolucji; vide P.A. Tusiński, Postępowanie..., passim. 


\section{BIBLIOGRAFIA}

\section{ŹRÓDŁA}

„Dziennik Praw Królestwa Polskiego” 1918.

„Dziennik Praw Państwa Polskiego” 1918-1919.

„Dziennik Ustaw Rzeczypospolitej Polskiej” 1919-1921.

Głąbiński S., Wspomnienia polityczne, Druk. i Księg. Sp. z O. Odp., Pelplin 1939.

„Kurier Polski” 1919-1922.

Rataj M., Wskazania obywatelskie i polityczne, Ludowa Spółdzielnia Wydawnicza, Warszawa 1987.

Sejm Rzeczypospolitej Polskiej. I kadencja 1922-1927. Spr. sten. z 16. posiedzenia, 16 lutego $1923 \mathrm{r}$.

Sejm Ustawodawczy Rzeczypospolitej Polskiej. Skorowidz rzeczowy do sprawozdań stenograficznych z posiedzeń plenarnych Sejmu pos. 1 (10.II.1919)-pos. 342 (27 XI 1922), Kancelaria Sejmu PRL, Warszawa 1972, maszynopis w Bibliotece Sejmowej.

Sejm Ustawodawczy Rzeczypospolitej Polskiej 1919-1922, druki.

Sejm Ustawodawczy Rzeczypospolitej Polskiej 1919-1922, sprawozdania stenograficzne.

Sudoł J., Wspomnienia z lat 1882-1945, t. V, maszynopis w Bibliotece Zakładu Narodowego im. Ossolińskich we Wrocławiu, sygn. 15329/I, II.

Tymczasowy Regulamin Obrad Sejmu Ustawodawczego Rzeczypospolitej Polskiej, oprac. T. Koperska, „Przegląd Sejmowy” 1993, nr 1.

Wierzbicki A., Wspomnienia, t. II, maszynopis w Bibliotece Instytutu Historii Polskiej Akademii Nauk w Warszawie.

Wierzbicki A., Wspomnienia i dokumenty (1877-1920), Państwowe Wydawnictwo Naukowe, Warszawa 1957.

Witos W., Moje wspomnienia, Ludowa Spółdzielnia Wydawnicza, Warszawa 1978.

Wojdaliński R., Relacje posła na Sejm Ustawodawczy (1919-1922), t. I-IV, maszynopis w Bibliotece Zakładu Narodowego im. Ossolińskich we Wrocławiu, sygn. 14108/II.

\section{PIŚMIENNICTWO}

Ajnenkiel A., Spór o model parlamentaryzmu polskiego do roku 1926, Książka i Wiedza, Warszawa 1972.

Banaszak B., Prawo konstytucyjne, C.H. Beck, Warszawa 2012.

Cybichowski Z., Polskie prawo państwowe na tle uwag z dziedziny nauki o państwie i porównawczego prawa państwowego, t. II, Wydawnictwo Seminarium Prawa Publicznego Uniwersytetu Warszawskiego, nr 16, Warszawa 1933.

Grodyński T., Zasady gospodarstwa budżetowego w Polsce na tle porównawczem, Polska Akademja Umiejętności, Kraków 1932.

Gwiżdż A., Burżuazyjno-obszarnicza Konstytucja z 1921 roku w praktyce, Wydawnictwo Prawnicze, Warszawa 1956.

Gwiżdż A., Formy pracy sejmów Drugiej Rzeczypospolitej, [w:] Sejmy Drugiej Rzeczypospolitej, red. A. Zakrzewski, Ludowa Spółdzielnia Wydawnicza, Warszawa 1990.

Kaczmarek Z., Wojciech Trąmpczyński, Urząd Wojewódzki w Poznaniu. Wydział Kultury i Sztuki, Poznań 1993.

Kijowski M., Udziat Sejmu i Senatu w ratyfikacji umów międzynarodowych (1919-2003), Wydawnictwo Uniwersytetu Rzeszowskiego, Rzeszów 2004. 
Komarnicki W., Polskie prawo polityczne (Geneza i system), F. Hoesick, Warszawa 1922.

Komarnicki W., Ustrój państwowy Polski współczesnej. Geneza i system, „Świt”, Wilno 1937.

Kraczkowski R., Dekretowanie ustaw w Polsce w latach 1918-1926, Wydawnictwo Sejmowe, Warszawa 1994.

Krukowski S., Geneza konstytucji z 17 marca 1921 r., Ludowa Spółdzielnia Wydawnicza, Warszawa 1977.

Krukowski S., Konstytucja Rzeczypospolitej Polskiej z 1921 r., [w:] Konstytucje Polski. Studia monograficzne z dziejów polskiego konstytucjonalizmu, t. II, red. M. Kallas, Państwowe Wydawnictwo Naukowe, Warszawa 1990.

Kulesza W.T., Uchwała Sejmu Ustawodawczego z dnia 20 lutego 1919 r. o powierzeniu Józefowi Pitsudskiemu dalszego sprawowania urzędu Naczelnika Państwa, „Przegląd Sejmowy" 2007, nr 5.

Kustra E., Proces ustawodawczy jako proces decyzyjny, „Acta Universitatis Nicolai Copernici. Prawo XII. Nauki Humanistyczno-Społeczne” 1973, z. 56.

Marszałek P.K., Rada Obrony Państwa z 1920 roku. Studium prawnohistoryczne, „Acta Universitatis Wratislaviensis" 1995, Prawo CCXXVIII.

Pietrzak M., Tryb uchwalenia konstytucji marcowej (17 marca 1921 r.), [w:] Tryby uchwalania polskich konstytucji, red. M. Wyrzykowski, Instytut Spraw Publicznych, Warszawa 1998.

Radziewanowska B., Ewolucja francuskiego systemu komisji parlamentarnych na tle porównawczym, praca doktorska: Wydział Prawa i Administracji UJ, sygn. 81/71, Archiwum Biblioteki Jagiellońskiej w Krakowie.

Rzepecki T., Sejm Rzeczypospolitej Polskiej 1919 roku, Wielkopolska Księg. Nakładowa, Poznań 1920.

Schreiner H.J., Procedury w niemieckiej tradycji parlamentarnej, „Przegląd Sejmowy” 1994, $\mathrm{nr} 4$.

Siemieński F., Uchwalanie konstytucji polskich, [w:] Przeobrażenia we współczesnym prawie konstytucyjnym, red. K. Działocha, „Acta Universitatis Wratislaviensis” 1995, Prawo CCXLVII.

Stownik języka polskiego, t. 2: L-P, Państwowe Wydawnictwo Naukowe, Warszawa 1979.

Stembrowicz J., Parlament V Republiki Francuskiej, Państwowe Wydawnictwo Naukowe, Warszawa 1963.

Stembrowicz J., Rzad w systemie parlamentarnym, Państwowe Wydawnictwo Naukowe, Warszawa 1982.

Tusiński P.A., Norma prawna i obyczaj jako podstawa wyłaniania i funkcjonowania organów kierowniczych parlamentu II Rzeczypospolitej, „Prace Naukowe Politechniki Radomskiej im. Kazimierza Pułaskiego: Ekonomika" 1999, nr 1.

Tusiński P.A., Postępowanie ustawodawcze w Sejmie i w Senacie II Rzeczypospolitej 1919-1939. Prawo - zwyczaje - praktyka parlamentarna, Politechnika Radomska, Radom 2008.

Wątor A., Działalność Zwiazku Ludowo-Narodowego w latach 1919-1922, Wydawnictwo Naukowe Uniwersytetu Szczecińskiego, Szczecin 1992.

Zieleniewski L., Regulamin Senatu na tle regulaminów oraz praktyki izb ustawodawczych w Polsce i innych państwach, t. II, F. Hoesick, Warszawa 1933.

Zieleniewski L., Regulaminy Sejmu i Senatu, „Nowe Państwo” 1936, z. 2. 



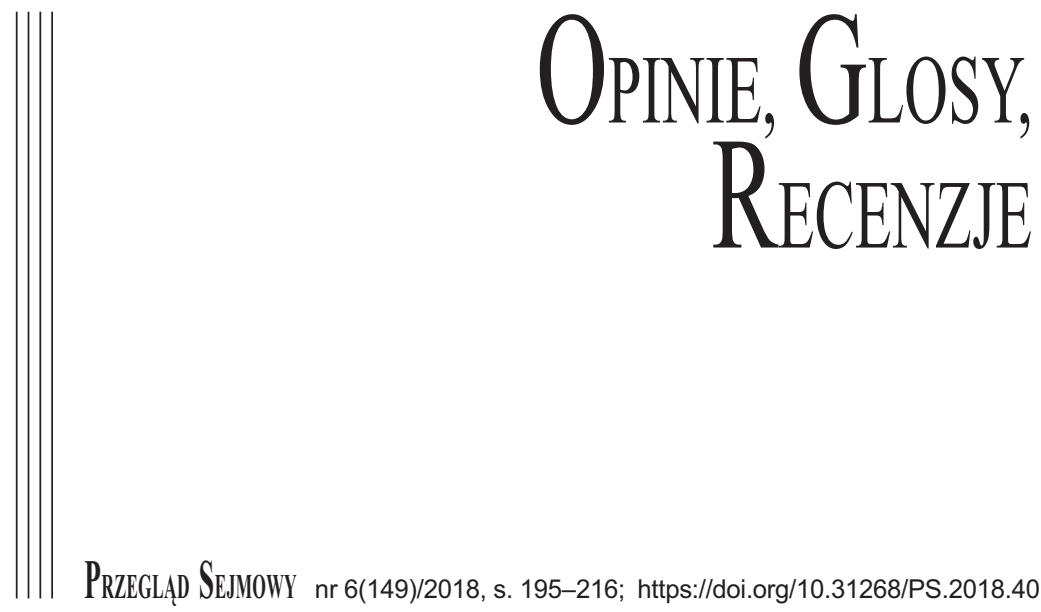

OPINIE

\author{
KONTROLA CYWILNA NAD WOJSKIEM \\ W STANACH ZJEDNOCZONYCH AMERYKI* \\ CIVILIAN CONTROL OVER THE MILITARY \\ IN THE UNITED STATES OF AMERICA
}

The opinion contains an analysis of various aspects of the civilian control of the U.S. armed forces. It refers to legal, institutional and political aspects of the civilian control. Due to the American strategic and political culture, the article refers to events and facts from before independence of the American republic, e.g. the phenomenon of voluntary draft, the so-called colonial, then state militia, which is so specific for the American strategic culture, that one cannot explain it without clarifying the history of English colonies in North America (the United States National Guard refers to this very tradition). Similarly, the attitude towards the regular army had been characterized by American citizens' distrust for over 150 years. The position, role, status and perception of the armed forces had greatly changed after the Second World War. Changes in the relation between the civilian and military spheres are thoroughly discussed.

Słowa kluczowe: Stany Zjednoczone Ameryki, republika, wojsko, sfera cywilna, polityka, kontrola

Key words: United States of America, republic, armed forces, civilian sphere, politics, control

Odpowiedź na pytanie o kontrolę cywilną nad wojskiem pozornie jest dość prosta. Każda decyzja państwowa w czasie wojny i pokoju — w tym każde rozstrzygnięcie dotyczace bezpieczeństwa narodowego - zapada poza siłami zbrojnymi. W demokracjach decyzje te podejmują ludzie wybrani w wyborach powszechnych lub mianowani na godności publiczne przez tych, którzy zostali wybrani. Jako zasada kontrola cywilna jest absolutna i wszechogarniająca, dotyczy tyleż kontroli nad instytucjami wojskowymi, co stanu sił zbrojnych w danym państwie. Oznacza również, że

\footnotetext{
* Opinia została napisana 1 października 2018 r. (przyp. red.).
} 
żadna decyzja ani uprawnienie nie jest dane wojskowym, o ile nie zostanie ono wprost lub pośrednio delegowane przez przywódców politycznych. Wszelkie sprawy - od największej, dotyczącej przystąpienia do wojny, po najdrobniejsze, rozstrzygające o karach za niesubordynację - emanują z władzy cywilnej lub są rozstrzygane przez cywilów. Nawet decyzje w sferze dowodzenia, wyboru strategii lub podjętej operacji wojskowej, zarządzania wojskiem w czasie wojny i pokoju płyną ze sfery cywilnej. Oczywiście są przypadki, kiedy sytuacja, zwyczaj czy nakaz skuteczności użycia sił zbrojnych sprawiają że decyzje podejmuje wojskowy.

Kontrolę cywilną można mierzyć, analizując zakres jej uprawnień i poddając ocenie jej efektywność, dzięki ustaleniu wpływu polityków i wojskowych na decyzje państwowe dotyczące wojny, bezpieczeństwa wewnętrznego, obrony kraju, spraw wojskowych (np. kwestia budżetu). Ta konstatacja, mająca statyczny charakter, nie ukazuje dynamiki sytuacji. Kilka przykładów obrazujących poszczególne kwestie pozwala ukazać istotne zmiany w tej sferze. Pod tym względem daleko idące konsekwencje niosła ze sobą II wojna światowa. Szczególnie dobitnie widać to na przykładzie powojennego ładu politycznego. Kiedy sekretarz stanu James Byrnes sugerował prezydentowi Harry'emu Trumanowi bezwarunkową kapitulację Japonii, ten przychylił się do rady głównodowodzącego armią adm. Williama Leahy’a, aby zachować cesarstwo, reformę systemu politycznego pozostawiając wojsku. Gen. Douglas MacArthur wpisał do japońskiej konstytucji zasady demokracji liberalnej. W ten sposób wojskowy wprowadził znaczące zmiany polityczne, które skądinąd w elitach politycznych USA upowszechniały przekonanie, że możliwy jest eksport amerykańskiej demokracji.

Dokonania wojenne gen. MacArthura oraz jego sukcesy polityczne w reformowaniu autorytarnej Japonii leżały u źródeł spektakularnej próby sił między politykami a siłami zbrojnymi w czasie wojny koreańskiej. Od czasów tzw. konspiracji z Newburg po wojnie o niepodległość Stanów Zjednoczonych Ameryki był to najpoważniejszy kryzys kontroli cywilnej nad wojskiem. Oficerowie amerykańskiego wojska od czasów wojny secesyjnej nie angażowali się w politykę, ostentacyjnie unikając wypowiedzi, czynów, aktywności czy afiliacji politycznej. Oczywiście zdarzały się przypadki karier politycznych generałów, były one jednak wyjątkami od reguły, jeśli chodzi o zachowania korpusu oficerskiego. Oficerowie podzielali przekonanie, że wojsko służy państwu, stojąc ponad ,brudną polityką”. Generał George Marshall zalecał nawet, aby oficerowie powstrzymywali się od elementarnego dla demokracji udziału $\mathrm{w}$ wyborach. Ustalił również regułę, że wojskowi nie wypowiadają się publicznie o ekipie aktualnie sprawującej władzę polityczną w republice amerykańskiej. Reguła ta została poważnie zakwestionowana podczas interwencji amerykańskich sił zbrojnych w Iraku, choć do jej osłabienia dochodziło już wcześniej.

Decyzja o wojnie w Iraku została podjęta przez polityków wbrew wątpliwościom zgłaszanym przez wojskowych. Już w programie polityki zagranicznej, sformułowanej przez Colina Powella, zakładano możliwość prawa weta wobec decyzji politycznych (echo praktyk generała G.B. McClellana z czasów wojny secesyjnej). Przy przedłużającej się wojnie w Iraku opór ze strony wyższych oficerów wobec sekretarza obrony 
Donalda Rumsfelda był już tak zdecydowany, że zaczęli oni naruszać podstawową regułę apolityczności wojska. Miarą ich niezadowolenia był niespotykany do tej pory w amerykańskich siłach zbrojnych publiczny atak grupy emerytowanych generałów w kwietniu 2006 r. na urzędującego sekretarza obrony. Do tego czasu oficerowie tej rangi w proteście wobec decyzji politycznej ustępowali ze stanowiska. Tak było chociażby w przypadku admirała Leahy'a po wymuszonym na Portoryko traktacie z 1949 r. (Leahy był również przeciwnikiem zrzucenia bomby atomowej na Japonię).

Konflikt wojskowych z Rumsfeldem oznacza symboliczny koniec epoki, w której siły zbrojne dystansowały się od świata polityki. Od tej chwili wojsko zaczęło być postrzegane jako jeszcze jedno lobby polityczne, zainteresowane obsadą stanowisk publicznych. Narastająca w latach 2007-2008 krytyka działań generała Davida Petraeusa, uznawanego za frontmana polityki administracji George'a W. Busha w Iraku klarownie pokazała, że neutralność wojska definitywnie należy do przeszłości.

Można wytyczyć punkty graniczne tej zmiany statusu i miejsca wojska w amerykańskim społeczeństwie. W republice zachodziły procesy cywilizacyjne i polityczne, które poważnie przedefiniowały relacje między sferą cywilną a wojskową przy czym należy wziąć pod uwagę co najmniej kilka czynników. Pierwszy pokazuje charakterystyczny dla Amerykanów pragmatyczny sposób myślenia, który utrwala przeświadczenie, że o jakości działania rozstrzyga odpowiednia reakcja na wymogi otoczenia oraz — ważna w tym kontekście — skuteczność. Za czasów Roberta S. McNamary, sekretarza obrony w latach 1961-1967, wartość doświadczenia czysto wojskowego została zakwestionowana w nowych teoriach i technikach zarządzania zapożyczonych z biznesu, np. bardzo popularna stała się teoria Total Quality Management. McNamara - wzorując się na ustaleniach naukowych ze sfery zarządzania, opartych na analizie systemowej, wprowadzonej przez tzw. cudowne dzieci (whiz kids) — podważył wyjątkowość wiedzy wojskowej. Idea skutecznego zarządzania wielkimi organizacjami bez względu na ich specyfikę zapoczątkowała proces profesjonalizacji, który osłabił wyjątkową pozycję wojska i wiedzy wojskowej, nadkruszył również etos oficera armii amerykańskiej. W konsekwencji wiele kompetencji należących do sił zbrojnych zostało oddanych prywatnemu sektorowi oraz cywilnym ośrodkom eksperckim (think tanks), ukierunkowanym na analizę zagadnień militarnych. Bycie wojskowym stało się jeszcze jednym zawodem spośród wyspecjalizowanych profesji przemysłowego społeczeństwa. Już w 1960 r. Morris Janowitz w klasycznej już pozycji The Professional Soldier przewidywał, że w rozwiniętych społeczeństwach będzie zanikać różnica między umiejętnościami właściwymi dla wojskowych a umiejętnościami cywilnymi. Wraz z profesjonalizacją postępował proces ucywilnienia wielu kompetencji dotychczas należących do wojska, co stało się wyjątkowo widoczne w latach dziewięćdziesiątych XX w. Tendencje te w dłuższym planie „zdemolowały” etos wojskowy, podważając szczególną pozycję sił zbrojnych w amerykańskim społeczeństwie.

Warto wspomnieć o jeszcze jednym trendzie, tym razem politycznym, który coraz mocniej wpływa na sferę militarną. W ostatniej dekadzie XX w. z całą ostrością wystapił problem polityzacji wojskowych, mający swoje przyczyny w relacjach mię- 
dzy wojskiem a amerykańskim społeczeństwem i w istotnym rozziewie między Amerykanami wyznającymi wartości liberalne a odrębną kulturą militarną. Korpus oficerski, porzucając długoletnią praktykę neutralności, zaczął wyraźnie wyrażać swoje sympatie polityczne. Co więcej, wojsko stało się celem kampanii wyborczych. Biuletyn „Voting Assistance Program” ujawnił na przykład, że w wyborach 1984 r. wojskowi szli do urn częściej niż cywile. Podczas wyborów 12 lat później ta dysproporcja była jeszcze większa (64\% do 49\%). Jeśli chodzi o tę tendencję, wyjątkiem były wybory prezydenckie z 2012 r., kiedy wojsko odpowiedziało absencją wyborczą ze względu na życiorysy kandydatów.

Polityka polaryzacji politycznej datuje się od czasów prezydentury Richarda Nixona. W wyniku strategii przyciagania głosów Południa oraz odwoływania się do „tych, co noszą hełmy”, republikanie na trwałe wpisali w swój program polityczny tradycyjny patriotyzm oraz bezpieczeństwo narodowe. W przeważającej mierze korpus oficerski opowiedział się po stronie Partii Republikańskiej. Wiele badań wskazuje na rosnąca — od lat osiemdziesiatych XX w. — sympatię oficerów do tej partii i malejącą grupę tzw. niezależnych. Jako przykład można przywołać projekt badawczy, w którym po raz pierwszy na taką skalę zbadano postawy wojskowych i który do dzisiaj jest punktem odniesienia w dyskusji na temat amerykańskich sił zbrojnych. Chodzi o „Project on the Gap Between the Military and Civilian Society" realizowany przez Triangle Institute for Security Studies. W latach 1998-1999 grupa badaczy podjęła bardzo szeroko zakrojone badania porównawcze, mające na celu zbadanie postaw, poglądów, wartości i oceny sytuacji w elitach oficerskich i cywilnych. Porównano je z postawami ogólnospołecznymi. Badania potwierdziły, że znacząca większość oficerów nie tylko głosuje, ale na stałe identyfikuje się z określonymi poglądami i partią polityczną.

W drugiej dekadzie XXI w. proces identyfikacji wojska z Partią Republikańską jest już oczywisty (choć to adm. William Crowe zapoczątkował zwyczaj publicznego popierania kandydatów na prezydenta, kiedy w 1992 r. wsparł Williama Clintona). Podziały socjopolityczne tworzą kontekst dla pierwszych decyzji personalnych i politycznych Donalda Trumpa po zwycięstwie w wyborach prezydenckich w 2016 r. Zmniejszyły one bowiem stan napięcia między siłami zbrojnymi a społeczeństwem amerykańskim. Generalnie poglądy wojskowych na temat bezpieczeństwa narodowego znajdują większy posłuch, kiedy u władzy są republikanie.

Siły zbrojne wykorzystały bezprecedensowy poziom sympatii społecznej po wygranej wojnie w Zatoce Perskiej w 1991 r. Starsi oficerowie przestali się wahać, jeśli chodzi o publiczne wyrażanie swoich sympatii partyjnych i ideologicznych. Co więcej, oczywiste stało się zaangażowanie emerytowanych oficerów w kampanię polityczną. C. Powell oraz Norman Schwartzkopf, bohaterowie wojenni z wojny w Zatoce, poparli w 1996 r. Roberta Dole'a. Większość korpusu oficerskiego wsparła kampanię G.W. Busha, a sam Powell został pierwszym sekretarzem stanu w jego rządzie. Analiza wyników wyborów z 2000 r. wyraźnie wykazuje, że liczny personel wojskowy w bazach na Florydzie przesądził o wynikach wyborów w tym istotnym stanie i ostatecznie o minimalnym zwycięstwie kandydata republikanów. W grudniu 2007 r. John McCain 
jako kandydat republikański uzyskał bezprecedensowe poparcie ponad 100 emerytowanych admirałów i generałów (w tym 54 generałów czterogwiazdkowych).

Tę tendencję odwróciła ostatnia kampania prezydencka. Wprawdzie Trump uzyskał zdecydowanie poparcie weteranów (61\%), ale większość wojskowych i ich rodzin poparła Hillary Clinton (56\% do 44\%). Badacze wyników wyborczych twierdza, że przyczyną tej znamiennej zmiany jest aktywna obecność H. Clinton w senackiej Armed Services Committee, jednej z najważniejszych — obok komisji spraw zagranicznych — komisji amerykańskiego Senatu, która wywiera wielki wpływ na cały sektor militarny (przez lata jej przewodniczącym był McCain). Z inicjatywy H. Clinton został uchwalony Heroes of Home Act (2006), ustawa dotycząca pomocy federalnej dla rodzin żołnierzy. Clinton współuczestniczyła także w inicjatywie legislacyjnej w sprawie wprowadzenia pełnej opieki medycznej dla członków Gwardii Narodowej i rezerwistów. Wojskowi cenili również jej zrozumienie operacji militarnych poza granicami kraju, gdy została sekretarzem stanu. To pokazuje, jak wnikliwie korpus oficerski śledzi poczynania polityków.

Jak więc widać, oczywiste konstatacje, które pozwalają ustalić podstawowe relacje między wojskowymi a sferą cywilną znacząco się zmieniają przez współczesne praktyki społeczne i polityczne. Można wręcz posunać się do stwierdzenia, że kontrola cywilna nie jest faktem, lecz pewnym procesem, który ma charakter sytuacyjny. To znaczy, że wprawdzie istnieją ramy konstytucyjne i instytucjonalne relacji między wojskiem a sferą cywilna, ale charakter tych relacji znacząco zmienia się pod wpływem sytuacji społecznej i politycznej. Nie można zatem zrozumieć problemu praktycznego realizowania kontroli cywilnej nad wojskiem i generalnie sektorem militarnym bez uwzględnienia relacji między tymi dwiema sferami w codziennej praktyce politycznej.

Można zauważyć pewne prawidłowości. Pierwsza dotyczy oczywistej polityzacji wojskowych, którzy nie wahają się publicznie wypowiadać swoich opinii na temat polityków i okazywać swoich preferencji partyjnych. Co więcej, wojskowi zaczęli angażować się w bieżącą politykę. Gen. Wesley Clark wziął aktywny udział w kampanii Barracka Obamy do tego stopnia, że zakwestionował przeszłość wojenną McCaina, co spotkało się nawet z reakcją samego Obamy.

Steve Corbett i Michael Davidson w swoim świetnym studium na temat upolitycznienia korpusu oficerów nie mają watpliwości, że etos wojskowy odszedł do lamusa. Uważają oni, że pierwsze, jeszcze subtelne oznaki tej tendencji przyniosła kandydatura Dwighta Eisenhowera, kiedy polityzacja przybrała niespotykaną do tego czasu formę. Prominentni oficerowie rezerwy zaczęli publicznie popierać kandydatów w kampaniach politycznych. Zachowanie uznawane dotychczas za niewłaściwe dla honoru oficerskiego stało się codziennością.

Żaden z prezydentów nie był przez wojskowych traktowany tak pogardliwie, jak W. Clinton. Nie tylko ze względu na wprowadzenie do wojska kobiet i homoseksualistów, ale również ze względu na ostentacyjne pomijanie sił zbrojnych w kwestiach kluczowych dla bezpieczeństwa narodowego. Wzajemne animozje i strach znajdowały wyraz w obraźliwych wypowiedziach wojskowych i ostentacyjnym pomijaniu sił 
zbrojnych w kwestiach strategicznych. Te konflikty zagroziły stabilności instytucji politycznych. Oficerowie armii lądowej rozważali rezygnację en masse ze względu na niedopełnienie obietnic finansowych przez Kongres. Les Aspin, sekretarz obrony, musiał ustapić za blamaż interwencji wojskowej w Somalii, cięcia w budżecie na potrzeby wojska (po przeglądzie potencjału militarnego w 1993 r.). Miarę cierpliwości wojskowych wyczerpały niezwykle krytykowane regulacje, znane jako don't ask, don't tell. Bezprecedensowym wydarzeniem było samobójstwo szefa operacji morskich. Erozja kontroli cywilnej stała się widoczna i publicznie dyskutowana.

Druga tendencja ma związek z republikańską kulturą strategiczną. W instytucjach politycznych, zwłaszcza w ciałach przedstawicielskich, znacząco maleje liczba ludzi, którzy mają za sobą służbę wojskowa. B. Obama był pierwszym kandydatem na prezydenta, który nie miał żadnego doświadczenia wojskowego, co przyniosło np. znacząco słabą frekwencję wojskowych przy urnach w wyborach 2012 r. Taka sytuacja sprawia, że znajomość spraw militarnych wśród elity politycznej jest coraz mniejsza. William Perry zrezygnował z funkcji sekretarza obrony w 1997 r., twierdząc, że spolaryzowany politycznie Kongres nie jest w stanie racjonalnie debatować o wydatkach militarnych. Congressional Research Service donosi, że jedynie 18,8\% członków Izby Reprezentantów poprzedniego 115. Kongresu przeszło jakąś formę przeszkolenia wojskowego. Wielokrotnie ponawiane badania wskazuja, że kongresmeni z doświadczeniem wojskowym bardzo uważnie śledzą poczynania Białego Domu, gotowi sprawować kontrolę nad decyzjami dotyczącymi sfery militarnej.

\section{RAMY INSTYTUCJONALNE I PRAWNE KONTROLI CYWILNEJ}

Od początku istnienia republiki amerykańskiej kontrola cywilna opierała się na czterech filarach. Eliminowały one możliwość stworzenia bezpośredniego zagrożenia wobec cywilnego rządu, ale utrzymywały wpływy wojskowych — nawet w czasach wojny - w bezpiecznych granicach, jako ekspertów z głosem doradczym.

P i e r w s z y fi l a r obejmuje porządek polityczny i konstytucyjny USA. W konstytucji 1787 r. jasno określono zasadę cywilnej kontroli nad sferą militarną. Wszelkie naruszenia porządku konstytucyjnego oznaczają kontrakcję jednej z władz federalnych lub całego państwa. Co więcej, taka kontrakcja cieszyłaby się masowym poparciem społecznym. Zgodnie z konstytucją siły zbrojne jednoznacznie podporządkowano władzy cywilnej. Wielkie decyzje dotyczące pokoju i wojny, zorganizowania armii lądowej i marynarki, wewnętrznej organizacji, warunków ich użycia znalazły się w gestii władz cywilnych. W art. $1 \S 8$ konstytucji wyraźnie określono kompetencje Kongresu, który ma prawo: wypowiadać wojnę, wystawiać listy kaperskie i wydawać przepisy dotyczące prawa do łupu na lądzie i wodach; wystawiać i utrzymywać armię, przy czym kredyty na ten cel mogą być przyznawane najwyżej na dwa lata; tworzyć i utrzymywać marynarkę wojenna; wydawać przepisy o kierowaniu lądowymi i morskimi siłami zbrojnymi oraz służbie wojskowej; stosować środki dla powoływania milicji w celu zapewnienia wykonania ustaw Unii, thumienia powstań i odpierania najazdów; stosować środki dla zorganizowania uzbrojenia i przeszkolenia milicji oraz dla 
kierowania tymi oddziałami milicyjnymi, które mogą być użyte w służbie Stanów Zjednoczonych, przy czym we właściwości poszczególnych stanów pozostawiono mianowanie oficerów milicji oraz nadzór nad przeprowadzaniem szkolenia milicji na zasadach ustalonych przez Kongres.

Uprawnienia prezydenta $\mathrm{w}$ sprawach militarnych uregulowano w art. $2 \S 2$ konstytucji. Prezydent jest głównodowodzącym armii i floty Stanów Zjednoczonych, jak również milicji poszczególnych stanów, gdy zostaje powołana do służby czynnej Stanów Zjednoczonych. Może on żądać od każdego kierownika resortu pisemnej opinii w jakiejkolwiek sprawie związanej z zadaniami jego urzędu. Jako głównodowodzący sprawuje nadzór nad armia, prowadzi wojnę po ogłoszeniu jej przez Kongres. Kongres aprobuje nominację wszystkich oficerów. Stanom przypada obowiązek utrzymania sił zbrojnych innych niż federalne.

„Prezydent stosuje prawo łaski w sprawach o przestępstwa przeciwko Stanom Zjednoczonych, z wyłączeniem spraw wszczętych wskutek postawienia w stan oskarżenia przez Izbę Reprezentantów”. W 1974 r. prezydent Gerald Ford zainicjował program warunkowej amnestii dla dezerterów i unikających poboru w czasie wojny wietnamskiej. Zakładając, że uzbrojony obywatel stanowi ostateczną ochronę wolności, zgodnie z II Poprawka, „Nie wolno ograniczać praw ludu do posiadania i noszenia broni, gdyż bezpieczeństwo wolnego stanu wymaga dobrze wyszkolonej milicji”.

Konstytucja tworzy jedynie ramy porządku demokratycznego Stanów Zjednoczonych, toteż pierwszy filar kontroli cywilnej w demokracji amerykańskiej zbudowany jest na jakości rządzenia, rządach prawa, stabilnej formule przekazywania władzy po wyborach oraz poziomie legitymizacji procesu rządzenia. Kontrola cywilna nad wojskiem jest koniecznym, lecz niewystarczającym warunkiem funkcjonowania amerykańskiej demokracji. Stabilny system polityczny, jaki wytworzyła republika amerykańska, uniemożliwia interweniowanie sił zbrojnych w politykę. Sprowadzanie sił zbrojnych do funkcji obrony państwa jest jednym z elementów cywilnej kontroli. Polaryzacja polityczna postawiła pod znakiem zapytania wiele zasad demokratycznego rządzenia w Stanach Zjednoczonych, tym bardziej, że towarzyszy jej postępująca polityzacja amerykańskich sił zbrojnych.

Kontrola cywilna wiąże się z codziennym funkcjonowaniem machiny państwowej, sposobem, w jaki władza cywilna rządzi siłami zbrojnymi. Jedną z najważniejszych cech amerykańskiego systemu politycznego jest transparentność decyzji publicznych, także w sferze bezpieczeństwa narodowego, co wzmacnia identyfikację Amerykanów z siłami zbrojnymi. W tej kwestii członkowie Kongresu mają — jako reprezentanci narodu — do odegrania szczególną rolę. Jego słabnąca pozycja w amerykańskim systemie odbija się na kontroli cywilnej.

Odrębną kwestią jest kontrola cywilna realizowana przez sądy. W ostatnich dekadach szczególnego znaczenia nabrała kwestia dotycząca zwalczania terroryzmu, która ukazała prawny aspekt cywilnej kontroli nad wojskiem. Należy wspomnieć chociażby o kilku przykładowych decyzjach Sądu Najwyższego [dalej: SN] z ostatniego czasu, jak w sprawie Hamdi v. Rumsfeld (2004 r.) oraz Hamadan v. Rumsfeld (2006 r.). 
Zwłaszcza ta druga sprawa jest interesująca ze względu na polski wątek. Federalny SN (z przeciwnym głosem mniejszości) orzekł, że ustanowione przez Departament Obrony trybunały wojskowe, zajmujące się więźniami w Guantanamo (Combatant Status Review Tribunals, CSRT), naruszają Uniform Code of Military Justice oraz konwencje genewskie. W odpowiedzi Kongres przegłosował United States Military Commissions Act (2006 r.), podpisany w październiku tego roku przez G.W. Busha. Ustawą autoryzowano przeprowadzone przez komisje wojskowe przesłuchania osób naruszających prawo wojenne. W reakcji na tę ustawę $\mathrm{SN}$, zdominowany przez liberalnych sędziów, stwierdził w sprawie Boumediene $v$. Bush (2008 r.), że art. 7 ustawy jest niekonstytucyjny — zatrzymani mają prawo petycji do sądów federalnych ze względu na naruszenie zasady habeas corpus. Cywilna kontrola realizowana przez sądy stanowi niezwykle ważki mechanizm ze względu na legalistycznie zorientowaną kulturę polityczną amerykańskiego społeczeństwa.

D r u g i f i 1 a r. Przez 150 lat istnienia republiki amerykańskiej regularne wojsko było niewielkie. Geopolityczne położenie Stanów Zjednoczonych stanowiło naturalną przeszkodę przed atakiem z zewnątrz, a wojna amerykańsko-meksykańska udowodniła, że sąsiedzi na kontynencie nie stanowią zagrożenia. Tak więc nie zaistniało żadne zagrożenie dla władz cywilnych. Regularne oddziały w czasach pokoju były nieliczne, ich liczebność rosła w czasach wojny. Nieprawdopodobne jednak było, aby na wskroś obywatelskie wojsko zgodziło się na niekonstytucyjne działania.

T r z e c i f i l a r. W sytuacji, kiedy siły zbrojne musiały polegać na społeczeństwie obywatelskim (obywatelach/żołnierzach), ich skład był zasadniczo odmienny niż ten w europejskiej kulturze militarnej. Dobrowolny udział w formacjach obywatelskich (kolonialnej, potem stanowej milicji), masowy udział ochotników oraz tymczasowy zaciag sprawiały, że w chwilach narodowej próby i potrzeby to obywatel republiki amerykańskiej był i jest gwarantem kontroli cywilnej. Wyposażony w broń obywatel stanowi przeciwwagę dla regularnych sił zbrojnych. Takie postawy obywatelskie wynikają z szacunku dla prawa oraz z kultury politycznej partycypacji. Bunt czy zdrada kończą się społecznym ostracyzmem. Akceptacja infamii, niełaski, kary, aresztu i wyroku stanowi w takiej sytuacji istotny element obywatelskiej samoświadomości. Wojskowy zamach stanu, rządy junty wojskowej (endemiczne dla Ameryki Południowej) są w warunkach republiki amerykańskiej nawet trudne do wyobrażenia. Regularne siły zbrojne zajmują się nade wszystko kwestiami bezpieczeństwa narodowego i obronności kraju. Napięcia i konflikty między władzą cywilną a wojskowymi mieszczą się w konstytucyjnych ramach.

$\mathrm{C}$ z w a r t y f i 1 a r. Posłuszeństwo amerykańskich sił zbrojnych wobec władzy cywilnej jest głęboko zinternalizowane, jest ono aksjomatem funkcjonowania amerykańskiej państwowości oraz podstawą etosu wojskowego. Omar Bradley, pierwszy przewodniczący Kolegium Połączonych Szefów Sztabu, wyraził to następująco: „32 lata mojej służby w armii czasu pokoju nauczyło mnie, żeby nie wypowiadać się bez potrzeby i unikać prasy". Ten podstawowy aksjomat amerykańskiej kultury militarnej sprowadzał się do demokratycznej samodyscypliny, której elementem było sta- 
łe samoograniczanie się wojskowych w krytykowaniu demokratycznych instytucji. To właśnie dystans wobec bieżącej polityki sprawił, że wojskowi cieszą się w Stanach Zjednoczonych wielkim zaufaniem społecznym.

\section{RYS HISTORYCZNY}

Krótkie wprowadzenie w dzieje republiki amerykańskiej jest niezbędne, aby ukazać dwa istotne zagadnienia, które wpływają na jakość i zakres kontroli cywilnej nad wojskiem. Pierwsze dotyczy kultury politycznej Amerykanów, w ramach której tworzy się przyzwolenie na działania wojska, wyznacza jego miejsce, status i prestiż. Drugie ma szczególne znaczenie dla zdefiniowania „ducha wojennego” (określenie Marcusa Cunliffe'a) Amerykanów od początku istnienia republiki, a nawet z uwzględnieniem czasów kolonialnych. Należy więc określić, jakie są szczególne cechy amerykańskiej kultury strategicznej.

W momencie ustanowienia republiki amerykańskiej w 1776 r. cywilna kontrola nad wojskiem była uznawana za aksjomat funkcjonowania władzy politycznej. Amerykanie, wyciagając lekcję z doświadczeń historycznych i teorii politycznych (zwłaszcza refleksja XVII-wiecznych Commonwealthmen), uznali stałą armię za dogodne narzędzie rządów tyrańskich. Poddane ścisłej dyscyplinie i uzbrojone wojsko miało naturalną przewagę nad cywilami, w każdej chwili mogło dokonać zamachu stanu i zagrozić wolności. Republika amerykańska miała wspólną cechę z republikańskim Rzymem - w obu przypadkach instytucje polityczne i wojskowe w dużej mierze nakładały się na siebie. Politycy byli gotowi chwycić za broń, aby po ustaniu zagrożenia powrócić do życia cywilnego. Nie jest przypadkiem, że Jerzy Waszyngton kojarzył się Amerykanom z rzymskim Cyncynatem. W przeciwieństwie do historii Rzymu amerykańscy bohaterowie wojenni nigdy jednak nie podjęli próby obalenia władzy ani tym bardziej konstytucji z 1787 r., aby ustanowić dyktaturę. Nigdy nie przekroczyli granic porządku politycznego i konstytucyjnego. Waszyngton swoim autorytetem skutecznie rozwiał wątpliwości dotyczące Society of the Cincinnati, założonego przez oficerów wojny o niepodległość. Osobisty przykład Waszyngtona, kiedy uroczyście zrzekł się przed Kongresem swoich uprawnień wojskowych, stworzył solidny zwyczaj polityczny. Wcześniej Waszyngton zdołał zażegnać najpoważniejszy kryzys z udziałem wojskowych — tzw. konspirację z Newburgh. Pod pływem jego reprymendy zdecydowana większość oficerów tej placówki odmówiła uczestnictwa w rewolcie wywołanej na fali żądań, by Kongres wypłacił zaległe po demobilizacji wynagrodzenie.

Ta postawa wobec instytucji politycznych ma swoje głębsze podłoże, które ustanowiło fundament republikańskiej kultury strategicznej. U jej podstaw leżała praktyka polityczna przejęta z Wielkiej Brytanii oraz zbiorowe doświadczenia kolonistów w Ameryce Północnej. Angielska wojna domowa oraz prawne ustalenia tzw. chwalebnej rewolucji usankcjonowały prymat Parlamentu nad stałą armia, tak aby nie zagrażała ona wolnościom cywilnym i politycznym. Parlament sprawował kontrolę nad wojskiem za pomocą corocznie uchwalanego budżetu. Przegłosowany Mutiny Act 
pozwolił uporządkować sprawy sił zbrojnych. Monarcha utrzymał dowództwo, administrując siłami zbrojnymi w czasach pokoju i wojny.

Kolonie angielskie w Ameryce Północnej stały się areną podobnego sporu między władzą ustawodawczą a wykonawczą. Stopniowo, używając argumentów finansowych, legislatury poszczególnych kolonii zwiększały swoje kompetencje wobec gubernatorów. To one tworzyły oddziały milicji, zwiększając liczbę ochotników przez dodatkowy zaciag. Obawy przed buntem żołnierzy były bezpodstawne, ponieważ obrona kolonii zależała od powoływanej z wolnych kolonistów milicji oraz woluntariuszy. $\mathrm{Na}$ czele tych oddziałów obywateli stali przedstawiciele lokalnej elity. Siły zbrojne złożone z ochotników nie miały powodów, aby obalać istniejący porządek.

Takie były początki armii obywatelskiej, która przystapiła do obrony interesów kolonii przeciw Koronie Brytyjskiej w latach siedemdziesiątych XVIII w. W czasach rewolucji amerykańskiej stała armia brytyjska, używana do represji, stała się symbolem opresji politycznej. Amerykańscy patrioci za oczywisty uznali związek między regularnym wojskiem a arbitralnymi rządami, a stałe wojsko za główny czynnik utraty wolności. Odpowiedzią na to zagrożenie była armia republikańska, którą powoływano na czas zagrożenia. Obywatele republiki amerykańskiej stali się — jako żołnierze — najważniejszym gwarantem niepodległości i wolności politycznej. Utworzenie w 1636 r. pierwszego oddziału milicji zapoczattkowało tradycję obywateli żołnierzy. Gwardia Narodowa, mimo zmienionego w 1947 r. statusu, czyniącego z niej rodzaj sił zbrojnych, nadal sięga do tej tradycji — jedynej siły zbrojnej mającej zadania ogólnopaństwowe (rezerwy na czas mobilizacji) i stanowe (powołanej w celu ochrony życia i własności).

Awersję amerykańskiego obywatela wobec regularnego wojska tłumaczą dzieje republiki amerykańskiej. Położenie geopolityczne oraz zasada neutralności wobec rywalizacji europejskich potęg pozwoliła amerykańskiemu państwu utrzymywać bardzo małe kontyngenty sił zbrojnych, których zadaniem była eksploracja kontynentu oraz obrona przed Indianami i piratami. Kongres rozstrzygał o kształcie, rozmiarze i organizacji sił zbrojnych (w tym milicji stanowych). Cywilna kontrola w codziennej praktyce sprowadzała się do administrowania siłami zbrojnymi przez sekretarzy wojny i marynarki przy pomocy (czasami przy oporze) dowódców wojskowych. Co ważniejsze, kontrolę cywilną uznawano w demokratycznym społeczeństwie za oczywistą zinternalizowaną przez siły zbrojne, a wiary w rządy prawa i konstytucji nigdy nie kwestionowano. Odseparowanie od polityki partyjnej nie podlegało dyskusji. Mimo zdarzających się konfliktów i walki o wpływy amerykańskie siły zbrojne całkowicie podlegały władzom cywilnym.

W okresie między wojną secesyjną a II wojną światową stopniowo pogłębiał się rozziew między amerykańskim społeczeństwem a korpusem oficerskim, krytycznym wobec zmian społecznych. Oficerowie negatywnie reagowali na rosnącą komercjalizację życia społecznego, utratę przez amerykańskie społeczeństwo tradycyjnych norm i wartości. W tym czasie Stany Zjednoczone włączyły się w światową politykę, a wymogi związane z prowadzeniem wojny zapewniały oficerom większy wpływ na kwe- 
stie militarne. Technika militarna, doktryny wojenne, potrzeby organizacyjne doprowadziły do stworzenia zwartych instytucji wojskowych. II wojna światowa nie tylko zwiększyła wpływ wojskowych na sprawy publiczne, ale także mocno wpisała wojsko w strukturę amerykańskiego społeczeństwa. Oczywista — i także ta bardziej ukryta - władza oraz prestiż profesjonalnego wojska osiagnęły apogeum. Tym bardziej korpus oficerski poczuwał się do odpowiedzialności społecznej.

Istotnego procesu militaryzacji społeczeństwa amerykańskiego nie zahamowała też zimna wojna. Jak określił to generał i prezydent Dwight Eisenhower, powstał wówczas „kompleks wojskowo-przemysłowy”. Rosnąca militarno-biurokratyczna machina wywołała przeciążenie tradycyjnych procedur i form kontroli nad wojskiem, sprawowanej przez sferę cywilną. Instytucje wojskowe rozrosły się ponad miarę, rodzaje ich aktywności były zbyt zróżnicowane, a wpływy zbyt istotne, aby władza cywilna mogła je skutecznie kontrolować. W 1951 r. nastapiła najbardziej spektakularna próba sił między politykami a wojskowymi. Prezydent Harry Truman zwolnił ze służby gen. MacArthura, jednego z najbardziej poważanych żołnierzy, kiedy ten zakwestionował decyzje polityczne w sprawie zakończenia wojny koreańskiej.

Cywilną odpowiedzią na organizacyjne i polityczne wymogi nowej epoki był $\mathrm{Na}$ tional Security Act z 1947 r. Po wielu sporach dotyczących sposobu dowodzenia amerykańskimi siłami zbrojnymi ostatecznie zwyciężyła wersja luźnej struktury dowódczej forsowana przez marynarkę wojenna.. W rezultacie powstało Kolegium Połączonych Szefów Sztabów (Joint Chiefs Staff, dalej: JCS). Wielokrotnie nowelizowana ustawa doprowadziła do najważniejszej po wojnie restrukturyzacji instytucji kontrolujących sferę militarna. Departamenty zajmujące się siłami zbrojnymi zostały połączone w jeden organ federalny - Departament Obrony. Ustawą powołano do życia także Radę Bezpieczeństwa Narodowego [dalej: RBN] oraz CIA.

Ustawą Goldwatera-Nicholsa z 1986 r. przyznano więcej kompetencji przewodniczącemu Kolegium oraz dowódcom operacyjnym w ramach Departamentu Stanu, co odzwierciedlało rosnąca rolę armii w strukturach cywilnych. Nowa generacja oficerów, wzmocniona zakończonymi sukcesem interwencjami militarnymi poza granicami kraju (wojna w Zatoce Perskiej), bardziej biegła w przetargach biurokratycznych na najwyższym szczeblu, istotnie zmieniła rolę i znaczenie wojskowych, jeśli chodzi o podejmowanie decyzji politycznych, nie tylko dotyczacych bezpieczeństwa narodowego. Tym bardziej, że atak z 11 września 2001 r. zatarł granice między bezpieczeństwem wewnętrznym a zewnętrznym. Takie podejście odzwierciedla opublikowana w grudniu 2017 r. strategia bezpieczeństwa narodowego. Znamienne jest to, że w dokumencie jako pierwszy filar bezpieczeństwa narodowego wymieniono działania mające na celu ochronę narodu amerykańskiego, ojczyzny (the Homeland) i amerykańskiego stylu życia.

$\mathrm{Na}$ koniec trzeba wspomnieć o swoistej logice republiki imperialnej (określenie francuskiego socjologia Raymonda Arona). Potęga militarna jest koniecznym warunkiem istnienia amerykańskiego mocarstwa. Stany Zjednoczone nadal sąjedynym światowym mocarstwem. Mapa świata umieszczona na stronach internetowych Departa- 
mentu Obrony, ukazuje obszary odpowiedzialności pięciu głównych dowództw regionalnych. Wynika z niej jednoznacznie, że strefa amerykańskich wpływów wojskowych wciąż jest globalna. Nieprzypadkowo dowódcy regionalnych jednostek bojowych są określani mianem prokonsulów tego imperium. Przykładowo dowództwo Stanów Zjednoczonych w Europie [United States European Command, dalej: EUCOM] obejmuje obszar od zachodniej Grenlandii do Cieśniny Beringa, od Oceanu Arktycznego do Przylądka Dobrej Nadziei, od Islandii po Izrael i rozciagga się na terytorium $54 \mathrm{mln} \mathrm{km}^{2}$. Strukturalny i organizacyjny problem związany ze sprawowaniem cywilnej kontroli nawet nad regionem jest kwestią otwartą. Ciekawostką może być fakt, że dowódca EUCOM zajmuje się nawet kondycją duchową żołnierzy. Od 1990 r. corocznie odbywają się spotkania wszystkich kapelanów armii Paktu Północnoatlantyckiego.

Od czasów II wojny światowej interwencje zbrojne są stałym i nieustannym elementem amerykańskiej polityki. Amerykańskie wojsko permanentnie prowadzi wojnę lub operacje militarne, nieunikniony jest więc proces militaryzacji społeczeństwa, który wzbudza zaniepokojenie także wśród samych wojskowych. Andrew Bacevich, emerytowany pułkownik sił lądowych, uważa, że militaryzacja społeczeństwa amerykańskiego w połączeniu z wiarą w uniwersalność amerykańskich wartości prowadzi do zaniku podstawowego czynnika kontroli cywilnej, czyli zmysłu obywatelskiego, a w konsekwencji do „wydrążenia” amerykańskiej demokracji z ideałów i wartości dla niej charakterystycznych.

\section{STRUKTURA RELACJI MIĘDZY SFERĄ CYWILNĄ A WOJSKIEM}

Nim zostaną wskazane instytucje cywilne bezpośrednio i pośrednio kontrolujące wojsko, należy wziąc pod uwagę relacje między wojskiem a sferą cywilną. Pozwalają one bowiem uchwycić zmieniające i przesuwające się pola kontroli nad sferą militarną, zakres przyzwolenia obywatelskiego na rosnącą rolę amerykańskich sił zbrojnych. W warunkach amerykańskiego systemu politycznego dynamika ta określa jakość relacji. Termin „relacje między wojskiem a sferą cywilną” odnosi się do interakcji między siłami zbrojnymi jako jedną z istotnych instytucji państwa a innymi sferami życia społecznego, w które wojsko jest uwikłane. Znamienne jest, że w Stanach Zjednoczonych problem ten nabrał znaczenia po II wojnie światowej, kiedy trzeba było na nowo, w pokojowych warunkach ustalić miejsce wojska w demokratycznym społeczeństwie.

Takie podejście zaproponował wybitny amerykański politolog Samuel Huntington w pionierskiej pracy The Soldier and the State (1957 r.). Stwierdził on, że relacje między sferą cywilną a wojskową odzwierciedlają charakter społeczeństwa oraz stopień rozwoju systemu politycznego państwa. Podstawowy problem sprowadza się do ustalenia, w jakim stopniu wojskowi różnią się od świata cywilnego w definiowaniu swoich interesów, w swoich poglądach na życie społeczne i instytucje polityczne. Huntington zaproponował, aby to zróżnicowanie analizować na trzech poziomach: poziom pierwszy — relacja pomiędzy wojskiem a społeczeństwem jako pewnymi całościami; drugi - relacja między kadrą oficerską (elitą wojska) a innymi grupami społecznymi; 
trzeci — relacje między dowództwem wojskowym a przywódcami politycznymi. Podstawowy problem dotyczy więc samych Amerykanów - na ile obywatel republiki jest gotów zaakceptować rosnąca rolę wojska w życiu publicznym.

Powszechnie zaakceptowano istnienie rozziewu — po części ideologicznego - między konserwatywną kadrą oficerską a liberalnym, indywidualistycznym społeczeństwem, który zmniejsza się wraz ze wzrostem zewnętrznego zagrożenia (potrzeba dużej armii stałej). Z tych gorących dyskusji wyłania się praktyczny wniosek, że wszelkie próby dostosowania wojska do wyobrażeń cywilów są bardzo groźne i osłabiają potencjał wojska. Zadaniem władzy cywilnej jest tolerowanie, a nawet przyjęcie konserwatywnych wartości podzielanych przez wojskowych.

Po zakończeniu wyścigu zbrojeń w trakcie zimnej wojny dyskusje prowadzone w wielu środowiskach na temat cywilnej kontroli nad wojskiem w demokracjach liberalnych „nabrały rumieńców”. Często wyraża są opinie, że istnieje przepaść między społeczeństwem liberalnym a z gruntu odmienną kulturą militarną. Peter Feaver nazywa te relacje problematycznymi, wpisane są one bowiem w konkretne warunki społeczne i polityczne. Jak pogodzić istnienie takich sił zbrojnych, które ochronią państwo, z istnieniem takiego wojskowego establishmentu, który nie zwróci się przeciw konkretnemu porządkowi politycznemu? Kwestia stabilności systemu politycznego okazuje się równie kluczowa, co świadomość obywatelska. Do tej pory w państwie amerykańskim ten dynamiczny alians między dwoma sferami, nie bez wielu konfliktów i kryzysów, był zachowany. Rzeczy na pozór oczywiste w bliższej perspektywie takie już jednak nie są.

Dwa główne czynniki sprawiają że relacje te mają swoją dynamikę, która narusza wewnętrzną równowagę. Pierwszy czynnik dotyczy sfery międzynarodowej. Niestabilność w wymiarze globalnym (pojawia się określenie „bezład globalny”), wynikająca z konfrontacji między mocarstwem światowym, jakim są Stany Zjednoczone, a mocarstwami pretendującymi do tego miana, nabiera ostrości. Ta konfrontacja zaczyna — szczególnie w Eurazji — przybierać formę nowej zimnej wojny. Zmiany geopolityczne określają w dużej mierze zakres i poziom kontroli cywilnej nad wojskiem. W sposób nieunikniony rola i znaczenie wojska wzrastaja. Dotyczy to nie tylko obronności i kręgów definiujących politykę bezpieczeństwa narodowego, ale wręcz całej polityki państwowej (np. bezpieczeństwo energetyczne). Amerykańskie imperium działa globalnie, toteż i jego wojsko działa w skali globalnej. Efektywność kontroli cywilnej, zwłaszcza władzy wykonawczej, polega na ustalaniu w porozumieniu z wojskowymi celów związanych z bezpieczeństwem narodowym. Skoro bezpieczeństwo narodowe Stanów Zjednoczonych ma wymiar globalny, to obejmuje też konfrontację ekonomiczna. Siły zbrojne są po to, aby wspierać amerykańskie interesy gospodarcze.

Drugi czynnik generujący dynamiczną zmianę dotyczy poziomu biurokratyzacji amerykańskiego społeczeństwa. Korpus oficerski jest przygotowany do zarządzania dużymi strukturami organizacyjnymi. W społeczeństwie nastawionym na skuteczność i efektywność oficer ma umiejętności menedżerskie, które może wykorzystać w zarządzaniu skomplikowanymi strukturami biurokracji cywilnej na szczeblu federalnym. 
Dotyczy to zwłaszcza rosnącej - w wyniku konfrontacji politycznej i militarnej — liczby instytucji zajmujących się szeroko pojętym bezpieczeństwem. Nie dziwi więc duża liczba wojskowych w administracji Trumpa, także tych, którym Senat musiał udzielić zgody na skrócenie siedmioletniego okresu dzielącego odejście z wojska a objęcie stanowiska politycznego (generałowie James Mattis, H.R. McMaster).

1. Instytucjonalny wymiar kontroli cywilnej

K o n g r e s: przez budżet i k o m is je. Pierwotnie w konstytucji przyznano Kongresowi kluczową pozycję w Unii, jeśli chodzi o podejmowanie decyzji politycznych. W XX w. to miejsce zajęła władza wykonawcza, przez co tym bardziej zwiększało się znaczenie funkcji kontrolnej Kongresu. Wiąże się to jednak z wieloma przeszkodami organizacyjnymi i instytucjonalnymi. Takim spektakularnym wydarzeniem było uchwalenie — na fali krytyki wojny w Wietnamie — ustawy War Powers Act, na mocy której ograniczono władzę prezydenta w zakresie prowadzenia wojny. Prezydent musi prosić Kongres o zgodę, jeśli działania zbrojne — w odpowiedzi na sytuację zagrożenia — trwają dłużej niż 60 dni.

W codziennej praktyce politycznej najważniejsza funkcja kontrolna Kongresu dotyczy budżetu. Prezydent przesyła jego projekt do obu izb. Prace nad budżetem pozwalają na rozpoczęcie przetargów politycznych, jak również na znaczącą modyfikację pierwotnego projektu. Kongresmeni wyrażają zgodę na poszczególne wydatki, dokonują poprawek, które pozwalają na krytykę przedstawionego planu wydatków. Mogą też monitorować wykonanie budżetu. To tłumaczy, dlaczego stałe komisje Izby Reprezentantów, zajmujące się budżetem i finansowaniem poszczególnych przedsięwzięć, są uznawane za najważniejsze i najbardziej prestiżowe. Komisja zajmująca się w Izbie Reprezentantów siłami (Armed Services) jest w tej hierarchii dopiero w trzeciej grupie, ponieważ uznaje się ją za komisję obsługująca konkretną grupę zawodową (constituency committee). W praktyce — z racji wysokości budżetu na cele obronne - komisja ta zyskuje jednak na znaczeniu.

Podobna hierarchia ważności występuje w podkomisjach i grupach roboczych. I tak np. podkomisja ds. budżetu obronnego (House Appropriations Sub-committee) jest ważniejsza niż te zajmujące się budowanymi bazami militarnymi. Partyjne konwentykle decydują o wyborze do stałych komisji i podkomisji. Od lat dziewięćdziesiątych XX w. widoczny jest wzrost kontroli partyjnej nad komisjami, a więc rośnie także znaczenie szefów frakcji parlamentarnych.

Na uwagę zasługuje także wiedza i doświadczenie poszczególnych kongresmenów. Tak było w przypadku senatora McCaina, którego znajomość sił zbrojnych była na tyle duża i niekwestionowana, że Partia Republikańska wybrała go na swojego kandydata w wyborach prezydenckich. W Senacie hierarchia komisji jest ustalona inaczej ze względu na ich uprawnienia. Komisja zajmująca się siłami zbrojnymi uważana jest za komisję mieszaną, ustalającą politykę państwową (mixed policy/constituency committee) oraz określającą działania sektorowe (w sprawach obronności) i dlatego znajduje się w drugiej grupie po tzw. policy committees. Niemniej jednak ta senacka ko- 
misja jest potężnym instrumentem nacisku i kontroli, tym bardziej, że ściśle współpracuje z pierwszoplanową komisją ds. stosunków zagranicznych.

Warto zwrócić uwagę na szczególną funkcję kontrolną w formie przesłuchań przed komisją (lub połączonymi komisjami Izby Reprezentantów i Senatu, może to być komisja specjalnie powołana), które są upublicznione. Tak było w przypadku przeprowadzonego śledztwa w sprawie Iran-Contras. W rezultacie połączone komisje obu izb sformułowały zarzuty karne wobec byłego sekretarza stanu Caspara Weinbergera i innych urzędników ministerstwa. G. Bush wydał w 1992 r. akt ich ułaskawienia.

W odpowiedzi na coraz bardziej skomplikowaną strukturę państwa Kongres odpowiada nowymi komisjami i podkomisjami. Rozrost władzy wykonawczej jest jedną z przyczyn słabości kontroli władzy ustawodawczej. Kilka czynników osłabia kontrolę Kongresu: fragmentaryzacja władzy w samym Kongresie, możliwe prezydenckie weto, skala komplikacji spraw państwowych, rola i znaczenie setek grup interesu (zorganizowane grupy maja prawo publicznie nagłaśniać swój punkt widzenia oraz różnymi metodami go promować). Potęga takich paramilitarnych organizacji, jak American Rifle Association, nie byłaby możliwa bez II Poprawki oraz republikańskiej kultury militarnej. Obecność grup interesu w Kongresie i polaryzacja polityczna tworzą istotne bariery w procesie legislacyjnym. Blokada instytucjonalna w formie ,wetokracji” (określenie Francisa Fukuyamy) oddziałuje na poziom cywilnej kontroli nad wojskiem.

$\mathrm{Na}$ uwagę zasługują także skuteczne przetargi prowadzone na różnych polach przez przedstawicieli sił zbrojnych. Od czasu, gdy politycznie i społecznie został usankcjonowany fakt, że wojsko stworzyło swoje lobby polityczne, jego udział w procesie tworzenia budżetu uznano za oczywisty. Tym bardziej, że o ile pod koniec XX w. poszczególne rodzaje sił zbrojnych lobbowały oddzielnie, często ze sobą rywalizując, o tyle w ostatnich latach obserwujemy konsolidację tej potężnej grupy interesu. Siły zbrojne wyciagnęły wnioski z lektury książki Edwarda Luttwaka The Pentagon and the Art of War. Ich znaczenie jest coraz większe, ponieważ skutecznie współpracują z amerykańskim przemysłem militarnym (ten oczywiście nie jest jednolity, między koncernami może występować ostra rywalizacja). Znamienne jest to, że żądania lobbystów sił zbrojnych i sektora militarnego są często uwzględniane przez Kongres w skali przewyższającej propozycje administracji prezydenckiej. Skądinąd rola emerytowanych oficerów w sektorze prywatnym, zwłaszcza w przemyśle obronnym, zasługuje na odrębne opracowanie.

Pre z y d e n t i je g o a d m in is tra c ja. Poziom komplikacji spraw państwowych, w tym konieczność zarządzania potężnymi i niezwykle złożonymi strukturami biurokratycznymi sprawia, że władza wykonawcza w sposób naturalny zajmuje najważniejszą pozycję w amerykańskim państwie (część z nich dotyczy struktur i operacji niejawnych). Spektakularne przywództwo polityczne jest częścią procesu demokratycznego. Nic tak nie zwiększa popularności prezydenta, jak skuteczne lub odważne przedsięwzięcia dyplomatyczne i operacje militarne: J.F. Kennedy'ego po kryzysie kubańskim, R. Reagana po inwazji Granady i bombardowaniu Libii, G. Bu- 
sha po wojnie w Zatoce Perskiej, działania jego syna po 11 września. Popularność przekłada się na poziom legitymizacji władzy, która czerpie swoje uprawomocnienie z poziomu akceptacji działań przez amerykańskich obywateli.

Sposób działania administracji prezydenta klarownie pokazuje, do jakiego stopnia nastapiło w ostatnich dekadach zbliżenie zakresu pojęć i sfery praktyki określanej terminami „polityka bezpieczeństwa narodowego” i ,polityka zagraniczna”. Prezydent wykonuje swoje konstytucyjne uprawnienia przez personel Białego Domu, struktury rządowe i ciała doradcze. Doradca ds. bezpieczeństwa narodowego należy do ścisłego grona współpracowników prezydenta w Białym Domu. Dwa ministerstwa zajmujące się sprawami sił zbrojnych należą do największych: Departament Obrony oraz Departament ds. Weteranów. Ten pierwszy ma do dyspozycji Departament Armii, Departament Sił Powietrznych, Departament Marynarki, Kolegium Połączonych Szefów Sztabów oraz wywiad.

Na uwagę zasługuje ścisła, choć zawierająca elementy ostrej rywalizacji, współpraca Departamentu Obrony i Stanu, obecnie realnie i symbolicznie potwierdzona przez nominację Michaela Pompeo na sekretarza stanu. W globalnej polityce Stanów Zjednoczonych zatarł się podział na politykę międzynarodową i bezpieczeństwo narodowe. Współpraca wyznaczona przez pakty polityczno-wojskowe jest oczywista i w dużej mierze oznacza także koordynację działań wojskowych (np. w Pakcie Północnoatlantyckim). Prezydentura Trumpa różni się zasadniczo od poprzednich (np. cichą reguła jest zakaz zatrudniania $\mathrm{w}$ administracji ludzi z ośrodków eksperckich; w ten sposób została podważona zasada „drzwi obrotowych”). Jeśli porównamy ją z rządami demokratów za czasów Billa Clintona, to zauważymy bardzo istotne różnice. Wysoki poziom zaufania do wiedzy i zdolności politycznych wojskowych wobec awersji i nieufności administracji Clintona. Wojskowi obok przedstawicieli biznesu tworzą istotną grupę obecnej elity władzy, która ulega stałym zmianom, czasami wywołanymi reakcją na ludzi pokroju Johna Flynna czy Johna Kelly'ego, jednak znaczenie wojskowych wzrosło znacząco. I znowu o ile Obama sięgał po doradców ds. bezpieczeństwa narodowego z ośrodków eksperckich, to Trump chętnie sięga po wojskowych (przynajmniej do czasu nominacji Johna Boltona). Ta tendencja dotyczy także służb specjalnych (intelligence community). Szczególnie interesujące są w tym względzie rozporządzenia prezydenckie (presidential orders), zwłaszcza te, które są pokłosiem decyzji SN w sprawie prezydenckich prerogatyw dotyczących zwalczania terroryzmu.

Codzienny nadzór nad siłami zbrojnymi sprawuje Departament Stanu. Jego częścią jest Dowództwo Połączonych Sił Zbrojnych powołane ustawą o bezpieczeństwie narodowym z 1947 r. Znamienny jest stały wzrost znaczenia Kolegium Połączonych Szefów Sztabów. Widać to wyraźnie w czasie obecnej prezydentury Trumpa, chociaż jest to trwała tendencja wynikająca nie tylko z osobowości dowódców, ale również z przygotowania organizacyjnego. Wojskowi biurokraci w strukturze Komitetu są lepiej zorganizowani, bardziej skuteczni niż cywilni urzędnicy Departamentu Obrony. Dobrym tego przykładem jest Joint Requirements Oversight Council, który 
skupia zastępców szefów sztabów oraz pod przewodnictwem wiceprzewodniczącego Komitetu ustala harmonogram działań dotyczących potrzeb wojska. Jest statutowym ciałem doradczym przewodniczącego Kolegium. Rada jest najważniejszym ciałem rozstrzygającym o zakupach broni i strukturze sił zbrojnych, zajmuje się planowaniem strategicznym, ustala doktrynę wojskową. Ponadto JCS ma swojego przedstawiciela działającego poza departamentem, który bierze udział w procesie podejmowania decyzji państwowych zapadających w gremiach skupiających kilka departamentów. W ten sposób siły zbrojne mogą formułować wnioski odrębne od oficjalnego stanowiska departamentu. Utrzymują również biuro łącznika z Kongresem i innymi urzędami.

Zmienia się również rola przewodniczącego Kolegium. Wykonuje on nie tylko funkcje wojskowe, ale także publiczne i polityczne. Na oddzielną uwagę zasługuje jego udział w kształtowaniu polityki bezpieczeństwa narodowego i polityki międzynarodowej, odzwierciedlający wzrastającą rolę JCS w szeroko pojętej sferze publicznej i w relacjach międzynarodowych. Kronika międzynarodowych wizyt gen. J. Dunforda (także spotkań z cywilnymi urzędnikami wysokiego szczebla innych krajów) jest tego wystarczającą egzemplifikacją.

Na odrębną uwagę zasługuje Rada Bezpieczeństwa Narodowego. Struktura Rady i jej skład jest regulowany dyrektywą prezydenta (National Security Presidential Memorandum). Zgodnie z memorandum z 4 kwietnia 2017 r. na obrady Rady zostali zaproszeni przewodniczący Kolegium Połączonych Szefów Sztabów oraz dyrektor Wywiadu Narodowego. Stałej pracy RBN przewodniczy — w ramach tzw. Principals Committee — doradca ds. bezpieczeństwa narodowego. Pełniąc tę funkcję, występuje on raczej jako koordynator prac najwyższych urzędników państwowych. Ma on jedną naturalną przewagę - bezpośredni i stały kontakt z prezydentem. Nic lepiej nie oddaje sytuacyjnej dynamiki relacji polityków z wojskowymi niż ostatnie perturbacje w RBN, które były także wynikiem starcia osobowości. W ciagu dwóch lat prezydent Trump zmienił doradcę już czterokrotnie. Trzema pierwszymi jego doradcami byli wojskowi: gen. M. Flynn, K. Kellogg, R. McMaster. Dopiero czwarty, J. Bolton, jest cywilem.

R o la ośrodków e k s percki c h. Proces wyprowadzania wiedzy wojskowej poza wojsko sprawił, że powstały ośrodki eksperckie (think tank) z dobrą i szczegółową wiedzą techniczną na temat spraw wojskowych. Część z nich ściśle współpracuje z siłami zbrojnymi, inne zajmują się analizą polityki bezpieczeństwa narodowego i międzynarodowego. Powstanie dużej liczby tego rodzaju ośrodków jest niewatpliwie efektem ubocznym procesu profesjonalizacji wojska. W związku z długo obowiązującą zasadą ,drzwi obrotowych” w ośrodkach analitycznych i eksperckich pracują politycy i wojskowi. Duża część z nich ma jednak ustalony profil polityczny, co sprawia, że wiedza ekspercka może być wykorzystana jako element kontroli nad sferą militarną w momencie przejęcia władzy przez drugą partię. Zwyczajowo głos ekspertów jest brany pod uwagę w dyskusji nad kandydaturami na centralne godności publiczne. Przykładowo 10 stycznia 2017 r. przed senacką Komisją 
ds. Sił Zbrojnych wystapiła Kathleen Hicks, pierwszy wiceprezydent Center for Strategic and International Studies [dalej: CSIS]. Senat kontroluje nominacje 2,5 tys. urzędników federalnych. W ramach kontroli cywilnej nad wojskiem prowadzi poprzez komisję przesłuchanie kandydatów m.in. na urząd sekretarza obrony i dyrektora CIA. W procesie selekcji kandydatów bierze się pod uwagę opinię różnych środowisk. Hicks wygłosiła oświadczenie, że w warunkach demokracji amerykańskiej nominacja gen. Mattisa na sekretarza obrony byłaby naruszeniem zasad kontroli cywilnej. Według Hicks sytuacja polityczna Stanów Zjednoczonych nie uprawniała do naruszenia zasady prawnej i zwyczaju siedmioletniej karencji od odejścia ze służby wojskowej do godności publicznej.

W warunkach amerykańskich nie wolno zapominać o III sektorze. Rozliczne inicjatywy obywatelskie oraz wiele ośrodków eksperckich wykonują funkcję tzw. watchdogs, wychwytując anomalie i niekorzystne procesy społeczne w określonym obszarze. Należy też zwrócić uwagę na poziom wiedzy fachowej, jaki prezentują eksperci niektórych z tych ośrodków. Tak jest w przypadku raportów i analiz CSIS, Brookings Institution czy Hoover Institute. Heritage Foundation publikuje coroczny, bardzo oczekiwany raport dotyczący stanu amerykańskich sił zbrojnych. Raport 2017 Index of U.S. Military Strength. Assessing America's Ability to Provide for the Common Defense jest ciekawy nie tylko ze względu na ustalenia, obnażające zaniedbania w siłach zbrojnych, ale także dlatego, że wywołał ożywioną debatę publiczną na temat kondycji i miejsca amerykańskich sił zbrojnych w amerykańskim społeczeństwie. Niewątpliwie wywarł istotny wpływ na duży wzrost budżetu na siły zbrojne.

\section{Zmiany współczesne}

Wobec trwałości instytucji republikańskich w dzisiejszych Stanach Zjednoczonych cywilną kontrolę nadal określa dynamika sytuacji — po konfliktach następuje czas uspokojenia. Na sytuację znacząco wpływają osobowości zarówno polityków cywilnych, jak i dowódców wojskowych. Aktualne kwestie bezpieczeństwa i obronności zmieniają charakter relacji. Negocjacje i konsultacje nie likwidują napięć i sporów. Jednocześnie relatywnie zmienia się znaczenie sfery militarnej w zakresie ustalania polityki państwowej i podczas podejmowania decyzji politycznych. Nadal jednak to Kongres i prezydent ustanawiają ład prawny, decydują o sprawach wojny i pokoju i dostosowują siły zbrojne do dyktatu prawa i cywilnej kontroli.

Obecna sytuacja znacząco różni się od historycznej w kilka aspektach.

Po pierwsze, siły zbrojne są dzisiaj zwartą całością. Pozwala to wojskowym skutecznie kształtować decyzje władz cywilnych jak również sprzeciwiać się im i je blokować. W przeszłości poszczególne rodzaje sił zbrojnych były wewnętrznie podzielone lub nawet działały w opozycji do siebie (np. przy kształtowaniu budżetu). Większość konfliktów między sferą cywilną a wojskiem powstawała w wyniku rywalizacji wewnętrznej w wojsku, wynikającej z określenia roli, misji, budżetu lub wprowadzania nowych systemów uzbrojenia. Jeszcze Huntington i Janowitz w połowie XX w. sugerowali, aby sił zbrojnych nie traktować jako jednorodnej całości. Dzisiaj sytuacja biurokracji wojskowej oraz generalnie sił zbrojnych jest odmienna. 
Po drugie, wiele zagadnień w sferze polityki państwowej wykracza poza wąsko pojmowane kwestie obronności oraz interesy sił zbrojnych i dotyczy zagadnień bezpieczeństwa narodowego, a nawet polityki zagranicznej. W niektórych kwestiach sprawy wojskowe wpływają na charakter i system wartości amerykańskiego społeczeństwa. Wojna kulturowa w narodzie amerykańskim jeszcze bardziej sprawę komplikuje.

Po trzecie, w ostatnim okresie znacząco ewoluuje rola dowódców wojskowych. Porzucają oni rolę doradców lub obrońców określonej sprawy, którą załatwia się jedynie poprzez przetargi w obrębie biurokracji (zwłaszcza władzy wykonawczej). Korpus oficerski, a zwłaszcza generałowie i admirałowie, wypełniają coraz więcej ważkich funkcji publicznych. Kilka przykładów pozwoli zilustrować tę tezę. Wielu generałów publicznie zabrało głos na temat racjonalności podpisania przez Stany Zjednoczone traktatu zabraniającego używania min lądowych. Brali oni również udział w dyskusji na temat sensowności operacji wojskowej na Bałkanach. Sprzeciw wobec udziału Stanów Zjednoczonych wobec ustanowionego Międzynarodowego Sądu Karnego był decydujący (warto przypomnieć, że obecny doradca ds. bezpieczeństwa narodowego za swoje główne osiagnięcie uznał negatywną decyzję władz amerykańskich w tej sprawie). Wojskowi swoimi publicznymi wypowiedziami próbują wpłynać na rozstrzygnięcia Kongresu i decyzje prezydenta, co już nie jest lobbingiem politycznym, ale kształtowaniem opinii społecznej poprzez aktywny udział w dyskursie publicznym.

Czy jest to odpowiedź na rozziew między wartościami reprezentowanymi przez wojsko a społeczeństwem amerykańskim, między siłami zbrojnymi a liberalnymi mediami? Problem dotyczy głębszych przemian społeczeństwa amerykańskiego. Jak zauważa Richard Kohn, ten zwrot w stronę rosnącej polityzacji może być powstrzymany, jeśli cywile zaczną traktować siły zbrojne z sympatią. Do tego trzeba także rosnącej wiedzy elit społecznych, zwłaszcza elit rządzących, na temat funkcjonowania wojska.

$\mathrm{Na}$ istotną zmianę wskazuje także liczba publicznych wystapień wojskowych oraz ich wpływ na wybór tematów i natężenie debaty publicznej. Można wręcz mówić o wyręczaniu cywilów w wielu kwestiach publicznych, a nawet o naruszaniu cywilnej kontroli nad wojskiem. Symptomy erozji tych tradycyjnych form kontroli stały się widoczne już za czasów Clintona, a obecnie mają one wymiar strukturalny. Przywołane badania Triangle Institute for Security Studies zawierały także pytanie, czy w określonych okolicznościach wojskowy może pominąć polecenia władzy cywilnej, na które nie wyraża zgody, i 68\% badanych odpowiedziało pozytywnie (zawsze, w większości, czasami).

Wreszcie czwarta przyczyna. Dzisiaj starsi oficerowie stoją na czele permanentnej, potężnej i skomplikowanej biurokracji wojskowej, która nie przestaje działać w czasach pokoju. Te wysoko profesjonalne siły, odseparowane na co dzień od kultury świata cywilnego, zostają uwikłane w światową politykę, a za sprawą swojej skuteczności stają się niezbędne (nawet w codziennej praktyce) do realizowania amerykańskiej polityki międzynarodowej, a nawet do urzeczywistniania celów amerykań- 
skiego państwa w polityce światowej. Szczególnie wzrasta zakres decyzji politycznych w sferze bezpieczeństwa narodowego lub użycia sił zbrojnych poza granicami kraju. Ta grupa interesu jest potężniejsza, aktywniejsza w przetargach biurokratycznych, bardziej zorientowana politycznie i ideologicznie. Wyznacza sobie jasne cele i przez to staje się bardziej wpływowa niż była kiedykolwiek przedtem w historii narodu amerykańskiego.

Pod koniec XX w. Sam Sarkosian, bardzo opiniotwórczy pułkownik wojsk lądowych i politolog, oraz James Webb, były sekretarz marynarki, publicznie wezwali wojskowych dowódców do aktywnego udziału w debatach na temat bezpieczeństwa narodowego. Ich apel, aby wojskowi stali się aktywnymi uczestnikami życia publicznego jako strona sporu, zamiast występować jedynie w roli doradców władzy cywilnej, spotkał się z gorącym przyjęciem samych wojskowych. Ten zapał, aby kształtować i realizować politykę państwowa, niesie ze sobą zagrożenia dla sił zbrojnych i dla cywilnej kontroli nad wojskiem. Równowaga między sferą cywilną a militarną wynika z właściwej obsady kierowniczych stanowisk we władzy wykonawczej i w komisjach Kongresu. Pytaniem otwartym jest, czy delegowanie większych uprawnień na sekretarza obrony gen. Mattisa przez prezydenta w istotny sposób zakłóca relacje między obiema sferami. Na pewno zdefiniowanie celów strategicznych w dziedzinie bezpieczeństwa narodowego w dokumencie podstawowym z grudniu $2017 \mathrm{r}$. jest sposobem na przywrócenie równowagi. W strategii bezpieczeństwa narodowego ustalono kierunki działania oraz warunki brzegowe funkcjonowania sił zbrojnych, w tym użycia sił zbrojnych w skali regionalnej i globalnej. Niemniej jednak głosy wielu środowisk ukazują skalę obaw o utratę kontroli władz cywilnych nad siłami zbrojnymi. Te obawy są wyrażane nawet $\mathrm{w}$ środowiskach republikańskich.

\section{KONKLUZJE}

1. Narastają wątpliwości dotyczące przyszłości cywilnej kontroli nad wojskiem (pojawia się nawet termin „erozja kontroli cywilnej”).

2. Istnieje „logika” działania amerykańskiego imperium, rośnie rola wojska w podejmowaniu decyzji politycznych na szczeblu federalnym i stanowym.

3. Przybiera na sile dyskusja społeczna, także w obrębie świata akademickiego, na temat „militaryzacji” społeczeństwa amerykańskiego.

4. Istotną kwestią staje się poziom zaangażowania amerykańskich sił zbrojnych w utrzymaniu porządku międzynarodowego, w operacjach zewnętrznych, a także roli Stanów Zjednoczonych w takich paktach polityczno-wojskowych, jak Pakt Północnoatlantycki.

5. Cywilna kontrola nad centralnymi i regionalnymi strukturami wojska jest problematyczna.

6. Praktyka polityczna rozstrzygnie o zakresie kontroli cywilnej nad wojskiem — szczególne znaczenie ma „wojna kulturowa” w społeczeństwie amerykańskim.

7. Znacząco zwiększyły się znaczenie i rola wojskowych w administracji prezydenta Trumpa. 
8. Wojsko, wspomagane przez sektor militarny, odgrywa znaczącą rolę jako grupa interesu i lobby polityczne w przetargach politycznych.

9. Następuje wzrost znaczenia wojska w określaniu strategii bezpieczeństwa narodowego i decyzji politycznych generalnie.

10. Coraz bardziej oczywisty staje się narastający wpływ wojska na realizowanie polityki wewnętrznej i zagranicznej.

Tomasz Żyro*

* Prof. dr hab. Tomasz Żyro, Uniwersytet Warszawski, Instytut Nauk Politycznych, tzyro@uw.edu.pl

BIBLIOGRAFIA

Bacevich A.J., The New American Militarism. How American Are Seduced by War, Oxford University Press, New York 2005.

Corbett S., Davidson M.J., The Role of the Military in Presidential Politics, 58 Parameters (2010).

Cunliffe M., Soldiers and Civilians: The Martial Spirit in America, 1775-1865, Little, Brown, New York 1968.

Doubler M.D., I Am The Guard: A History of the Army National Guard, 1636-2000, United States. National Guard Bureau.

Ferguson N., Kolos. Cena amerykańskiego imperium, Wydawnictwo Literackie, Kraków 2010.

Gerstein D., Is America Losing Civilian Control of the Military? „The National Interest”, 27 VII 2017.

Janowitz M., The Professional Soldier. A Social and Political Portrait, Glencoe, Free Press 1960.

Kohn R.H., The Erosion of Civilian Control of the Military in the United States Today, „Naval War College Review” 2018, t. 55, nr 3.

Langston T.S., Uneasy Balance: Civil-Military Relations in Peacetime America Since 1783, John Hopkins University Press, Baltimore and London 2003.

Lupton D.I., Reexamining Reputation for Resolve: Leaders, States, and the Onset of International Crises, ,Journal of Global Security Studies”2018, t. 3, nr 2, https://doi.org/10.1093/ jogss/ogy004.

Luttwak E.N., The Pentagon and the Art of War, Simon \& Schuster, New York 1984.

Policy Expertise in Contemporary Democracies, red. S. Brooks, P. Stasiak, T. Żyro, Ashgate, Farnham 2012.

Rovere R., Schlesinger A.M. Jr., General MacArthur and President Truman: The Struggle for Control of American Foreign Policy, Transaction Books, New Brunswick, New York 1992 (reprint).

Stevenson Ch.A., Bridging the Gap between Warriors and Politicians paper presented at the annual meeting of the American Political Science Association, Atlanta, Georgia, 2-5 IX 1999. 
Soldiers and Civilians: The Civil-Military Gap and American National Security, red. P.D. Feaver, R.H. Kohn, MIT Press, Cambridge 2001.

The Chairmanship of the Joint Chiefs of Staff, 1949-2016, revised and updated by Nathan S. Lowrey, Joint History Office, Office of the Chairman of the Joint Chiefs of Staff, Washington 2016.

The Oxford Companion to American Military History, red. J.W. Chambers II, Oxford University Press, Oxford 1999, https://doi.org/10.1093/acref/9780195071986.001.0001.

The Princeton Encyclopedia of American Political History, red. M. Kazin, R. Edwards, A. Rothman, Princeton University Press, Princeton 2010, 2 t., https://doi.org/10.1515/ 9781400833566. 
GLOSA DO WYROKU SĄDU NAJWYŻSZEGO STANÓW ZJEDNOCZONYCH Z DNIA 4 CZERWCA 2018 R. W SPRAWIE MASTERPIECE CAKESHOP, LTD. V. COLORADO CIVIL RIGHTS COMMISSION

\author{
COMMENTARY TO THE JUDGMENT OF THE SUPREME COURT \\ OF THE UNITED STATES OF 4 JUNE 2018 IN MASTERPIECE CAKESHOP, LTD. \\ $V$. COLORADO CIVIL RIGHTS COMMISSION CASE
}

The discussed judgment refers to the problem of law prohibiting the discrimination in access to goods and services. Colorado Rights Commission, and then the Colorado Court of Appeal decided that the bakery owner Jack Phillips discriminated homosexual persons with his refusal to provide a wedding cake for the prospective spouses of the same sex on the basis of his religious beliefs. The U.S. Supreme Court annulled the Commission's decision and the contested judgment of the state court. In the opinion of the federal Supreme Court, the Commission, in the course of the proceedings before it, did not employ neutrality and impartiality and displayed hostility and bias against the religious views of the bakery's owner. The discussed judgment shall be approved as an individual act of applying the law. Unfortunately, the Supreme Court did not decide on the circumstances allowing an entrepreneur to evade the antidiscrimination provisions on the basis of his conscientious objection.

Słowa kluczowe: sprawo antydyskryminacyjne, sprzeciw sumienia, Stany Zjednoczone, Sąd Najwyższy

Key words: antidiscrimination law, conscientious objection, the United States, Supreme Court

Sąd Najwyższy USA komentowanym wyrokiem ${ }^{1}$ uchylił decyzję Komisji Praw Obywatelskich stanu Kolorado, w której Komisja stwierdziła, że cukiernik Jack Phillips naruszył stanowe prawo antydyskryminacyjne, odmawiając z powodu swoich przekonań religijnych przygotowania i sprzedaży weselnego tortu dla homoseksualnej pary².

Przedmiotowa sprawa dotyczy kolizji zasad i wartości prawnych towarzyszących stosowaniu przepisów zakazujących dyskryminacji w sprzedaży dóbr i usług (public accomodation law). Zgodnie z ustawą stanu Kolorado bezprawną dyskryminacją jest odmówienie innym osobom pełnego i równego dostępu do dóbr i usług w placówkach handlowo-usługowych ze względu na niepełnosprawność, rasę, wyznanie, kolor, płeć, orientację seksualną, stan cywilny, narodowość czy pochodzenie tych osób [Colorado Anti-Discrimination Act, dalej: CADA $]^{3}$. Z jednej strony przepisy te chronia prawa, a jednocześnie godność osób jako konsumentów, in concreto osób homoseksualnych, którzy w związku planami matrymonialnymi chcieli zamówić w cukierni weselny tort. Z drugiej strony egzekwowanie od przedsiębiorców świadczenia określonych dóbr

1 Masterpiece Cakeshop, Ltd. v. Colo. Civil Rights Comm'n, 584 U. S. (2018), <https://www. supremecourt.gov/opinions/17pdf/16-111_new2_22p3.pdf >, dostęp 15 VI 2018. Cytowane w glosie fragmenty tego orzeczenia podaję poprzez wskazanie numeru strony z tekstu wyroku z własnym tłumaczeniem.

2 Komisja nakazywała Phillipsowi zaprzestania dyskryminowania par jednopłciowych, wzięcia udziału w szkoleniu z zakresu prawa antydyskryminacyjnego oraz sporządzanie raportów dokumentujących przypadki odmówienia klientom świadczenia usług. 
i usług na mocy przepisów antydyskryminacyjnych może w poszczególnych przypadkach zmuszać osoby prowadzące działalność handlowo-usługową do działań sprzecznych z ich religijnymi czy — szerzej — światopoglądowymi przekonaniami. Właściciel cukierni „Masterpiece Cakeshop”, J. Phillips, uznał, że z powodu chrześcijańskich przekonań nie jest w stanie bez pogwałcenia swojego sumienia i wyznawanej wiary przygotować i sprzedać weselnego tortu dwóm homoseksualistom zamierzającym zawrzeć związek małżeński ${ }^{4}$. W jego przeświadczeniu uczynienie tego oznaczałoby afirmowanie przez niego jednopłciowego małżeństwa i partycypowanie w jego celebracji. Komisja Praw Obywatelskich stanu Kolorado uznała zachowanie cukiernika za sprzeczne z CADA. Decyzję Komisji utrzymał w mocy Sąd Apelacyjny stanu Kolorado5.

Glosowany wyrok Sądu Najwyższego zapadł stosunkiem głosów siedem do dwóch, a autorem jego uzasadnienia został sędzia Anthony Kennedy. Do wyroku złożono trzy zdania zbieżne (polemiczne) i jedno zdanie odrębne ${ }^{6}$. Orzeczenie zasługuje w pełni na aprobatę jako indywidualny akt stosowania prawa. Natomiast tylko częściowo Sąd Najwyższy odniósł się w nim do sedna wątpliwości i pytań prawnych powiązanych z obowiązywaniem przepisów antydyskryminacyjnych w dostępie do dóbr i usług, czego można było od niego oczekiwać jako sądu konstytucyjnego. Komentowane orzeczenie znamionuje „,decyzyjny minimalizm”, tj. sąd poprzestał na przywołaniu argumentacji wystarczającej, a zarazem koniecznej do uzasadnienia rozstrzygnięcia w jednostkowej sprawie J. Phillipsa ${ }^{7}$. Sąd uchylił decyzję Komisji dlatego, że ta rozpatrując sprawę Phillipsa nie zachowała religijnej neutralności (bezstronności) sprzecznie z I Poprawką do konstytucji USA. Kwestią otwartą pozostała natomiast zarówno sama konstytucyjność przepisów antydyskryminacyjnych, jak i ewentualna możliwość odmowy stosowania się do nich ze względu na sprzeciw sumienia. Sędzia Kennedy w orzeczeniu, a sędziowie Gorsuch i Thomas w swoich zdaniach zbieżnych zasugerowali, że prawdopodobnie sprawa analogiczna do kazusu Phillipsa w perspektywie kilku lat ponownie trafi na wokandę Sądu Najwyższego, który tym razem będzie już musiał dokonać rozstrzygnięcia wspomnianej kolizji zasad prawa.

Sąd Najwyższy konkluzję o braku religijnej neutralności Komisji Praw Obywatelskich stanu Kolorado wobec Phillipsa wyprowadził z dwóch okoliczności. Po pierw-

${ }^{3}$ Colo. Rev. Stat. § 24-34-601(2)(a) (2017).

${ }^{4}$ J. Phillips postapił analogicznie wobec co najmniej sześciu innych par jednopłciowych, odmawiając im wykonania i sprzedaży weselnego tortu. W orzeczeniu był podkreślony fakt, relewantny jedynie na gruncie rozpatrywanej sprawy, że w czasie gdy Phillips odmówił wykonania zamówienia, prawo stanowe Kolorado nie przewidywało jeszcze możliwości zawierania małżeństw dla osób homoseksualnych.

${ }^{5}$ Craig v. Masterpiece Cakeshop, Inc., 370 P. 3d 272 (2015).

${ }^{6}$ Zdanie zbieżne (polemiczne) złożyli: sędzia Elena Kagan (do którego przyłączył się sędzia Stephen Breyer), sędzia Neil Gorsuch (do którego przyłączył się sędzia Samuel Alito), sędzia Clarence Thomas (do którego przyłączył się sędzia Neil Gorsuch). Zdanie odrębne złożyła sędzia Ruth Bader Ginsburg (do którego przyłączyła się sędzia Sonia Sotomayor). Zdanie polemiczne lub zbieżne do orzeczenia (concurrence), tym różni się od zdania odrębnego (dissent), że składający je sędzia podziela meritum rozstrzygnięcia sądu, natomiast przedstawia nieco inne czy dodatkowe argumenty prawne za tym rozstrzygnięciem, niż racje podane przez sąd.

${ }^{7}$ Postawę decyzyjnego minimalizmu postuluje sądom, zwłaszcza w sprawach kontrowersyjnych, np. Cass Sunstein. Vide One Case at a Time - Judicial Minimalism on the Supreme Court, Cambridge 1999. 
sze, zwrócił uwagę na wypowiedzi członków Komisji podczas procedowania jego sprawy. W wypowiedziach tych dano wyraz poparciu prywatystycznej wizji religii, w myśl której religijnych przekonań nie należy wnosić do sfery publicznej, w tym działalności handlowej ${ }^{8}$. Co jednak istotne, jeden z komisarzy w czasie posiedzenia Komisji, odnosząc się do religijnego sprzeciwu sumienia Phillipsa nakreślił bardzo krytyczny i jednostronny obraz religii, stwierdzając: „Wolność religii i religię wykorzystywano do uzasadniania na przestrzeni historii wszelkich rodzajów dyskryminacji, jak w przypadku niewolnictwa czy holokaustu. Możemy wymienić setki sytuacji, gdy wolnością religii usprawiedliwiano dyskryminację. Dla mnie jest to najbardziej podła retoryka do jakiej ludzie mogą sięgnąć, tj. posłużyć się swoją religią do krzywdzenia innych"9. Wypowiedź ta wpisuje się w ogląd religii bliski tzw. liberalnej doktrynie ekskluzywizmu, zgodnie z którym religia to irracjonalny, antydeliberatywny, apodyktyczny, konfliktogenny, a nawet opresyjny system wierzeń i przekonań ${ }^{10}$. W trafnej ocenie sądu cytowany komentarz jednego z komisarzy ujawnia wrogość wobec religii. Religijną wiarę potraktowano jako coś nieistotnego i nieszczerego. Zrównując przekonania religijne Phillipsa, będące podstawą odmówienia przygotowania weselnego tortu dla homoseksualnej pary, z holokaustem i niewolnictwem, Komisja podała w wattpliwość swoją zdolność i gotowość do uczciwego i bezstronnego rozpatrzenia ewentualnej prawnej relewantności argumentacji cukiernika w procedowanej sprawie. Sąd zwrócił uwagę, że przywołane słowa nie spotkały się z żadną reakcją pozostałych członków Komisji, jak i stanowego sądu apelacyjnego utrzymującego decyzję Komisji w mocy. Mając to na uwadze, Sąd Najwyższy zasadnie zaliczył wypowiedź jednego członka Komisji na rachunek całej Komisji jako organu władzy publicznej. O ile bowiem problematyczne byłoby przypisywanie wypowiedzi pojedynczego parlamentarzysty prawodawcy, o tyle zachowanie członka organu adjudykacyjnego podczas wykonywania swoich obowiązków rzutuje na ocenę bezstronności całego organu ${ }^{11}$.

Drugą okolicznością przemawiającą za brakiem bezstronności Komisji w rozpatrywaniu sprawy Phillipsa były jej decyzje w trzech innych analogicznych sprawach. Komisja uznała, że nie złamali prawa ci cukiernicy, którzy odmówili Williamowi Jackowi przygotowania i sprzedaży tortu zawierającego napis i symbole wyrażające religijnie motywowaną krytykę małżeństw homoseksualnych i homoseksualizmu ${ }^{12}$. Zdaniem Komisji, cukiernicy nie podejmując wykonania tego zamówienia, chronili swoje sumienie niepozwalające im afirmować treści postrzeganych za „obraźliwe”,

${ }^{8}$ G. Maroń, Integralność religijna sędziego oraz argumentacja religijna $w$ amerykańskim procesie orzeczniczym, Rzeszów 2018, s. 96-103.

${ }_{9}$ Masterpiece Cakeshop, Ltd...., s. 13.

${ }^{10}$ G. Maroń, Integralność..., s. 62-72.

11 Podobne wątpliwości pojawiły się w kontekście konstytucyjności zarządzeń prezydenta D. Trumpa ograniczających obywatelom kilku państw muzułmańskich możliwość wjazdu do USA, tj. czy jego antymuzułmańskie i antyimigranckie wypowiedzi z okresu kampanii wyborczej mają wpływ na konstytucyjność aktów prawnych wydanych później przez niego jako urzędującej już głowy państwa. Vide G. Maroń, Glosa do wyroku federalnego Sadu Apelacyjnego dla 4. Okręgu z 25 maja 2017 roku w sprawie International Refugee Assistance Project v. Trump, 857 F. 3D 554 (4th CIR. 2017), ,Zeszyty Naukowe Uniwersytetu Rzeszowskiego. Seria Prawnicza” 2017, nr 21, s. 182 i 188. 
„poniżające”, „,dyskryminacyjne”, „wyrażające nienawiść” wobec homoseksualistów. Sąd prawidłowo wskazał na niespójność interpretowania i stosowania przez Komisję tych samych przepisów antydyskryminacyjnych. W sprawie Phillipsa Komisja przyjęła, że przesłanie czy wymowa tortu weselnego idzie na rachunek klienta, a nie sprzedawcy. Wniosku takiego Komisja nie podzieliła natomiast w odniesieniu do tortu o symbolice antyhomoseksualnej. W sprawie Phillipsa Komisja za prawnie nieistotną potraktowała okoliczność, że cukiernik wyrażał gotowość sprzedaży osobom homoseksualnym wszelkich wyrobów cukierniczych poza tortem weselnym, w tym np. tortu urodzinowego. W sprawach natomiast trzech innych cukierników za legalnością odmówienia klientowi sprzedaży tortu udekorowanego treściami antyhomoseksualnymi — zdaniem Komisji — przemawiało to, że cukiernicy ci przejawiali chęć sprzedaży temu klientowi innych wyrobów, a innym osobom sprzedawali torty i ciastka prezentujące chrześcijańskie treści.

Zdaniem Sądu Najwyższego, Komisja dopuściła się dyskryminacji, doszukując się naruszenia prawa przez Phillipsa, ale już nie przez trzech pozostałych cukierników. Komisja nie mogła zróżnicować tych spraw ze względu na własną ocenę obraźliwości inskrypcji czy dekoracji na wyrobach cukierniczych. Stanowy sąd apelacyjny broniąc takiego podejścia, tym samym ,wysłał sygnał oficjalnej dezaprobaty dla religijnych przekonań Phillipsa"13. Case law Sądu Najwyższego nie pozostawia wątpliwości, że władzy publicznej nie wolno dyskryminować obywateli ze względu na ich poglądy ${ }^{14}$. „Żaden urzędnik, wysokiego czy niskiego szczebla, nie może nakazywać, co ma być ortodoksją w polityce, nacjonalizmie, religii i innych sprawach opinii" ${ }^{15}$. Sędzia Gorsuch w zdaniu polemicznym wskazał, że „największą dumą naszej doktryny wolności religijnej jest to, że chronimy nawet te religijne przekonania, które uważamy za obraźliwe"16. Wyznacznikiem kondycji wolności religijnej nie jest ochrona niekontrowersyjnych religijnych przekonań, ale tych niepopularnych i mniejszościowych.

Represyjne działania władz motywowane przeświadczeniem o obraźliwości czy irracjonalności pewnych poglądów obywateli nie mogą pozytywnie zaliczyć tzw. testu ścisłego (strict scrutiny). Zgodnie z nim regulacja prawna lub praktyka władz ingerująca w wolność religii czy wolność słowa ze względu na treść reglamentowanych przekonań i wypowiedzi może uchodzić za konstytucyjną po spełnieniu trzech warunków:

— działanie władzy było uzasadnione nieodpartym (compelling) interesem;

— zastosowano środek najmniej inwazyjny spośród wszystkich możliwych równie skutecznych środków;

${ }^{12}$ W. Jack chciał zamówić tort zawierający symbol dwóch panów młodych trzymających się za ręce przekreślony czerwonym znakiem X oraz napisy: „Bóg nienawidzi grzechu, Psalm 45:7”, „Homoseksualizm jest odrażającym grzechem, Księga Kapłańska 18:2”, „Bóg kocha grzeszników”, „Chrystus umarł za nas, gdyśmy byli jeszcze grzesznikami. List do Rzymian 5:8".

${ }^{13}$ Masterpiece Cakeshop, Ltd...., s. 16.

${ }^{14}$ G. Maroń, Ochrona mniejszości seksualnych przed mowa nienawiści a wolność słowa w państwach common law, „Przegląd Prawa Publicznego” 2016, nr 7-8, s. 103-105.

${ }^{15}$ West Virginia State Board of Education v. Barnette, 319 U.S. 624, 642 (1943).

${ }^{16}$ Masterpiece Cakeshop, Ltd...., (Gorsuch, concurring), s. 7. 
— ograniczenie nie znosiło innych sposobów wyrażania swoich poglądów ${ }^{17}$.

W przypadku gdy regulacja prawna czy praktyka władzy ingerująca w konstytucyjne wolności obywateli ma nie tylko ,treściowy” charakter (content based), ale odnosi się do poglądów (viewpoint) ${ }^{18}$, wówczas domniemuje się ich niekonstytucyjnośćc ${ }^{19}$. Kryterium „obraźliwości”, jakim posłużyła się Komisja, jest właśnie tego typu ${ }^{20}$. Stanowisko sędziego Gorsucha podzielił sędzia Thomas, stwierdzając, że państwo „nie może karać chronionej mowy dlatego, że pewne grupy uważają ją za obraźliwa, bolesną, stygmatyzująca, nieracjonalną czy niegodną"21. Należy jednak podkreślić, że powyższe uwagi dotyczyły praktyki stosowania prawa przez Komisję, a nie samego prawa, tj. CADA.

Zarówno sędzia Kagan w zdaniu zbieżnym, jak i sędzia Ginsburg w zdaniu odrębnym wyraziły przekonanie, że Komisja mogła sprawę Phillipsa potraktować inaczej niż sprawę trzech pozostałych cukierników. W ich ocenie, o ile Phillips dopuścił się dyskryminacji ze względu na orientację seksualną klientów, o tyle pozostali cukiernicy ze względu na obraźliwość treści i symboli, jakie miały znaleźć się na zamówionym u nich torcie. Kryterium orientacji seksualnej jest natomiast, w przeciwieństwie do kryterium obraźliwości, wyraźnie wymienione w ustawie (CADA) jako zakazane kryterium dyskryminacyjne.

Niniejsze rozumowanie jest wątpliwe co najmniej w kontekście amerykańskiego porządku prawnego. Sędziowie ci przyjęli zbyt wąskie rozumienie religii i przekonań religijnych. Na gruncie amerykańskiego case law konstytucyjną zasadą wolności religijnej (Free Exercise Clause) obejmowano np. świecki humanizm² ${ }^{22}$, czary (Wicca) i neopogaństwo ${ }^{23} \mathrm{czy}_{\text {nawet ateizm }}{ }^{24}$. W. Jack, wyrażając z powodu religijnych przekonań dezaprobatę dla małżeństw homoseksualnych, realizował własną wolność religijną z I Poprawki do konstytucji. Wolność religijna gwarantuje nie tylko możliwość uczestniczenia w aktach kultu, ale i także publicznego głoszenia nauczania etycznego wywodzonego z wyznawanej wiary. W tym kontekście w porządku prawnym USA bez znaczenia jest obraźliwość czy skandaliczność treści tego nauczania, jak i jego prawowierność w sensie koherentności z oficjalną doktryną danego kościoła. Zgodnie z tzw. doktryną kwestii religijnej (Religious Question Doctrine) władzy publicz-

${ }_{17}$ Ward v. Rock Against Racism, 491 U.S. 781, 790 (1989).

18 Przykładowo regulacja prawna czy działania władz ingerujące w wolność słowa mają charakter treściowy (content based), gdy np. zakazują wypowiedzi tak pro- jak i antyaborcyjnych przed kliniką aborcyjną. Natomiast ich podstawą jest preferencja co do poglądów (viewpoint), jeśli zakazują wyłącznie wypowiedzi pro-life, dopuszczając wyraźnie lub implicite te o charakterze pro-choice.

19 Rosenberger $v$. Rector \& Visitors of Univ. of Va., 515 U.S. 819, 830 (1995).

${ }^{20}$ Matal $v$. Tam, 137 S. Ct. 1744, 1763 (2017).

21 Masterpiece Cakeshop, Ltd...., (Thomas, concurring), s. 12.

22 Torcaso v. Watkins, 367 U.S. 488, 495, n. 11 (1961); Am. Humanist Ass'n v. U.S., 63 F. Supp. 3d 1274, 1283 (D. Or. 2014).

${ }^{23}$ Dettmer $v$. Landon, 799 F. 2d 929, 932 (4th Cir. 1986); O’Bryan v. Bureau of Prisons, 349 F. 3d 399, 400-01 (7th Cir. 2003); Kay v. Bemis, 500 F. 3d 1214, 1218-20 (10th Cir. 2007).

${ }^{24}$ Kaufman v. McCaughtry, 419 F. 3d 678, 681 (7th Cir. 2005); Jackson v. Crawford, 2015 WL 506233 (W.D. Mo. 2015). 
nej nie wolno rozstrzygać wątpliwości co do treści norm religijnych. Sądy i inne organy władzy „nie są arbitrami w kwestii interpretacji” świętych tekstów ${ }^{25}$. Arbitralne jest implikatywnie wyrażone stanowisko wspomnianych sędziów, zgodnie z którym obraźliwość religijnego przesłania pozbawia je religijnej natury. Religijne przesłanie jest udziałem zarówno np. inskrypcji na torcie w brzmieniu „Boże błogosław młodej parze”, jak i w brzmieniu „Homoseksualizm jest odrażającym grzechem”.

Sędzia Gorsuch w zdaniu polemicznym przekonująco wyeksponował podobieństwa spraw Phillipsa i Jacka, a zarazem niejednolitość praktyki decyzyjnej Komisji. Po pierwsze, w obu sprawach decyzje cukierników zrodziły ten sam skutek w postaci odmowy dostępu do dóbr i usług dla klientów. Po drugie, w obu sprawach cukiernicy kierowali się chęcią uszanowania swojego własnego światopoglądu. Po trzecie, w obu przypadkach odmowa usługi zdarzyła się nie tyle „z powodu” orientacji seksualnej czy wiary klienta, ale ze względu na nieakceptowane przez sumienie cukierników przesłanie tej usługi, o którą byli przez klienta proszeni. Phillips nie sprzedałby tortu weselnego celebrującego małżeństwo gejowskie także osobie heteroseksualnej (np. matce homoseksualnego nupturienta), z kolei trzej inni cukiernicy nie sprzedaliby tortu $\mathrm{z}$ antyhomoseksualnym przesłaniem także ateiście ${ }^{26}$.

Sędzia Gorsuch zasadnie wytknął też Komisji stosowanie niejednolitych standardów co do zamiaru (mens rea) osób naruszających przepisy antydyskryminacyjne. W sprawie Phillipsa Komisja przyjęła na zasadzie domniemania, że towarzyszył mu zamiar dyskryminacji osób homoseksualnych. Rzekomo zamiar ten był „nierozerwalnie” powiązany z orientacją seksualną klientów. Tymczasem w sprawie W. Jacka Komisja apriorycznie przyjęła, że cukiernikom obcy był zamiar dyskryminacji, a swoją odmową wykonania zamówienia chcieli jedynie odciąć się od obraźliwego przesłania dekoracji tortów. Zdaniem sędziego Gorsucha, Komisja musi albo w każdej sprawie udowodnić rzeczywisty zamiar dyskryminacji chronionej kategorii osób, albo za każdym razem odmowy świadczenia dobra czy usługi zamiar ten domniemywać. Nie wolno jej wybiórczo stosować reguł interpretacji i dowodzenia faworyzujących przedsiębiorców o świeckim sprzeciwie sumienia, a innych — mniej korzystnych — wobec przedsiębiorców odmawiających sprzedaży dóbr czy usług z powodu przekonań religijnych.

Bardziej interesujące, ale niestety mniej konkluzywne są wywody zawarte w samym orzeczeniu, jak i w zdaniach zbieżnych sędziów Gorsucha i Thomasa dotyczące istoty problemu prawnego będącego podstawą rozstrzyganej sprawy. Na pytania o dopuszczalność stosowania wobec przepisów antydyskryminacyjnych tzw. religijnych

${ }_{25}$ Thomas v. Review Bd., Ind. Empl. Sec. Div., 450 U.S. 707, 715 (1981). Vide szerzej M. Helfand, Litigating Religion, „Boston University Law Review” 2013, t. 93, nr 4, s. 499-519.

${ }^{26}$ Podobne rozumowanie przyjął Sąd Apelacyjny stanu Kentucky w wyroku z 12 maja 2017 r. w sprawie Lexington Fayette Urban Cnty. Human Rights Comm'n v. Hands On Originals, Inc. Uznał, że agencja promocyjno-reklamowa mogła z powodu religijnych przekonań swojego właściciela odmówić organizacji reprezentującej interesy osób homoseksualnych wykonania zlecenia polegającego na nadruku na T-shirtach napisów i symboli wyrażających ,dumę z bycia homoseksualistą" (in concreto chodziło o napis promujący święto środowisk LGBT oraz symbol tęczy). Zdaniem sądu, odmowa wykonania usługi była motywowana nie orientacją seksualną, ale sprzeciwem wobec przesłania czy wymowy (message) zamówionej usługi. 
czy — szerzej — światopoglądowych wyłączeń (religious exemptions jako odpowiednik znanej prawu polskiemu klauzuli sumienia) oraz warunków skorzystania z takiej możliwości finalnie nie udzielono wprost odpowiedzi. Wspomniany decyzyjny minimalizm można tłumaczyć i częściowo usprawiedliwiać złożonością zagadnienia, z którym sądowi - podobnie jak sądom w innych państwach ${ }^{27}$ — przyszło się zmierzyć. Pewna zachowawczość sądu potwierdza, że w przedmiotowej kwestii nie istnieją proste odpowiedzi i łatwe rozwiązania niekiedy przywoływane przez niektórych przedstawicieli doktryny prawniczej w mylnym przeświadczeniu o oczywistości tych odpowiedzi i rozwiązań. Sprawa Phillipsa to tzw. sprawa trudna (hard case) w terminologii Ronalda Dworkina ${ }^{28}$. Z komentowanego orzeczenia można wyczytać trafne przekonanie sądu, że towarzyszący sprawie problem prawny nie da się rozstrzygnąć „zero-jedynkowo", lecz wymaga on proporcjonalnego wyważenia kolidujących dóbr, interesów i wartości prawnych oraz wyważenia samych argumentów prawnych.

Wiążący precedens Sądu Najwyższego ze sprawy Employment Div., Dept. of Human Resources of Ore. $v$. Smith ${ }^{29}$ stanowi, że konstytucyjna wolność religijna nie zwalnia z obowiązku stosowania się do „neutralnego prawa o ogólnym zastosowaniu”. Błędem byłoby jednak przyjąć, że wyrok ten kategorycznie przesądza o niemożliwości powoływania się w jakichkolwiek okolicznościach na Free Exercise Clause w celu uchylenia się od wymogów prawa antydyskryminacyjnego w zakresie dostępu do dóbr i usług. Sędzia Kennedy w glosowanym orzeczeniu mianem „delikatnej kwestii” określa pytanie: „,kiedy wolność religii musi ustapić” obowiązującemu prawu? ${ }^{30} \mathrm{O}$ ile Kennedy sygnalizuje jedynie ten problem, o tyle sędziowie Gorsuch i Thomas w zdaniu polemicznym rozważają nie to „,zy w ogóle?”, ale „kiedy?”, „pod jakimi warunkami?" przedsiębiorca może uzasadniać swoim sprzeciwem sumienia odmowę sprzedaży dóbr czy usług w konkretnym przypadku.

Sędziowie Kennedy i Thomas podnieśli, że sprawa Phillipsa angażuje nie tylko wolność religii, ale i wolność słowa, jeśli uznać weselny tort nie za zwykły wyrób cukierniczy, ale za akt twórczy, dzieło artystyczne o określonej wymowie czy przesłaniu. W szczególności sędzia Thomas zauważył, że przepisy antydyskryminacyjne na podobieństwo CADA jakkolwiek dotyczą „,postępowania”, a nie „,mowy” (dystynkcja na conduct i speech), to jednak w pewnych przypadkach swoim zakresem obejmuja zachowania będące zarazem aktem ekspresji (expressive conduct), czyli aktem komunikującym poglądy bądź przekonania tego, kto zachowanie takie podejmuje. Zdaniem sędziego Thomasa, postępowanie osoby jest jednocześnie aktem ekspresji, jeśli osoba ta zamierzała swojemu zachowaniu nadać wymiar komunikatywny i jeśli zachowanie to rozpatrywane kontekstualnie byłoby racjonalnie odebrane przez obserwatora za mające taki wymiar. W ocenie Thomasa tworzenie tortu weselnego jest właśnie przy-

27 Vide np. Bull v. Hall and Preddy [2013] UKSC 73; Brockie v. Brillinger (No. 2), 2002 CanLII 63866 (ON SCDC).

${ }_{28}$ J. Zajadło, Co to sq hard cases?, [w:] Fascynujace ścieżki filozofii prawa, red. J. Zajadło, Warszawa 2008, s. 7-18.

29494 U. S. 872 (1990).

${ }^{30}$ Masterpiece Cakeshop, Ltd...., s. 3. 
kładem aktu ekspresji, wymagającego zdolności artystycznych. Sędzia ten odrzuca rozumowanie stanowego sądu apelacyjnego, zgodnie z którym racjonalny obserwator przygotowanie tortu weselnego dla pary homoseksualnej odebrałby nie jako udzielenie przez Phillipsa poparcia dla małżeństw jednopłciowych, ale jako jedynie podporządkowanie się obowiązującemu prawo. Rozumowanie to uzasadniałoby bowiem każdy przypadek ingerencji władzy w wolność słowa i wolność religii jednostki. Podobnie Thomas niebezpodstawnie kwestionuje argumentację, w myśl której Phillips mógł po sprzedaży tortu weselnego parze homoseksualnej wydać oświadczenie, w którym odciąłby się od popierania małżeństw jednopłciowych. Argumentację taką uznaje za przykład petitio principii. „Skoro władza nie może wymuszać mowy, to również nie może «wymagać od mówców, aby jednym tchem zaaprobowali to, czemu przeczą w kolejnym»" ${ }^{31}$. Jeśli zachowanie Philipsa było expressive conduct, to do ukarania go trzeba wykazać, że CADA zalicza powyżej wspomniany test ścisły. Sędzia Thomas finalnie uchyla się jednak od odpowiedzi, czy CADA pozytywnie zalicza ten test. Tymczasem to właśnie zgodność przepisów antydyskryminacyjnych z I Poprawką do konstytucji, a w jeszcze większym stopniu warunki tej zgodności, są zagadnieniem kluczowym dla sprawy Phillipsa i spraw podobnych.

W przyszłości okaże się, czy rację ma sędzia Thomas, twierdząc, że to interpretacja konstytucyjnej zasady wolności słowa, a nie wolności religii stanie się kluczowa przy rozstrzyganiu spraw analogicznych. Wydaje się, że nie można wszystkich przypadków sprzeciwu sumienia wobec prawa antydyskryminacyjnego sprowadzać do kategorii expressive conduct. W orzeczeniu nie wskazano jednak klarownych kryteriów pomocnych w ustaleniu tego, kiedy świadczenie dobra bądź usługi można potraktować za akt osobistej ekspresji komunikującej przesłanie sprzeczne z wyznawanymi przekonaniami religijnymi czy światopoglądowymi. Granicę pomiędzy sprzedażą „Zwykłych” dóbr i usług, a sprzedażą dóbr i usług mających postać „aktu ekspresji” niełatwo jest wyznaczyć. Zawodne może być oparcie się na sugerowanym przez sędziego Thomasa kryterium artyzmu czy sui generis dzieła sztuki. O ile wykonanie weselnego tortu ewentualnie można rozpatrywać jako akt ekspresji o cechach artyzmu, o tyle watpliwe byłoby upatrywać pierwiastków artyzmu np. w czynności poligraficznej ${ }^{32}$. Zasadność traktowania przez Phillipsa sprzedaży weselnego tortu parze homoseksualnej jako poparcie przez niego małżeństwa jednopłciowego nie jest o większej oczywistości niż trafność i szczerość przeświadczenia drukarza, że drukując materiały promocyjne na zamówienie organizacji LGBT implikatywnie afirmuje postulaty środowisk homoseksualnych.

Podejmując próbę wyznaczenia warunków dopuszczalnego uchylenia się z powodu sprzeciwu sumienia od wymogów przepisów antydyskryminacyjnych, nie sposób uniknąć pewnej kazuistyki. Sędzia Kennedy w kontekście rozpatrywanej sprawy wskazał różne możliwe stany faktyczne, w których cukiernik odmówił sprzedaży tortu klientowi i jednocześnie lakonicznie zasygnalizował, że prawna ocena każdego z tych

${ }^{31}$ Masterpiece Cakeshop, Ltd...., (Thomas, concurring), s. 10.

${ }^{32}$ Wyrok Sądu Najwyższego Rzeczypospolitej Polskiej z 14 czerwca 2018 r., sygn. akt II KK 333/17. 
stanów faktycznych — na podstawie zasady wolności słowa i zasady wolności religijnej - mogłaby być inna. Niestety nie podejmuje się jednak dokonania tej oceny. Wśród podanych egzemplifikacyjnie przez Kennedy’ego przypadków można wymienić:

- cukiernik odmawia homoseksualnej parze przygotowania tortu, na którym miałby zamieścić inskrypcję czy symbolikę celebrującą małżeństwo, np. słowa o religijnym przesłaniu;

- cukiernik odmawia homoseksualnej parze sprzedaży gotowego tortu weselnego przeznaczonego do nabycia przez dowolnego klienta, który już jednak zawiera napis czy symbol o religijnej treści;

- cukiernik odmawia przygotowania dla homoseksualnej pary jakiegokolwiek tortu weselnego lub sprzedaży im jakiegokolwiek gotowego już tortu weselnego.

O tym, że prawna relewantność takiej dystynkcji nie jest kwestią oczywistą świadczy stanowisko sędziego Gorsucha, dla którego samo przygotowanie tortu weselnego dla pary homoseksualnej, nawet bez jakichkolwiek inskrypcji czy symboli, komunikuje celebrowanie czy afirmowanie takiego małżeństwa przez cukiernika. Trudno zgodzić się z sędzią Gorsuchem, kiedy ten sugeruje, że przedsiębiorca może za każdym razem skutecznie powołać się na I Poprawkę, ilekroć autonomicznie uzna, że sprzedaż danego towaru czy usługi kłóci się z jego religijnymi powinnościami. W ocenie Gorsucha powinnością sądu jest ,przyznać ochronę prawną jakiemukolwiek szczeremu aktowi wiary" ${ }^{33}$. Stanowisko takie mogłoby doprowadzić do dysfunkcjonalności przepisów antydyskryminacyjnych. Jakkolwiek sędzia Gorsuch ma in generale rację, twierdząc, że władza nie może definiować ani hierarchizować religijnych powinności wyznawców, to jednak mylił się, kiedy stwierdził, że władza ma obowiązek uszanowania w każdym przypadku religijnego sprzeciwu sumienia przedsiębiorcy.

Sąd nie odniósł się do podawanych w doktrynie prawniczej kryteriów uwzględnianych przy ocenie dopuszczalności wyłączenia światopoglądowego (klauzuli sumienia) wobec prawa antydyskryminacyjnego ${ }^{34}$. Czynienie tego wykracza też poza ramy niniejszej glosy. Jedynie egzemplifikacyjnie można nadmienić stanowisko prezentowane przez Kathleen Brady w odniesieniu do problematyki pokrewnej sprawie Phillipsa. Zdaniem autorki, osoby wierzące na podstawie konstytucyjnej wolności religijnej mogą powstrzymać się od świadczenia homoseksualistom pewnych dóbr czy usług, gdy inni przedsiębiorcy oferują im te same dobra i usługi. Jeśli ci inni świadczeniodawcy są liczni, to negatywny skutek wynikający z powołania się na sprzeciw sumienia będzie dla homoseksualistów minimalny. Ograniczeniu ujemnych następstw służyłoby też ujawnienie ex ante potencjalnym klientom zasad świadczenia usług przez danego przedsiębiorcę. Uchroniłoby to osoby homoseksualne przed przykrością, niepewnością czy niepokojem podczas poszukiwania świadczeniodawcy wybranej usługi. Akomodacja sprzeciwu sumienia przedsiębiorcy mogłaby natomiast negatywnie

${ }_{33}$ Masterpiece Cakeshop, Ltd...., (Gorsuch, concurring), s. 9.

${ }^{34}$ Vide W. Ciszewski, Wyłaczenia światopogladowe jako przedmiot dyskusji teoretycznoprawnej próba systematyzacji, „Forum Prawnicze” 2016, nr 2, s. 59-73. 
zaciążyć na prawach homoseksualistów jako konsumentów, gdyby dany świadczeniodawca miał dominująca pozycję na rynku, albo wielu drobnych świadczeniodawców z określonego obszaru geograficznego chciało skorzystać z klauzuli sumienia. W postępowaniu sądowym okoliczności te należy — zdaniem Brady — jednak udowodnić, a nie je domniemywać. Zakwestionowanie osobom wierzącym prawa do religijnego sprzeciwu sumienia tylko dlatego, że homoseksualiści mogą odbierać odmówienie im konkretnego świadczenia jako wytknięcie niemoralności czy grzeszności ich zachowań, byłoby pogwałceniem konstytucyjnej wolności słowa ${ }^{35}$.

Orzeczenie sędziego Kennedy'ego jest najbardziej obiektywne w podejściu do problemu prawnego będącego podstawą sprawy. Tego samego nie można powiedzieć w odniesieniu do zdań polemicznych i zdania odrębnego, w których zaprezentowano poniekąd jednostronną perspektywę. W zdaniach polemicznych sędziów Thomasa i Gorsucha zasadnej trosce o możliwość akomodacji sprzeciwu sumienia osób będących adresatami prawa antydyskryminacyjnego nie towarzyszy podobna troska o poszanowanie interesów osób będących z kolei beneficjentami prawa antydyskryminacyjnego. Odwrotnie sprofilowane jest zdanie zbieżne sędzi Kagan, a tym bardziej zdanie odrębne sędzi Ginsburg, w których w odpowiednio niewielkim lub żadnym stopniu nie dostrzeżono negatywnego wpływu prawa antydyskryminacyjnego na poszanowanie wolności słowa i wolności religii osób prawem tym związanych.

W orzeczeniu podkreślono doniosłość prawa antydyskryminacyjnego dla chronionych nim kategorii osób, in concreto osób homoseksualnych. „Nasze społeczeństwo uznało, że osoby i pary homoseksualne nie mogą być traktowane jako społeczne wyrzutki czy jako niższe w swej godności i wartości. Z tego powodu ustawy i konstytucja moga, a w pewnych przypadkach muszą chronić ich w korzystaniu z praw obywatelskich. Korzystaniu przez nich ze swoich wolności na równi z innymi osobami sądy muszą przyznać wielką wagę i szacunek”. Równie zasadnie wskazano, że „religijne czy filozoficzne obiekcje wobec małżeństw homoseksualnych są chronionymi poglądami, a w pewnych przypadkach także chronionymi formami ekspresji" ${ }^{\prime 36}$.

Jakkolwiek w komentowanym orzeczeniu nie podano warunków, po spełnieniu których można z powołaniem się na wolność religii czy wolność słowa uchylić się spod wymogów prawa antydyskryminacyjnego, to jednak w wyroku znalazło się kilka istotnych wskazań co do stosowania tego typu prawa. W pełni podzielić można stanowisko Sądu Najwyższego, że przepisy prawa antydyskryminacyjnego w zakresie dostępu do dóbr i usług muszą być interpretowane i egzekwowane w sposób niedyskryminacyjny i jednolity. Organom władzy publicznej, takim jak Komisja Praw Obywatelskich stanu Kolorado, nie wolno stosować podwójnych standardów. Przejawienie przez te organy braku bezstronności stanowi podstawę do zakwestionowania wydanych przez nie decyzji.

${ }^{35}$ K. Brady, The Distinctiveness of Religion in American Law: Rethinking Religion Clause Jurisprudence, Cambridge 2015, s. 247-249.

${ }^{36}$ Masterpiece Cakeshop, Ltd...., s. 19. Nie oznacza to, że sędzia Kennedy przejawił pełną symetrię w responsywnym podejściu do interesów adresatów i beneficjentów CADA, bardziej eksponując konieczność poszanowania interesów osób homoseksualnych. 
Glosowane orzeczenie pokazuje ponadto, że przepisy antydyskryminacyjne sa, a przynajmniej mogą być, ,bronią obosieczną”. Wbrew przekonaniu niektórych prawników i obywateli konieczność przestrzegania tych przepisów rodzi dylematy i konflikty sumienia nie tylko u osób głęboko wierzących czy osób, którym bliski jest prawicowy i konserwatywny światopogląd. Przyjęcie, że Jack Phillips naruszył prawo, odmawiając parze homoseksualnej przygotowania i sprzedaży tortu weselnego, musi iść w parze z uznaniem, że cukiernicy, którzy odmówili wykonania tortu z religijnie motywowanym antyhomoseksualnym przesłaniem również naruszyli prawo. Zwolennicy ukarania drukarza za odmówienie przez niego z przyczyn światopoglądowych wydrukowania plakatów dla Fundacji LGBT powinni mieć świadomość, że analogicznie trzeba by potraktować proaborcyjnego drukarza za odmowę wydrukowania dla zwolenników pro-life plakatów przedstawiających abortowane płody ${ }^{37}$. Odmówiwszy fotografowi możliwości odrzucenia zlecenia sfotografowania ceremonii zawarcia małżeństwa jednopłciowego ${ }^{38}$, należałoby za bezprawne uznać także niewyrażenie przez fotografa zgody na wykonanie sesji zdjęciowej dla celów propagandowych Kościoła Westboro, w ramach której fotografowałby członków tej kontrowersyjnej wspólnoty religijnej w momencie, gdy ci wulgarnie obrażają homoseksualnych żołnierzy podczas ich pogrzebów ${ }^{39}$.

Jak już wskazano, problematyczne byłoby usprawiedliwianie odmowy wykonania zlecenia W. Jacka czy hipotetycznego zlecenia członków Kościoła Westboro, że podstawą odmowy była chęć uniknięcia choćby pośredniego afirmowania obraźliwych treści antyhomoseksualnych, a nie przekonania religijne konsumenta. Uznawanie aktów religijnie motywowanej ekspresji — wpisujących się w aktywność prozelicką i kaznodziejską - za niemieszczące się w zakresie konstytucyjnej wolności religijnej z powodu ich obraźliwości, nie znajduje potwierdzenia w orzecznictwie Sądu Najwyższego. Gdyby przyjać jednak takie stanowisko, to wówczas w wielu przypadkach odmowy sprzedaży dóbr czy świadczenia usług z przyczyn światopoglądowych, dałoby się powołać na kryterium obraźliwości, np. drukarz odmawiający muzułmanom drukowania Koranu, ale drukujący na zlecenie chrześcijan Pismo Święte mógłby twierdzić, że kieruje się nie przekonaniami religijnymi klientów, ale obraźliwością — w jego przekonaniu — treści świętej księgi islamu.

Przykłady tego typu można mnożyć. Traktowanie prawa antydyskryminacyjnego jako ius absolutum mające zawsze pierwszeństwo przed innymi prawami i wolnościami jednostki potencjalnie grozi wnioskami absurdalnymi, że np. osoba zawodowo i legalnie trudniąca się prostytucją nie może odmówić świadczenia „usług” seksualnych osobie homoseksualnej czy Afroamerykaninowi, gdyż byłoby to sprzeczne z zakazem

${ }^{37}$ Podobnie M. Iwański, Odpowiedzialność za odmowę świadczenia ustugi (art. 138 Kodeksu wykroczeń) na tle kolizji zasad konstytucyjnych. Rozważania na kanwie kazusu łódzkiego drukarza o styku prawa karnego sensu largo oraz prawa konstytucyjnego, „Czasopismo Prawa Karnego i Nauk Penalnych” 2018, nr 7 .

${ }^{38}$ Elane Photography $v$. Willock, 309 P.3d 53 (N.M. 2013). Sąd Najwyższy USA odmówił rozpoznania tej sprawy, 134 S.Ct. 1787 (2014).

39 Snyder $v$. Phelps, 562 U. S. 443 (2011). 
dyskryminacji ze względu na orientację seksualną bądź rasę (sic! ${ }^{40}$. Egzemplifikacyjnie podane kazusy mogą wydawać się przejaskrawione, prowokacyjne i mało realne, ale praktyka co raz częściej zaprzecza „teoretyczności” tych przykładów. Osoby bezkrytycznie popierające prawo antydyskryminacyjne zapewne nie przewidywały, że będą na nie powoływać się także chrześcijański kaznodzieja i aktywista William Jack.

Jak trafnie podniósł Sąd Najwyższy, prawa antydykryminacyjnego nie wolno stosować selektywnie według kryterium politycznej poprawności. Rację ma sędzia Thomas, twierdząc, że celem przepisów o równym dostępie do dóbr i usług nie może być inżynieria społeczna polegająca na eliminowaniu rzeczywistych czy rzekomych uprzedzeń wobec określonych grup osób, gdyż wówczas prawo staje się w pierwszej kolejności narzędziem wymuszania nowej światopoglądowej ortodoksji, a nie chronienia praw współobywateli.

Konieczne jest proporcjonalne wyważenie interesów osób, pragnących na równych zasadach i z poszanowaniem ich godności korzystać z praw konsumenta, z interesem innych osób do zachowania integralności osobistej w ramach prowadzonej działalności handlowo-usługowej ${ }^{41}$. Pozostaje mieć nadzieję, że Sądowi Najwyższemu USA w kolejnym orzeczeniu w sprawie analogicznej do sprawy Jacka Phillipsa ${ }^{42}$ uda się takie kompromisowe - nieoptymalne i niezadowalające w pełni każdej ze stron sporu - wypracować rozwiązanie.

Grzegorz Maron**

* Dr Grzegorz Maroń, Uniwersytet Rzeszowski, Wydział Prawa i Administracji, Katedra Nauk Historyczno i Teoretycznoprawnych, grzegorzmaron@op.pl

${ }^{40}$ Confer Since prostitution represents a taxable fiduciary relationship, can a prostitute working at a Nevada brothel be sued for discrimination if she rejects a racial minority or gay/lesbian customer?, $<$ https: //www.quora.com/Since-prostitution-represents-a-taxable-fiduciary-relationship-can-a-prostitute-workingat-a-Nevada-brothel-be-sued-for-discrimination-if-she-rejects-a-racial-minority-or-gay-lesbian-customer>, dostęp 20 III 2018; Should a prostitute in Nevada be required to accept African American customers under the 1964 Civil Rights Act?, <https://www.reddit.com/r/PoliticalDiscussion/comments/31ir8q/should_a prostitute in nevada be required to/>, dostęp 20 III 2018.

${ }^{41}$ Odmiennie W. Ciszewski, Czy wolność uprawnia do dyskryminowania? Rozważania teoretycznoprawne na kanwie sprawy drukarza z Łodzi, „Forum Prawnicze” 2017, nr 5, s. 51-52.

42 Sąd Najwyższy USA nie skorzystał z takiej możliwości w kontekście sprawy State v. Arlene's Flowers, Inc., w której sąd stanowy orzekł, że odmowa sprzedaży osobom homoseksualnym kwiatów na ich wesele stanowiła bezprawną praktykę dyskryminacyjną. Postanowieniem z 25 czerwca 2018 r. federalny Sąd Najwyższy uchylił zaskarżone orzeczenie i nakazał sądowi stanowemu ponowne rozpoznanie sprawy z uwzględnieniem wyroku Masterpiece Cakeshop, Ltd. v. Colorado Civil Rights Comm'n. 
PrZegląi SejM0wy nr 6(149)/2018, s. 229-236; https://doi.org/10.31268/PS.2018.42

RECENZJE

KAMIL KACPERSKI

\section{Koncepcje systemu wyborczego do Sejmu na ziemiach Królestwa Polskiego w latach 1917-1918}

Wydawnictwo Sejmowe, Warszawa 2018, s. 297

Concepts of the electoral system to the Sejm at the lands
of the Polish Kingdom in the years 1917-1918

The reviewed book presents the origin and course of the systemic dispute, whose participants were almost all political groups, concentrated into three camps: active, passive and the pro-independence left in the period preceding the regaining of independence by Poland. The author points to law-making features of the discourse, which mobilized political and social centres to develop an electoral procedure at the Polish lands. The discourse took place in the extreme conditions of war and occupation, and reflected the state of the legal culture with numerous exclusions from civil rights. The list of qualifications comprised: domicile, property, nationality, sex, social origin, education, religion and occupation. The temporary approach to the research problem, evidenced in the three chapter of the monograph, allowed to present the legal and political actions in their institutional and personal dimension. As regards the institutions, documents were analysed, produced by the Provisional Council of State in the Polish Kingdom, the Sejm-Constitutional Committee of the Provisional Council of State, the Regency Council and its government cabinets, as well as the Council of State and the Sejm Committee of the Council of State. As regards activity of individuals, the research is focused on the production of eminent thinkers, scientists, publicists, politicians, party leaders. Confronting different concepts of electoral laws led to laying down knowledge on specific elements of the process of restituting the independent Polish State in 1918.

Słowa kluczowe: system wyborczy, Królestwo Polskie, Tymczasowa Rada Stanu, Rada Regencyjna, Rada Stanu, pasywiści, aktywiści, lewica niepodległościowa

Key words: electoral system, Kingdom of Poland, Provisional Council of State, Regency Council, Council of State, passivists, activists, pro-independence left

Problem kształtowania wyobrażeń o ustroju prawnym i politycznym państwa należał do kanonu myślenia o niepodległej Polsce. Znajdował się w sferze zainteresowania ideologów, polityków, ludzi nauki i kultury, przedstawicieli mediów, duchowieństwa różnych wyznań religijnych. Był elementem rozważań o sytuacji społeczeństwa polskiego, o stanie politycznym, gospodarczym i kulturalnym ziem polskich, ale też mieścił w sobie elementy antycypowania struktury państwa suwerennego, do jakiego aspirowano w XIX w. i na początku XX w. Tematyka dotycząca przebiegu publicznej debaty, a następnie ustalania rozwiązań systemu wyborczego stanowiła dobry przedmiot refleksji naukowej. Dlatego z satysfakcją należy przyjąć publikację monografii Kamila Kasperskiego poświęconej zagadnieniom kreowania zrębów ustroju prawno-politycznego Polski w warunkach nadzwyczajnych, a więc w trakcie wojny i okupacji. 
Tytułowa problematyka była już częściowo spożytkowana przez autora we wcześniejszych publikacjach na łamach „Przeglądu Sejmowego”, gdy analizie poddał kwestie budowania podstaw politycznych i prawnych służących unormowaniu zasady powszechności prawa wyborczego do instytucji przedstawicielskich na ziemiach polskich okupowanych przez państwa centralne ${ }^{1}$. Miała też poniekąd odzwierciedlenie w jego rozprawie doktorskiej, obronionej na Wydziale Dziennikarstwa i Nauk Politycznych Uniwersytetu Warszawskiego, następnie opublikowanej przez Wydawnictwo Sejmo$w^{2}$. Dysertacja dotyczyła systemu wyborczego do parlamentu na początku istnienia suwerennego bytu politycznego Polski w 1918 r. Ta sama oficyna wydała kolejne książki K. Kacperskiego, który swobodnie przemieszczał się w poszczególnych jednostkach czasu między odzyskaniem przez Polskę niepodległości a okresem rewidowania konstytucji z 17 marca 1921 r. w warunkach przemian ustrojowych zachodzących po przewrocie majowym ${ }^{3}$. Monografie System wyborczy do parlamentu Drugiej Rzeczypospolitej w pracach Sejmu i Senatu pierwszej kadencji (1922-1927) oraz Próby reformy systemu wyborczego do Sejmu i Senatu w procesie rewizji konstytucji marcowej w latach 1928-1930 potwierdzały kompetencje autora, który ze znawstwem prezentował w nich zagadnienie kształtowania systemu wyborczego Rzeczypospolitej Polskiej. Ponadto poświadczały słuszność wyboru pola eksploracji naukowej pełnego wielu zagadnień godnych zainteresowania ze strony wytrawnego znawcy.

Pozostając w sferze zagadnień temporalnych, należy docenić wybór ram czasowych recenzowanej monografii. Trafnie wskazano wydarzenia $z$ lat 1917-1918, kiedy formowały się podstawy praw wyborczych użytecznych dla państwowotwórczych procesów zachodzących na ziemiach polskich. Poprawnie wyodrębniono okres dynamicznych zmian uwidocznionych w przestrzeni publicznej. Zatem wybór konkretnego czynnika czasu był efektem prawidłowego rozeznania w ówczesnej sytuacji politycznej, społecznej, organizacyjnej i intelektualnej. Konceptualizacja tematu pozwoliła na przeprowadzenie ustaleń definicyjnych, określenie istoty problemu badawczego, delimitowanie zakresu przedmiotowego monografii, oszacowanie prawdopodobieństwa poznania i zdiagnozowania komponentów obiektu eksploracji naukowej. Dzięki temu mogła powstać zwarta i klarowna formuła opracowania, w którym odzwierciedliła się wiedza o polityce, o ustroju prawnym i rolach pełnionych przez podmioty polityczne $\mathrm{w}$ toku tworzenia systemu wyborczego $\mathrm{w}$ okresie poprzedzającym odzyskanie suwerenności państwa polskiego.

Zgodnie z deklaracją autorską celem książki było „scharakteryzowanie inicjatyw prawnych i politycznych" podejmowanych przez Tymczasową Radę Stanu w Króle-

${ }^{1}$ K. Kasperski, Wstęne koncepcje unormowania zasady powszechności prawa wyborczego do Sejmu na ziemiach Królestwa Polskiego po wybuchu I wojny światowej (styczeń-lipiec 1917 r.), „Przegląd Sejmowy” 2016, nr 1, s. 85-106; idem, Koncepcje reformy systemu wyborczego do Sejmu i Senatu w świetle rozważań ustrojowych obozu sanacyjnego (marzec-wrzesień 1928 r.), „Przegląd Sejmowy” 2014, nr 2, s. 41-58.

${ }^{2}$ K. Kacperski, System wyborczy do Sejmu i Senatu u progu Drugiej Rzeczypospolitej, Warszawa 2007, s. 294.

${ }^{3}$ K. Kacperski, System wyborczy do parlamentu Drugiej Rzeczypospolitej w pracach Sejmu i Senatu pierwszej kadencji (1922-1927), Warszawa 2013, s. 209; idem, Próby reformy systemu wyborczego do Sejmu i Senatu w procesie rewizji konstytucji marcowej w latach 1928-1930, Warszawa 2015, s. 326. 
stwie Polskim, Komisję Sejmowo-Konstytucyjną Tymczasowej Rady Stanu, Radę Regencyjną i jej gabinety rządowe, a także Radę Stanu oraz Komisję Sejmową Rady Stanu. Był też wyartykułowany cel o szerszym wymiarze, gdy autor przedkładał plan „ukazania genezy trwającego w latach 1917-1918 sporu ustrojowego, którego uczestnikami były niemal wszystkie, skupione w trzech obozach — aktywistycznym, pasywistycznym i lewicy niepodległościowej — stronnictwa polityczne w Królestwie Polskim". Jest to zadanie niewątpliwie ambitne, dające szansę na zapełnienie niedostatków literatury przedmiotu, ale potrzebne ze względu na wprowadzenie do obiegu naukowego wielu istotnych spostrzeżeń dotyczących procesu emancypacji politycznej społeczeństwa polskiego bezpośrednio przed odzyskaniem niepodległości. Zwraca uwage podmiotowość działań wybitnych postaci, myślicieli, teoretyków różnych dziedzin prawoznawstwa, twórców rozmaitych koncepcji prawa wyborczego. Ujęcie instytucjonalne, w tym poddanie oglądowi działalności urzędów publicznych oraz ugrupowań politycznych, a także podejście personalne, skumulowane na nieprzeciętnych dramatis personae, dawały prawie pełny obraz postaw i zachowań intelektualistów wobec procesów państwowotwórczych. Takie podejście do tematu pozwoliło na przeprowadzenie analizy dwóch składników problemu badawczego. Po pierwsze, zwrócono uwagę na kwestię formowania poglądów dotyczących modelu ustrojowego odradzającego się państwa. Po drugie, skoncentrowano się na sprawie zaangażowania organów administracji publicznej, ugrupowań politycznych, stowarzyszeń społecznych w proces interakcji towarzyszących procesom legislacji. Dzięki temu zabiegowi monografia K. Kacperskiego zawiera niemal kompletny przegląd urzędowych decyzji ustrojowych, ale też indywidualnych stanowisk, wizji i wyobrażeń znawców zagadnień prawa wyborczego.

Monografia składa się z trzech obszernych rozdziałów mających proporcjonalną objętość. Liczba rozdziałów różni się od konwencjonalnie przyjętych limitów, jednak ich treść potwierdza, że autor trafnie ustalił kompozycję opracowania. Systematyka była ukonkretniona, dzięki czemu struktura tekstu tworzy koherentną całość bez zbędnej rozwlekłości i dłużyzn. Rozdziały ujęto według kryterium problemowego z zachowaniem wewnętrznego następstwa czasu przy rezygnacji z rozdziału wprowadzającego, który zwyczajowo zawiera ustalenia teoretyczne, terminologiczne, niekiedy też metodyczne. Dzięki temu uniknięto ryzyka złamania reguły rzeczowości konstrukcyjnej i klarowności tytulatury poszczególnych części monografii. Rozkład treści pozwolił na skonfrontowanie ze sobą różnych koncepcji praw wyborczych, sprzyjał poszukiwaniom genezy procesów politycznych i zjawisk społecznych, wydobywając detale koncepcyjne charakterystyczne dla terytorialnego i temporalnego zakresu pracy. Interwał czasowy w każdym rozdziale ulegał korekcie, obejmując odpowiednio okres 14 miesięcy (rozdział pierwszy), siedmiu miesięcy (rozdział drugi), wreszcie trzech miesięcy (rozdział trzeci). System wyborczy był rozpatrywany pod względem rekonstruowania konkretnych zbiorów norm prawnych i ich oddziaływania na tryb organizacji aktu elekcyjnego do instytucji powołanych przez okupantów.

Rozdział pierwszy poświęcony został początkowym próbom uregulowania systemu wyborczego do Sejmu, podejmowanym przez Tymczasową Radę Stanu i Komisję 
Sejmowo-Konstytucyjną. Przedmiotem zainteresowania była sytuacja prawna i polityczna wyznaczona cezurą czasową między styczniem 1917 r. a marcem 1918 r. Rekonstrukcja istotnego okresu pracy urzędów i ludzi dała możliwość zaprezentowania ich oblicza strukturalnego, ideowego, naukowego. Tło historyczne tworzyły poczynania ugrupowań politycznych i ich liderów oddziałujących na sytuację Królestwa Polskiego, ale mających też ugruntowany autorytet poza jego granicami. Odtworzenie losów Tymczasowej Rady Stanu i Komisji Sejmowo-Konstytucyjnej sprzyjało ukazaniu komponentów systemu wyborczego do dwuizbowego parlamentu na podstawie postanowień zawartych w projekcie konstytucji z 28 lipca 1917 r. przyjętym przez Komisję. Znalazły się nim istotne rozstrzygnięcia dotyczące liczebności obu izb parlament, przykładowo w art. 46 zapisano, że „Liczebny skład Senatu odpowiadać będzie dwom trzecim ustawowej liczby posłów"4. Wpisano w nim konkretne odniesienia do prawa wyborczego, jak w art. 38: „Prawo głosowania może być wykonywane tylko osobiście, głosowanie z upoważnienia nie jest dopuszczalne"s. Finałem były autorskie rozważania przeprowadzone na kanwie przepisów umieszczonych w projekcie ordynacji wyborczej do Senatu oraz do Izby Poselskiej z 6 marca 1918 r.

W treści rozdziału sporo miejsca poświęcono sprawom personalnym. Bohaterami refleksji autorskiej stali się: Wacław Niemojewski, przewodniczący Tymczasowej Rady Stanu, Józef Mikułowski-Pomorski, jego zastępca, a także członkowie Wydziału Wykonawczego TRS: Stanisław Bukowiecki, Stanisław Janicki, Michał Łempicki, Józef Piłsudski, który stał na czele Referatu Wojny. Ponadto w sferze zainteresowań autora znajdowali się m.in.: Józef Buzek, Zygmunt Cybichowski, Ludomir Grendyszyński, Stanisław Kutrzeba, Mieczysław Niedziałkowski, ksiądz Henryk Przeździecki, Józef Siemieński, Władysław Gizbert-Studnicki. Czytelnik otrzymał informację o ich afiliacjach partyjnych, ewentualnie o przynależności do obozu politycznego czy związkach z konkretnym środowiskiem ideowym, np. o Alfonsie Parczewskim, że był ,zdeklarowanym zwolennikiem orientacji aktywistycznej” (s. 25). Pozyskiwał wiedzę o ich statusie społecznym, zawodowym, organizacyjnym w warunkach zmiany sytuacji na ziemiach polskich. Przy okazji rekonstruowania ważnych czynności normotwórczych zaznaczał, że w ich ustalaniu prym „,wiedli głównie reprezentanci nauki” (s. 65), jak Feliks Ochimowski, specjalista z zakresu prawa konstytucyjnego i prawa administracyjnego, autor poczytnych książek zawierających wyniki badań porównawczych prawa wyborczego. Kiedy indziej doceniał obecność polityków, podkreślając ich doświadczenie wywiedzione z czynnego udziału w życiu publicznym. Za każdym razem czytelnik otrzymywał uszczegółowione dane na temat okoliczności i przebiegu debaty, a także meandrów koncepcyjnych pojawiających się w wypowiedziach poszczególnych uczestników prac dotyczących prawno-politycznego ustroju ziem polskich.

W rozdziale drugim podjęta została kwestia przebiegu kreowania zasad wyborczych przez dwa gabinety rządowe Rady Regencyjnej w okresie od grudnia 1917 r. do lipca

${ }^{4}$ Projekt Konstytucji Państwa Polskiego (Projekt T. Rady Stanu), „Ojczyzna i Postęp”, 9 X 1917, nr 64, s. 14.

${ }^{5}$ Ibidem, s. 13. 
1918 r. Był to czas rozpadu Tymczasowej Rady Stanu, rozwijania administracji publicznej pod kierunkiem Rady Regencyjnej, a także funkcjonowania gabinetów rządowych, na czele których kolejno znajdowali się Jan Kucharzewski oraz Jan Kanty Steczkowski. W przestrzeni geopolitycznej zachodziły historyczne zmiany wskutek: modyfikowania oceny sytuacji na froncie wojennym przez przywódców Rzeszy Niemieckiej oraz Austro-Węgier; przekształceń w Rosji po rewolucji bolszewickiej; skondensowania poczynań politycznych państw centralnych wobec kwestii ukraińskiej, przynoszących realny stan oderwania Chełmszczyzny od polskiego terytorium narodowego. Okres ten był burzliwy w odniesieniu do dynamicznie toczących się wydarzeń historycznych, natomiast z punktu widzenia nowatorstwa prawa elekcyjnego pozostał mało innowacyjny. Prace podjęte przez rząd J.K. Steczkowskiego pod tym względem należały do działań konserwujących koncepcje ustrojowe z przełomu XIX i XX w. Jednak czynności poświęcone systemowi wyborczemu przyniosły efekt w postaci uchwalenia 12 czerwca 1918 r. projektu ordynacji wyborczej do dwuizbowego Sejmu. Jak konkludował K. Kacperski, dokument miał walor szczególny jako pierwszy akt prawny o charakterze „porządkującym problematykę elekcji organów ustawodawczych, przyjęty oficjalnie przez rząd polski na obszarach Królestwa Polskiego po wybuchu w 1914 r. konfliktu światowego" (s. 189).

Rozdział trzeci, zatytułowany „Zagadnienie systemu wyborczego do organów przedstawicielskich w Radzie Stanu i Komisji Sejmowej (czerwiec-wrzesień 1918 r.)", został poświęcony analizie debat $\mathrm{w}$ obu instytucjach oraz w szeregach partii politycznych z okresu poprzedzającego restytucję państwa polskiego. Uwidoczniły się w nim działania Franciszka Pułaskiego, którego Rada Regencyjna mianowała marszałkiem Rady Stanu Królestwa Polskiego. Opisane zostały inicjatywy Wojciecha Rostworowskiego, Feliksa Starzyńskiego i wielu innych osób, które były już przywoływane we wcześniejszych rozdziałach książki. W sferze zainteresowań — obok przedstawicieli środowiska aktywistów — znalazły się poczynania pasywistów jak Eugeniusz Krasuski czy August Popławski (ziemianin, literat, przyszły senator w latach 1930-1935), a także Józef Świeżyński, kolejny szef gabinetu rządowego powołanego przez Radę Regencyjną. Zwrócono uwagę na wypowiedzi członków mniejszości żydowskiej, gdy Jerzy Rosenblatt, członek Rady Stanu, podczas posiedzenia 26 czerwca 1918 r. przypominał o wojennych warunkach, w jakich prowadzono prace legislacyjne. Był krytyczny względem dotychczasowych efektów stanowienia norm wyborczych w Kongresówce. Jego zdaniem, o losach Polski decydowała niereprezentatywna grupa osób, z których połowa otrzymała mandat na mocy mianowania, zaś „,druga połowa została wybrana, ale jakie to są wybory. Wszak ta instytucja, która wybrała obecnych posłów do Rady Stanu, też powstała na zasadzie spaczonego systemu wyborczego"6.

Instytucje i ludzie zaangażowani w proces kształtowania systemu wyborczego Królestwa Polskiego z lat 1917-1918 wykazywali zainteresowanie wieloma sprawami fundamentalnymi dla uwarunkowań praw elekcyjnych, odnosząc się do konkretnych etapów ustalania cech organów przedstawicielskich oraz przeprowadzania wyborów deputowanych. Zajmowali się sprawami różnej proweniencji: prawnej,

${ }^{6}$ Spr. sten. z 2. posiedzenia Rady Stanu Królestwa Polskiego, 26 czerwca 1918 r., ł. 9. 
politycznej, statystycznej, demograficznej. W ich koncepcjach objawiały się zagadnienia bikameralizmu, statusu izb parlamentarnych, kompetencji ich członków, powszechności głosowania, formuły wyborczej, struktury głosowania, wielkości i granic okręgów wyborczych, przy czym dostrzegalne było zjawisko gerrymanderingu, czyli wpływania na przebieg granic okręgów wyborczych w celu uzyskania korzyści politycznej. W sferze dociekań znajdowało się zagadnienie pluralnego prawa wyborczego, ale też rozpatrywany był problem unormowania domicylu, powoływania wirylistów, a także określania ich liczby i składu (np. poruszano kwestię obecności naukowców czy też hierarchów Kościoła katolickiego). Sporo wysiłku poświęcono na sporządzenie listy wykluczeń spod biernego i czynnego uczestnictwa w procesie ustalania składu parlamentu bądź urzędów administracji samorządu terytorialnego. Zajmowano się sprawami cenzusów ze względu na narodowość, wiek, płeć, stan majątkowy, wykształcenie, wyznanie religijne.

Materia badawcza przedłożona w książce pozwoliła na sformułowanie dwóch opinii zawierających wzajemnie przeciwne wartościowanie na temat przebiegu dyskursu pod koniec I wojny światowej oraz jego znaczenia dla przyszłej Polski. Po pierwsze, należałoby zauważyć stosunkowo małą użyteczność wysiłku poniesionego przez uczestników debat z lat 1917-1918, gdy toczono spory o sprawy, które już wkrótce straciły na znaczeniu, np. kwestia ustaleń elekcyjnych użytecznych w ustroju monarchicznym. O części z nich od razu wypowiadali się jako o rozwiązaniach anachronicznych, zbytecznych, pozbawionych znaczenia w nieodległej przyszłości. Po drugie, wypadałoby podkreślić, że środki ekspresji stosowane w tych sporach, sposoby argumentowania, metody kreowania wyobrażeń o rzeczywistości politycznej, a nade wszystko definicje i normy prawa wyborczego dawały asumpt do kształtowania kultury prawnej, z której mogła czerpać klasa polityczna suwerennej Polski. Kamil Kacperski słusznie zauważył, że reguły prawa wyborczego ustalone w toku prac instytucji i ludzi z lat 1917-1918 „stały się kanonem licznych rozstrzygnięć stosowanych w tej dziedzinie nie tylko w latach międzywojennych, ale przede wszystkim, po dostosowaniu ich treści do wymogów współczesnej demokracji, także w dzisiejszej Polsce" (s. 126). Niektóre z nich znalazły odzwierciedlenie w ordynacji wyborczej 28 listopada 1918 r., choćby w odniesieniu do nadmienionego wcześniej zagadnienia osobistego wykonywania aktu wyborczego czy pozbawienia wojskowych służby czynnej prawa udziału w wyborach? Sumarycznie wypada zauważyć, że powiodła się próba pokazania zabiegów twórców koncepcji systemu wyborczego o jego dostosowanie do tradycji polskiej, do warunków i potrzeb społeczeństwa, do doświadczeń historycznych, a po części również do zróżnicowania kulturowego i etnicznego.

Monografia powstała na podstawie starannej kwerendy materiałów archiwalnych i bibliotecznych. Eksploracji poddane zostały zasoby archiwaliów usytuowanych w Warszawie (Archiwum Akt Nowych, Archiwum Zakładu Historii Ruchu Ludowego, Biblioteka Narodowa, Biblioteka Sejmowa, Centralna Biblioteka Wojskowa

${ }^{7}$ Art. 4. „Wojskowi wszystkich stopni i wszystkich rodzajów broni w służbie czynnej nie biorą udziału w głosowaniu", dekret z 28 listopada 1918 r. o ordynacji wyborczej do Sejmu Ustawodawczego. 
w Warszawie), w Krakowie (Biblioteka Jagiellońska, Biblioteka Polskiej Akademii Nauk), w Lublinie (Biblioteka Katolickiego Uniwersytetu Lubelskiego) i we Wrocławiu (Zakład Narodowy im. Ossolińskich). Wykorzystano zawartość dzienników urzędowych Królestwa Polskiego i Rzeczypospolitej Polskiej oraz sprawozdań stenograficznych z posiedzeń Rady Stanu.

W merytorycznej części opracowania znalazły się kilkukrotne odniesienia do stanu źródeł pierwotnych, m.in. wzmianki na ten temat pojawiły się na stronach 31, 57, 61, 63. W autorskiej narracji bezkolizyjnie przedkładano treści rzeczowe wraz z równolegle prowadzoną oceną dokumentacji, jaką pozostawiły po sobie instytucje publiczne Królestwa Polskiego z lat 1917-1918. Wobec deficytu części danych, pochodzących ze źródeł sformalizowanych, urzędowych, a więc dających pewność źródła wiarygodnego — w myśl zasady scripta publica probant se ipsa (dokumenty publiczne same z siebie są dowodami) - autor zdecydował się spożytkować wiedzę pochodzącą ze źródła mniej wiarygodnego w postaci przekazów prasowych. Nie bez powodu poczynił zastrzeżenia w odniesieniu do jej użyteczności, ponieważ badanie prasy jako świadectwa historycznego wymaga starannie przeprowadzonej procedury krytyki wewnętrznej oraz konfrontowania z innymi dokumentami. Dobór periodyków był zgodny z zasadą reprezentatywności: tytułów prasowych, profilu ideowego i politycznego, częstotliwości ukazywania się na rynku czytelniczym. Wykorzystano 31 czasopism, wśród których znalazły się prasa partyjna, dzienniki ogólnoinformacyjne, a także specjalistyczne tygodniki i miesięczniki. W sferze eksploracji znalazły się między innymi: „Czas”, „Droga”, „Gazeta Sądowa Warszawska”, „Jedność Robotnicza”, „Kurier Warszawski”, „Myśl Niepodległa”, „Myśl Polska”, „Nowa Reforma”, „Piast”, „Przegląd Wszechpolski”, „Ruch Prawniczy, Ekonomiczny i Socjologiczny”, „Wyzwolenie”, „Zorza”. Skrupulatność badawcza nakazuje zwrócenie uwagi na publicystykę warszawskiego organu Związku Budowy Państwa Polskiego „Tydzień Polityczny”, wydawanego w latach 1916-1918. Tygodnik był poświęcony zagadnieniom państwowym, politycznym i społecznym.

Istotną część źródeł stanowiła publicystyka polityczna i twórczość naukowa wybitnych uczestników procesu kształtowania systemu wyborczego z lat 1917-1918. Wykorzystano niemal cały zestaw materiałów wytworzonych przez członków gremiów decyzyjnych Królestwa Polskiego. Spożytkowane zostały różnorodne manifesty ideowe o treści związanej z tytułem monografii. Jedynie z obowiązku recenzenta można zauważyć, że zabrakło kilku deklaracji ideowych, przykładowo, pominięto enuncjacje Pauliny Kuczalskiej-Reinschmit, „hetmanki” ruchu kobiecego na ziemiach polskich. Była autorką publikacji Wyborcze prawa kobiet, zawierającej ocenę sytuacji politycznej Polek pod zaborami. Analiza miała charakter porównawczy ze stanem walki o prawa wyborcze kobiet w Europie i Ameryce Północnej ${ }^{8}$. Kończąc ocenę bogatej

${ }^{8}$ P. Kuczalska-Reinschmit, Wyborcze prawa kobiet, Warszawa 1911. W odniesieniu do spraw polskich krytycznie wypowiadała się o partiach politycznych i ich liderach, pisząc o niezgodności między wypowiedziami publicznymi a programami partyjnymi. Za egzemplifikację posłużyły poczynania socjalisty Ignacego Daszyńskiego oraz narodowego demokraty Stanisława Głąbińskiego, którzy oficjalnie deklarowali poparcie żądań politycznego równouprawnienia płci, ale zaniedbali wprowadzenie stosownych zapisów do enuncjacji partyjnych. 
podstawy źródłowej służącej przygotowaniu monografii, należy podkreślić, że w sferze zainteresowań eksploatatorskich K. Kacperskiego były egodokumenty, w tym diariusze, pamiętniki i wspomnienia. Stanowiły znakomite dopełnienie wiadomości pozyskanych z innych dokumentów. W tym miejscu warto wspomnieć, że Dzienniki Juliusza Zdanowskiego, oprócz postaci archiwalnej, doczekały się też publikacji w starannym opracowaniu Janusza Farysia wraz z zespołem.

Monografia została napisana poprawnym językiem z uwidocznioną logiką znaczeniową i poszanowaniem tradycji terminologicznej właściwej dla dyscypliny naukowej. Lektura książki pozwoliła dostrzec klarowność i łatwość przekazu informacji przez autora, a nieliczne lapsusy językowe (,geneza powstania” — s. 13) nie zmieniły pozytywnej oceny poprawności wywodu. Natomiast mniej pobłażliwości można okazywać w wypadku błędów rzeczowych, przykładowo, w imieniu Eweliny (nazywanej też Elina) Pepłowskiej, przyszłej posłanki na Sejm III kadencji, członkini Klubu Narodowego. W monografii omyłkowo nazwano ja Elizą (s. 294). Podobna usterka dotyczy Felicjana (a nie Feliksa - s. 273, 293) Lechickiego, członka Rady Stanu, oraz Adhémara (błędnie wpisano: Aldhémar — s. 291) Esmeina, francuskiego prawnika, konstytucjonalisty i historyka prawa. Wadliwy jest zapis nazwiska Pauliny Kuczalskiej-Reinschmit (pomyłkowy zapis: Reinschmidt — s. 187, 293). Merytoryczną zawartość monografii wzbogaciły obszerne i zróżnicowane przypisy: słownikowe, dygresyjne, polemiczne. Znalazły się w nich cenne biogramy postaci przywołanych w zasadniczej części pracy. Funkcjonalną wartość książki wzmacniał materiał ilustracyjny w postaci ośmiu tabel, w których znalazły się zestawienia okręgów wyborczych, kół wyborczych, a także nazwiska członków Rady Stanu wybranych przez rady miejskie i sejmiki powiatowe, a także osób, które ex officio w niej zasiadały. Czytelnik powinien poczuć satysfakcję w związku $\mathrm{z}$ łatwością przemieszczania się po zawartości pracy dzięki zaopatrzeniu jej w indeks osobowy oraz wykaz skrótów.

Podsumowując, można stwierdzić, że opracowanie Kamila Kacperskiego należycie oddaje rozmaitość stanowisk zaprezentowanych przez uczestników dyskursu z lat 1917-1918. W moim przekonaniu książka stanie się pozycją obowiązkową dla badaczy procesów państwowotwórczych i kultury politycznej kształtowanej w szczególnym czasie trwania okupacji ziem polskich podczas Wielkiej Wojny. Autor odzwierciedlił relacyjny charakter budowy podstaw odrodzonej Polski, określił składniki debaty, umieścił bogatą faktografię, przedłożył wiedzę o atrybutach polemik prowadzonych w elitach władzy publicznej. Rozważania były rzetelnie osadzone w systemie wartości politycznych, etycznych, kulturowych. Pozwoliły na zrekonstruowanie rudymentów prawodawstwa w zakresie tworzenia aktów elekcyjnych ulokowanych w realiach dwóch pierwszych dekad XX w., ale też z możliwością ich recypowania sto lat później.

Ewa Maj*

* Prof. dr hab. Ewa Maj, Uniwersytet Marii Curie-Skłodowskiej w Lublinie, emaj1@wp.pl 
Wiek burzy i spokoju. Kalendarium dziejów Polski 1918-2018

PWN, Warszawa 2018, s. 231

The age of storm and peace. The calendar of Polish history 1918-2018

The reviewed book by professor Andrzej Piasecki presents an overview of key events from the last one hundred years in the history of Poland in the form of a calendar. The author adopted an interesting approach - each year of independence is illustrated with a specific political, social or legal event, analysed in detail, sometimes also discussed in a broader context of global transformations.

Słowa kluczowe: recenzje, historia Polski, niepodległość

Key words: reviews, history of Poland, independence

W jubileuszowym roku 100-lecia niepodległości na rynku księgarskim można znaleźć wiele mniejszych i większych publikacji, które mają puentować miniony wiek najnowszych dziejów Polski. Pośród licznych książek o charakterze zarówno monografii, jak i prac zbiorowych są takie, które szczegółowo analizuja pierwsze lata odzyskania samodzielnego bytu państwowego, diagnozując przyczyny, przebieg i konsekwencje „wybicia się na niepodległość”, jak i takie, które retrospekcyjnie przedstawiają cały okres minionych 100 lat. Do tych ostatnich zalicza się oryginalne i interesujące studium krakowskiego profesora Andrzeja Piaseckiego pt. Wiek burzy i spokoju. Kalendarium dziejów Polski 1918-2018. Należy stwierdzić, że pomysł, aby na 100-lecie odzyskania niepodległości opracować pracę typu kalendarium wydarzeń, w którym każdy rok z kolejnych 100 lat ilustrowany jest najważniejszymi wydarzeniami ustrojowymi zarówno dynamicznymi i brzemiennymi w swoich skutkach (tytułowa „burza”, jak i cichymi, aby nie powiedzieć nudnymi, które najczęściej nie przykuwają uwagi wszystkich i przeminęły niemal niezauważone (tytułowy „spokój”) jest przysłowiowym „strzałem w dziesiątkę". Kalendarium wydarzeń, których autor nie sprowadza wyłącznie do polityki, a tym bardziej ustroju, ale postrzega znacznie szerzej, bo także w perspektywie społecznej, ekonomicznej czy międzynarodowej, jest pracą wręcz nieocenioną. Dzięki takiemu zabiegowi czytelnik przygląda się kolejnym latom najnowszych dziejów Polski w szerokim kontekście, co niewątpliwie przydaje książce atrakcyjności i pokazuje historię w jej różnych odsłonach (wydarzeń konstytucyjnych, politycznych, społecznych, kulturalnych, religijnych, ekonomicznych, międzynarodowych czy nawet sportowych). Dzięki temu narracja prowadzona przez autora jest niezwykle żywa i wielowątkowa, co sprawia, że właściwie każdy może w tym kalendarium dziejów Polski odnaleźć rzeczy najbardziej go interesujące, ale takie — co stanowi dodatkowy atut pracy — które uleciały naszej pamięci, a z różnych powodów warte są przypomnienia. Zaprezentowane przez autora podejście pokazuje, jak wielowymiarowa jest historia każdego państwa, jak wiele wydarzeń, zarówno waż- 
nych, jak i mniej ważnych, tworzy wszystko to, co zwykło się nazywać dziedzictwem państwa i konstytuującego go narodu. Zawsze bowiem dziedzictwo to tworzą nie tylko fundamentalne, najbardziej brzemienne w swoich skutkach wydarzenia, ale również takie, które są tłem dziejącej się historii pisanej przez wielkie „H”. Zawsze też mają one własną niekwestionowaną specyfikę znaczoną piętnem lokalizmu, ale też - w mniejszym czy większym stopniu — są refleksem szerszych wydarzeń i przemian, które dzieją się w skali kontynentu, a niekiedy całego świata. Zwłaszcza te ostatnie wydarzenia są dzisiaj tym bardziej ważne, że świat wyraźnie przyśpieszył, że przybierające na sile procesy globalizacji i integracji mieszają z coraz większą siłą to co krajowe czy państwowe, z tym co ponadpaństwowe i uniwersalne. Dzieje każdego państwa - w tym także Polski, szczególnie ostatnie stulecie — to dzieje, które należy postrzegać w ponadpaństwowej perspektywie, w którym rzeczy polskie mieszają się z rzeczami, faktami, procesami i zjawiskami powszechnymi. Wszystkie one razem wzięte stanowią dorobek minionych 100 lat, które uformowały obecną Polskę. Należy zaznaczyć, że to spojrzenie na historię Polski, w których znalazły się także wydarzenia z europejskiej areny dziejów, jest ważnym atutem recenzowanej pracy. Unaocznia ona bowiem, że historii naszego państwa nie można postrzegać w oderwaniu od tego wszystkiego, co działo się poza jego granicami.

Autor, jak na pracę typu kalendarium, zrezygnował — i słusznie — $\mathrm{z}$ budowania skomplikowanej struktury rozdziałów. W zamian zaproponował, żeby każde z poszczególnych lat stanowiło samodzielną jednostkę systematyzacyjną książki. Jednocześnie każdą taką jednostkę A. Piasecki opatrzył tytułem, który ma pokazywać kluczowe — zdaniem autora — zdarzenia i procesy, jakie w danym roku nastapiły. Większość z nich to zdarzenia i procesy polityczne (vide: „1919 Pierwszy Sejm i walka o granice”, „1921 Konstytucja marcowa”; „1926 Zamach majowy”; „1930 Wybory brzeskie i represje wobec opozycji”; „1945 Układ jałtański”; „1956 Poznański czerwiec i polski Październik”; „1964 List 34”; „1975 Przeciwko zmianie konstytucji”; „1980 Strajki i Solidarność”; „1989 Wybory czerwcowe”; „2005 Sukces braci Kaczyńskich” „2010 Katastrofa smoleńska”). Sa jednak także wydarzenia gospodarcze („1924 Złoty polski”; „1936 Budowa COP”; „1950 Wymiana pieniędzy”; „1961 Gospodarczy zastój”; „1984 Reglamentacja i regres”; „2008 Globalny kryzys finansowy”), wydarzenia międzynarodowe („1925 W cieniu Locarno”; „1933 Hitler kanclerzem”; „1938 Pakt w Monachium i aneksja Zaolzia”; „1949 RWPG - NATO — RFN”; „1955 Podpisanie Układu Warszawskiego”; „1962 Wokół kryzysu kubańskiego”) oraz wydarzenia społeczne, kulturalne i religijne (np.: „1951 Nowa Huta w Krakowie”; „1953 Aresztowanie prymasa Wyszyńskiego”; „1959 Walka władzy z Kościołem”; „1966 Uroczystości Milenijne”; „1978 Karol Wojtyła papieżem”; „1982 Opór społeczny i represje”; „2006 Emigracyjna fala”; „,2017 Antyrządowe marsze”). Oczywiście akcenty położone przez autora, zaznaczone w tytułach poszczególnych „rozdziałów” mają charakter wybitnie autorski, mimo to wydaje się, że są dobrze, obiektywnie dobrane, a co za tym idzie, trafnie oddaja ,temperaturę" danych lat oraz to, co stanowiło sedno życia społeczno-polityczno-gospodarczego w danym momencie. Siłą rzeczy autorski dobór jest 
jednak doborem ze wszech miar merytorycznym, możliwie kompleksowym, co oczywiście nie znaczy, że tzw. historia polityczna nie wybija się z książki A. Piaseckiego na pierwszy plan. Zasługą pracy przedstawionej przez A. Piaseckiego jest to, że oddał do rąk czytelnika nie tylko proste wyliczenie dat i suchych faktów, ale zaprezentował udaną próbę autorskiej oceny i analizy najważniejszych wydarzeń w skali kraju i świata, jeśli tylko miały one swój polski rykoszet. Konwencja kalendarium pozwoliła autorowi potraktować każdy rok jako swoisty punkt wyjścia do przybliżenia czytelnikowi wybranych zjawisk, wydarzeń czy procesów społeczno-politycznych, które zaciążyły na losach państwa i narodu oraz z różnych względów przykuły uwagę na dłuższą bądź krótszą chwilę. Zaproponowana formuła pozwoliła stworzyć prawdziwy przewodnik po minionym stuleciu, który powinien być lekturą obowiązkową dla każdego zainteresowanego losami państwa i narodu. Po pracę A. Piaseckiego sięgną też z pewnością czytelnicy „Przeglądu Sejmowego”, gdyż większość uwag zawartych w książce plasuje się wokół kwestii ustrojowych dotyczących konstytucji, partii politycznych, wyborów czy referendum. Należy zaznaczyć, że awantażem recenzowanej pracy jest to, że zagadnienia stricte ustrojowe autor umieszcza zawsze w szerszej perspektywie, dając wyraźnie do zrozumienia, że np. tworzenie konstytucji jest w każdym przypadku funkcją wielu innych zdarzeń i wydarzeń zarówno krajowych, jak i międzynarodowych. Konstytucja np., co wynika z lektury książki A. Piaseckiego, zawiera określone poglądy doktryny obowiązującej w danym momencie, ale też stanowi odpowiedź na zapotrzebowanie dziejowe, które kształtują czynniki społeczne, polityczne i - last but not least - międzynarodowe. W ten sposób, co dobrze oddaje konwencja kalendarium, o treści konstytucji rozstrzygają rozmaite czynniki, takie jak poglądy doktryny, stanowiska partii politycznych i ich liderów; presja opinii publicznej; wpływy zewnętrzne, które mogą być większe i mniejsze; wreszcie to wszystko, co stanowi tło historyczne, a co zawsze - w jakimś stopniu — oddziałuje na przyszłe konstrukcje ustrojowe. Konstytucja, co dobrze oddaje formuła kalendarium, jest więc zawsze funkcją historycznego ciagu logicznego, na który oddziałują — choć w niejednakowym stopniu — różne czynniki. Podobnie jest $\mathrm{z}$ aplikacją konstytucji w rzeczywistości ustrojowej, która dodatkowo niuansuje konstytucję, czyniąc z niej konstrukcję żywa, a nie tylko suchy tekst. Czytelników „Przeglądu Sejmowego” zainteresują zwłaszcza niektóre rozdziały, zwłaszcza: „1921 Konstytucja marcowa”; „1927 Rządy sanacji”; „1928 Partie i politycy”; „1935 Konstytucja kwietniowa i śmierć Marszałka”; „1946 Referendum ludowe”; „1947 Likwidacja opozycji”; „1952 Ustanowienie PRL”; „1975 Przeciwko zmianie konstytucji”; „1987 Pomostowe inicjatywy”; „1988 Droga do okragłego stołu”; „1990 Transformacja systemu”; „1992 Mała konstytucja”; „1997 Konstytucja i powódź”; „1998 Lustracja i cztery reformy”; „2003 Referendum unijne”; „2015 Początek dobrej zmiany”.

Niewatpliwie książka autorstwa A. Piaseckiego stanowi wartościowe kompendium wiedzy o polskich przemianach XX i XXI w. Nie jest to ze zrozumiałych względów pełna kronika minionego stulecia, ale kalendarium puentujące kluczowe, choć niepozbawione subiektywnego osądu autora, wydarzenia, które ukształtowały polską pań- 
stwowość. Dla każdego roku A. Piasecki wybrał najczęściej jedno ważne wydarzenie, które stało się pretekstem do ukazania szerszego tła i tamtego okresu, często ukazanego w szerszym, europejskim tle. Perspektywę oglądania opisywanych i komentowanych wydarzeń poszerza ponadto fakt, że autor nie ogranicza się jedynie do wąskiej historii ustroju czy historii politycznej. Przyjęty przez A. Piaseckiego zabieg jest ze wszech miar zasadny, gdyż historia polityczna często kształtuje się pod wpływem zgoła niepolitycznych czynników, które jednak mogą mieć — i jak pokazują dzieje Polski - często mają polityczne konsekwencje. Lekki i przystępny styl autora, wartka narracja, wiele ciekawych, niekiedy też oryginalnych spostrzeżeń sprawia, że recenzowana książka jest niewątpliwie interesującą lekturą dla każdego, kto jest zainteresowany najnowszymi dziejami naszego państwa i jego losami od pamiętnego roku 1918 aż po dziś.

Reasumując, należy przede wszystkim pogratulować Andrzejowi Piaseckiemu znakomitego pomysłu na książkę. Ponadto - co ważne — realizacja tego pomysłu jest jak najbardziej udana, dzięki czemu mamy do czynienia z ciekawym, dobrze napisanym studium dziejów Polski minionych stu lat. Dzieje te to mieszanka rozmaitych wydarzeń, procesów, tendencji i koncepcji, z których summa summarum wyłania się obraz współczesnej Polski. Obraz ten jest wielowymiarowy, żeby je wszystkie lepiej poznać i zrozumieć, żeby dobrze poznać często zagmatwane i niejednoznaczne koleje polskich losów, warto z pewnością sięgnąć po recenzowaną książkę. W ciekawej formie, w przystępny sposób, nie tracąc nic ze swoich merytorycznych i warsztatowych atutów, przypomina ona ostatni wiek zdarzeń i wydarzeń, które uformowały obecną Polskę.

Jarosław Szymanek*

* Dr hab. Jarosław Szymanek, prof. w Instytucie Prawa, Administracji i Ekonomii Uniwersytetu Pedagogicznego im. KEN w Krakowie, ekspert Biura Analiz Sejmowych Kancelarii Sejmu, jaroslaw.szymanek@sejm.gov.pl 


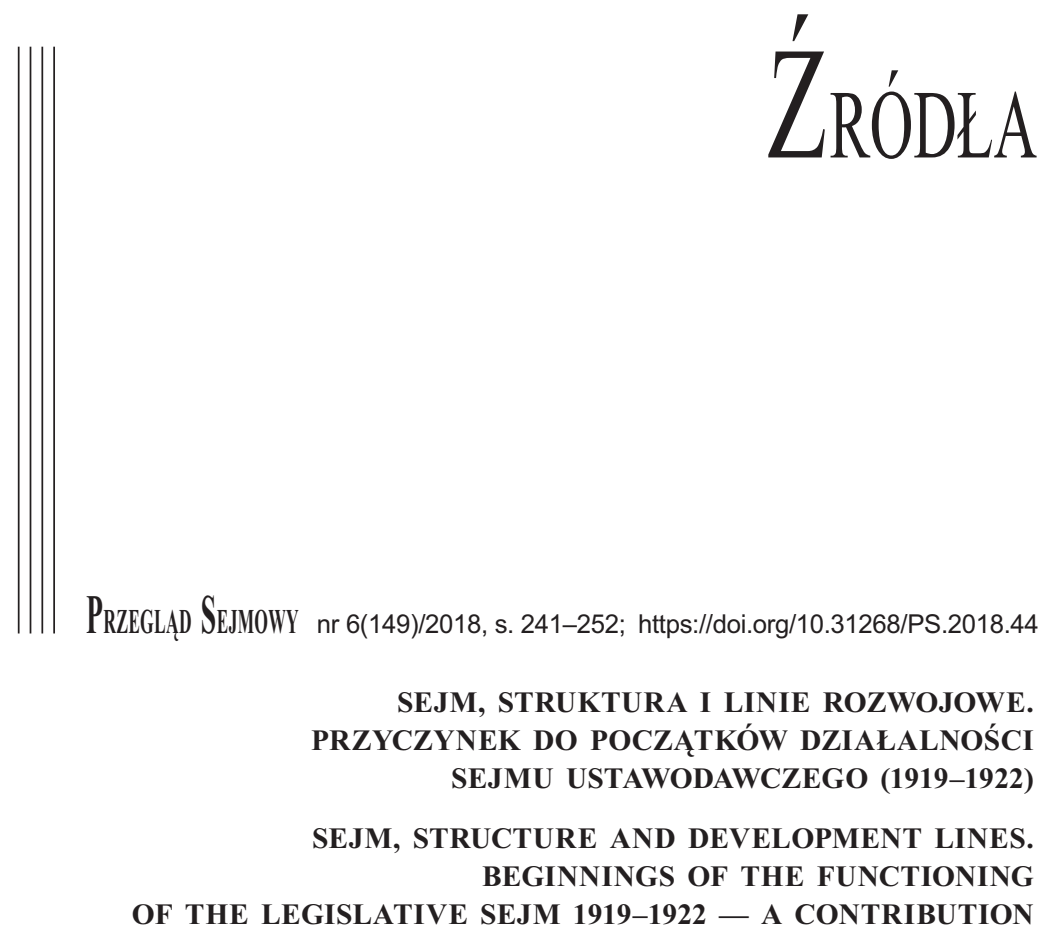

The discussed document presents in detail the process of establishing political divisions and Deputies' clubs in the first six months of the activity of the Legislative Sejm, from February to August 1919. Author or authors of the document - the analysis was produced by the Information Section of the Ministry of Foreign Affairs - distinguished four breakthrough moments in shaping the structure of the first parliamentary representation of the independent Polish State. The first two resulted from a by-election conducted during the first session of the Sejm, i.a. at eastern lands and Greater Poland. Further changes in the distribution of the Sejm clubs were the effect of splits within peasant parties and the Popular National Union in July/August 1919. They were mostly inspired by the People's Peasant Party "Piast"'s aspiration to establish a stable majority around the club within the chamber's centre, allowing to appoint a government based on peasants' and workers' parties of national character. The other camp aiming to establish its own cabinet was the Popular National Union.

Słowa kluczowe: Sejm Ustawodawczy, parlamentaryzm, wybory, partie polityczne,

II Rzeczpospolita, Ministerstwo Spraw Zagranicznych

Key words: Legislative Sejm, parliamentarism, elections, political parties, Second Republic of Poland, Ministry of Foreign Affairs

Fakty: Jedna z pierwszych decyzji rzadu Jędrzeja Moraczewskiego, pierwszego gabinetu niepodległej Rzeczypospolitej, było przygotowanie ordynacji wyborczej do przedstawicielstwa narodowego, którego głównym zadaniem miało być opracowanie konstytucji. Podstawowym celem odradzajacego się parlamentu miało być opracowanie podstaw ustrojowych państwa, a to powodowało, że przyjęto klasyczna dla systemów republikańskich formułe jednoizbowej konstytuanty. Ogłoszony 28 listopada $1918 \mathrm{r}$. dekret Naczelnika Państwa o ordynacji wyborczej określat podstawowe zasady prawa wyborczego, które miaty regulować wybory do Sejmu Ustawodawczego [dalej: SU], a któ- 
re - zgodnie z kolejnym dekretem wydanym tego samego dnia - odbyty się 26 stycznia 1919 r. Wybory można było przeprowadzić jedynie na części ziem byłego zaboru rosyjskiego i austriackiego ze względu na toczace się walki o granice. Natomiast z części pozostałych ziem m.in. Wielkopolski, Pomorza i Ślaska Cieszyńskiego do Sejmu delegowano przedstawicieli tych ziem, którzy zasiadali z wyboru w przedstawicielstwach państw zaborczych (Reichstagu i wiedeńskiej Rady Państwa) ${ }^{2}$.

Sejm Ustawodawczy rozpoczat obrady 10 lutego 1922 r. W pierwszym posiedzeniu odrodzonego po przeszło wieku niewoli polskiego parlamentu mogło uczestniczyć, jak wynika z danych powyborczych i przedstawianego dokumentu, ok. 339 postów ${ }^{3}$. Niestety ani prasa, ani stenogramy pierwszego posiedzenia nie podaja dokładnej imiennej listy parlamentarzystów, którzy brali udziat w tym historycznym wydarzeniu, choć „Robotnik” wspomina, że wzięli w nim wszyscy wybrani w wyborach posłowie 4 . Uwarunkowania procesu wyborczego zasadniczo wptynęło na strukturę polityczna SU i zmiany w jej kształcie, które omawia przedłożony tekst. Proces kształtowania się największych klubów poselskich, które przez kolejne trzy lata nadawały pracom izby, odbyt się w pierwszych dniach poprzedzajacych rozpoczęcie obrad. Ze względu na ramy czasowe, określone czasem powstania źródła, we wstępie zostana zarysowane jedynie zmiany $w$ strukturze konstytuanty $w$ pierwszym półroczu jej działalności.

Wybory zakończyly się zwycięstwem narodowej demokracji, szczególnie na ziemiach byłej „, Kongresówki”, która stanowiła matecznik polskiego ruchu narodowego. Klub Zwiazku Ludowo-Narodowego w Sejmie zawiąat się w przededniu rozpoczęcia obrad i liczył prawdopodobnie 96 posłów. W ciagu pierwszych dni działalności kon-

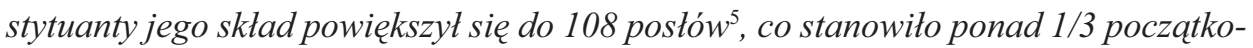
wego składu Izby. Do klubu dołaczyli także posłowie z Wielkopolski, przedstawiciele Chrześcijańskiej Demokracji, Polskiego Zjednoczenia Ludowego i bezpartyjni posłowie chłopscy. Również 9 lutego 1919 r. ukonstytuowat się trzeci co wielkości klub poselski konstytuanty PSL „Piast”. Ustępowat on w liczbie posłów przedstawicielstwu Polskiego Stronnictwa Ludowego „Wyzwolenie” liczacemu 57 posłów, którego klub zawiazat się 10 lutego. W dalszej kolejności należy wymienić kluby: Zwiazku Polskich Posłów Socjalistycznych, Polskiego Zjednoczenia Ludowego, Narodowego Zwiazku Ludowego, Pracy Konstytucyjnej, Polskiego Stronnictwa Ludowego Lewica, Wolnego Zjednoczenia i Niemieckiego Stronnictwa Ludowego. W momencie rozpoczęcia prac

1 Dz.U. z 1918 r. nr 18, poz. 46 i 47.

2 A. Ajnenkiel, Parlamentaryzm II Rzeczypospolitej, Warszawa 1975, s. 120-121; idem, Historia Sejmu Polskiego, t. II, cz. II, II Rzeczpospolita, Warszawa 1989, s. 18-19.

3 A. Ajnenkiel wskazywał, że liczba posłów w chwili rozpoczęcia obrad wynosiła 340. Różnicę tę można wytłumaczyć składem tzw. ,grupy Stapińskiego”, na którą wskazano przy analizie dokumentu. A. Ajnenkiel, Parlamentaryzm II Rzeczypospolitej..., s. 121.

4 Otwarcie Sejmu, „Robotnik”, 11 II 1919, nr 65, s. 2.

5 Pełną imienną listę posłów klubu ZLN na dzień 13 lutego 1919 r. podała narodowa „Gazeta Warszawska”. Vide Zwiazek Ludowo-Narodowy, „Gazeta Warszawska”, 13 II 1919, nr 43, s. 3. A. Tomaszewska w przygotowanych aneksach do „Historii Sejmu Polskiego” podaje liczbę 109 posłów SU. Na obecnym etapie badań nie można wskazać źródeł tych rozbieżności. A. Tomaszewska, Aneksy, [w:] A. Ajnenkiel, Historia Sejmu Polskiego..., s. 285. 
parlamentu funkcjonowało 10 klubów poselskich, a niezrzeszonych było kilkunastu posłów, m.in. Józef Buzek, Antoni Chłapowski i Marszałek Wojciech Trąmpczyński'.

Na liczbę posłów zrzeszających się w poszczególnych klubach mogła mieć wpływ uchwała Konwentu Seniorów z 10 lutego 1919 r. o minimalnej liczbie członków, która powinien mieć klub poselski, aby jego członkowie mogli zasiadać w tym gremium. Ostatecznie przyjęto, że musiat on liczyć co najmniej 12 czlonków ${ }^{7}$. Należy zwrócić uwage na sklad Konwentu, w którym miejsca przydzielono proporcjonalnie do liczby postów zasiadajacych $w$ danym klubie. W pierwszym historycznym posiedzeniu tego gremium wzięli udział z ramienia: Zwiazku Ludowo-Narodowego - Stanisław Grabski, Wojciech Korfanty i Marian Seyda; Polskiej Partii Socjalistycznej — Ignacy Daszyński, Norbert Barlicki i Emil Bobrowski; PSL „Piast”- Wincenty Witos, Jan Dabski, Franciszek Bardel; PSL - grupa Thugutta8: Stanisław Osiecki i Btażej Stolarski; NZR — Bolesław Fichna; PZL — Witold Kamieniecki i Andrzej Maj, Nojach Pryluc$k^{9}$; klubu żydowskiego - Abraham Thon i Moszek Ela Halpern ${ }^{10}$. Na kolejnych posiedzeniach Konwentu rozpatrywano sprawę ustalenia składu poszczególnych komisji sejmowych oraz ustalano terminy posiedzeń kolejnych Sejmu.

W pierwszych miesiqcach prac Sejmu jego skład ulegat dość istotnym przeksztatceniom. Wynikało to z konieczności uzupetnienia składu Izby o przedstawicieli ziem, na których wybory nie mogły się odbyć. Spór o rozwiqzanie tego problemu zdominowat pierwsze tygodnie dziatalności SU. Lewica uważata, że w Sejmie moga zasiadać jedynie ci postowie, którzy uzyskali legitymizacje swego mandatu w wyborach. Poza tym sprzeciwiała się przeprowadzeniu wyborów na tych ziemiach bytego zaboru rosyjskiego, na których dominowała mniejszość białoruska lub w stosunku do których roszczenia mogłoby wysuwać państwo litewskie. Negowata również zasadność właczenia w skład Sejmu 71 przedstawicieli Naczelnej Rady Ludowej, kwestionujac charakter ich wyboru ${ }^{11}$. Stąd też jedynie w przypadku listy zgtoszonej na Ślasku Cieszyńskim Sejm, w zwiazku z zajęciem tych ziem przez wojska czeskie, uznat za postów kandydatów niepochodzacych z bezpośrednich wyborów ${ }^{12}$.

Stanowisko to podzielita większość Izby, co było między innymi pokłosiem objęcia funkcji marszałka Sejmu przez Wojciecha Trąmpczyńskiego. Spowodowato to powsta-

${ }^{6}$ A. Tomaszewska, op. cit., s. 285.

7 P.A. Tusiński, ,, Sejm Polski domu swego ojczystego jedynym panem i gospodarzem” (odrodzenie Sejmu Rzeczypospolitej w 1919 r.), „Niepodległość i Pamięć” 2008, t. 15, nr 2, s. 146-147.

${ }^{8}$ Mianem „grupy Thugutta” określano w pierwszych dniach działalności Sejmu klub PSL „Wyzwolenie".

${ }^{9}$ Nojach Pryłucki kandydował z listy Żydowskiego Stronnictwa Ludowego w Warszawie. Uzyskał mandat, który następnie wygaszono w maju 1919 r. w wyniku orzeczenia Sądu Najwyższego. Powodem był brak obywatelstwa polskiego, które N. Pryłucki uzyskał w 1922 r.

10 Posiedzenie konwentu seniorów, „Kurier Warszawski”, 11 II 1919, nr 42, s. 3; Ustalenie regulaminu Sejmowego, „Gazeta Warszawska”, 13 II 1919, nr 45, s. 1.

${ }^{11}$ T. Hołówko, W sprawie dopuszczenia do Sejmu tzw. „,przedstawicieli” I, „Robotnik”, 21 II 1919, nr 67, s. 1; idem, W sprawie dopuszczenia do Sejmu tzw. ,przedstawicieli” II, „Robotnik”, 13 II 1919, nr 69, s. 1; Jeszcze o przedstawicielach Naczelnej Rady Ludowej, „Robotnik”, 13 II 1919, nr 69, s. 1; K. Domosławski, Memorial w sprawie przedstawicielstwa Polaków z Litwy i Rusi, „Robotnik”, 18 II 1919, nr 78, s. 1.

12 A. Ajnenkiel, Parlamentaryzm II Rzeczypospolitej..., s. 126. 
nie w Sejmie szerokiej koalicji, która wsparła projekt PPS i odrzucita możliwość kooptowania przedstawicieli NRL i innych organizacji społecznych z Wielkopolski. Podobnie negatywne stanowisko SU zajat wobec możliwości właczenia do swojego składu przedstawicieli Rady Narodowej Polskiej na Litwie ${ }^{13}$, Polskiego Komitetu Wykonawczego na Rusi ${ }^{14}$ oraz postów wybranych na poczatku lutego w okręgach grodzieńskim i biatostockim ${ }^{15}$. Wniosek o rozstrzygnięcie kwestii uzupetnienia Izby o przedstawicieli tych wymienionych terytoriów byt rozpatrywany przez Komisje Konstytucyjna SU. W pierwszym przypadku komisja, a nastęnie Sejm zająt stanowisko, że uzupetnienie składu konstytuanty o przedstawicieli cześsi ziem bylego zaboru pruskiego nastapi $w$ drodze wyborów przeprowadzonych na podstawie odrębnej ordynacji wyborczej ${ }^{16}$. W drugim przypadku większość komisji sktaniała się do przeprowadzenia tego procesu poprzez kooptację 16 przedstawicieli Kresów Wschodnich ${ }^{17}$. Jednak w czasie obrad większość klubów poparła wniosek mniejszości, który został złożony m.in. przez PPS i Piasta. Zakladat on, że wybory na tzw. Kresach wschodnich powinny odbyć się dopiero po ich wtaczeniu do Rzeczypospolitej zgodnie z wolq ich mieszkańców. W wyniku kompromisu kwestię rozstrzygnięcia tej sprawy przestano do komisji oraz uchwalono przeprowadzenie wyborów w obwodach bielskim i bialostockim ${ }^{18}$. Wybory na ziemiach bylego zaboru pruskiego oraz we wskazanych obwodach wschodnich zamykaty proces rozbudowy sktadu Izby w okresie pierwszej sesji sejmowej, która zamknęła się liczba 84 posiedzeń 2 sierpnia 1919 r. Rozstrzygnięcie problemu uzupetnienia skladu Izby zaciażyło na ocenach pierwszych miesięcy prac SU. Zwiqzana z ruchem syjonistycznym lwowska ,Chwila” "wskazywata, że nie stworzono ,,reprezentacji odpowiadajacej faktycznemu ustosunkowaniu się ludności na ziemiach polskich"'19.

Jednak jak podkreślali autorzy dokumentu, do najpoważniejszych zmian w strukturze politycznej Izby doszło w jej ostatnim tygodniu obrad, na przetomie lipca i sierpnia 1919 r. Wówczas to w wyniku dwóch secesji z przedstawicielstwa Zwiqzku Ludowo-Narodowego osłabieniu uległa pozycja dotychczas największego klubu sejmowego. W ich wyniku powstaly kluby: Polskiego Zjednoczenia Ludowego na czele z Edwardem Dubanowiczem i Leopoldem Skulskim oraz Narodowo Chrześcijański Klub Robotniczy skupiony wokót ks. Stanisława Adamskiego ${ }^{20}$. W zwiqzku z powyższymi zmianami powiększyła się również liczba klubów poselskich, która wzrosła na poczatku sierpnia do 13.

13 Kronika sejmowa, ,Gazeta Warszawska”, 9 II 1919, nr 39, s. 2.

14 Posłowie z Rusi, „Gazeta Warszawska”, 8 II 1919, nr 38, s. 3-4.

15 O odmowie włączenia wybranych wówczas posłów do SU miały przesądzić błędy o charakterze formalnym oraz fakt, że na części tych terenów toczyły się cały czas walki z bolszewikami, powodowało to, że na tym obszarze zawieszone były wolności obywatelskie, co uniemożliwiało przeprowadzenie wyborów zgodnie z zasadami określonymi w ordynacji wyborczej. Vide Posłowie z Grodna, „Monitor Polski” 1919, nr 34, s. 3. Confer Dz.U. z 1919 r. nr 240, poz. 295.

16 Sejm Ustawodawczy 1919-1922 [dalej: SU], druk nr 305, spr. sten. nr 26, ł. 13-14.

17 SU, druk nr 322.

18 Spr. sten. nr 28, 1. 43-44.

19 Pierwsza sesja sejmowa, „Chwila” 4 VIII 1919, nr 201, s. 1.

20 S. Krukowski, Geneza konstytucji z 17 marca 1921 r., Warszawa 1977, s. 168-169. 
Prezentowane źródło znajduje się w zbiorach Działu Starych Druków i Rękopisów Biblioteki Publicznej m.st. Warszawy w zespole Zarządu Cywilnego Ziem Wschodnich, wśród komunikatów Wydziału Narodowościowego i Prasy, którym kierował wówczas Ludwik Abramowicz, publicysta i zwolennik autonomii ziem byłego Wielkiego Księstwa Litewskiego w ramach państwa polskiego. Dokument zatytułowany „Sejm. Struktura i linie rozwojowe” liczy dziewięć numerowanych stron ${ }^{21}$. Stan zachowania dokumentu należy ocenić jako dobry. Niestety nieczytelne są niektóre fragmenty stanowiące jedną z najważniejszych części tekstu tabeli, pozwalające określić wielkość poszczególnych klubów poselskich. Częściowo braki te uzupełniono na podstawie literatury przedmiotu.

Materiał został opracowany i wytworzony w Sekcji Informacyjnej Ministerstwa Spraw Zagranicznych. W znajdujących się w Archiwum Akt Nowych zasobach znajdują się materiały ilustrujące strukturę MSZ w okresie jego pierwszych miesięcy działania pod kierownictwem Leona Wasilewskiego (pierwszego ministra spraw zagranicznych), który pełnił tę funkcję od listopada 1918 do stycznia 1919 r., komórki tej nie odnajdujemy jako wyodrębnionego działu w ramach Ministerstwa ${ }^{22}$. Ze względu na brak odpowiednich materiałów za kolejne miesiące działalności ministerstwa, kiedy funkcję tę sprawował premier Ignacy Jan Paderewski, musiałem się uciec do przypuszczeń wynikających z analizy materiałów porównawczych dostępnych w AAN. Sekcja Informacyjna działała w strukturach Wydziału Politycznego lub Wydziału Prasowego MSZ. Za umiejscowieniem $w$ pierwszym dziale przemawia specyfika przygotowywanych i redagowanych treści. Za lokacją w drugim wydziale mogą wskazywać cytowania materiałów przygotowanych przez Sekcję Informacyjną w ówczesnej prasie codziennej. Nie można jednak wykluczyć, że Sekcja Informacyjna jako odrębna jednostka w ramach ministerstwa została powołana dopiero po objęciu kierownictwa przez I. Paderewskiego. Henryk Wereszycki wspomina o rozpoczęciu działalności wydawniczej przez Sekcję w sierpniu $1919 \mathrm{r}$., tj. w okresie powstania prezentowanego źródła ${ }^{23}$. Należy również wskazać na podobieństwo między omawianym dokumentem a sprawozdaniami przygotowywanymi przez Wydział Ogólny MSZ z lat 1920-1921, w których również informowano o działalności organów państwowych, a w przypadku SU dokładnie omawiały podziały polityczne i charakter stosunków między głównymi obozami politycznymi ${ }^{24}$.

Dokument powstał już po zakończeniu pierwszej sesji sejmowej. Wskazują na to informacje zawarte w tekście oraz analiza jego elementów zewnętrznych, przede wszystkim pieczęci pozwalających na określenie jego źródła i przybliżonej daty powstania. Najważniejsza z nich, zamieszczona w górnym prawym rogu pierwszej stro-

${ }^{21}$ Biblioteka Publiczna m.st. Warszawy, Dział Starych Druków i Rękopisów, Zarząd Cywilny Ziem Wschodnich [dalej: BPK ZCZW], nr akc. 1773/13 I, k. 108-116.

${ }^{22}$ Archiwum Akt Nowych, Ministerstwo Spraw Zagranicznych [dalej: AAN MSZ], sygn. 1478, k. $1-2,5-6$.

${ }^{23}$ H. Wereszycki, Historia Austrii, Warszawa 1972, s. 25.

${ }^{24}$ AAN, MSZ, sygn. 9342, k. 5-10 i kolejne. 
ny dokumentu, pozwala przypisać autorstwo dokumentu wcześniej wymienionej sekcji, bowiem zawiera treść: „Ministerstwo Spraw Zagranicznych — Sekcja Informacyjna z numerem 3644". Pozostałe dwie pieczęcie wskazują natomiast, na obieg dokumentu, którego adresatem były Wydział Narodowościowy i Prasy Zarządu Cywilnego Ziem Wschodnich oraz Departament dla Spraw Polaków Ziem Wschodnich. Do obu wymienionych instytucji dokument wpłynął 13 sierpnia $1919 \mathrm{r}$.

Tym samym można z dużą pewnością przyjąć, że dokument został opracowany między 3 a 13 sierpnia 1919 r. Potwierdzają to również fakty. Jedną z najważniejszych informacji w nim zawartych jest ta dotycząca powiększenia się pod koniec pierwszej sesji sejmowej klubu PSL „Piast”. Do zmian tych, jak wskazywał „Czas” z 3 sierpnia 1919 r., powołując się na depeszę Polskiej Agencji Telegraficznej z dnia poprzedniego, doszło na początku tegoż miesiąca, tuż przed sejmowymi wakacjami. Między informacją podaną przez konserwatywny dziennik a treścią dokumentu zachodzi jednak pewna różnica. W cytowanej notce znalazła się informacja, że po przyłączeniu się reprezentacji „Piasta”, posłów zrzeszonych pod nazwą „Niezawiśli Ludowcy”, klub ten miał liczyć 53 posłów ${ }^{25}$. Natomiast jak wynika z cytowanego dokumentu, liczba ta wynosiła 54 posłów.

Prezentowane źródło w znacznym stopniu uzupełnia naszą dotychczasową wiedzę na temat kształtowania się polskiej sceny politycznej w pierwszych miesiącach niepodległości, poprzez przedstawienie głównych uwarunkowań przekształceń w strukturze politycznej pierwszego Sejmu niepodległej Rzeczypospolitej. Dotychczasowe opracowania tematu ze względu na stan zachowania archiwaliów bazowały głównie na źródłach porównawczych, to jest prasie i wspomnieniach ${ }^{26}$, co nie zawsze pozwalało na dokładne odzwierciedlenie zmian omawianych w źródle.

W tekście zachowano oryginalny charakter narracji, uwspółcześniono natomiast pisownię, interpunkcję i ortografię. Tekst źródła został opatrzony przypisami, których zadaniem było wyjaśnienie lub uzupełnienie nieczytelnych fragmentów dokumentu.

\section{,Sejm \\ /Struktura i linie rozwojowe/}

Nieustalone stosunki polityczne na terenie Sejmu ustawodawczego, brak stałej większości o jasnym i określonym programie i zmiany spowodowane powoływaniem coraz to nowych posłów z ziem, na których wybory w swoim czasie odbyć się nie mogły, powodują konieczność nadzwyczaj bacznego śledzenia rozwoju stosunków sejmowych.

Dla poznania ustosunkowania sił poszczególnych frakcji i kierunku, w jaki Sejm co do swej struktury wewnętrznej podążał, podajemy poniżej tablicę przedstawiająca liczebność poszczególnych klubów i zmian, jakie w nich zaszły w czasie pierwszej sesji sejmowej, dzieląc ją na cztery okresy:

25 „Czas”, 3 VIII 1919, nr 195, s. 1.

26 A. Ajnenkiel, Spór o model parlamentaryzmu polskiego do roku 1926, Warszawa 1972; idem, Parlamentaryzm II Rzeczypospolitej...; idem, Historia Sejmu Polskiego...; S. Krukowski, Geneza konstytucji z 17 marca $1921 \mathrm{r}$... 


\begin{tabular}{|c|c|c|c|c|}
\hline Nazwa Klubu & I & II & III & IV \\
\hline Związek Sejmowy Ludowo-Narodowy & 109 & 132 & 121 & 79 \\
\hline Narodowe Zjednoczenie Ludowe & - & - & - & 63 \\
\hline $\begin{array}{l}\text { Polskie Stronnictwo Ludowe/ } \\
\text { Grupa Wyzwolenia }\end{array}$ & $\begin{array}{c}5 ? \\
{[\text { nieczytelne }} \\
\text { w oryginale }]^{27}\end{array}$ & 57 & 57 & 57 \\
\hline Polskie Stronnictwo Ludowe/Grupa Piasta/ & 44 & 42 & 42 & 54 \\
\hline Polska Partia Socjalistyczna & 35 & 35 & 35 & 35 \\
\hline Narodowo Chrześcijański Klub Robotniczy & - & - & 30 & 30 \\
\hline Polskie Zjednoczenie Ludowe & 31 & 34 & 27 & - \\
\hline Klub Pracy Konstytucyjnej & \begin{tabular}{|c|}
$1 ?$ \\
{$\left[\begin{array}{c}\text { [nieczytelne } \\
\text { w oryginale }]^{28}\end{array}\right.$} \\
\end{tabular} & 17 & 17 & 17 \\
\hline Narodowy Związek Robotniczy & \begin{tabular}{|c|}
$1 ?$ \\
{$[$ nieczytelne } \\
w oryginale $]^{29}$ \\
\end{tabular} & 32 & \begin{tabular}{|c|}
-[nieczytelne \\
w oryginale $] ?$ \\
5
\end{tabular} & 15 \\
\hline $\begin{array}{l}\text { Polskie Stronnictwo Ludowe/ } \\
\text { Grupa Stapińskiego }\end{array}$ & $\begin{array}{c}- \\
{[\text { [nieczytelne }} \\
\text { w oryginale }]^{30}\end{array}$ & 12 & 12 & 12 \\
\hline Niezawiśli Ludowcy & - & 7 & 12 & - \\
\hline $\begin{array}{l}\text { Posłowie bez określonej przynależności } \\
\text { partyjnej }\end{array}$ & 7 & 12 & 12 & 12 \\
\hline Wolne Zjednoczenie Posłów Żydowskich & 10 & 10 & 10 & 10 \\
\hline Niemieckie Stronnictwo Ludowe & 2 & 2 & 2 & 2 \\
\hline $\begin{array}{l}\text { Secesjoniści z Polskiego Zjednoczenia } \\
\text { Ludowego }\end{array}$ & - & - & - & 6 \\
\hline
\end{tabular}

Rubryka I obejmuje stosunki od chwili powołania Sejmu do chwili przybycia posłów wielkopolskich i z dwóch okręgów wschodnich ${ }^{31}$.

Rubryka II ilustruje zmiany, jakie zaszły w ustosunkowaniu sił w Sejmie z chwilą przybycia posłów wielkopolskich ${ }^{32}$, oraz posłów z dwóch okręgów wschodnich /białostockiego i bialskiego/ ${ }^{33}$.

${ }^{27}$ Klub PSL „Wyzwolenie” liczył początkowo 57 posłów.

28 Klub Pracy Konstytucyjnej liczył 17 posłów.

29 Klub NZR liczył 17 posłów.

${ }^{30}$ Zdaniem A. Ajnenkiela, klub, którym kierował Jan Stapiński, liczył 13 posłów. Vide A. Ajnenkiel, Parlamentaryzm II Rzeczypospolitej..., s. 131.

31 Dwa okręgi wschodnie to: okręg suwalski, w którym wybory odbyły się 16 lutego 1919 r. oraz okręg podlaski, w którym głosowanie odbyło się 9 marca 1919 r. Vide T. Rzepecki, Sejm Rzeczypospolitej Polskiej 1919 roku, Poznań 1920, s. 100, 147; A. Ajnenkiel, Historia Sejmu Polskiego..., s. 17.

32 Proces elekcji przedstawicieli ziem byłego zaboru pruskiego do Sejmu Ustawodawczego, regulowała specjalna ustawa z 5 kwietnia 1919 r. Vide Dz.U. z 1919 r. nr 30, poz. 253; druk nr 305, Sejm Ustawodawczy RP, Okres 1919-1922 [dalej: SU], s. 5.

${ }^{33}$ Wybory w okręgu białostockim i bielskim odbyły się 15 czerwca 1919 r. Vide Dz.U. z 1919 r. nr 240, poz. 295. 
Rubryka III przedstawia okres, który trwał prawie do ostatniego tygodnia sesji sejmowej; jedyną zmianą w stosunku do okresu poprzedniego jest wystapienie ze Związku Ludowo-Narodowego grupy Chrześcijańskiej Demokracji, oraz z Narodowego Związku Robotniczego grupy Narodowego Stronnictwa Robotniczego /stronnictwo wielkopolskie/ i utworzenie przez te dwie występujące grupy jednego klubu pod nazwą „Narodowo-Chrześcijański Klub Robotniczy”.

Rubryka IV przedstawia zmiany, jakie zaszły pod sam koniec sesji sejmowej, zmiany z dotychczasowych najgłębiej podrywające istniejący stan rzeczy.

Podane w tej rubryce (IV) liczby mogą po rozpoczęciu się jesiennej sesji sejmowej ulec pewnym zmianom, gdyż niektórzy posłowie nie chcieli decydować o przynależności swej do nowo powstałych klubów lub pozostania lub pozostania w formacjach bez porozumienia się z organizacjami wyborczymi działającymi w ich okręgach.

Pierwszym nowym ugrupowaniem, które powstało z powodu rozłamu istniejących klubów sejmowych, był Narodowo-Chrześcijański Klub Robotniczy w skład, którego weszły: Chrześcijańska Demokracja pozostająca dotychczas w Związku Ludowo-Narodowym i Narodowe Stronnictwo Robotnicze, które początkowo stworzyło klub z Narodowym Związkiem Robotniczym.

We wspólnym klubie z Narodowym Związkiem Robotniczym Narodowe Stronnictwo Ludowe stanowiło prawe skrzydło klubu. N.Z.R. zmuszony do prowadzenia uciążliwej walki z partiami socjalistycznymi i komunistami na terenie byłego zaboru rosyjskiego, mając w szeregach swoich elementy położeniem kraju [i - M.W.] usilną agitacją daleko więcej zradykalizowane, będąc stronnictwem wyraźnie klasowym, stawiając jako jeden ze swych zasadniczych postulatów usamodzielnienie polityki klasy robotniczej i wyeliminowanie zeń wpływów sfer posiadających i duchowieństwa, nieufnie odnosił się do organizacji robotniczej byłego zaboru pruskiego, posiadającej w swych szeregach poważną ilość duchowieństwa o dużych i dobrze ugruntowanych wpływach w organizacji /w liczbie 17 posłów N.S.R. jest trzech księży ${ }^{34}$. Tarcia między dwoma grupami klubu ujawniły się też w sprawach pierwszorzędnej wagi, rozstrzyganych w Sejmie. Przy głosowaniu nad reformą rolną obie grupy głosowały wręcz przeciwnie. W rozbieżności zapatrywań i głosowania w sprawie reformy rolnej upatrywano przyczynę ostatecznego rozłamu. Pogląd ten jest błędny, rozłam bowiem nastapił już po pewnym czasie po uchwaleniu reformy. Przyczyna rozłamu polega z jednej strony na akcji sfer klerykalnych wewnattrz N.S.R. zmierzającej do utrzymania całkowitego swego wpływu w stronnictwie, z drugiej strony na rozpoczęciu bardzo usilnej akcji ze strony duchowieństwa w Chrześcijańskiej Demokracji dążącej do przyciagnięcia do siebie stronnictwa robotniczego nowo przyłączonej dzielnicy. Akcja sfer klerykalnych obu stronnictw została uwieńczona pomyślnym rezultatem. Rozłam w klubie N.Z.R. nastapił niespodziewanie, bez podania jakichkolwiek poważnych motywów ze strony występujących, którzy odmówili także wydania komunikatu do prasy, uzasadniającego wystapienie.

${ }^{34}$ Byli to: ks. Zygmunt Kaczyński, ks. Kazimierz Maliński i ks. Tadeusz Styczyński. 
Krok posłów sejmowych wielkopolskich wywołał żywe poruszenie w samych organizacjach robotniczych byłego zaboru pruskiego. Organizacje poznańskie i część górnośląskich solidaryzują się z nim, zaś organizacje robotnicze Prus Zachodnich i najpotężniejsze polskie organizacje robotnicze, jakie istnieją w Westfalii znalazły się w opozycji. W dniu 10-tym sierpnia odbyć się ma w Poznaniu zjazd przedstawicieli wyżej wymienionych organizacji, poświęcony sprawom rozłamu i który ma zadecydować o dalszym kierunku polityki swego przedstawicielstwa sejmowego.

Nowy klub (Nar. Chrześć. Kl. Rob.) pozostaje w stosunkach przyjaznych ze Związkiem Ludowo-Narodowym, jego przedstawiciele pozostają nadal w sekretariacie Związku L.N. prowadząc wspólnie akcję organizacyjną w kraju.

Przegrupowania przedstawione w rubryce IV-ej, podanej tablicy, polegają na:

wystapieniu ze Związku Ludowo-Narodowego 42 posłów, należących do Zjednoczenia Narodowego, Narodowego Stronnictwa Ludowego /stronnictwo dzielnicowe, wielkopolskie/ i bezpartyjnych;

zlikwidowaniu klubu Polskiego Zjednoczenia Ludowego i utworzeniu przez te dwie grupy wspólnego klubu pod nazwą „Narodowe Zjednoczenie Ludowe”;

wstapieniu posłów figurujących, na podanej tablicy, pod nazwą „Niezawisłych Ludowców" składających się z secesjonistów ze Związku Ludowo-Narodowego i Zjednoczenia Ludowego, do klubu Piastowców.

Rozłam jaki dokonał się w Związku Ludowo-Narodowym, organizacji sejmowej obejmującej cały szereg stronnictw oraz dużą ilość posłów bezpartyjnych (na 121 — 42), nie polegał na rozbieżności poglądów na kwestie większej doniosłości, tyczące się zarówno zagadnień politycznych jak i społecznych. Sprawa sojuszu z Entente'a, stosunku państwa Polskiego do kresów wschodnich nie wywoływały w łonie związku żadnych nieporozumień. Nawet kwestia tak drażliwa, jak sprawa reformy rolnej, a więc kwestia społeczna i gospodarcza, co do których regulamin związku pozwalał na samodzielne stanowisko poszczególnych grup, została wewnątrz związku solidarnie załatwiona, pomimo, iż związek liczył 40 posłów włościańskich; podczas głosowania na plennum Izby, zaledwie trzech posłów wyłamało się w ostatniej chwili z solidarności.

Przyczyna ostatecznego rozłamu polega głównie na niemożności zrealizowania zasadniczego, taktycznego celu związku t.j. utworzenia większości sejmowej. Początkowo obliczenia, jeszcze na zebraniach organizacyjnych związku, pozwalające przypuszczać, iż związek sam będzie tak liczny, że stanowić będzie większość zawiodły. Można było ją stworzyć jedynie przez przyciagnięcie do siebie klubu Polskiego Zjednoczenia Ludowego, Piastowców, ew. Narodowego Związku Robotniczego. W stosunku do Piastowców stało się to niemożliwe z powodu rozpoczętej przez nich akcji, zmierzającej do uzyskania dominującego wpływu na stronnictwa ludowe, stojące więcej na lewicy, co nie pozwalało im, z powodów taktycznych na nawiązywanie, jakichkolwiek ściślejszych stosunków ze stronnictwami, uchodzącymi za prawicę Izby. Porozumienie tym bardziej utrudnione zostało przez brak na terenie Sejmu ugrupowania konserwatywnego, prowadzącego wyraźną politykę zachowawczą przy jednoczesnym istnieniu takich organizacji i takiej polityki w kraju. Prawicą pomimo swych usilnych 
starań stał się Związek Ludowo-Narodowy, który dążył do stworzenia silnego centrum sejmowego. Do tego stanu rzeczy przyczyniła się w wysokim stopniu taktyka stronnictw lewicowych, w szczególności klubu socjalistycznego, zmierzająca do wpojenia w licznie reprezentowane w Sejmie, a mało politycznie wyrobione włościaństwo, pojęcia o skrajnym konserwatyzmie związku.

Bankructwo koncepcji utworzenia większości sejmowej przez Związek Ludowo-Narodowy, a jednocześnie zdawanie sobie sprawy z konieczności jej utworzenia, wśród najszerszych warstw posłów, którzy upatrywali przyczynę owego bankructwa w zachowawczości związku, w szczególności zaś w odgrywaniu w nim dominującej roli przez stronnictwo narodowo-demokratyczne, skłoniło niektóre grupy wchodzące w skład jego jak: Zjednoczenie Narodowe, Narodowe Stronnictwo Ludowe (wielkopolskie) i grupe posłów bezpartyjnych do zerwania dotychczasowych tak ścisłych stosunków z resztą stronnictw związku. Postanowiono utworzyć klub o charakterze więcej demokratycznym w celu umożliwienia zbliżenia się z innymi klubami Sejmu. Tak, jak wystapienie Chrześcijańskiej Demokracji ze Związku L.N. pozwoliło na rozbicie klubu Narodowego Związku Robotniczego i przyciagnięcie do siebie Narodowego Stronnictwa Robotniczego (wielkopolskiego), tak samo i obecnie stronnictwa występujące doprowadziły do zupełnego zlania się z dotychczas samodzielnie istniejącym klubem Polskiego Zjednoczenia Ludowego. Utworzony został nowy klub pod nazwą: „Narodowe Zjednoczenie Ludowe". Pomimo tych przegrupowań akcja ta do utworzenia większości nie doprowadzi bez wciagnięcia do niej Narodowego Związku Robotniczego, co przy obecnych stosunkach w kraju i na terenie Sejmu jest rzeczą więcej niż wątpliwa.

Różnic programowych między Związiem Ludowo-Narodowym a nowo powstałym Narodowym Zjednoczeniem Ludowym prawie, że nie ma. Prawdopodobną jest rzecza, że rozdwojenie to pozostanie jedynie na terenie Sejmu, zaś praca organizacyjna w kraju odbywać się będzie nadal solidarnie. Jest to zagadnienie nadzwyczaj wielkiej wagi, gdyż mało wyrobione politycznie i mało uświadomione szerokie warstwy ogółu przez ciagłe zmiany form organizacyjnych doprowadzone byłyby do stanu coraz to większego rozproszkowania, a nawet anarchii. Ucierpieć by na tym musiała też powaga samego Sejmu. Z niebezpieczeństw tych zdają sobie dokładnie sprawę przywódcy obu ugrupowań. Kwestia ta prawdopodobnie rozstrzygnięta będzie na zjeździe nowo powstałego stronnictwa, który odbędzie się w najbliższych dniach. Sekcja Informacyjna nie omieszka natychmiast przesłać odnośnego komunikatu.

W pozostałej, po wystapieniu 42 posłów, części Związku Ludowo-Narodowego utworzyła się grupa mieszczańska, która w Sejmie przyjęła nazwę Zjednoczenia Mieszczańskiego ${ }^{35}$, zaś jako stronnictwo zwać się będzie „Narodowe Stronnictwo Postępowe". Ugrupowanie to liczy 12 członków, pozostaje nadal w Związku L.N. zaznaczyć jednak należy, iż istnieją w nim tendencje separatystyczne.

Drugi ośrodek akcji zmierzającej do utworzenia silnego centrum, składającego się przeważnie ze stronnictw ludowych i stanowiącego większość sejmowa, spoczywa na klubie Piastowców. Jako najstarsze stronnictwo ludowe, posiadające wybitnych działaczy ludowych, pochodzących z samego ludu, posiada wielką siłę przyciaggającą i asy-

${ }^{35}$ Grupa postów miejskich w Sejmie, „Kurier Lwowski”, 3 VIII 1919, nr 212, s. 3. 
milacyjną dla ogółu posłów włościańskich o niezdecydowanych poglądach politycznych. Wszyscy dotychczasowi secesjoniści włościanie z innych klubów figurujący w podanej tablicy, w rubryce III-ej pod nazwą „Niezawisłych Ludowców” w ostatnim tygodniu działalności sejmu wstapili do klubu „Piastowców”.

O utworzenie większości klub Piastowców zabiega $\mathrm{z}$ wielką energią. Z chwilą powstania Narodowo-Chrześcijańskiego Klubu Robotniczego natychmiast przez posła Witosa zostało mu zaproponowane utworzenie komisji porozumiewawczej. Propozycja ta została przez Klub Narodowo-Chrześcijański przy bliższym wejrzeniu w skład owej komisji odrzucona, ze względu na to, iż byłby w niej zmajoryzowany przez stronnictwa włościańskie, co nie pozwoliłoby mu na skuteczną obronę warstw przezeń reprezentowanych. Prace prowadzące do stworzenia większości przez klub Piastowców zmierzały w dwóch kierunkach. $Z$ jednej strony dąży on do rozbicia Związku Ludowo-Narodowego i wyeliminowania zeń posłów włościańskich, z drugiej strony do nawiązania jak najściślejszych stosunków z lewicą ludową, t.j., z klubem Wyzwolenia i zapewnienia sobie tam poważnych wpływów.

Usilnej agitacji klubu Piastowców należy też w części zawdzięczać powstanie Narodowego Zjednoczenia Ludowego. Stosunek tego nowo powstałego klubu do Piastowców nie da się obecnie ostatecznie ustalić z powodu ferii sejmowych. Stwierdzić jednak należy, iż ze strony tych ostatnich podjęte będą wszelkie wysiłki w celu wciągnięcia Narodowego Zjednoczenia Ludowego w orbitę swej polityki.

Dotychczasowe jednak wysiłki ze strony klubu Piastowców skierowane były do ugruntowania swych wpływów, a ewen.[tualnie - M.W.] nawet w przyszłości do rozbicia grupy lewicy ludowej, jakim jest klub Wyzwolenia i zbudowania na jego gruzach jednego wielkiego stronnictwa ludowego, w którym rola kierownicza przypadłaby prawdopodobnie posłom Piastowców, choćby ze względu na ich daleko większą dojrzałość polityczna. Akcja ta choć znajduje poparcie u pewnych posłów klubu Wyzwolenia $\left(\operatorname{Erdman}^{36}\right.$, Małupa $\left.{ }^{37}\right)$ nie ma poważnych szans powodzenia. Wpływy lewicy socjalistycznej głęboko sięgające w tym klubie, choćby drogą ustępstw ze swego stanowiska, na korzyść prawicy klubowej nie dopuszczą do poważniejszych nieporozumień wewnętrznych. Tarcia zachodzące wewnątrz klubu Wyzwolenia do pomniejszenia liczby jego członków nie doprowadzą. Dalsze zaangażowanie się klubu Piastowców w politykę zmierzającą do jak największego zespolenia z klubem Wyzwolenia, posiada w sobie możliwość pewnej zmiany kierunku polityki Piasta przede wszystkim w zakresie zagadnień polityki zagranicznej. Klub Wyzwolenia zarówno w stosunku do spraw naszych granic wschodnich, w stosunku do Litwy i Białorusi, Komitetu Narodowego i jego koncepcji politycznych szedł solidarnie z klubem Polskiej Partii Socjalistycznej. Stanowisko dotychczasowe Sejmu w sprawach powyższych zawdzięczać należy zdecydowanej postawie klubu Piastowców. Czy postawa ta nie ulegnie pewnym zmianom dzięki zbyt bliskim stosunkom z Wyzwoleniem, twierdzić obecnie stanowczo nie można, lecz leży to w każdym razie w sferze najbliższych możliwości.

${ }^{36}$ Alfons Erdman (1886-1943), inspektor szkolny, wybrany w okręgu nr 27 z siedzibą w Pińczowie.

37 Jan Małupa (1892-1962), kierownik szkoły rolniczej. W kolejnych latach używał nazwiska panieńskiego matki Gawlikowski, został wybrany w okręgu nr 28 z siedzibą w Olkuszu. 
Przy obecnym stanie stosunków sejmowych wysuwają się dwa sposoby rozwiązania sprawy większości sejmowej.

Pierwszy, to większość o przewadze stronnictw ludowych, do której utworzenia dąży przede wszystkim klub Piastowców;

W skład jej weszłyby:

Narodowe Zjednoczenie Ludowe............................................... 63

Wyzwolenie ..................................................................... 57

Piastowcy......................................................................... 54

Narodowo-Chrześcijański Kl. Robot. .................................. 30

Narodowy Związek Robotniczy ......................................... 15

Na ogólną liczbę 392 posłów.

Drugi sposób rozwiązania sprawy większości za ośrodek, którego należy uważać Związek Ludowo-Narodowy przedstawia się jak następuje:

Związek Ludowo-Narodowy ............................................... 79

Narodowe-Zjednoczenie Ludowe ......................................... 63

Narodowo-Chrześcijański K1. Robot. ................................. 30

Klub Pracy Konstytucyjnej ................................................... 17

Narodowy Związek Robotniczy / ?/ ........................................ 15

Dotychczasowa taktyka klubu Socjalistycznego w Sejmie starała się o niedopuszczenie do utworzenia większości, na której oprzeć by się mógł silny rząd. Niezdecydowane z powodu braku większości oblicze Sejmu i wynikający stąd brak silnego oparcia dla rządu, przy jednoczesnym posiadaniu przez Polską Partię Socjalistyczną silnej i rozgałęzionej sieci organizacyjnej stwarzały dla niej sytuację bardzo dogodną i powiększająca jej wpływy w kraju. Taktyka ta utrzymana będzie prawdopodobnie i w przyszłości. W ostatecznym razie gdyby miało przyjść do utworzenia większości, wszelkie wysiłki klubu Socjalistycznego skierowane będą ku temu, aby w większości tej odgrywały pewną rolę stronnictwa, w których PPS posiada zapewnione wpływ, tj. grupa Wyzwolenia i grupa Stapińskiego.

Sejm rozjechał się na ferie w chwili, kiedy nowe stosunki wywołane bardzo poważnymi przegrupowaniami nie miały czasu ustalić się, linii kierunkowych dalszego rozwoju prawie iż uchwycić nie można, kiedy nowe ugrupowania co do swej taktyki są niezdecydowane i chwiejne. Odbiera się wrażenie, iż rząd stworzywszy sobie jasny program swej polityki sejmowej mógłby owe linie Sejmowi narzucić i doprowadzić do stworzenia większości”.

Maciej Wojtacki*

* Dr Maciej Wojtacki, Akademia Sztuki Wojennej, Wydział Bezpieczeństwa Narodowego, adiunkt w Instytucie Prawa i Administracji Obronnej, mawojta77@sejm.gov.pl 


\title{
AUSTRALIA: WYROK SĄDU NAJWYŻSZEGO Z 27 PAŹDZIERNIKA 2017 R. W SPRAWIE RE CANAVAN I INNI, SYGN. (2017) HCA 45*
}

\author{
AUSTRALIA: JUDGMENT OF THE HIGH COURT OF AUSTRALIA \\ OF 27 OCTOBER 2017 IN THE CASE RE CANAVAN ET AL., \\ CASE REF. NO. (2017) HCA 45
}

In its judgment, the High Court of Australia interpreted Article 44 of the Constitution, stating that "Any person who is under any acknowledgment of allegiance, obedience, or adherence to a foreign power, or is a subject or a citizen or entitled to the rights or privileges of a subject or a citizen of a foreign power, shall be incapable of being chosen or of sitting as a senator or a member of the House of Representatives". The case referred to six senators and one member of the House of Representatives elected in the elections of 2 July 2016. It was to be decided, whether their dual citizenship allows them to exercise the mandate of an MP. It stems from the judgment that the citizenship of another country - even if it is involuntary - shall result in the expiry of the holder's mandate.

Słowa kluczowe: demokracja, podwójne obywatelstwo, prawo do kandydowania Key words: democracy, dual citizenship, right to be elected

Fakty: Sad Najwyższy Australii posiada kompetencję w zakresie kontroli konstytucyjności prawa oraz wykładni przepisów konstytucyjnych. Rozpatruje również spory wyborcze. Zgodnie z art. 47 Konstytucji Zwiazku Australijskiego z 1900 r.: „Jeżeli Parlament nie postanowi inaczej, każda watpliwość dotyczaca zdolności do wykonywania mandatu senatora lub członka Izby Reprezentantów, lub braku obsady mandatu w każdej z izb Parlamentu, jak również każdy spór w sprawie ważności wyboru do każdej z izb, jest rozstrzygana przez izbę, w której się pojawi "'. Już w 1902 r. Parlament Australii zdecydowat, że kompetencje do rozstrzygania sporów z zakresu wyborów, określone w australijskiej ustawie wyborczej z 1918 r. (Commonwealth Electoral Act 1918), będzie posiadat specjalny sqd (Court of Disputed Returns), którego funkcje powierzono Sadowi Najwyższemu. Ustawa wyborcza z 1918 r. postanowiono, że do jego kompetencji będzie należało m.in. rozstrzyganie sporów w zakresie prawa do kandydowania $w$ wyborach parlamentarnych oraz stwierdzenia wygaśnięcia mandatu parlamentarzystów, w przypadku podjęcia przez danq izbę parlamentarna odpowiedniej uchwaty $w$ tej sprawie.

Zgodnie z konstytucja Australii prawa do kandydowania w wyborach do obu izb parlamentarnych, tj. Izby Reprezentantów i Senatu, nie posiadaja osoby, które maja zobowiqzania wobec innej władzy (art. 44i). Kwestia interpretacji tego przepisu była przedmiotem ważnego wyroku Sąu Najwyższego z 25 listopada 1992 r. w sprawie Sykes v. Cleary ${ }^{2}$. Zgodnie z wyrokiem w tej sprawie prawa do kandydowania do izb par-

* Tekst wyroku został opublikowany na stronie internetowej <http://www.hcourt.gov.au>.

${ }_{1}^{1}$ Tłumaczenie przepisów Konstytucji Związku Australijskiego zaczerpnięto z pozycji: Konstytucja Zwiqzku Australijskiego, tłum. i wstęp P. Winczorek, Warszawa 2014.

${ }^{2}$ Wyrok SN z 25 listopada 1992 r. w sprawie Sykes v. Cleary (1992) 176 CLR 77. 
lamentarnych nie ma - na podstawie art. $44 i$ konstytucji - osoba posiadajaca podwójne obywatelstwo, chyba że podjęta ona wszystkie możliwe kroki w celu skutecznego zrzeczenia się obywatelstwa innego państwa. Problem interpretacji tego przepisu powrócit 25 lat później w zwiazku z prawem do kandydowania siedmiu parlamentarzystów (senatorów: Scotta Ludlama, Larissy Waters, Matta Canavana, Malcolma Robertsa, Fiony Nash oraz Nicka Xenophona oraz członka Izby Reprezentantów Barnaby'ego Joyca).

Przedmiotowa sprawa dotyczyła sześciu senatorów - przy czym dwóch z nich, a konkretnie senator Ludlam oraz Waters, zrezygnowało z mandatu w lipcu 2017 r., jeszcze przed podjęciem sprawy przez Senat - oraz jednego czlonka Izby Reprezentantów wybranych $w$ wyborach z 2 lipca 2016 r. Do sprawy w charakterze amicus curiae wtaczyt się Antony Windsor, kwestionujacy legalność sprawowania mandatu przez B. Joyca - swojego kontrkandydata w wyborach z $2016 \mathrm{r}$.

Obie izby Parlamentu Australii podjęty uchwaty o skierowaniu sprawy do Sadu Najwyższego. W uchwałach zawarto wniosek o udzielenie przez Sad Najwyższy odpowiedzi na kilka pytań, w przede wszystkim o to, czy mandaty wymienionych parlamentarzystów wygasty. W przypadku pozytywnej odpowiedzi, Sad miat dodatkowo wskazać sposób uzupetnienia składu izb parlamentarnych.

W tym kontekście należy przedstawić ogólne założenia systemów wyborczych obowiqzujacych w obu izbach parlamentarnych, istotnych w kontekście decyzji Sadu w zakresie ewentualnego określenia sposobu obsady opróżnionych mandatów. Wybory do Izby Reprezentantów przeprowadza się w jednomandatowych okręgach wyborczych zgodnie z zasadami ordynacji preferencyjnej (glosowanie alternatywne), w ramach której wyborca stopniuje swoje preferencje wyborcze, stawiajac przy nazwiskach kandydatów kolejne cyfry. Jeżeli po przeliczeniu wylacznie "pierwszych głosów” (tylko glosów oddanych za pomoca cyfry ", 1 " żaden z kandydatów w okręgu nie uzyska bezwględnej większości, bierze się pod uwagę kolejne preferencje aż do uzyskania bezwzględnej większości. Ten system wyborczy sprawia, że poszczególne partie polityczne z reguly wystawiaja w wyborach tylko po jednym kandydacie w każdym okręgu. Jeśli chodzi o wybory do Senatu, to obowiqzuje system głosu przenoszonego (STV), bardzo zbliżony do głosowania alternatywnego - tu wyborca również wskazuje swoje kolejne preferencje. Podstawowa różnica polega na tym, że system ten jest stosowany w wielomandatowych okręgach wyborczych, co sprawia, że partie polityczne zwykle nie ograniczają się do wystawienia tylko jednego kandydata ${ }^{3}$.

1. [...] Art. 44 konstytucji stanowi, że:

„Do Senatu lub do Izby Reprezentantów nie może zostać wybrana, ani nie może sprawować mandatu, osoba:

${ }^{3}$ M. Wincławska, Glosy nieważne w wyborach do australijskiej Izby Reprezentantów 2001-2013, „Studia Wyborcze" 2016, t. 22, s. 90-91. 
(i) na której ciąży zobowiązanie lojalności, posłuszeństwa lub wierności obcemu państwu, lub która jest poddanym lub obywatelem takiego państwa, lub przysługuja jej uprawnienia i przywileje poddanego lub obywatela takiego państwa”.

2. Zgodnie z art. 45i konstytucji, jeśli senator lub członek Izby Reprezentantów „spełni którąkolwiek z przesłanek, o których mowa w poprzednim artykule”, jego mandat $\mathrm{z}$ tą chwilą wygasa.

3. [...] Żadna ze stron nie kwestionuje, że sformułowanie ,nie może zostać wybrana" z art. 44 odnosi się do procedury wyboru, której nominacja jest istotnym elementem. W związku z tym art. 44i ma zastosowanie od daty nominacji na kandydata do zakończenia procedury wyborczej [...].

Przeciwstawne podej ścia dow y kładni art. 44i

13. W podejściu zaproponowanej przez pana Windsora (amicus curiae) uwzględnia się przede wszystkim językową wykładnię przepisu, ograniczone jedynie dorozumianym zastrzeżeniem wyinterpretowanym z art. 44i, zgodnie z którym prawo innego państwa, przyznającego obywatelstwo tego państwa, musi być zgodne z konstytucyjnym imperatywem leżącym u podstaw danego przepisu [...]. Obywatel australijski nie może na mocy prawa innego państwa zostać pozbawiony uczestnictwa w wyborze reprezentatywnego rządu, jeśli możliwe jest udowodnienie, że podjął on wszelkie dostępne kroki określone w prawie tego państwa w celu skutecznego zrzeczenia się jego obywatelstwa.

Zaproponowano trzy odmienne interpretacje przedstawionego podejścia. W każdej z nich wykładnia zasadniczo odbiega od językowej wykładni analizowanego przepisu. [...]

14. Zgodnie z pierwszym podejściem, zaproponowanym przez prokuratora generalnego, popieranym przez senatorów: Canavana, Robertsa oraz Xenophona, art. 44i wymaga, aby obywatelstwo innego państwa zostało uzyskane lub też dobrowolnie zachowane. Element dobrowolności występuje wówczas, gdy dana osoba jest świadoma posiadania obywatelstwa innego państwa lub też jest rozmyślnie nieświadoma tego faktu. Z niektórych punktów przedstawionej przez prokuratora generalnego opinii wynika, że wystarczająca byłaby ,znaczna i poważna perspektywa” lub ,realna i istotna perspektywa" posiadania obywatelstwa innego państwa.

15. Zgodnie z podejściem zaproponowanym przez prokuratora generalnego należy rozróżnić dwie grupy Australijczyków: posiadających obywatelstwo tego państwa w uwagi na miejsce swojego urodzenia oraz naturalizowanych. Obywatel Australii na zasadzie prawa krwi powinien zostać pozbawiony prawa do kandydowania oraz sprawowania mandatu, jeśli podjąłby kroki w celu uzyskania obywatelstwa innego państwa i mimo posiadania odpowiedniej wiedzy co do konsekwencji posiadania innego obywatelstwa nie podjął wszystkich koniecznych działań w celu zrzeczenia się tego obywatelstwa. Natomiast naturalizowani Australijczycy, którzy nie podjęli wszelkich możliwych działań w celu zrzeczenia się obywatelstwa innego państwa, byliby uważani za osoby dobrowolnie zachowujące obywatelstwo innego państwa, nawet jeśli byli przekonani, że naturalizacja obejmuje również zrzeczenie się obywatelstwa innego państwa. Należy 
bowiem przyjąć, że od naturalizowanego obywatela Australii można oczekiwać wiedzy w zakresie posiadania przez niego obywatelstwa innego państwa.

16. Zgodnie z drugim stanowiskiem, zajmowanym przez członka Izby Reprezentantów pana Joyce'a oraz panią senator Nash, art. 44i nie łączy utraty biernego prawa wyborczego z wymogiem świadomego wyboru lub zachowania obywatelstwa innego państwa. Istota tego podejścia polega na założeniu wiedzy co do posiadania obywatelstwa innego państwa. Przyjęto założenie, że obywatel nie może zadecydować o zachowaniu lub zrzeczeniu się obywatelstwa innego państwa, jeśli nie ma świadomości posiadania tego obywatelstwa. Jakkolwiek poziom wiedzy, o którym mowa, nie obejmuje konieczności znajomości przepisów prawa, obejmuje jednak świadomą ignorancję.

17. Zgodnie z trzecim stanowiskiem, zaproponowanym przez pana Ludlama oraz panią Waters [byłych senatorów, którzy zrzekli się mandatu - M.R.], art. 44i wymaga, aby osoba, której dotyczy ten przepis, miała świadomość posiadania innego obywatelstwa. Zgodnie z tym podejściem taka osoba powinna zostać pozbawiona prawa do kandydowania na podstawie art. 44i, jeśli była świadoma faktów, w przypadku których obywatel przestrzegający konstytucji [...] powinien rozwiać swoje wattpliwości co do posiadania obywatelstwa innego państwa i podjać odpowiednie działania w celu wyjaśnienia tej kwestii. [...]

$[\ldots]$

19. Należy zaakceptować podejście zaproponowane przez pana Windsora. Wykazuje ono największą zgodność z językową wykładnią art. 44i. Nie odbiega również od poglądów wyrażonych przez większość składu orzekającego w spraiwe Sykes v. Cleary $[\ldots]$.

Ratio legis a r t. $44 \mathrm{i}$

24. W wyroku Sykes v. Cleary większość sędziów składu orzekającego [...] stwierdziła, że art. 44i został przyjęty, ,aby członkowie Parlamentu nie mieli sprzecznych zobowiązań”. Sędzia Brennan wyjaśnił, że celem art. 44i ,jest zapewnienie, że żaden kandydat, senator, jak również członek Izby Reprezentantów nie jest zobowiązany do wierności lub posłuszeństwa obcej władzy”. Sędzia Dean stwierdził natomiast, że podstawowym celem art. 44i jest ,zapobiegnięcie, aby osoby lojalne wobec obcej władzy lub posiadający wobec niej zobowiązania były członkami Parlamentu Australii”.

$[\ldots]$

Poddany 1 ub obywate 1 - rola prawa obcego

37. To, czy dana osoba posiada status poddanego lub obywatela obcej władzy, jest uzależnione od prawodawstwa innych państw, ponieważ tylko prawo innej władzy może stanowić o statusie obywatela lub też o prawach i obowiązkach związanych z tym statusem. W wyroku Sykes $v$. Cleary [...] skład orzekający zauważył, że „,w prawie zwyczajowym kwestia tego, czy dana osoba jest obywatelem danego państwa, determinuje prawo tego państwa". Ta reguła prawa zwyczajowego znajduje po części uzasadnienie w ważnej zasadzie prawa międzynarodowego, zgodnie z którą „,w kom- 
petencji każdego państwa [...] jest określenie we własnym ustawodawstwie zasad dotyczących nabywania obywatelstwa". [...]

$[\ldots]$

39. [...] Wszyscy sędziowie orzekający w sprawie Sykes v. Cleary zgodzili się z tym, że w art. 44i nie przewidziano, aby o stosowaniu tego przepisu miało decydować prawodawstwo innych państw. Sąd australijski nie stosuje art. 44i w celu pozbawienia danej osoby możliwości kandydowania lub stwierdzenia wygaśnięcia jej mandatu z powodu posiadania obywatelstwa innego państwa, jeśli podważałoby to system reprezentatywnego oraz odpowiedzialnego rządu ustanowionego na podstawie przepisów konstytucyjnych.

40. Na potrzeby przedmiotowej sprawy należy również przytoczyć art. 16 konstytucji, zgodnie z którym „Wymogi, jakie winni spełniać senatorowie, są tożsame z wymogami dotyczącymi deputowanych do Izby Reprezentantów”.

41. Natomiast — zgodnie z art. 34 konstytucji — jeżeli Parlament nie postanowi inaczej, prawo bycia wybranym do Izby Reprezentantów przysługuje osobie, która: (i) ukończyła dwadzieścia jeden lat oraz ma prawo głosowania w wyborach do Izby Reprezentantów; prawo bycia wybranym przysługuje również osobie, która przez co najmniej trzy lata zamieszkiwała na terytorium Związku, w granicach istniejących w chwili jej wyboru; (ii) z urodzenia jest poddanym Królowej lub w następstwie co najmniej pięcioletniej naturalizacji — przewidzianej prawem Zjednoczonego Królestwa — kolonii, która stała się lub stanie się stanem, albo prawem Związku lub stanu.

$[\ldots]$

44. [...] Sąd w wyroku Sykes v. Cleary stwierdził, że obywatel australijski, który posiada również obywatelstwo innego państwa nie zostanie pozbawiony prawa uczestnictwa w przedstawicielskiej formie rządu, o której stanowi się w konstytucji, z powodu prawa innego państwa, które sprawia, że nieodwracalnie traci on prawo do bycia wybranym do obu izb Parlamentu. Zgodnie z wyrokiem w sprawie Sykes v. Cleary: „Błędna byłaby taka wykładnia przepisów konstytucyjnych, która skutkowałaby pozbawieniem tego prawa obywateli australijskich, którzy podjęli wszelkie możliwe kroki w celu wyzbycia się wszelkich konfliktowych zależności [...]”.

45. Należy jednak zauważyć, że sędziowie nie stwierdzili, że kandydat, który podjął duży wysiłek, aby dochować wymogów art. 44, będzie posiadał prawo do kandydowania. Jak wyjaśnił sędzia Brennan, „W przypadku osoby posiadającej podwójne obywatelstwo nie wystarczy [...] jej jednostronna deklaracja o zrzeczeniu się obywatelstwa innego państwa, jeśli — zgodnie z prawem tego państwa - mogła podjąć jeszcze inne działania, które uwalniałyby ją z wymogu podległości wobec tego państwa. Dopóki taki obowiązek będzie zgodny z prawem innego państwa, jego realizacja — np. dotycząca obcych sił zbrojnych — stanowi przeszkodę w zakresie zadeklarowania bezwarunkowej wierność Australii. Dopiero po podjęciu wszelkich możliwych działań - zgodnie z prawem innego państwa - w celu utraty tego statusu, praw i przywilejów związanych z obowiązkiem wierności czy posłuszeństwa, można stwier- 
dzić, że cel art. 44i nie zostałby zrealizowany jedynie w odniesieniu do rozwiązań prawnych tego państwa".

$[\ldots]$

Wiedza o posiadaniu obywatelstwa innego państwa j a k o e 1 e ment a r t. 44 i

47. W art. 44i nie ustanowiono, że wynikająca z niego sankcja znajduje zastosowanie, tylko jeśli potencjalny kandydat posiada wiedzę o istnieniu okoliczności dyskwalifikującej jego kandydaturę. Jest to znaczące odejście od językowej wykładni drugiej części przepisu i przyjęcia rozumienia, zgodnie z którym: „Każda osoba która: (i) [...] jest świadoma tego, że jest poddanym lub obywatelem".

48. Ponadto zaakceptowanie dowodu świadomości posiadania obywatelstwa innego państwa, jako warunku ograniczenia wynikającego z art. 44i, byłoby niekorzystne dla stabilności reprezentatywnego rządu. Stabilność już od dnia zarejestrowania kandydatury wymaga pewności w zakresie tego, czy kandydat rzeczywiście jest uprawniony do kandydowania czy — ewentualnie - sprawowania mandatu w Parlamencie. Ta okoliczność przemawia przeciwko takiej interpretacji art. 44i, która zmieniałaby językową wykładnię przepisu przez konieczność przeprowadzania postępowania wyjaśniającego w zakresie stanu wiedzy kandydata.

49. Podejście prezentowane przez prokuratora generalnego wykazuje podobieństwo do stanowiska sędziego Deane'a w wyroku Sykes v. Cleary. [...] Art. 44i powinien być rozumiany jako włączający element mentalny, w wyniku czego można go stosować ,jedynie do spraw, w przypadku których zainteresowana jednostka zabiegała o odpowiedni status, prawa i przywileje lub też status ten został przez nią zaakceptowany lub potwierdzony".

$[\ldots]$

54. Zgodnie ze stanowiskiem pana Windsora konstytucyjna gwarancja jednostronnej lojalności, przewidziana w art. 44i, nie powinna zależeć od staranności, jaką kandydat przykłada do przestrzegania przepisu. [...] Uwzględnienie zakresu wiedzy kandydata oraz jego wysiłków oznacza merytoryczne oraz praktyczne problemy związane ze stosowaniem tego przepisu. Te niejasności mogą wpływać na stabilność reprezentatywnego rządu.

55. Na poziomie koncepcyjnym konieczne jest zadanie pytania o naturę oraz zakres wiedzy, jaką — w kontekście celów art. 45i — musi mieć kandydat lub też sprawujący mandat, aby można było uznać, że nie podjął on wszystkich możliwych działań w celu pozbycia się obywatelstwa innego państwa. Zakres wiedzy tej osoby może być różny, od braku najmniejszych podejrzeń co do posiadania obywatelstwa innego państwa poprzez inne stany wiedzy, jak: podejrzenie, uzasadniona wiara aż po pewność w tym zakresie. Z artykułów 44i oraz 45i nie wynika, który z wymienionych stanów wiedzy jest wystarczający, jeśli chodzi o stosowanie tych przepisów. Nie jest to zaskoczeniem, biorąc pod uwagę, że w tych przepisach nie wspomina się o poziomie wiedzy tych osób czy też ich zdolności do uzyskania wiedzy jako przesłanki stosowania tych przepisów. 
56. Związaną z tym merytoryczną trudność można wyrazić poprzez następujące pytanie: Czy kandydat, który otrzymał informację, że prawdopodobnie jest obywatelem innego państwa, ,posiada wiedzę, że jest obywatelem obcego państwa, zgodnie z rozumieniem art. 44i”? [...].

$[\ldots]$

58. Praktyczne problemy związane z zastosowaniem standardów, które proponują członek Izby Reprezentantów B. Joyce oraz senator F. Nash są związane z trudnym do udowodnienia stanem wiedzy. Jedną z tych trudności mógłby stanowić brak szczerości kandydata lub osoby sprawującej mandat, w którego interesie by to leżało. $\mathrm{W}$ trakcie postępowania dowodowego uprawnienie członka parlamentu do zachowania swojego statutu mogłoby być podawane w wątpliwość.

59. Ponadto — zgodnie z podejściem zaproponowanym przez wymienionych parlamentarzystów — osobie, która została wybrana do Parlamentu i następnie dowiedziała się, że jest obywatelem obcego państwa, należałoby przyznać odpowiedni czas na podjęcie wszelkich możliwych kroków w celu zrzeczenia się przez nią obywatelstwa przed zastosowaniem przepisów art. 44i oraz $45 \mathrm{i}$. W tym okresie osoba ta posiadałaby jednak podwójne obywatelstwo. Tego stanu rzeczy nie da się pogodzić z konstytucyjnymi gwarancjami wymienionych przepisów.

60. Należy również zauważyć, że jakkolwiek problematyczne jest stosowanie art. 44i w celu pozbawienia prawa do kandydowania osoby, która urodziła się w Australii oraz nigdy nie miała okazji do tego, aby uważać siebie za obywatela państwa innego niż Australia, nominacja na kandydata jest bardzo dobrą okazją dla przemyślenia tej kwestii. W formularzu nominacji dla kandydatów zarówno do Senatu, jak i do Izby Reprezentantów zawarto bowiem wymóg, że osoba chcąca kandydować musi złożyć oświadczenie, że nie jest pozbawiona prawa do kandydowania na podstawie art. 44i. Trzeba pamiętać, że każda z izb parlamentarnych może wszcząć postępowanie w zakresie pozbawienia mandatu, tylko jeśli fakty, które stanowią podstawę pozbawienia mandatu, zostały przedstawione w Parlamencie. Z natury rzeczy fakty te muszą być powszechnie znane. Kandydat powinien wykazać się jednak nie mniejszą starannością w zakresie ustalenia w odpowiednim czasie tych faktów niż osoba, która — jakkolwiek po fakcie — jednak skutecznie przedstawiła je Parlamentowi.

Uza s a d n i o n e d z i ałania

61. Stosowanie art. 44i nie jest uzależnione od tego, czy kandydat dopuścił się zaniedbania w zakresie spełnienia stawianych wymogów. [...] Art. 44i został sformułowany w sposób bezwarunkowy. Jeżeli osobista sytuacja potencjalnego kandydata może doprowadzić do utraty przez niego prawa do kandydowania na podstawie art. 44i, zasadność działań podjętych w celu przeprowadzenia dochodzenia w sprawie ustalenia, czy okoliczności te istnieja, jest nieistotna w kontekście zastosowania art. $44 \mathrm{i}$.

62. Z uzasadnienia większości sędziów składu orzekającego w wyroku Sykes v. Cleary nie wynika, że posiadanie obywatelstwa innego państwa, o którym mowa 
w drugiej części art. 44i, stanowiłoby przesłankę utraty prawa do kandydowania, jedynie jeśli ta osoba wiedziałaby, że posiada obce obywatelstwo, oraz jeśli nie podjęłaby uzasadnionych działań w celu utraty tego statusu, zgodnie z prawem obcego państwa. Z uzasadnienia większości sędziów składu orzekającego nie wynika również, że osoba posiadająca obywatelstwo innego państwa powinna zostać pozbawiona prawa do kandydowania, jeśli nie jest świadoma swojego statusu oraz jeśli nie podejmuje działań w celu utraty tego statusu, zgodnie z prawem tego państwa.

63. Szczególną uwagę należy przywiązać do wyroku w sprawie Sykes v. Cleary w odniesieniu do drugiego oraz trzeciego skarżącego, a mianowicie pana Delacretaz oraz pana Kardamitsis. Pan Delacretaz wprawdzie urodził się w Szwajcarii oraz posiadał obywatelstwo tego państwa od urodzenia, ale przez ponad 40 lat — przed kandydowaniem w wyborach do Izby Reprezentantów - mieszkał w Australii. Obywatelstwo australijskie nabył 32 lata przed wspomnianą nominacja, w wyniku procesu naturalizacyjnego. W momencie naturalizacji wypowiedział wierność innym suwerenom oraz państwom, których był wcześniej poddanym lub obywatelem. Natomiast pan Kardamitsis urodził się w Grecji i od tego czasu posiadał greckie obywatelstwo. Zanim został nominowany mieszkał w Australii od ponad 20 lat, naturalizowany został ponad 17 lat przed nominacją na kandydata. W momencie naturalizacji również zrzekł się wszelkich związków z innymi państwami.

64. Większość sędziów składu orzekającego [...] stwierdziła, że pan Delacretaz utracił prawo do kandydowania na podstawie art. 44i, ponieważ ,nie skierował żądania pozbawienia go obywatelstwa Szwajcarii, na co automatycznie powinna zostać wyrażona zgoda w związku z tym, że nie mieszkał w Szwajcarii oraz był obywatelem australijskim przez 32 lata. Ponieważ nie wystosował takiego żądania, nie można twierdzić, że podjął wszelkie możliwe działania w celu utraty obywatelstwa Szwajcarii oraz praw i przywilejów związanych z posiadaniem tego obywatelstwa".

65. Większość sędziów składu orzekającego stwierdziła, że pan Kardamitsis nie miał prawa do kandydowania w związku z art. 44i, ponieważ ,w związku z niezłożeniem wniosku do właściwego ministra [Grecji — M.R.], który posiada kompetencję w zakresie utraty obywatelstwa, nie można twierdzić, że podjął wszelkie możliwe działania w celu utraty obywatelstwa Szwajcarii oraz praw i przywilejów związanych z posiadaniem tego obywatelstwa".

$[\ldots]$

67. Żaden z sędziów — stanowiących większość składu orzekającego w sprawie Sykes $v$. Cleary — nie stwierdził, że kandydat, który nie jest świadomy tego, że posiada obywatelstwo innego państwa, podjął wszelkie dostępne działania w celu zrzeczenia się tego obywatelstwa. [...]

68. Większość z sędziów składu orzekającego w wyroku Sykes v. Cleary stwierdziła, że ocena spełnienia wymogu podjęcia przez kandydata wszelkich dostępnych działań w celu zerwania więzi obywatelstwa z innym państwem zależne są od ,sytuacji jednostki, wymogów obcego prawa oraz zakresu powiązań między jednostką a państwem obcym. [...]" 
$[\ldots]$

Podsumowanie w zakresie właściwejwykładni art. 44i

$[\ldots]$

71. Intencją twórców art. 44i było uniemożliwienie wyboru osoby, która jest poddanym lub obywatelem innego państwa, lub objęcia przez nią mandatu. To, czy dana osoba jest poddanym lub obywatelem innego państwa, wynika z prawa innego państwa. W celu zastosowania ograniczenia wynikającego $\mathrm{z}$ art. 44i nie jest konieczne udowodnienie posiadania przez kandydata wiedzy (lub faktów, które mogą spowodować wszczęcie postępowania mającego na celu ustalenia posiadania przez niego obywatelstwa innego państwa) o posiadaniu innego obywatelstwa

72. Osoba, która w okresie rejestrowania kandydatury w wyborach była podanym lub obywatelem obcego państwa, jest niezdolna do uzyskania oraz wykonywania mandatu na podstawie art. 44i, z wyjątkiem sytuacji, gdy działanie prawa obcego jest sprzeczne z konstytucyjnym imperatywem, zgodnie z którym obywatel australijski nie może zostać nieodwracalnie pozbawiony możliwości partycypacji w demokracji przedstawicielskiej na mocy prawa innego państwa. Jeśli możliwe jest wykazanie, że obywatel podjął wszystkie dostępne działania, które są wymagane zgodnie z prawem innego państwa w celu zrzeczenia się jego obywatelstwa, znajduje zastosowanie wspomniany imperatyw konstytucyjny.

$[\ldots]$

Senator Matthew Canavan

74. Senator Canavan został nominowany na kandydata w wyborach parlamentarnych zarządzonych na dzień 2 lipca 2016 r. W tym czasie senator Canavan by przekonany, że posiadania jedynie obywatelstwo australijskie [...]. Pytanie dotyczy tego, czy senator Canavan posiadał obywatelstwo włoskie w dniu nominacji.

75. Senator Canavan urodził się w Southport w Queensland w 1980 r. Jego ojciec urodził się w Toowoomba w Queensland. Jego matka, Maria Canavan, urodziła się w Ayr w Queensland w październiku 1955 r. Senator Canavan był związany z Włochami jedynie poprzez swoją babcię oraz dziadka ze strony matki (Gaetano and Rosalia Zanella), którzy urodzili się w Lozzo di Cadore we Włoszech; w 1951 r. wyemigrowali oni do Australii i po pewnym czasie nabyli obywatelstwo australijskie. Gaetano został naturalizowany we wrześniu 1955 r., a Rosalia we wrześniu 1959 r. W związku z uzyskaniem australijskiego obywatelstwa oraz posiadaniem w Australii stałego miejsca zamieszkania Gaetano and Rosalia Zanella — zgodnie z włoskim prawem - utracili włoskie obywatelstwo. Kiedy urodził się senator Canavan, jego rodzice oraz dziadkowie posiadali jedynie obywatelstwo australijskie.

76. Senator Canavan nigdy nie przebywał we Włoszech i nie podejmował żadnych działań w celu uzyskania włoskiego obywatelstwa.

77. [...] W 2006 r. matka poinformowała senatora Canavana, że jest on uprawniony do wnioskowania o nadanie mu włoskiego obywatelstwa oraz że posiada dokumenty, które pomoga mu w jego uzyskaniu. Senator Canavan nie zamierzał jednak starać 
się o włoskie obywatelstwo i nie złożył potrzebnych dokumentów. Miał jednak świadomość, że jego brat podjął działania w celu uzyskania włoskiego obywatelstwa.

78. W dniu 18 lipca $2017 \mathrm{r}$. senator Canavan uzyskał od matki informację, że może zarejestrować się jako obywatel włoski w związku z działaniami, które podjęła w celu uzyskania obywatelstwa tego państwa. Następnego dnia senator Canavan udał się w podróż w celu ustalenia swojego statusu w zakresie prawa włoskiego. W dniu 24 lipca 2017 r. otrzymał we włoskim konsulacie informację, że w 2006 r. uzyskał włoskie obywatelstwo. Następnego dnia senator Canavan otrzymał pisemne potwierdzenie $\mathrm{z}$ włoskiej ambasady o zarejestrowaniu go we włoskim konsulacie w Brisbane, a także o tym, że jego dane znajdują się na liście osób uprawnionych do głosowania za granica. O rejestrację wnioskowała matka senatora, a jej wniosek dotyczył nie tylko niej samej, ale także braci i siostry senatora. [...]

79. Dnia 31 lipca 2017 r. senator Canavan skierował pismo do włoskiego konsulatu w Brisbane, prosząc o poradę w zakresie jego statusu ,niezależnie od posiadanego uprawnienia do włoskiego obywatelstwa", ponieważ chciałby zrezygnować z obywatelstwa oraz wszelkich powiązań rejestracyjnych łączących go z włoskim rządem. W 7 sierpnia 2017 r. senator Canavan udał się do ambasady włoskiej w Canberze i formalnie zrzekł się włoskiego obywatelstwa. Zrzeczenie to stało się prawomocne 8 sierpnia $2017 \mathrm{r}$.

80. Analiza włoskiego prawa w zakresie zasad nabywania obywatelstwa zawarta jest w raporcie sporządzonym przez Maurizia Delfino oraz prof. Beniamina Caravita di Toritto, którzy są praktykującymi prawnikami. Z raportu wynika, że status senatora Canavana jako obywatela włoskiego nie może wynikać z kroków podjętych przez jego matkę w 2006 r., a raczej z okoliczności, że jego babcia ze strony matki nie zrzekła się włoskiego obywatelstwa na dzień narodzin matki. Fakt, że matka senatora Canavana posiadała obywatelstwo włoskie w dniu narodzin, nie oznacza posiadania obywatelstwa tego państwa przez niego. Zgodnie z ustawą z 1912 r. jedynie dziecko ojca, który posiadał włoskie obywatelstwo uzyskiwało to obywatelstwo na zasadzie krwi. Matka senatora Canavana urodziła się w październiku 1955 r., miesiąc po tym, jak jej ojciec został naturalizowany jako obywatel australijski. Obywatel włoski, który nabył obywatelstwo innego państwa oraz stale zamieszkuje w tym państwie, automatycznie traci włoskie obywatelstwo. Na dzień swoich narodzin matka senatora posiadała wyłącznie obywatelstwo australijskie. W związku z tym również senator Canavan w dniu narodzin (1980 r.) posiadał wyłącznie obywatelstwo australijskie.

81. W raporcie wyjaśniono, że w 1983 r. Sąd Konstytucyjny Włoch uznał przepisy ustawy z 1912 r. za niekonstytucyjne w zakresie, w jakim naruszają one równość kobiet i mężczyzn. Od daty wyroku Sądu Konstytucyjnego (ze skutkiem od daty wejścia w życie konstytucji Włoch z 1948 r.) obywatelstwo włoskie zostaje przyznane dzieciom, których rodzice byli obywatelami włoskimi. Wskutek tego wyroku senator Canavan został obywatelem włoskim „retroaktywnie” od dnia swoich narodzin.

82. W związku z wyrokiem Sądu Konstytucyjnego małżeństwo matki senatora Canavana z jego ojcem w 1979 r. nie wywarło żadnych skutków w zakresie obywatel- 
stwa małżonków. W tym czasie prawo włoskie przewidywało, że kobiety traciły włoskie obywatelstwo w przypadku małżeństwa z obywatelem innego państwa, jeśli wraz z małżeństwem kobieta nabywała obywatelstwo tego samego państwa, które posiadał jej małżonek. W odniesieniu do matki senatora Canavana przepisy te nie miały zastosowania, ponieważ ona już posiadała obywatelstwo australijskie. Zasady nabywania włoskiego obywatelstwa reguluje ustawa z 1992 r., która stanowi, że dziecko obywatela włoskiego nabywa obywatelstwo tego państwa na zasadzie krwi.

\section{$[\ldots]$}

86. Senator Canavan nie złożył wniosku o stwierdzenie posiadania obywatelstwa włoskiego. Dowody przedstawione przed Sądem nie pozwalają przyjąć, że senator Canavan posiadał włoskie obywatelstwo. Konkluzja raportu jest taka, że senator Canavan nie posiadał obywatelstwa włoskiego. Biorąc pod uwagę tendencję do rozszerzania, pokolenie po pokoleniu, wpływu na życie publiczne nowego „domu”, należy przyjać, że — zgodnie z włoskim prawem - w celu uzyskania tego obywatelstwa konieczne jest podjęcie pozytywnych kroków wskazanych w raporcie.

87. Z tych względów odpowiedź na pierwsze pytanie, a mianowicie, czy w związku z art. 44i konstytucji, mandat przedstawiciela stanu Queensland w Senacie, który sprawuje senator Canavan, wygasł, brzmi „nie”.

Pan Scott Ludla m

88. Pan Ludlam złożył w Australijskiej Komisji Wyborczej dokument nominacji na kandydata w wyborach do Senatu w stanie Zachodnia Australia w dniu 18 maja 2016 r. Na dzień nominacji pan Ludlam nie był świadomy tego, że posiada obywatelstwo inne niż australijskie [...].

89. W lipcu 2017 r. z biurem pana Ludlama skontaktował się pan John Cameron, który poinformował, że ma powody podejrzewać, że pan Ludlam może być obywatelem nie tylko Australii, ale również Nowej Zelandii. W konsekwencji pan Ludlam podją działania w celu ustalenia, czy posiada podwójne obywatelstwo. Posiadanie przez niego podwójnego obywatelstwa zostało w dniu 10 lipca 2017 r. potwierdzone przez misję dyplomatyczną Nowej Zelandii w Wielkiej Brytanii. 14 lipca 2017 r. pan Ludlam skierował do przewodniczącego Senatu oświadczenie o rezygnacji z mandatu senatora stanu Zachodnia Australia.

90. Pan Ludlam nie kwestionuje, że posiadanie obywatelstwa Nowej Zelandii, o którym dotychczas nie wiedział, pozbawia go możliwości kandydowania do Senatu, jak również do sprawowania mandatu senatora. Natomiast okoliczności uzyskania przez niego obywatelstwa Nowej Zelandii są następujacee. Pan Ludlam urodził się w Palmerston w Nowej Zelandii w styczniu 1970 r. Jego rodzice opuścili Nową Zelandię w 1973 r. W październiku 1978 r. przybył on wraz z rodziną do Perth w Zachodniej Australii. Pan Ludlam, jego brat oraz rodzice zostali obywatelami australijskim w wyniku procesu naturalizacji w kwietniu 1989 r. Pan Ludlam był przekonany, że po przejściu procedury naturalizacji pozostawał on wyłącznie obywatelem australijskim.

91. Informacje dotyczące zasad nabywania i utraty obywatelstwa Nowej Zelandii zawarte są w raporcie sporządzonym przez pana Davida Goddarda, honorowego 
członka nowozelandzkiej palestry. W podsumowaniu raportu znajduje się stwierdzenie, że na dzień narodzin pana Ludlama obowiązywała ustawa regulująca kwestie dotyczące obywatelstwa Nowej Zelandii (British Nationality and New Zeland Citizenship Act 1948). Oprócz wyjątków nieistotnych w przedmiotowej sprawie w regulacji tej przewidziano, że osoba urodzona w Nowej Zelandii jest obywatelem tego państwa na zasadzie krwi. Ustawa z 1948 r. została uchylona ustawą o obywatelstwie (Citizenship Act 1977), która wciąż obowiązuje. Pan Ludlam uzyskał obywatelstwo na podstawie ustawy z 1948 r. i zachowal je na podstawie ustawy z 1977 r. Zgodnie z obowiązującą ustawą obywatel Nowej Zelandii może utracić status obywatela przez zrzeczenia się obywatelstwa lub też w pewnych wyjątkowych sytuacjach poprzez zarządzenie ministra. [...]

92. Pan Ludlam nie posiadał prawa do kandydowania jak również prawa do sprawowania mandatu senatora na podstawie art. 44i konstytucji, w związku z czym jego mandat przedstawiciela stanu Zachodniej Australii w Senacie wygasł.

Sposób obsadzenia wy aśniętych mandatów

136. Zgodnie z ustaloną wykładnią art. 44i, senator F. Nash, senator M. Roberts, S. Ludlam [były senator - M.R.], L. Waters [były senator - M.R.] oraz B. Joyce nie byli uprawnieni do kandydowania w wyborach przeprowadzonych w $2016 \mathrm{r}$.

137. W pytaniach dotyczących byłych i obecnych senatorów [...] chodziło o ustalenie tego, czy należało na nowo obsadzić wygasłe mandaty senatorskie.

138. W tym zakresie należy wskazać, że nie jest konieczne przeprowadzenie kolejnego głosowania, nie ma też powodów, aby przypuszczać, że dodatkowe przeliczenie głosów „skutkowałoby zniekształceniem prawdziwych intencji wyborców” [...]. W związku z tym w każdym z tych przypadków głosy nadwyżkowe oddane na partię, która nominowała kandydata, którego mandat wygasł, powinny zostać przeniesione na kolejnego kandydata na liście kandydatów tej partii.

139. Jeśli chodzi o B. Joyca, to odwołując się do dotychczasowego orzecznictwa (Sykes v. Cleary), należy stwierdzić, że skoro B. Joyce nie był uprawniony do kandydowania do Izby Reprezentantów, to jego wybór należy uznać za nieważny, w związku z czym konieczne jest przeprowadzenie wyborów uzupełniających w celu wyboru nowego przedstawiciela stanu Nowa Anglia.

Tłumaczenie i opracowanie: Marcin Rulka*

* Dr Marcin Rulka, Państwowa Wyższa Szkoła Zawodowa w Wałczu, marcinrulka2@o2.pl 


\section{KSIȨGARNIE WSPÓŁPRACUJACE}

Z WYDAWNICTWEM SEJMOWYM

\section{Katowice}

Księgarnia Liber

ul. Bankowa 11, 40-007 Katowice, tel. 32 359-12-72

\section{Dom Handlowy Nauki. Zakład OR PAN}

ul. Bankowa 11, 40-007 Katowice, tel. 32 258-77-09

\section{Kraków}

Academicus. Uniwersytet Pedagogiczny w Krakowie

ul. Podchorążych 2, 30-084 Kraków,

tel. 12 626-13-99

\section{Lublin}

\section{Księgarnia Iuris Prudentia}

pl. Marii Curie-Skłodowskiej 5 (budynek Wydziału Prawa UMCS),

20-031 Lublin, tel./fax 81 537-54-75

\section{Księgarnia Iuris Prudentia}

ul. Mełgiewska 7-9 (punkt sprzedaży w budynku WSEI),

20-209 Lublin, tel. 81 476-19-09

\section{Rzeszów}

Księgarnia Iuris Prudentia

ul. Sobieskiego 2d/2 (obok Urzędu Wojewódzkiego),

35-002 Rzeszów, tel. 17 852-39-26

\section{Szczecin}

Księgarnia Akademicka

ul. Jedności Narodowej 31, 70-453 Szczecin,

tel. 91 489-09-26

\section{Toruń}

Księgarnia Uniwersytetu Mikołaja Kopernika

ul. Reja 25, 87-100 Toruń,

tel. 56 611-42-98, 56 611-48-86

\section{Warszawa}

Księgarnia Ekonomiczna Kazimierz Leki

ul. Grójecka 67, 02-094 Warszawa,

tel. 22 822-90-41

\section{Wroclaw}

Księgarnia Naukowa im. M. Kopernika

ul. Kuźnicza 30/33, 50-137 Wrocław,

tel. 71 343-29-77

\section{Zamość}

Księgarnia Iuris Prudentia

ul. Kolegiacka 2 (budynek hotelu Orbis),

22-400 Zamość, tel. 84 643-85-85 
